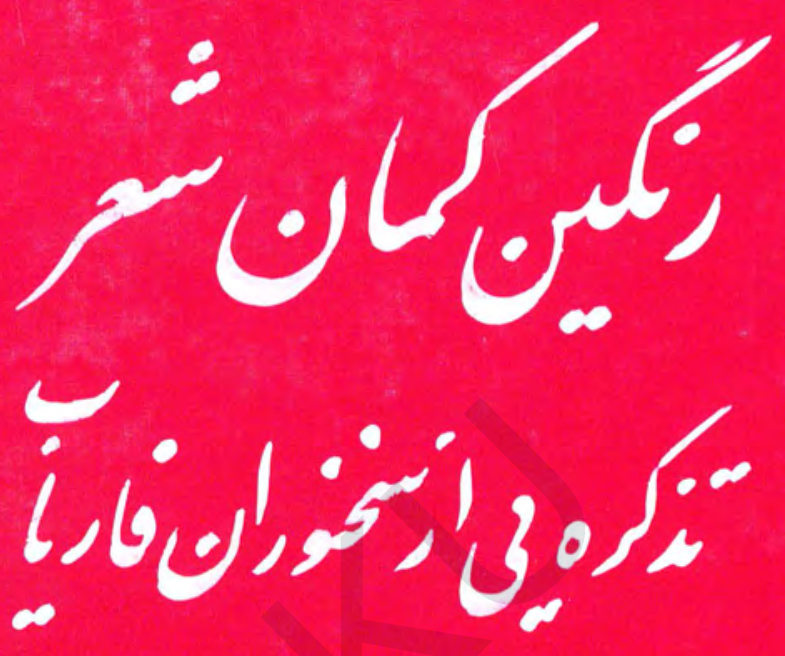

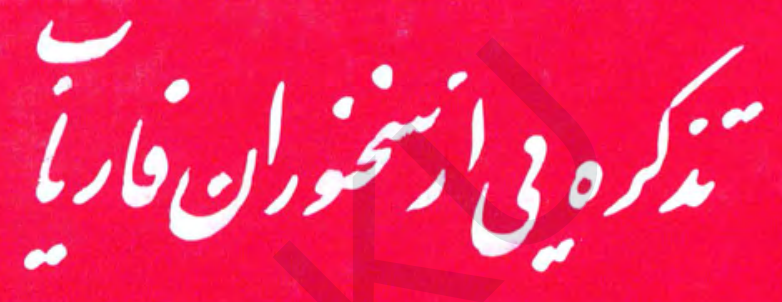

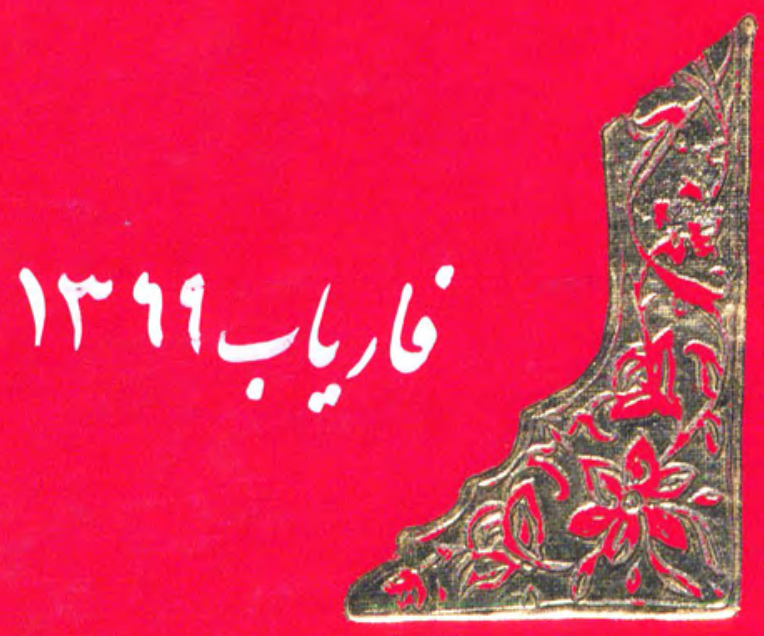




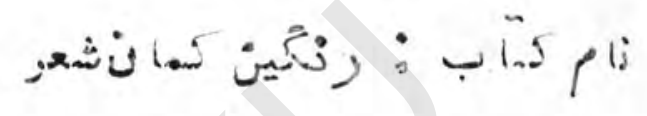

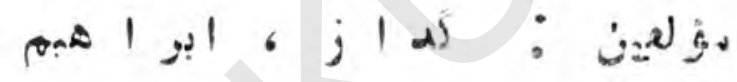

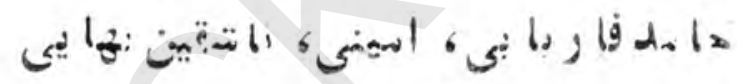
و شادق وصال ناشر : جز يدة فلار ياب

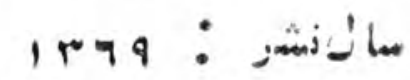

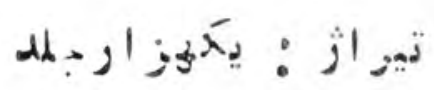
شهاره نشرو اتى :

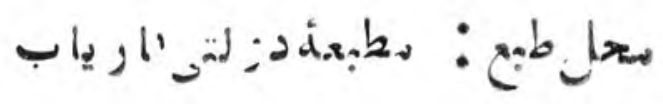




\section{رنكين كمانشعر}

$$
\begin{aligned}
& \text { تذكره يىاز مدخنو ران فار ياب }
\end{aligned}
$$

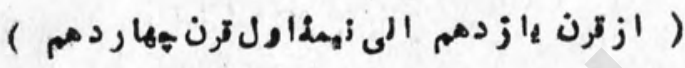

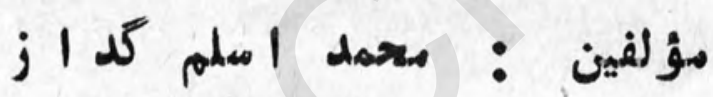

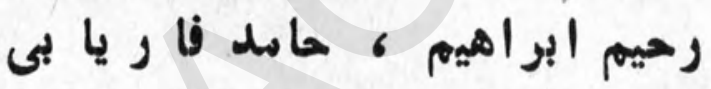

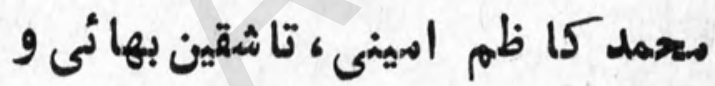
عبد الهتحمد شا يق وصل الهمن

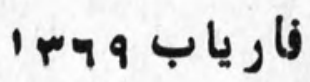


بسماللهالر حمن الر حيم 


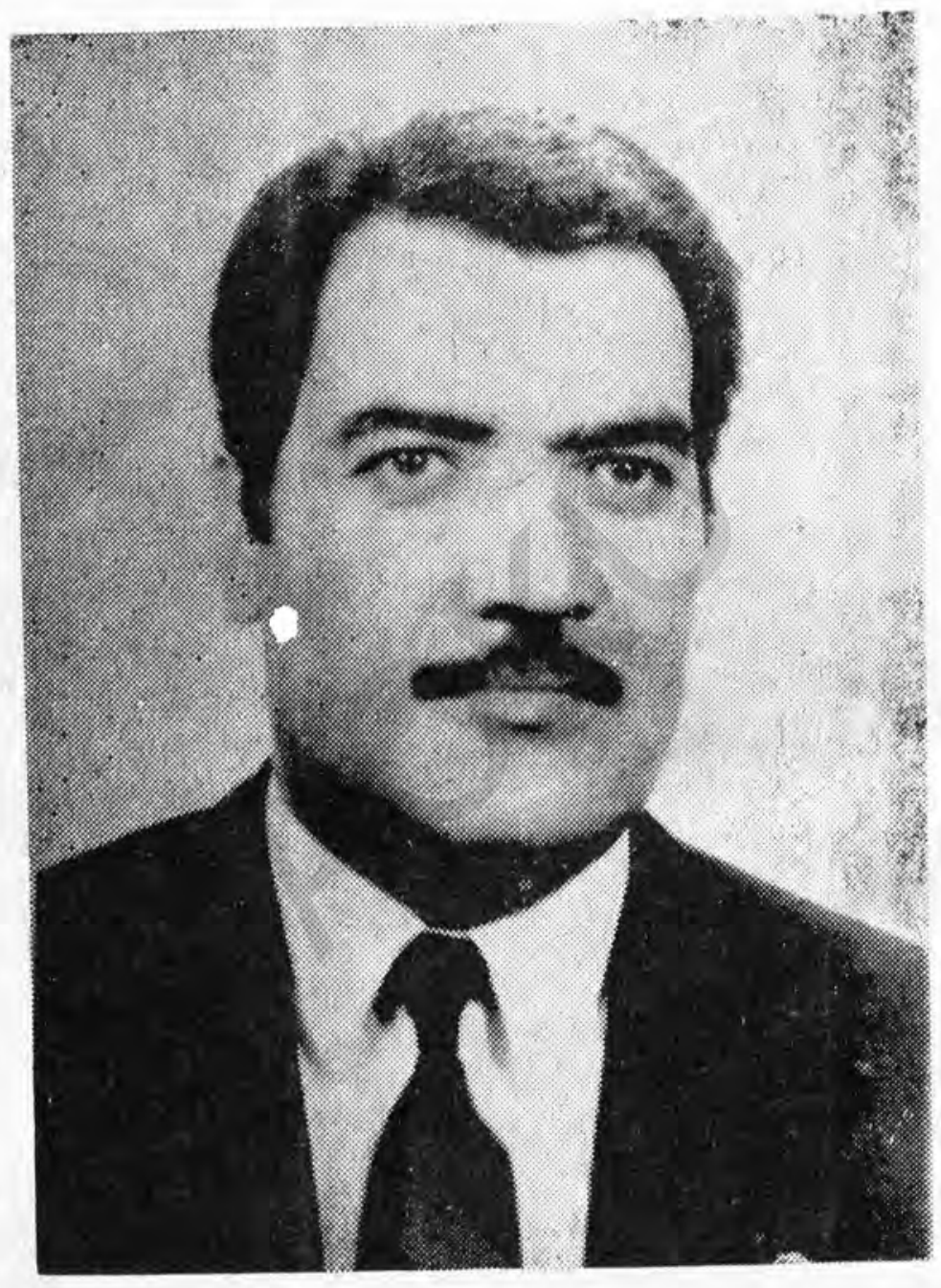

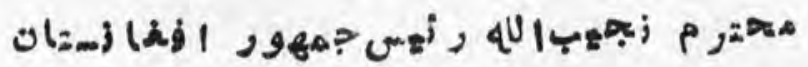


فهر سي مطان لنب

صفنr

rVE - rVt

عنال و ين الثمعالو

ماعر

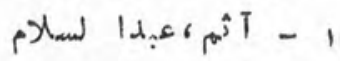

فيض :هار

lon $-10 v$

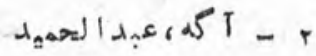

إزميا انت برحنا

$r . r-r .$.

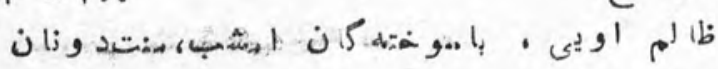

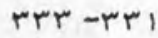

6.

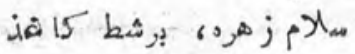

$r \varepsilon \varepsilon g \varepsilon r$.

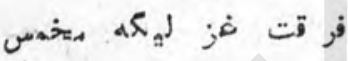

pliolarstant - o

daras,

vo-vr

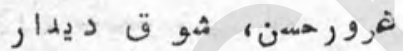

$190-195$

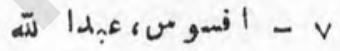

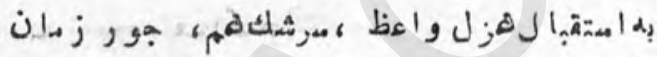

$\vee q-\vee \vee$

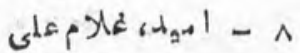

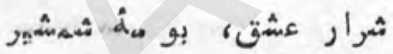

$\varepsilon \cdot 1$ r

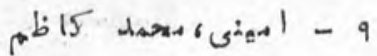

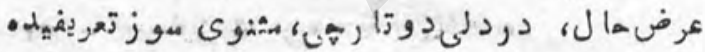

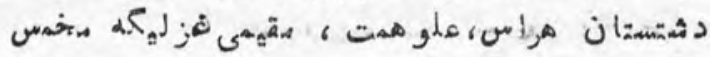
$17 \varepsilon-17 r$

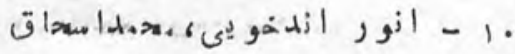

زاوك

$107-10 \%$

- 11

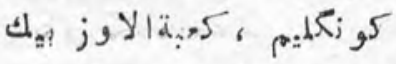

$r \circ r-r \varepsilon q$

$6=0$

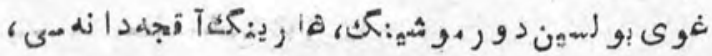

ك

$r \varepsilon r-r \varepsilon r$

س

ज, id ل

s'? 


$$
\begin{aligned}
& \text { صنهle } \\
& \varepsilon \cdot 9-\varepsilon \cdot \wedge
\end{aligned}
$$

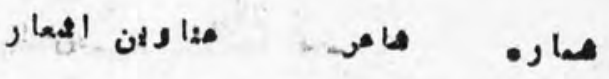

$$
\begin{aligned}
& \text { rrrore. }
\end{aligned}
$$

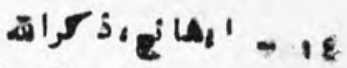

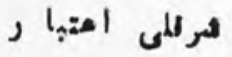

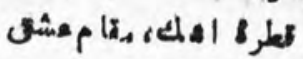

$$
\begin{aligned}
& \text { 79-7V } \\
& \text { d. li des } \\
& \text { 每 } 17 \\
& \text { MTP }
\end{aligned}
$$

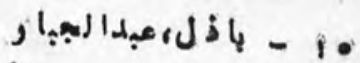

$$
\begin{aligned}
& \therefore \Delta / d-1 d a-c \mid \Delta 4,-i v
\end{aligned}
$$

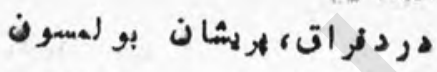

$$
\begin{aligned}
& r \varepsilon V-r \varepsilon 7 \text { I r r r }
\end{aligned}
$$

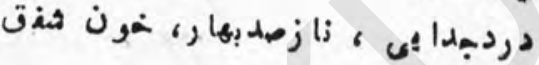

$$
\begin{aligned}
& \varepsilon \varepsilon-\varepsilon r
\end{aligned}
$$

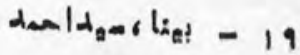

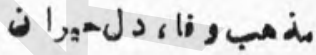

$$
\begin{aligned}
& \text { late }
\end{aligned}
$$

$199-197$

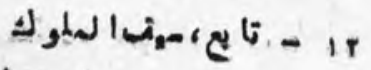

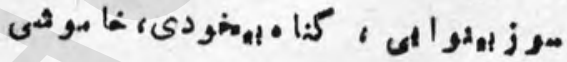

rrverte

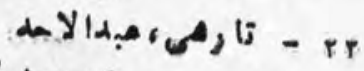

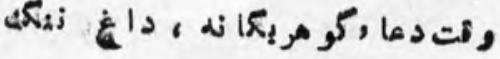

rve-rq

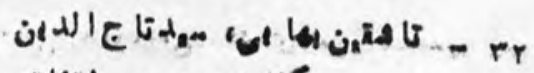

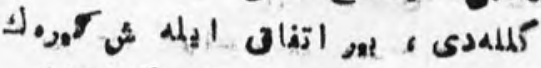

rบด-ry

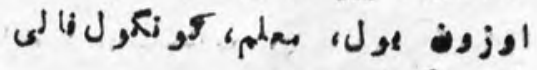

זฯงートท a d e وطن:

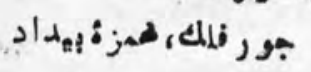

$|\varepsilon \cdot-| r \wedge$

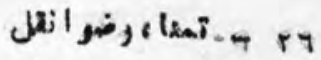

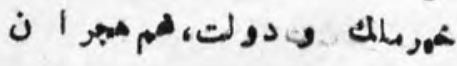

r. A • rar - rv

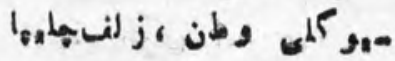


مات ع:ا و ين المعها ر (2) ماعر

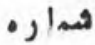
$r \varepsilon \Lambda, r \varepsilon 06 r \varepsilon \varepsilon$ ^ آ $\wedge \wedge-\wedge \circ$ ن

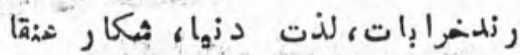
$1 v-12$

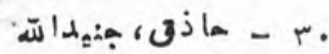

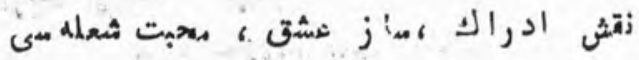

a. $\quad 10,-1 \leqslant \varepsilon$

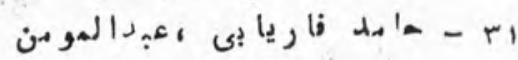

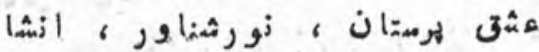

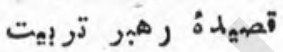

$r|q-r| \varepsilon$

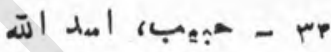

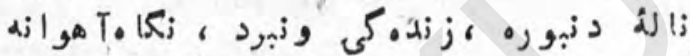
$v 1-v$. ل زק

rı

ع

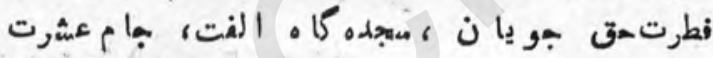
rrverta

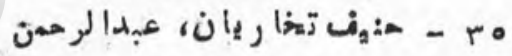

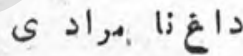

$1 \cdot 0-1 \cdot r$

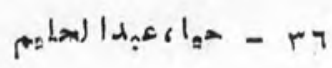

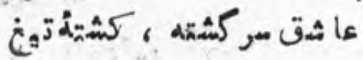

$1 \wedge \varepsilon-1 \wedge r$

is عشثى وطن

$|\vee \wedge-| \vee 7$

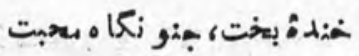

$\operatorname{lr} \varepsilon-1, r$

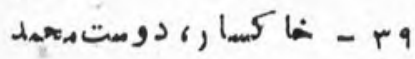

خوند

rレヘーหขフ

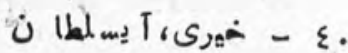

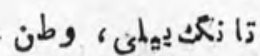

$7 フ ー 71$

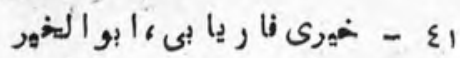

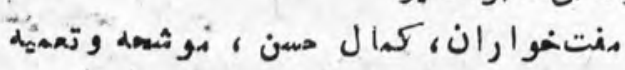
ה

4 m 
صim

$$
\varepsilon \cdot r-\varepsilon \cdot r
$$

$\varepsilon r r-\varepsilon r \mid$

$r|r-r| \mid$

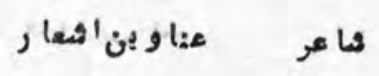

os 10

Oو أis, - Er

undikg an!

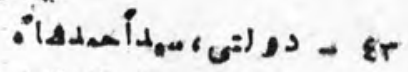

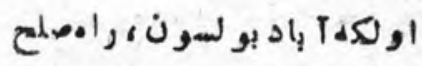

$$
\text { pas }
$$

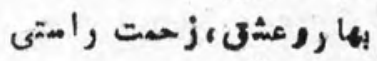

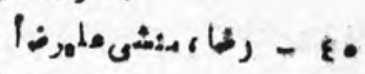

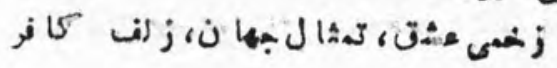

rrnーrrT

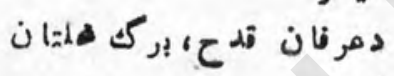

$r \bullet v-r \cdot \bullet$

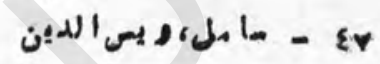

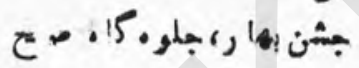

$\varepsilon, 7-\varepsilon, r$

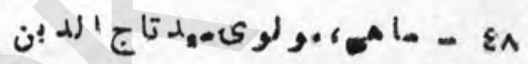

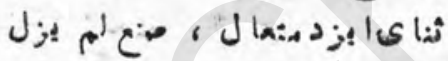

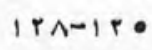

- E9

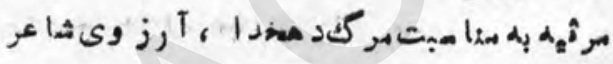

ز A

$\varepsilon r \cdot-\varepsilon i v$

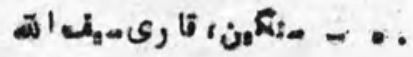

وطن

$|\wedge r-| \wedge \mid$

ئز

$\ln A_{n-1} \mid$

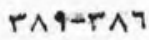

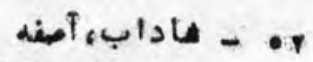

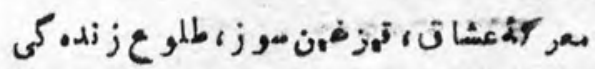

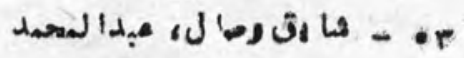

rVI-rq

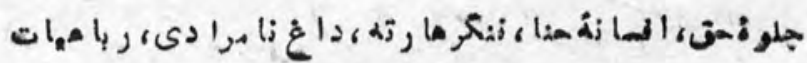
$r r-r$.

ع

زو

$r \wedge \bullet-r \wedge r$

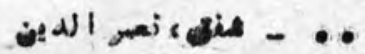

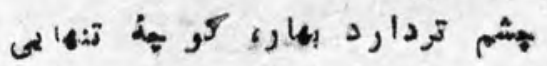

s? 
ن

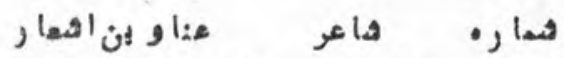
irp-iry

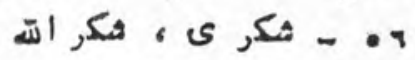

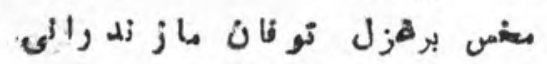

rro-res

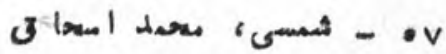

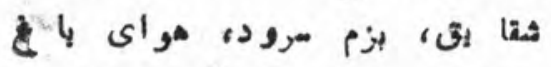

9A -9.

A

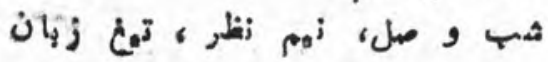

$|\varepsilon r-| \varepsilon \mid$

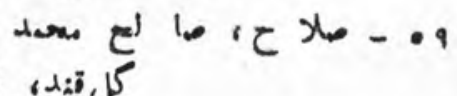

$\bullet r-\bullet$

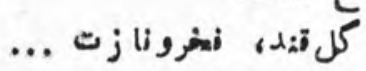

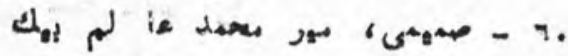

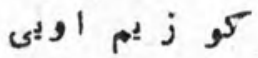

$r \cdot .-r \varepsilon \wedge$

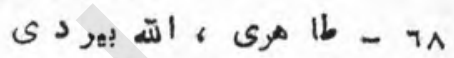

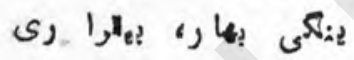

$7-1$

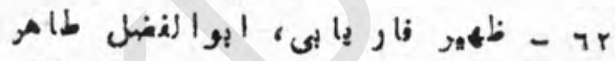

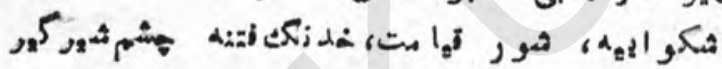

1.P-19

rا

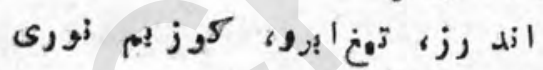

vห-v

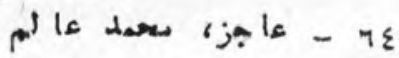

قد د لهو المو

$r \varepsilon 1-r+1$

ن - Tle

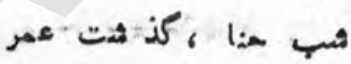

\&ro- $\varepsilon r \varepsilon$

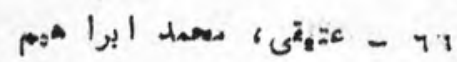

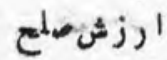

rVA-tRo

- TV

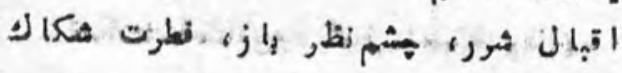

$|M|-\mid A N$

1

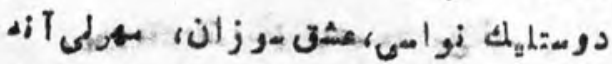

$\Delta \varepsilon-\lambda$.

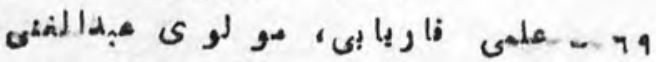

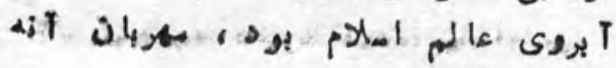

$1.9-1.7=$

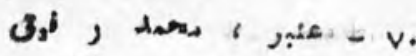

كالثن

๘ं? 
مفنri

IVo-IVR

7.- 9

$r 1 \cdot-r \cdot A$

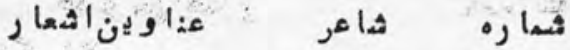

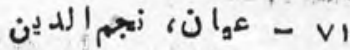

ज

ضا

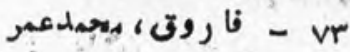

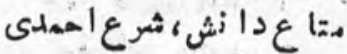

rooror

ع - فروتن، عبدا الرحمن

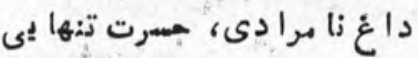

r9องหาוーหา.

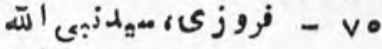

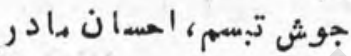

$\mid 10-11 \varepsilon$

VT

15.0.

$r \varepsilon v-r \leqslant 0$

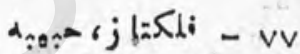

جوا نان نو ون وصنس وحسن

- $1-\sum 9$

- VA

كأش,

מיום

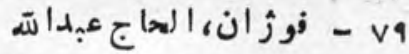

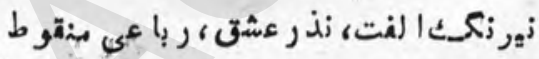

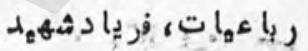

איטם

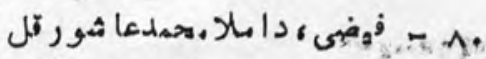

ها

$9-V$

ز!

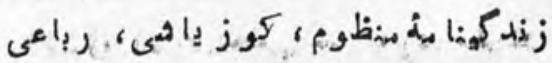

$r \wedge r=r \vee q$, \&

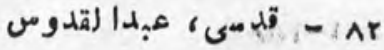

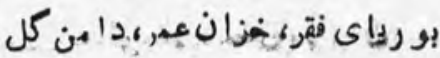

$\varepsilon \wedge-\varepsilon 0$

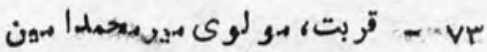

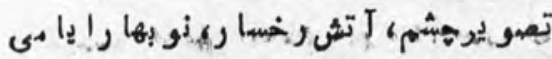

rirarar

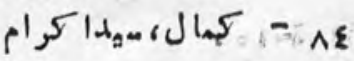

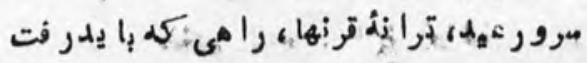

is 
صin

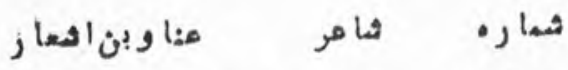
raropve

pqr-rq.

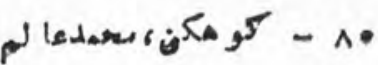

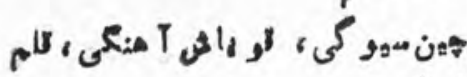

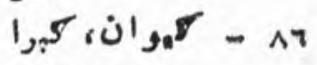

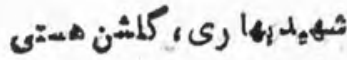

r.r-rAs

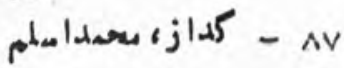

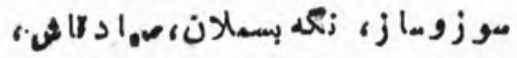

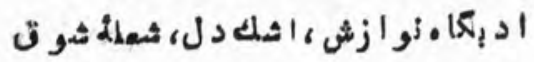

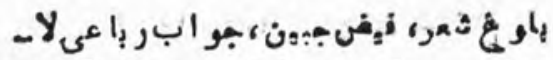

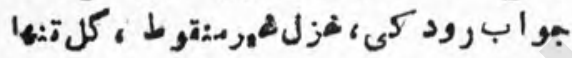

$r \cdot \wedge-r \cdot \varepsilon$

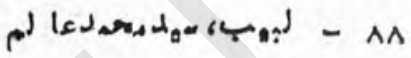

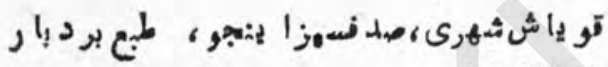

$\varepsilon 1-\varepsilon$.

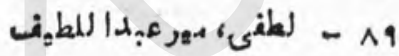

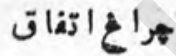

|A.-1V9

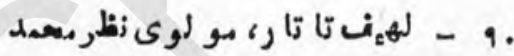

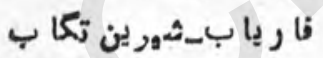

$r \cdot v-r \cdot \xi$

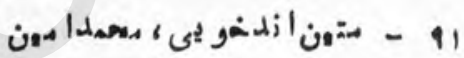

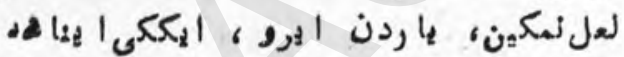

irv-irs

r

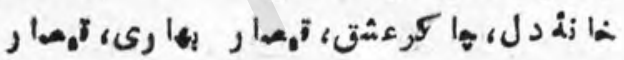

rrourt

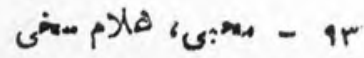

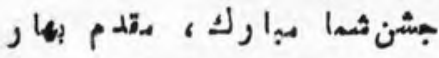

$\varepsilon \cdot v-\varepsilon \cdot \cdot$

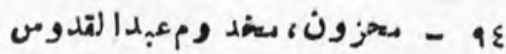

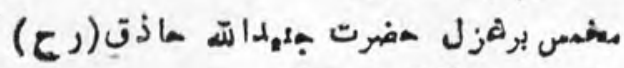

$\mid r-1$.

10

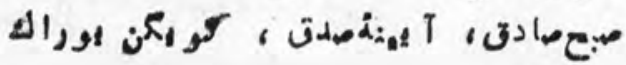

irr-ir.

14

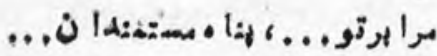


صف:حات

هاعر عنا و ين اثدعار

- $\operatorname{los}$

$17 \wedge-170$

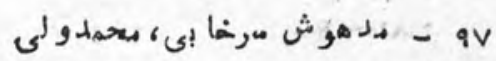

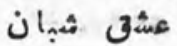

IVr-1 T9

1

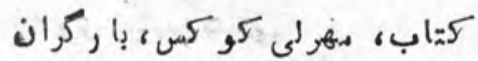

$\varepsilon|r-\varepsilon|$.

9 - 9

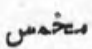

$\varepsilon r .-\varepsilon r \wedge$

ـ

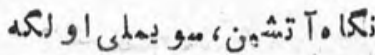

rฯ.

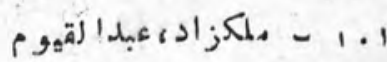

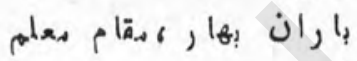

r०\&-r०।

年

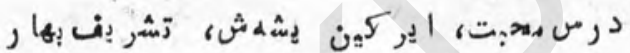

rqーr^

r

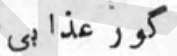

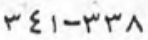

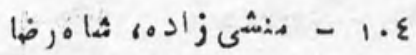

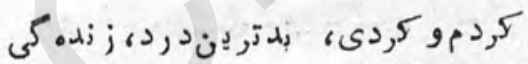

$|r|-\mid r q$

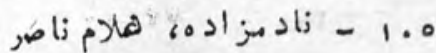

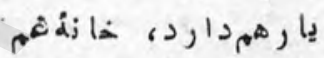

$1 \wedge-1 r$

ل

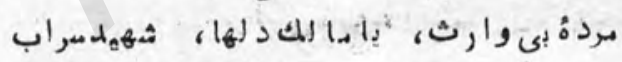

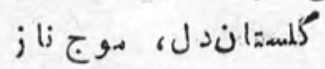

$|7|-109$

ض

آتش حسرت، آتش هعبران

rrqurr

- 1.1

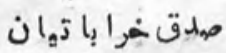

$\circ 7$ ○r

مئم 1.9

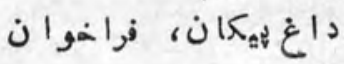

هA 
صغ

$119-117$

$\mid 1 r-11$.

$91-\wedge 9$

rra-rr.

rq-rq

rדםr

$\varepsilon r V-\varepsilon r Y$

$1 \wedge \vee-1 \wedge 0$

rONArOT

r^^ーr^ฯ

ヘ

१ะ-१ห

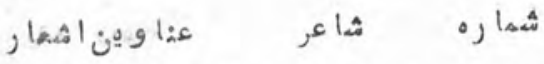

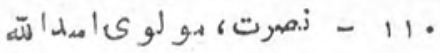

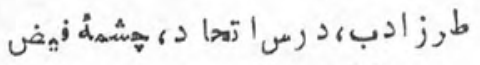

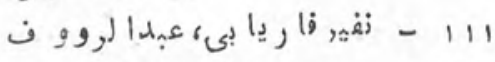

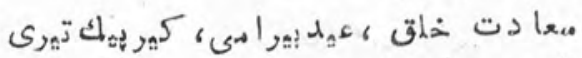

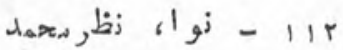

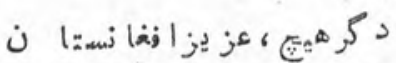

r

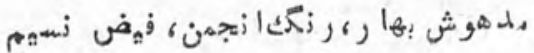

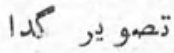

ع 11

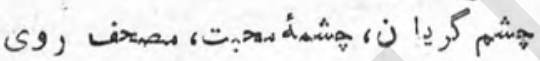

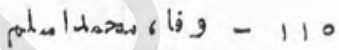

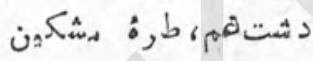

$$
\text { ब }
$$

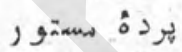

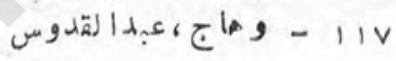

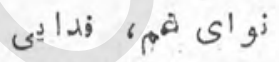

ischaran 6 phas - 111

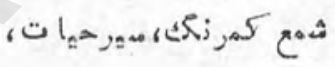

$$
\text { الهان }
$$

:

$$
\begin{aligned}
& \text { ي } \\
& \text { و طن عششقى، الى خم الهر عزيز } \\
& \text { ا اr| - إيهى - }
\end{aligned}
$$

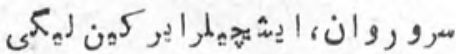


درستنا مd

درمت

بهـد.

مئم

داكو

إen

1, بونا

T T T T

دلما زبى تهوز بهاى

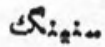

45

$d: i_{a} j$

زادم

علمهرا ت:كك

जintens

بإه نغ

$d_{i, 5} 5$

ما قaمسى

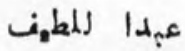

$l_{i}$ ! jl

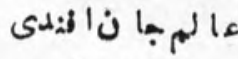

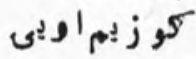

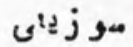

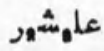

- di $\hat{j}$

•

?

إ:تะט

SC: $\mathrm{B}_{\mathrm{a}}$ arias i

dising

داكوى

+e)

, tris

آلود

。

sर्.inj

$\omega^{5}$

$\lambda i_{a} j$

p ij

علهر رضاء

Sर्.

जines

زفمس

$a_{2} \times 5$

$\operatorname{cong} g$ L

عبدا لط لهن

lis?

عالمخان أزماند

تو زيم او أهى

موز مدلم

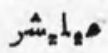

odia

جمة

هود

|توتى

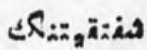

ميطر

anip

$\wedge$

$r$

1^

$y$

ir

$1 \varepsilon$

1

$1 \cdot$

IV

IV

19

r

$\varepsilon r$

rT

$r$.

ry

rT

r.

mo

$\varepsilon$.

$\varepsilon r$

عنو ان

عنو ان

$\begin{array}{cc}r & 0 r \\ r & 0 r \\ 0 & 0 v \\ 1 & 0 v \\ 11 & 09 \\ 1 r & 70\end{array}$

- 1

or

० 


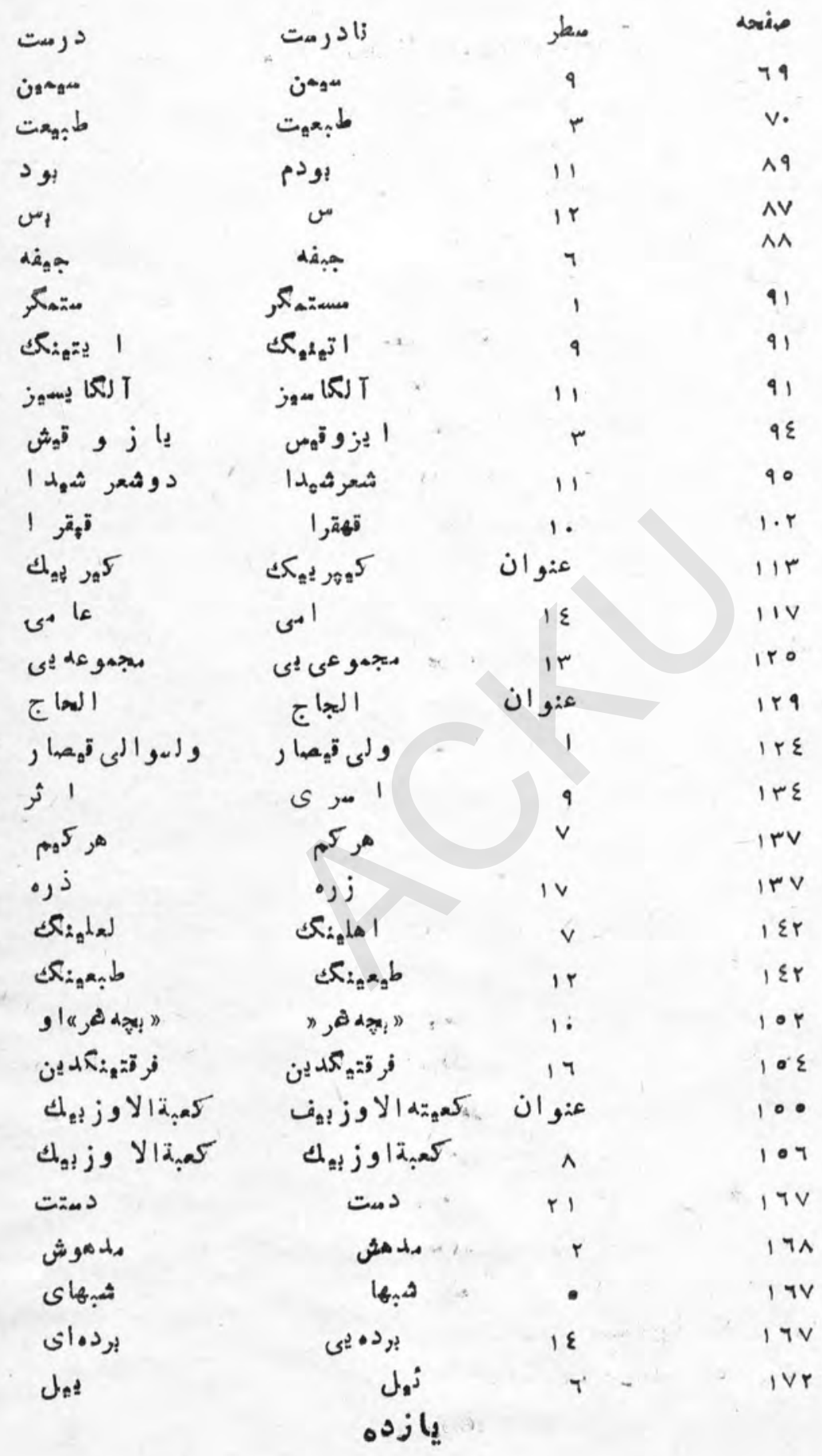




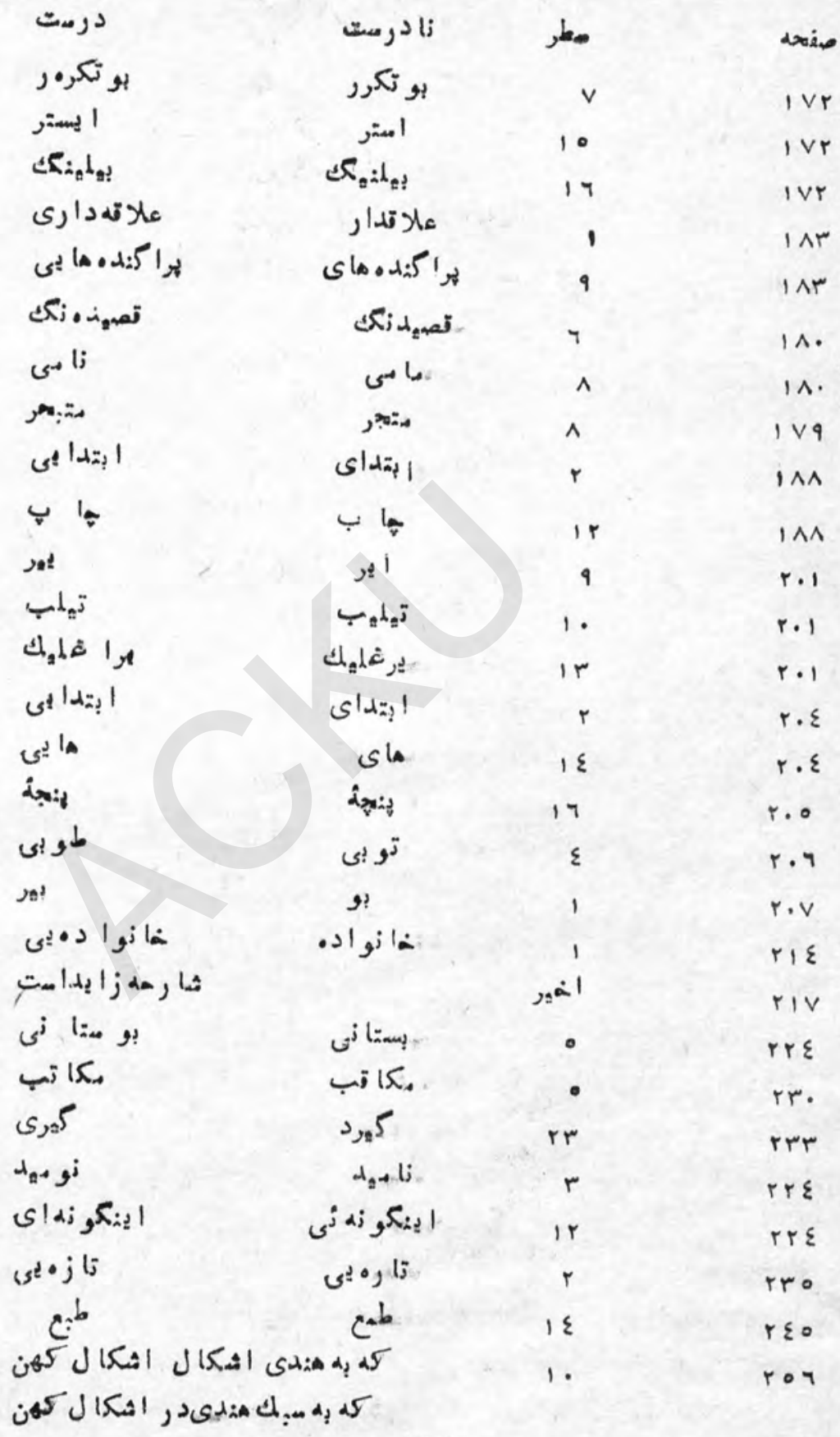




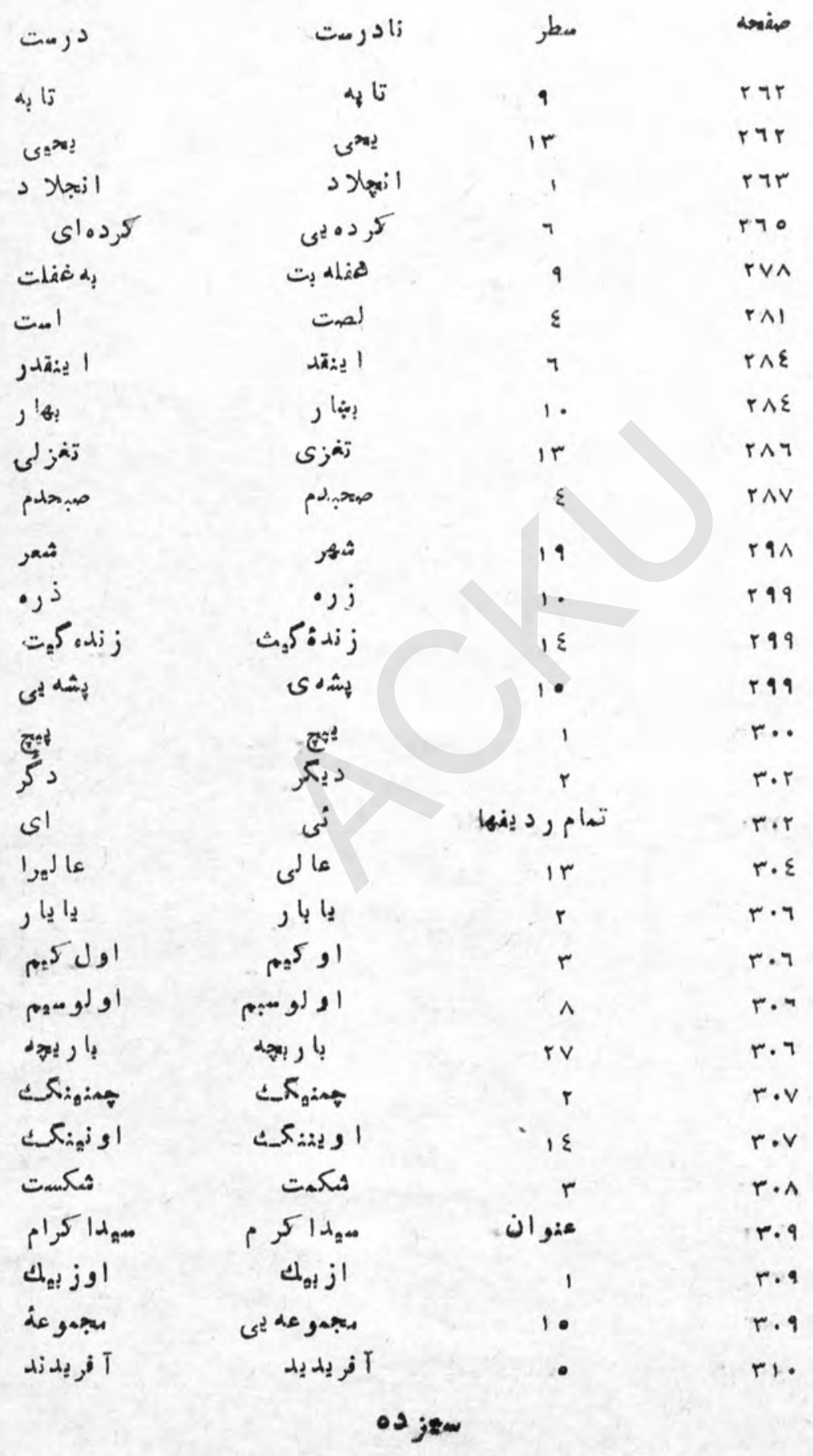




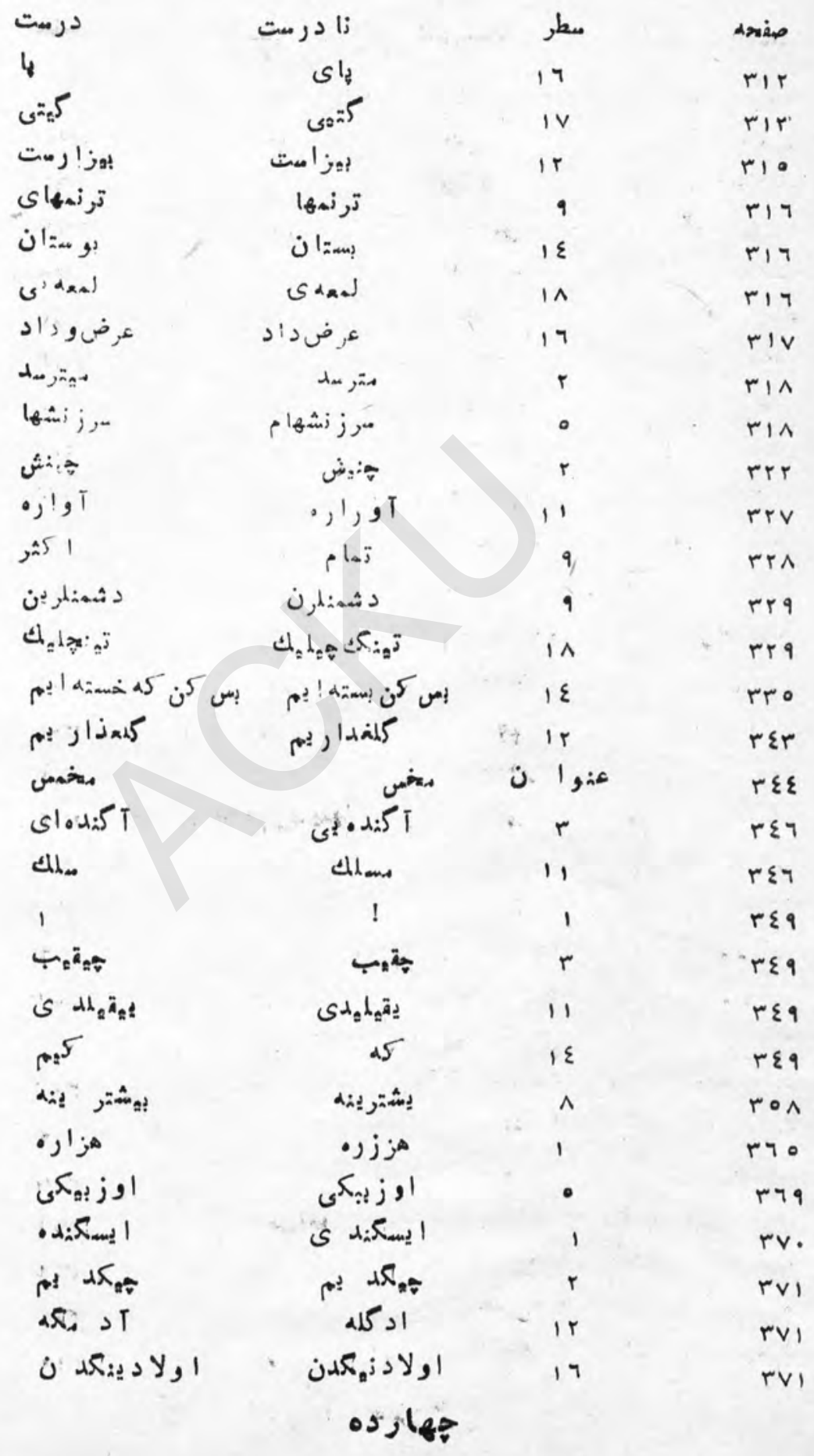




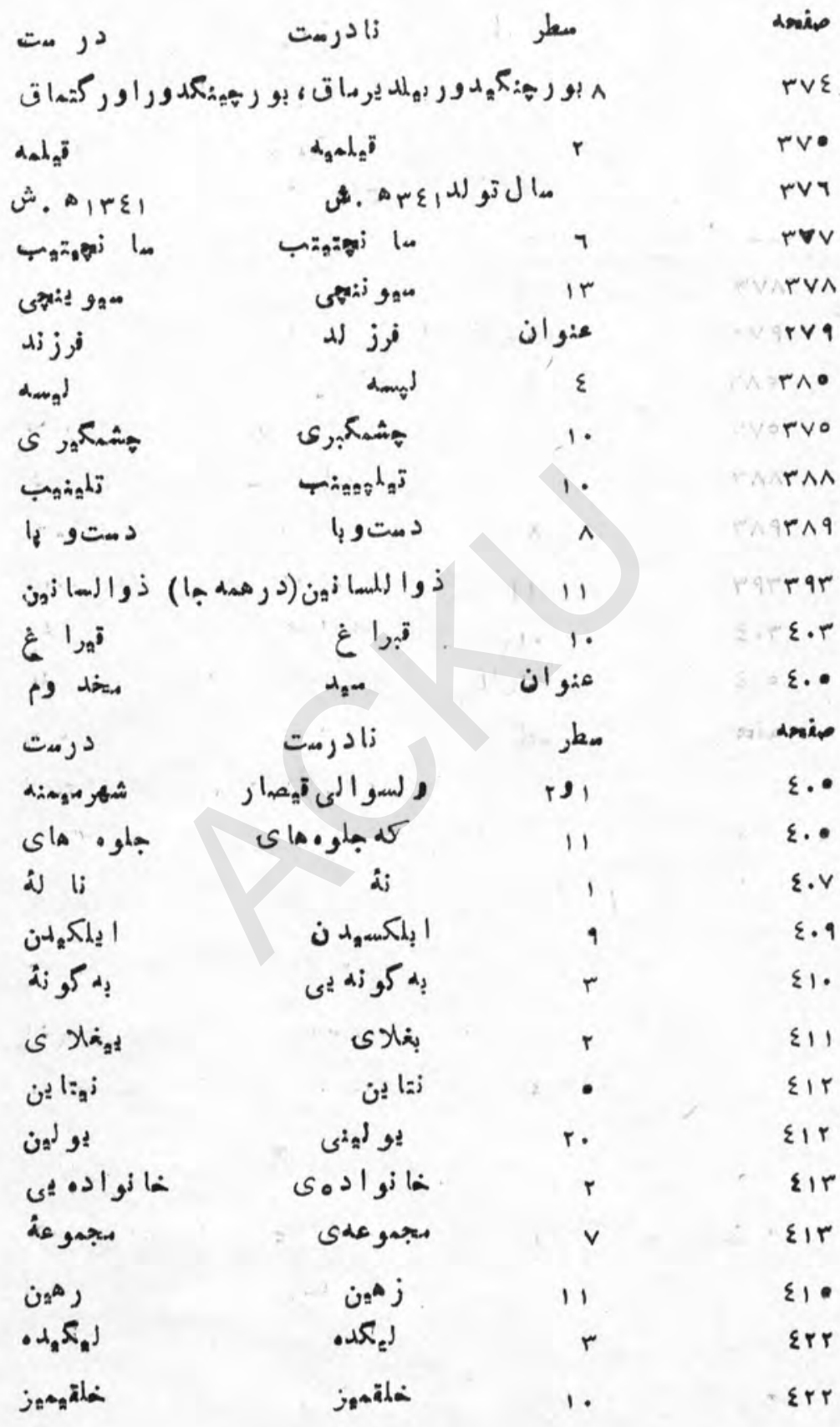




\section{بسمم الله الوحهن الرحيم}

\section{زتكرشىبه اين كتاب}

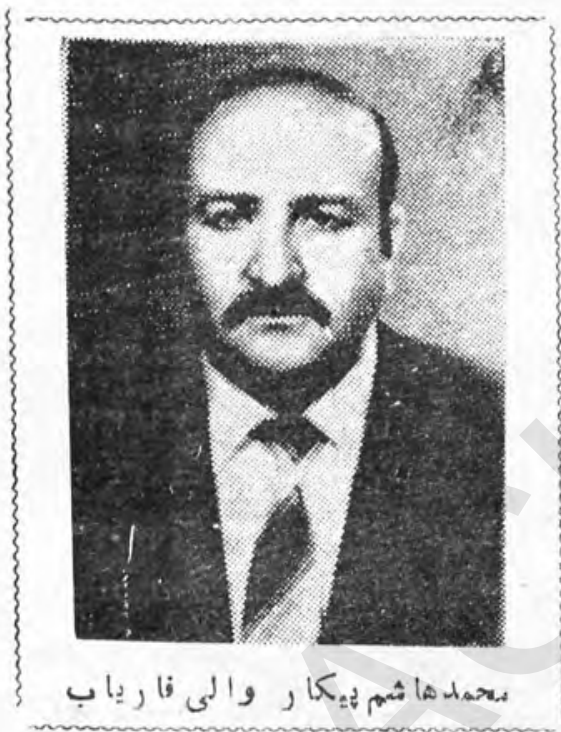

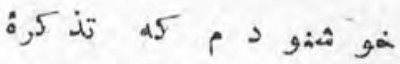

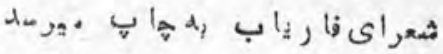

$$
\begin{aligned}
& \text { هر }
\end{aligned}
$$

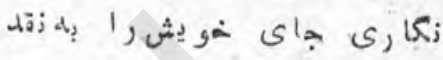

$$
\begin{aligned}
& \text { و : ور) }
\end{aligned}
$$

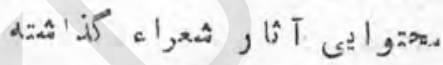

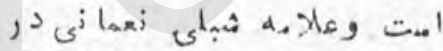

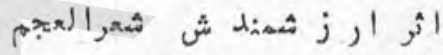

$$
\begin{aligned}
& \text { تذ S, } \\
& \text { !ٕ لا لا برد }
\end{aligned}
$$

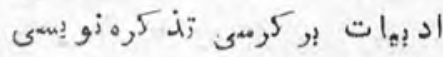

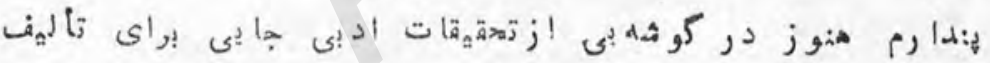
ه:ثن

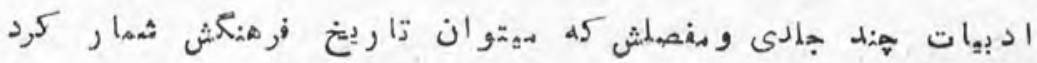

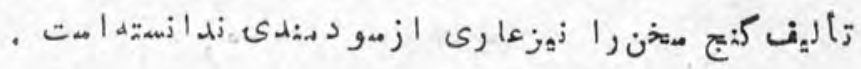

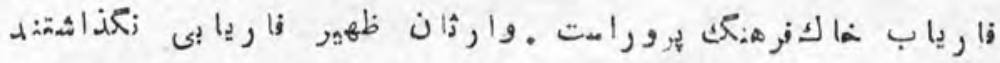

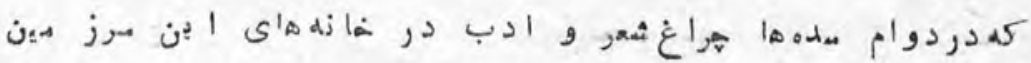

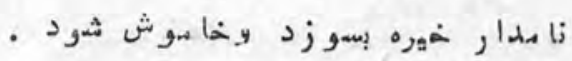

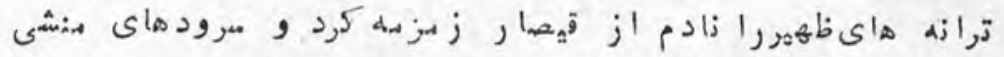

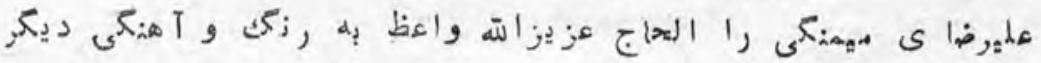
. . ما 


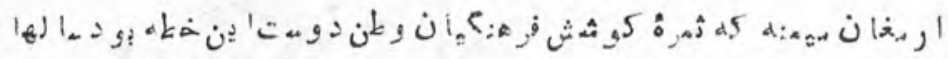

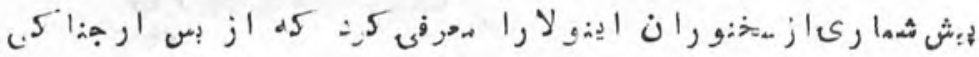

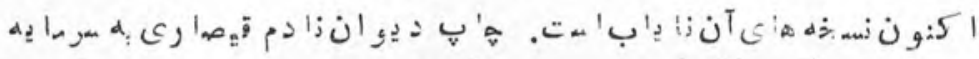
شاخص

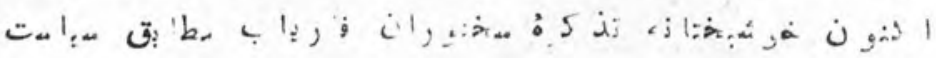

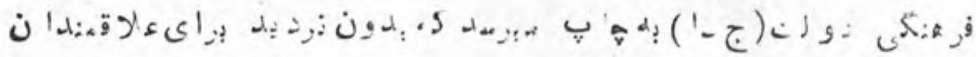

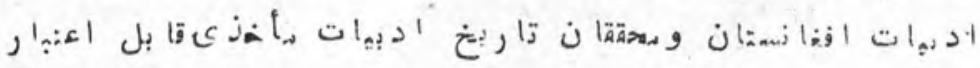

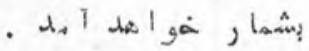

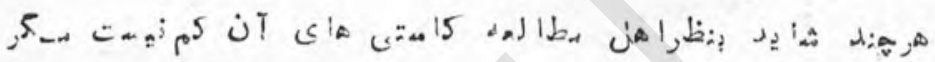

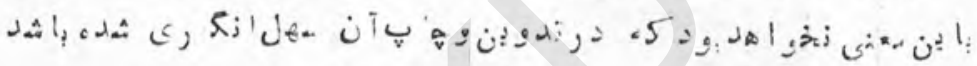

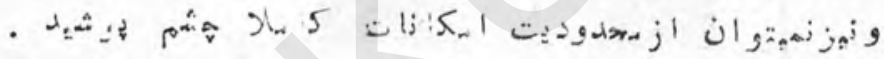

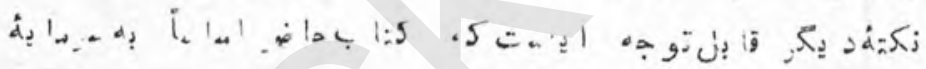
Dز

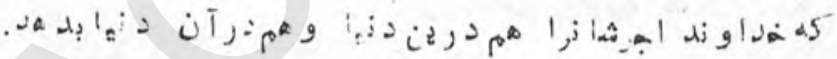

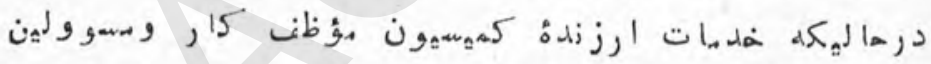

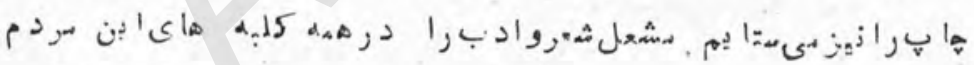

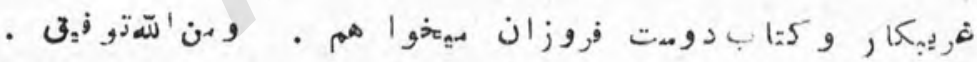

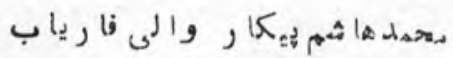




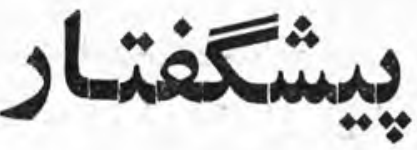

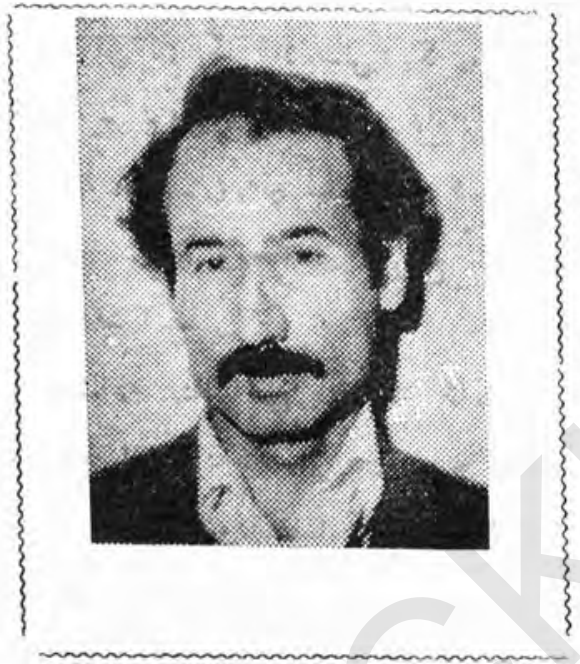

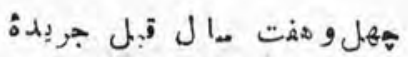

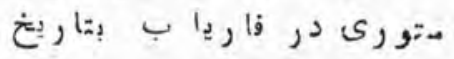

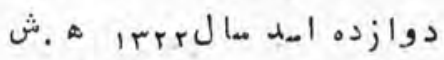

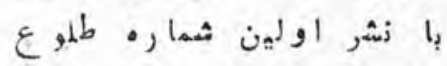

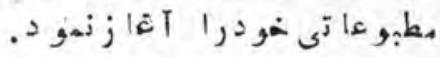

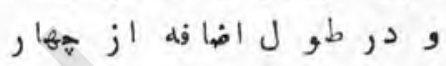

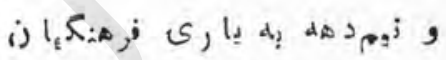

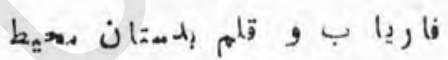

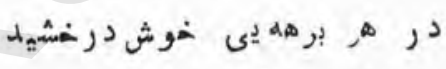

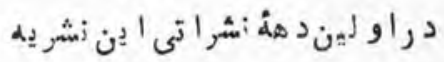

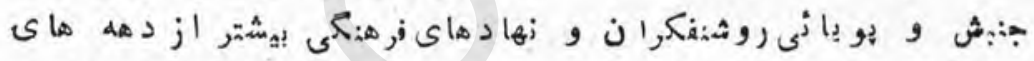

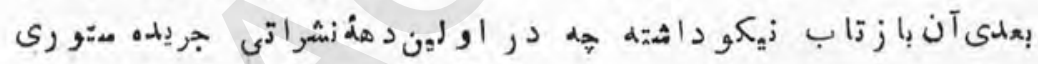

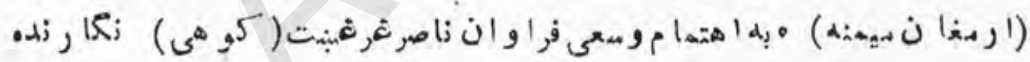

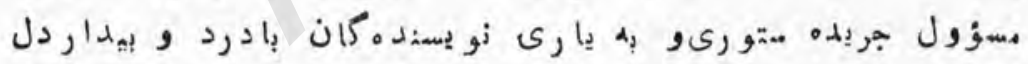

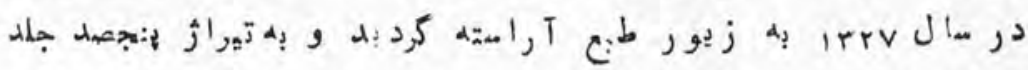

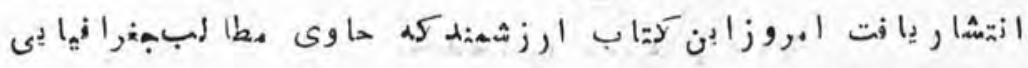

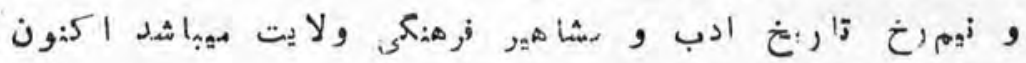
.

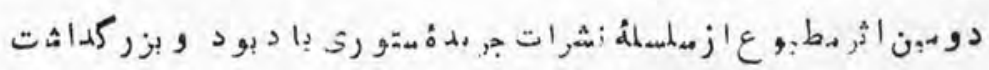

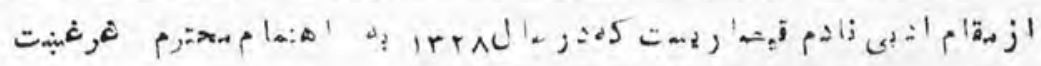
. A 


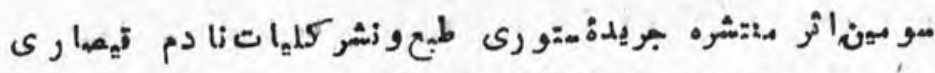

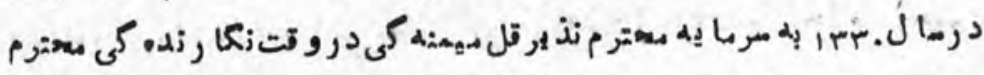

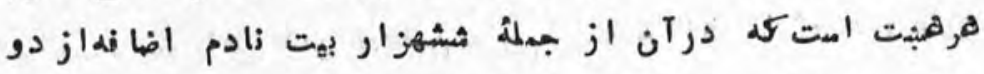

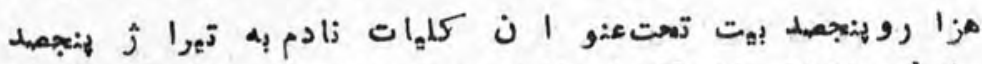

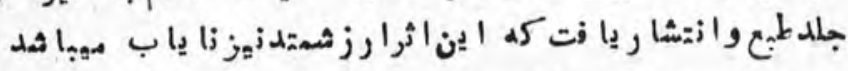

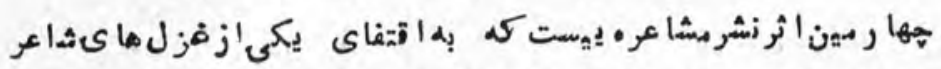

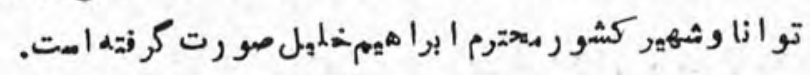

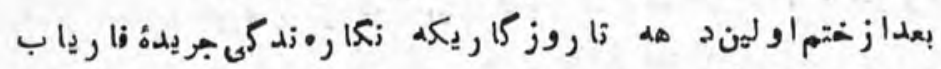

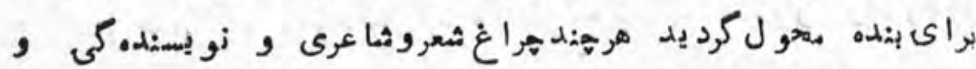

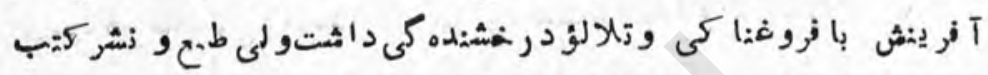

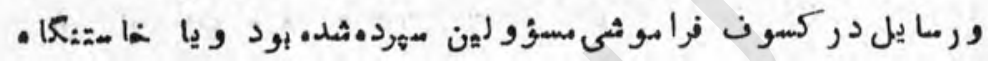

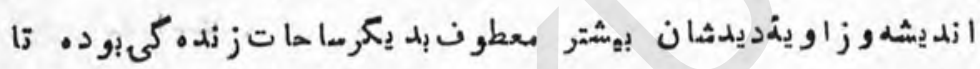

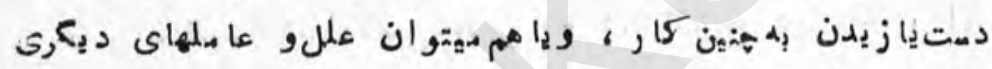

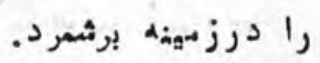

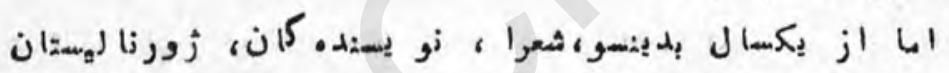

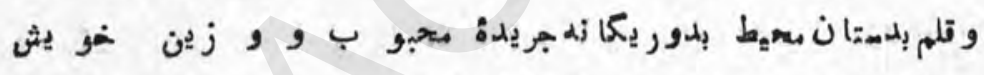

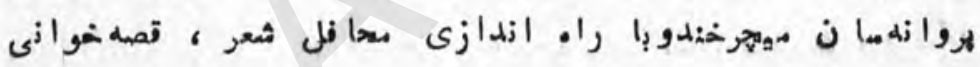

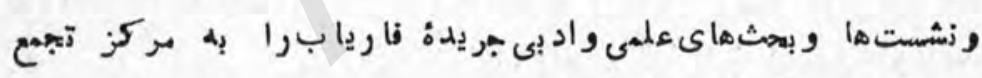

$$
\begin{aligned}
& \text { ا هل شعرو فرهنكث تبهد يل نمو دها اند. }
\end{aligned}
$$

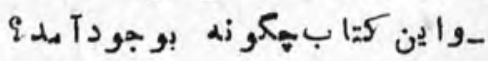

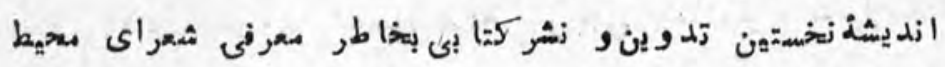

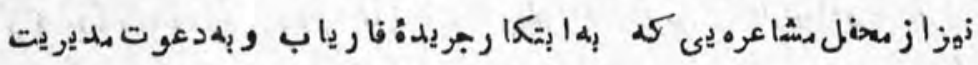

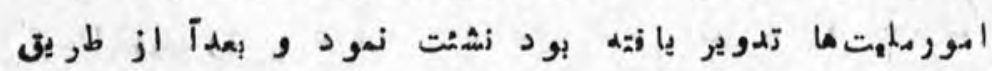

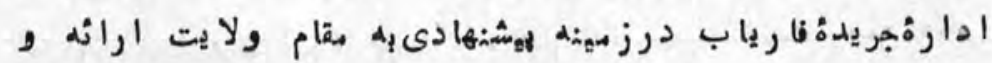

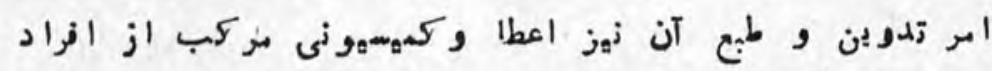

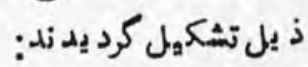




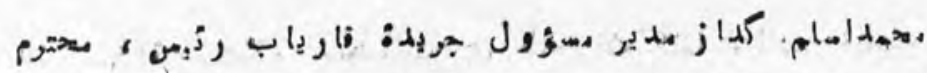

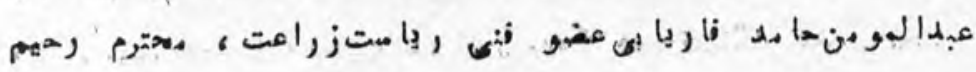

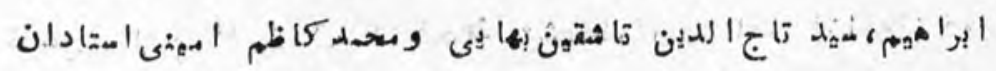

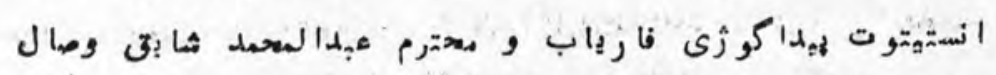

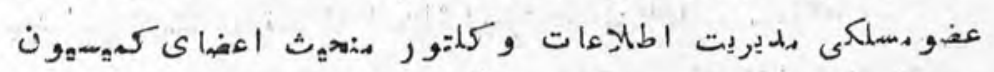

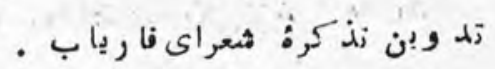

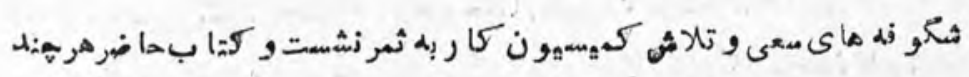

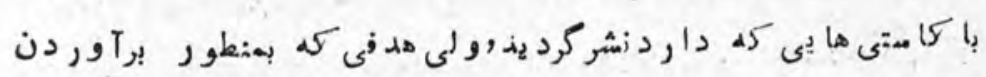

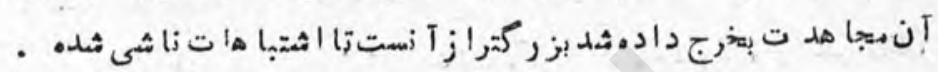

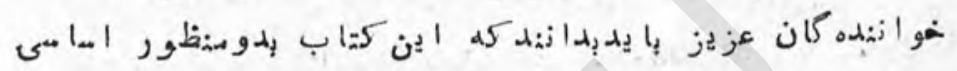

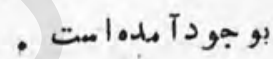

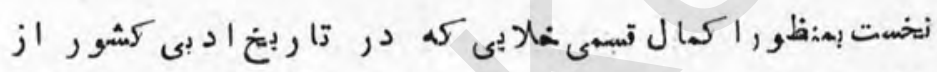

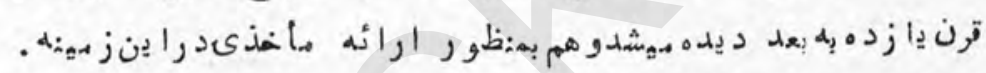

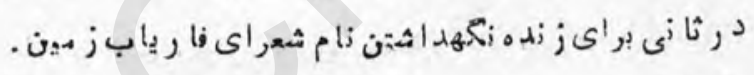

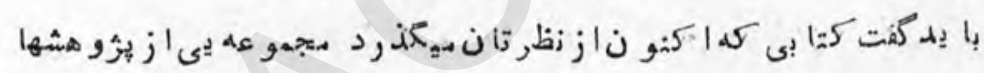

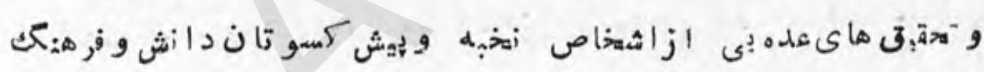

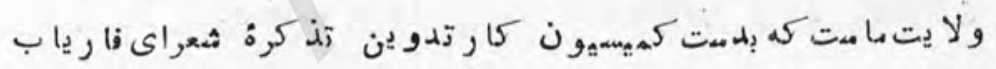

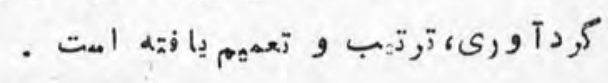

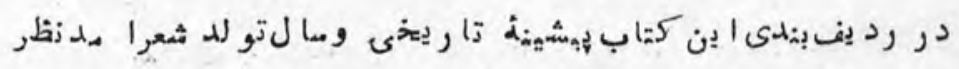

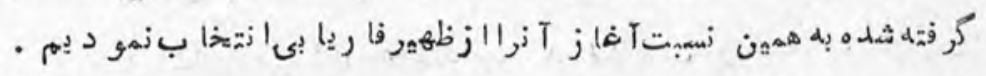

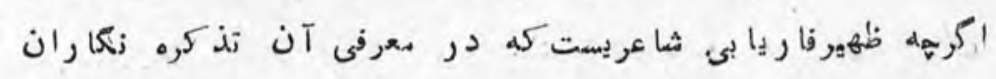

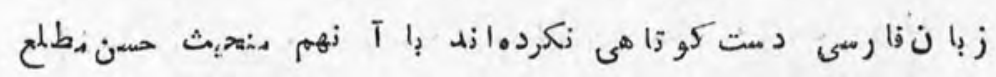




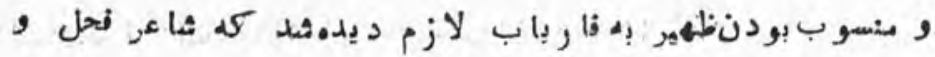

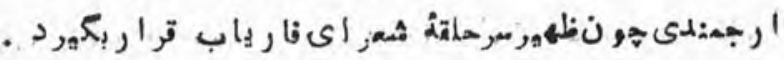

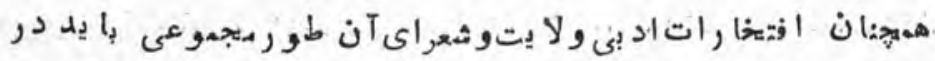

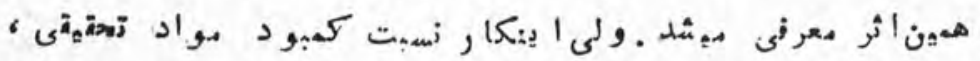

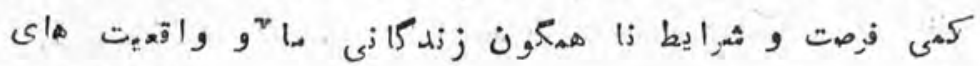

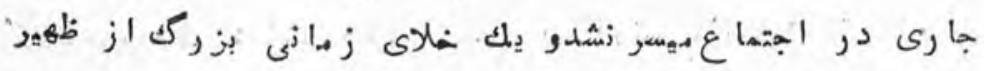

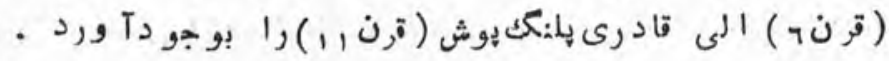

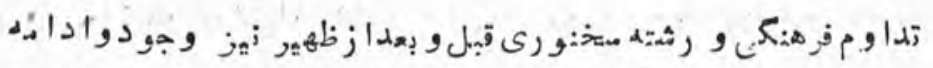

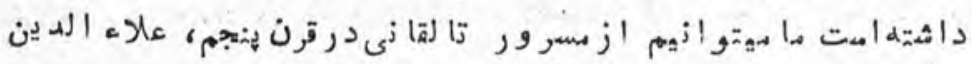

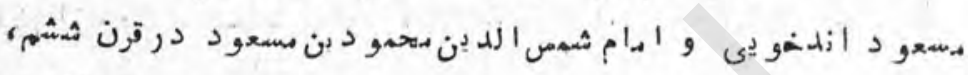

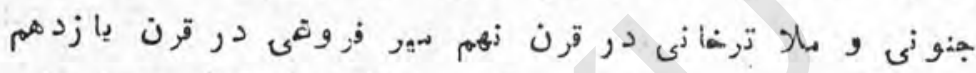

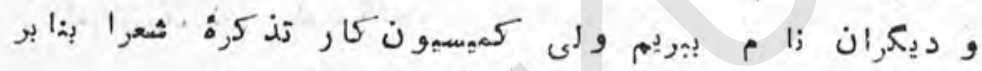

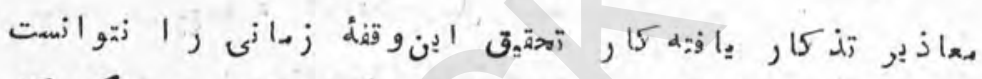

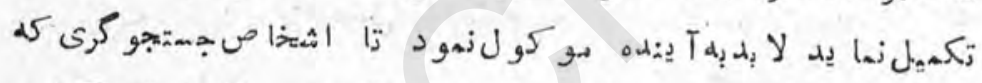

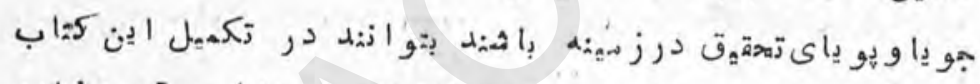

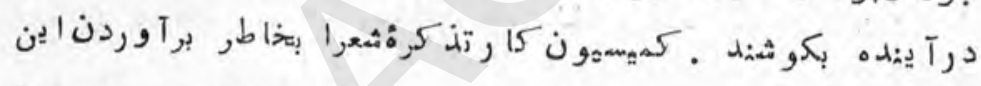

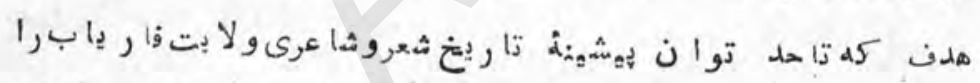

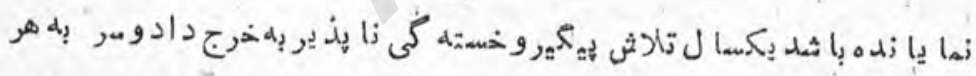

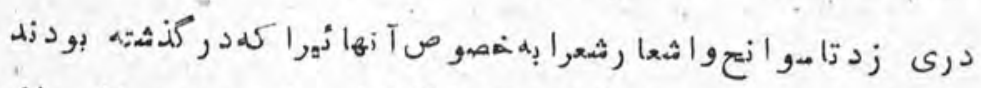

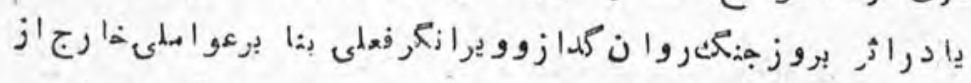

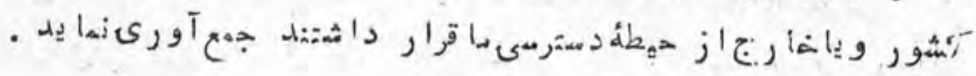




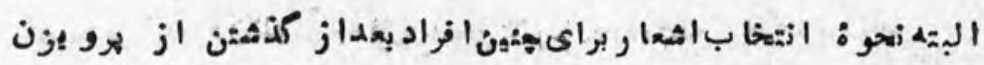

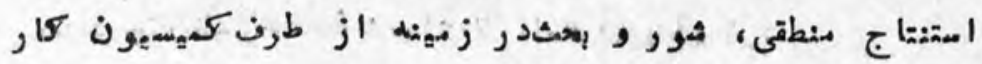

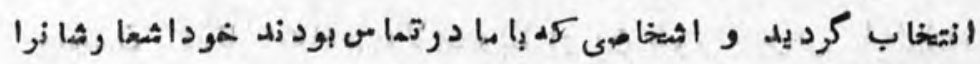

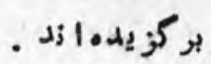

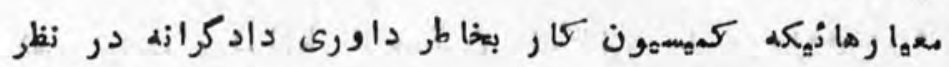

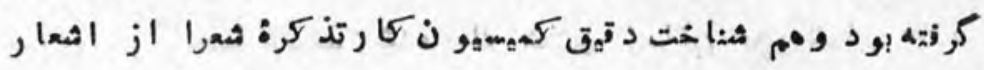

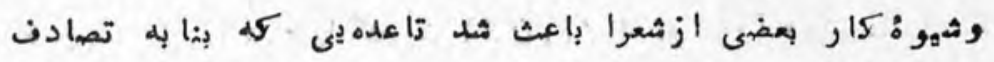

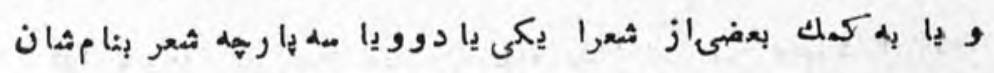

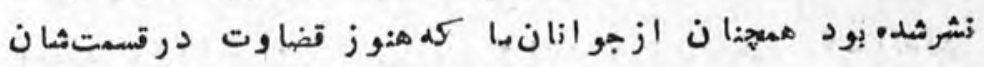

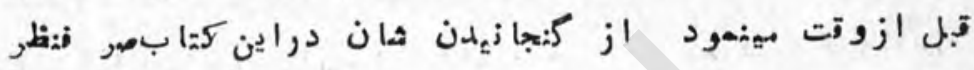
شمد مي

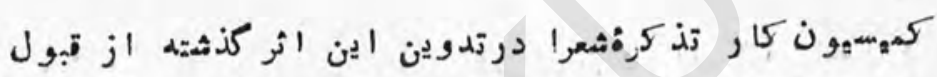

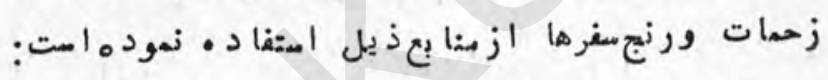

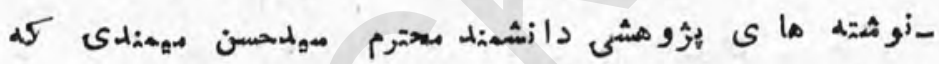

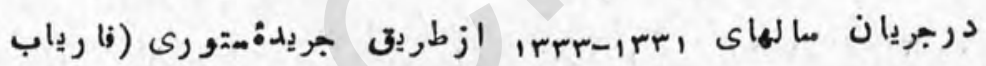

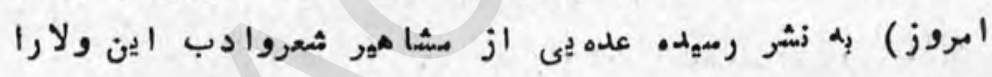

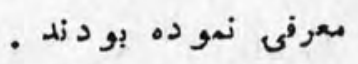

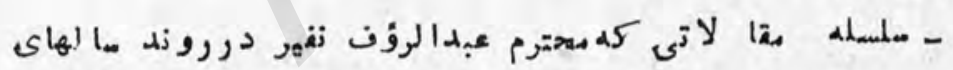

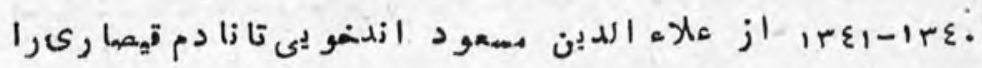

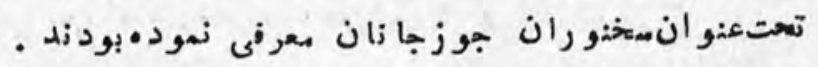
ازمال

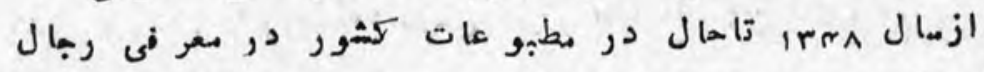

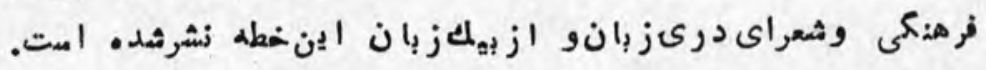

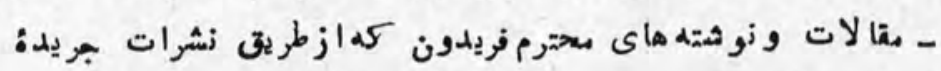

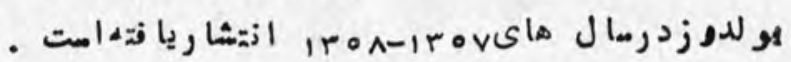




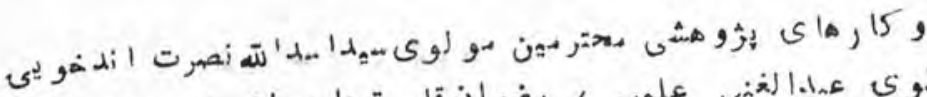

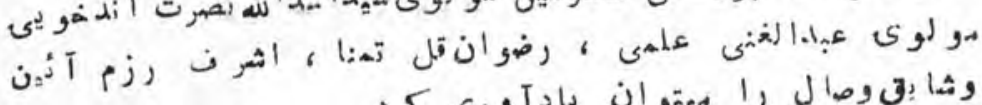

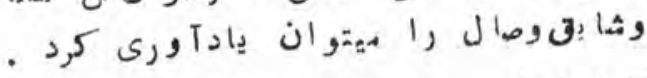

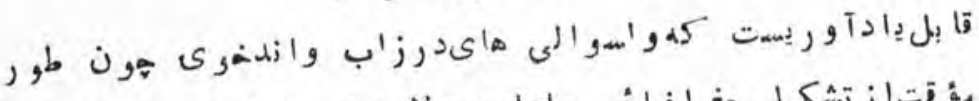

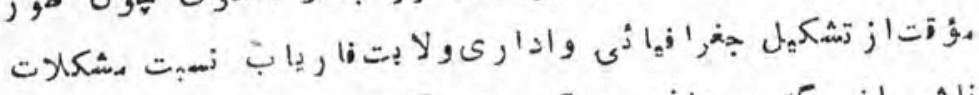

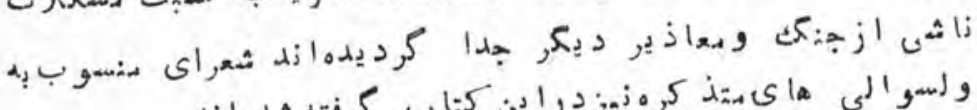

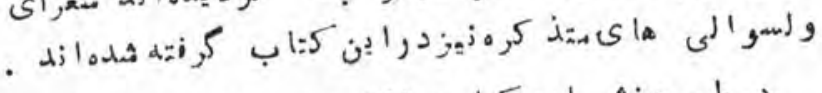

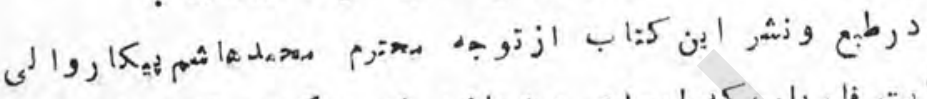

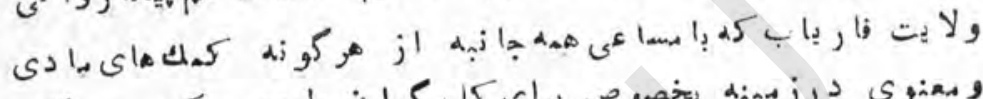

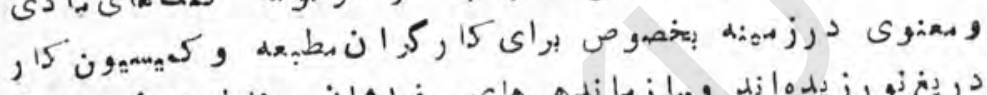

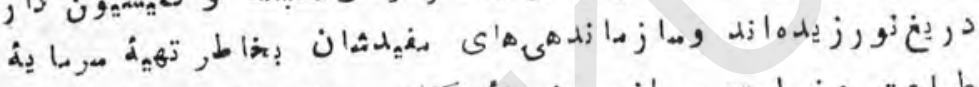

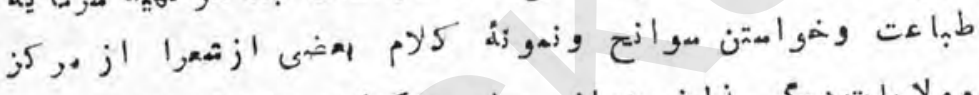

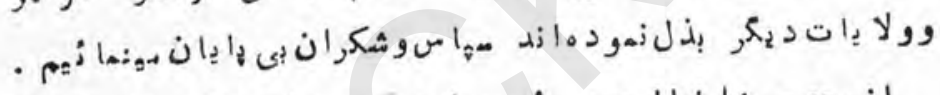

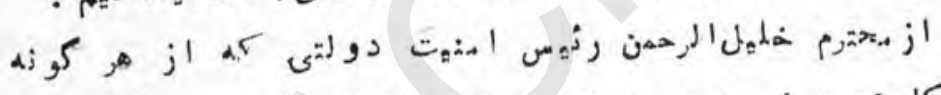

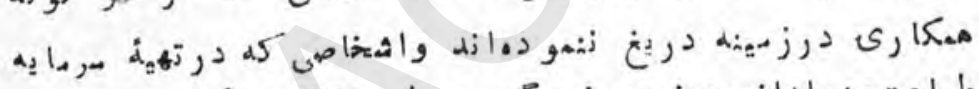

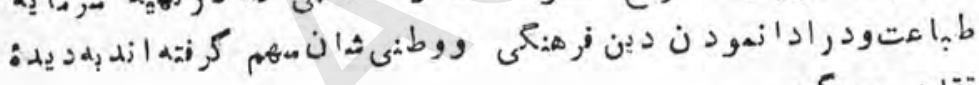

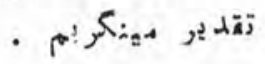

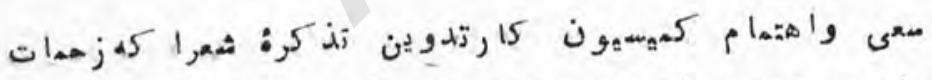

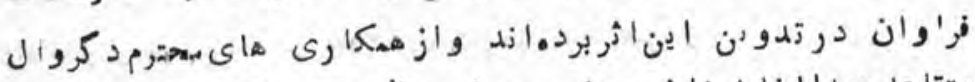

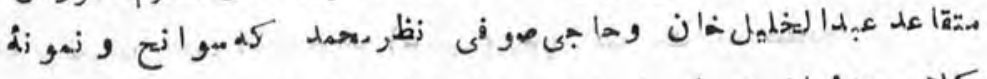

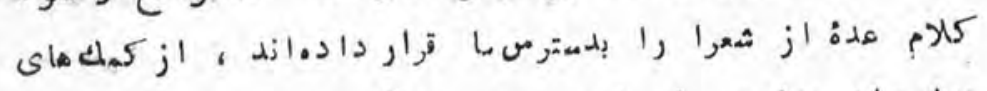

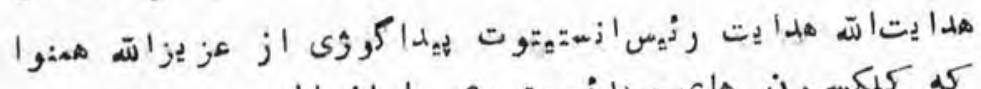

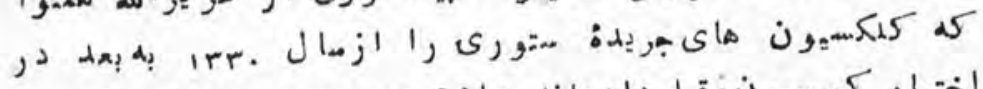

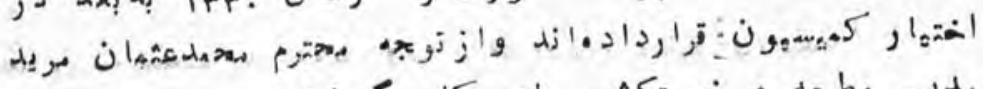

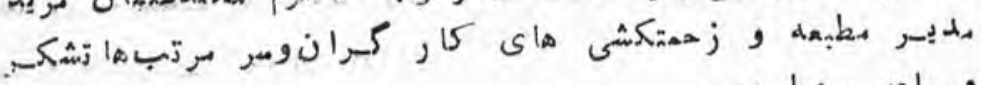
- و

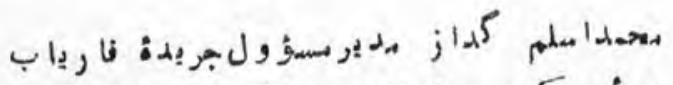

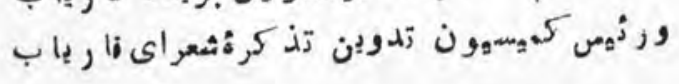




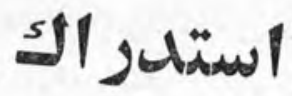

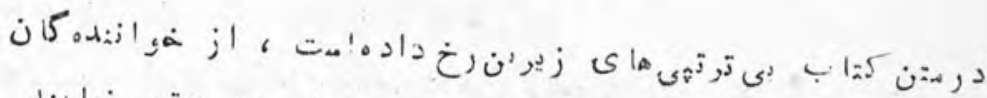

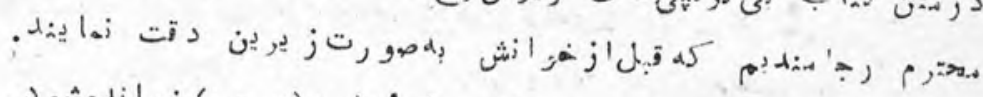

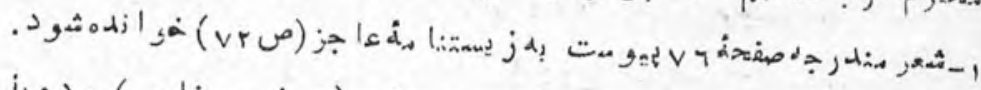

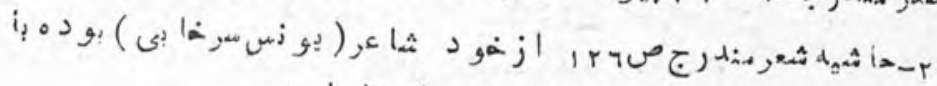

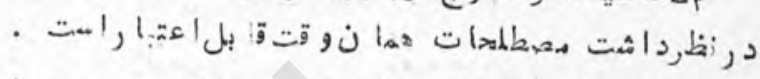

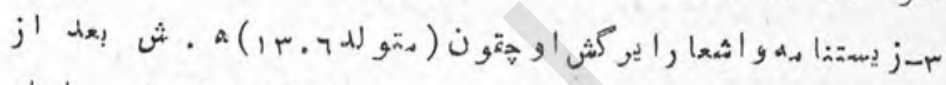

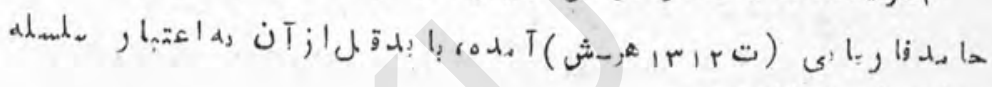

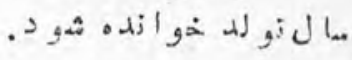

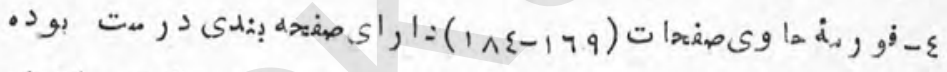

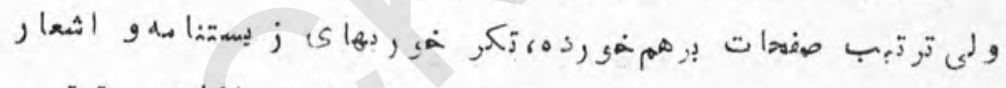

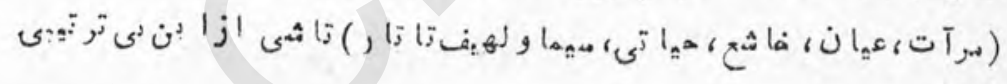

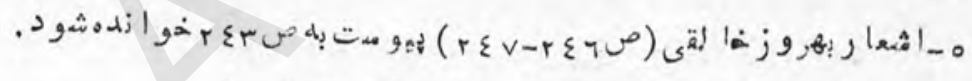

$$
\begin{aligned}
& \text { r } \\
& \text {. } 2 \text { و }
\end{aligned}
$$$$
\text { م شعر به: }
$$

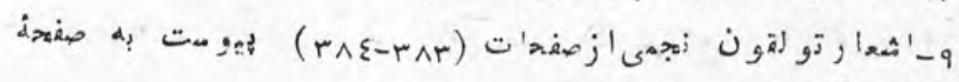

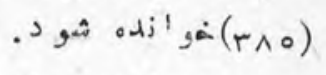

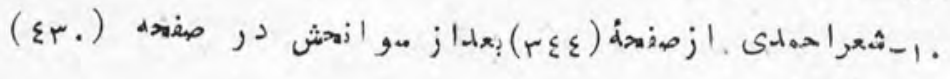

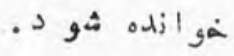
كما

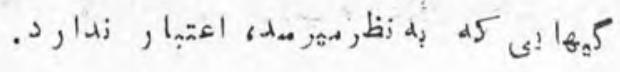




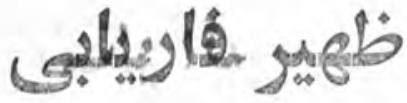

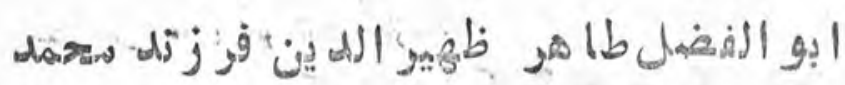

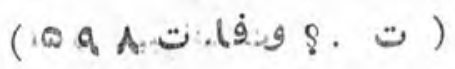

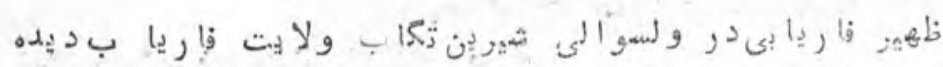

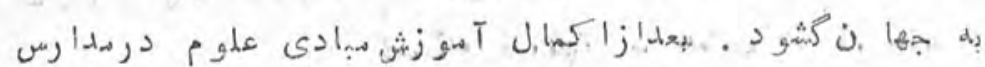

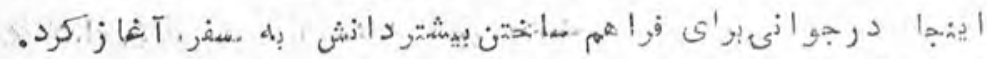

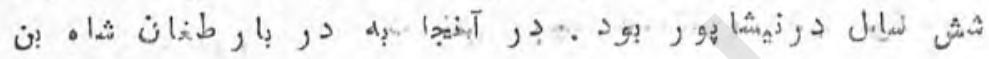

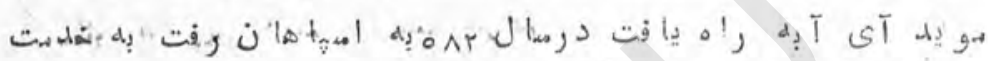

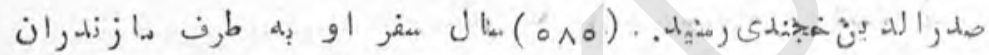

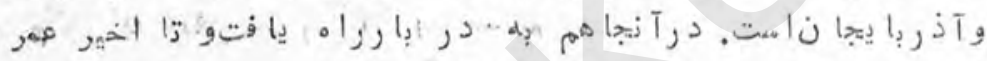

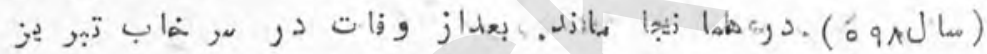

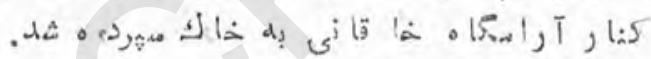

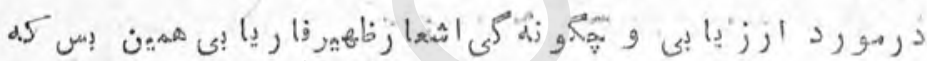

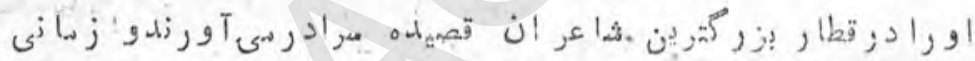

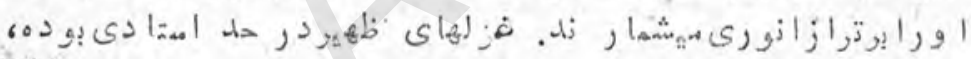

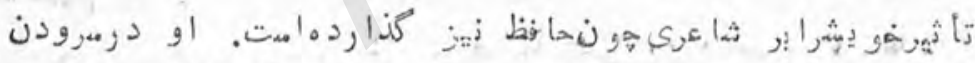

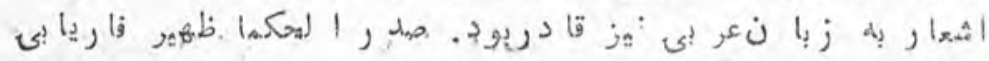

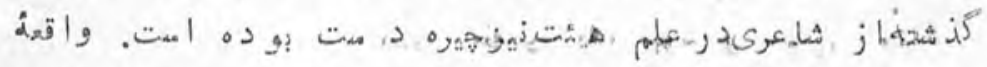

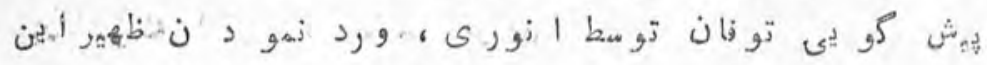

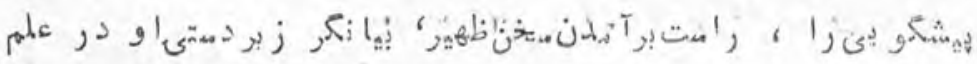

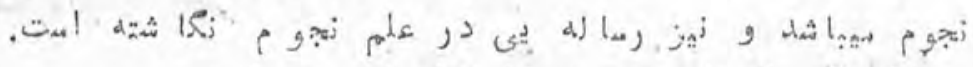

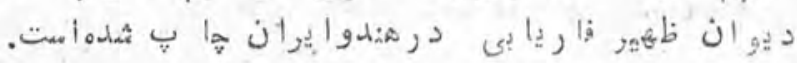

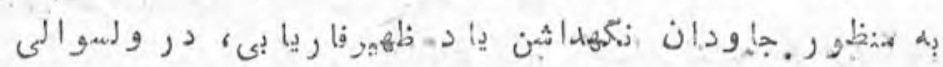

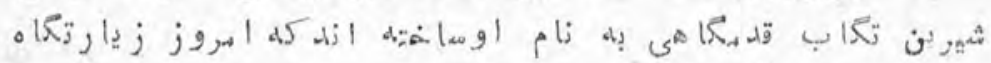

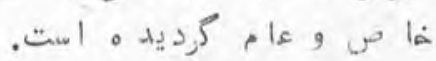


شككو ائيه

مرا ز دمت هنر هاى خو يشتين فرياد

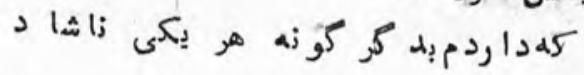

بـزركتر ز هنر در عراق عيبى iميست

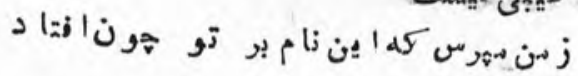

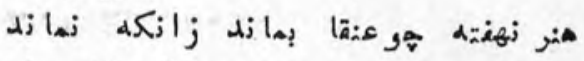

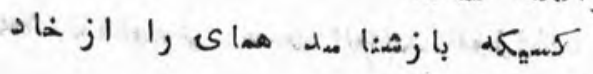

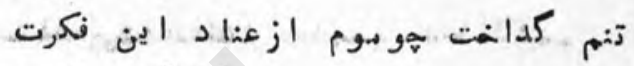

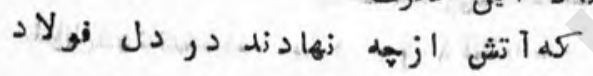

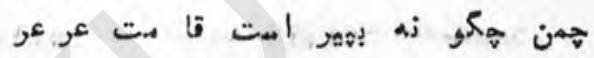

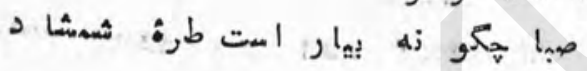

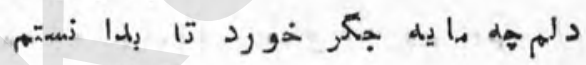

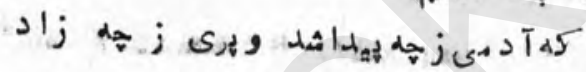

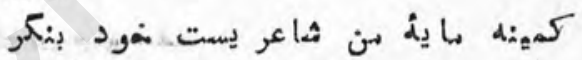

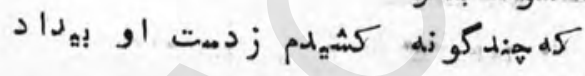

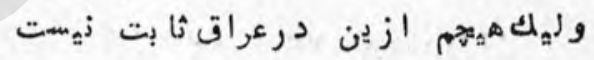

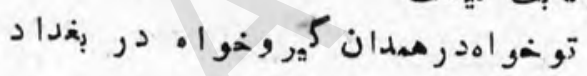

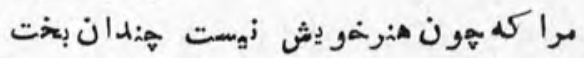

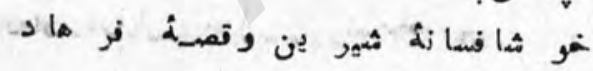

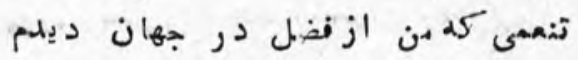

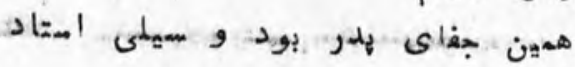

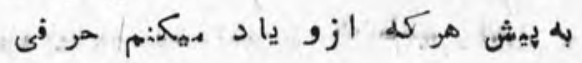

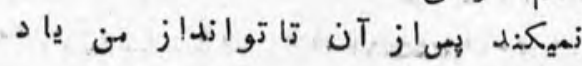

زجنسشعرفزل إهتراستو آن كم زيست

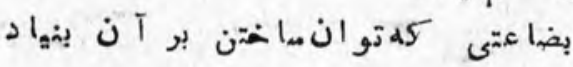

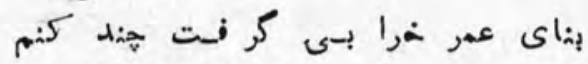

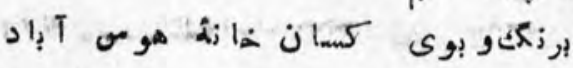




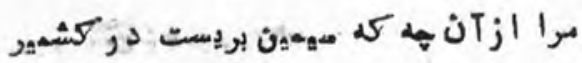

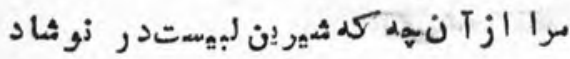

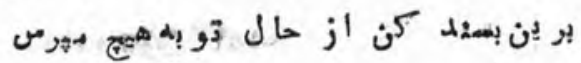

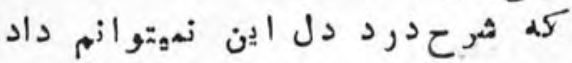

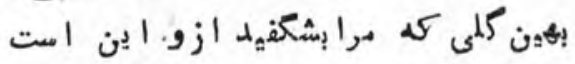

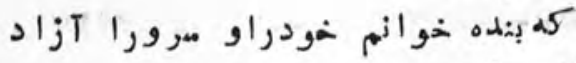

ر أكا

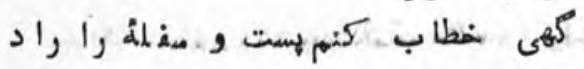

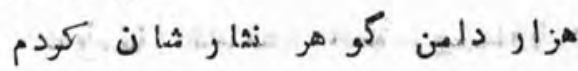

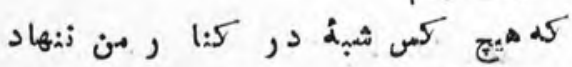

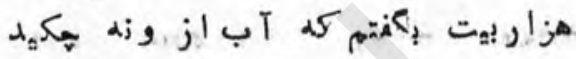

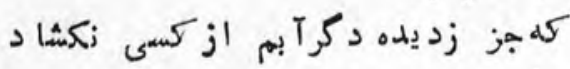

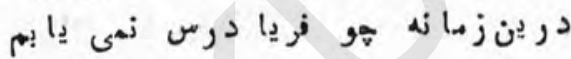

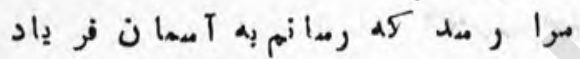

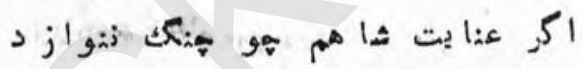

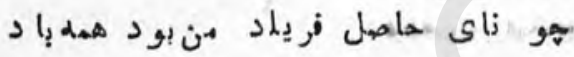

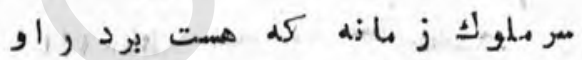

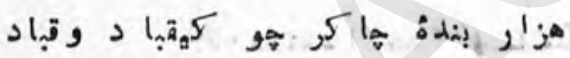

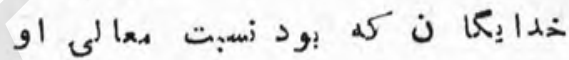

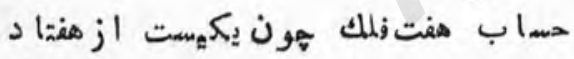

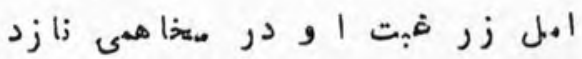

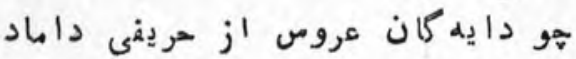

فلك زبار بزر كيش عاجزاست و رمد

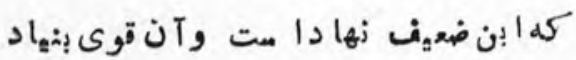

قضا دفر شده آ زبجا كله حكم تو بنششست

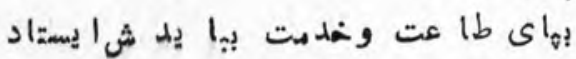

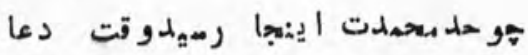

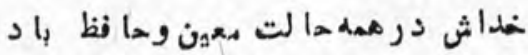




\section{شوز قيان متت}

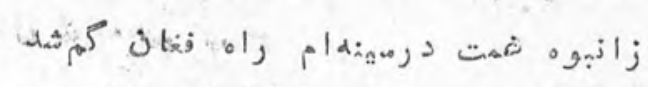

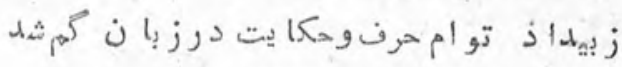

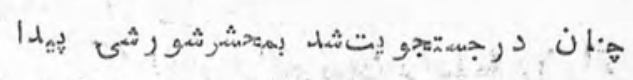

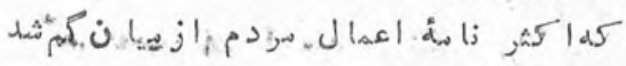

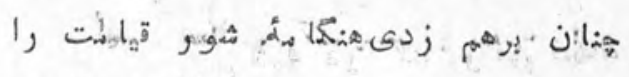

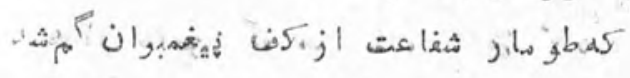

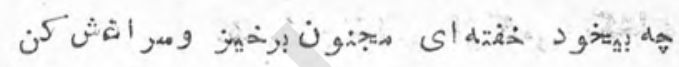

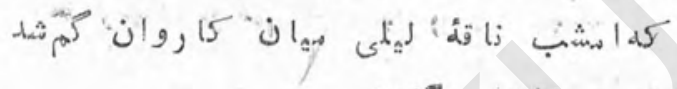

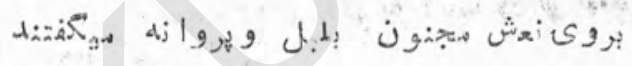

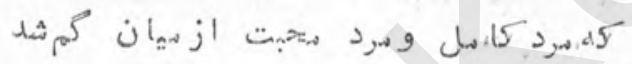

$$
\text { jo, }
$$

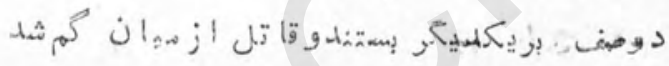

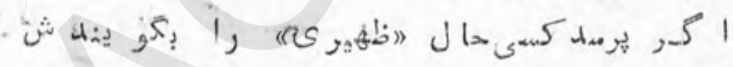

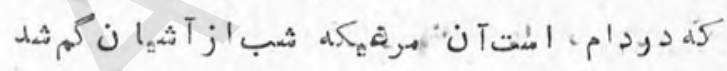




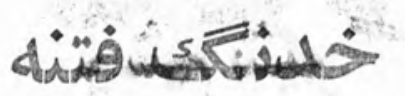

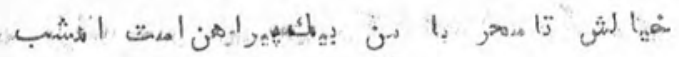

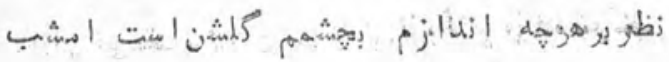

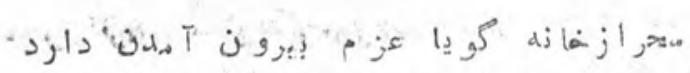

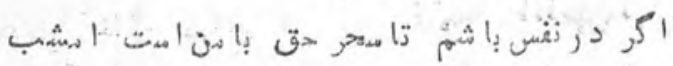

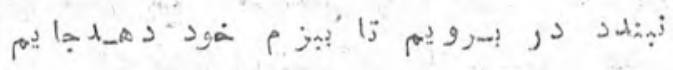

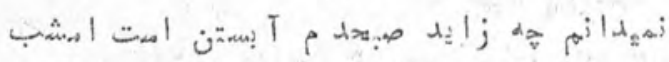

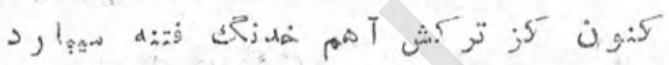

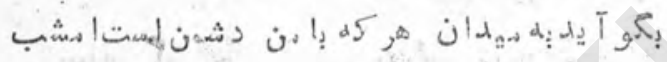

A A

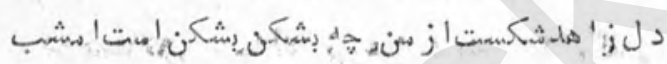

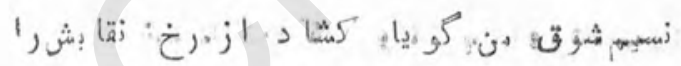

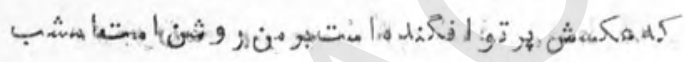

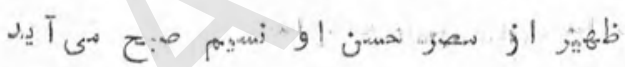

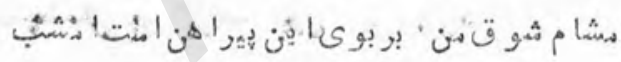

C 


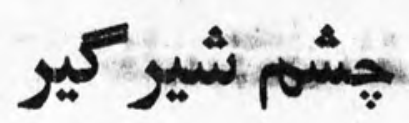

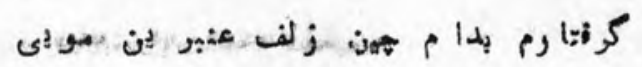

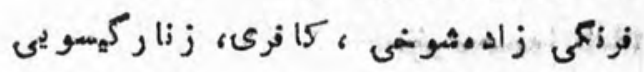

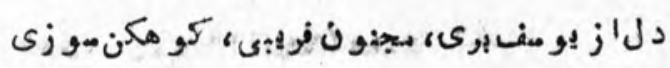

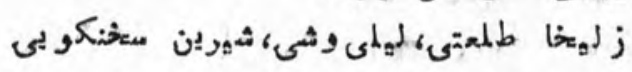

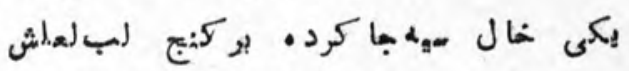

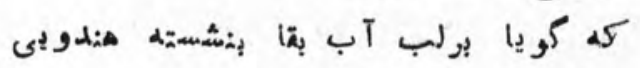

مراها زاز دالدارى، تذروى، كبك رف:ارى

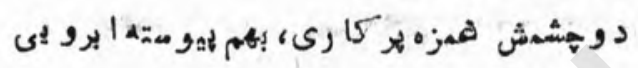

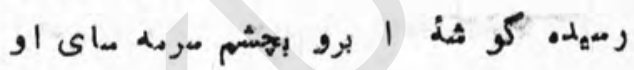

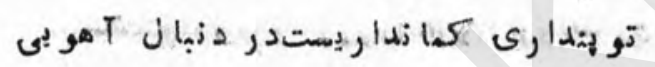

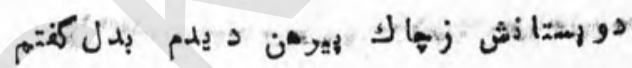

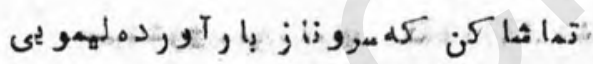

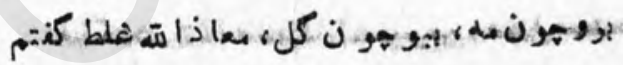

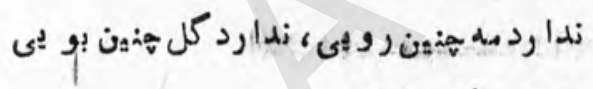

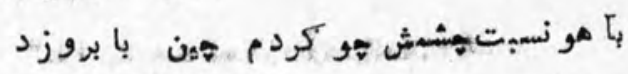

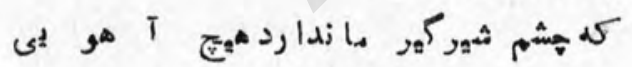

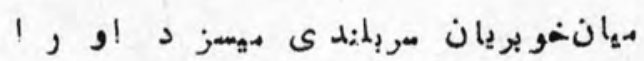

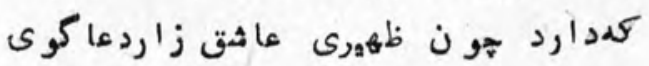




\section{قاد نادرزياز قادورى

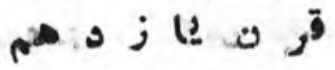

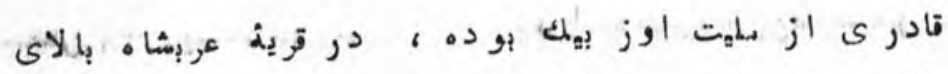

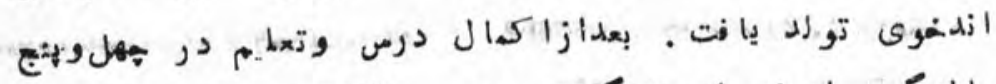

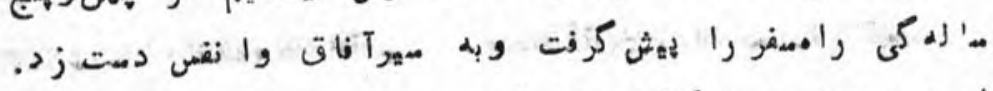

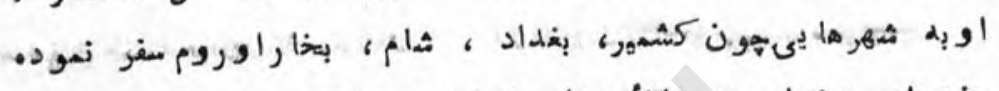

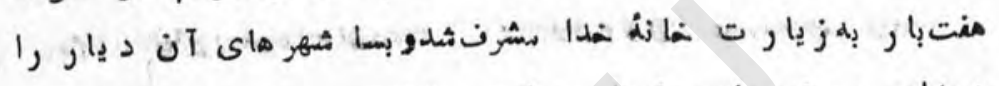

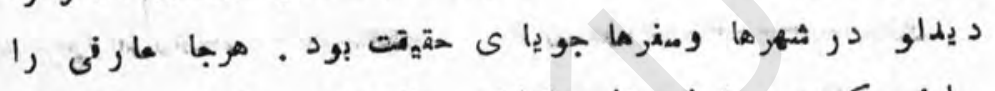

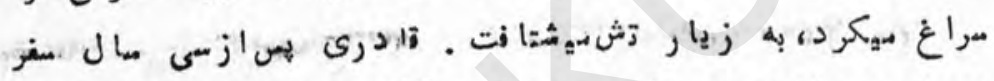

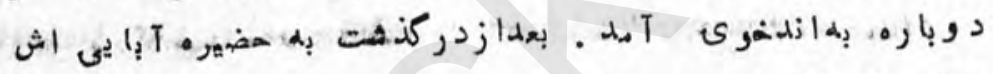

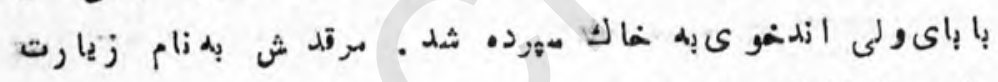

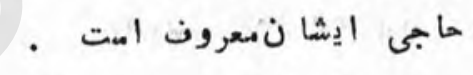

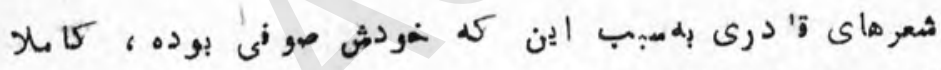

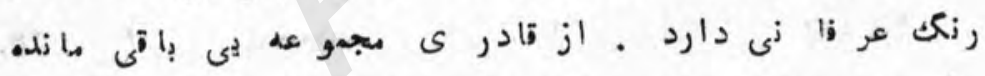

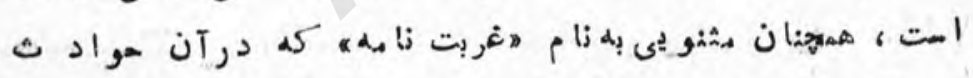

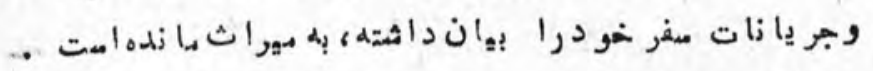

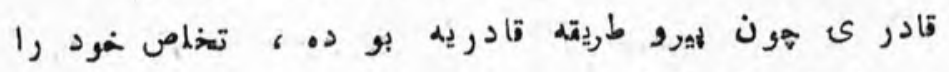

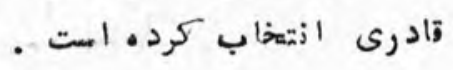




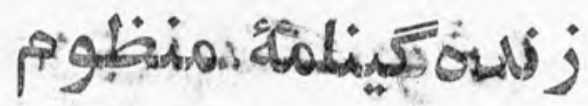

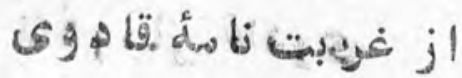

لن

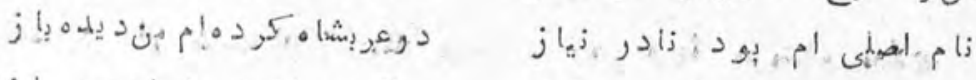

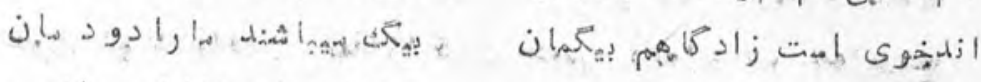

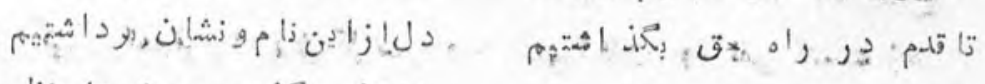
定

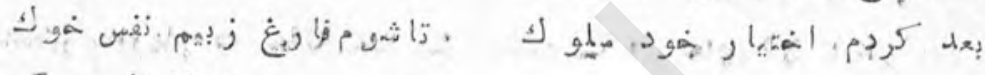

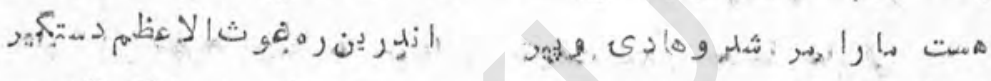

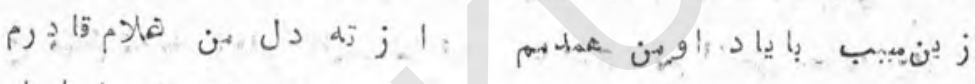

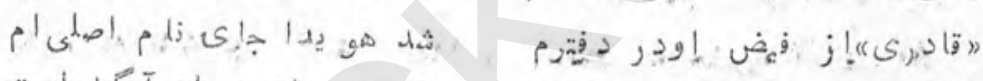

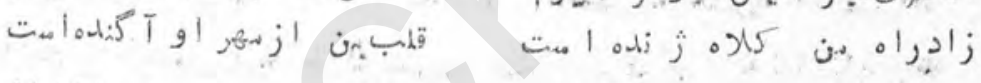

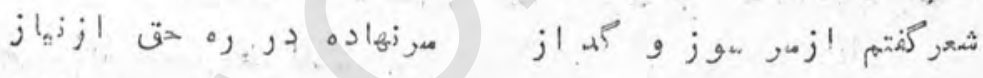

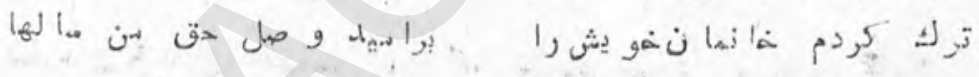

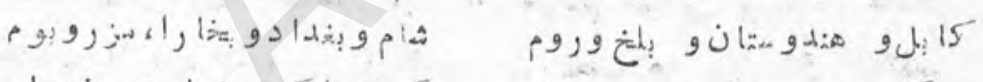

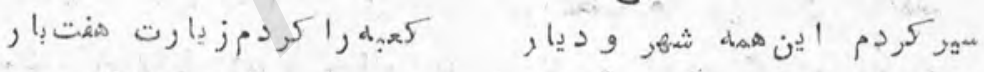

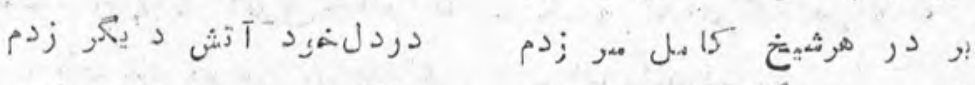

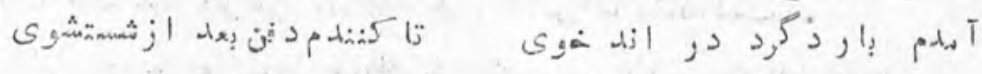

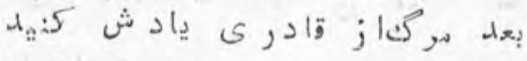

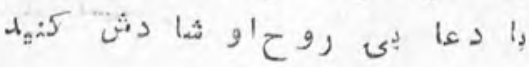




\section{كوز ياشى}

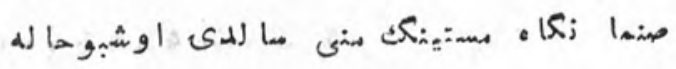

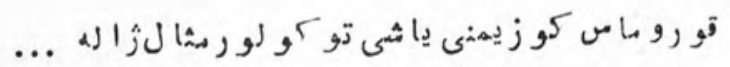

$$
\text { قا درى قو نو :كك قريجدور كه مقا لى آ قريب دور }
$$

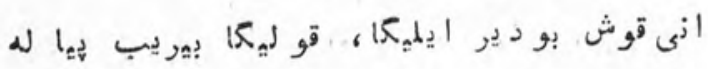

\section{رباعى}

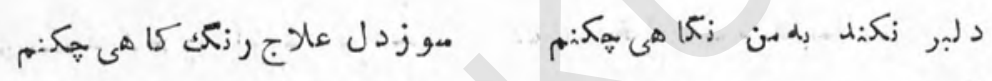

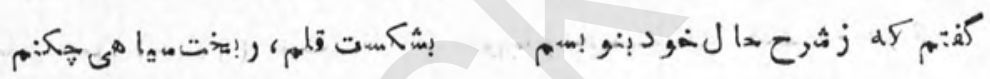

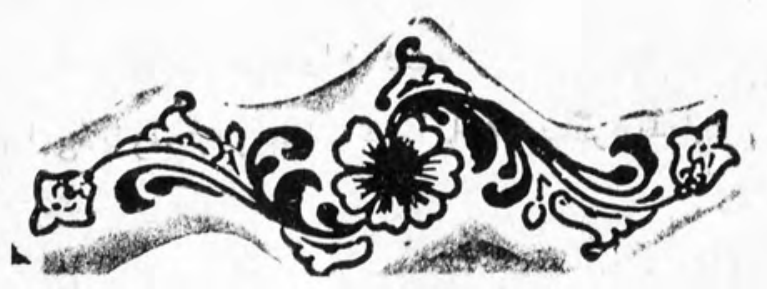




\section{(5) و

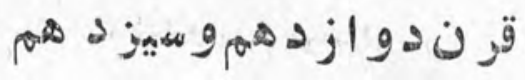

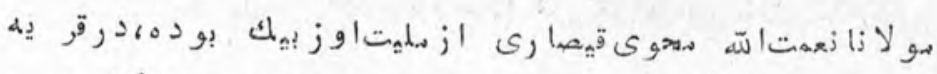

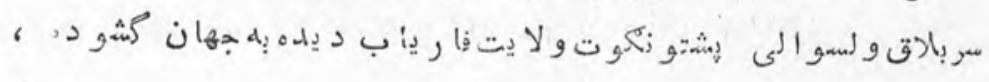

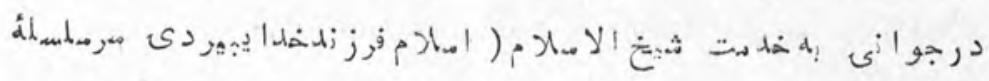

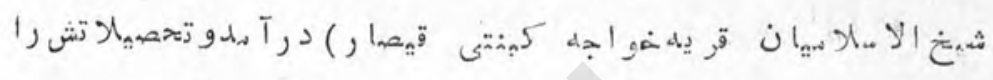

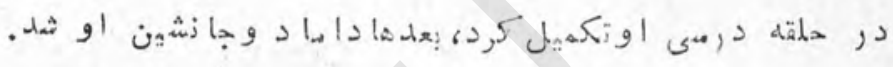

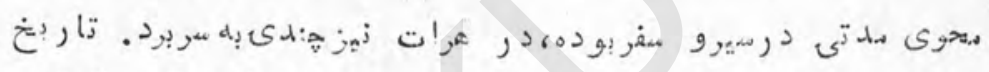

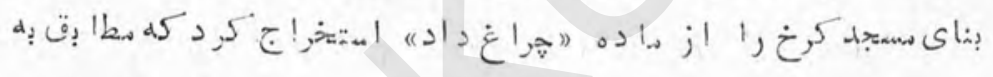

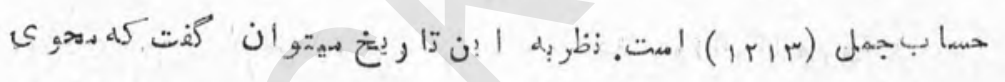

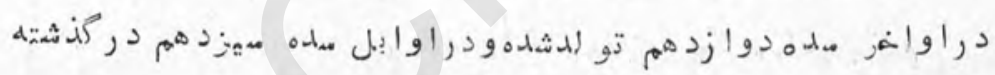
1

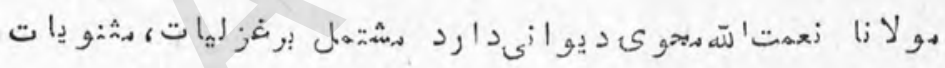

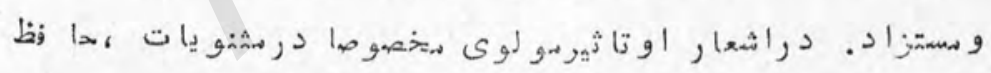

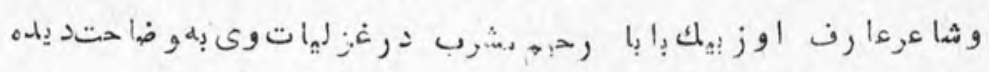

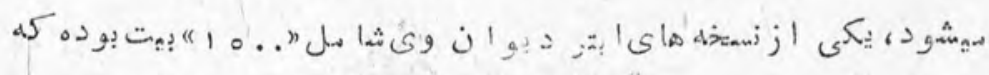

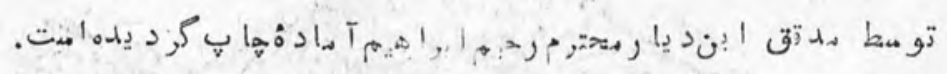


ص.ح صادق

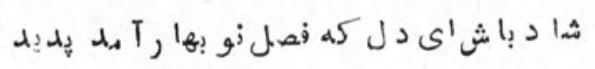

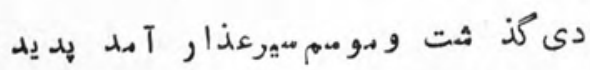

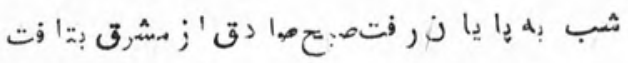

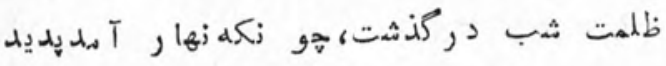

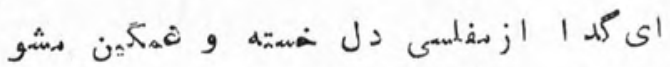

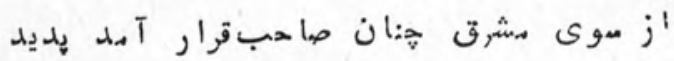

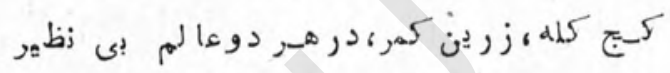

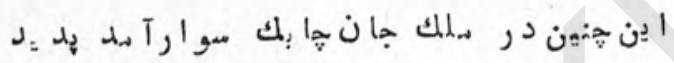

عيسى صاحب قران از سقف همار رم آسمان

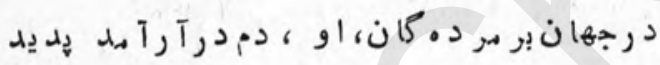

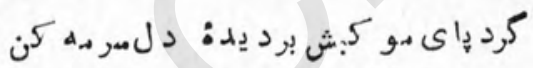

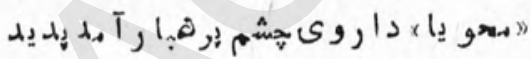

II 


\section{Tٓينائكائ}

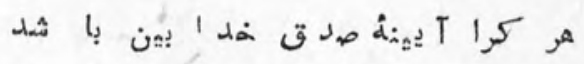

صأف أز كبرو ريا وحمسد وكين باشد

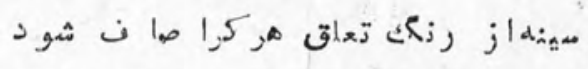

صاحب مذهب و كيش ود ين وآيدين با شه

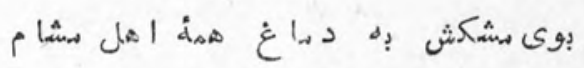

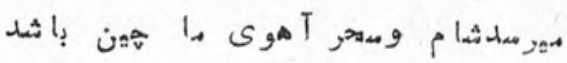

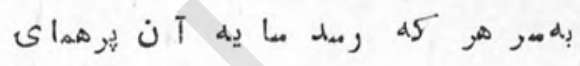

صا هب همدكت و ال فسر زرين باشي شد

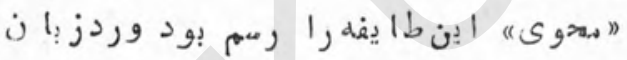

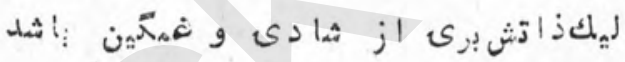

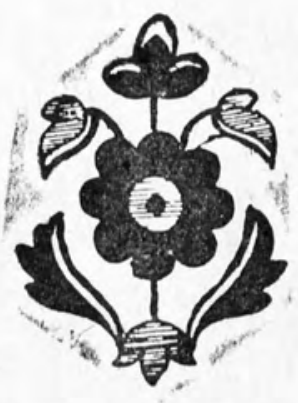


كويتنيوراكي

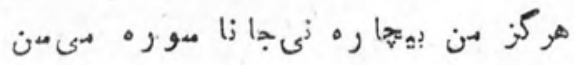

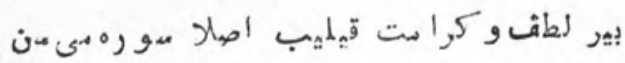

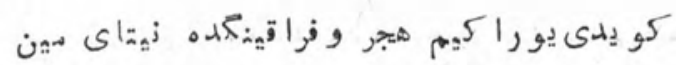

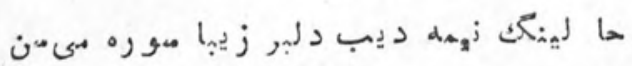

آهو قرمشئكك قيملدى هينى والهل وحيران

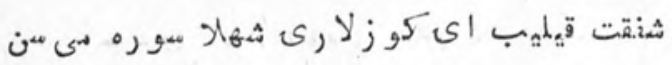

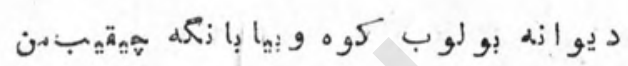

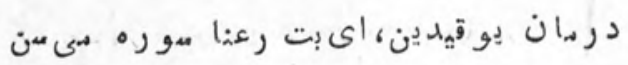

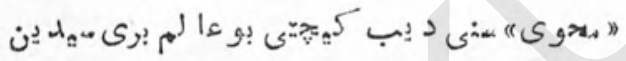

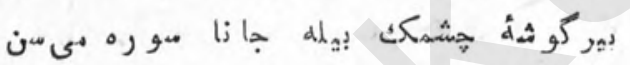




\section{حاذق

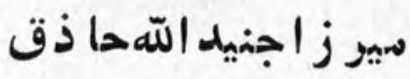 \\ و فات اجrIr هـ - ش}

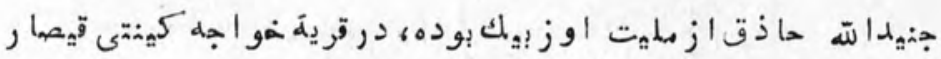

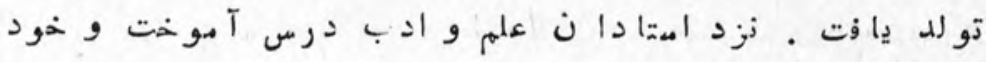

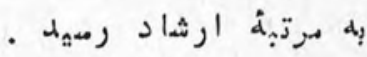

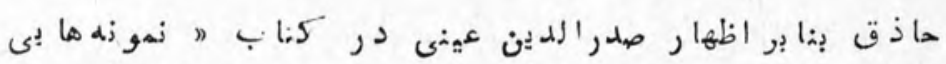

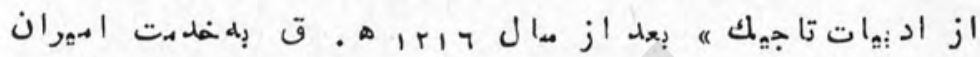

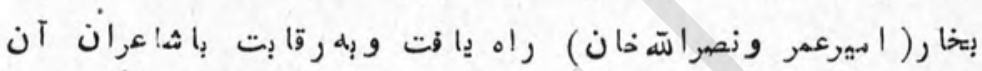

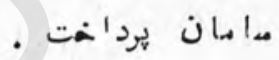

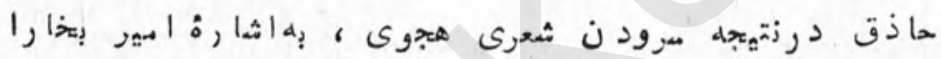

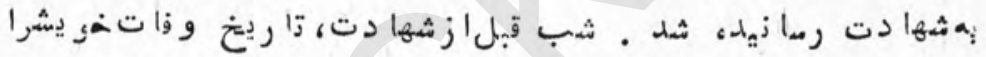

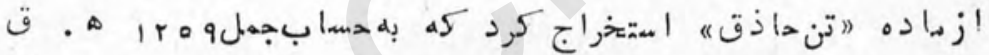

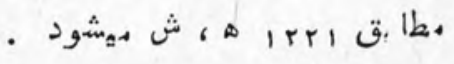

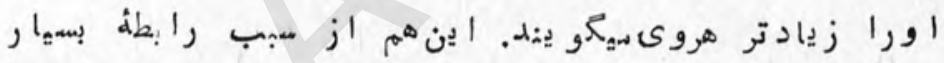

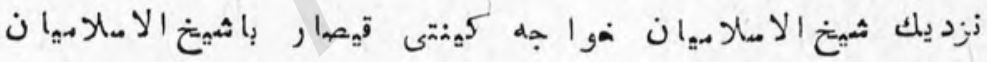
. 
زقش الدراكى

كلى

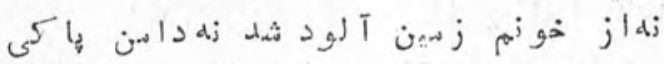

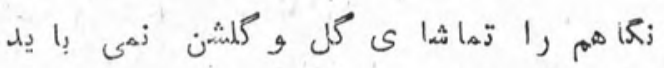

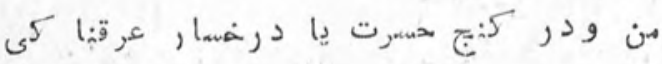

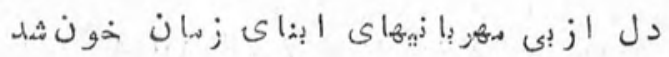

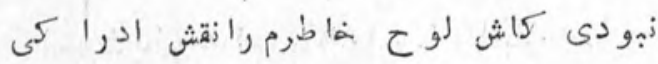

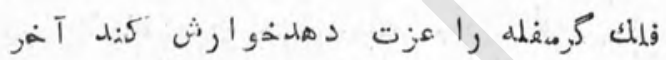

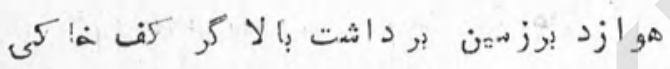

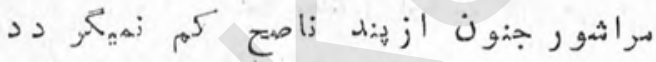

كى

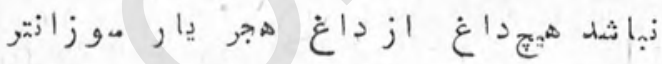

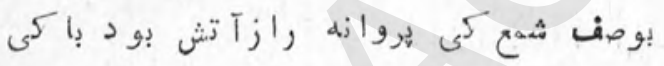

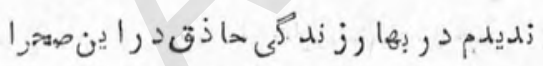

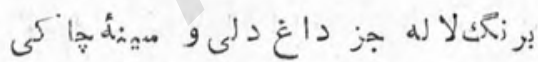

10 
سازعشتق

درعروج امستغ:ا ست مسكيكى كم سن مارم

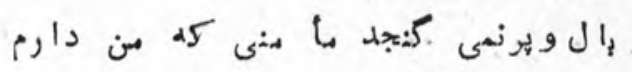

از صفاى دل كو كب رزكثة دو ديوازدازد

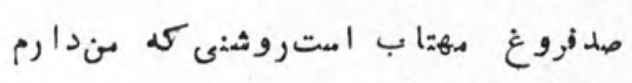

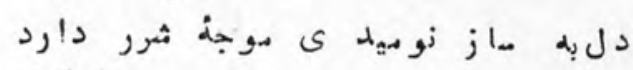

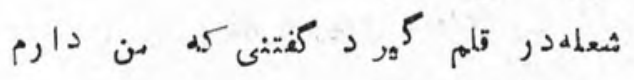

خوند دل درابن كالشن قطره قطره مهريزد

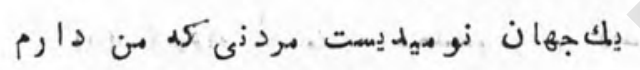

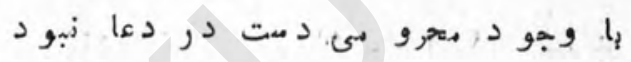

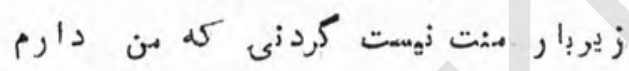

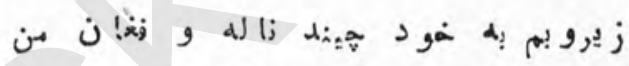

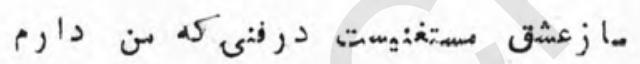

هررك كلاز خونم رنكث و بوى زو دارد

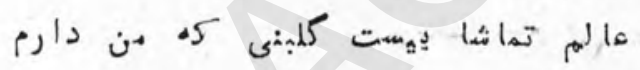

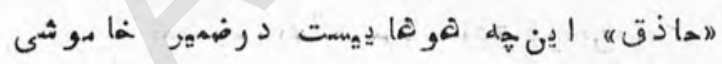

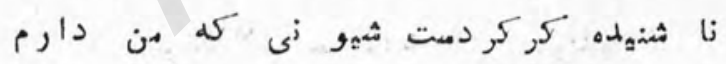




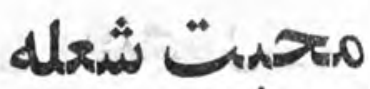

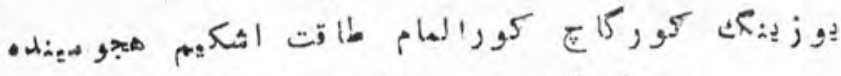

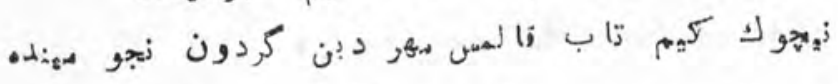

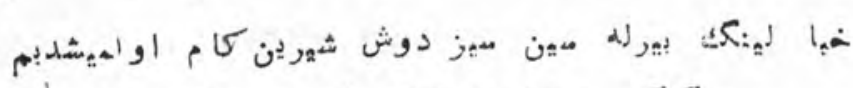

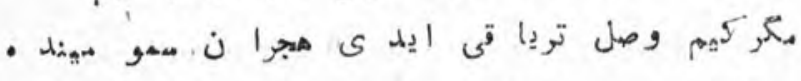

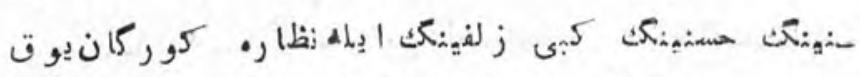

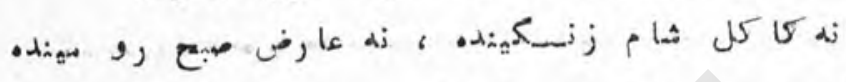

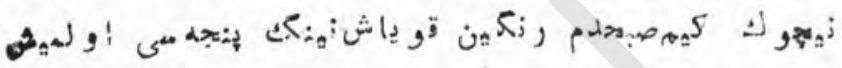

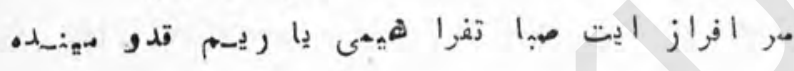

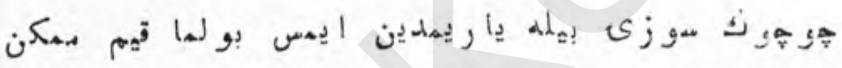

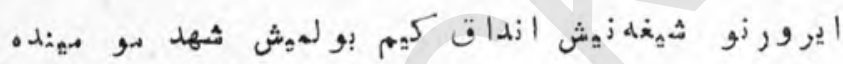

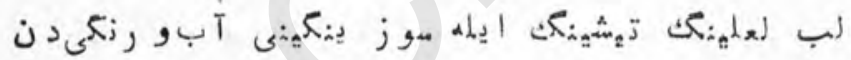

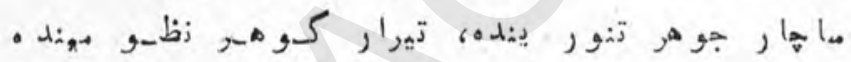

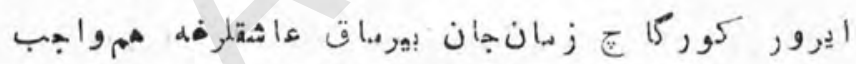

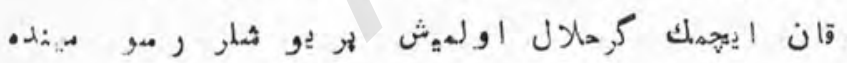

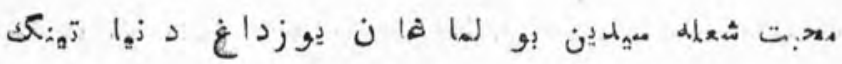

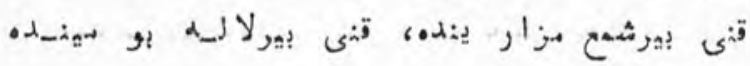

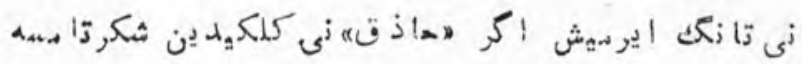

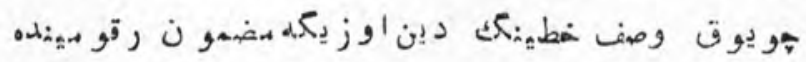

iv 


\section{نادمقيهارى}

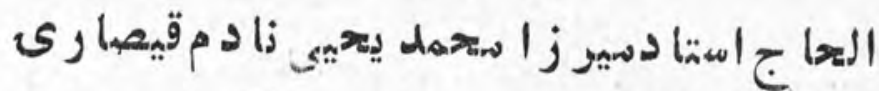

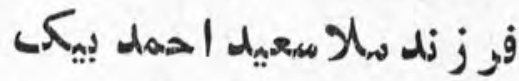

\section{( A. A I A - IFPA)}

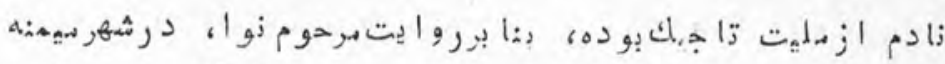

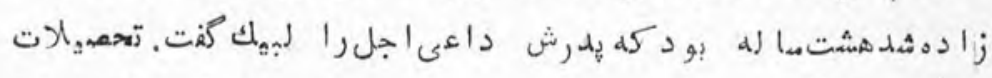

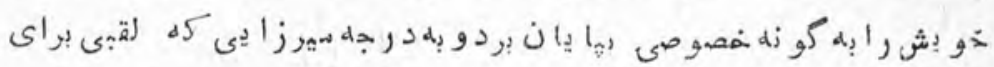

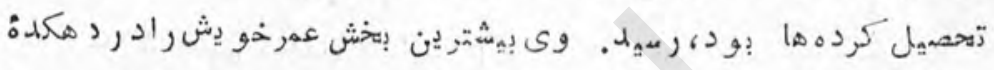

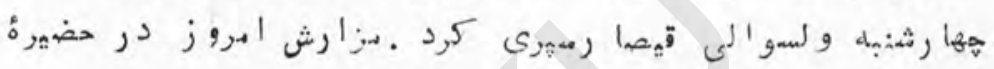

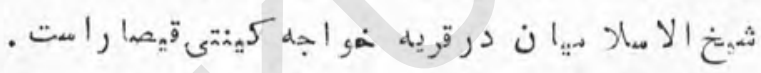

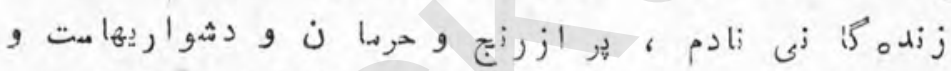

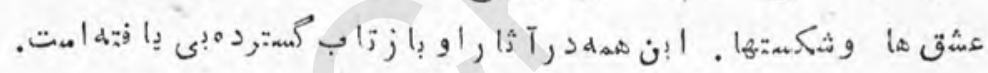

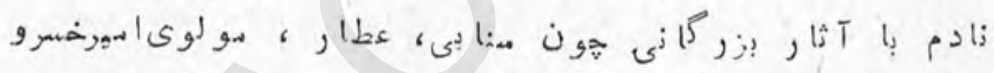

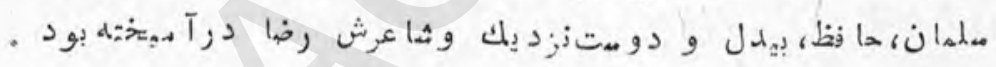

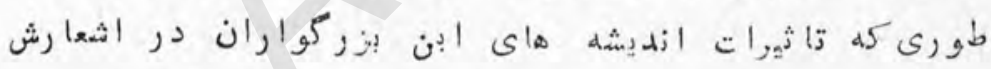

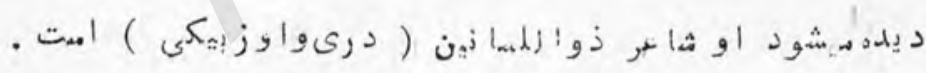

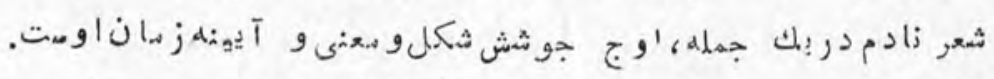

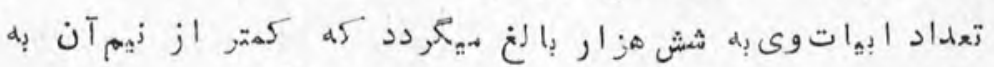

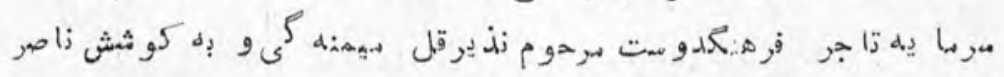

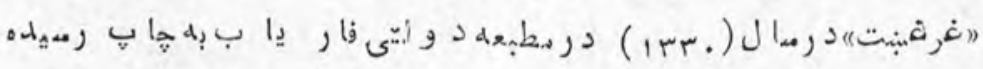

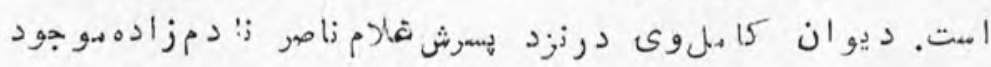

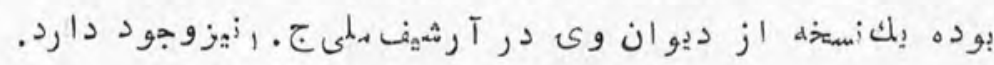


ثرو

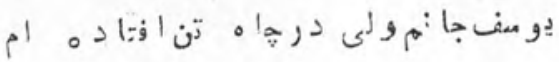

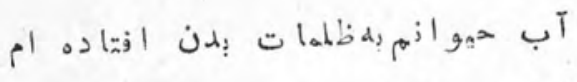

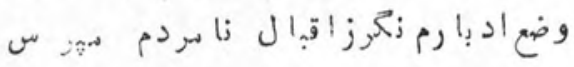

باز

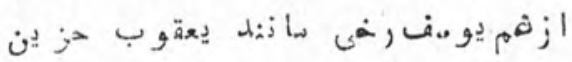

روزوشببدر كوثله بمتإلحزن اف:ادهام

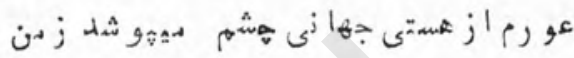

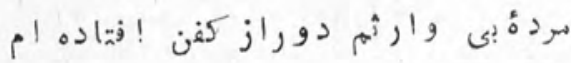

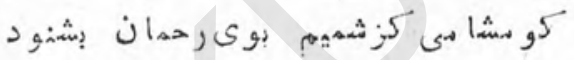

و بس وقتمدر بـا بان قرن افتهاده ام

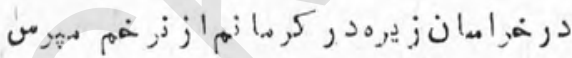

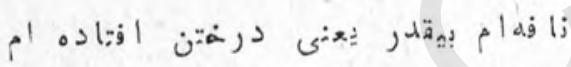

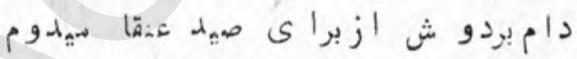

كس jيف

ا

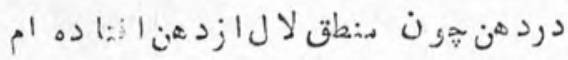

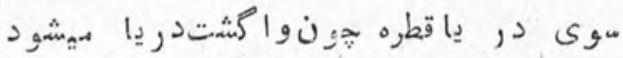

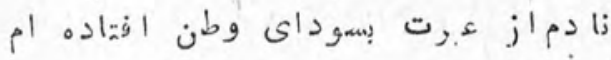

19 


\section{يأt}

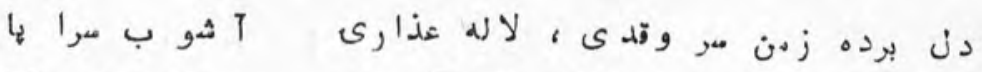

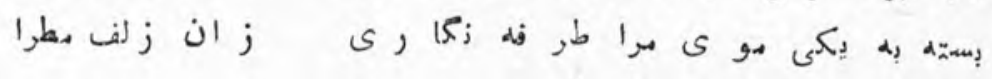

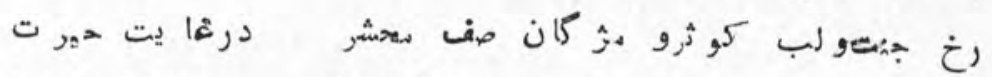

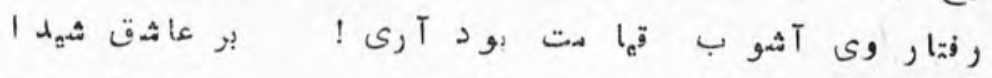

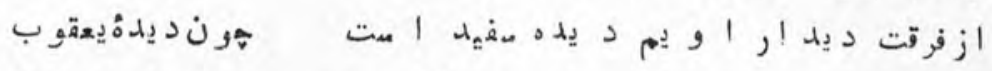

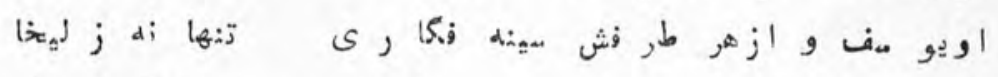

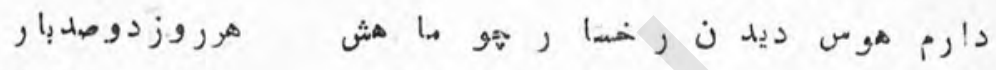

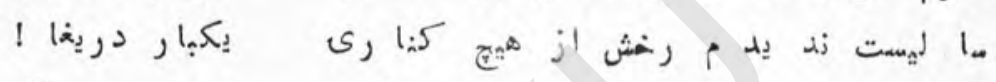

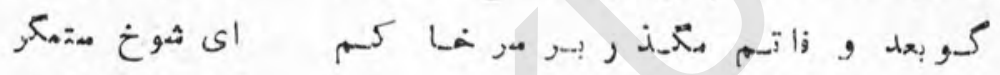

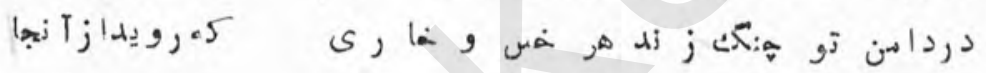

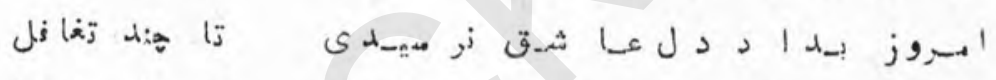

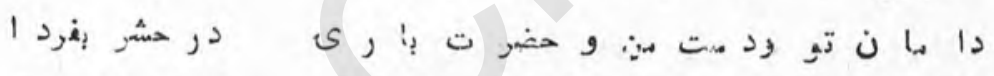

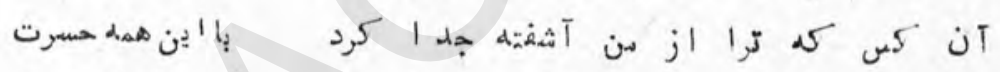

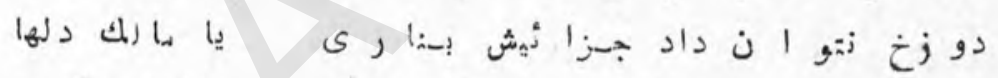

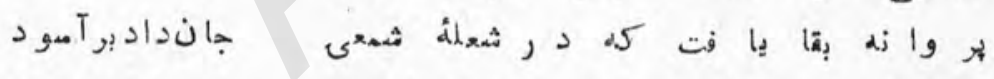

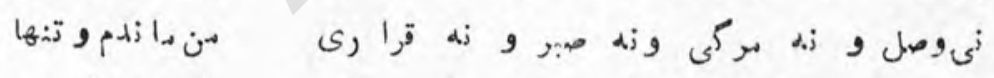

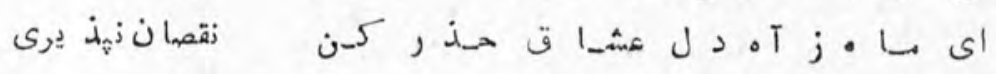

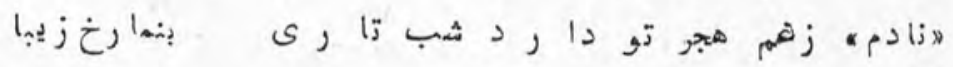




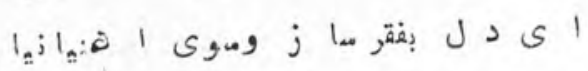

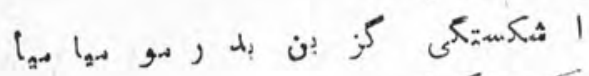

?

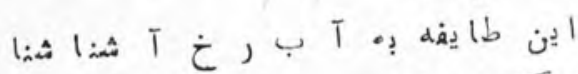

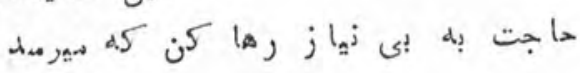

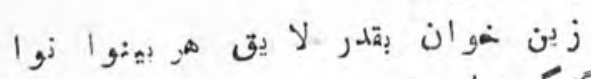

از دمت دو مـت زهرشكر مديك كو هر امت بت ان

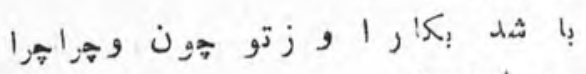

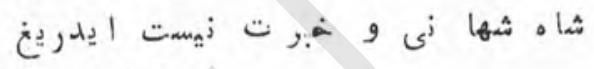

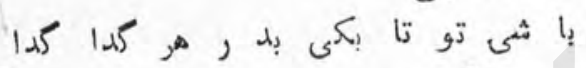

بىعشق رفع ظلمهت د ل زيست مدك:ت

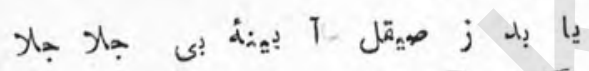

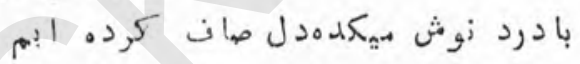

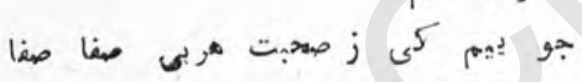

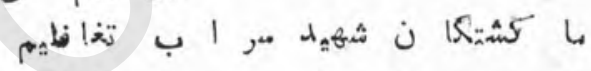

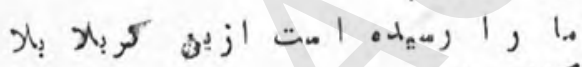

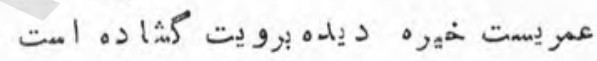

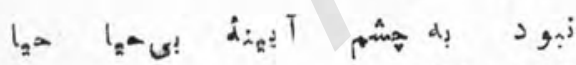

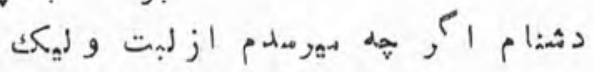

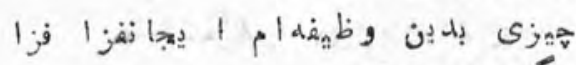

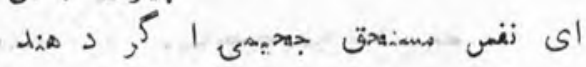

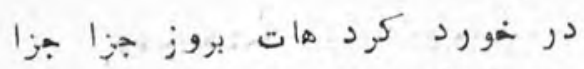

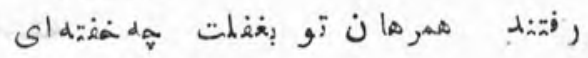

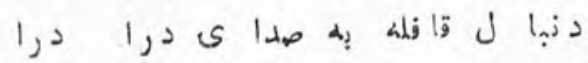

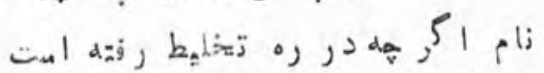

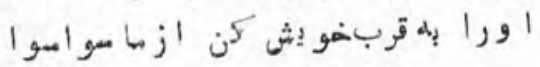

PI 


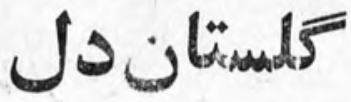

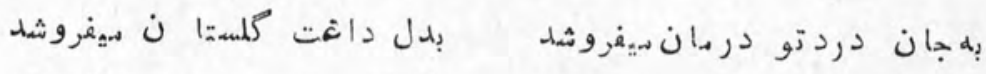

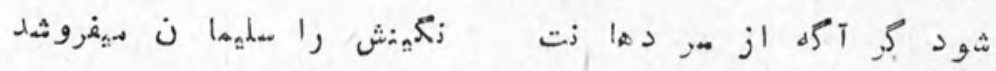

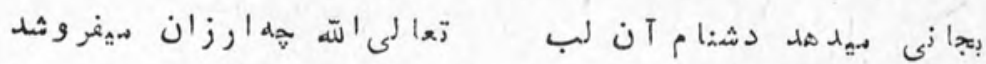

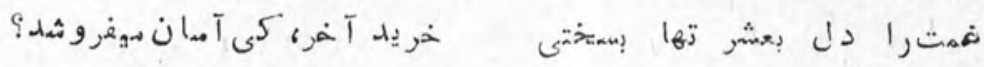

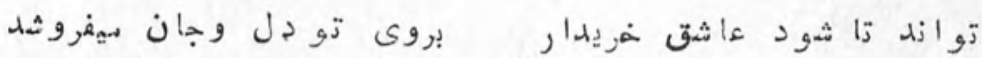

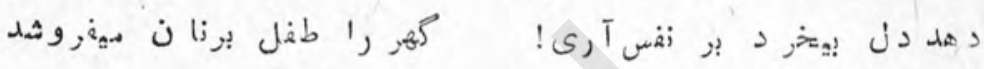

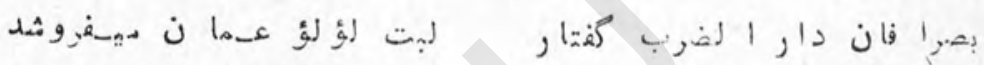

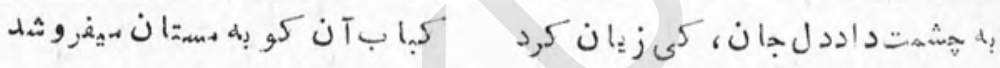

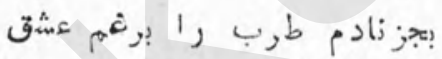

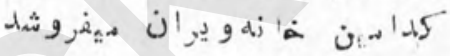

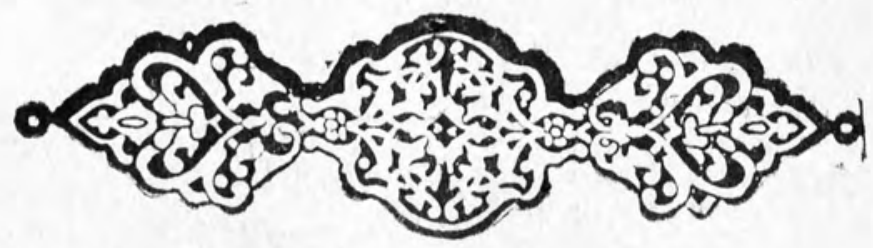




\section{موج ناز}

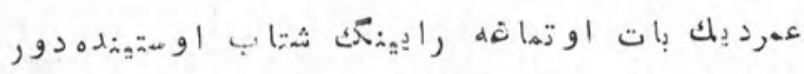
ران

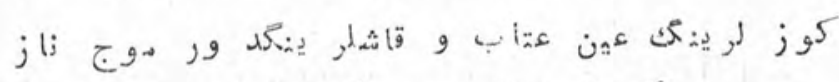

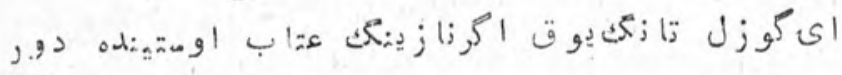

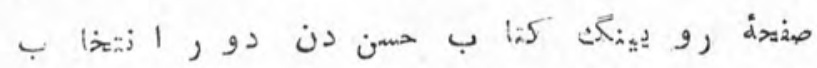

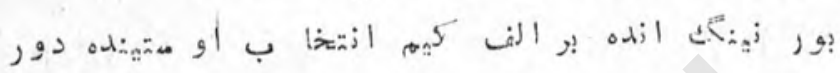

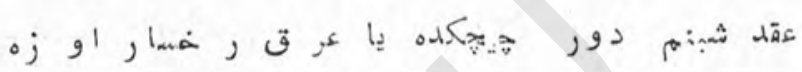

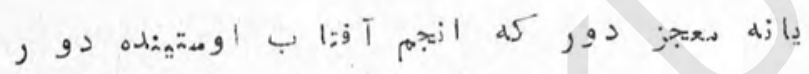

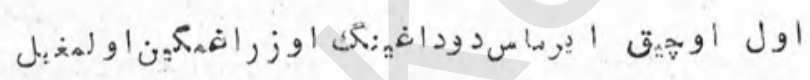

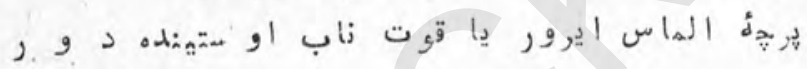

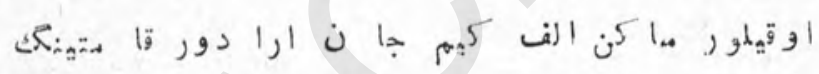

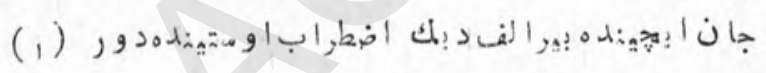

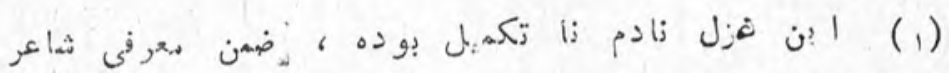

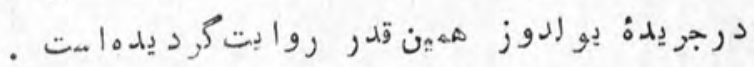


رضأ

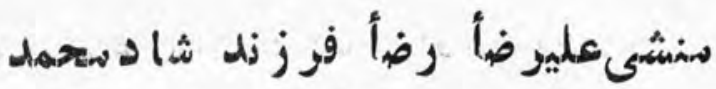


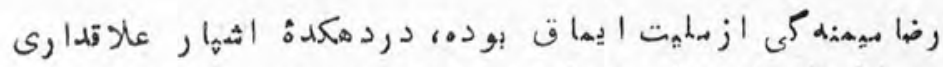

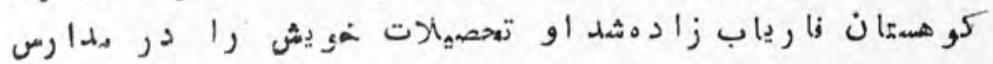

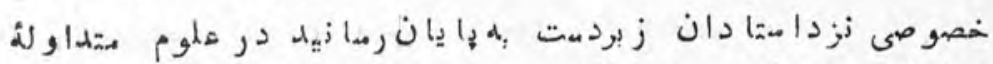

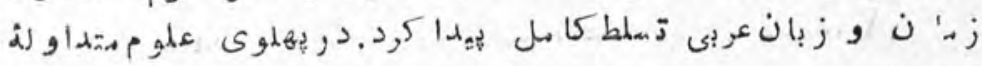

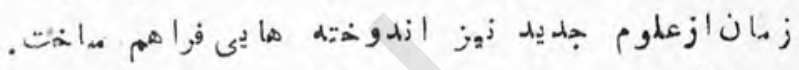

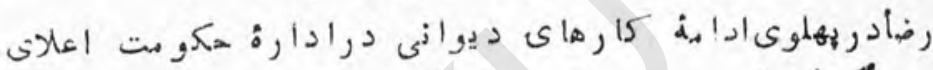

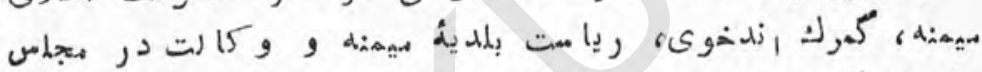

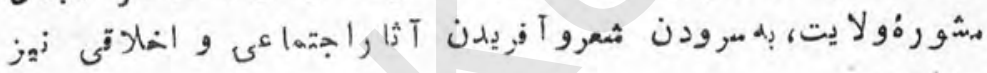

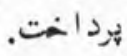

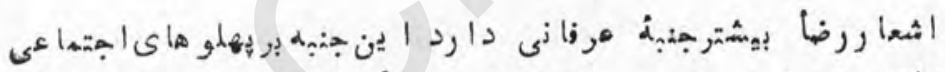

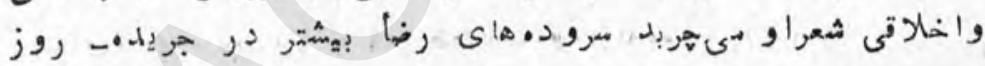

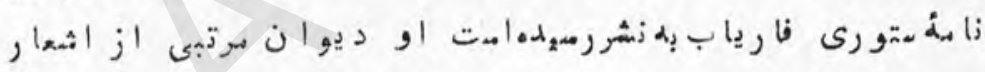

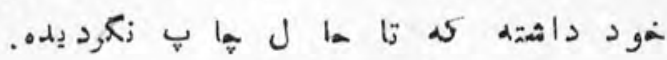

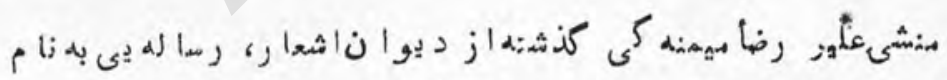

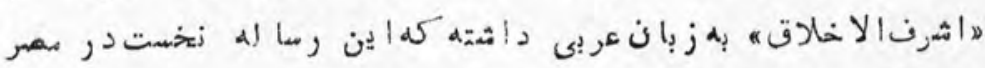

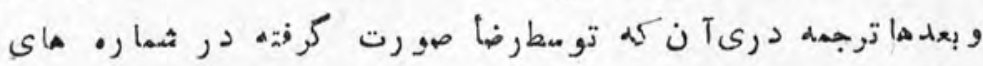

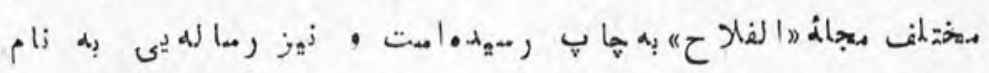

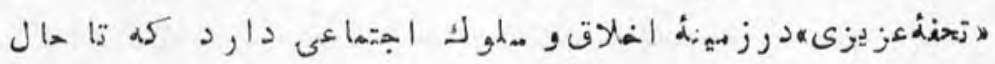

ها ها بـ

pr 


\section{زخمىشق

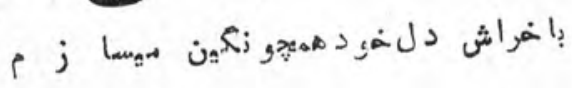

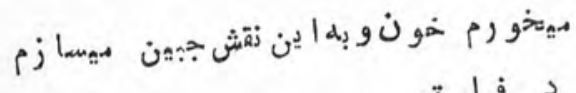

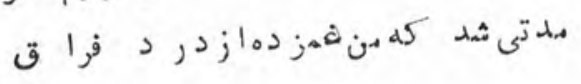

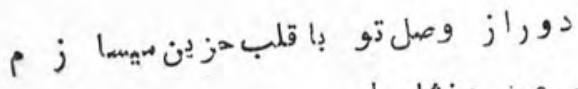

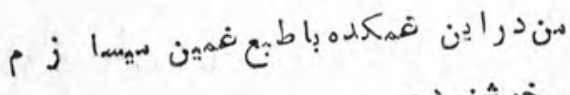

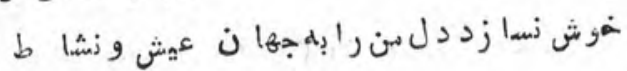

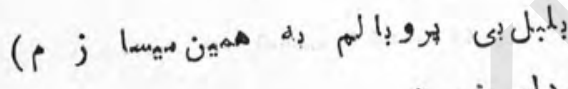

$$
\text { (1) }
$$

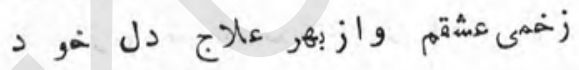

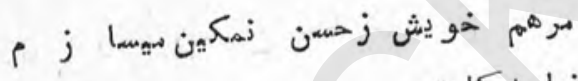

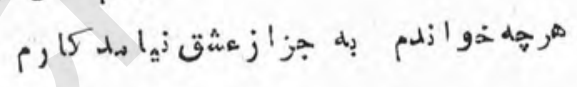

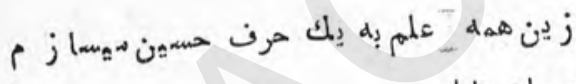

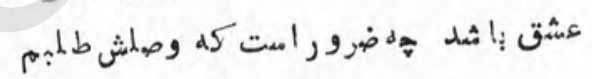

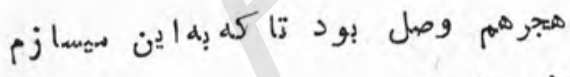

كربرد هر خ غبا رم به فللك فخرم زهيست

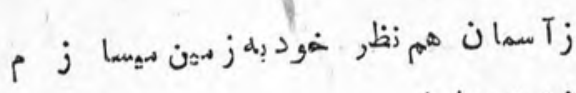

$$
\text { عشق جازى بِه من المروز نبا شدبهجها ن }
$$

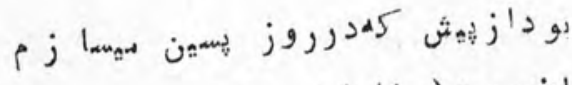

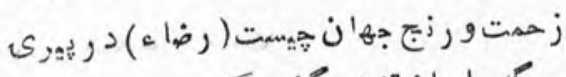

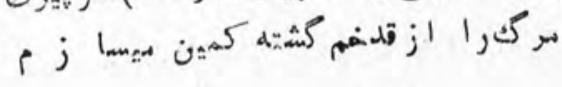


تمثال جهان

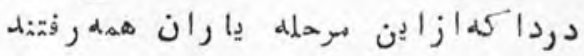

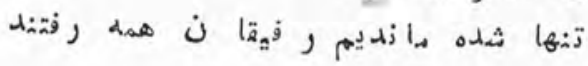

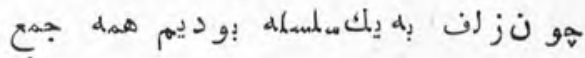

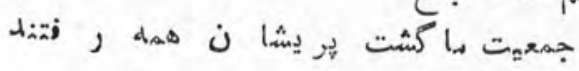

فرصت حهل قدر بود كله ازدديلههو اشكى

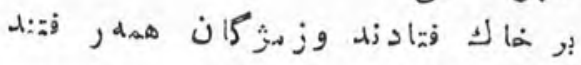

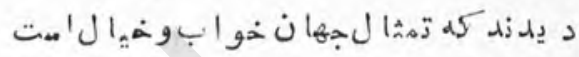

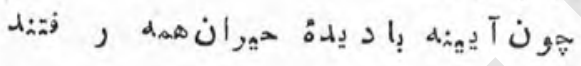

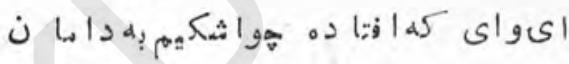

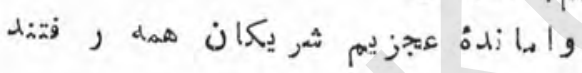

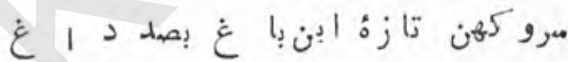

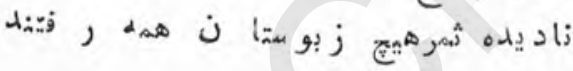

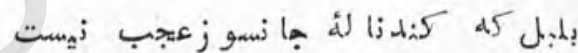

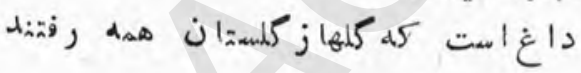

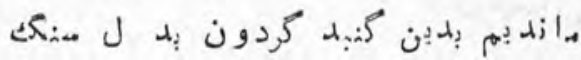

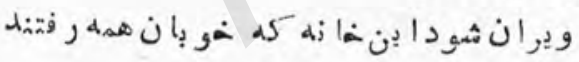

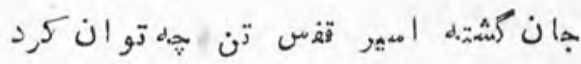

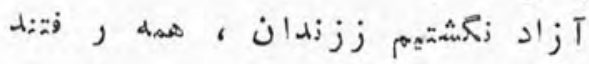

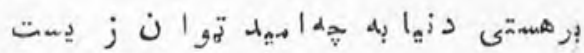

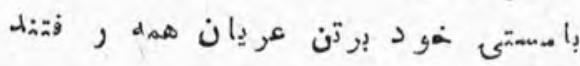

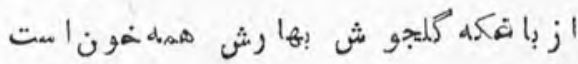

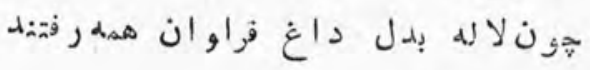

$$
\text { خا }
$$

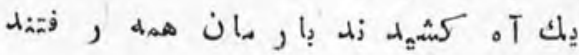

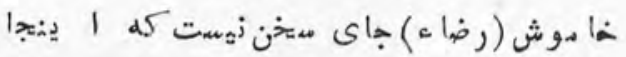

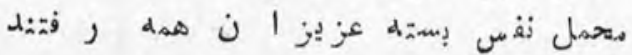


زلف كاف

زلف كا فر تا بروى ههرة:ز يِبا زششهت

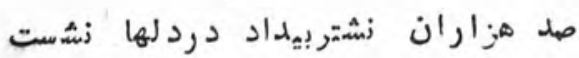

جاى بلمبل زاغ إئد دركلمتان

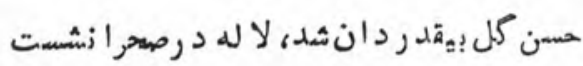

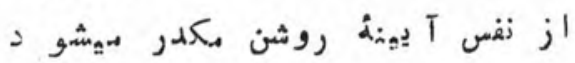

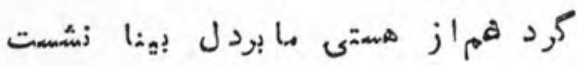

مر كسى آمود دهو آرامدر جاى خود امت

فرقشدها هى اكربر كشتيىدريا نشست

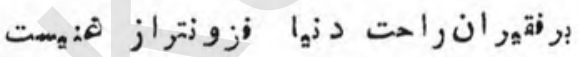

بونوا يان هفت دارد برغم د ديرا زششست

از 'قوشاعتبا ر هردو دزيا فارغ امت

دلاكربر زقش ياد هضرت مول مولا نشست

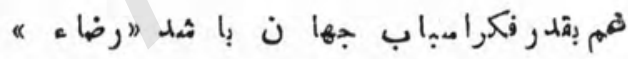

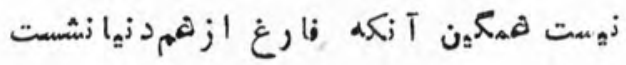

pV 


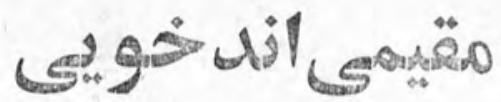

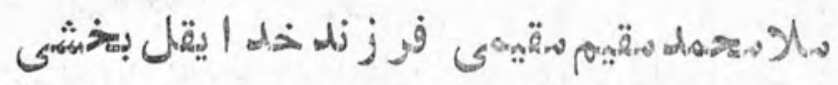
(A $D(F \% \cdot-9 P Q \varphi)$

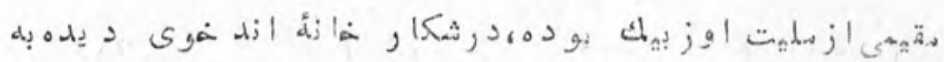

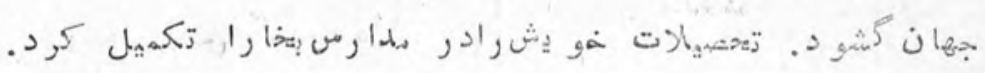

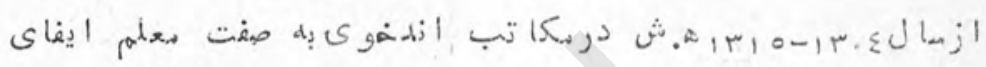

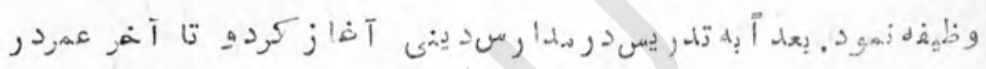

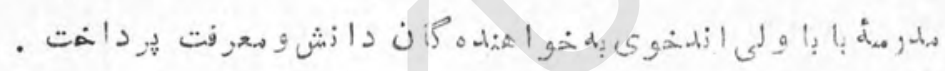

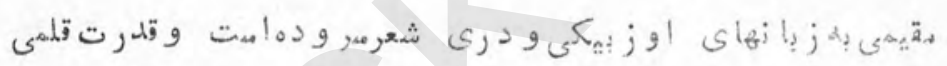

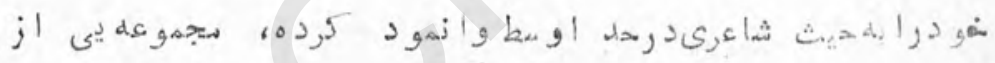

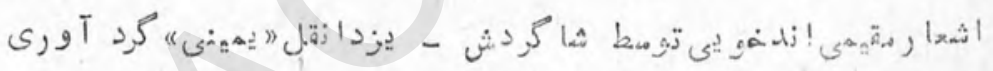

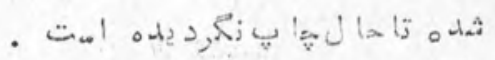

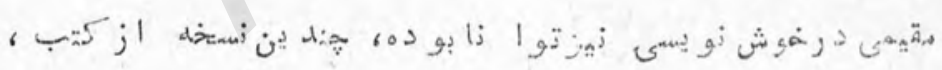

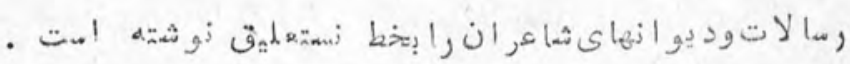

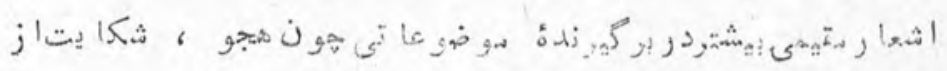

. .

PA 
glicsos

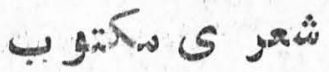

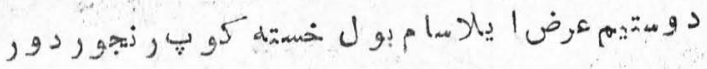

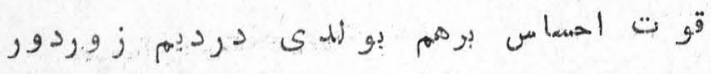

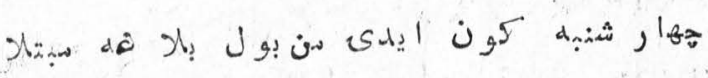

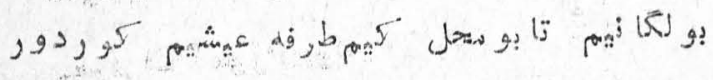

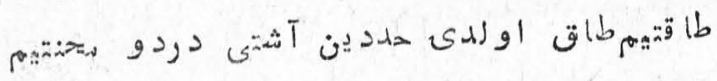

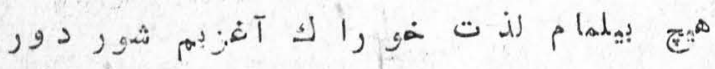

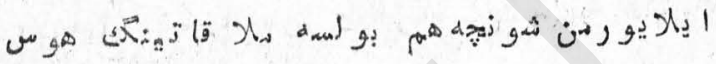

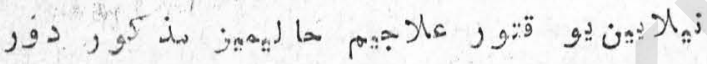

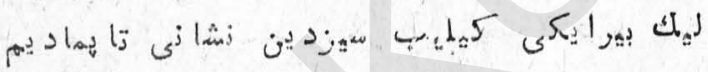

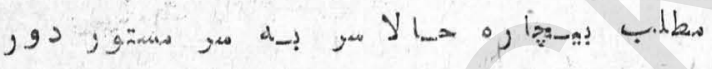

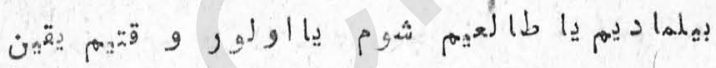

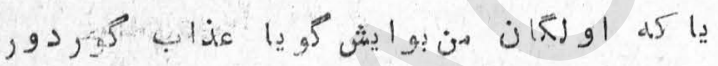

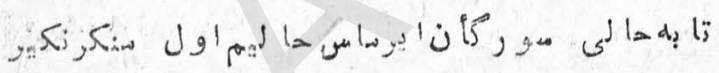

بولامقيهى

بها ين

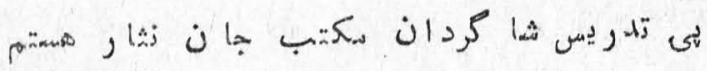

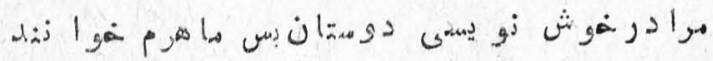

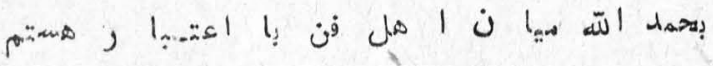

ra 


\section{شرف}

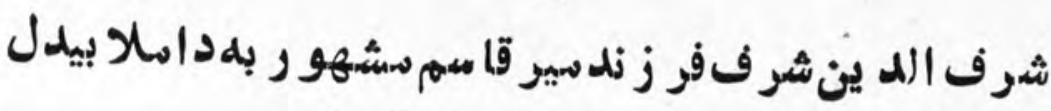

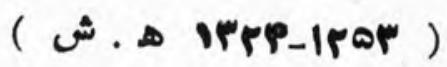

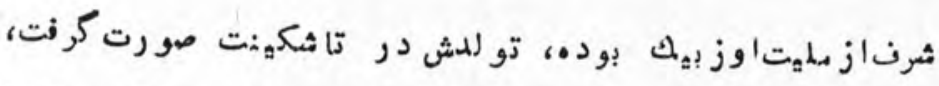

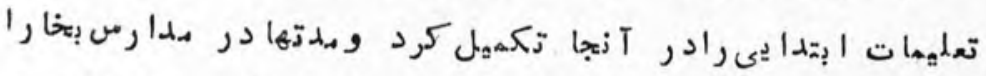

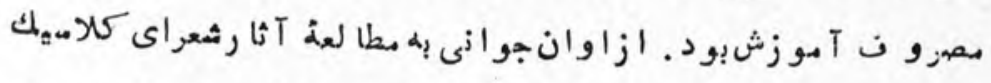

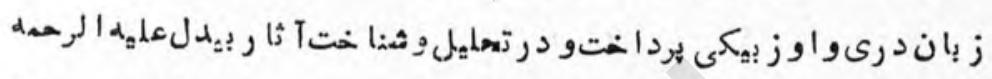

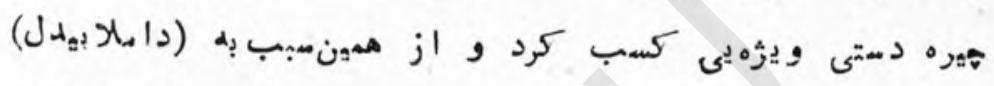

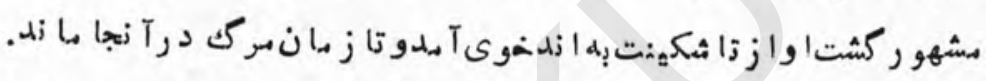

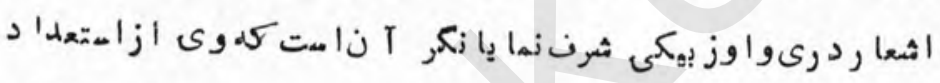

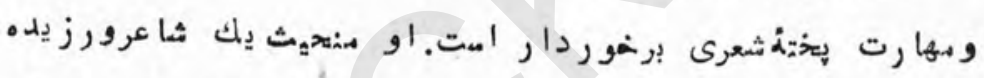

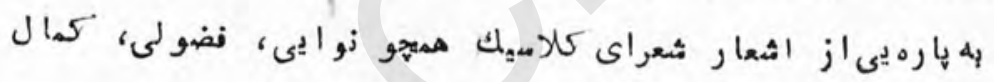

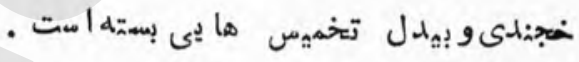

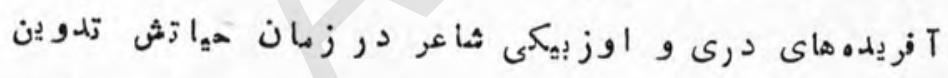

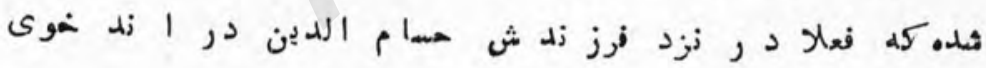

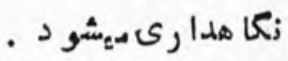


كوز كمنى ياش

زاز 1, اكيلتو ر مافيل هين فضب قاش اوستينه

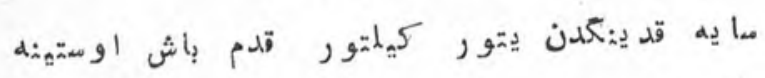

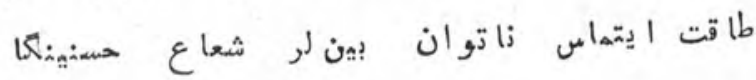

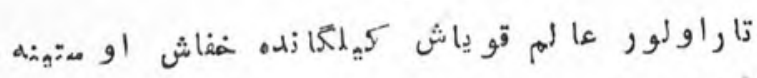

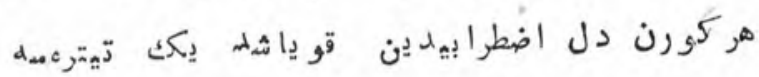

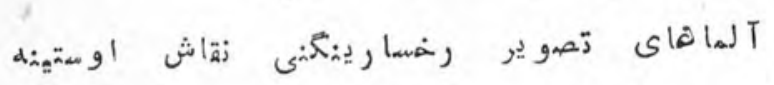

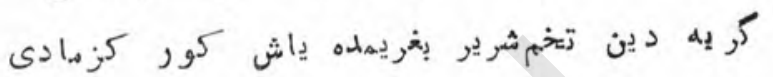

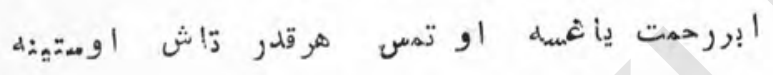

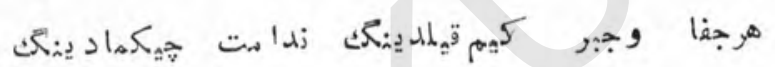

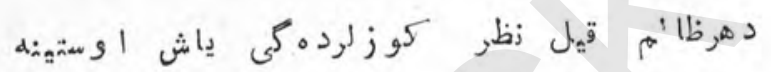

ذكر وصفيده تالش ايتسه دل ولمجانئى شرف

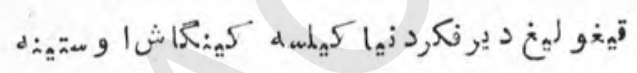

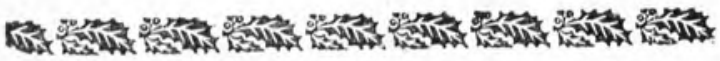

PI 
تالعتون يوز

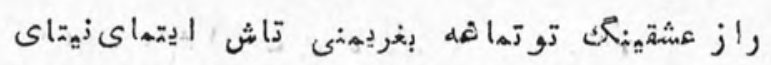

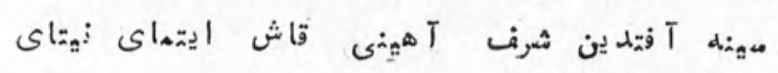

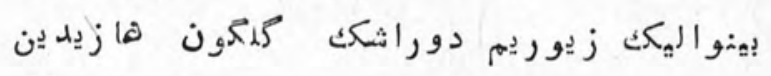

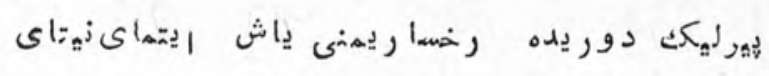

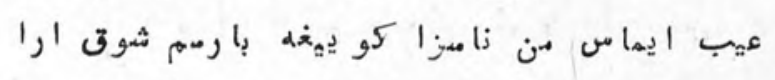

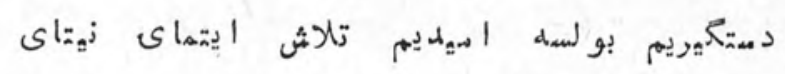

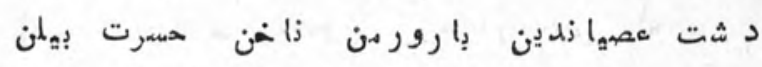

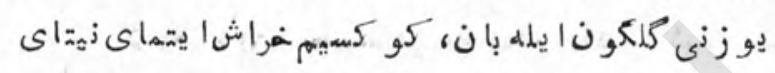

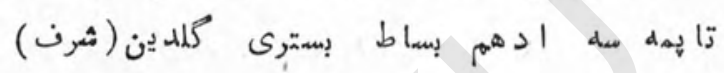

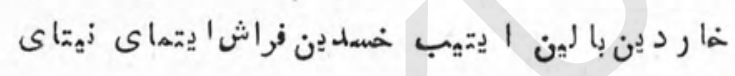




\section{فيضى}

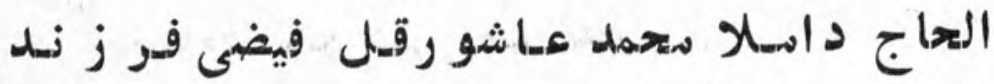

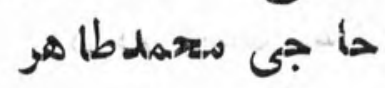

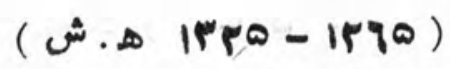

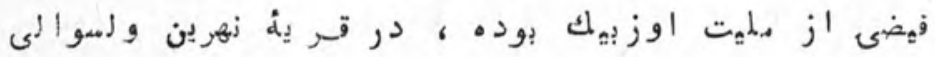

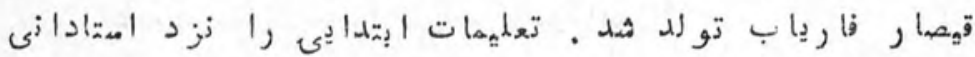

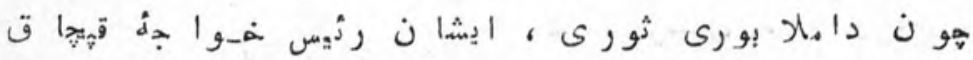

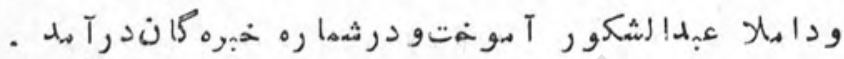

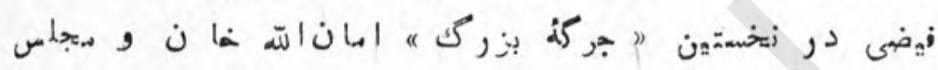

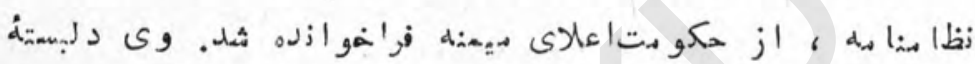

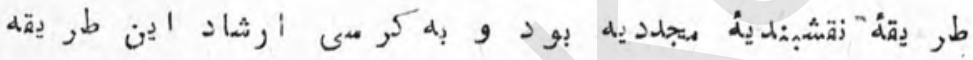
. 2 ; $\alpha_{n}{ }_{n}$

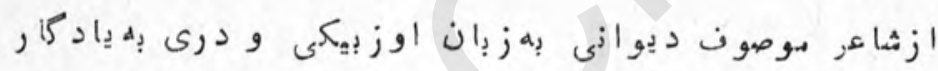

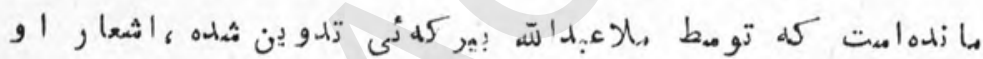

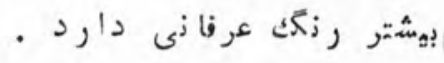


جإك-رعشق

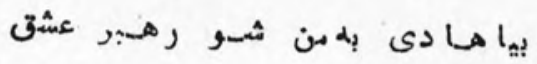

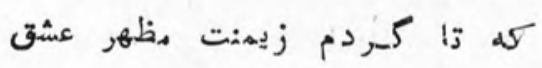

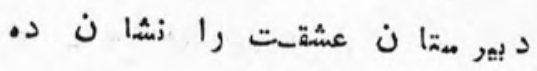

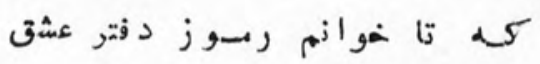

اد بِ عشق ، مرا آزاد كـردان

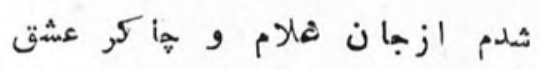

كميم هـو اصى با دريأى شوقت

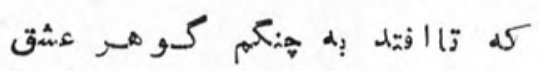

بسى دارم الميلم ا ز فضل وهـاب

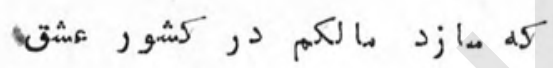

به بيـد ان مهبت ر خشش تـازم

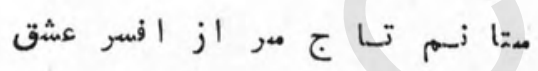

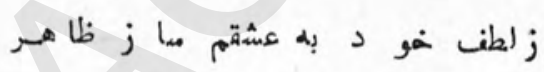

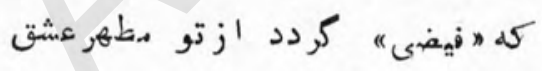


كونكول صحر اسى

قبله و, كعية اليرور ه:كا يو زو زكث

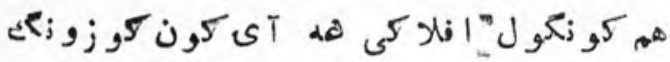

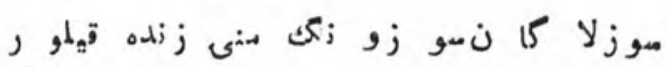

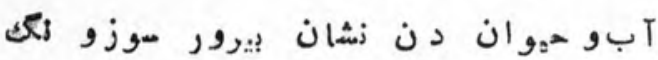

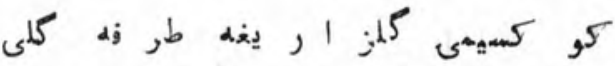

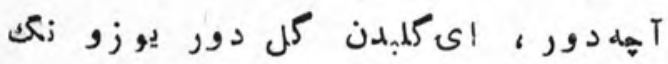

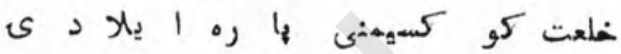

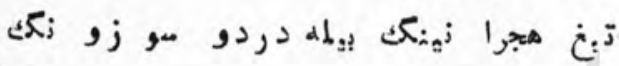

كو زملايهى صهرا مسى بيل كلزار, دور

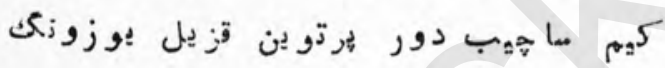

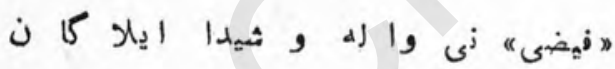

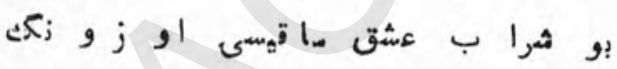

P 
biclg

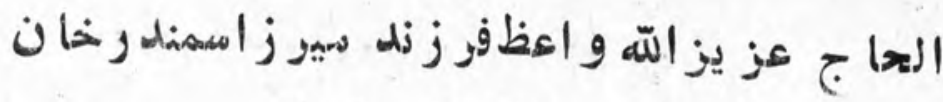

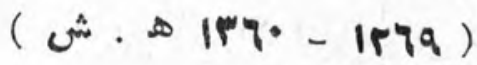

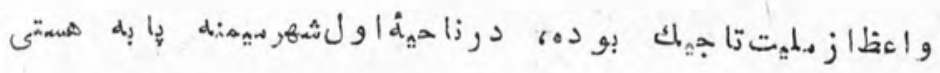

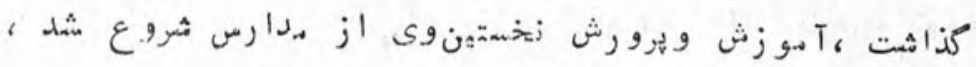

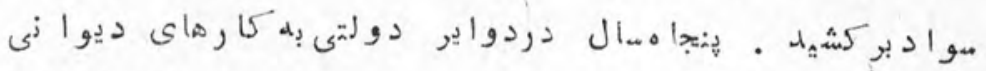

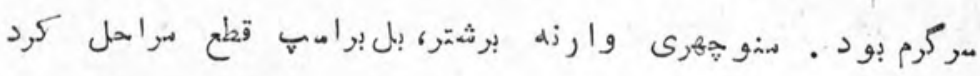

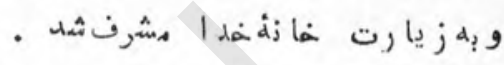

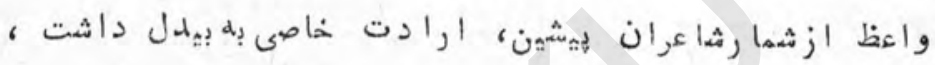

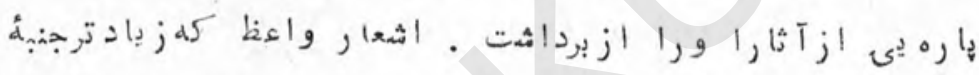

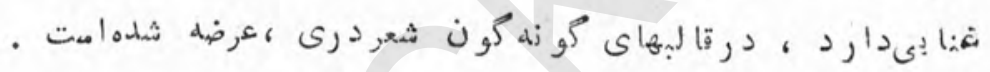

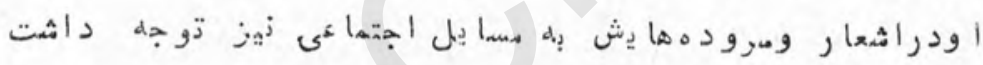

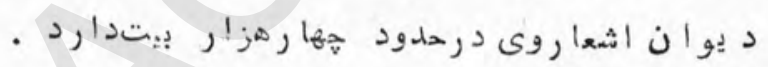

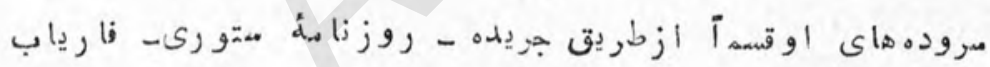

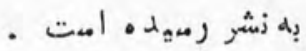




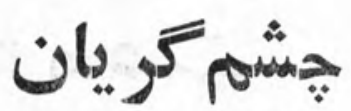

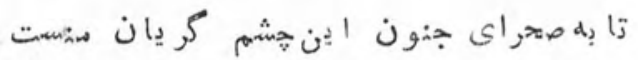

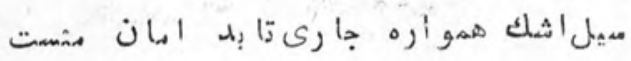

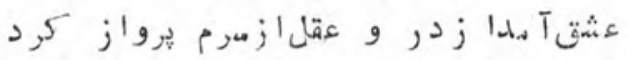

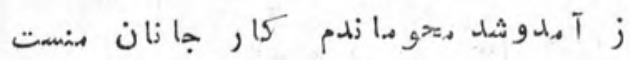

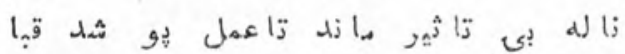

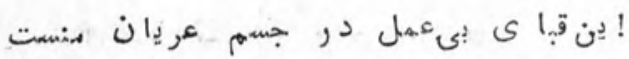

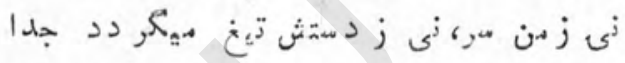

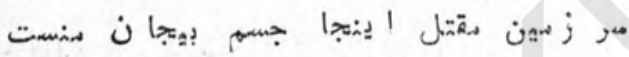

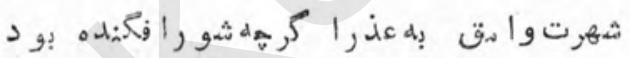

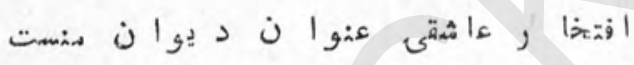

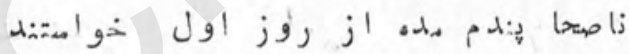

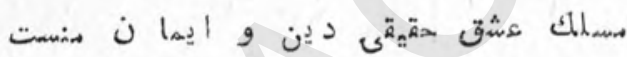

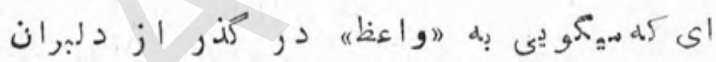

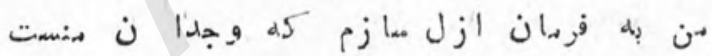

Pr 
جشهمة مححبت

هجرم كداخمت تاكله بهر جا كريستم

تاص:هدم هو ثمع سرالها كر يستم

دردم زشثد علاج وطب:مجوابم داد

در آر زوى وصل مسريها كريستم

زادان ملمول كردد لمرا ز وضع خوي

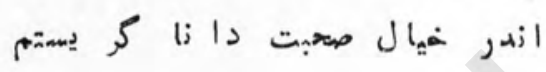

صشراى هاتهيست ز مجنون دلفكار

از هجو او إه ماتم لهيلى كريستم

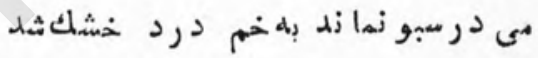

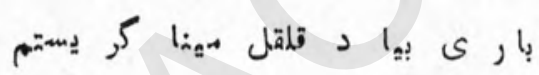

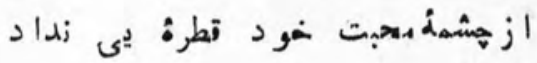

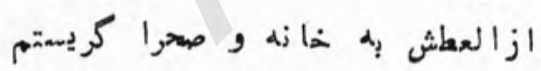

واءظ إكفت تا كله كنثشتمازاين و آن

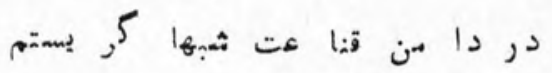

ra 


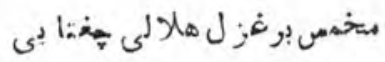

مص:حف رون

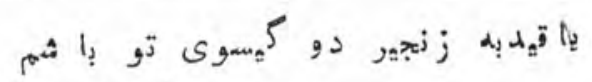

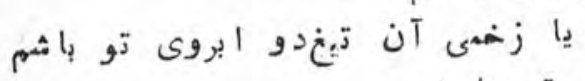

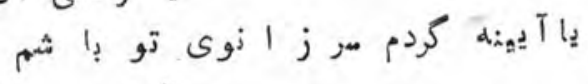

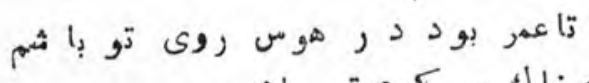

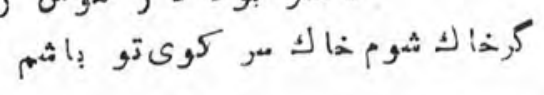

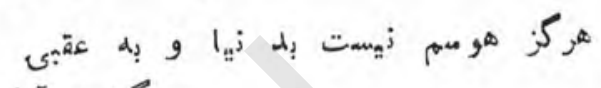

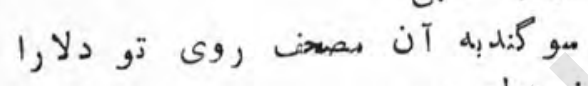

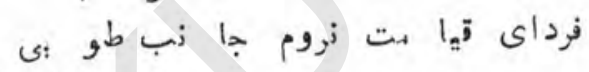

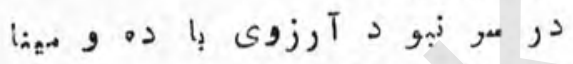

در مدائل سروقد دلجوى تو با شمي

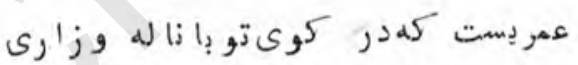

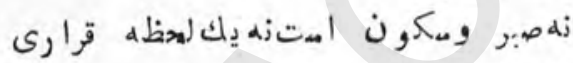

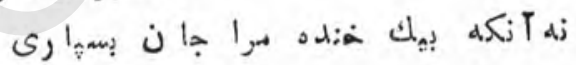

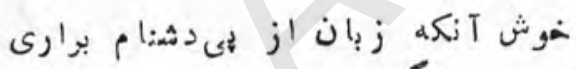

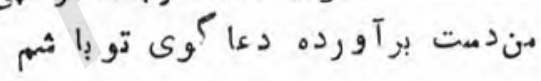

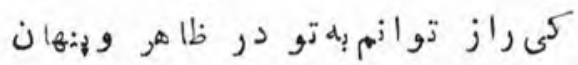

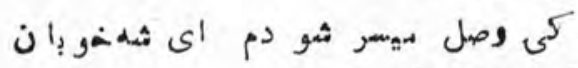

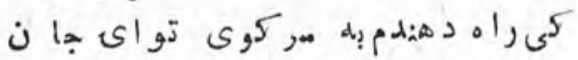

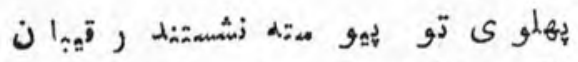

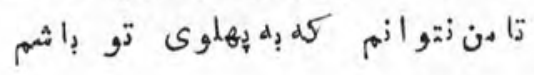

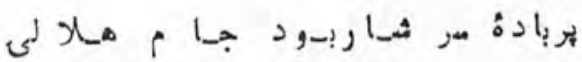

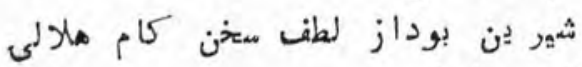

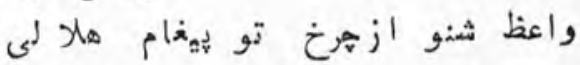

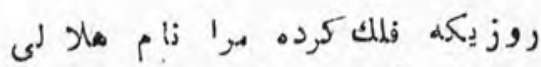

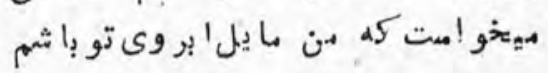




\section{لزطفى}

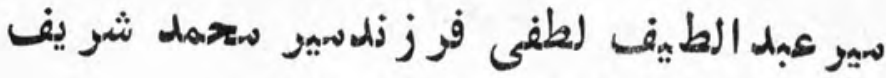
(ش. A) Apqf-1Fqq)

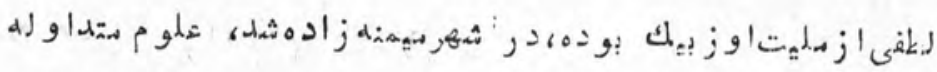

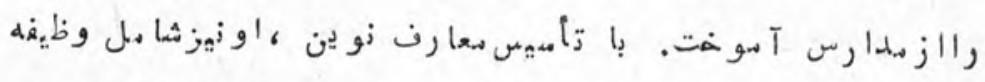

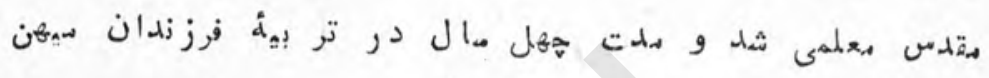

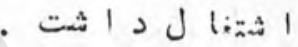

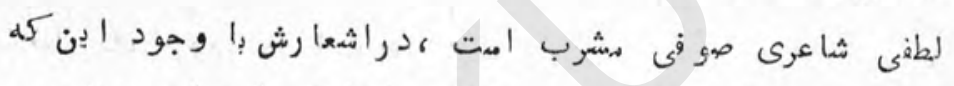

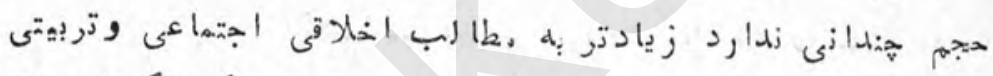

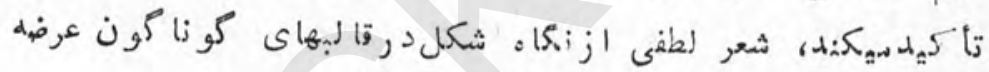

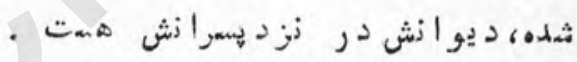

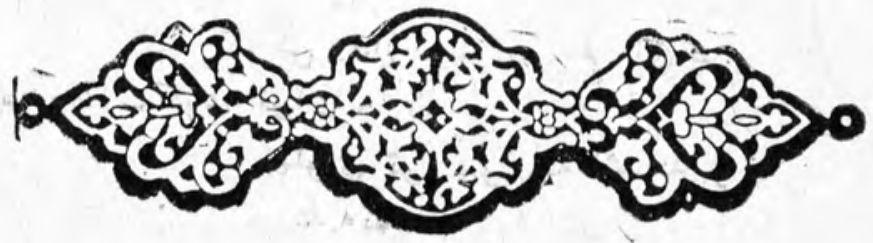




\section{جر اغ اتفاق}

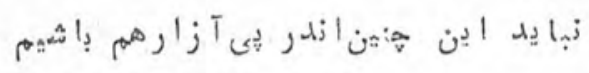

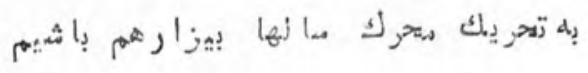

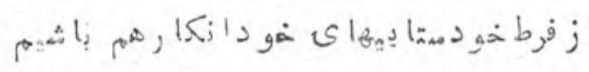

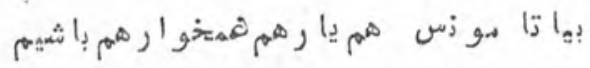

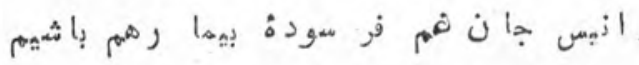

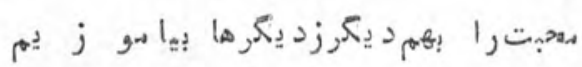

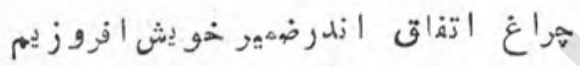

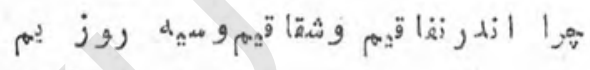

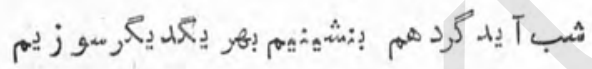

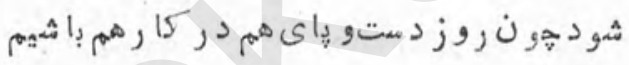

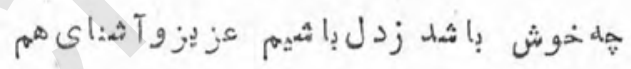

ز

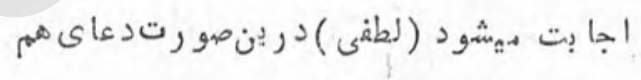

دواى

$$
\text { دل هم جا ن هم جا زان هم لدار مهم با شيم }
$$




\section{ling \\ سيد احهل بينا فر ز نل بو رى بهان

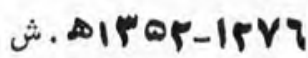

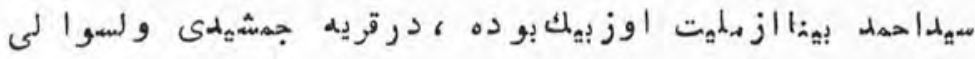

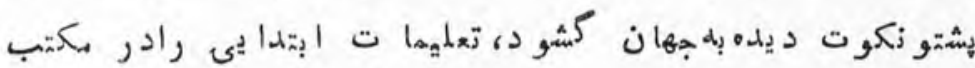

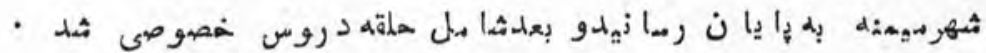

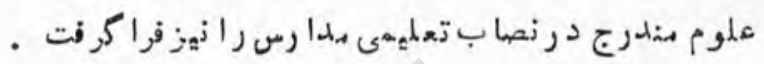

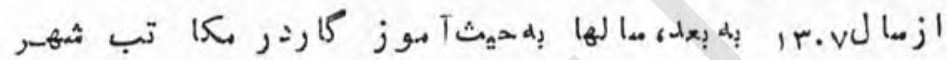

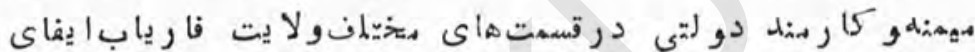

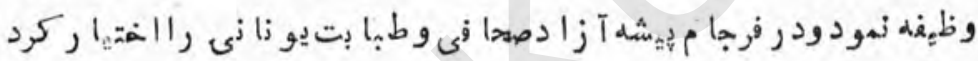

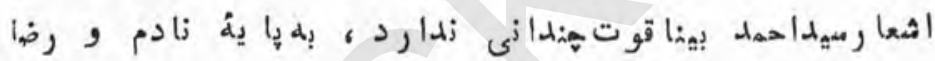

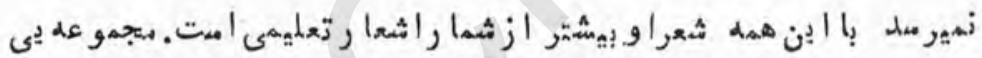

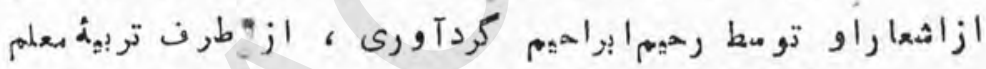

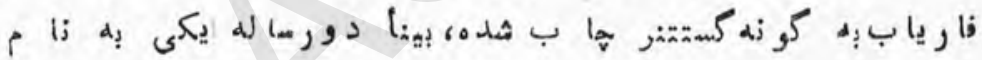

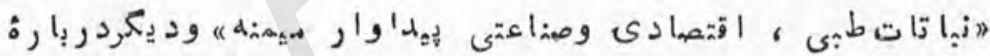

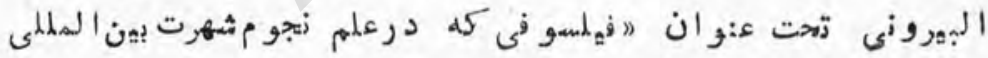

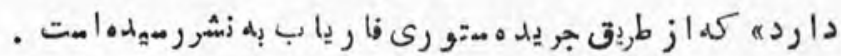


مذهب وفا

جا زا اكرتو زاز كنى مرترامهز اهـت

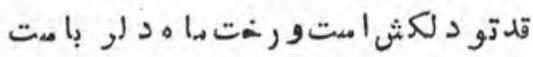

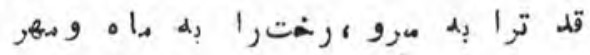

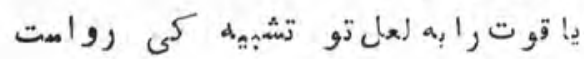

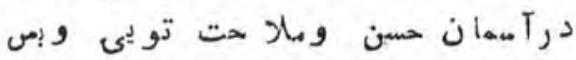

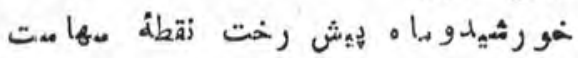

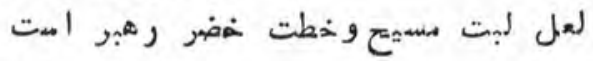

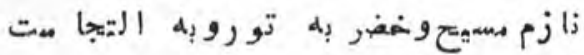

فرز زله زيك كو هر ى از آدم وحموا

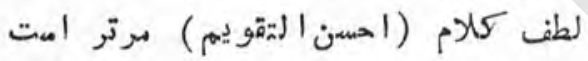

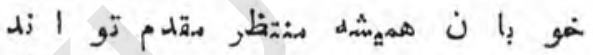

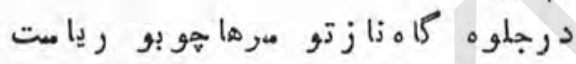

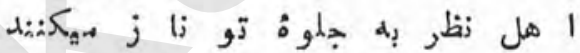

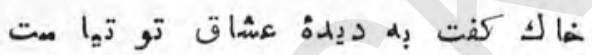

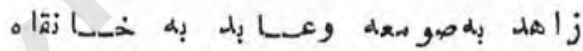

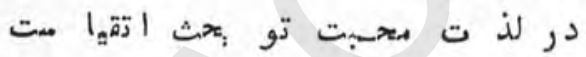

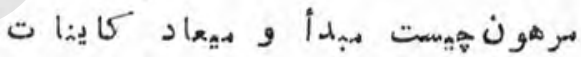

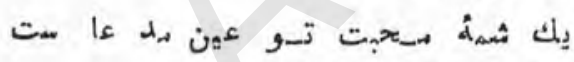

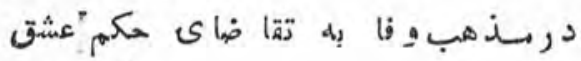

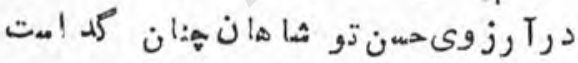

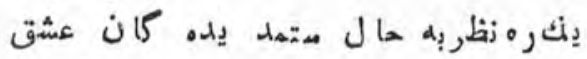

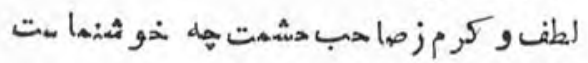

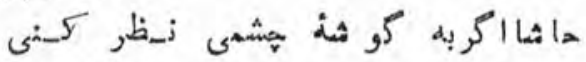

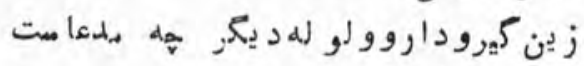

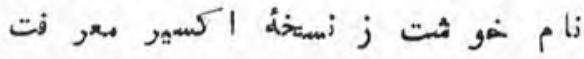

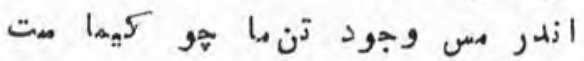

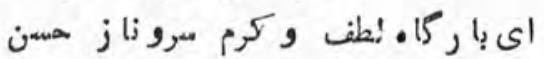

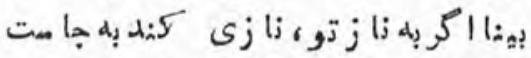




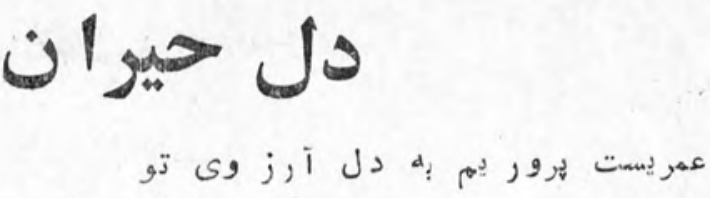

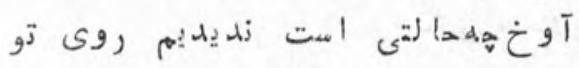

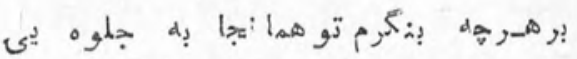

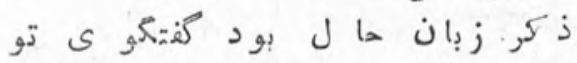

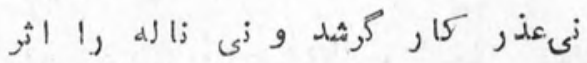

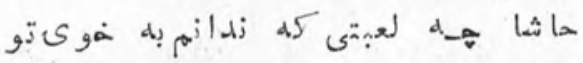

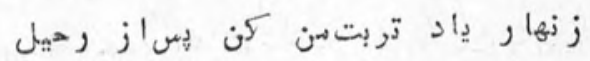

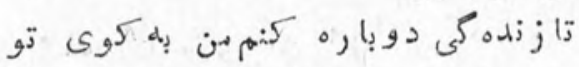

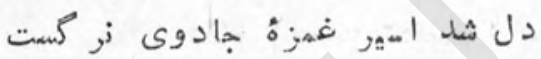

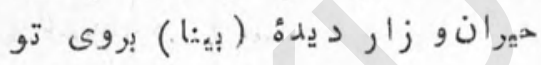




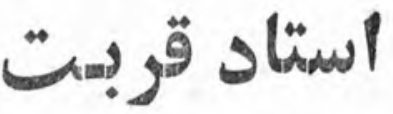

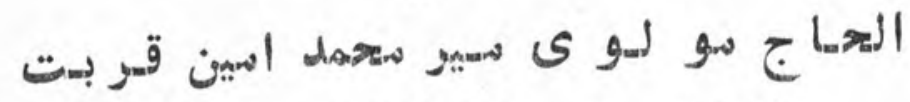

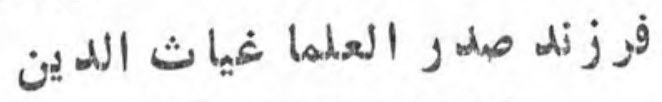
(A. A IF

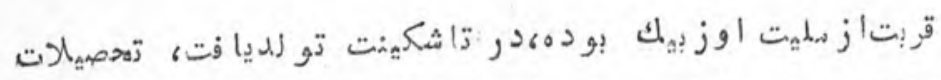

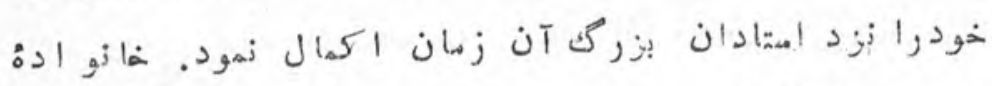

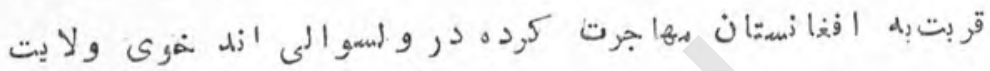

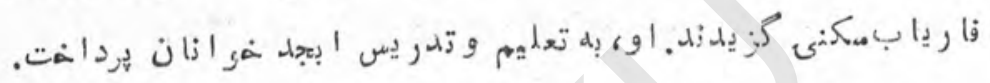

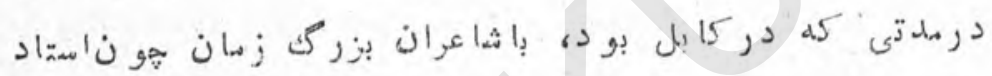

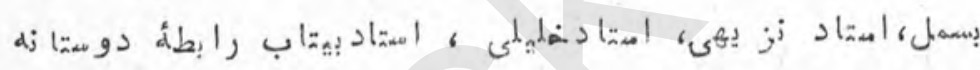

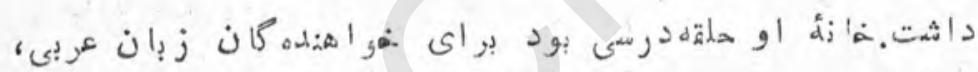

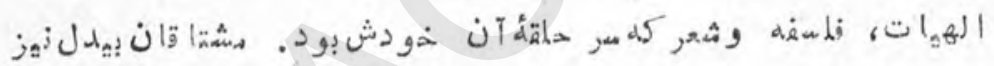

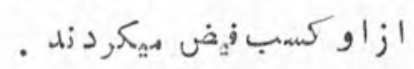

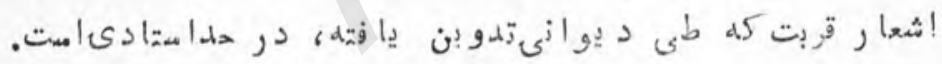

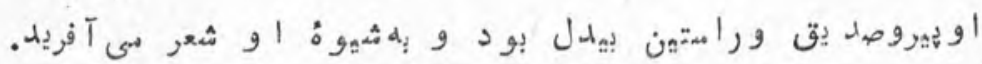

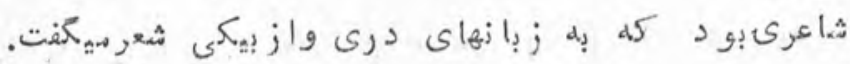


تصغ-و يو جششم

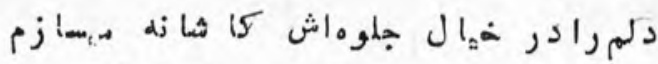

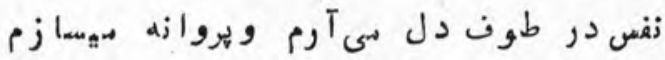

درآغوشمديه بتختى امت اقبالى كه من دارم

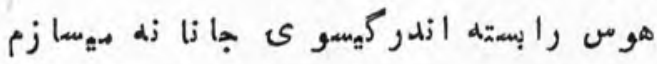

وداع كلفت از مضمون رزازينم زشد حاصل

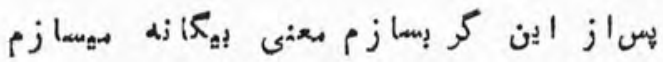

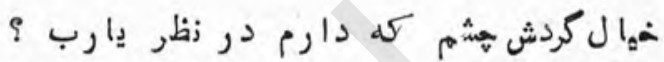

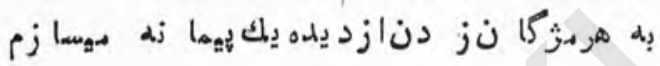

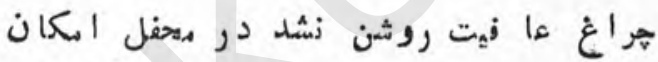

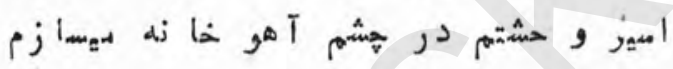

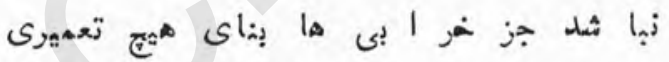

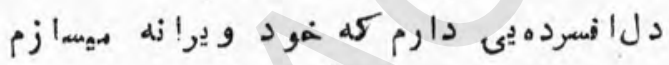

زمرف لعل جان بختش تو T كم زيستم الها

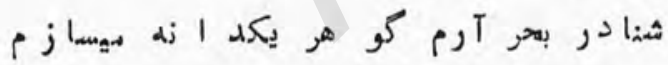

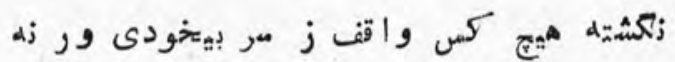

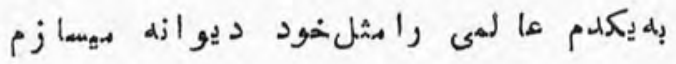

خراهش رابها ين ازداز شوخى نقش نتوان كرد

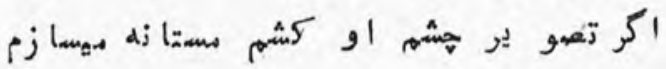

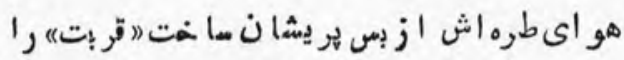

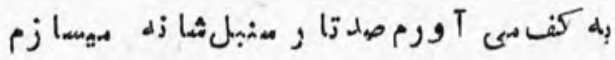

p 
آتشرخسار

تاسرم رابه مبرزلف مروكارى هست

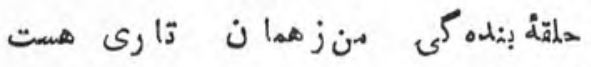

بادماز ماغرحشهت زتوان نوشيمن

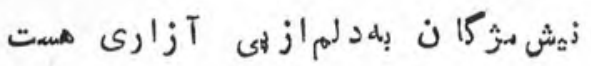

بركك كل همهوس هيخمل زازت دارد

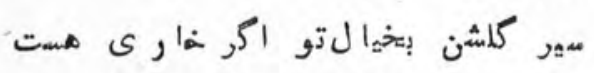

زوش تو ني كه د ديدهاستد را ين دير كهن

تدران

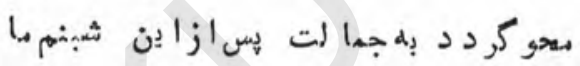

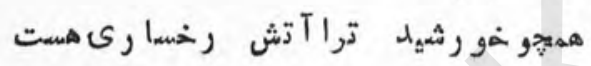

فكر آن از قديت راهبرم شده هو عصيا

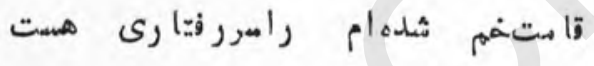

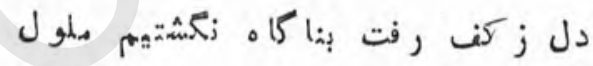

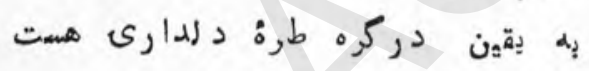

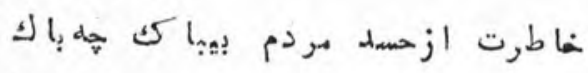

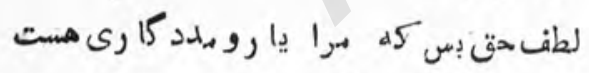

ايدل ازدهت مدهد قربتو طرزز بهدل

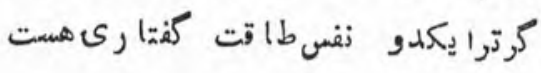

pr 
نو بهار اياميى

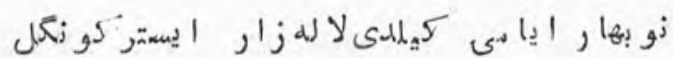

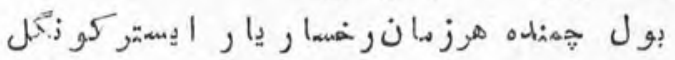

جاده جير بله

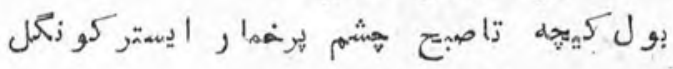

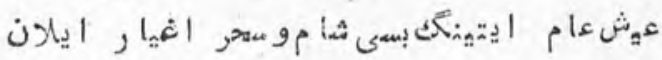

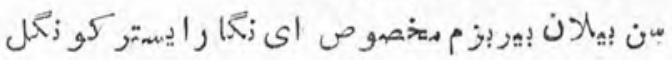

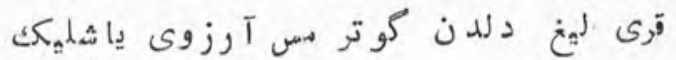

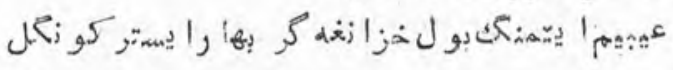

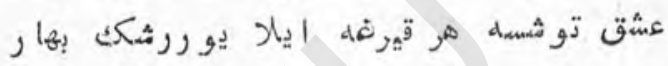

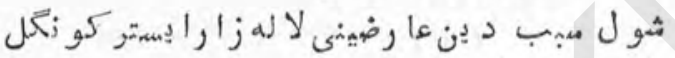

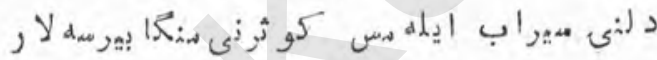

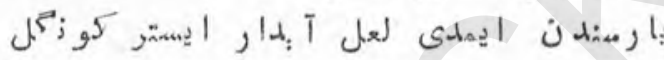

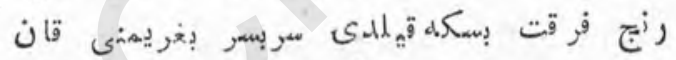

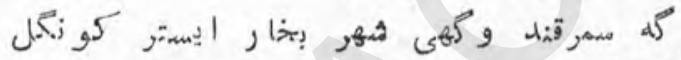

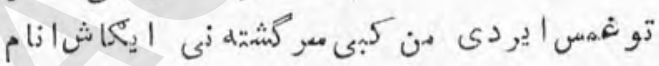

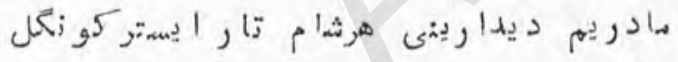

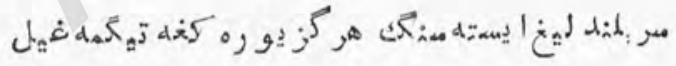

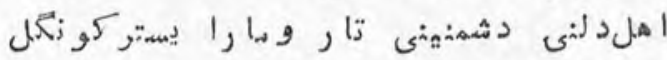

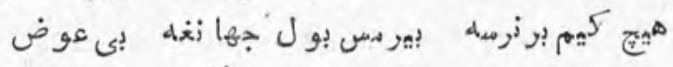

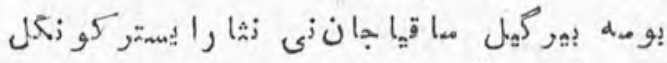

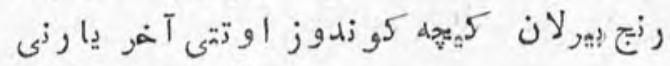

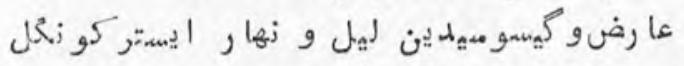

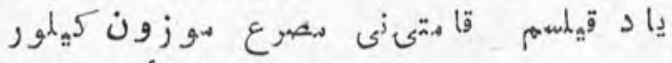

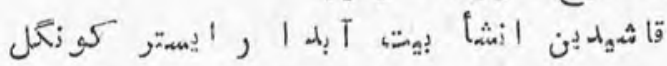

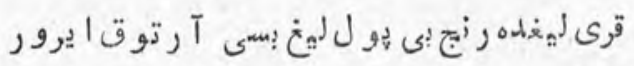

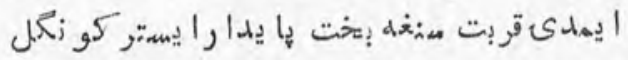

PA 


\section{فوزى}

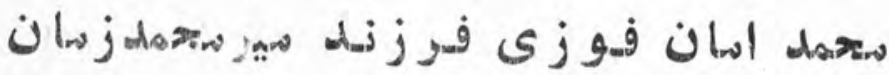

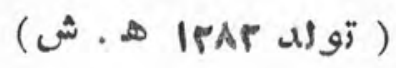

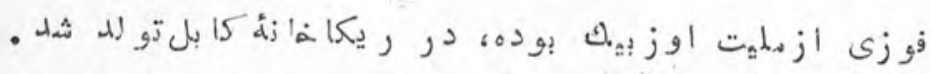

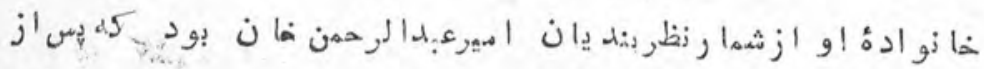

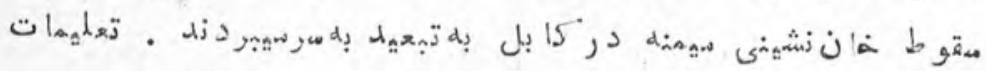

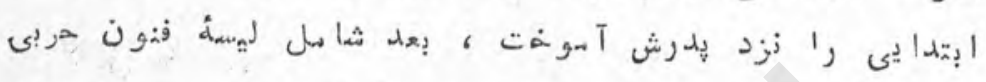

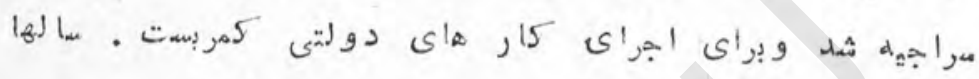

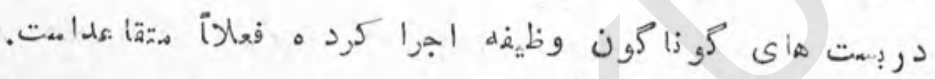

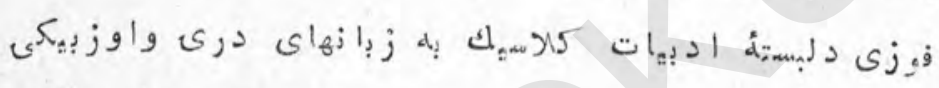

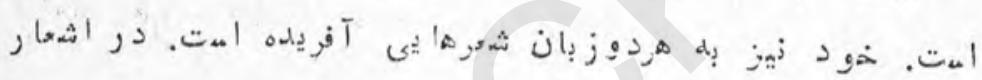

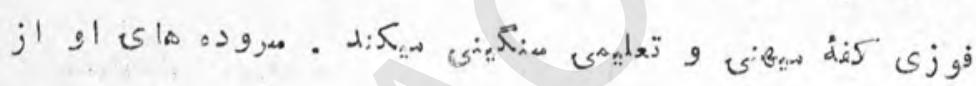

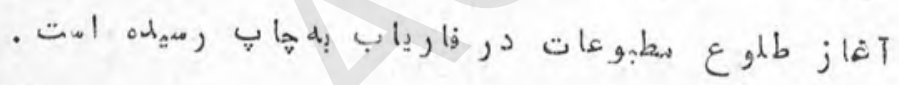

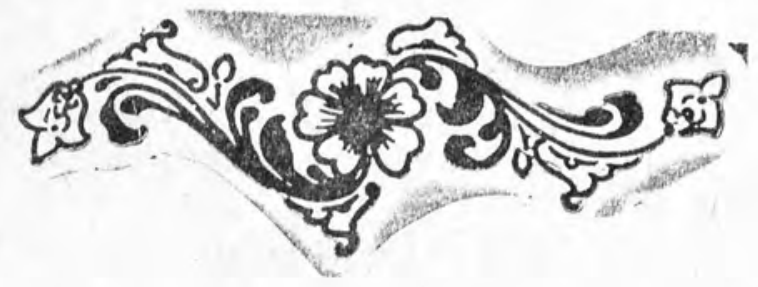


كشور آبايیى

الى كشور ازغا نى بسيا ر دلارابه

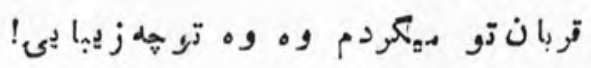

كا بل هقة رخو بست دمسن وجما ل لخود

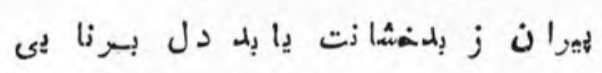

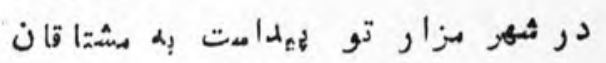

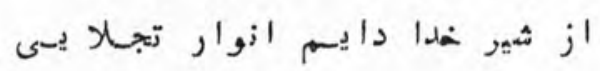

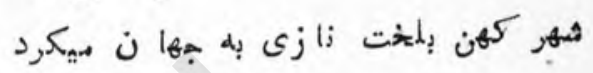

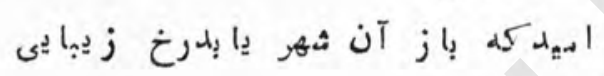

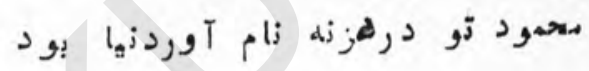

مرافسرشا هان بود دو دروزمان

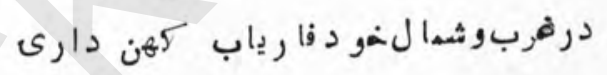

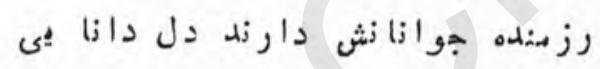

خاك هربت صهدها جا مى و زوايى داشت

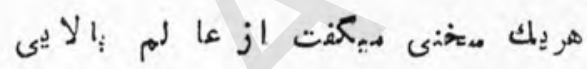

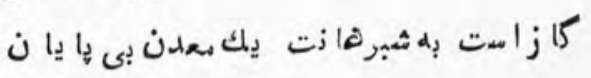

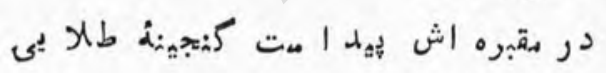

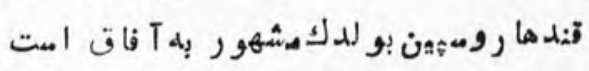

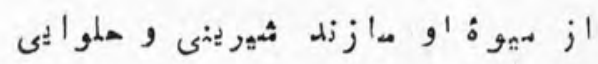

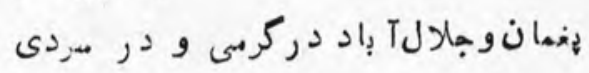

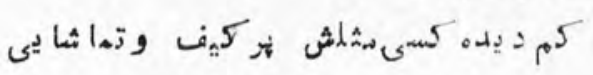

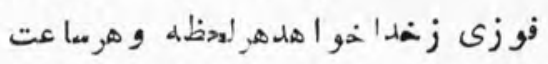

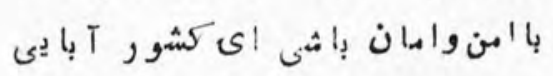




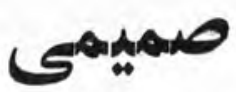

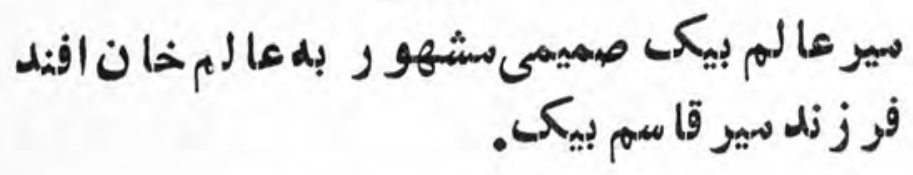

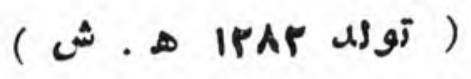

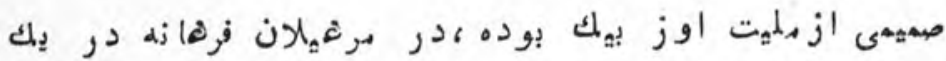

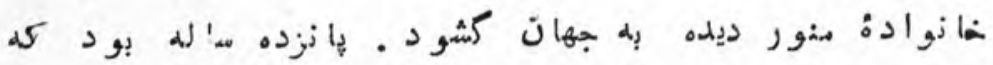

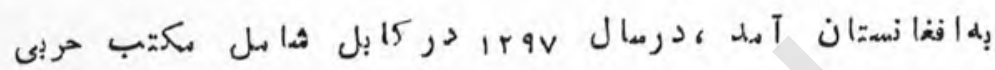

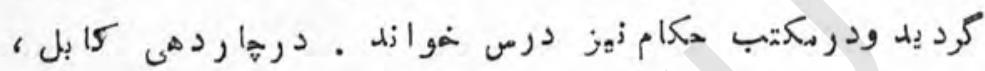

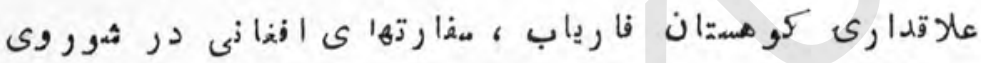

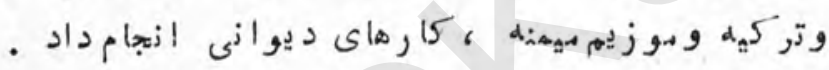

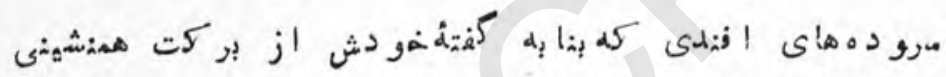

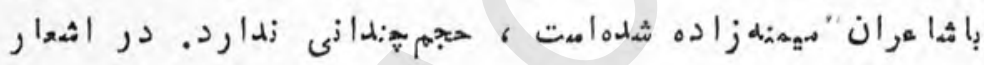

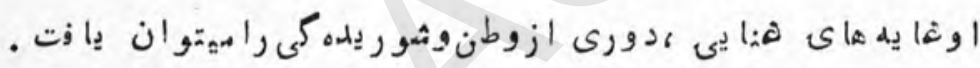

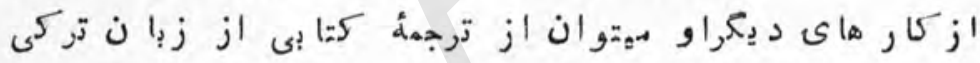

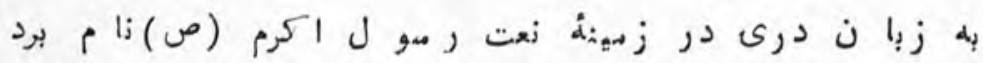

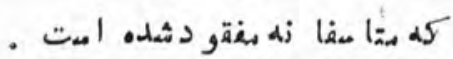

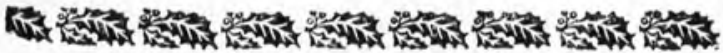




$$
\begin{aligned}
& \text { (5) } 21 \text { pois }
\end{aligned}
$$

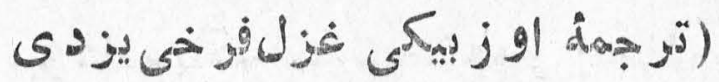

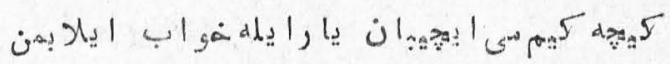

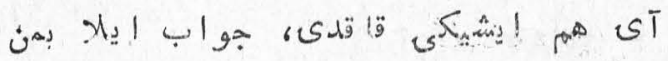

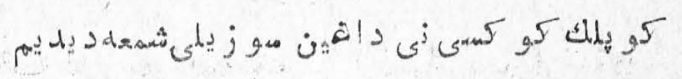

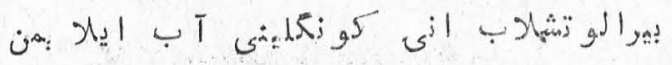

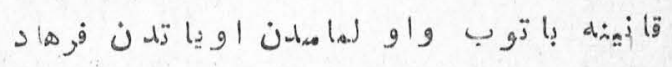

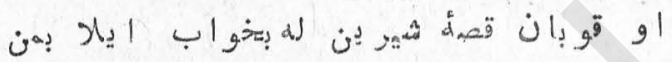

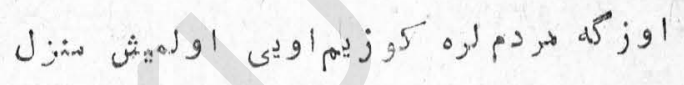

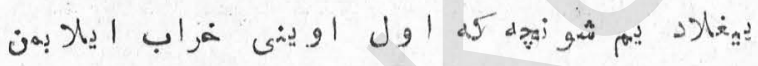

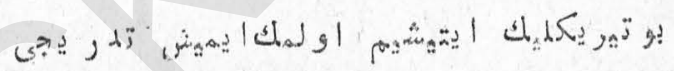

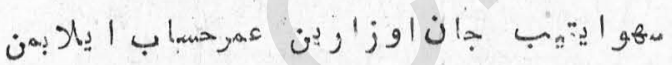

$$
\begin{aligned}
& \text { دوست لار اوشجو }
\end{aligned}
$$

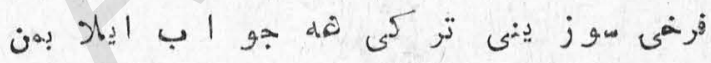

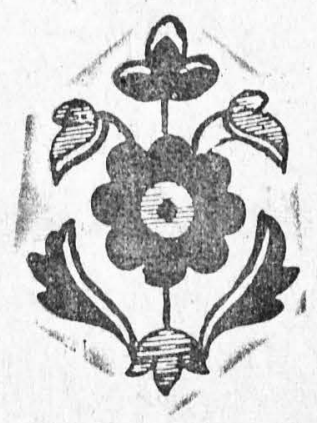




\section{ogla $(58) \ddot{j}$}

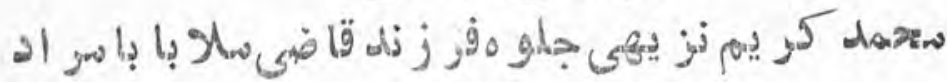

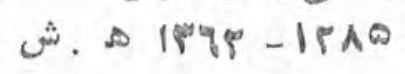

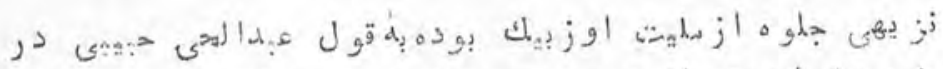
15

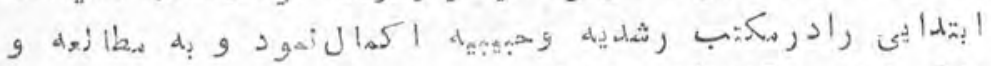

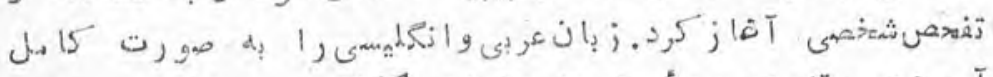

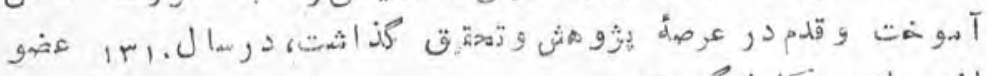

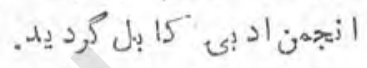

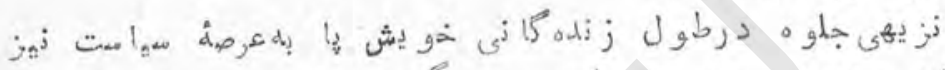

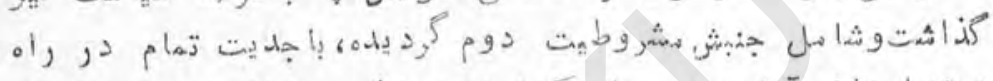

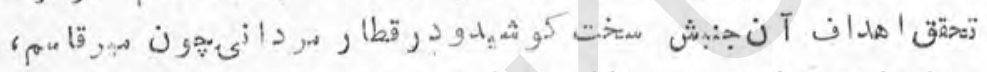

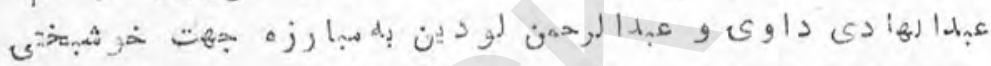

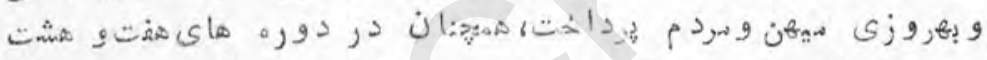

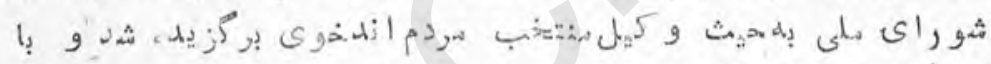

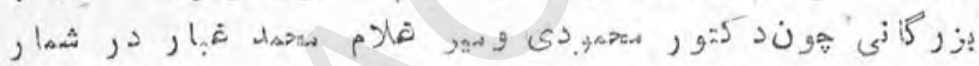
定

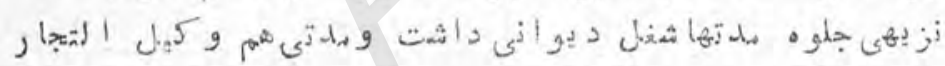

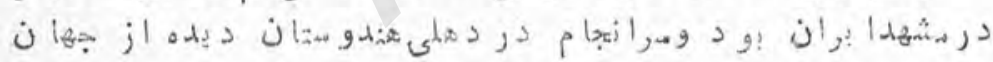
فو

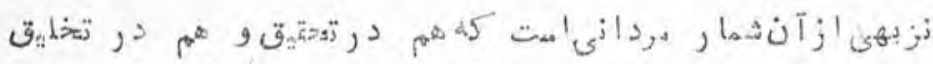

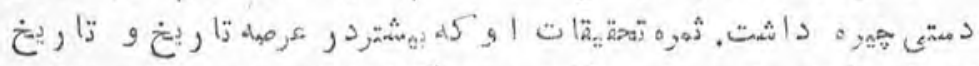

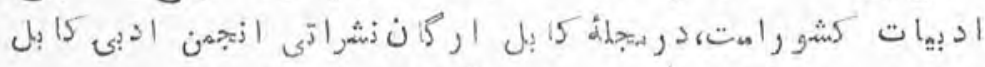

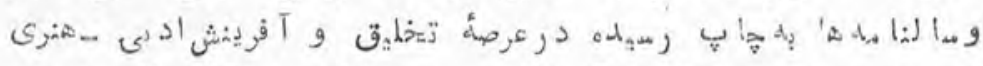

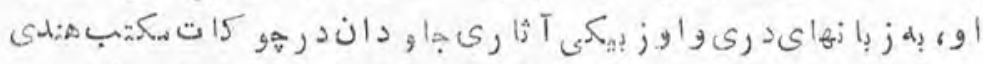

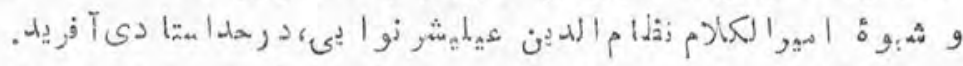

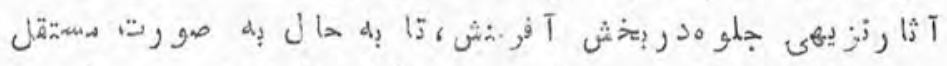

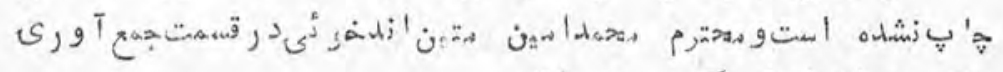

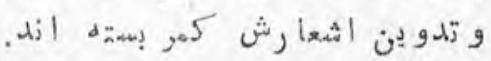


داغ بيكان

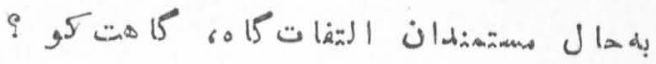

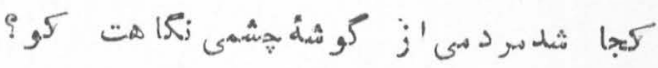

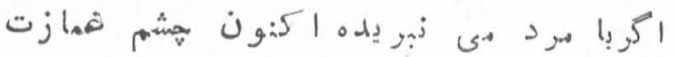

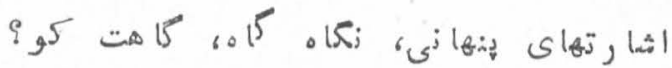

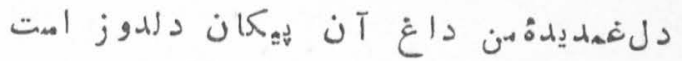

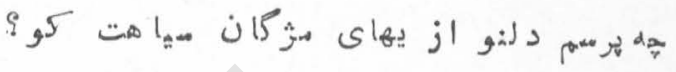

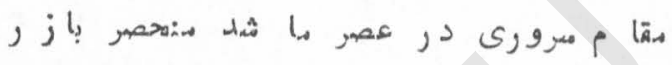

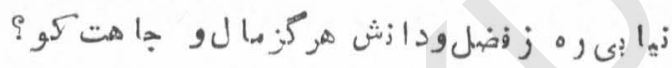

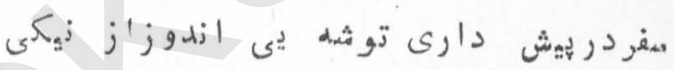

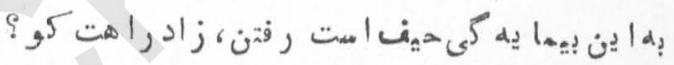

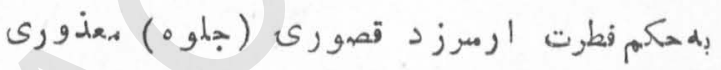

هزماز

(n)

nom

op 
فر اخوهان

تاكى ازجو رومتمبم شكوه و فر ياد كنيد

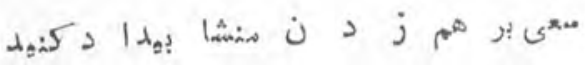

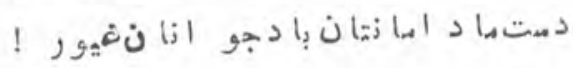

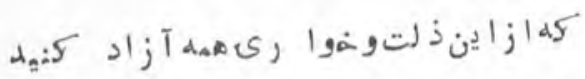

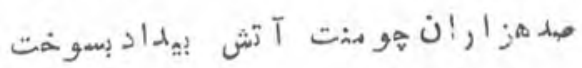

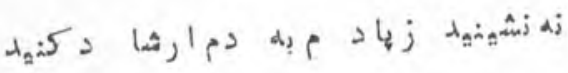

j

فكر, آ يتدة: هلك خو دوان

هندى ازخو ان زعمبرخوش وشمير ين 15 هنديد

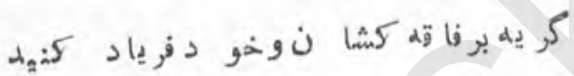

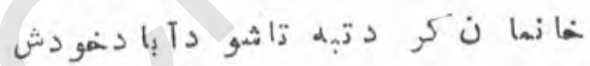

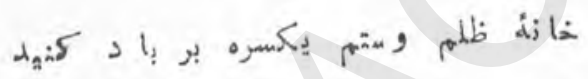

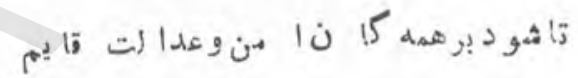

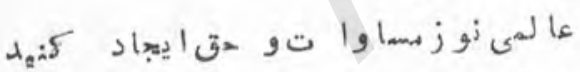

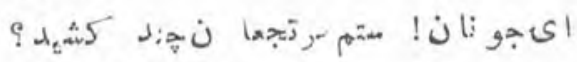

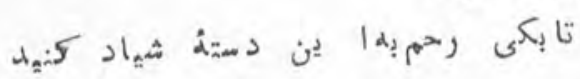

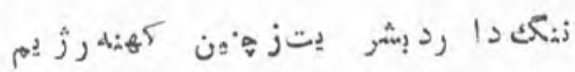

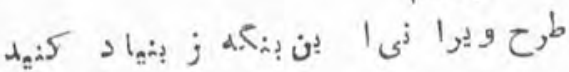

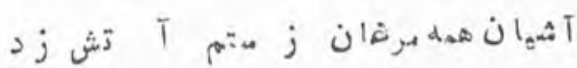

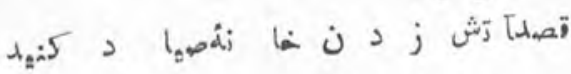

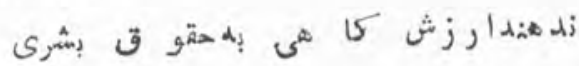

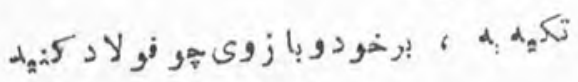

D 


$$
\text { 1) }
$$

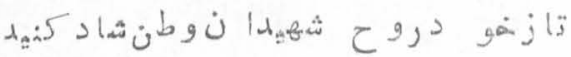

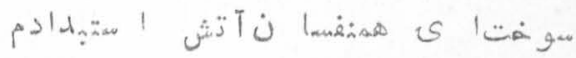

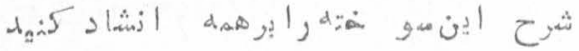

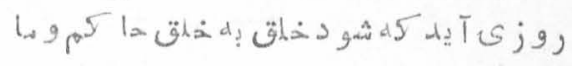

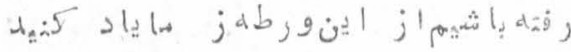

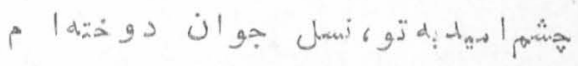

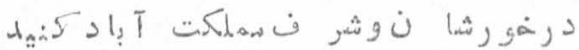

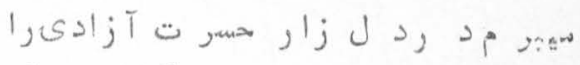

أش

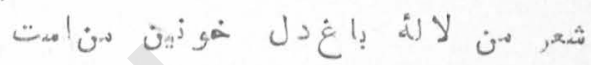

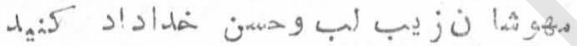

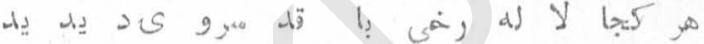

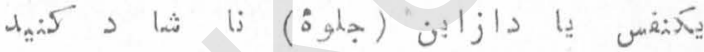

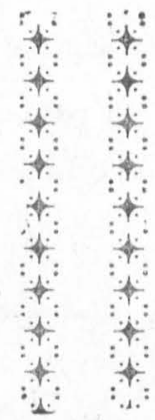




\section{,}

\section{Shas}

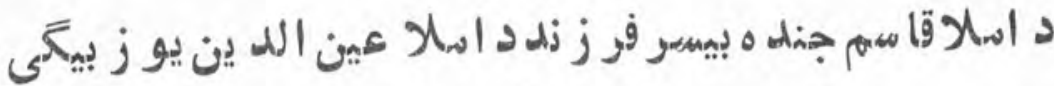
(تو (1) )

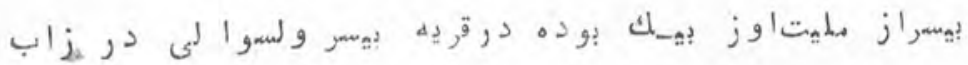

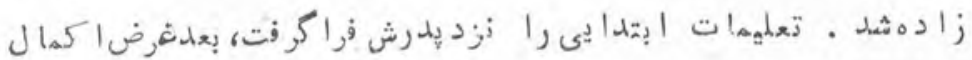

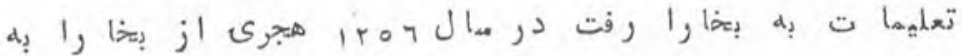

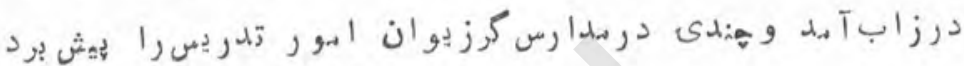

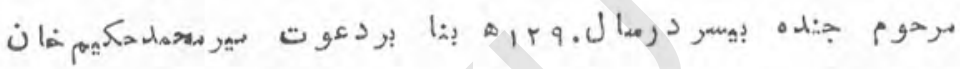

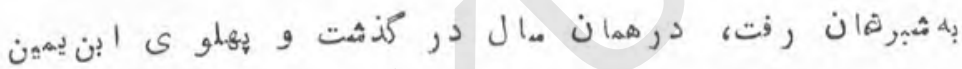

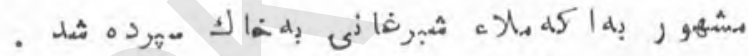

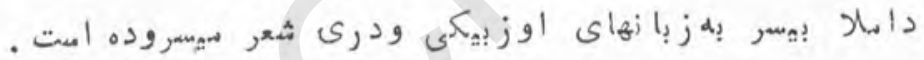

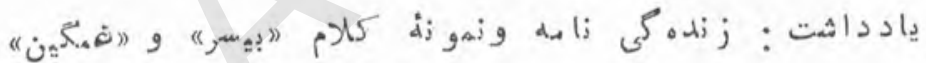

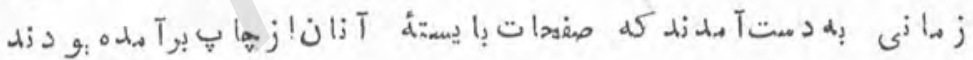

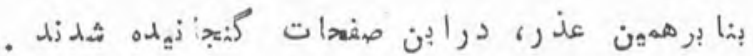

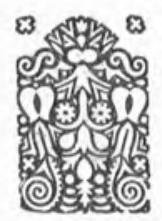


بيضه عنقا

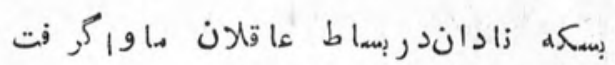

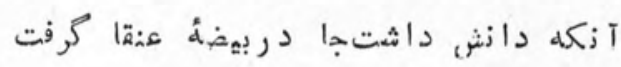

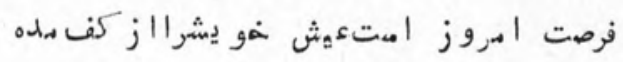

بى تمهزان همهجو طفلان ن وعده فردا كرفت

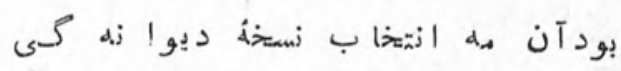

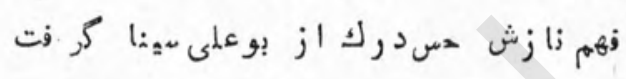

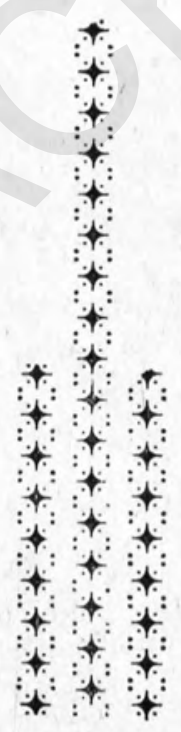

$\nabla \wedge$ 


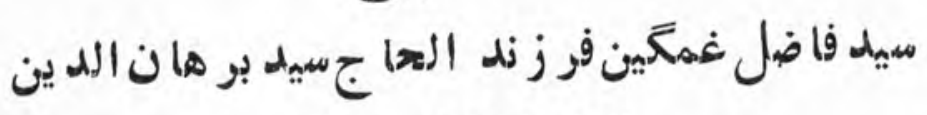

$$
\text { ش_D IPID-I rYP }
$$

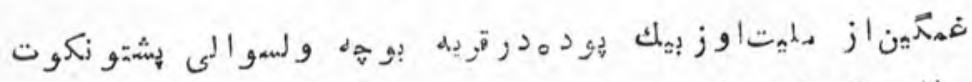

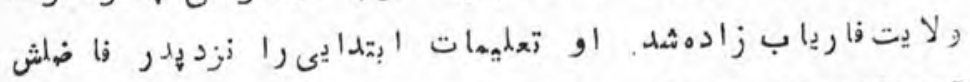
إ

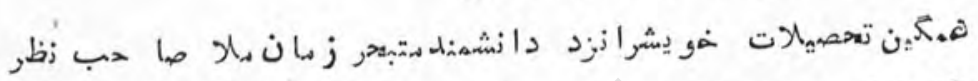

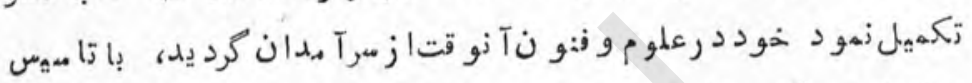

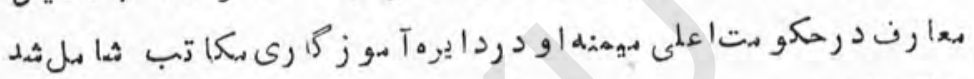

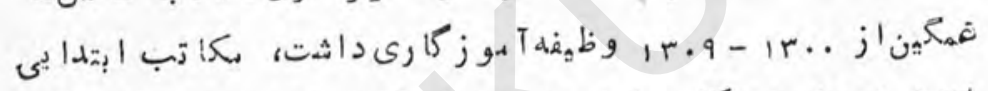

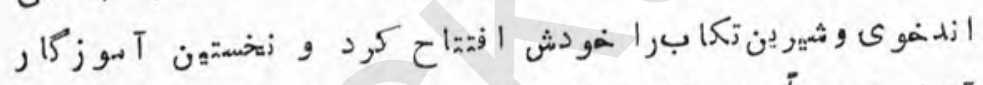

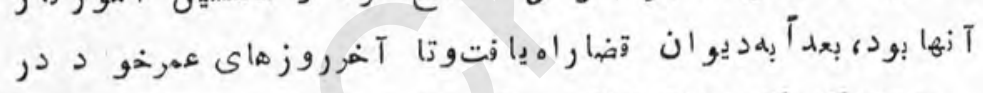

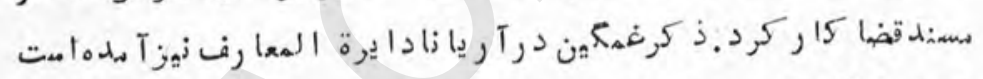

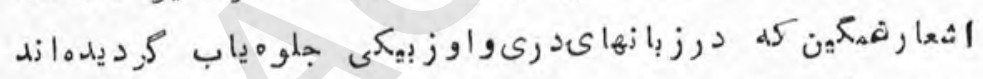

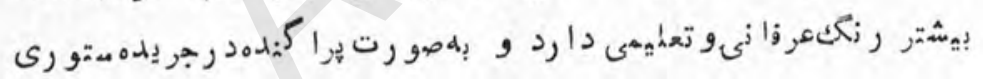

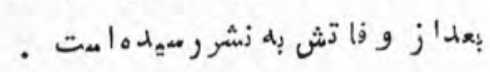

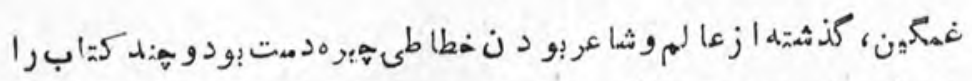

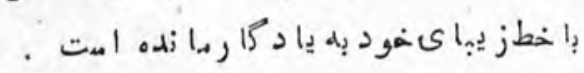

Qq 


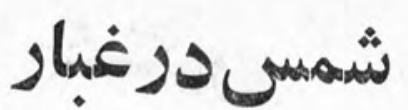

مu

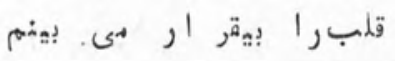

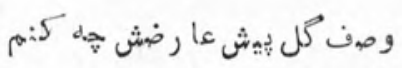

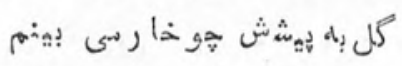

آفتاب رخش كمندهو طلموع

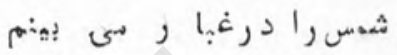

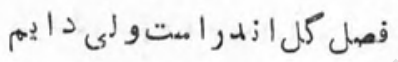

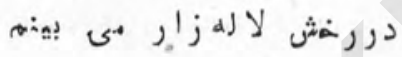

ن

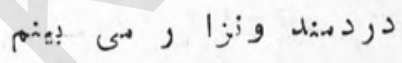

23.

7. 
خيرى فار يابى

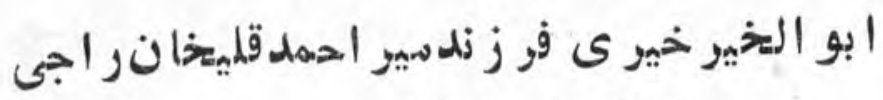

$$
\text { ( A . I IFOV - IFAY) }
$$

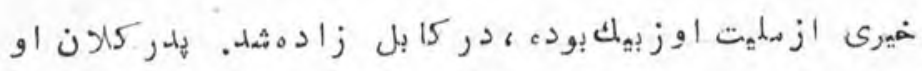

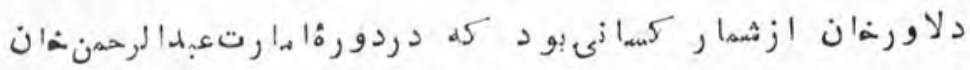

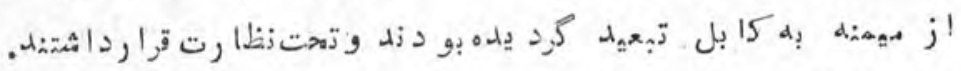

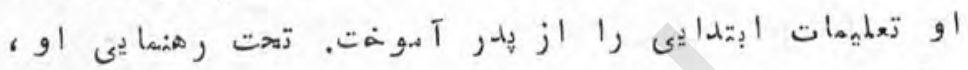

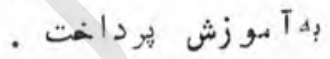

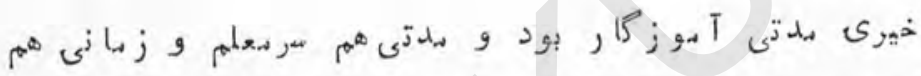

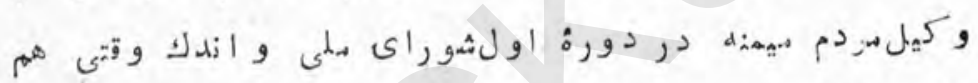

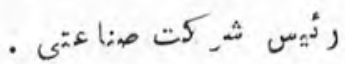

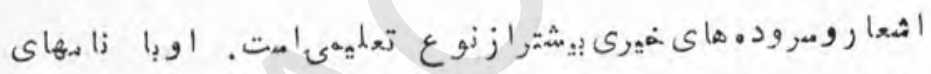

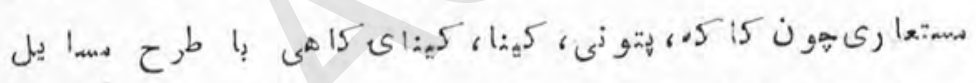

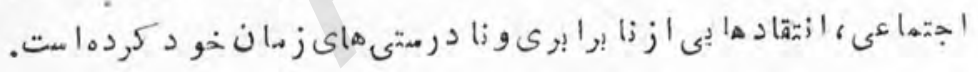

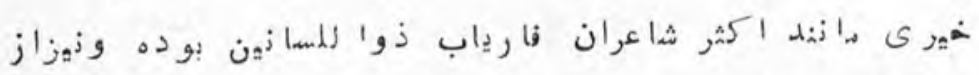

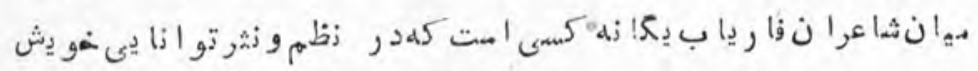

را إه هردو ز زبان به ثبوت رسا زيدهامت .

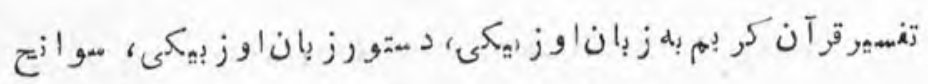

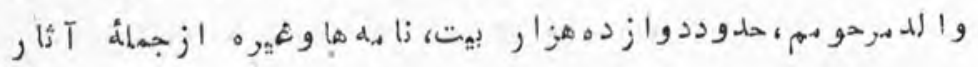

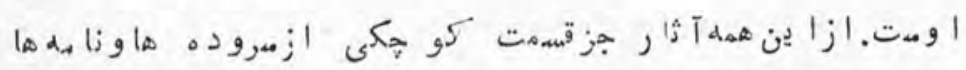

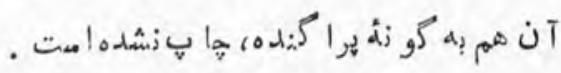

91 
مفتخ خوار ان

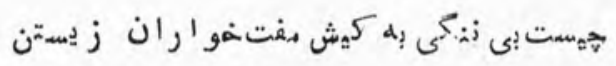

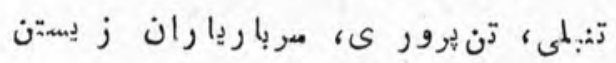

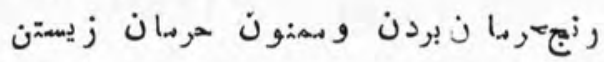

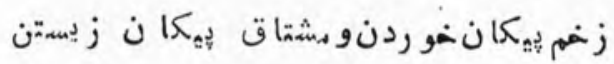

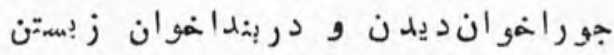

كرها تست

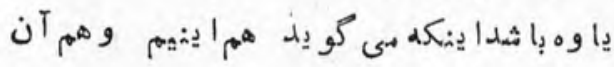

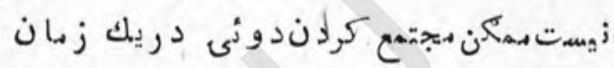

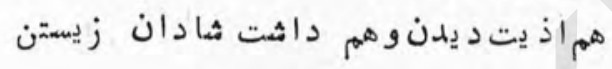

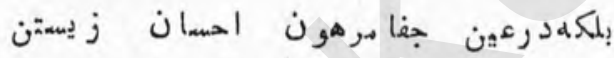

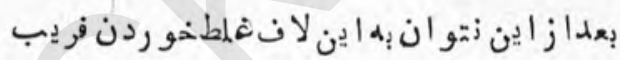

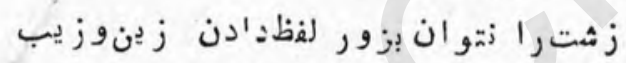

لان يارى ها زدنازندر عمل خصهم ورقيب

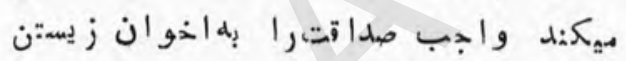

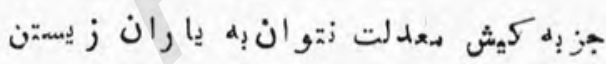

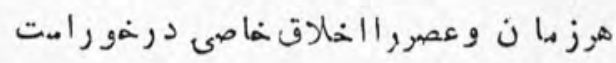

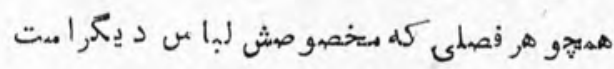

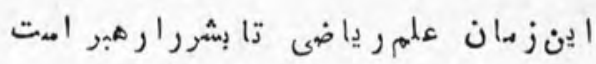

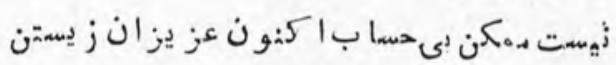

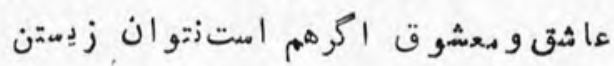

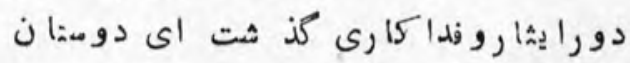

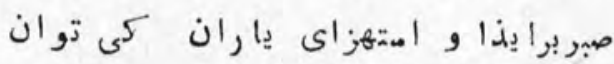

ir 


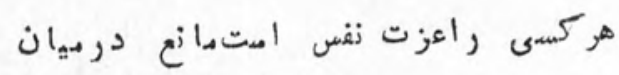

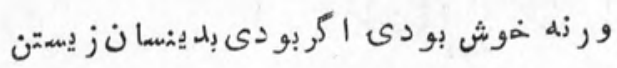

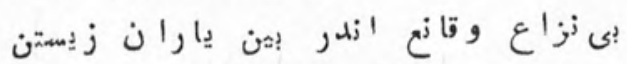

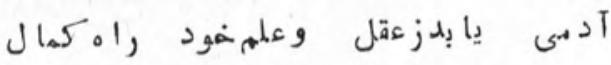

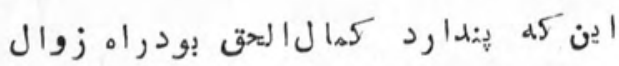

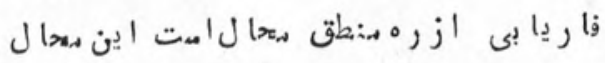

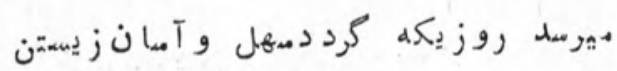

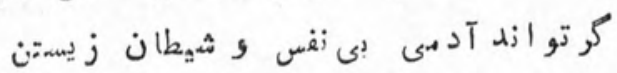

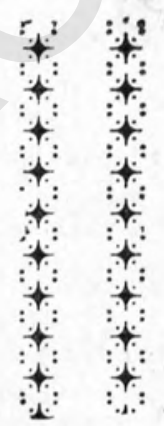

ir 


\section{كمال حسن}

مصور ازلى هون نمود طرح وجود

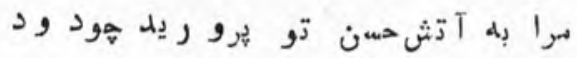

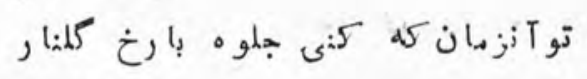

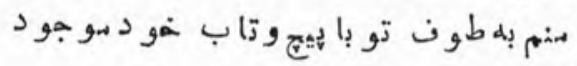

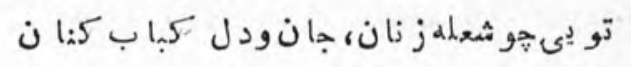

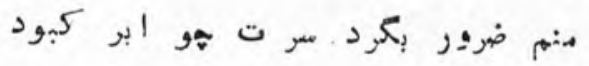

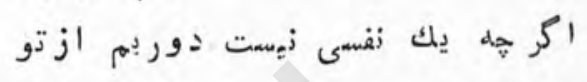

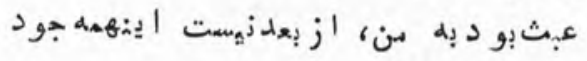

$$
\text { تو يى كم مرده ز تو ميهرد فيوض حهات }
$$

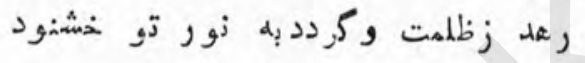

تو يى كلهد زوصا لاتو زنده، افسرده

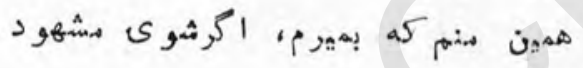

كمال حسن تو مربوط برزوال هنست فئ

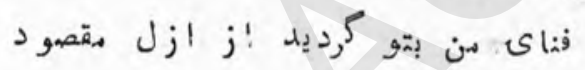

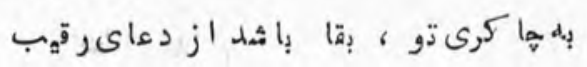

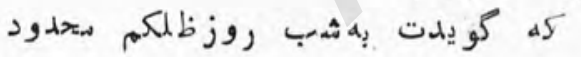

إدين طريق بروت به بنستم كردد

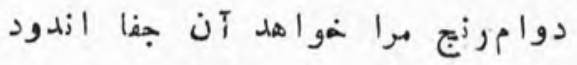

هله سازم ا بن كه وصأل تو بر بهنست كداز

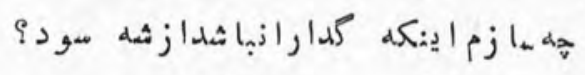

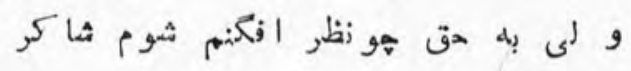

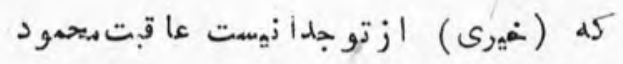


موشئ

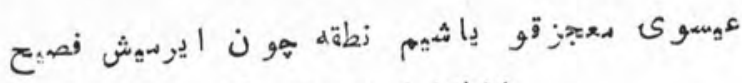

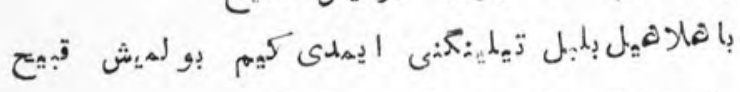

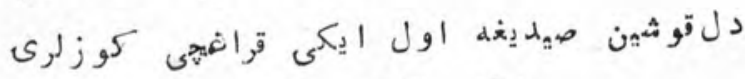

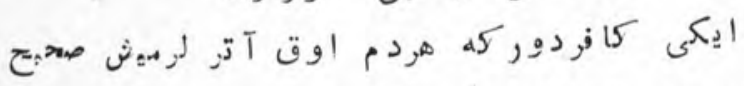

لعل جانبخشى دورورو جان كوز لرى كر آلسيد هم

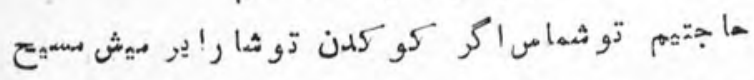

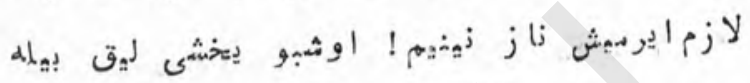

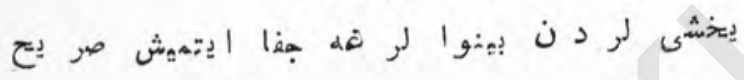

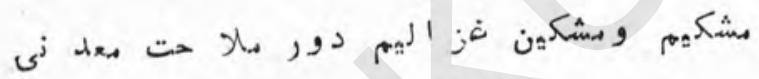

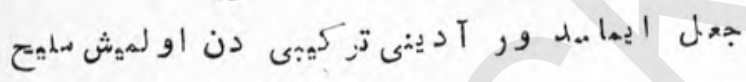

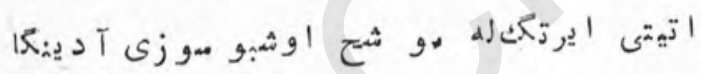

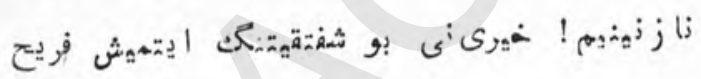

90 
قو انتكو كيجֶ)

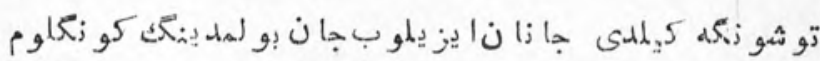

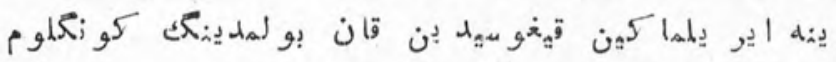

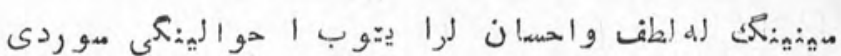

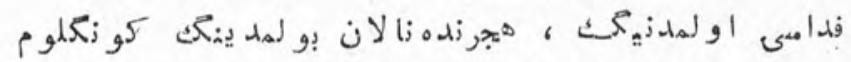

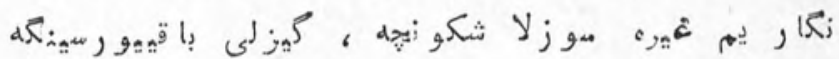

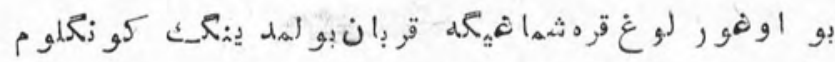

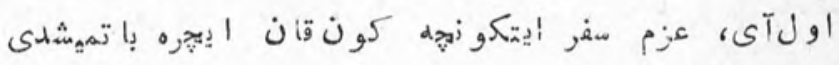

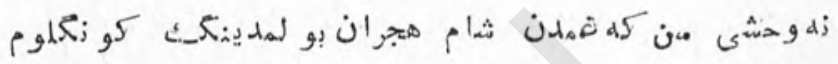

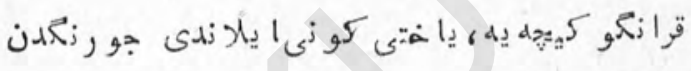

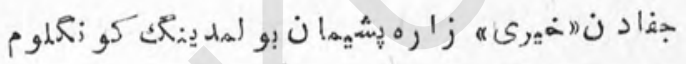

77 


\section{$\$$}

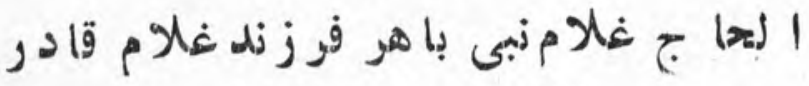

$$
\text { (ش.A IFهA-1FAY) }
$$

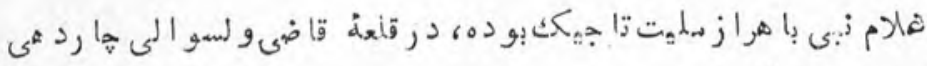

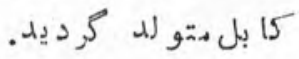

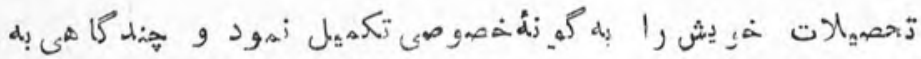

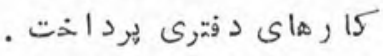

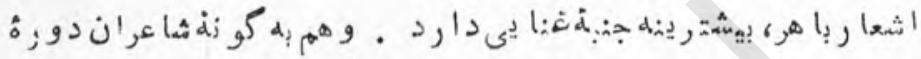

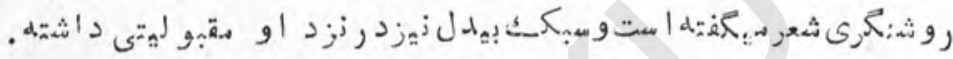

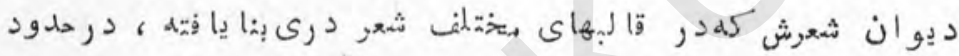

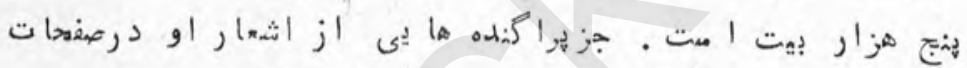

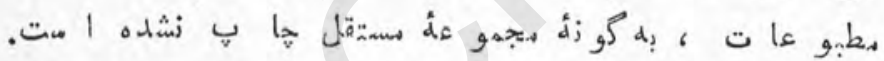

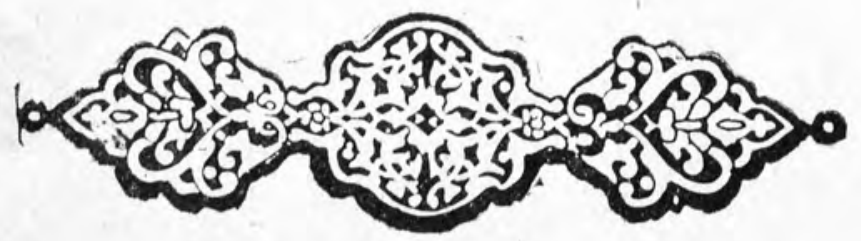


dolivis:

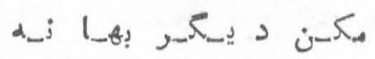

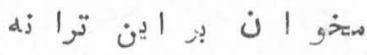

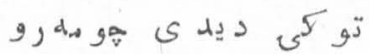

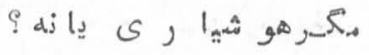

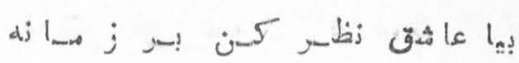

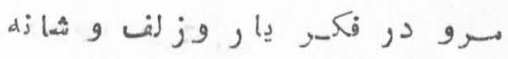

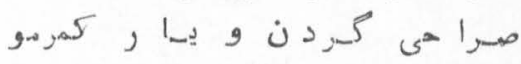

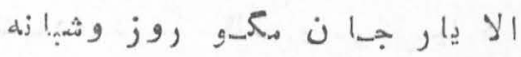

*

s;lig g $X_{n} j$ oT d 5

\&

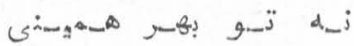

بله إنا

*

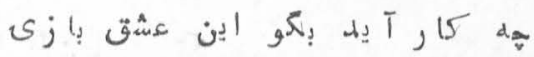

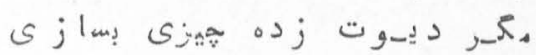
जinj j j ا s ز
头

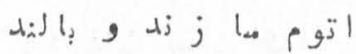

dis

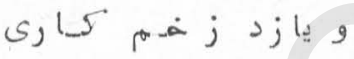

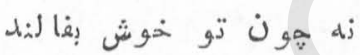

* * *

$d_{\text {ij }} 1.5$,

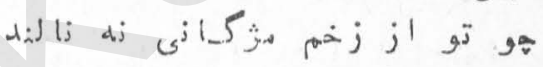
ى) la

ی

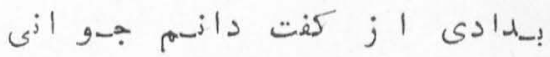

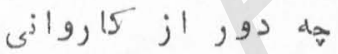

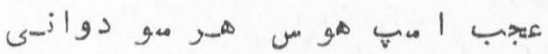

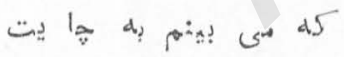

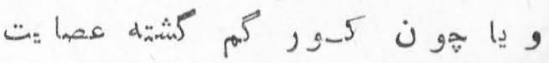

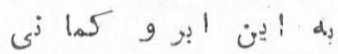

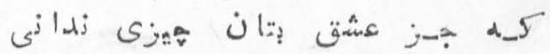

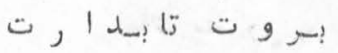

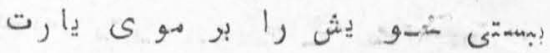

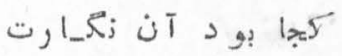

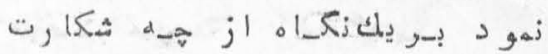

بل ! ين وصنا

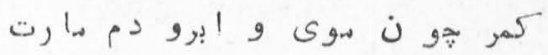

ئ

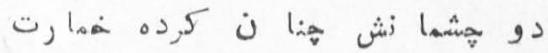

*

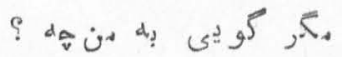

؟ d ه

تراب إl إبن

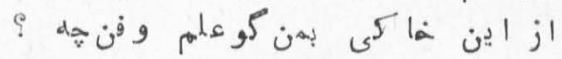

71 
د.

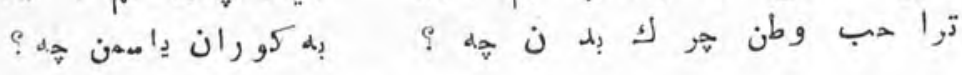

إلى

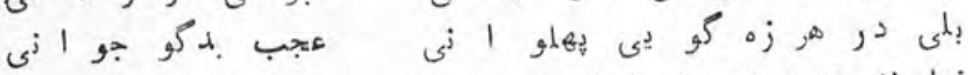

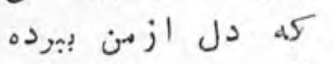
ه) هله

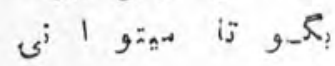
لكر *

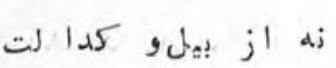

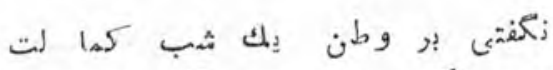

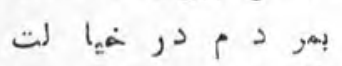

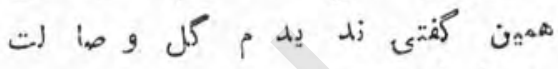

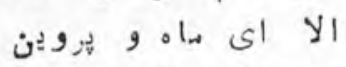

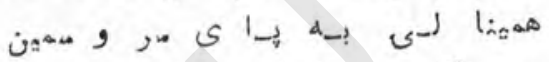

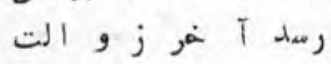

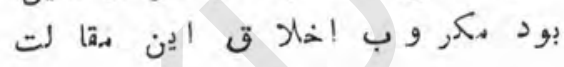

د, مu

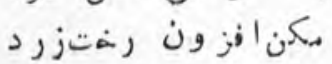

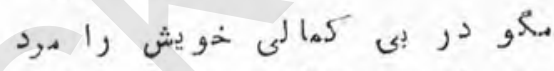

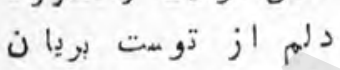

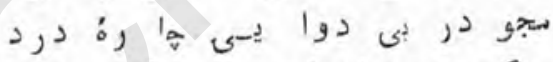

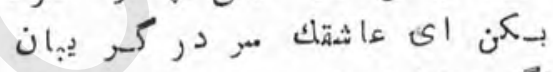

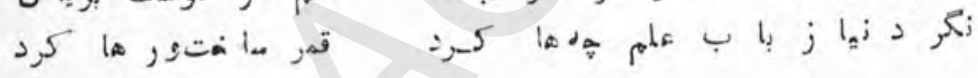

*

*

*

كر به

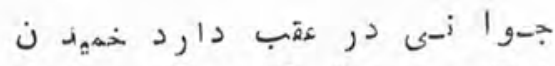

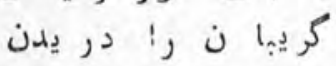

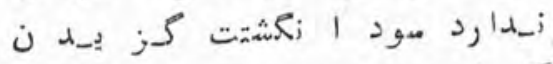

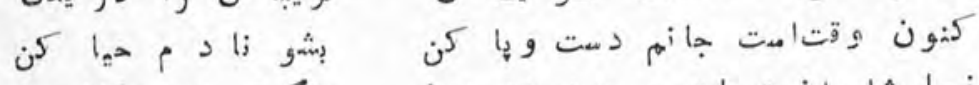

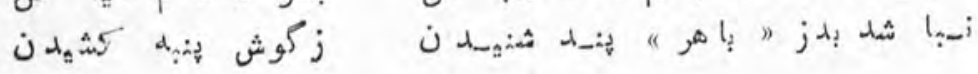
*

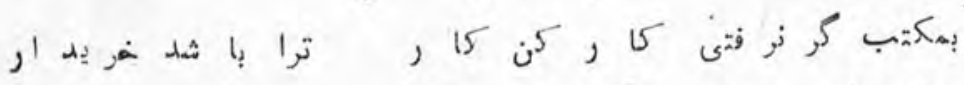

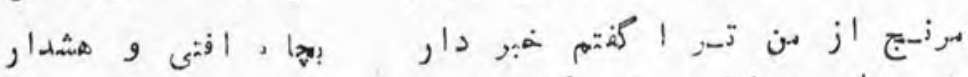

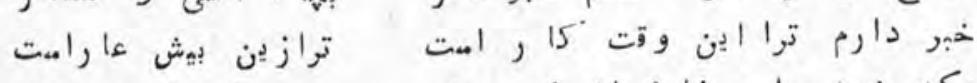

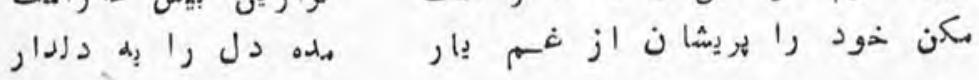

79 
oldo

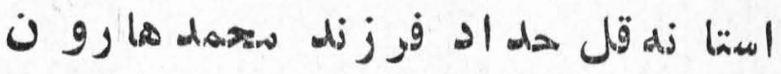

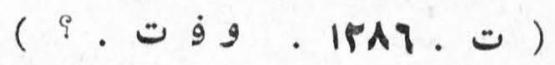

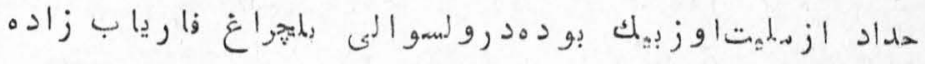

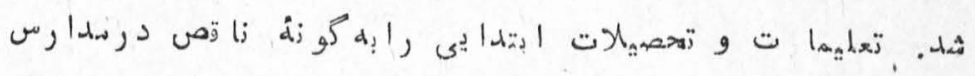

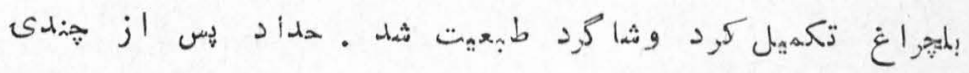

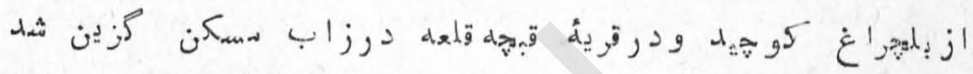

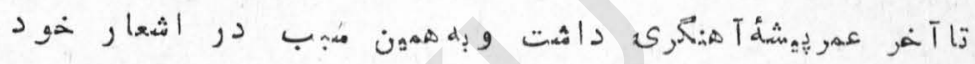

ملداد

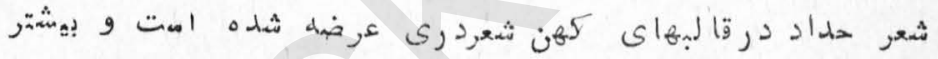

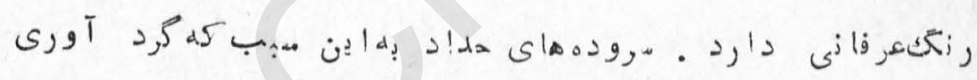

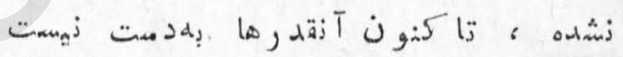

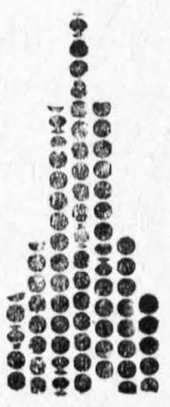

$v \cdot$ 
نجمثن

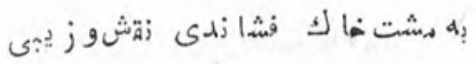

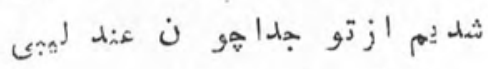

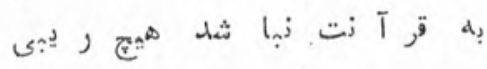

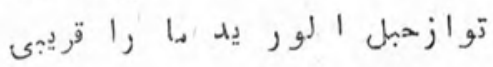

ज:

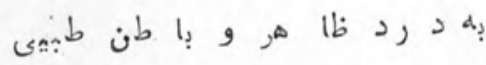

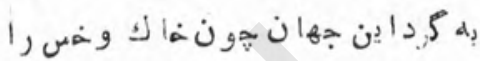

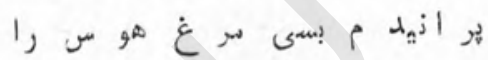

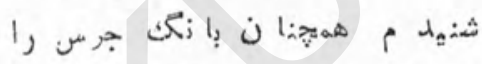

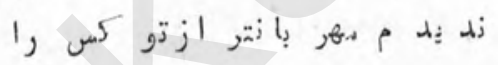

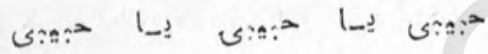

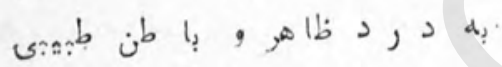

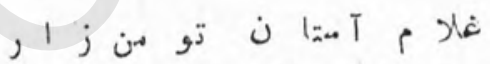

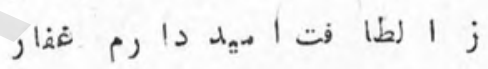

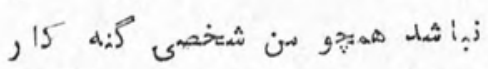

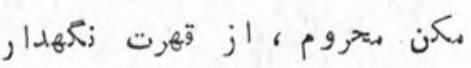

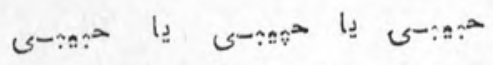

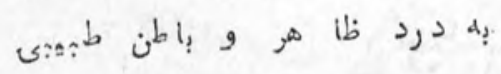

YI 
عاجز

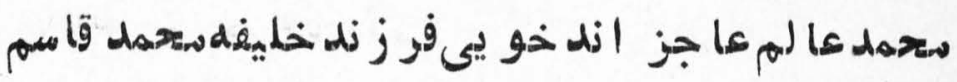

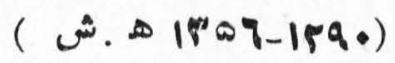

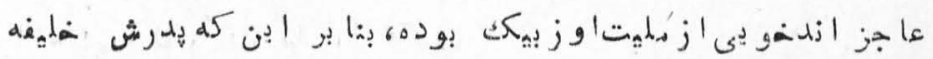

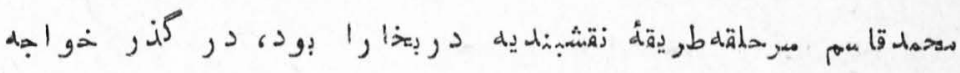

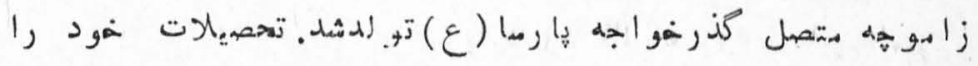

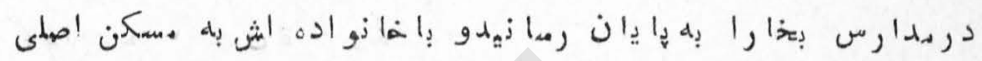

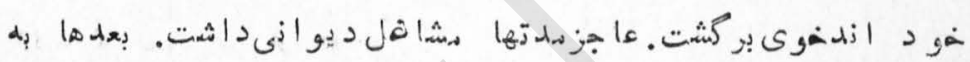

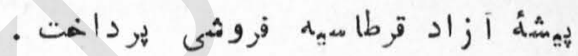

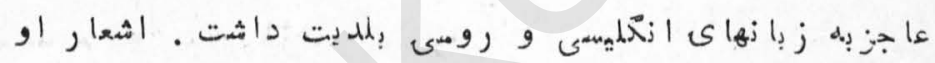

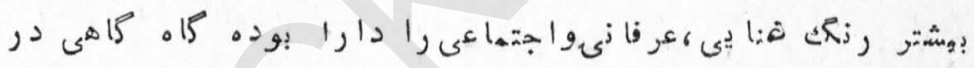

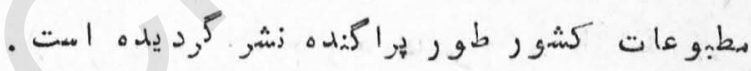

,

vr 


\section{أز}

\section{زظو دهمال اغزى فوز زله عبد اليجما و \\ (A A (prpa-irqu)}

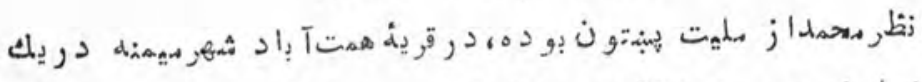

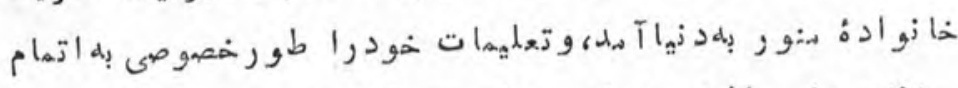

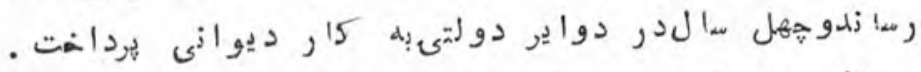

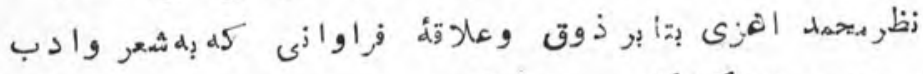

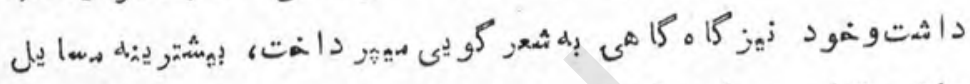

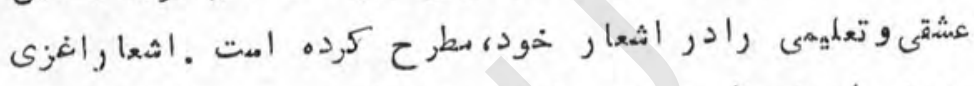

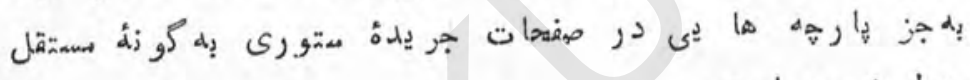
- بa

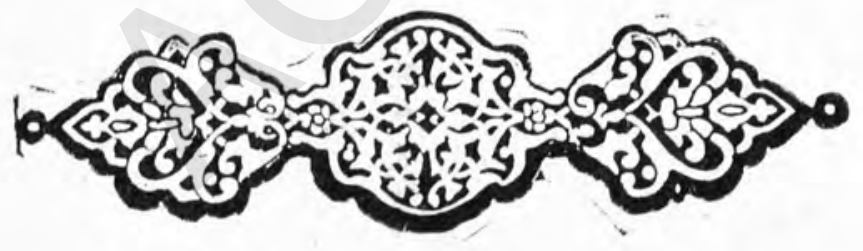

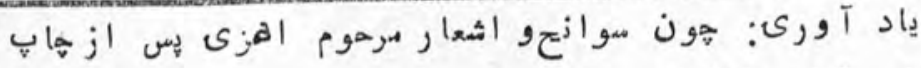

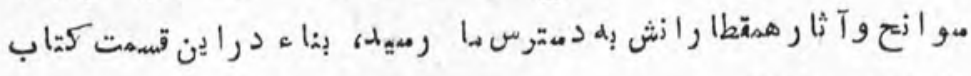
. 


\section{غرور حسن}

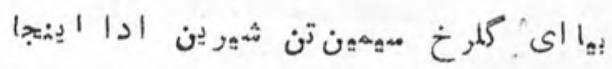

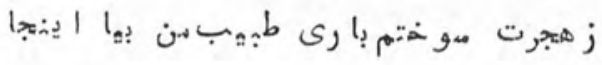

$$
\text { زاحو المب اكريومبى شوم دهكو م احسا نت }
$$

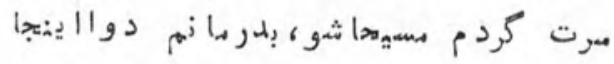

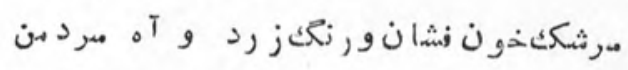

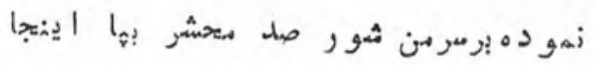

$$
\text { ثده عمرى زهجرتو هلمول ومنةته و زارم }
$$

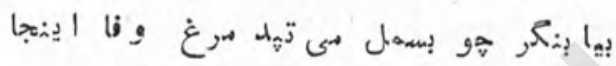

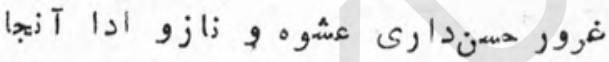

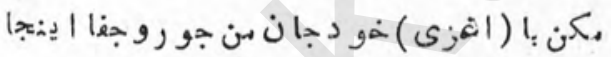

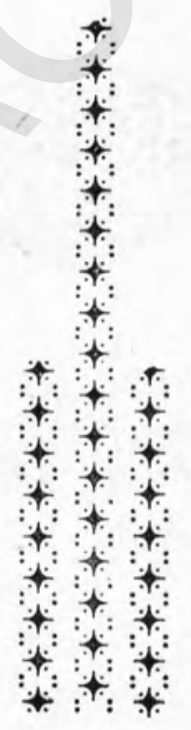


شوقديدار

براز خلوت وصلش لبام فخر زوثميدم

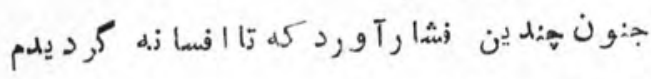

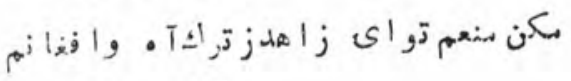

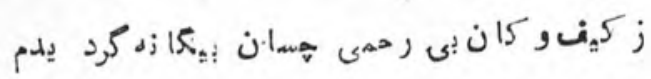

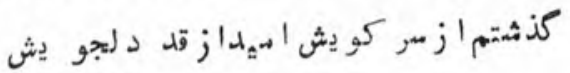

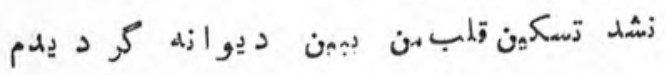

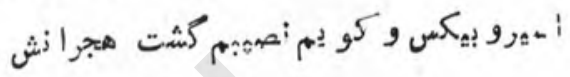

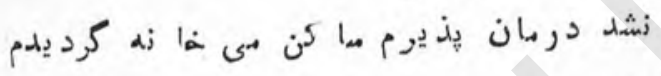

كشيد م ديح:ت هجران زدأرم ثشكو مُاز دهر

?

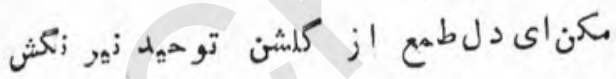

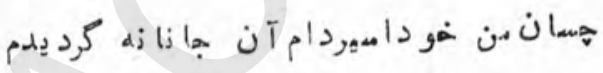

va 


\section{قد دلمتجو}

$$
\text { ز يُتت كلزار جنتبى كل "روى تو زيست }
$$

مرو. بالين راستى ههون قدد لجزوى تو زيست

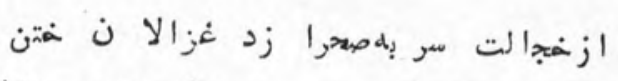

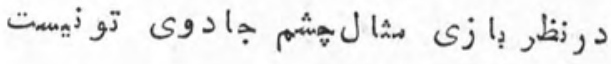

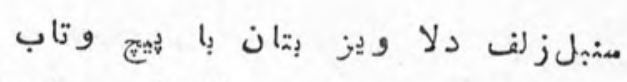

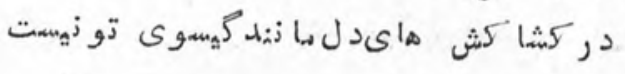

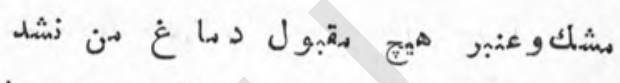

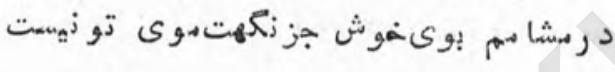

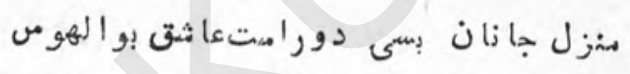

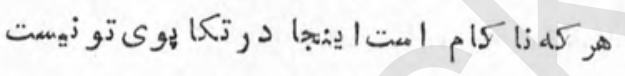

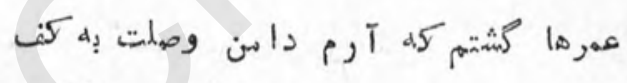

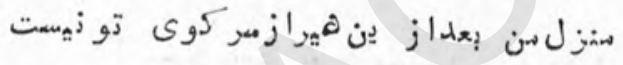

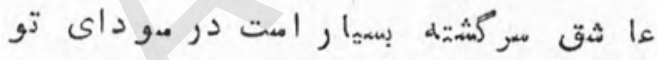

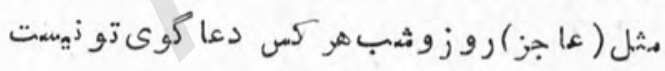

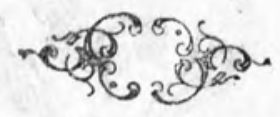




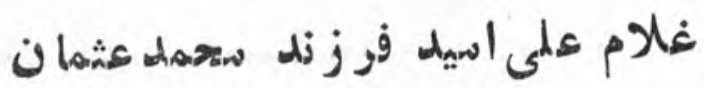
( ش. . 1

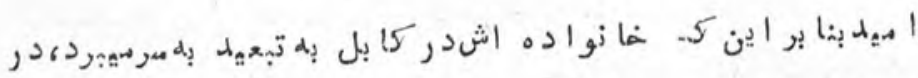

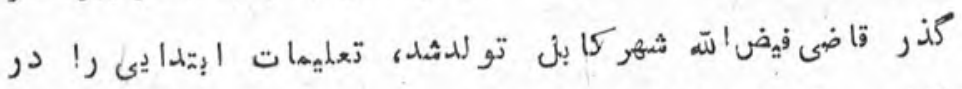

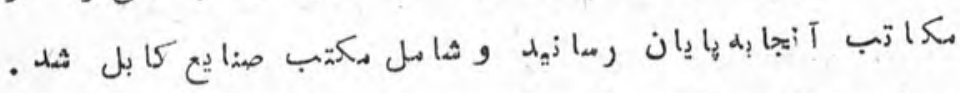

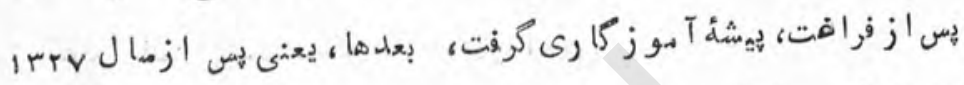

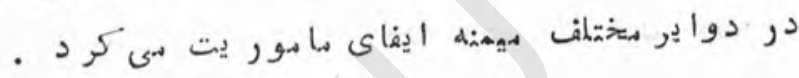

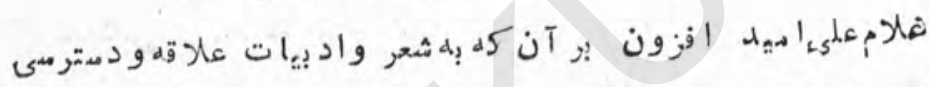

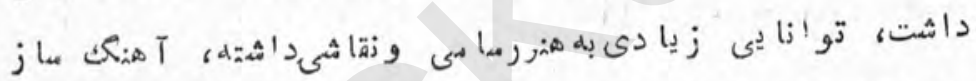

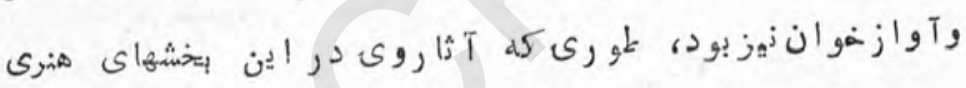

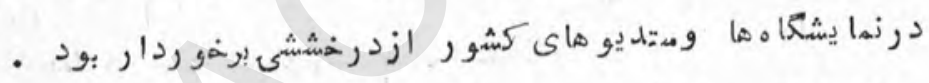

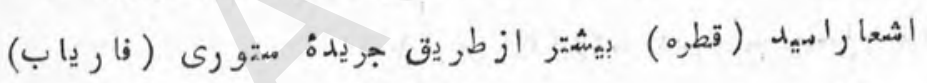

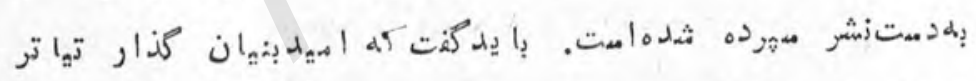

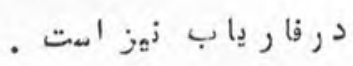




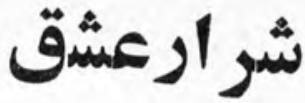

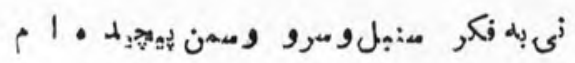

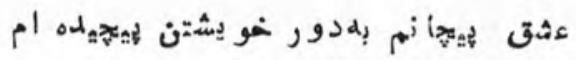

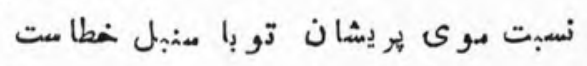

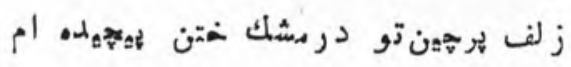

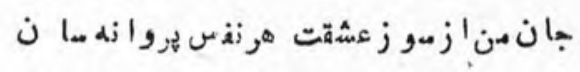

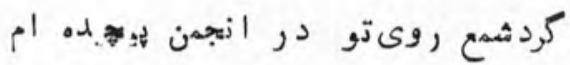

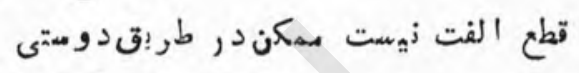

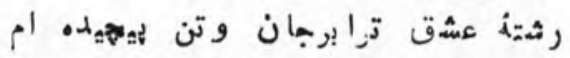

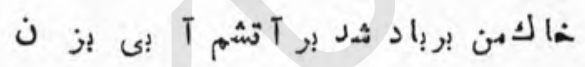

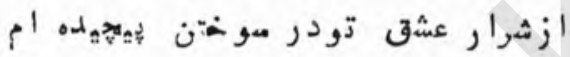

درهو ائ عشتى ثير إنجا نشير بند ادور نت

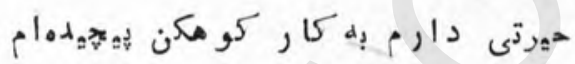

$$
\text { ازجفا و جور كردون شيد نص:مبماشكوآ. }
$$

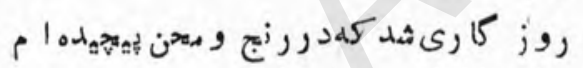

舟

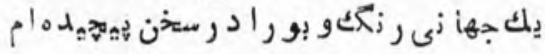

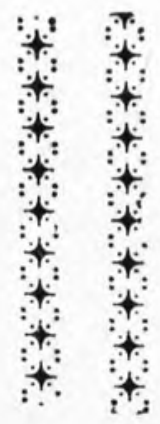


بو برأشمشئر

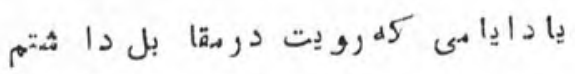
دمت خمود بركردن زازت مها يلم يل داشتم

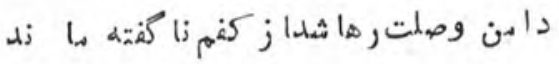

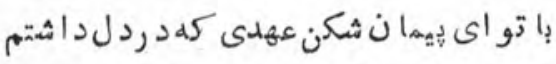

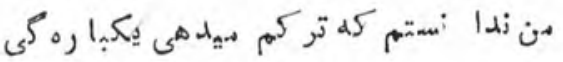

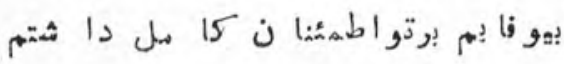

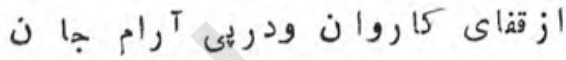

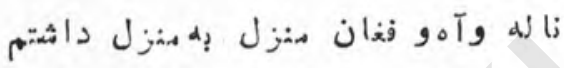

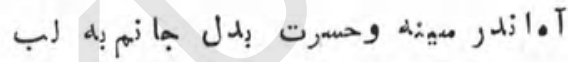

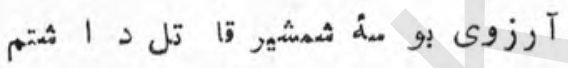

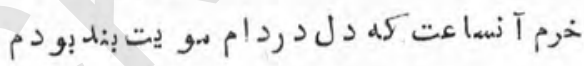

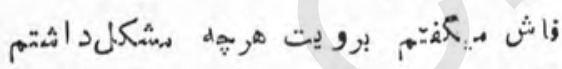

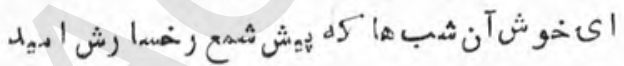

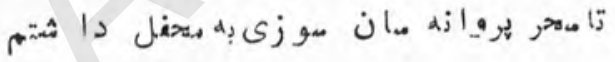

va 


\section{علمى فاريابى}

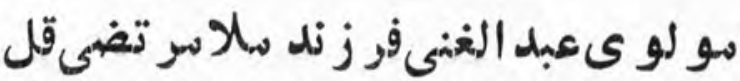 (A. $\Delta$ ( r D - I rqp)}

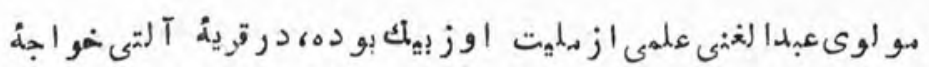

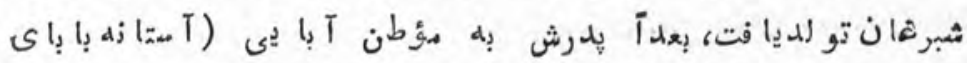

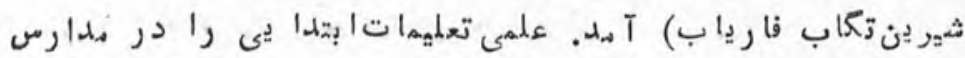

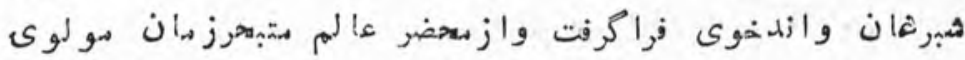

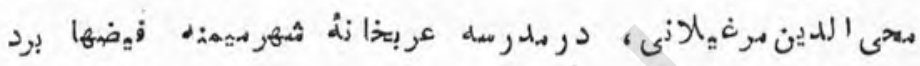

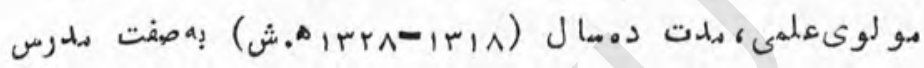

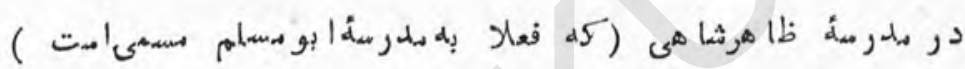

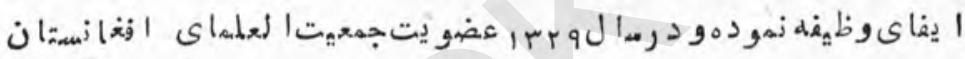

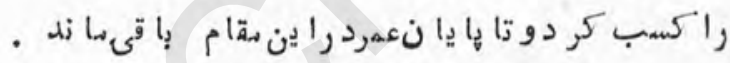

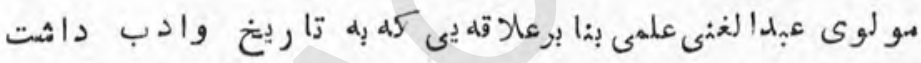

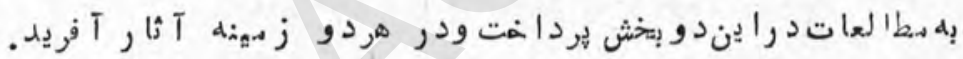

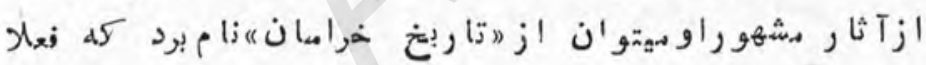

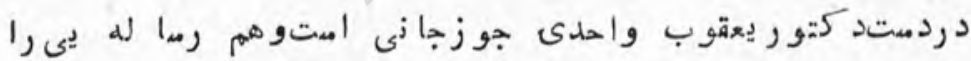

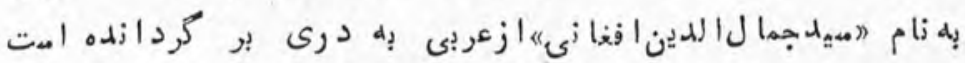

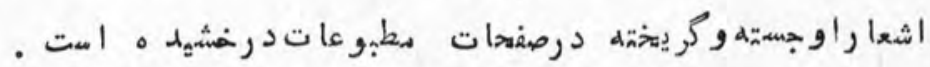

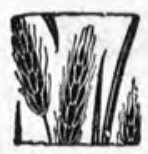


آبروى الهم اسلامبود

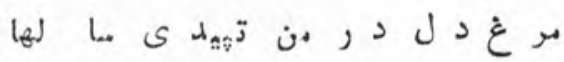

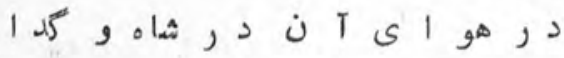

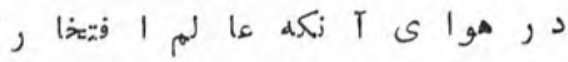

, läj la la

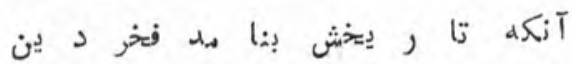

جا

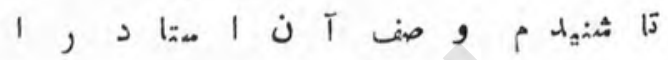

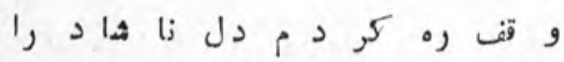

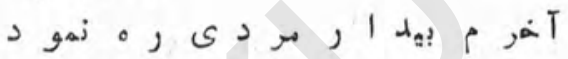

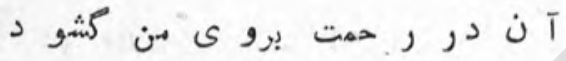

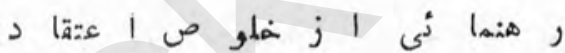

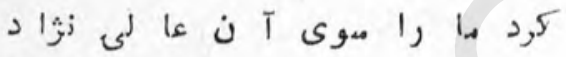

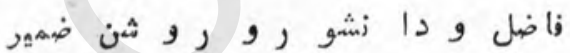

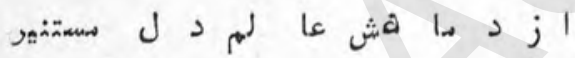

تر بتش بر

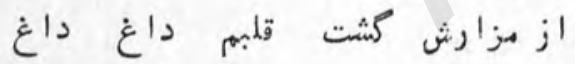

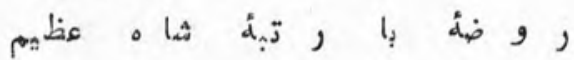

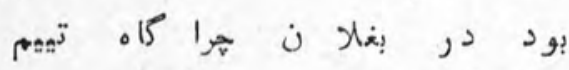

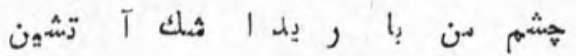

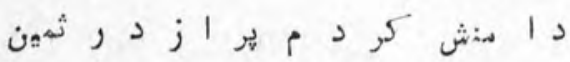

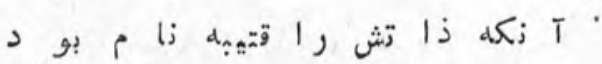

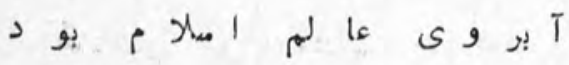

AI 
ازدم ان ر و ح در دين آر بيد

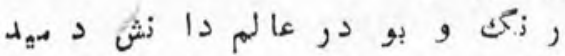

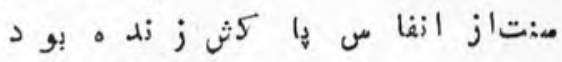

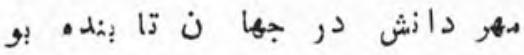

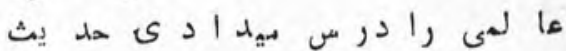

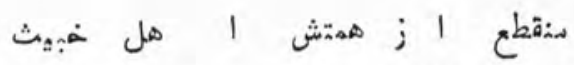

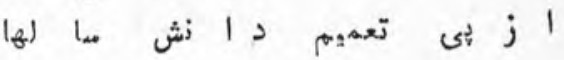
تر ك كت كته

حضر تش بدر عطل نى أبو دم ا مت

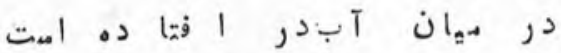

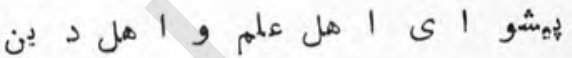
و إنها

در زئو ن عـلم آن السما د إبو د

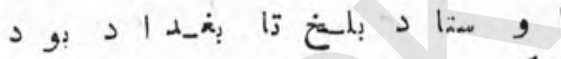

هو ن بذخارى دار د آن شـا كرد د دين

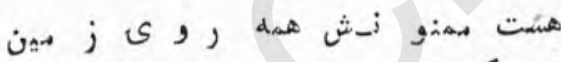

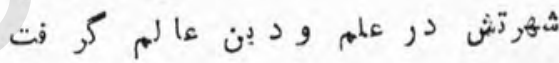

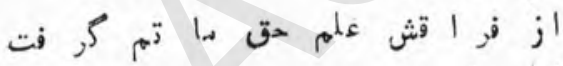

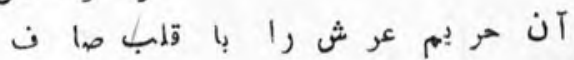

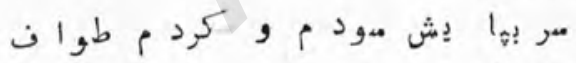

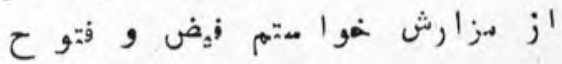

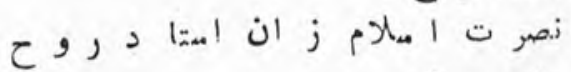

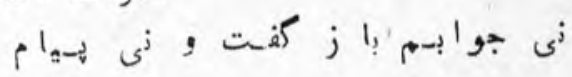

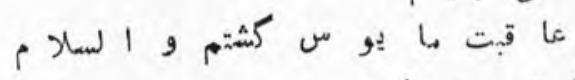

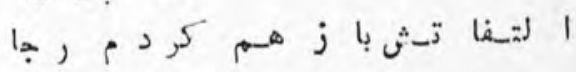

ا

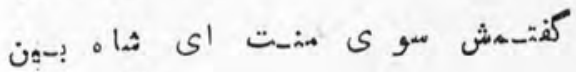

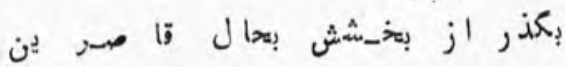

Ar 


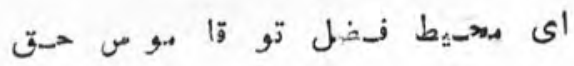

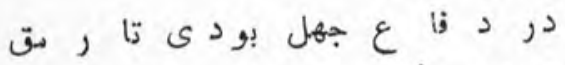

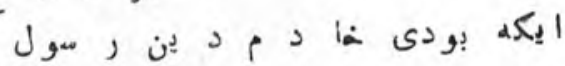

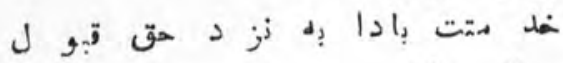

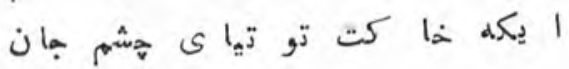

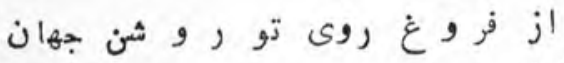

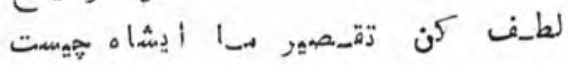

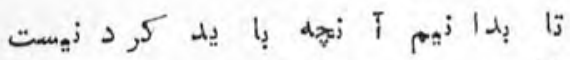

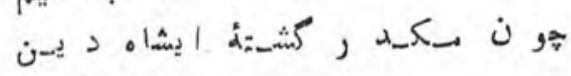

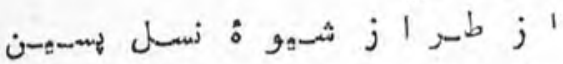

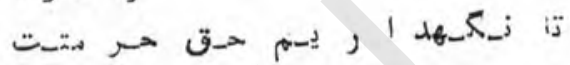

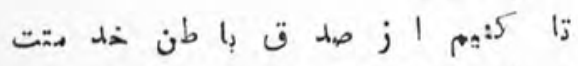

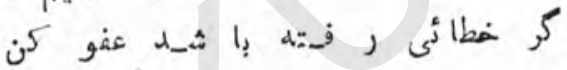

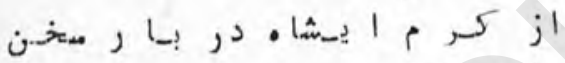

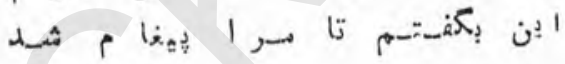

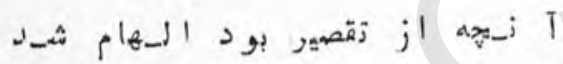

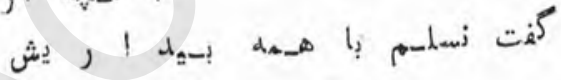

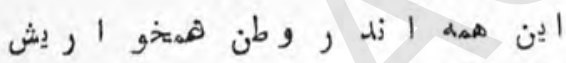

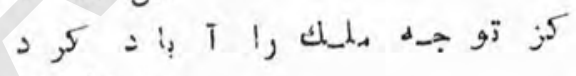

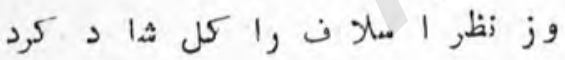

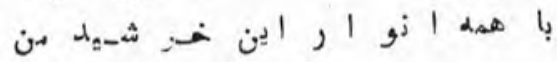

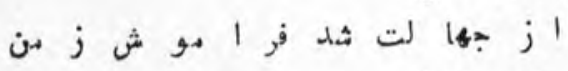

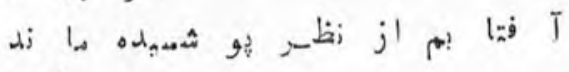

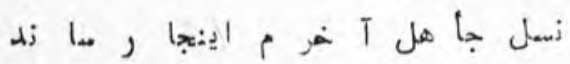

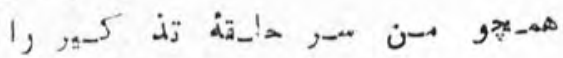

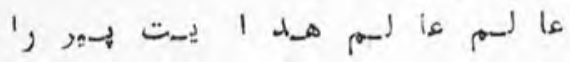

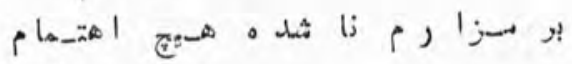

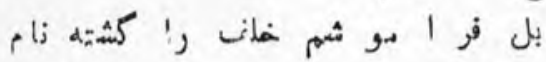

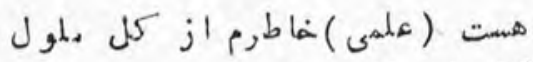

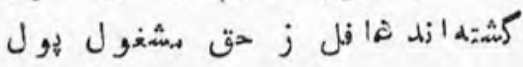

AP 


\section{مهربان آنه}

ثين ايرورمن اي وطن جا زانه ميز

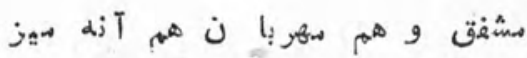

$$
\text { صدق دلدن خدلمتيمك واجب ايرور }
$$

قويسمةهموز كرعاة قل ودوديوانه مثيز

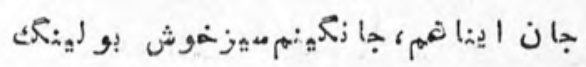

شادونمر شيرو شكر نوش بوليمكن

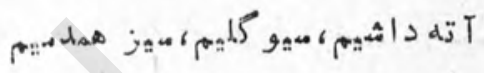

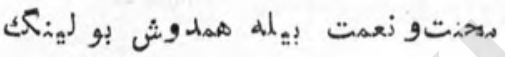

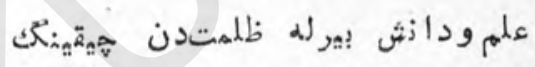

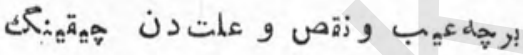

$$
\text { او لكهلى نى آباد و عمران إيتما لى }
$$

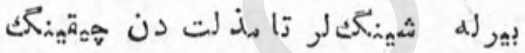

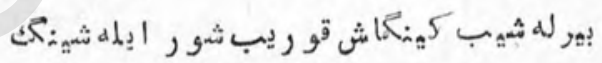

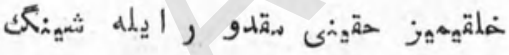

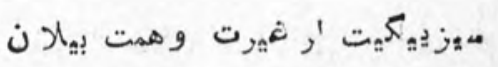

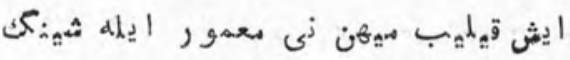

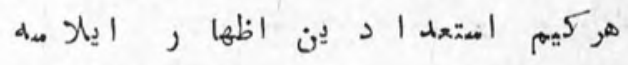

عاطل اولمكك دن بوتون عار ايلهه

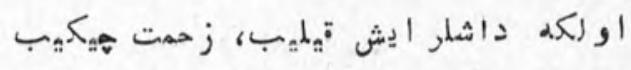

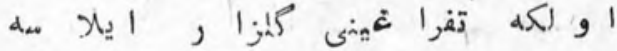




\section{جويان بلجر اغعى}

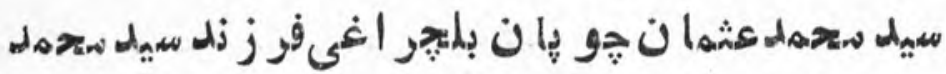

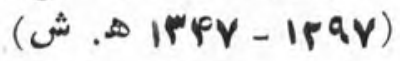

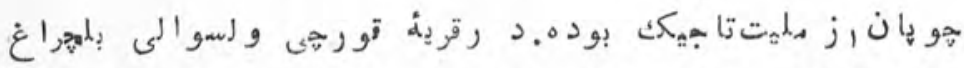

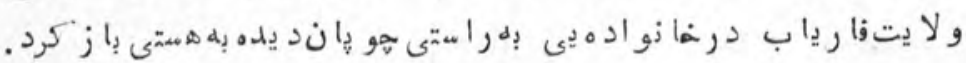

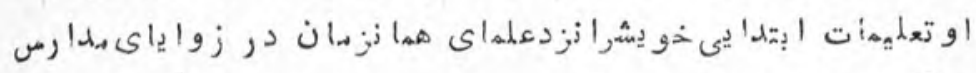

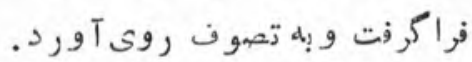

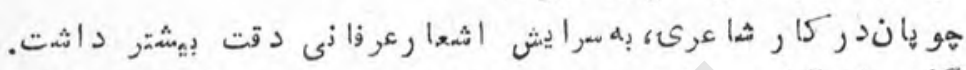

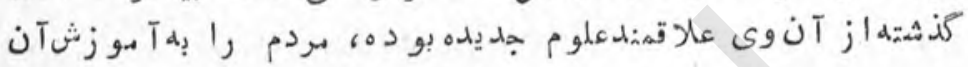
تشو يق ميكرد

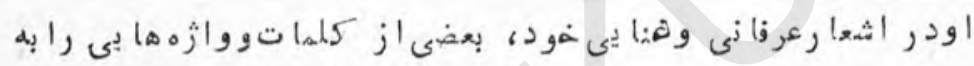

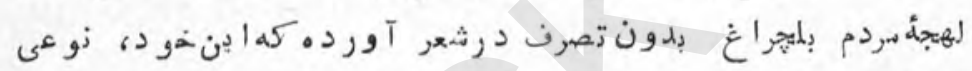

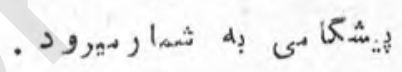

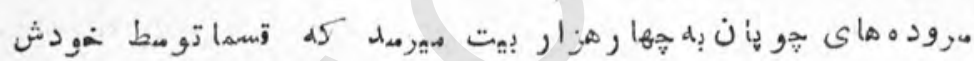

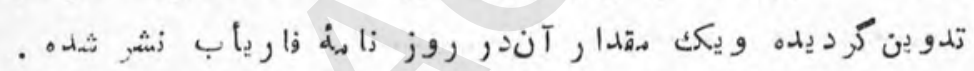

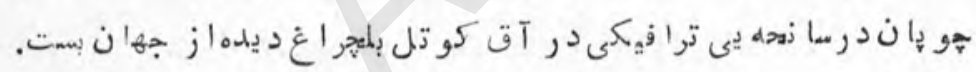

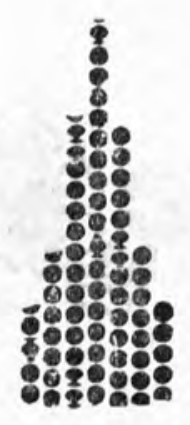


رندخر ابات

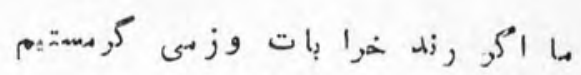

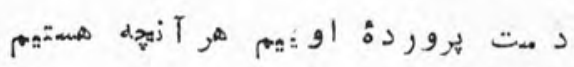

$$
\text { ها مبريد بى ديربن و خهر اب دياريم }
$$

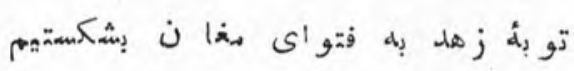

از ر يا إيمرهغان كفت بهرهيز به جان

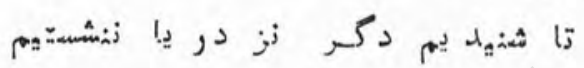

زانز نانست كله اززهد فروشان نمان

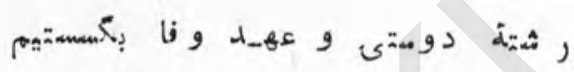

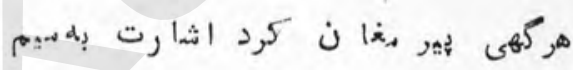

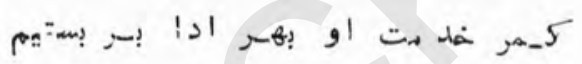

تا كلها فتماد بهي خا نه مبرو 15 رم دوش

حمداسلة

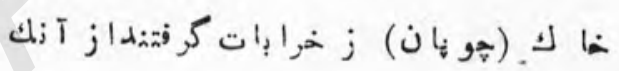

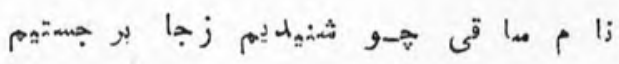

A7 
لذت دنيا

عا شقا ن را عشّق دلدارش بس امت

از دو عا لم ههر ديدارش إس المت

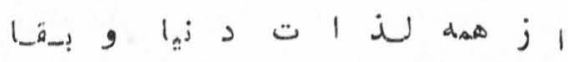

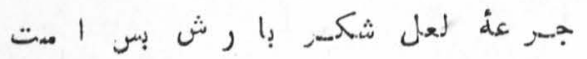

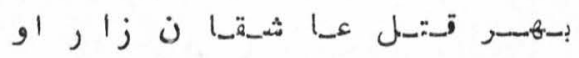

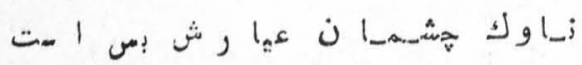

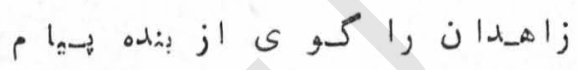

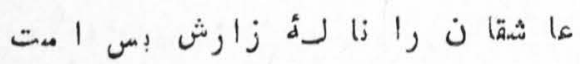

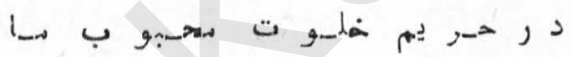

ثشيوه ها ى را'ز و اسرارش بس امت

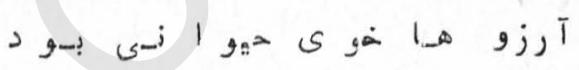

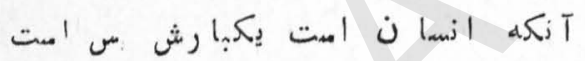

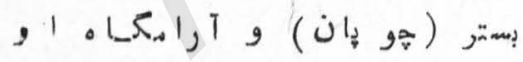

روى خار م ، خماكد لكربا رش بس امهت

AV 
شكارعنقا

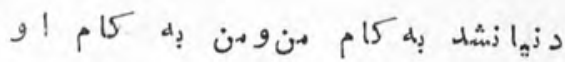

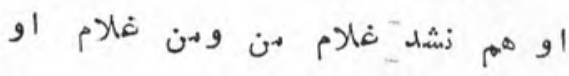

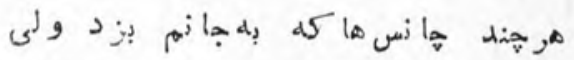

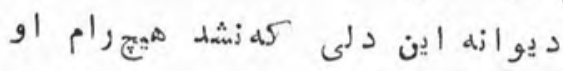

عنقا ثيكا ركس زششود، اين گما ن سبر

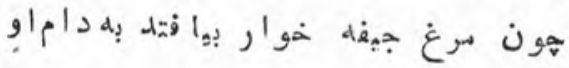

كو ابلمهى فريب عر و س كهن خهو رد هرع

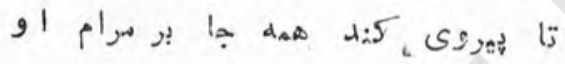

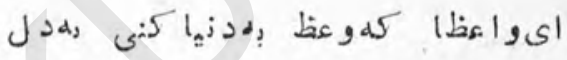

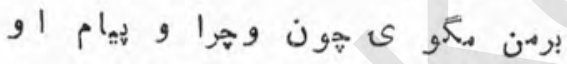

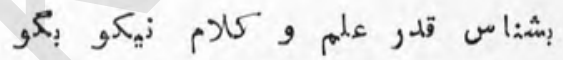

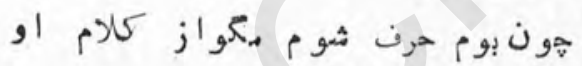

ها را باو زروز ازل آثشى زبود

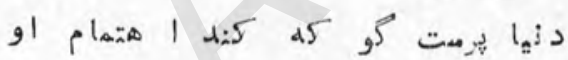

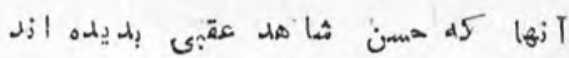

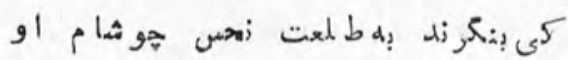

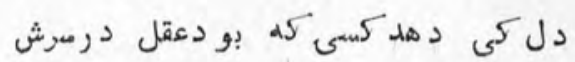

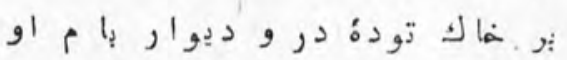

هندين هزارميال كذ شت وزيديد كس

هركز وفا.ى وعده ونه و عهد دوام او

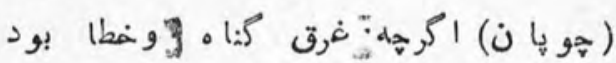

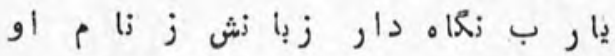

AA 


\section{ز}

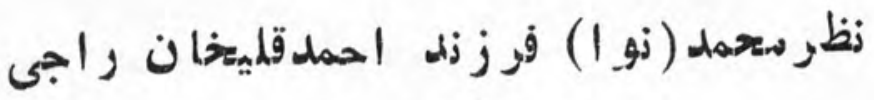

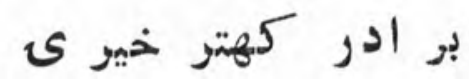
( ش I HAF - Ir..)

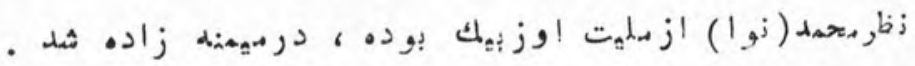

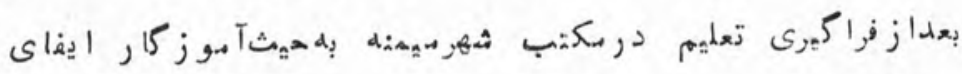

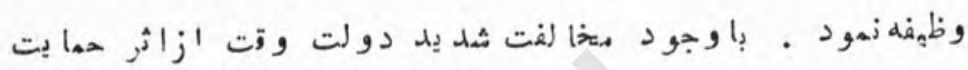

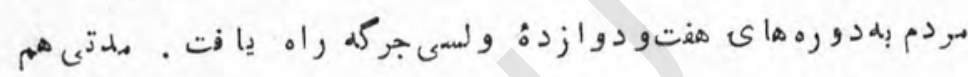

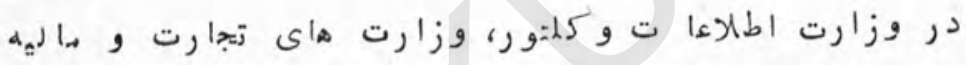

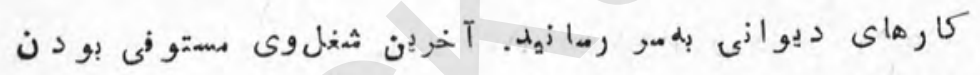

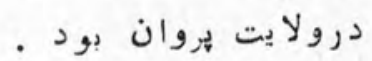

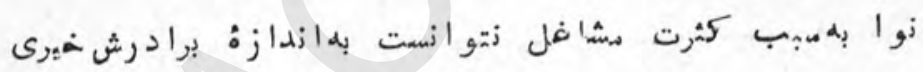

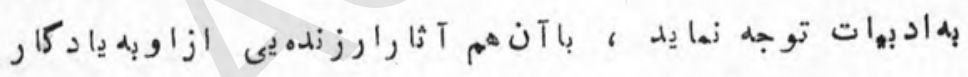

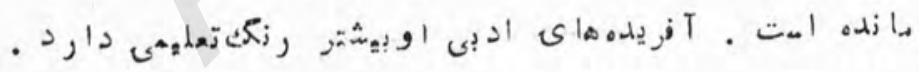

\section{(5)}


ها دإ:

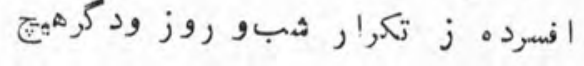

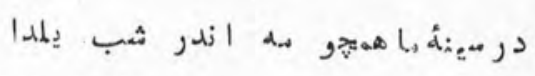

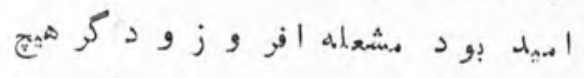
هاو

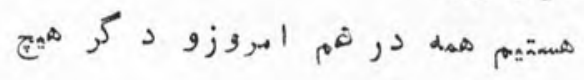

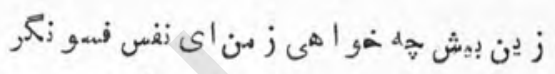

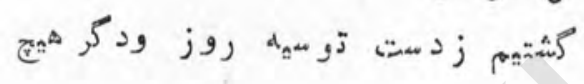

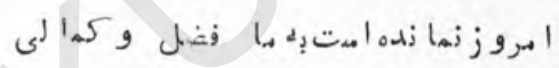
هائمه

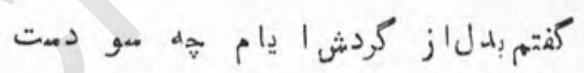

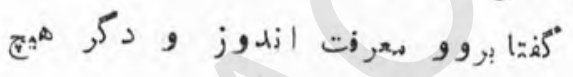

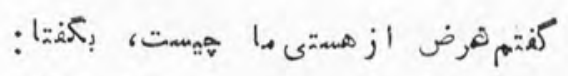

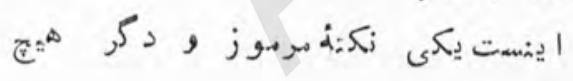

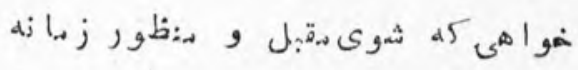
Eم

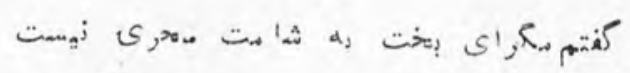

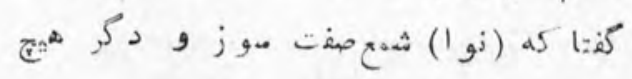

$a$. 


\section{عزيز أفخانسيتان}

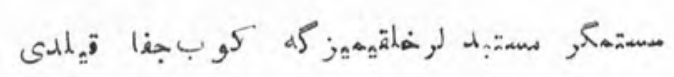

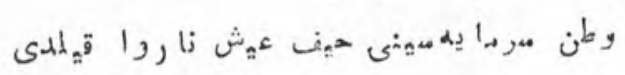

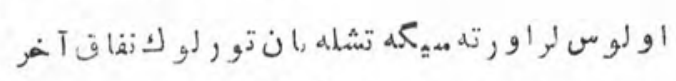

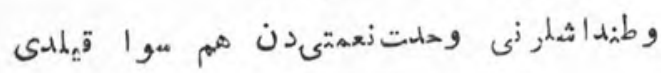

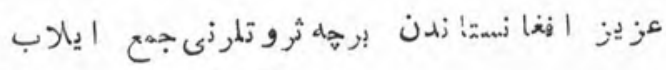

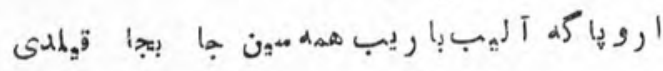

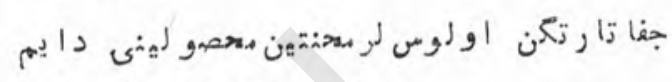

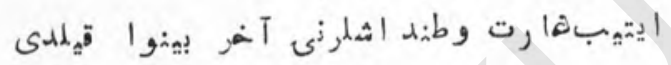

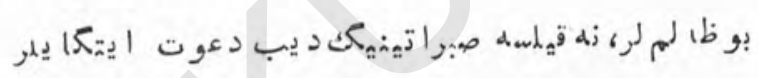

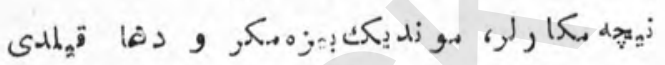

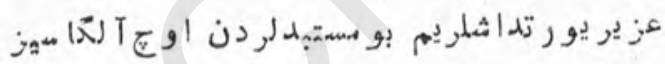

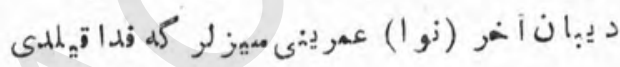

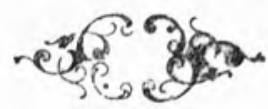


انله خويى

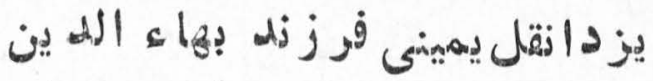

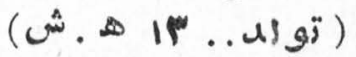

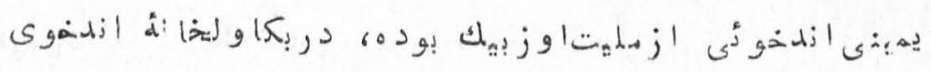

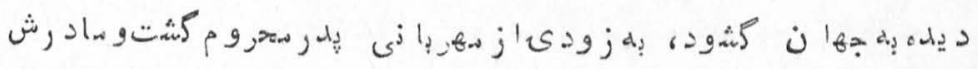

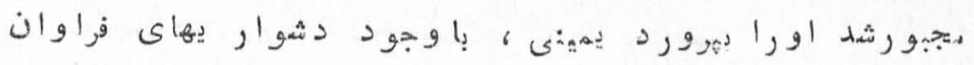

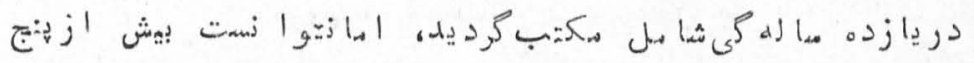

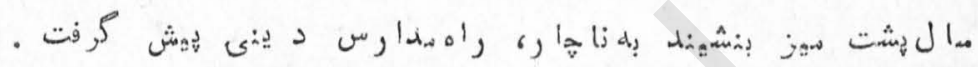

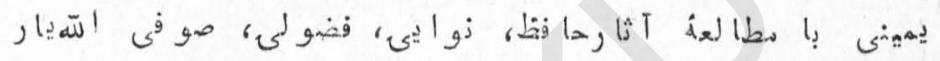

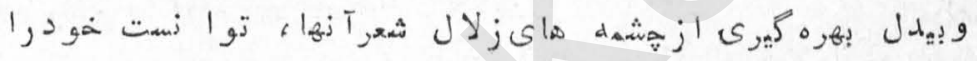

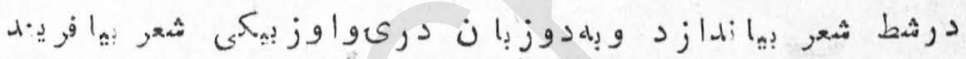

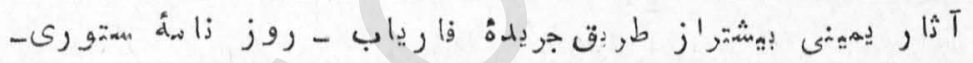

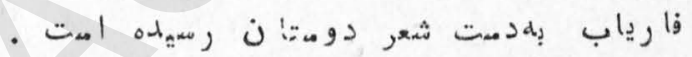

از

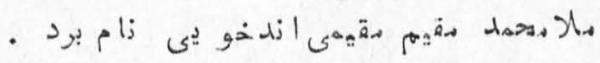

पूरे

ap 
سوو روان

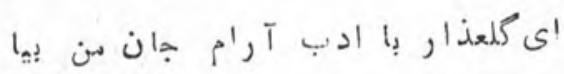

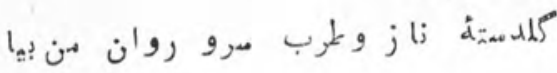

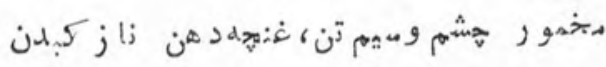

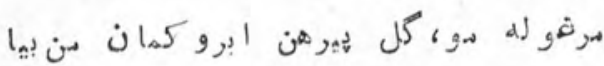

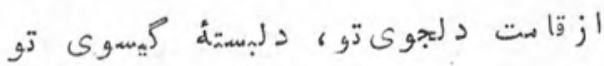

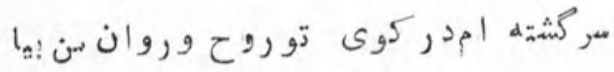

ازعشق تو د بو ازهلهام توشمعْو سن ميروازهام

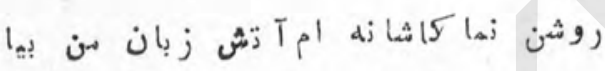

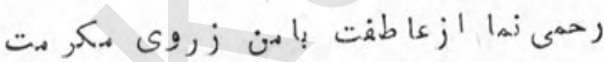

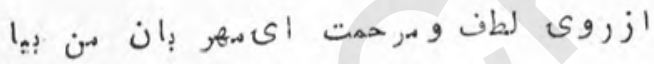

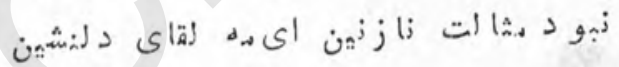

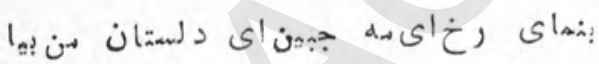

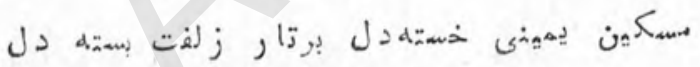

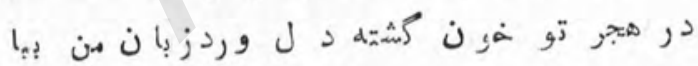

ap 


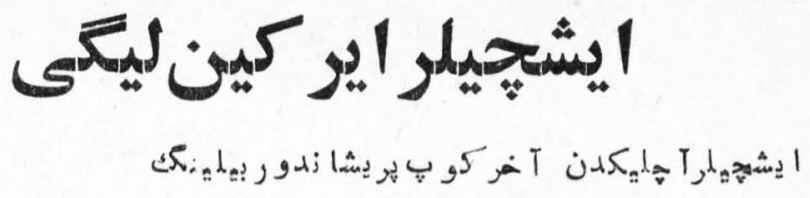

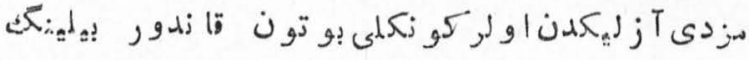

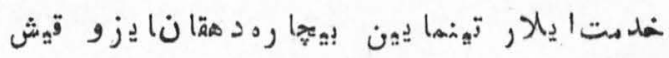

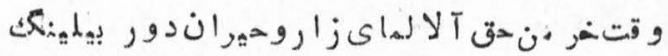

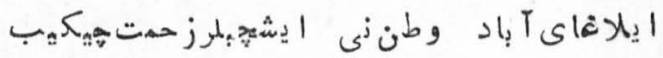

قدرى يوق واحسر تا قنداق بو دور را ند دو ر بيهيم:كك

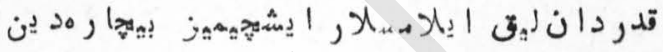

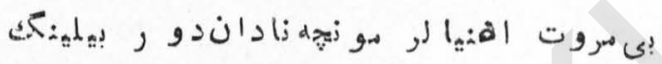

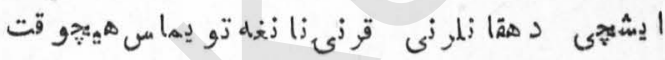

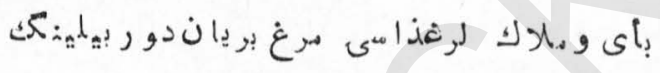

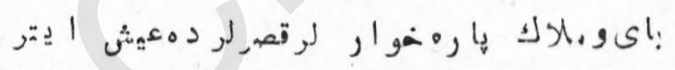

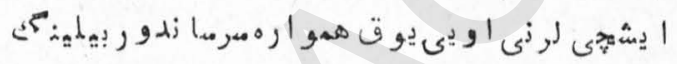

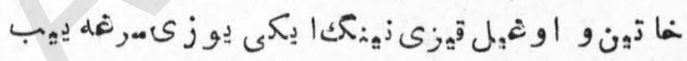

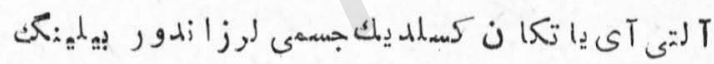

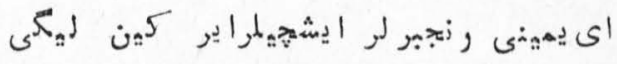

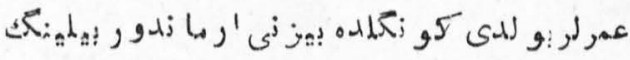

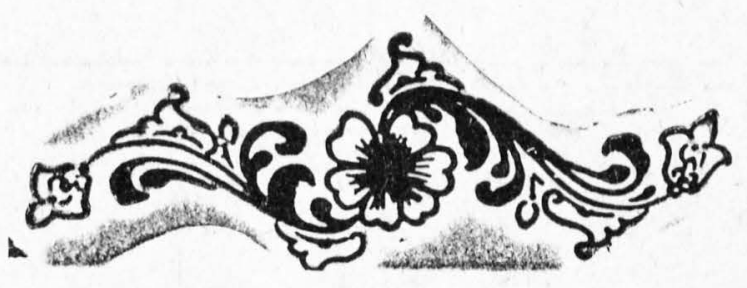




\section{شيال}

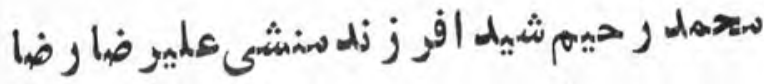 ( ش. .}

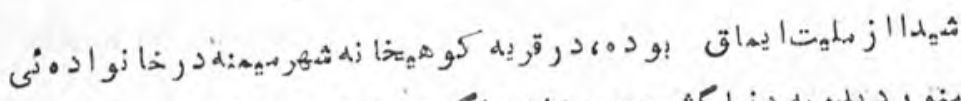

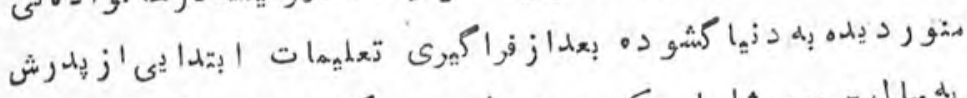

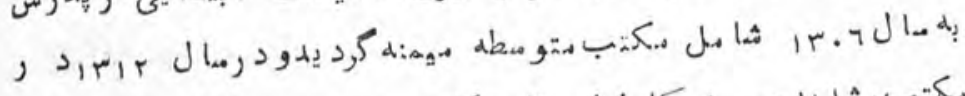

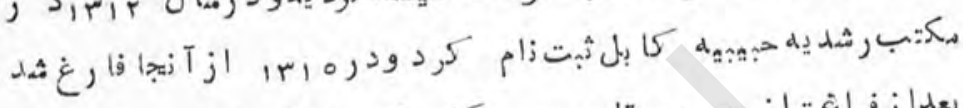

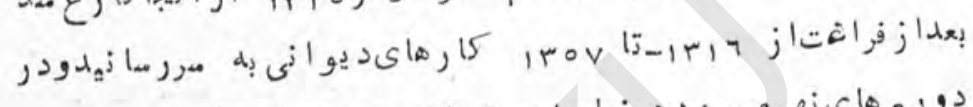

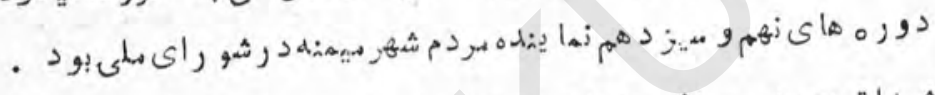

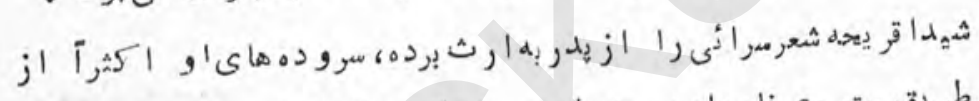

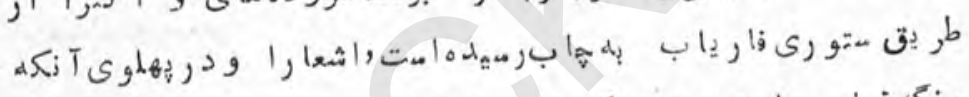

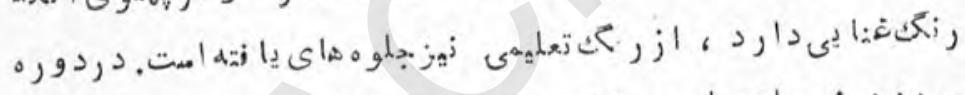

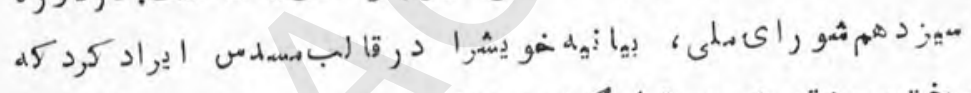

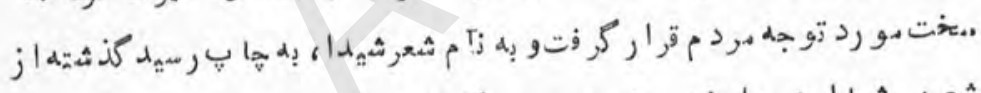

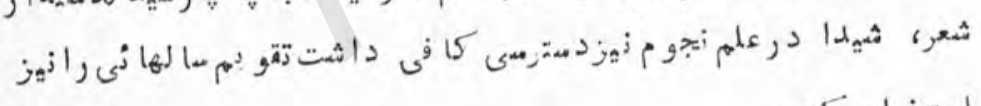

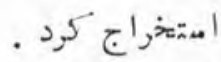

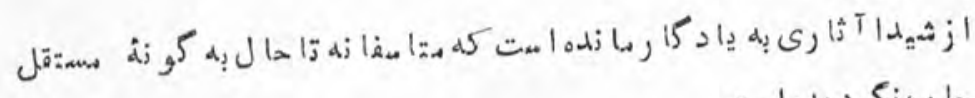

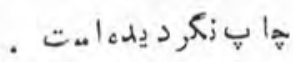




\section{شبوصل}

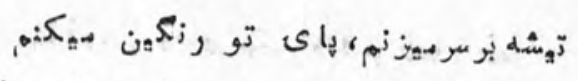

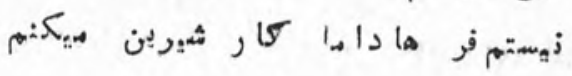

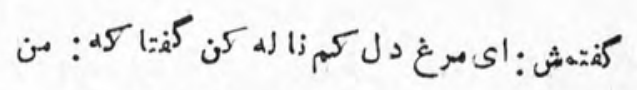

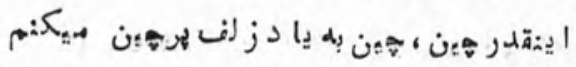

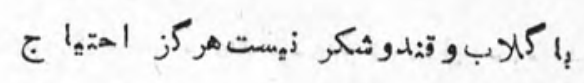

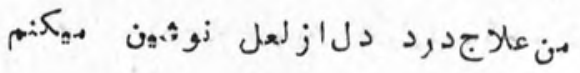

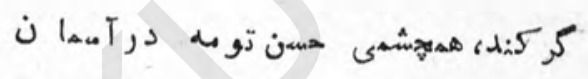

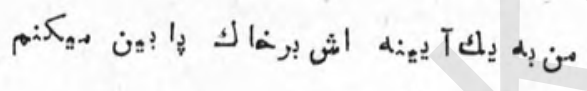

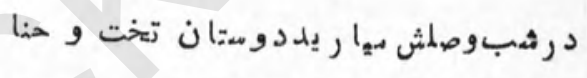

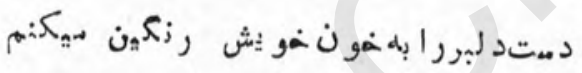

$$
\begin{aligned}
& \text { خ }
\end{aligned}
$$

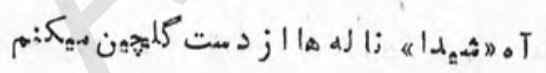

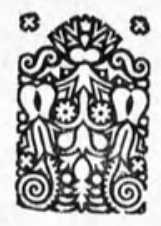


نيم نظر

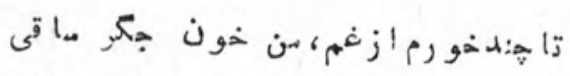

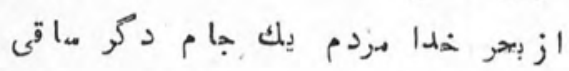

اهشب كله به دمهت تست زيهما زلة عمرها

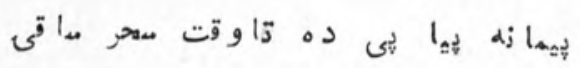

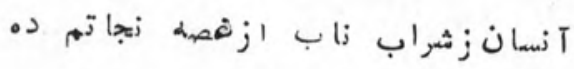

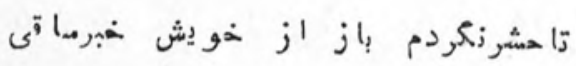

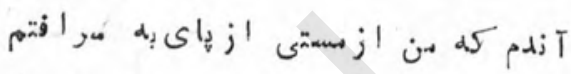

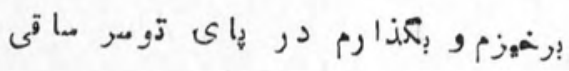

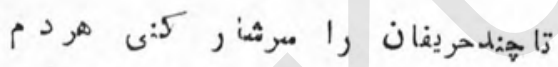

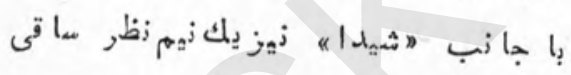

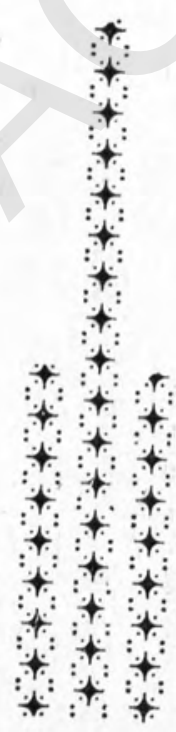

aY 


\section{تيغ ز بان}

T تشمم باززغم بردل و جان سهبا ثشد

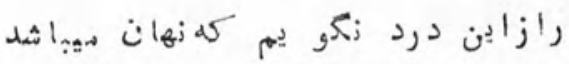

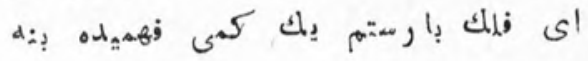

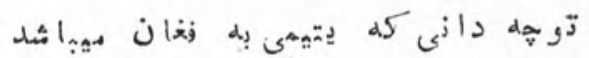

دمت همت شيو و ا ز إير فتياده بر كير

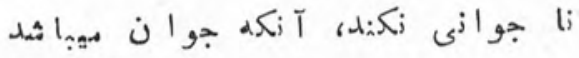

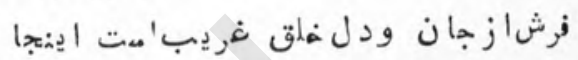

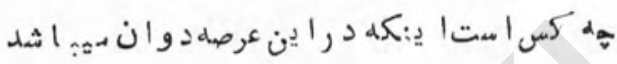

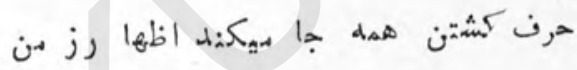

بلd

:

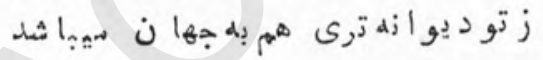

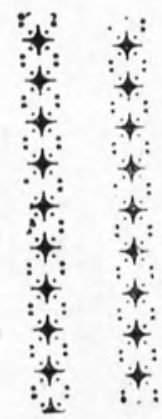




\section{عا بر \\ خد اينظرعا برفو زند خا لنظر

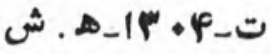

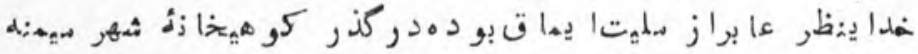

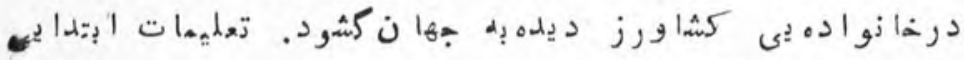

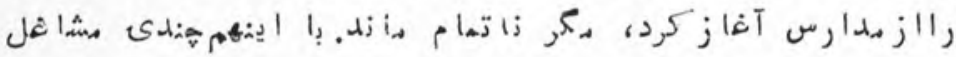

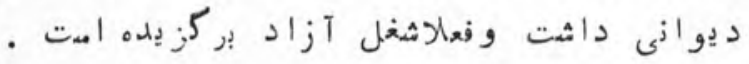

عا بر، بنا برذوق فظرى كله داثيته شعروششاعرى روى آورد

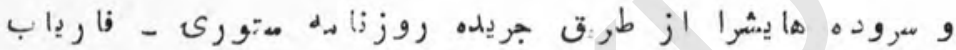

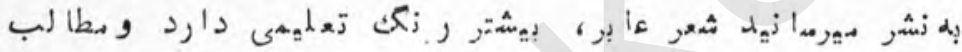

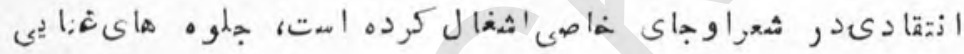

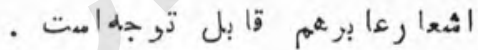

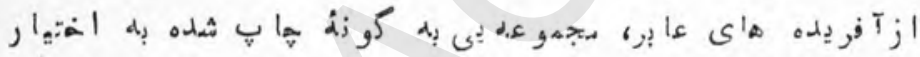

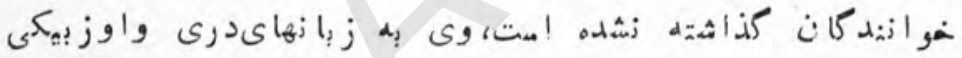
.

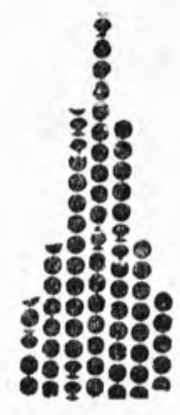




\section{انلهرز}

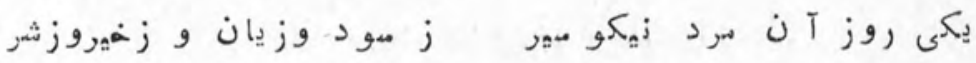

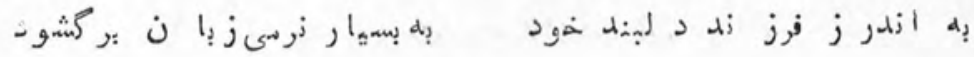

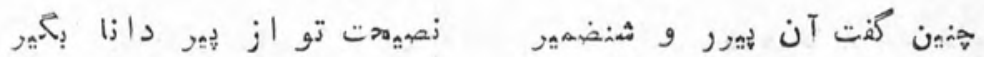

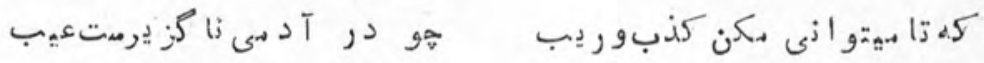

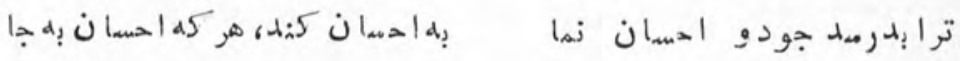

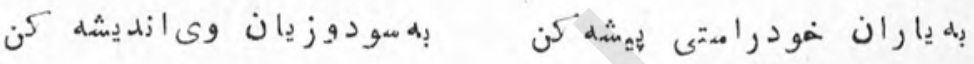

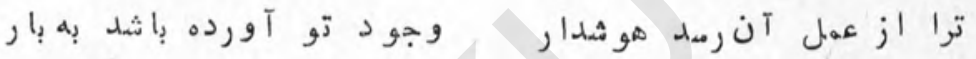

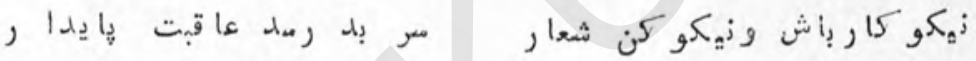

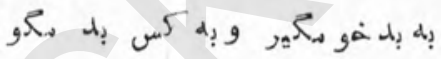

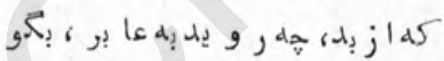

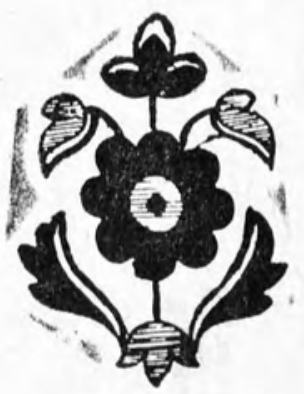




\section{تيغ ابوو}

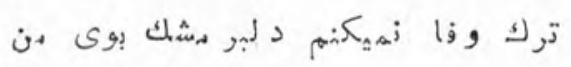

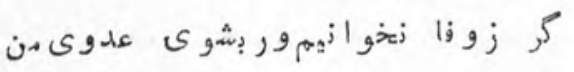

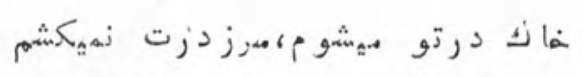

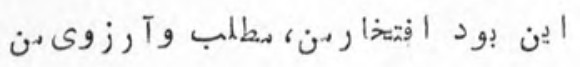

$$
\text { تا زفسى كه زعذذرد كى برمبم برآرزو }
$$

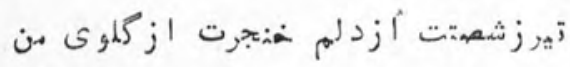

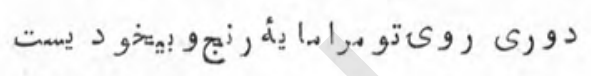

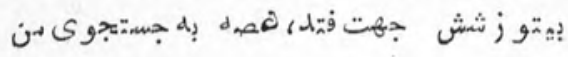

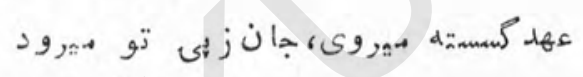

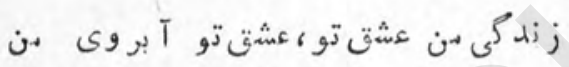

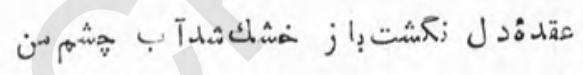

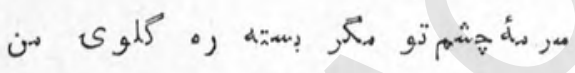

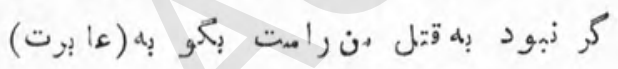

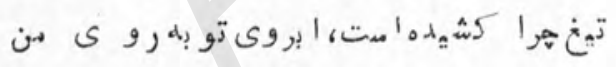

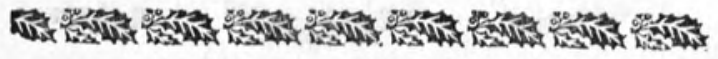


كوزيمنورى

اى كـوز يم زى زو رى جازابن دلربا

جور رلر كو تو كورديم إيهدى قيلمونا

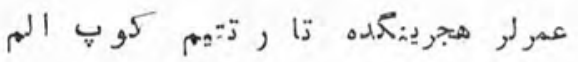

ليك هـركـز تار تـه ده ديم داد و زور

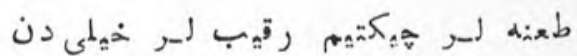

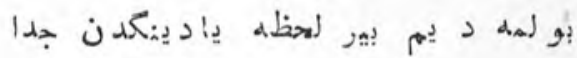

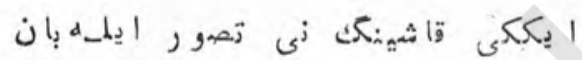

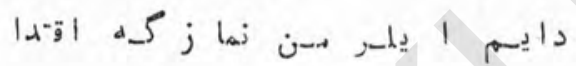

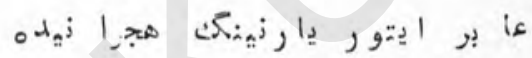

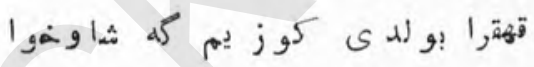

$1 \cdot 5$ 
عبد المحلميم حيا فوز ند نياز قل ت . A H.r.

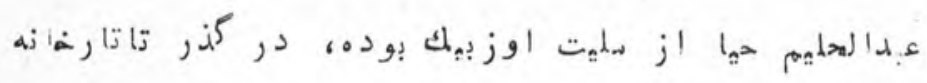

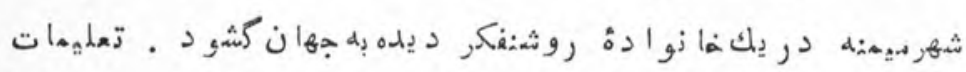

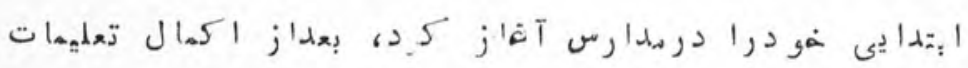

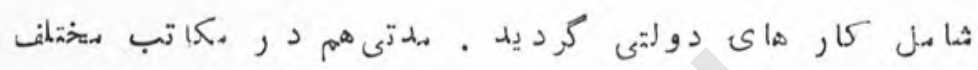

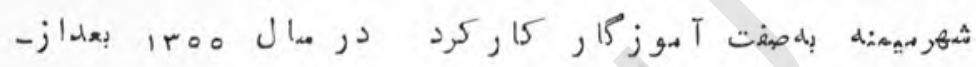

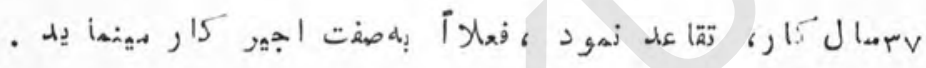

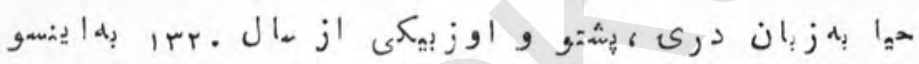

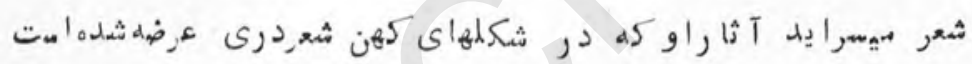

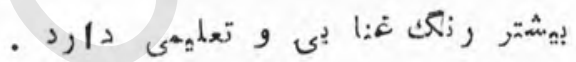

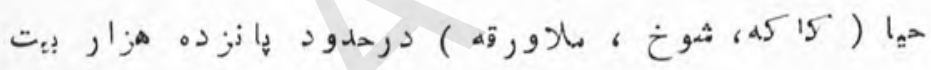
.

$1+\mu$ 
عاشق سر كشته

عهر يستت امير تو و دودام توا م من

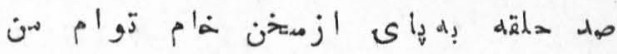

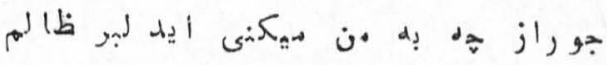

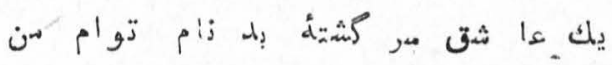

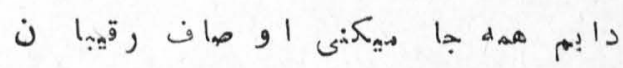

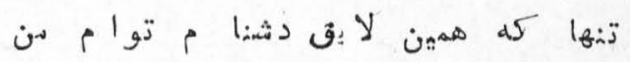

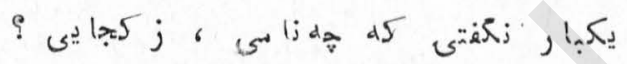

هر

تا اليذكه بر آيى وفتيد حهشم تو بر من

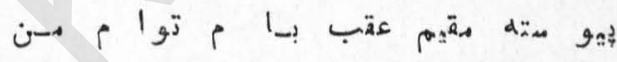

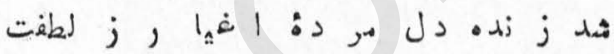

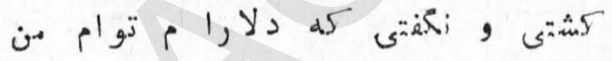

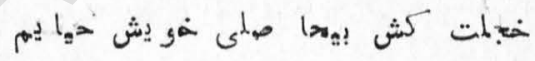

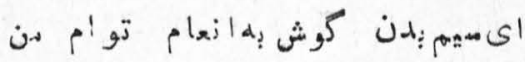

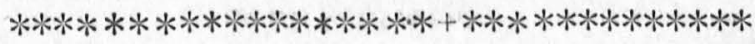

$1+f$ 


\section{كشتئ تيغ}

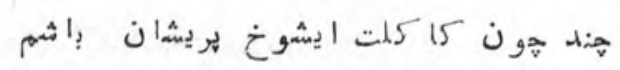



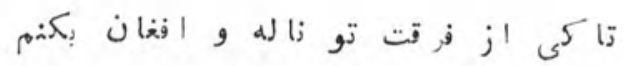

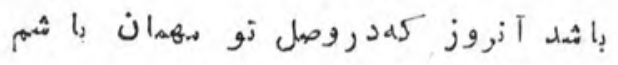

هرم آن لهظه كلهآيى ز مررلطف و كرم

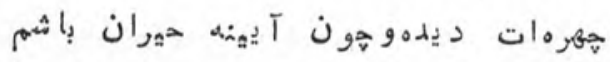

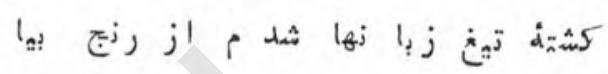

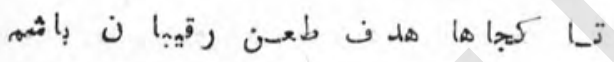

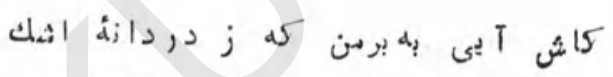

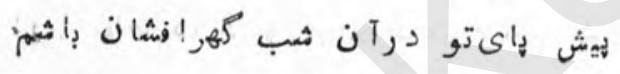

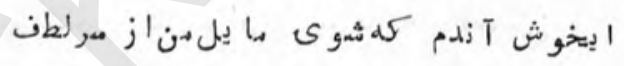

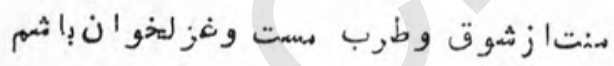

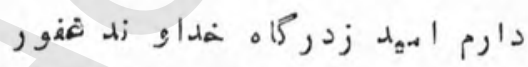

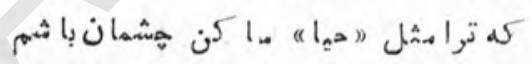




\section{gris}

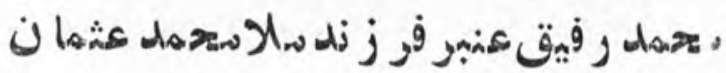

$$
\text { ت. ت. }
$$

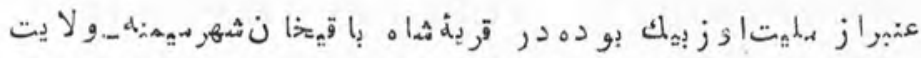

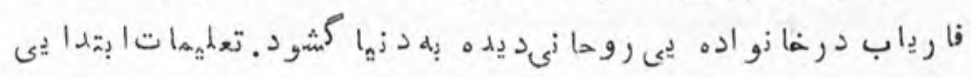

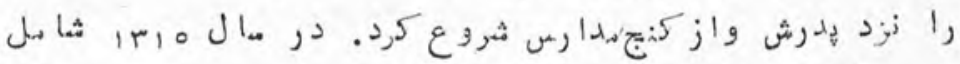

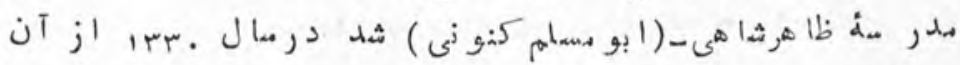

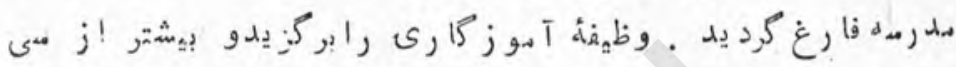

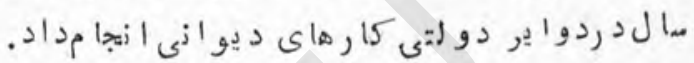

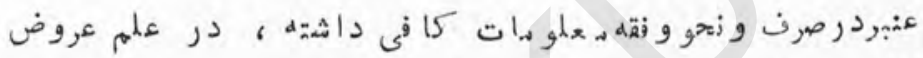

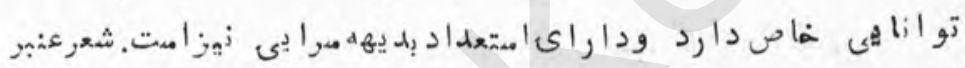

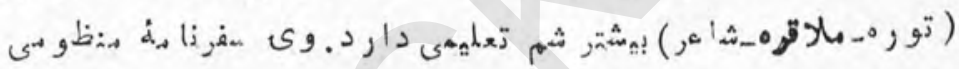
. 2 is

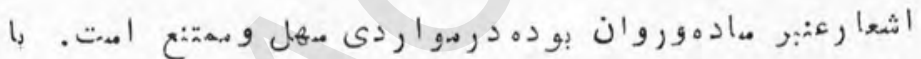

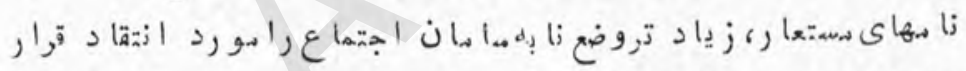

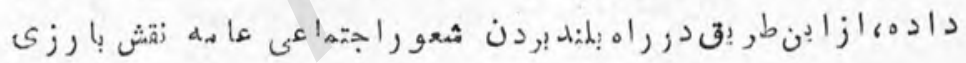
$.2,5,1$;

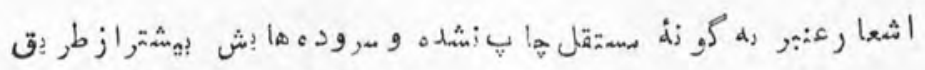

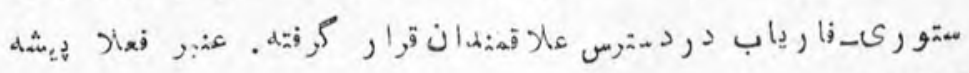

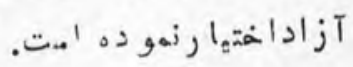

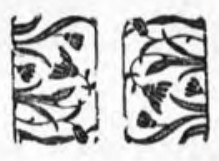




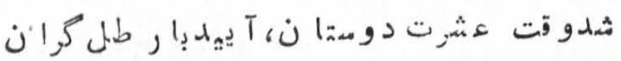

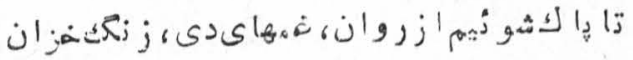

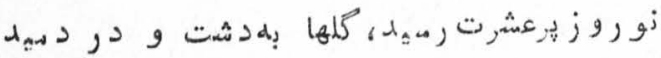

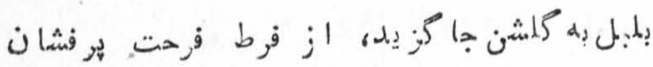

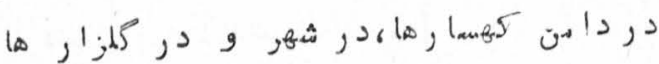

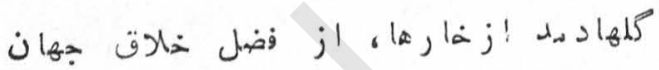

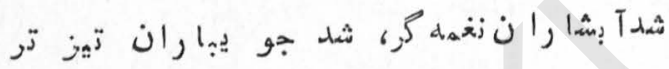

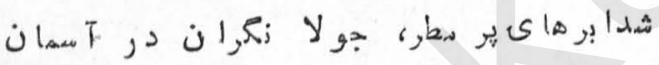

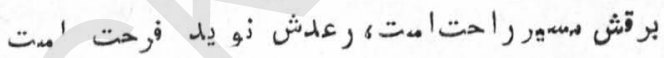

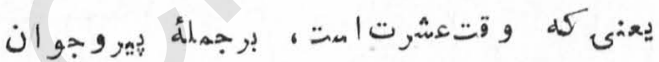

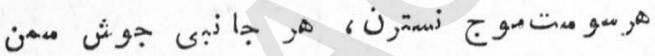

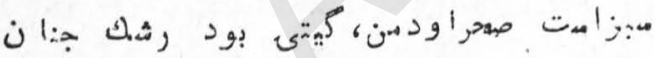

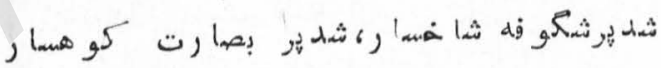

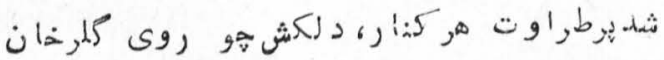

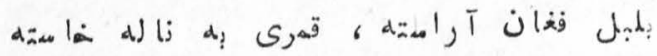

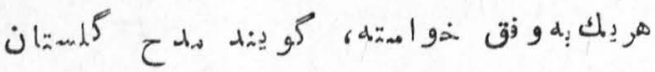

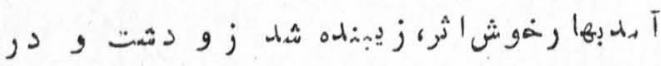

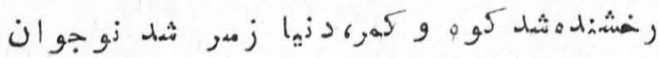

ا

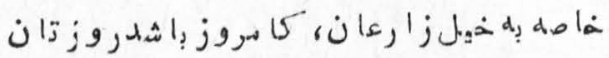

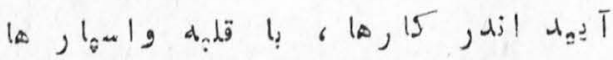

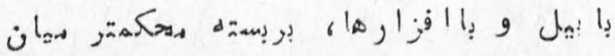




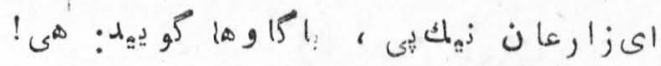

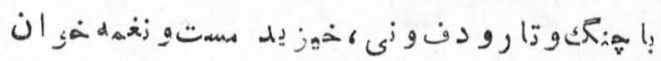

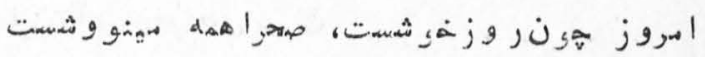

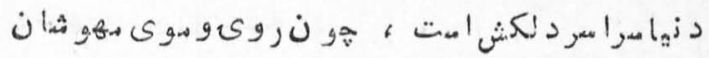

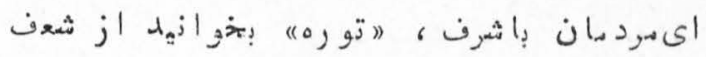

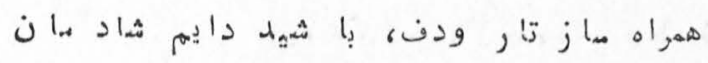

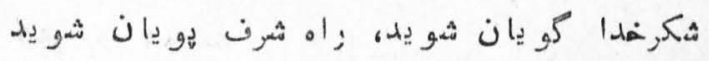

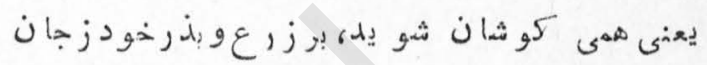

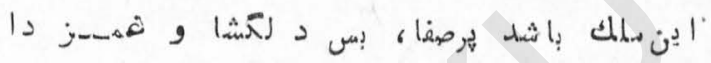

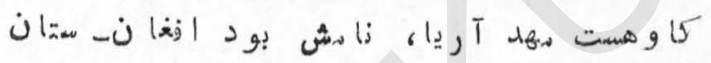

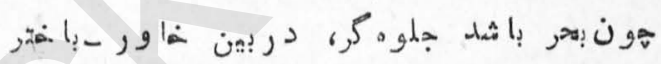

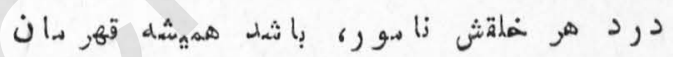

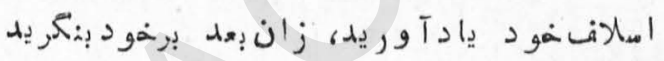

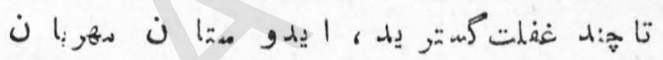

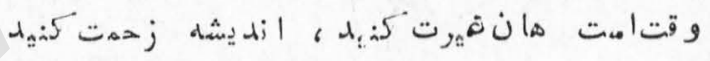

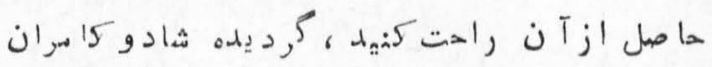

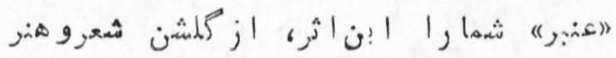

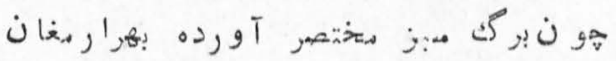

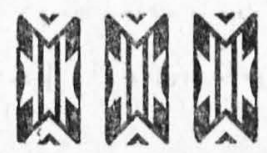




\section{داع فراق}

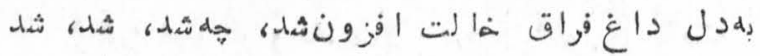

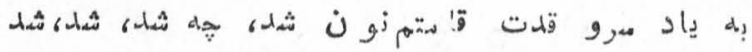

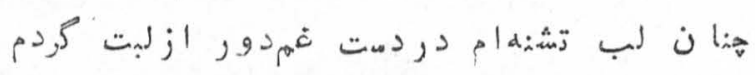

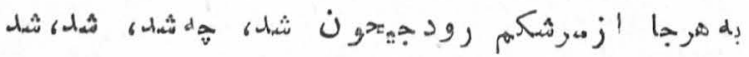

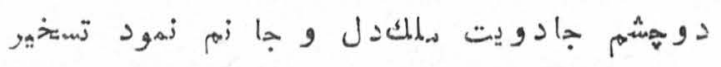

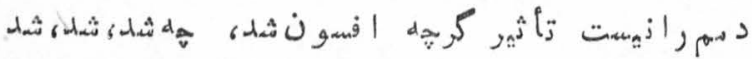

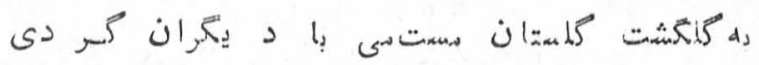

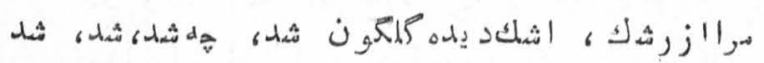

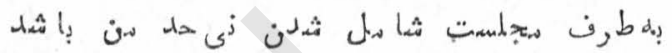

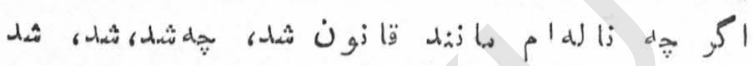

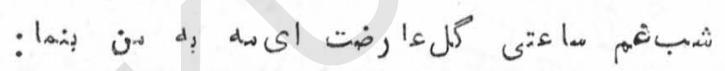

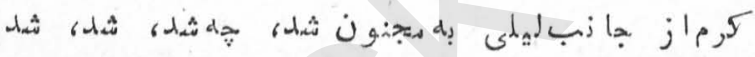

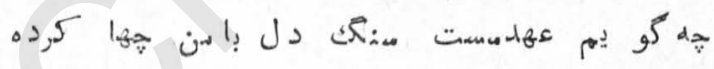

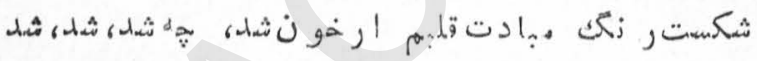

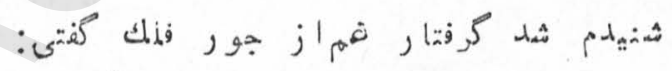

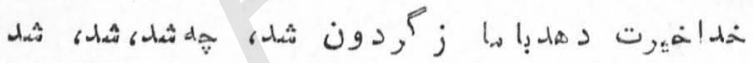

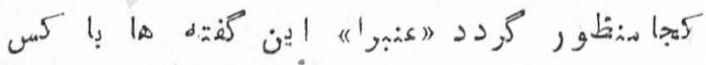

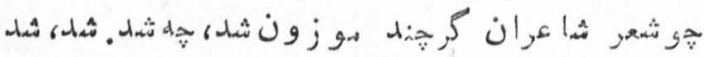

res 


\section{نفير فاريابى}

عبد الرو وف نفير فر ز ند ملا رسو لقلى بر لات

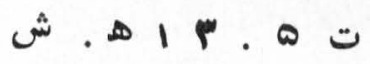

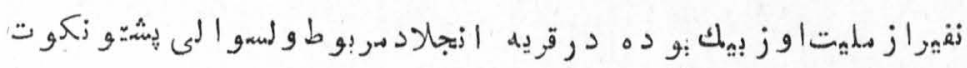

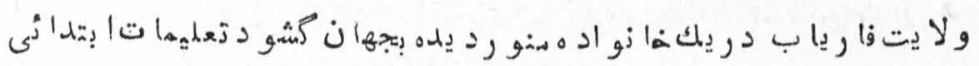

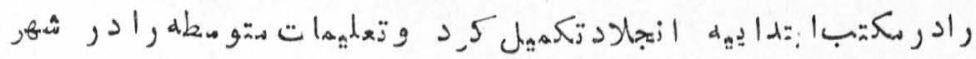

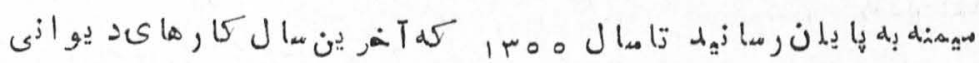

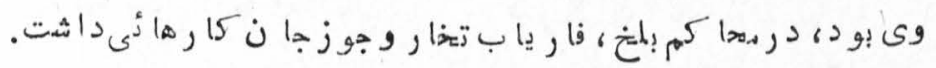

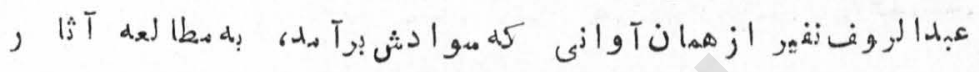

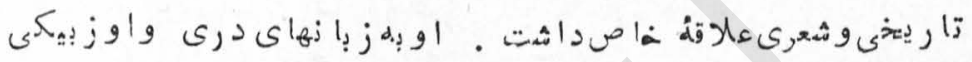

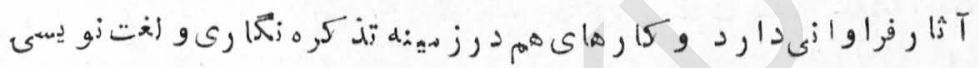

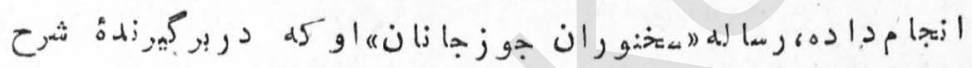

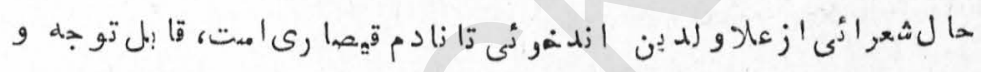

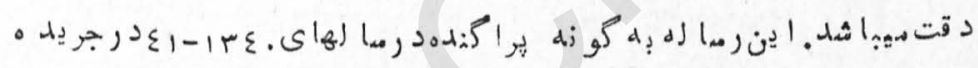

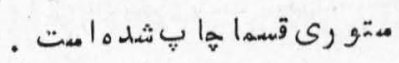

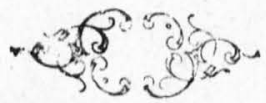


سمأدتخلق

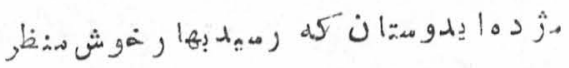

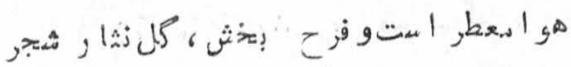

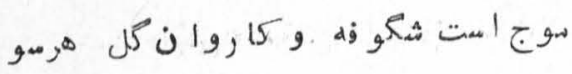

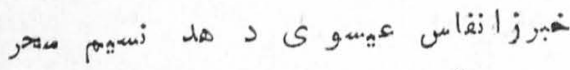

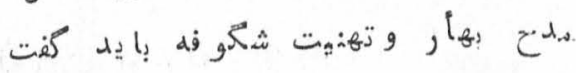

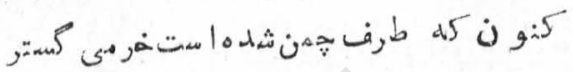

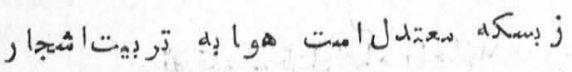

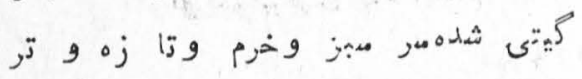

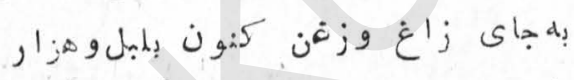

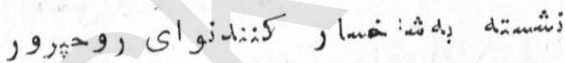

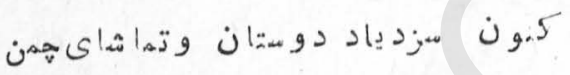

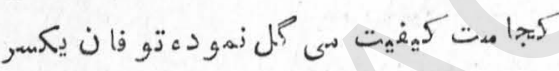

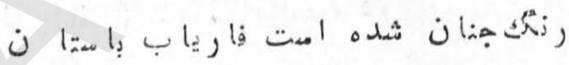

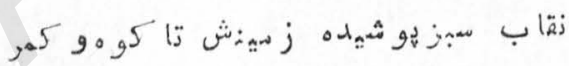

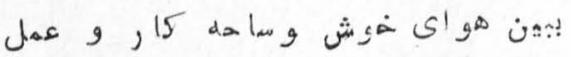

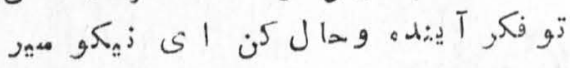

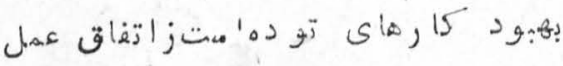

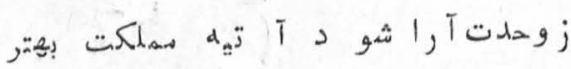

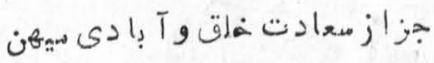

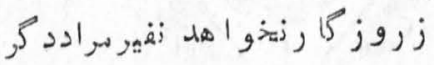


عيل بير أ مى

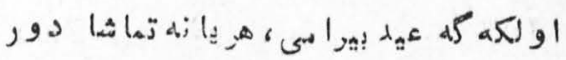

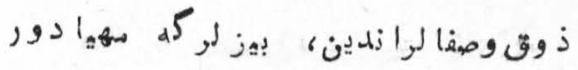

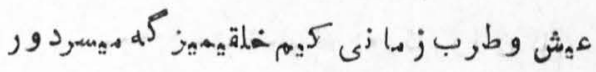

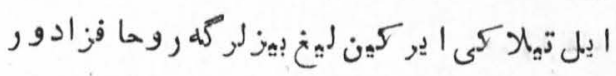

ثو رT يى كمه او زمر يش او زدى بو تون تو لقو زلمر

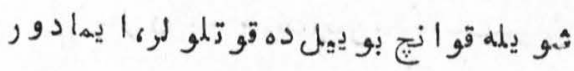

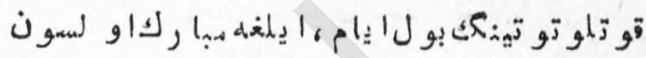

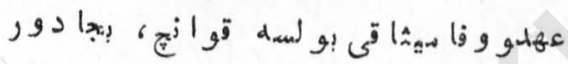

إش ا يلمغاى يو ر تله اشلر يخششى او يلمو لر بيرله

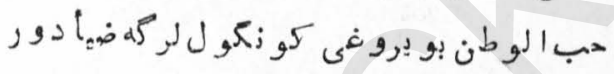

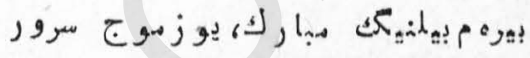

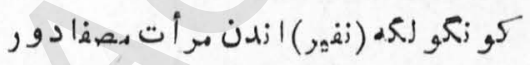

115 


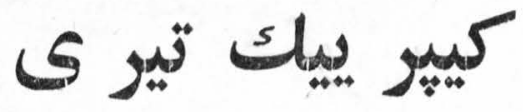

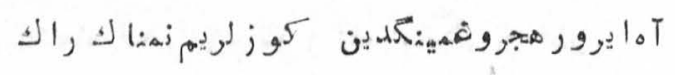

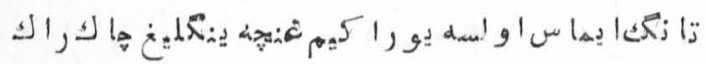

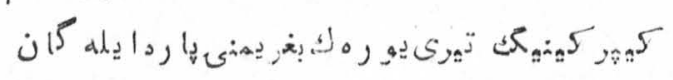

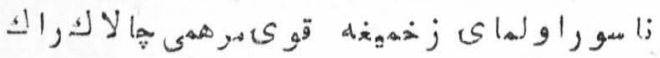

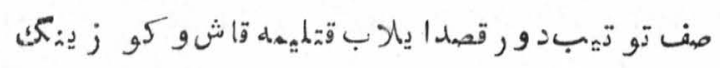

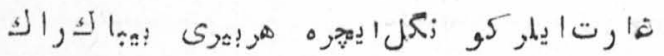

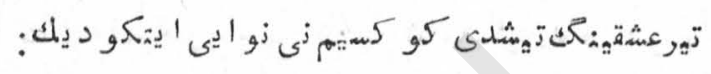

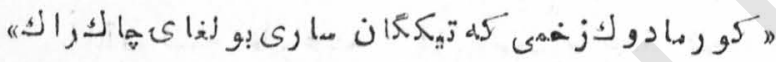

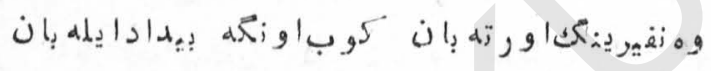

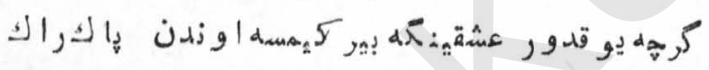

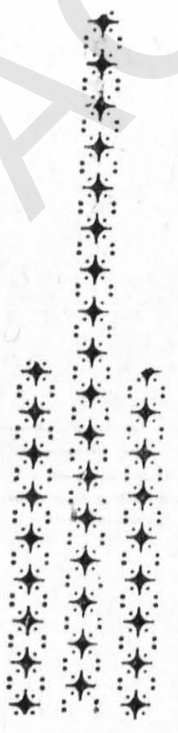




\section{فكرى}

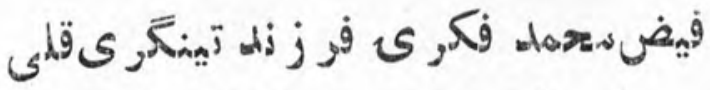$$
(1+91-1 p \cdot 0)
$$

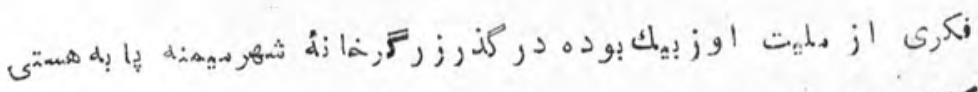

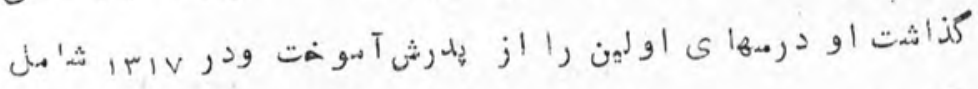

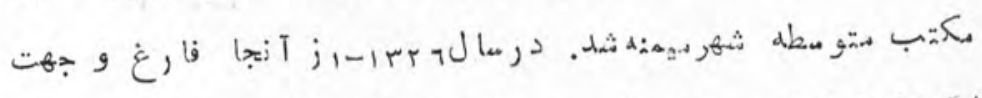

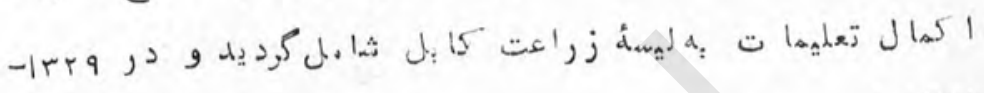

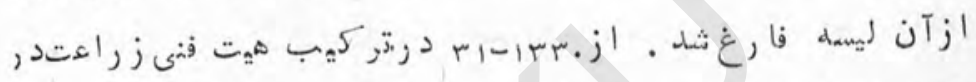

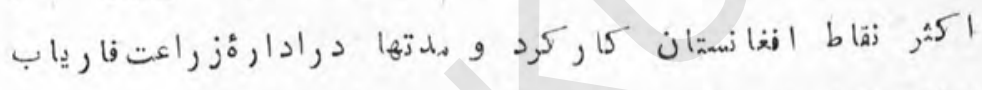

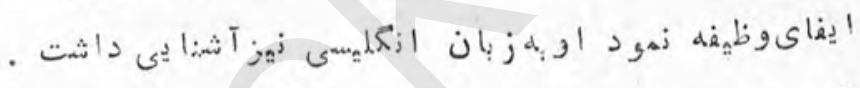

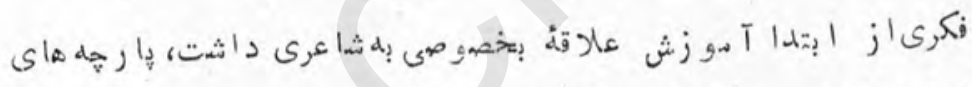

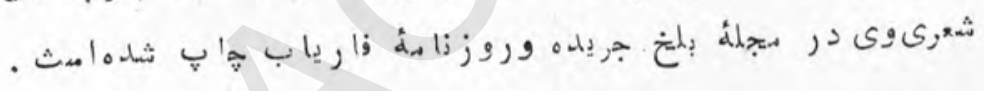




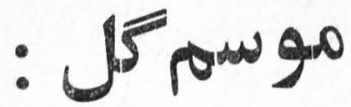

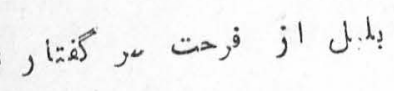

عاشةقان را وصلت دريدار

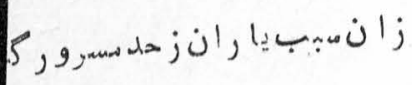

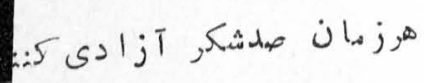

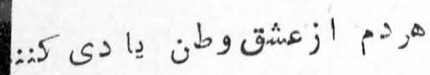

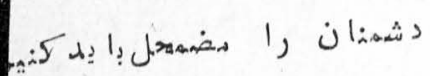

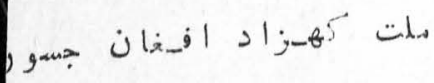

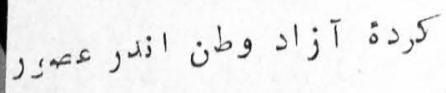

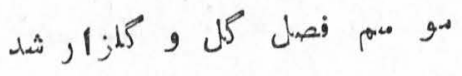

زخل

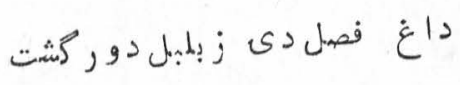

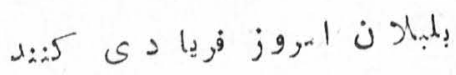

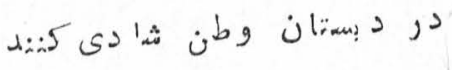

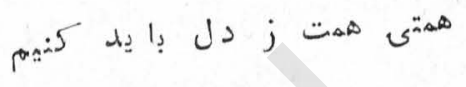

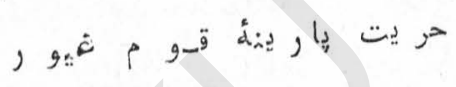

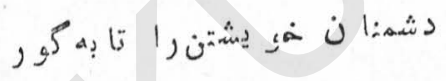

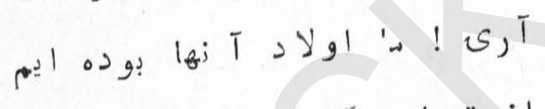
ا 1

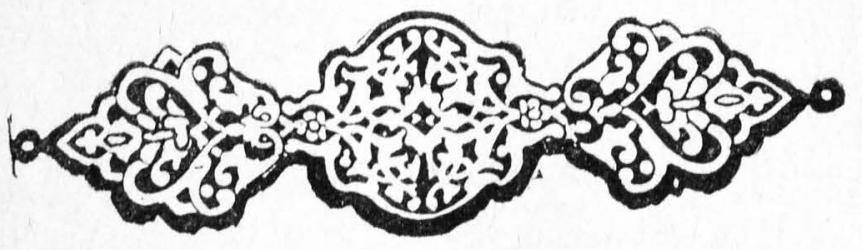




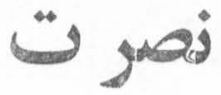

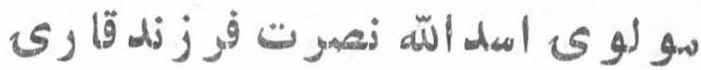

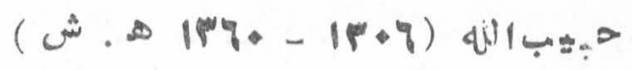

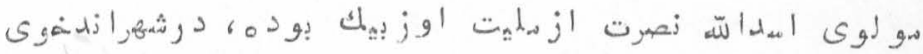

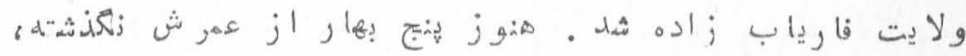

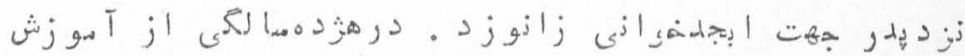

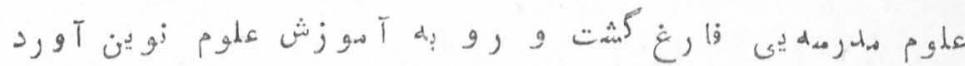

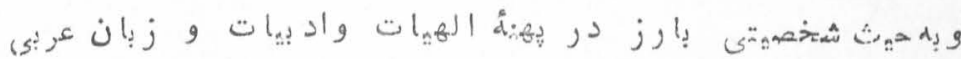

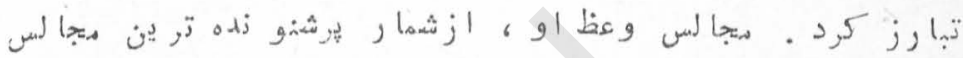

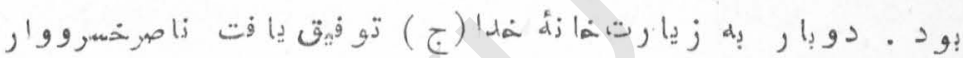

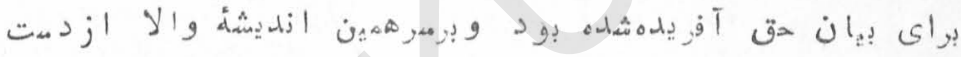

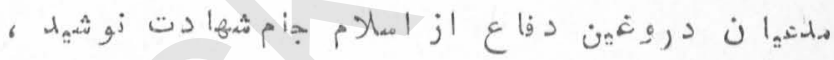

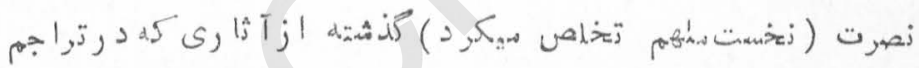

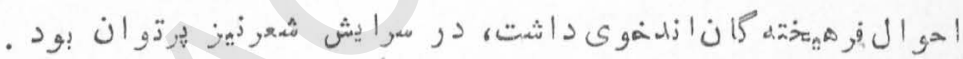

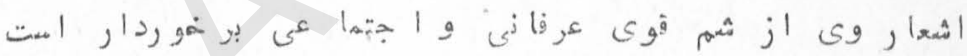

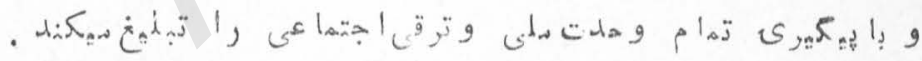

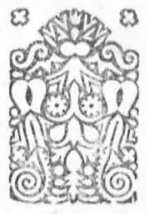




\section{طوز مادب}

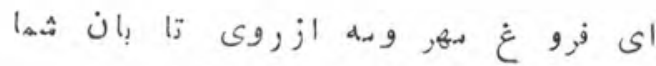

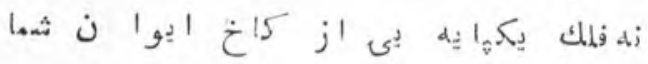

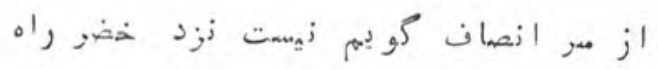

مشها

آشش دوز خ زشا نى ازمراق هجر تان

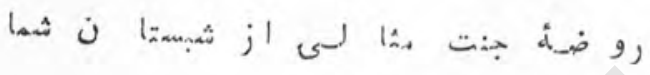

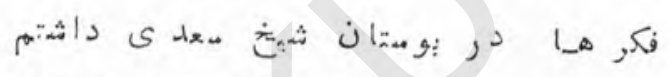

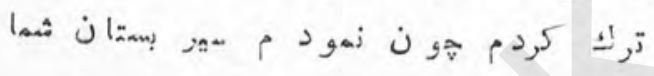

$$
\text { از }
$$

شكر هذو شهله

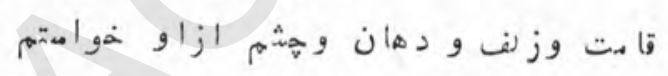

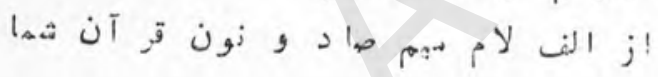

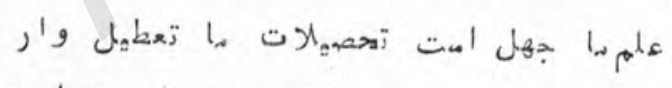

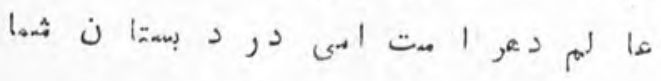

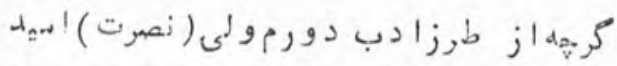

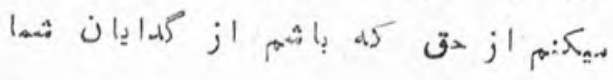

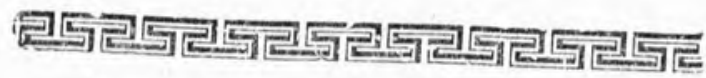


درس اتحاد

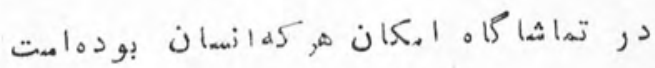

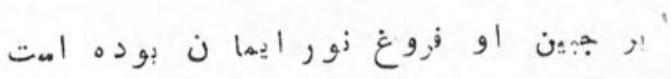

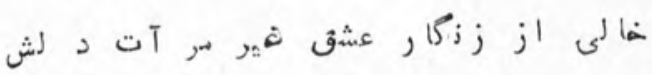

هظهر حسن عر وس علم و عرفان إوده امتي

در ضمير ش از لمعازى أكته هالى دلفر يدب

درك:ارش شا هد رعاى قرآن بوده امت

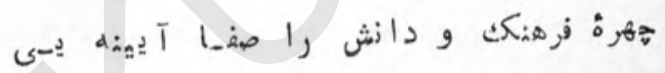

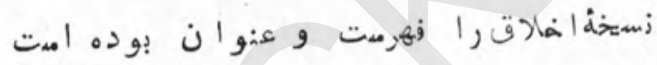

جأ ن غو د بر كف زها ده إهر زالموس وطن

دثمن رو بـه صفترا شير غران إو ده ا ست

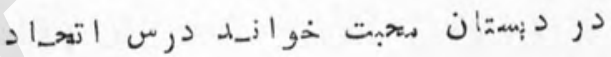

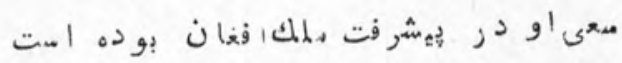

IIN 


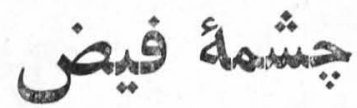

ماللوجان وقنس م كوى جنا بش كردم

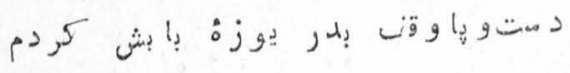

更

ز

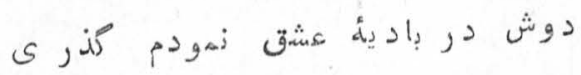

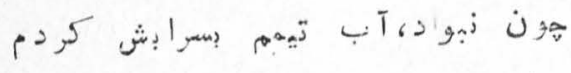

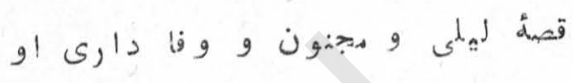

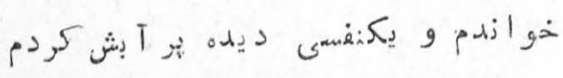

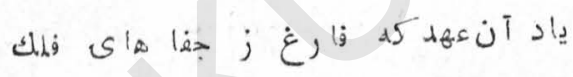

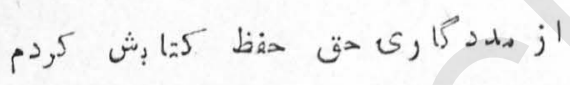

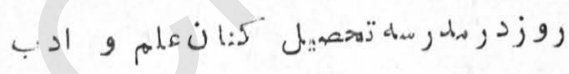

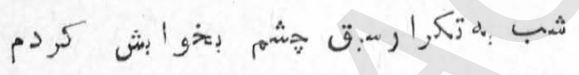

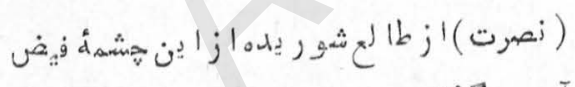

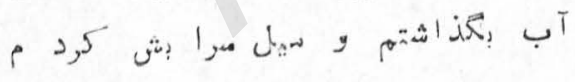

119 
مخخلص

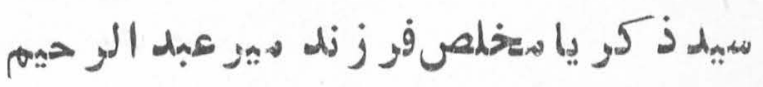
(ش. $)$ - |rqm-|r+q)

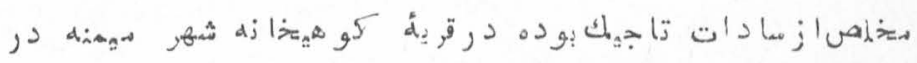

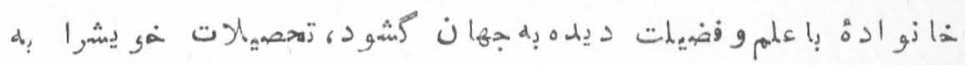

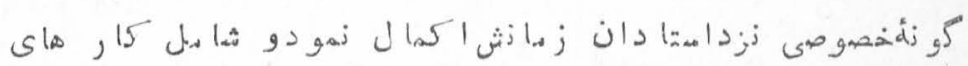

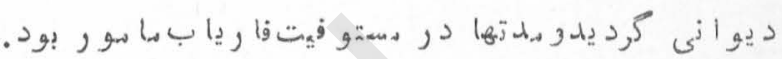

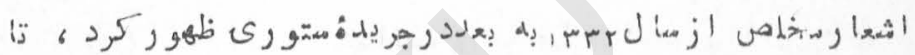

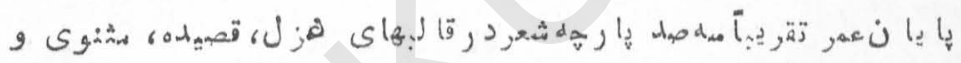

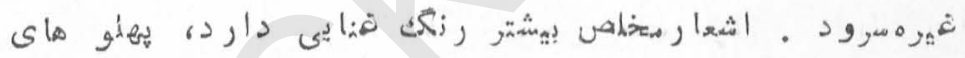

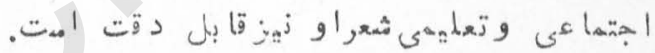

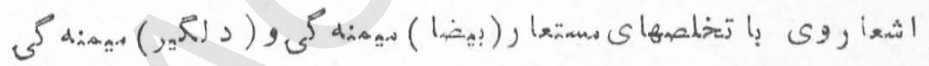

ز

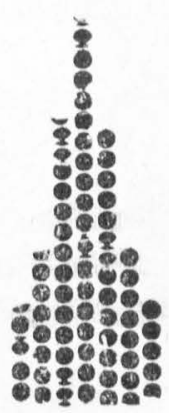




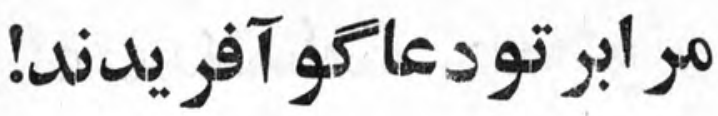

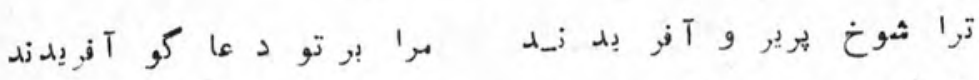

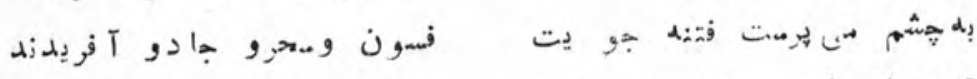

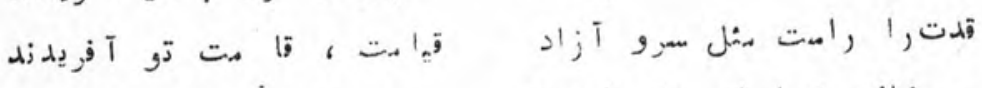

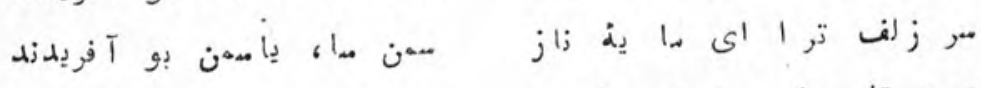

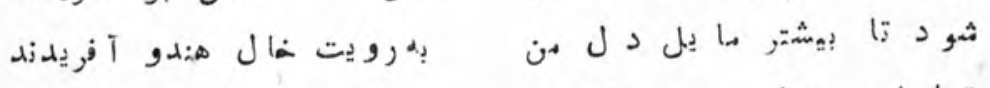

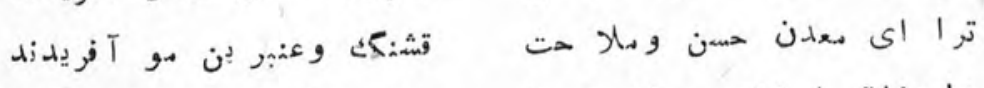

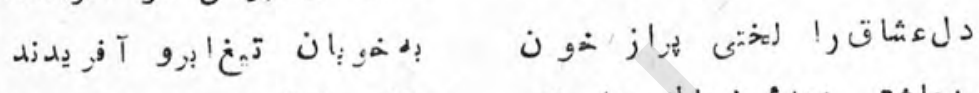

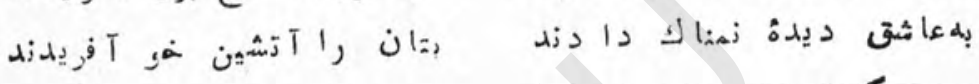

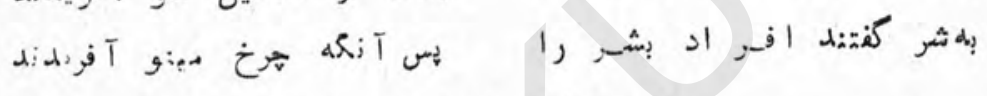
زو بـهد تا كله اشعاردل آوليز

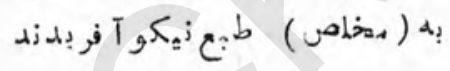

$|F|$ 


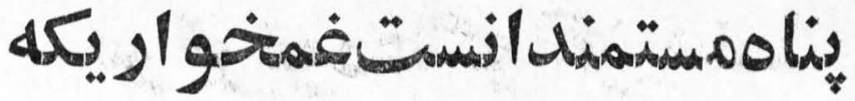

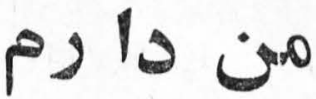

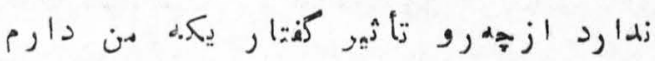

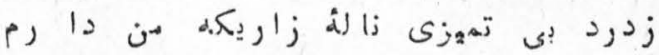

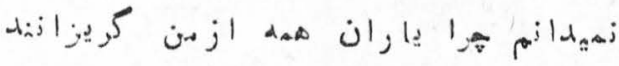

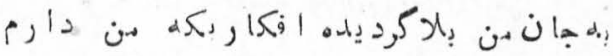

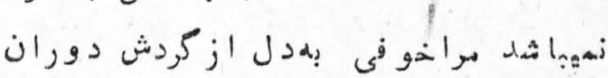

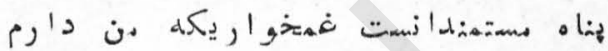

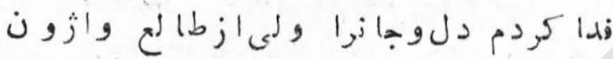

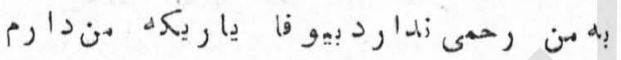

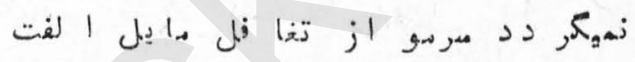

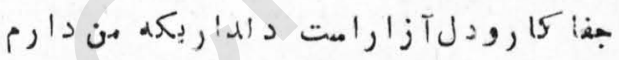

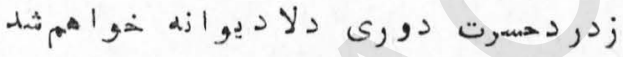

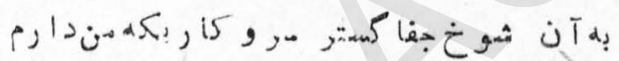

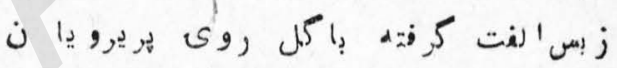

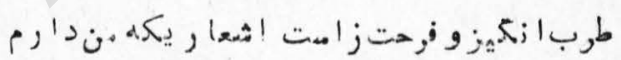

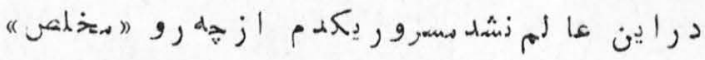

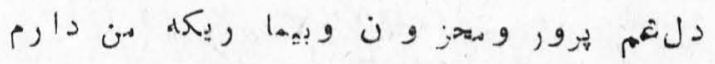

ny

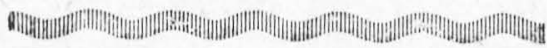

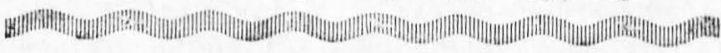




\section{Sis}

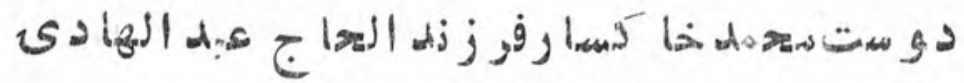

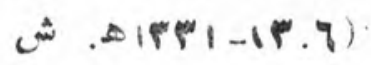

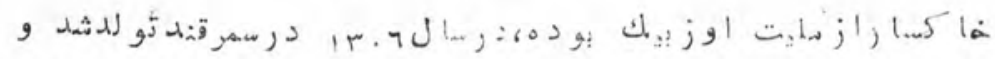

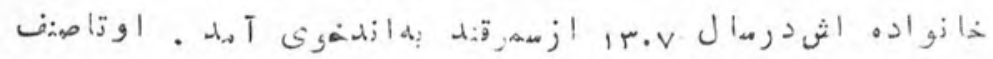

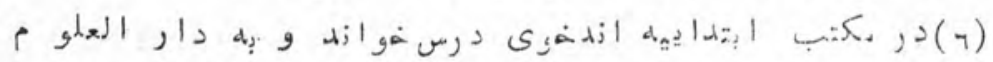

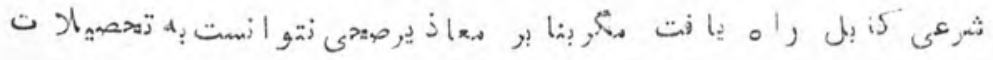

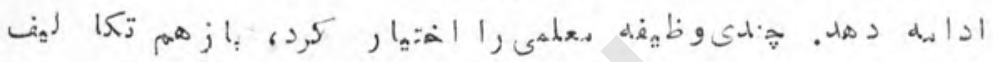

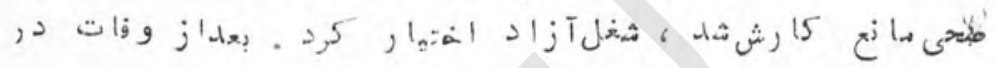

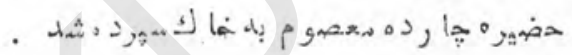

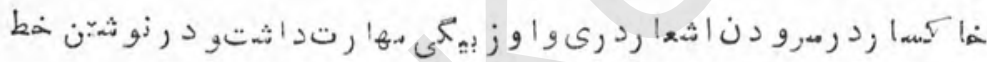
$\therefore$ ن

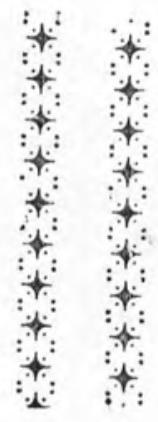


خونهل

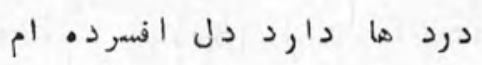

|زمك:

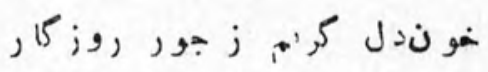

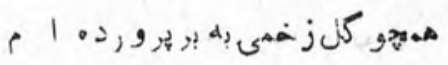

حاصل منغ غير ا شك و آه زمست

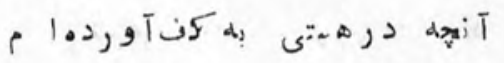

ثمئو بسهم إيت هزسوز زى ز ديأ س

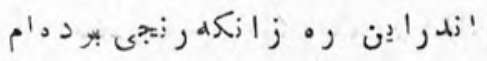

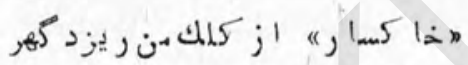

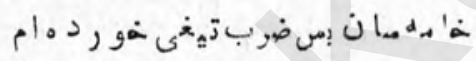

ipp 
يونس "سرخ خابي

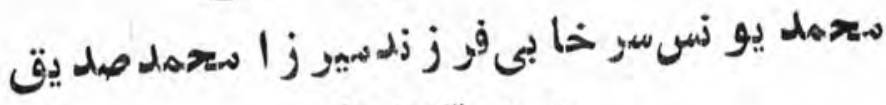

$$
\text { ت ت }
$$

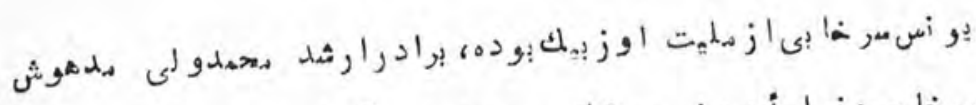

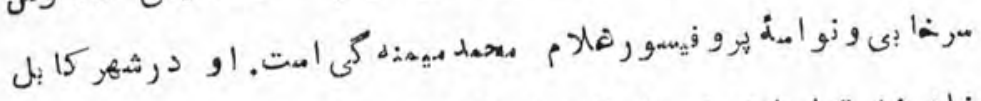

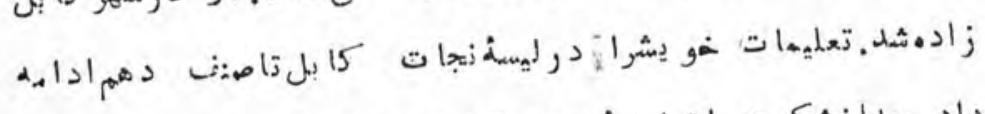

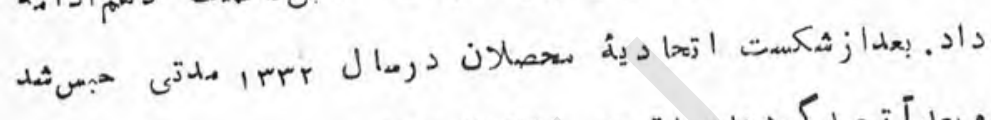

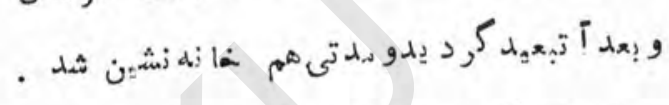

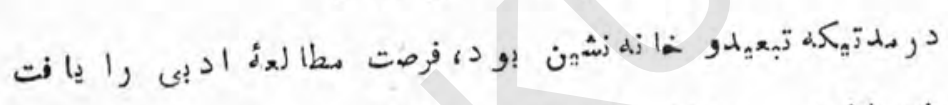

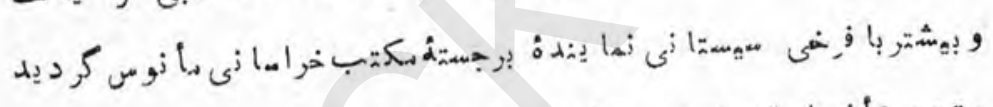

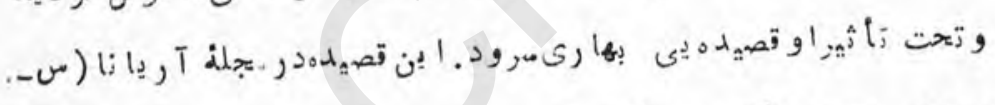

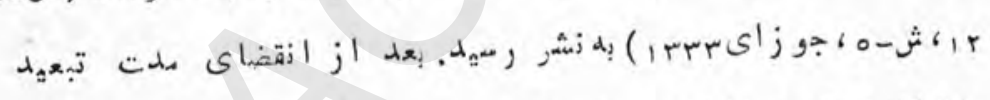

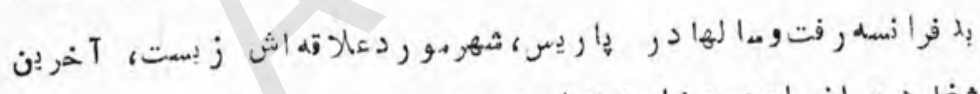

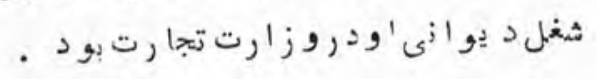

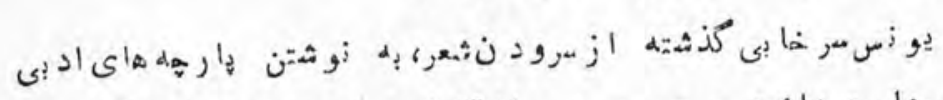

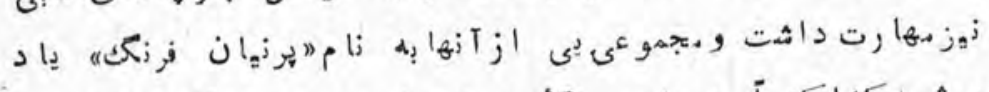

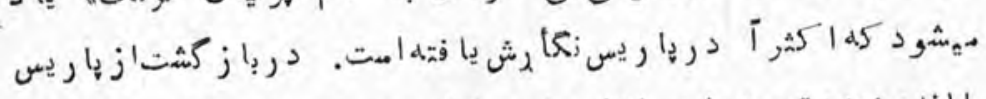

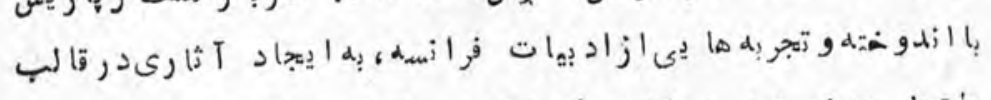

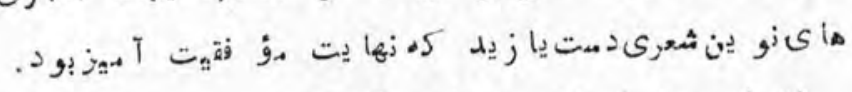

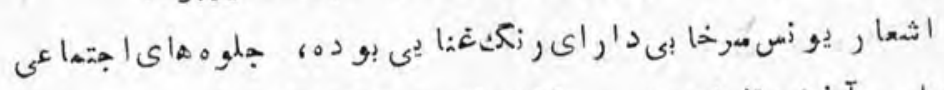

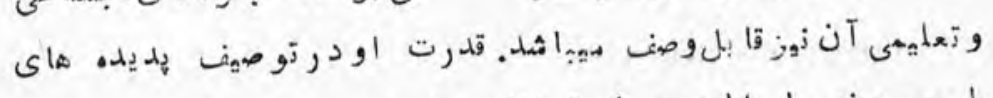

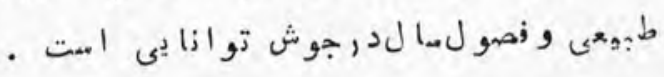

IFD 
5

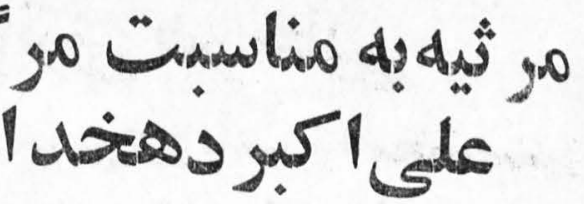

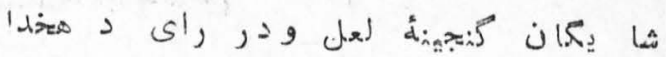

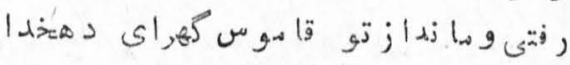

صد كملمة:ان

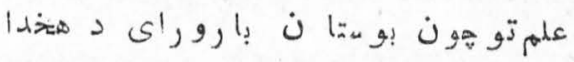

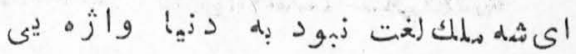

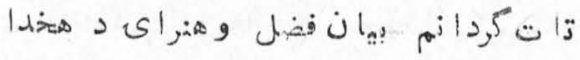

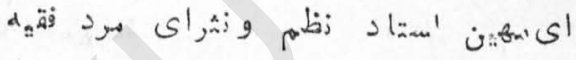

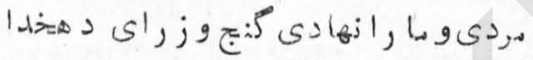

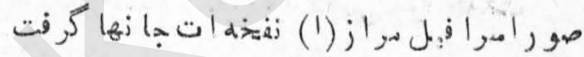

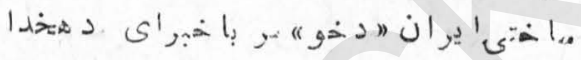

次

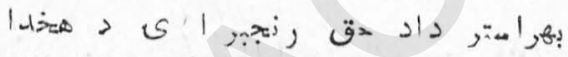

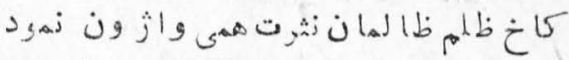

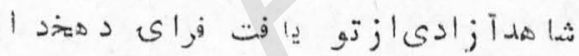

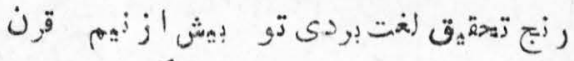

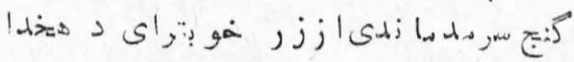

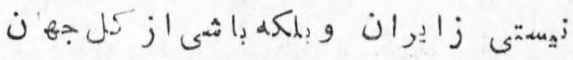

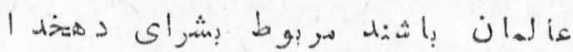

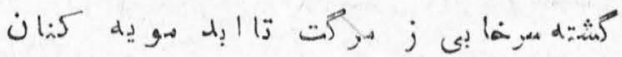

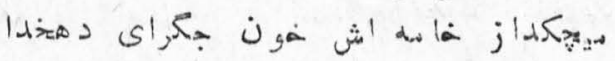

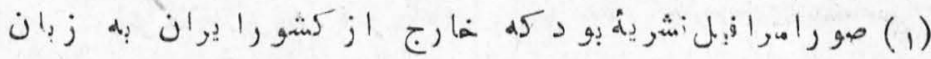

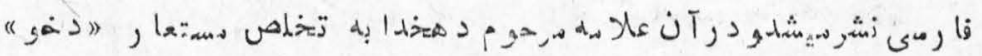

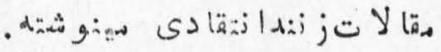


آرزوى شا

شب وشا مدد، شر اب و شمع و شاعر

لهى و دمتى و

د ن ود لبر، ده. و د الد اده. و دل

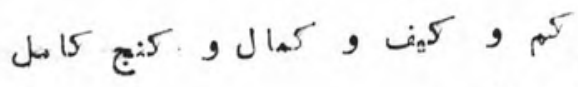

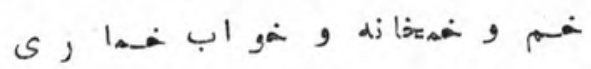

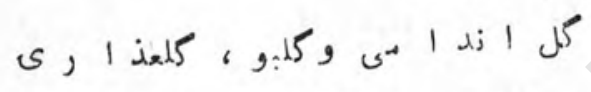

ง) la

ن

s ز إl ز ز

تر

تب و تا بك، تسن و تار تر ا زهل

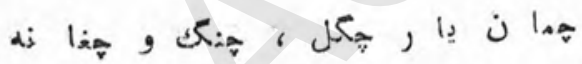

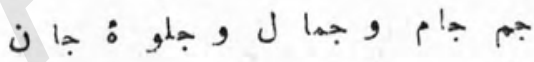

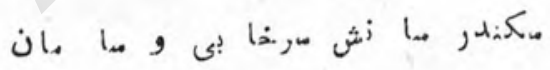

If $V$ 


$$
\begin{aligned}
& \text { جشم شهبا ز }
\end{aligned}
$$

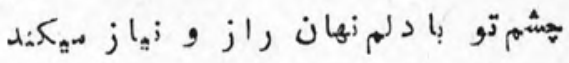

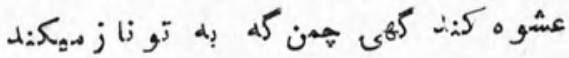

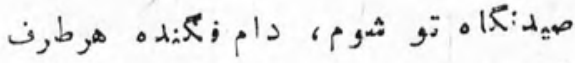

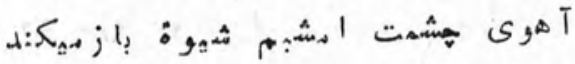

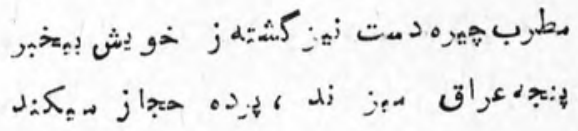

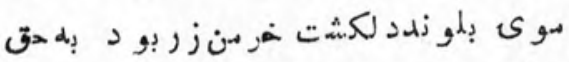

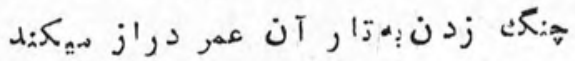

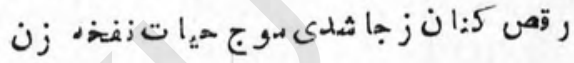

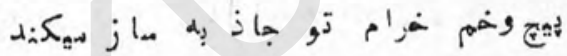

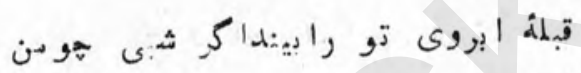

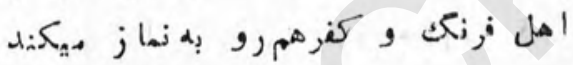

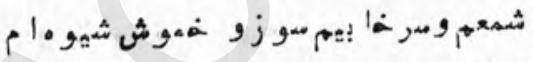

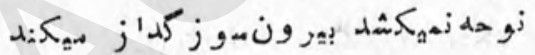

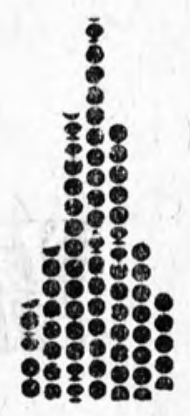




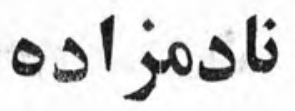

غلام ناصونا دمز ادهوف ز ند الجاج استيا دميرز

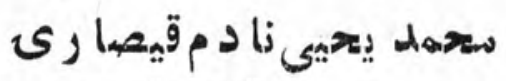
ت. ت

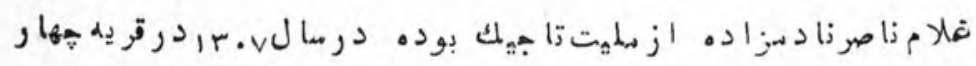

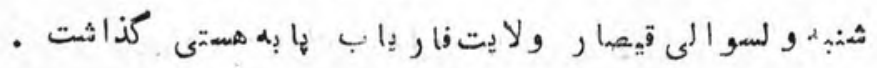

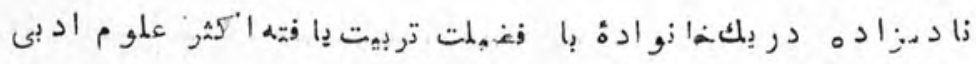

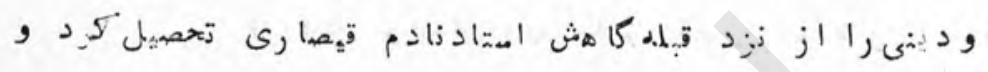

مو 'اد بركشيد.

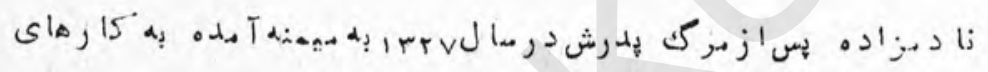

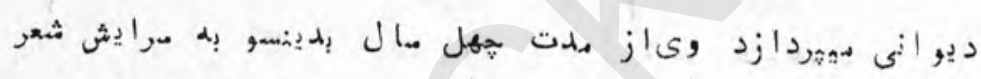

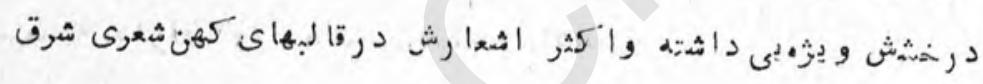

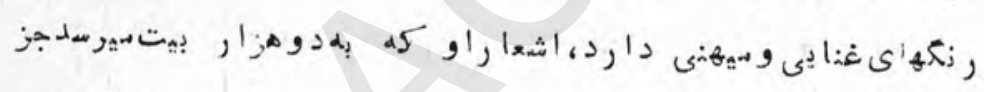

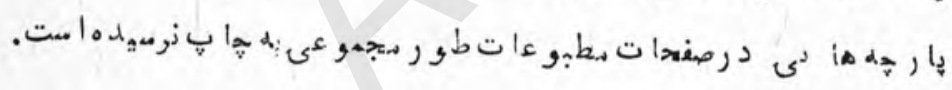

159 
يارهم دارد

دار

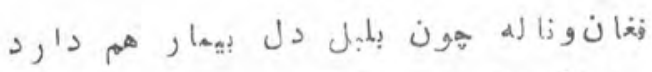

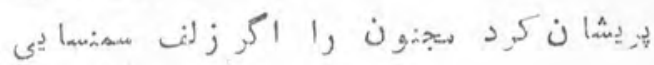

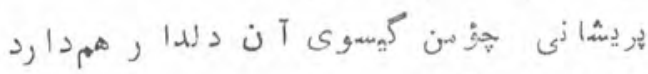

|

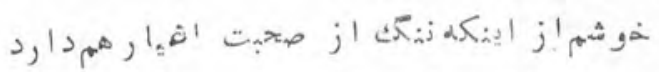

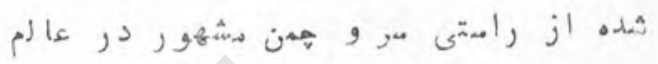

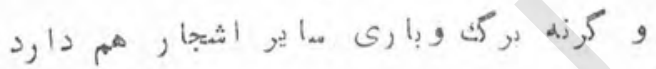

هشيو دغرور حسبنو مال و جاه وعزت دوران

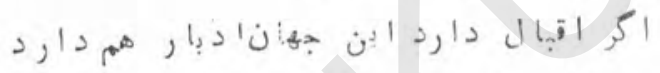

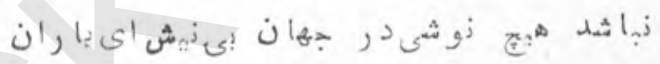

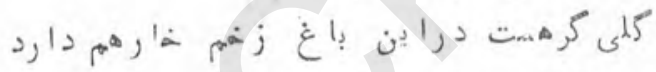

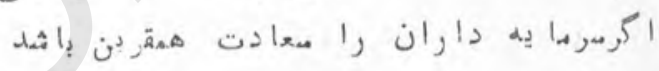

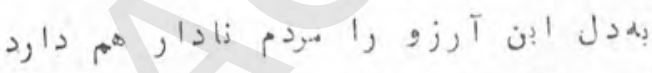

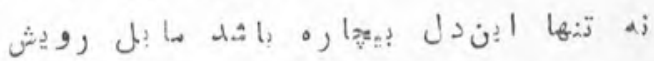

J

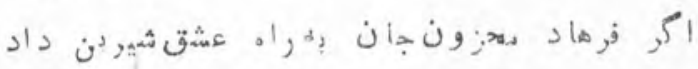

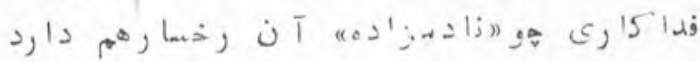


خانة غمث

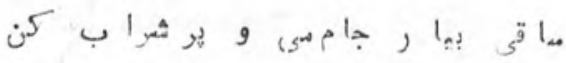

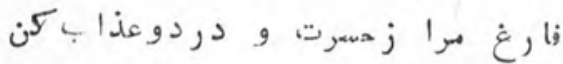

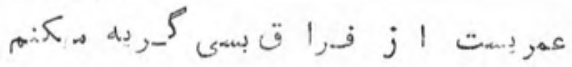

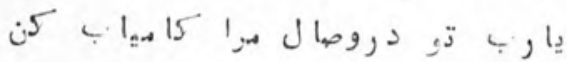

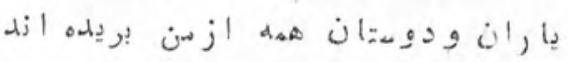

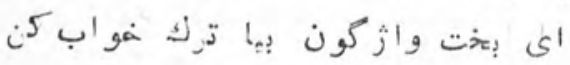

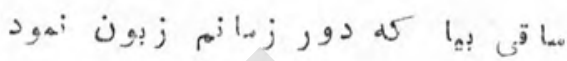

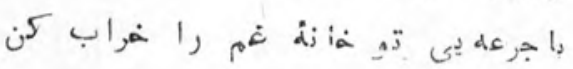

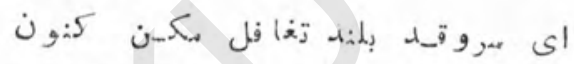

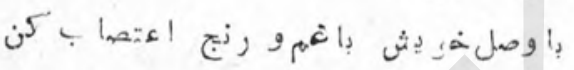

!

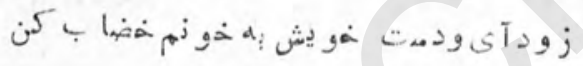

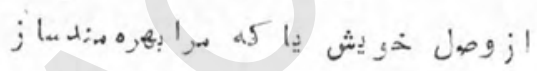

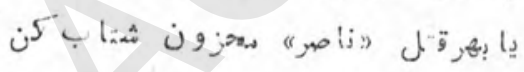

$|F|$ 
شكرى

شكر اللششكرى فو ز زند الجا جعباد الله ت

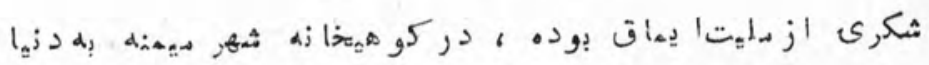

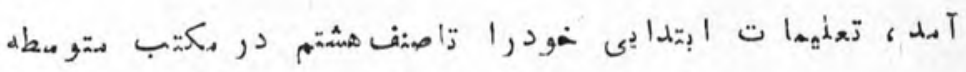

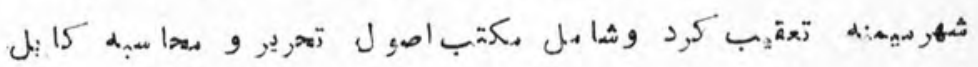

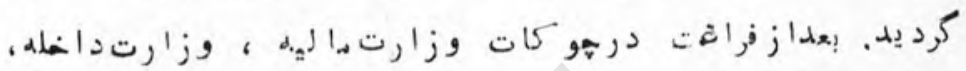

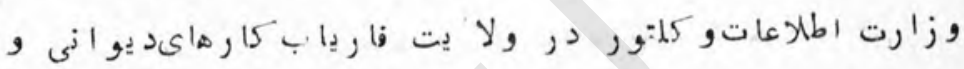

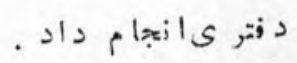

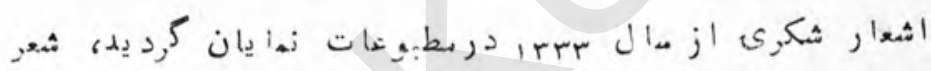

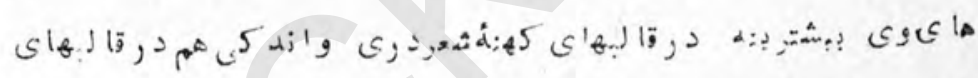

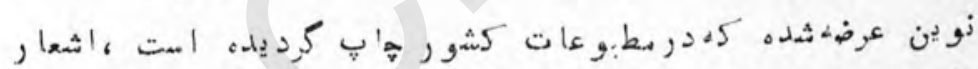

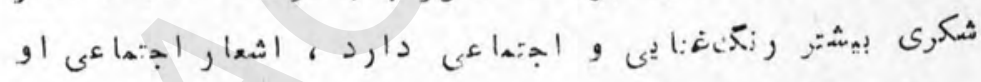

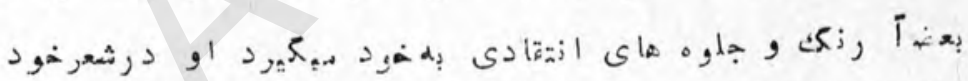

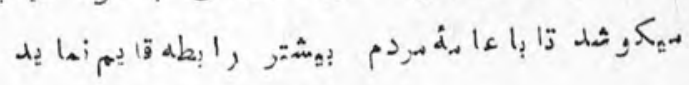

ifr 


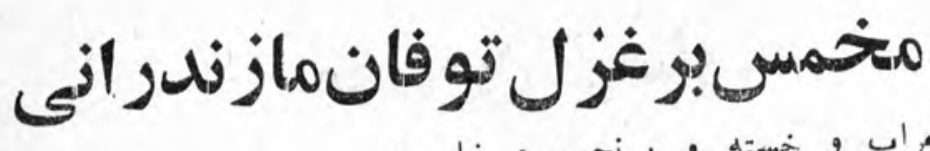
خراب

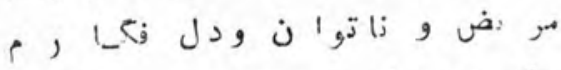

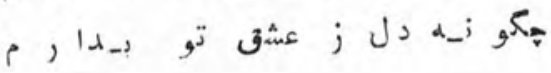

ثن (, 1, , la

زلمك از تهو زئد بر بر ى

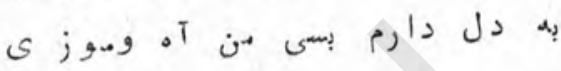

تنم شاد

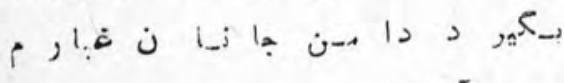

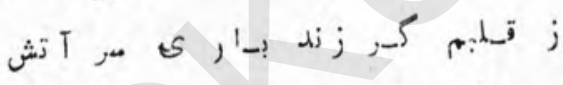

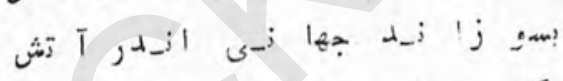

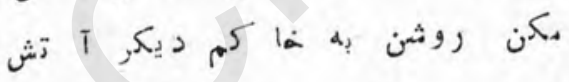

ز

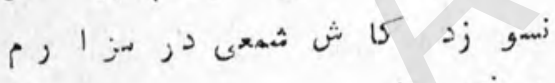

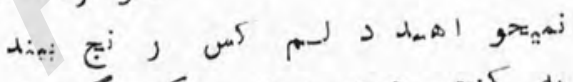

in

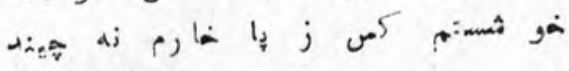

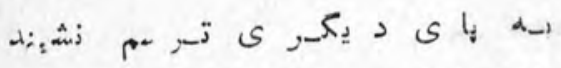

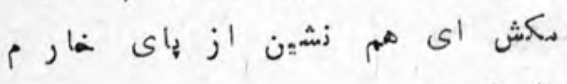

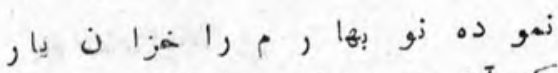

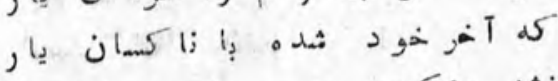

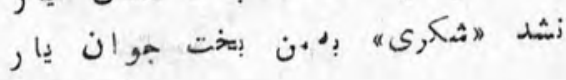

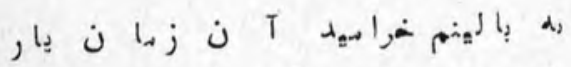

كله حهو ن " تو فا ن " كن شيت 
S Shägis:0

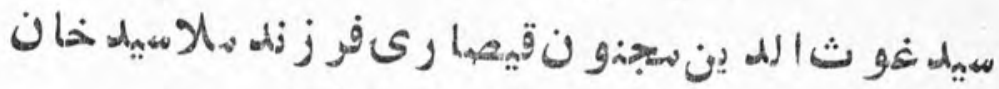

( $ش$.

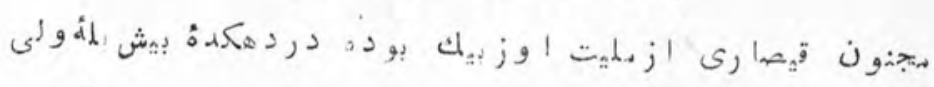

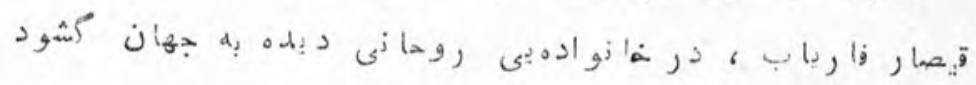

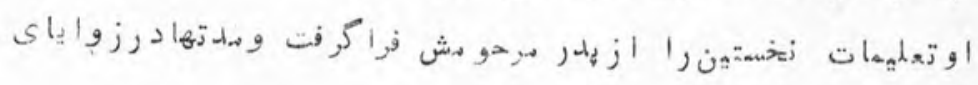

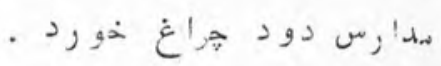

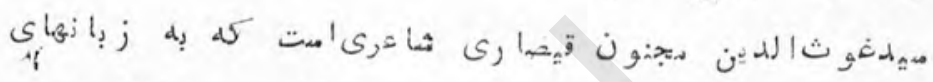

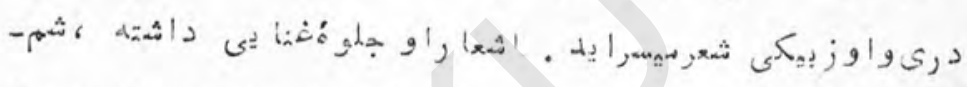

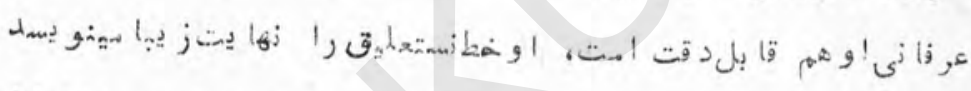

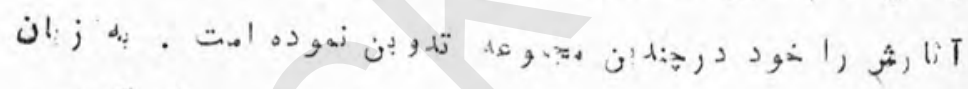

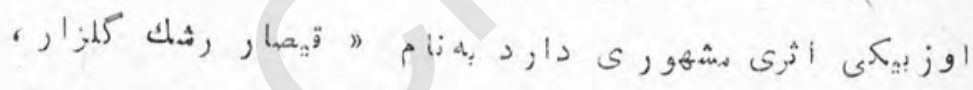

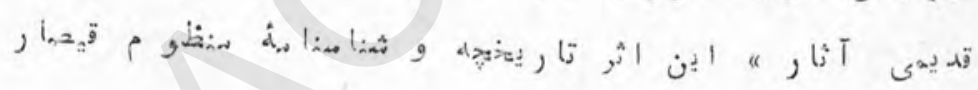

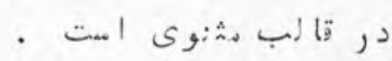

ipe 
Ját>

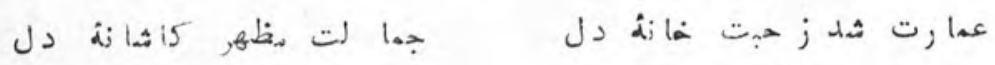

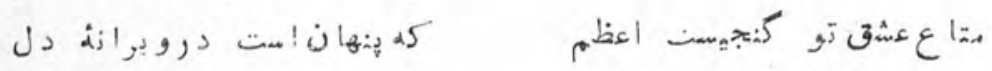

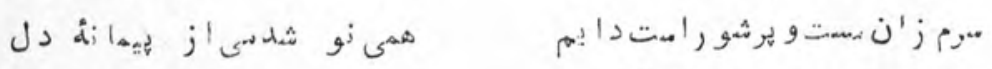

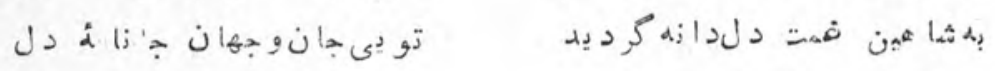

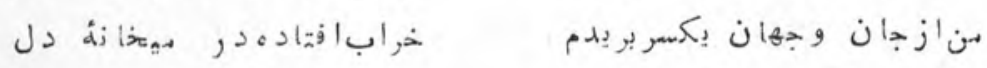

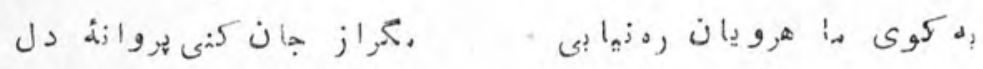
من و تصو يرجا نان ن زقئ كردون

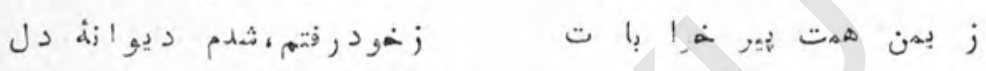

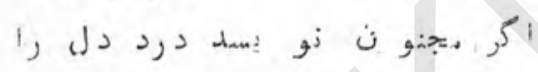

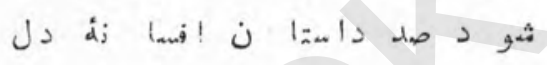

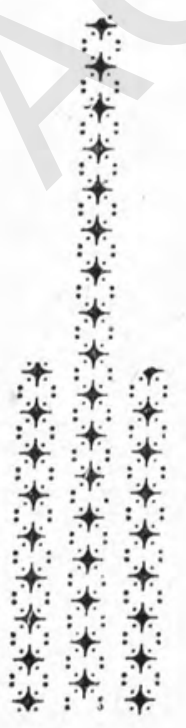

Iro 


\section{جاكرعشق}

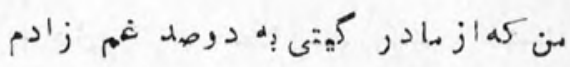

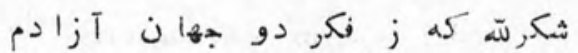

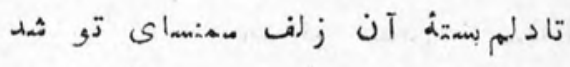

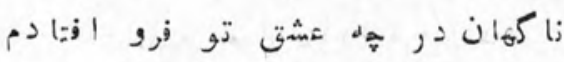

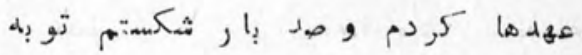

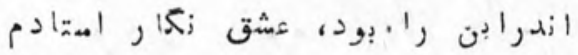

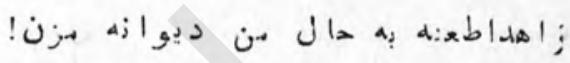

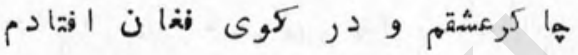

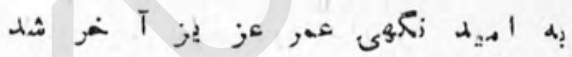

ز

$$
\text { هرجه ف, دياد }
$$

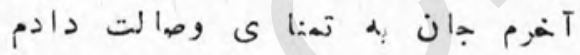

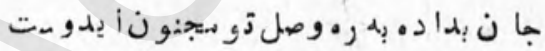

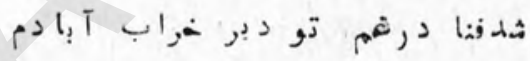

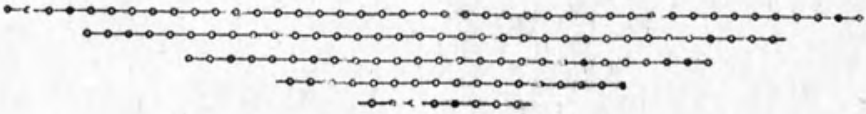




\section{(5) g g g}

ى

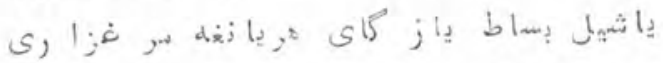

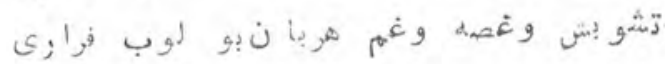

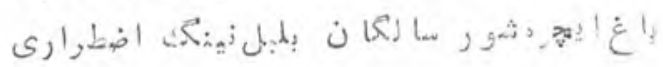

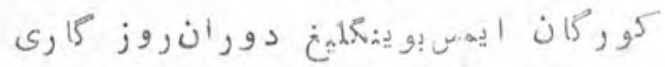

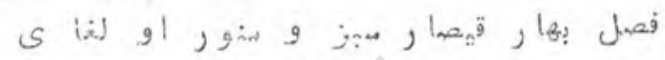
كمان

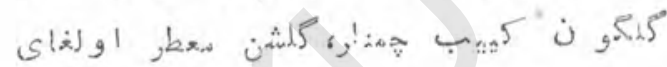
(a)

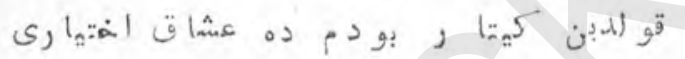

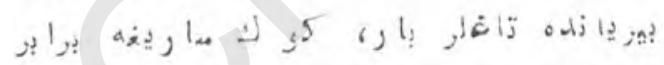

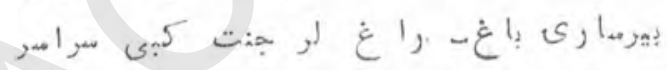

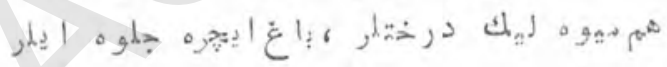

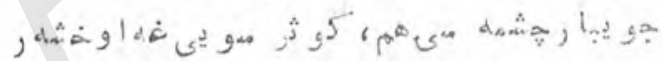

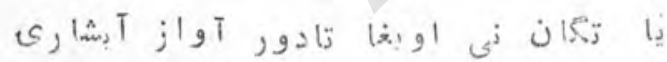

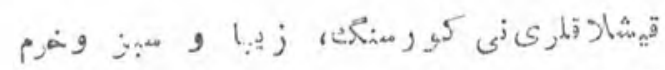

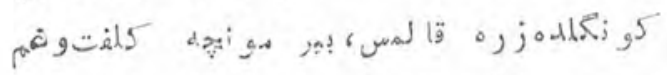

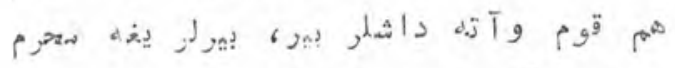

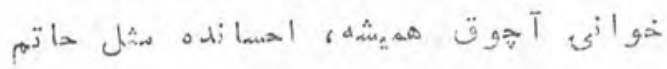
...vis

F 


\section{ت5م}

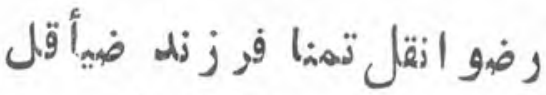 \\ ت -}

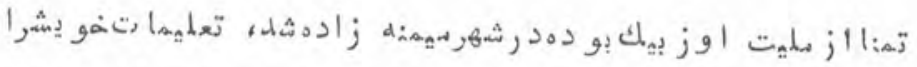

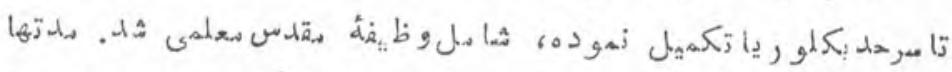

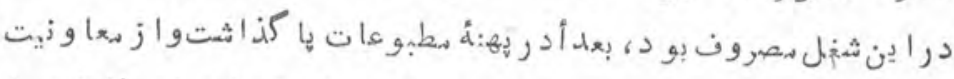

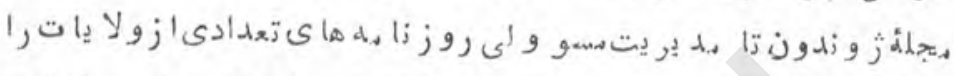

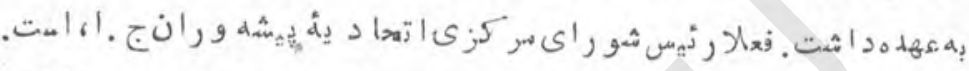

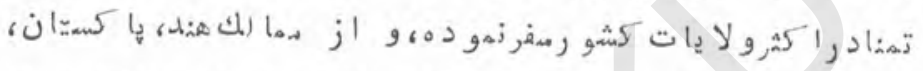

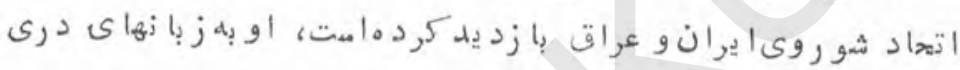

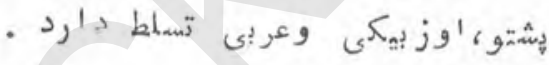

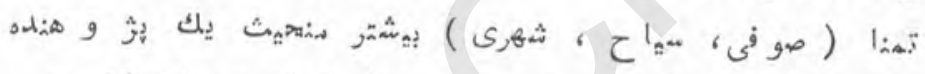

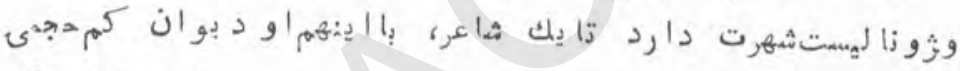

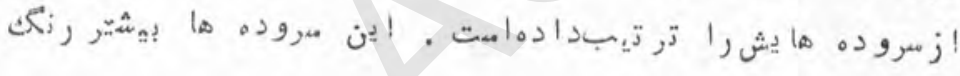

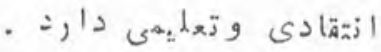

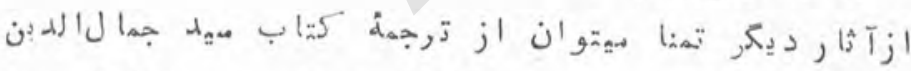
|

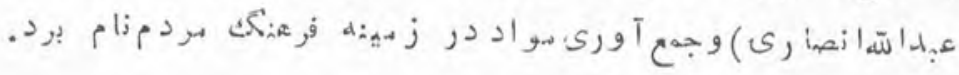

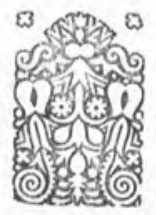




\section{خير ماك \\ هلتاز هردان راشى إس كرفتار همب ا ست}

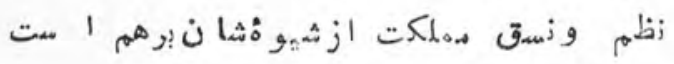

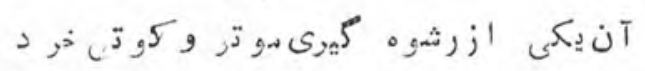

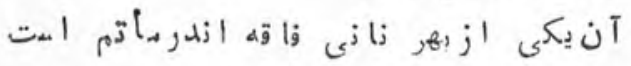

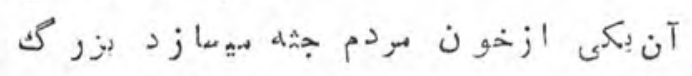

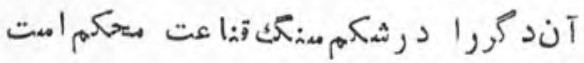

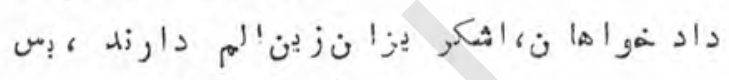

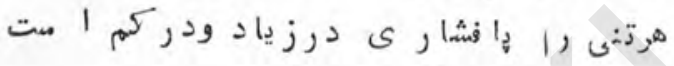

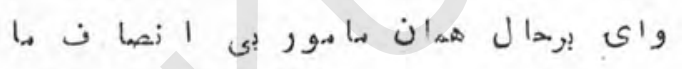

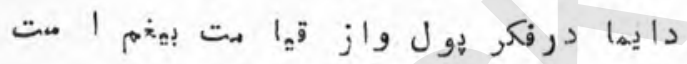

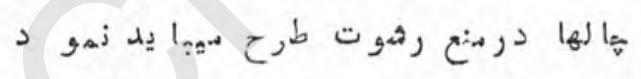

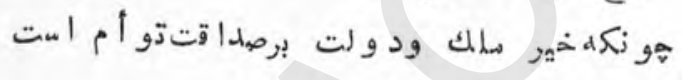

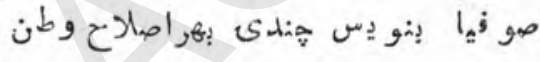

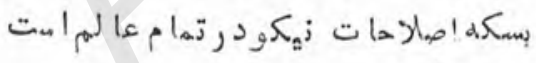

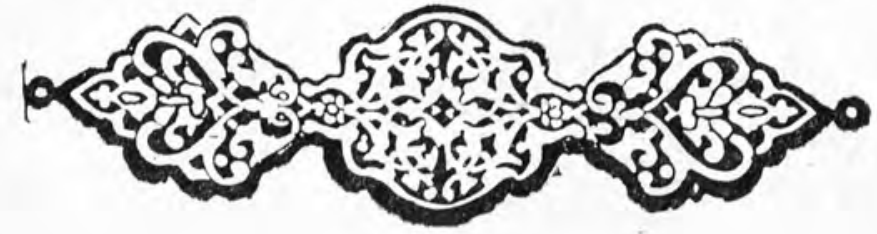




\section{غمرهجر ان}

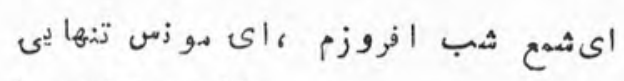

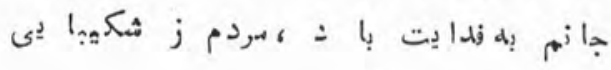

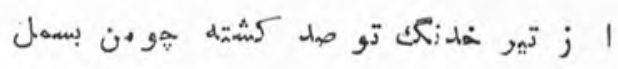

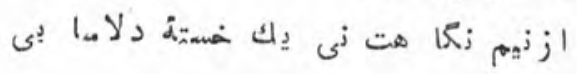

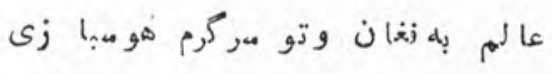

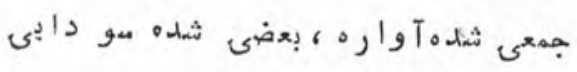

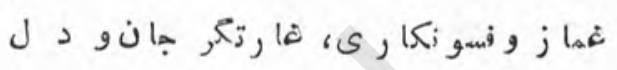

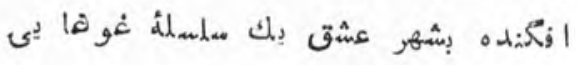

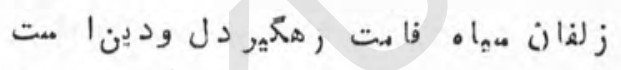

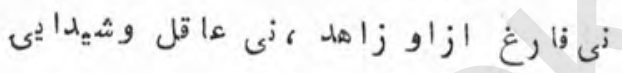

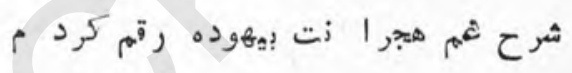

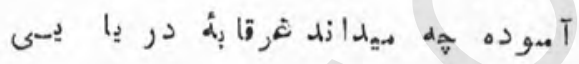

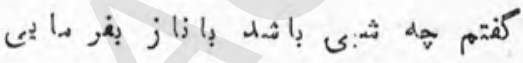

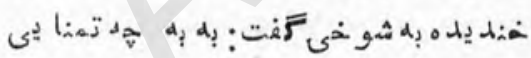

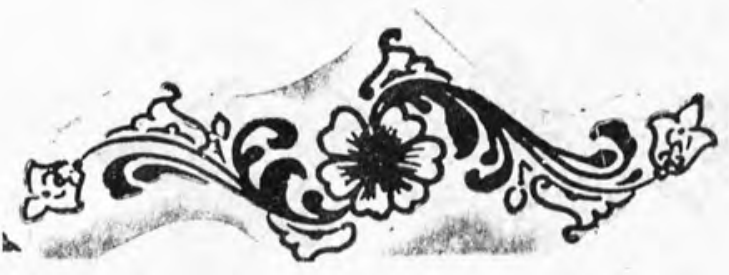




\section{Cllo}

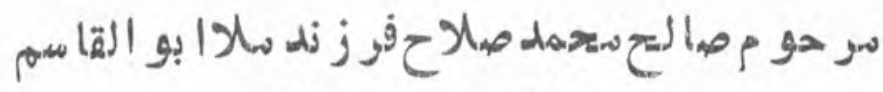

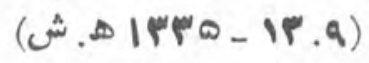

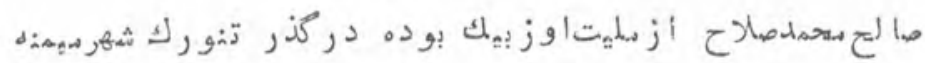

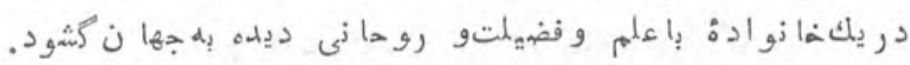

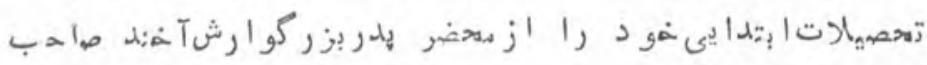

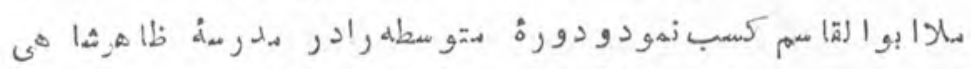

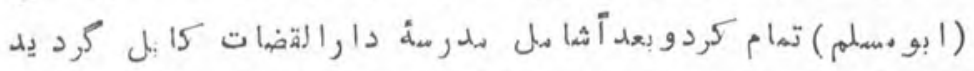

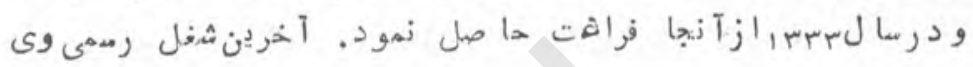

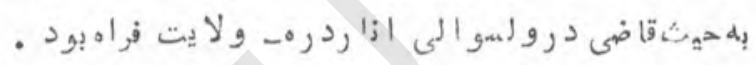

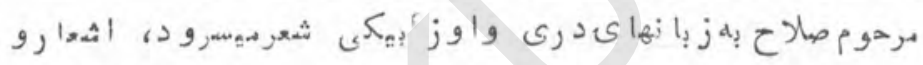

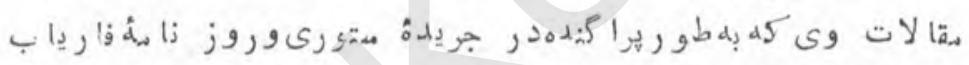

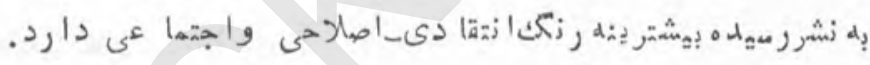

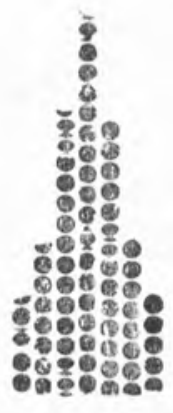

$|f|$ 
Fلرقند

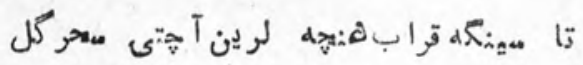

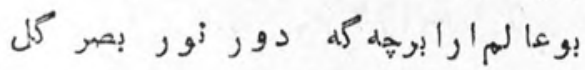

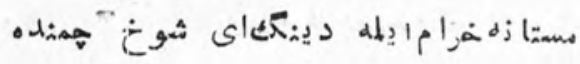

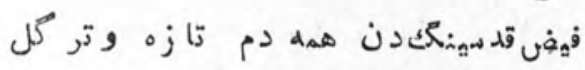

عهب يتهله، جها لوينكنى فراقيده سهرلر

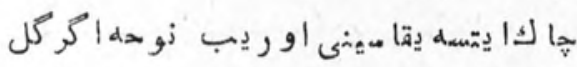

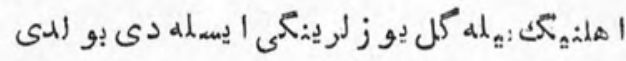

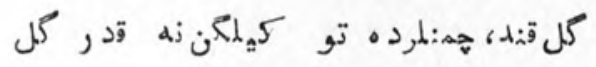

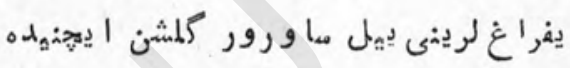

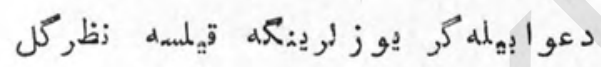

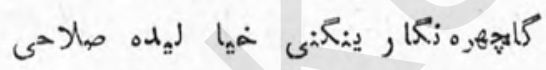

b

IfP 


\section{فخر ونازت تميسز ه برعلمموفن}

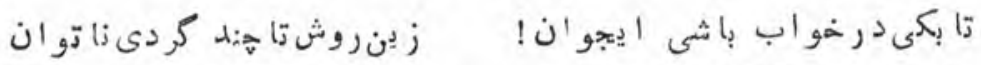

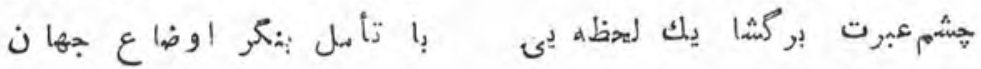

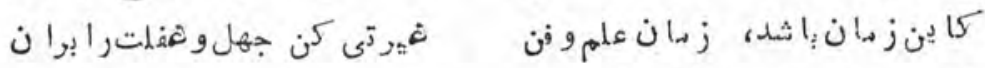

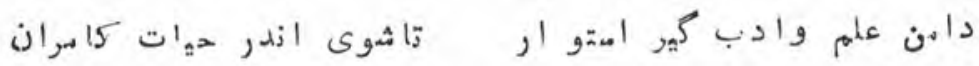

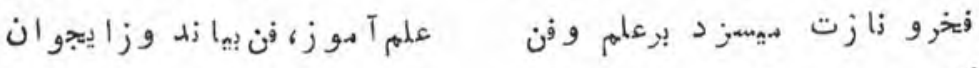

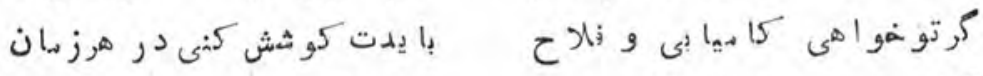

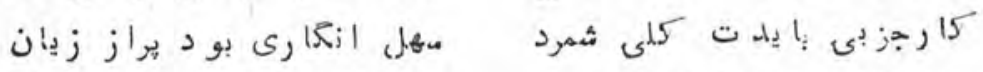

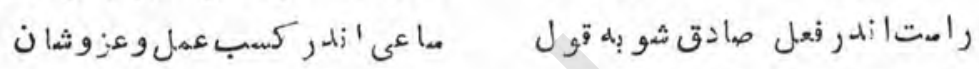

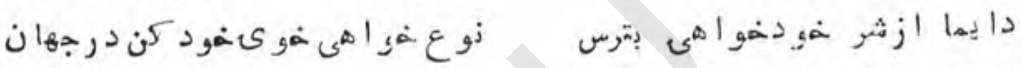

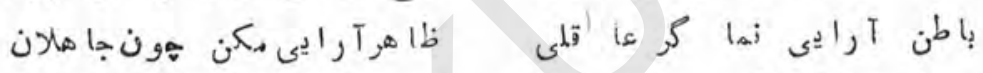

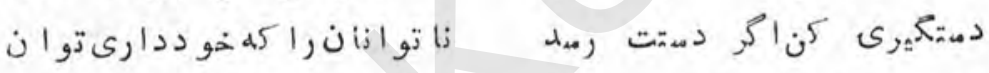

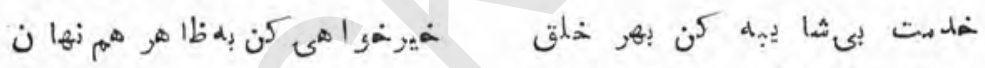

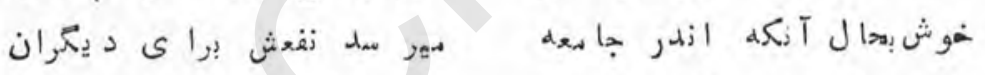

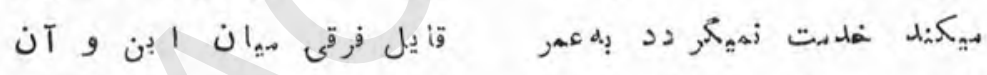

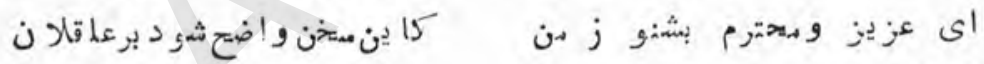

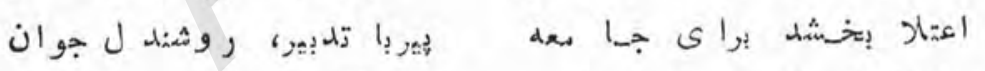

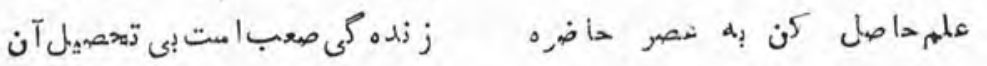

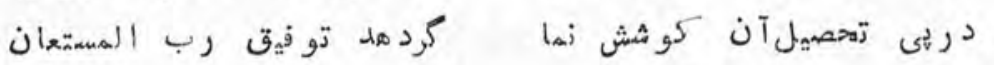

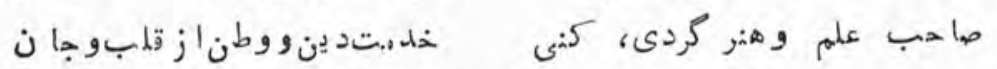

$$
\begin{aligned}
& \text { كر ماته }
\end{aligned}
$$

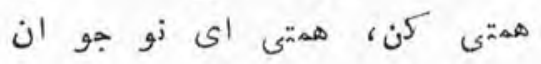




\section{حامناف فاريابى}

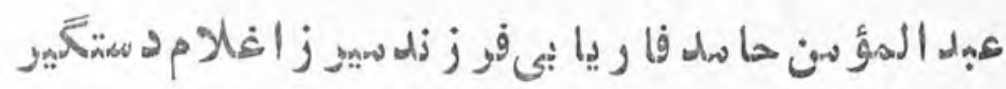
ت ت

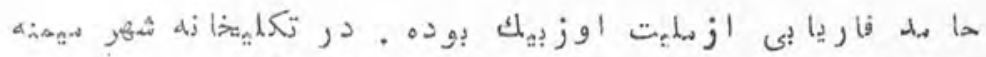

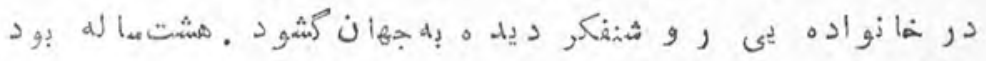

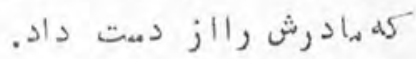

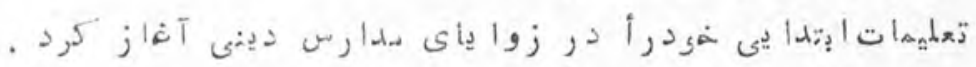

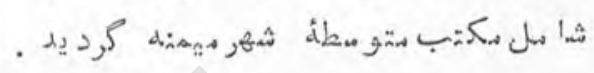

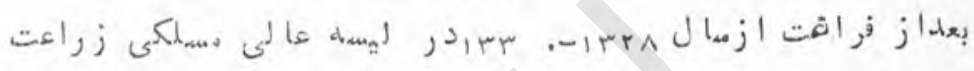

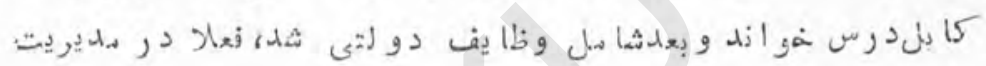

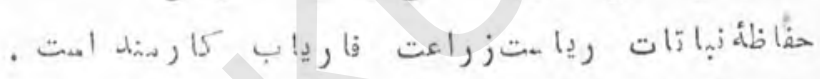

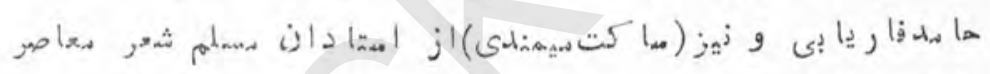

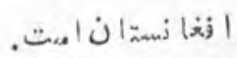

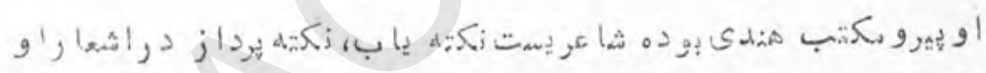

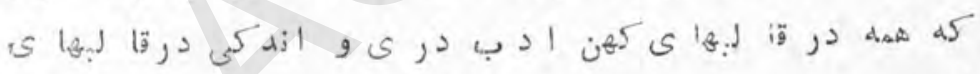

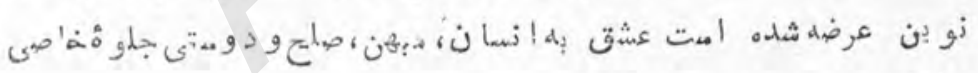

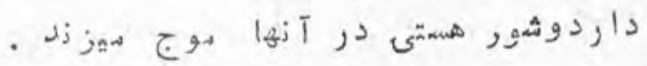

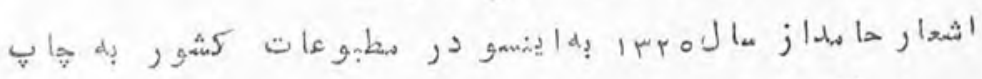

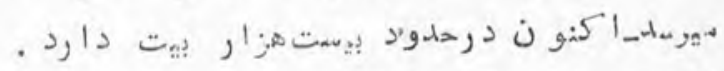

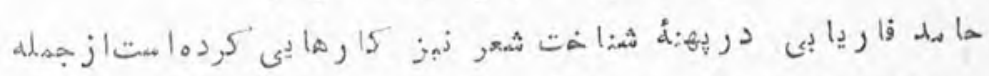

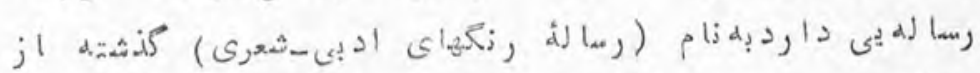

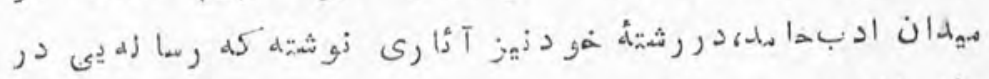

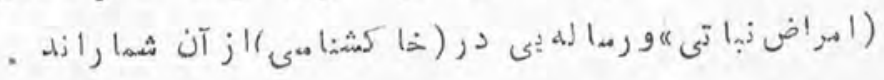




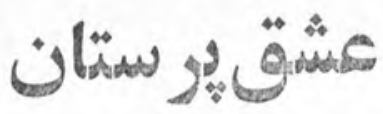

ज"

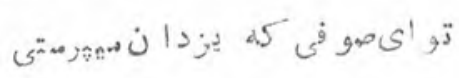

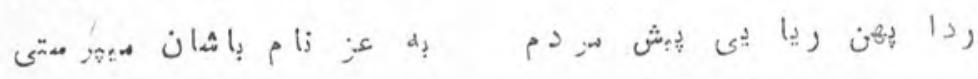

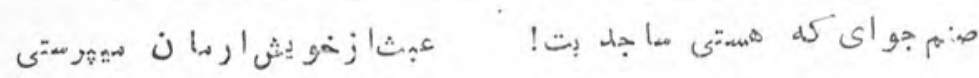

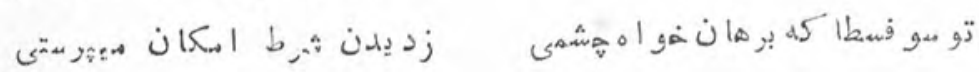

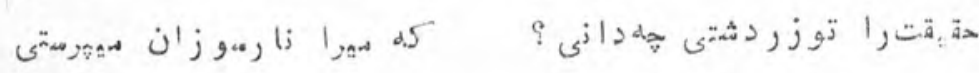

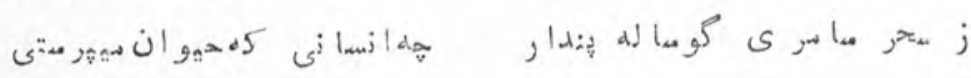

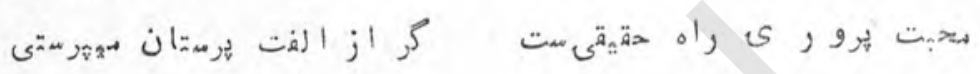

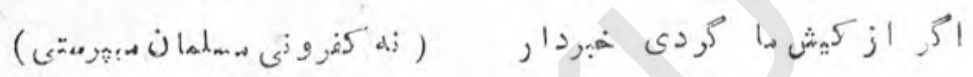

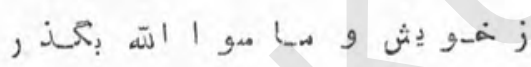

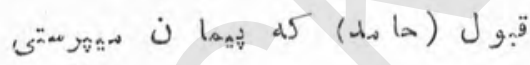

Ifo 


\section{نور شناور}

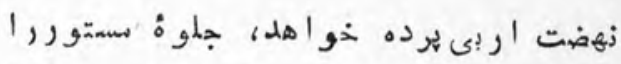

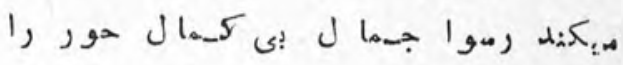

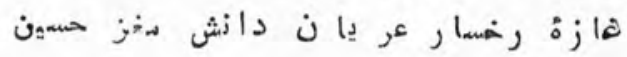

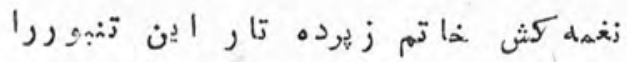

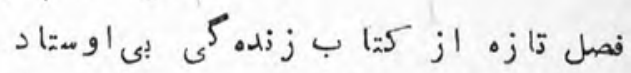

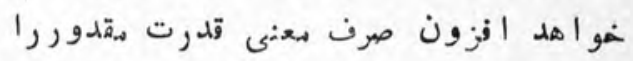

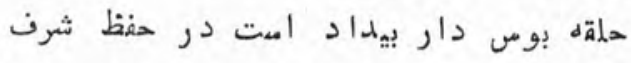

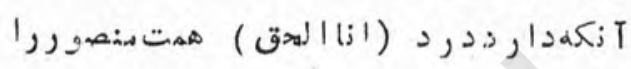

جيكدإز دل زمكردد جذ ب زشاء: در بدرن

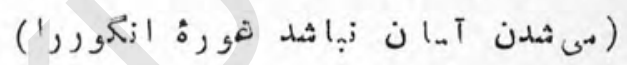

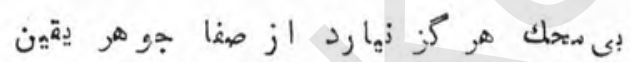

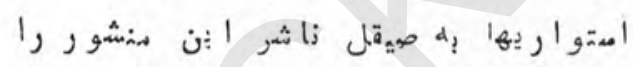

دان

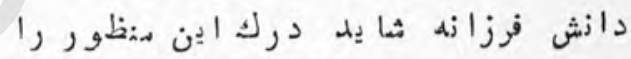

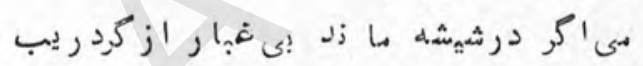

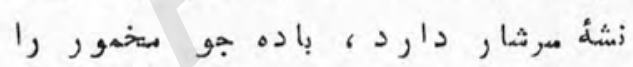

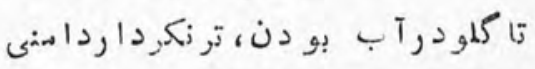

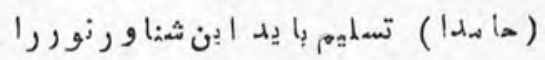

Ingy

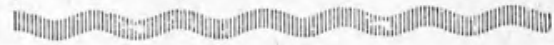

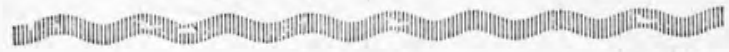


انشا

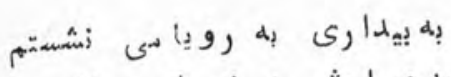

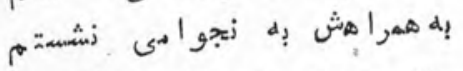

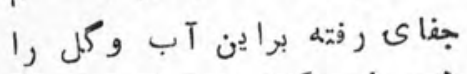

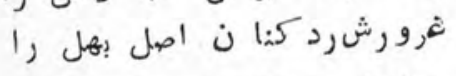

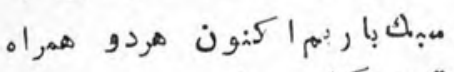

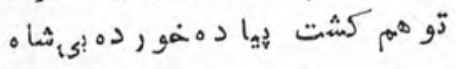

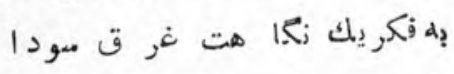

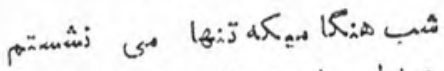

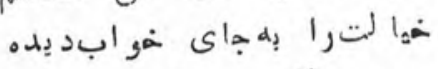

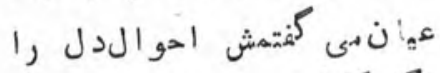

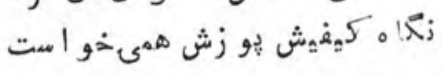

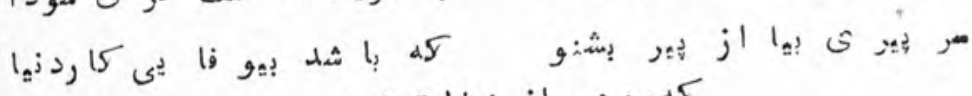

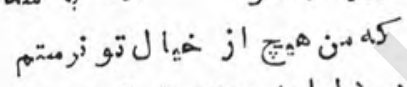

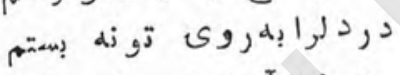

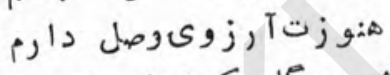

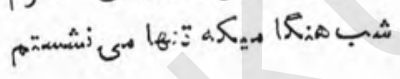

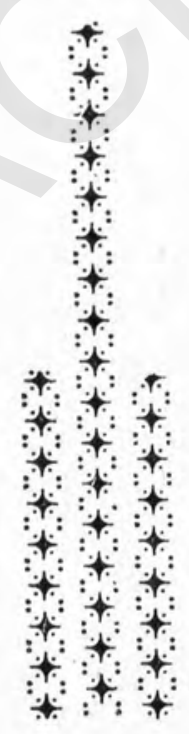

Ifv 


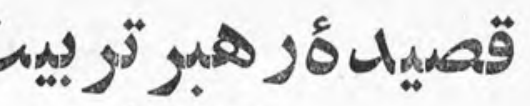

دالجهإل

جها ردال هركرا، كز دال لهنجمب رهبراست

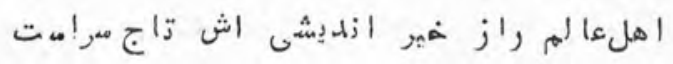

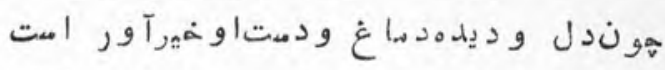

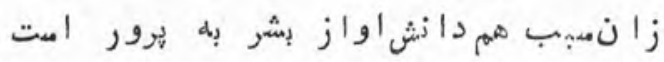

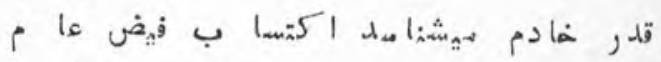

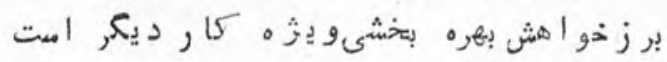

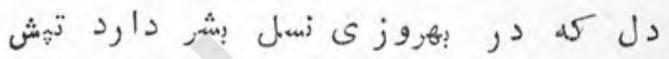

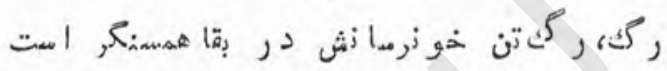

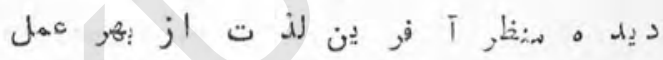

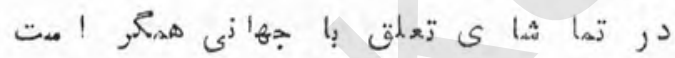

دمت الحسا ن دمتيمير زا رمايا ن طريق

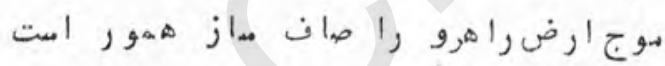

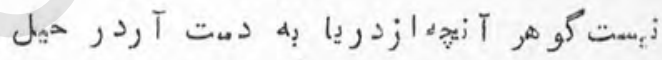

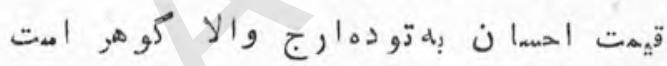

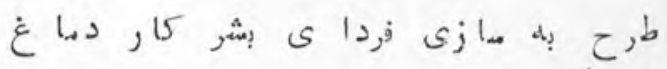

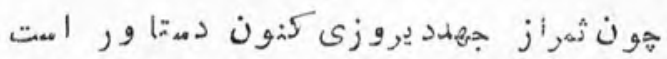

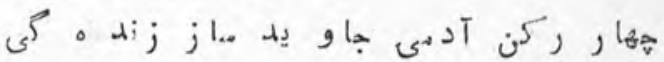

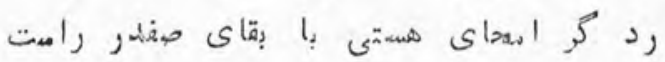

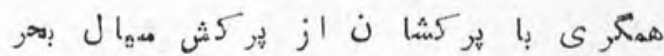

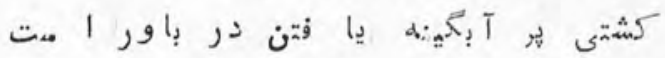

IFA 


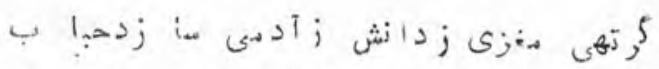

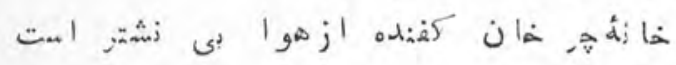

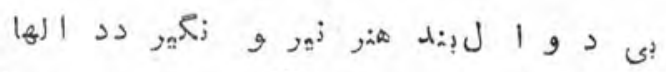

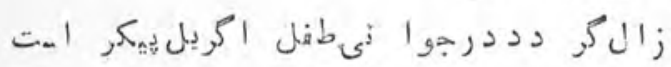

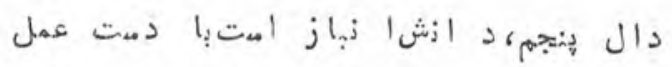

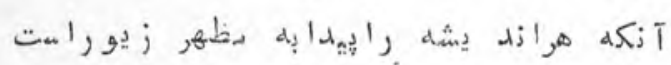

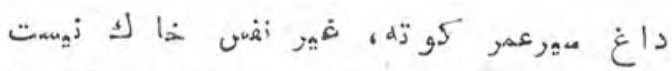

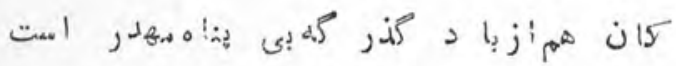

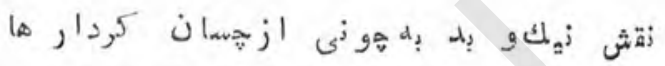

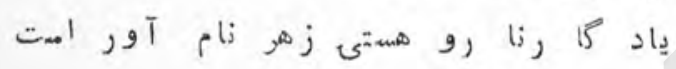

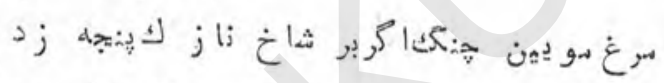

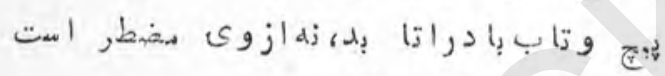

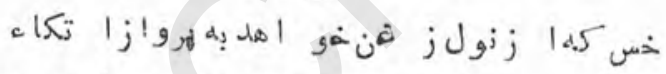

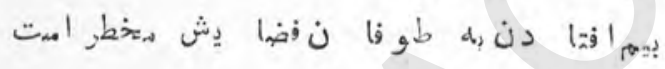

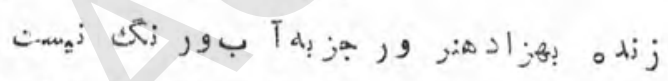

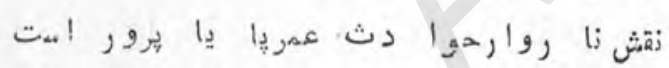

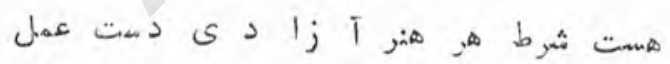

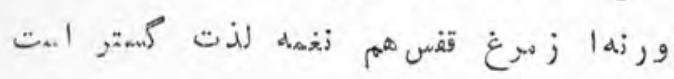

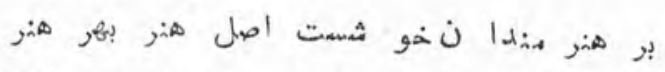

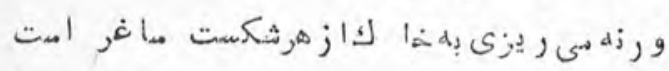

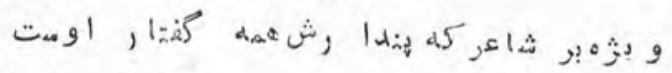

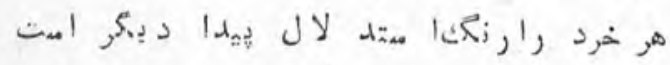

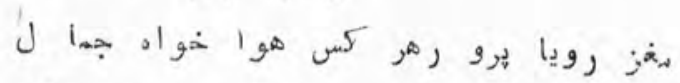

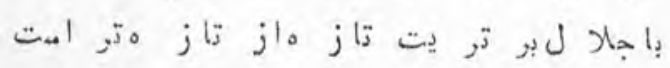

IfPQ 


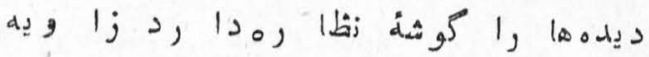

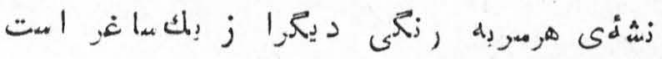

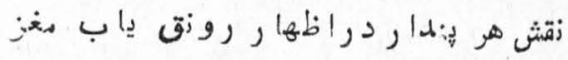

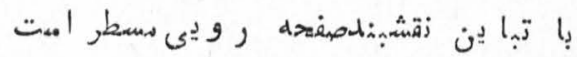

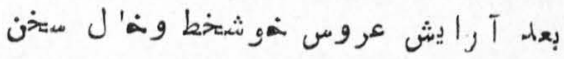

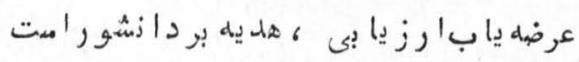

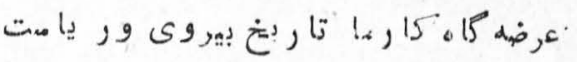

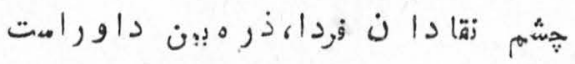

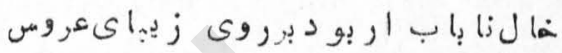

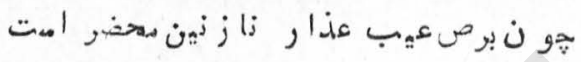

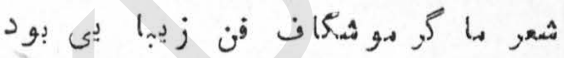

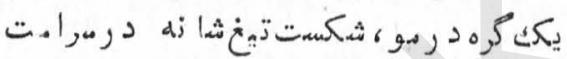

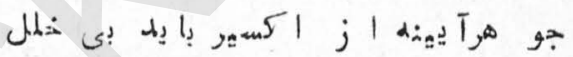

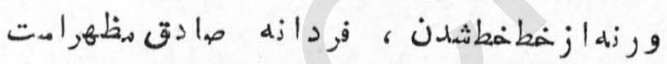

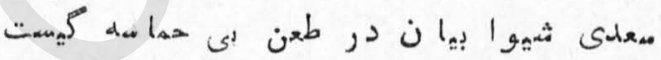

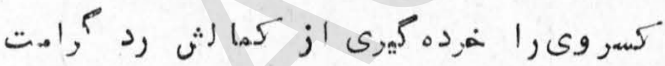

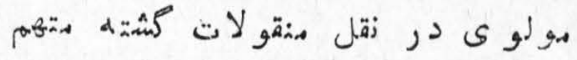

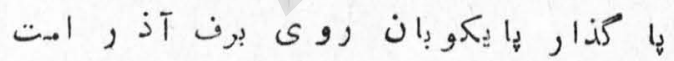

بهدل كم كرده د درا اتها م تركذخاق

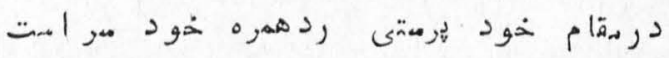

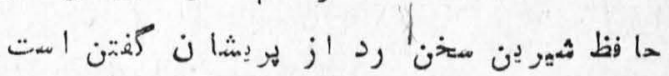

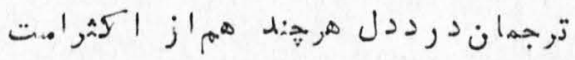

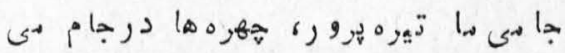

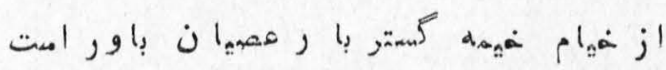

10. 
ز عنصرى وفرخي واز هنو

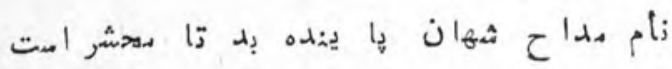

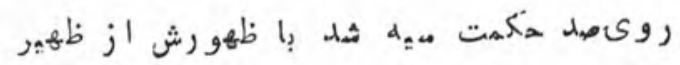

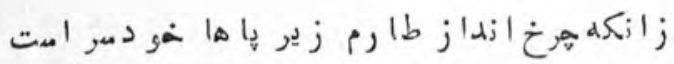

زام فردوسى زحفظوازه تا فردوس روت

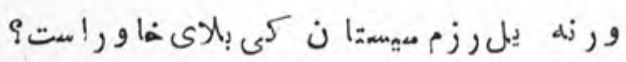

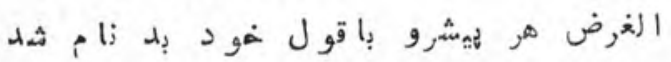

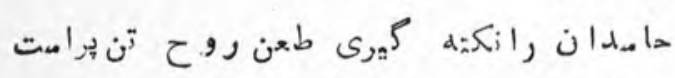

د آ

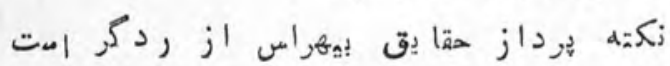

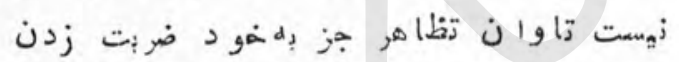

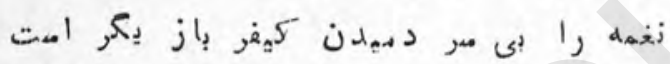

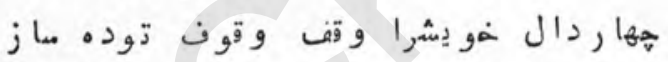

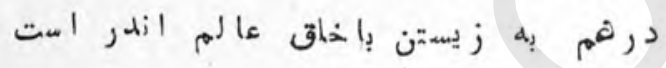

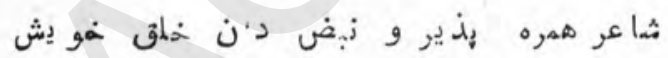

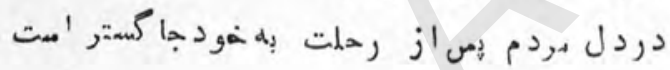

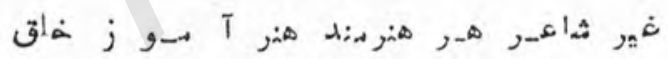

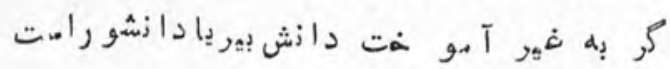

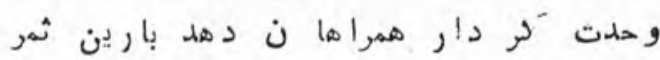

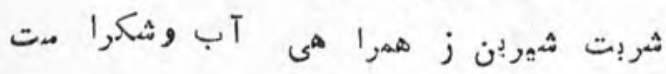

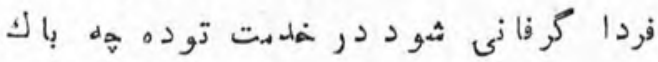

نشأه

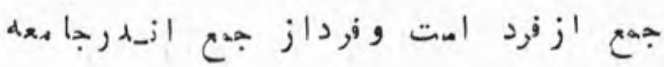

101 


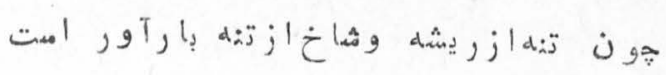

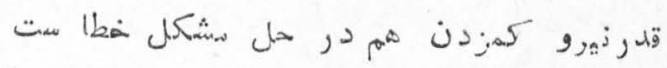

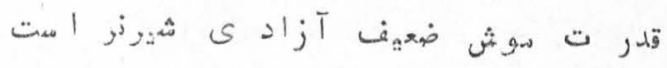

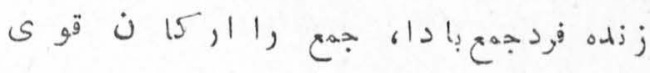

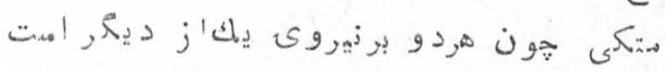

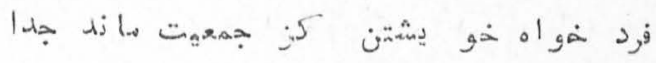

دأ

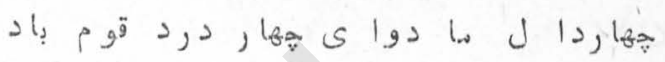

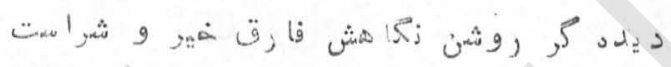

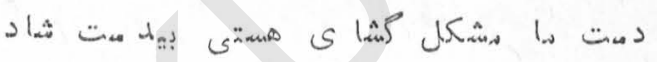

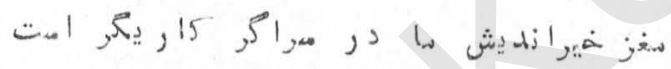

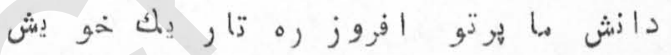

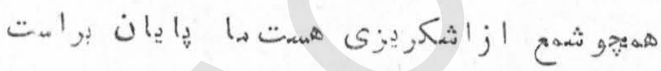

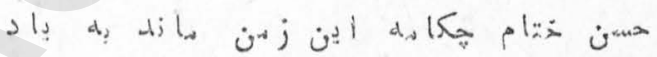

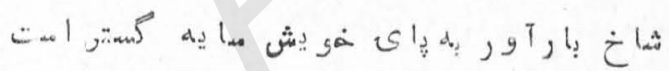

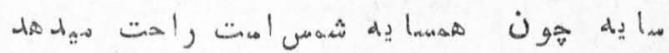

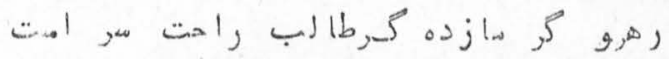

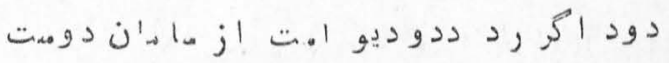

جأ

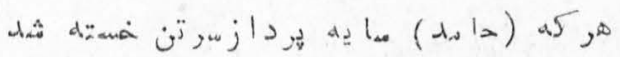

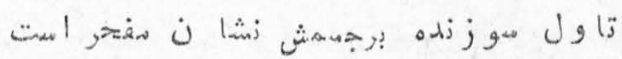

10p 


\section{او تُجْون}

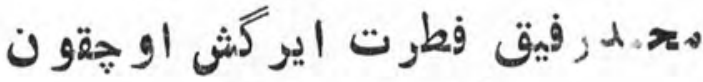

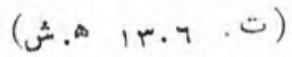

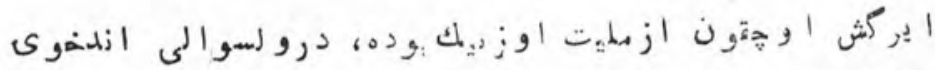

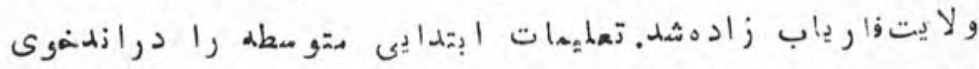

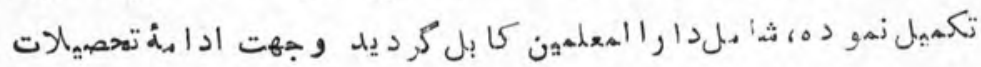

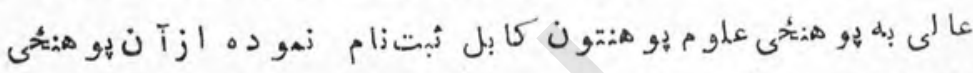

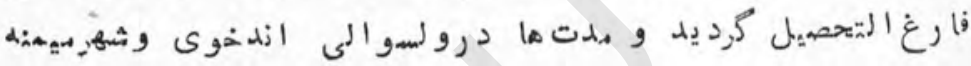

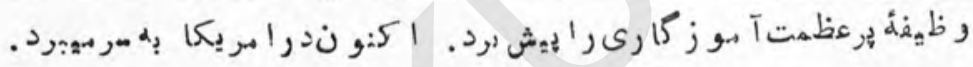

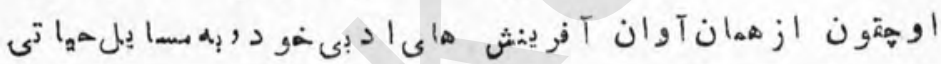
وضرورى مردم عتهديده توجه داشت وزالكنون إه همين روش

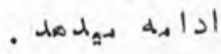

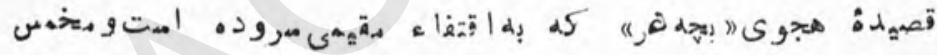

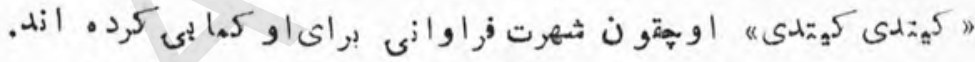

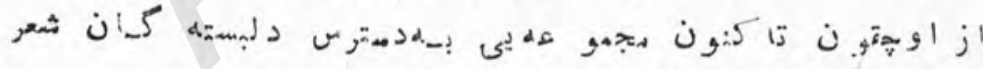
.

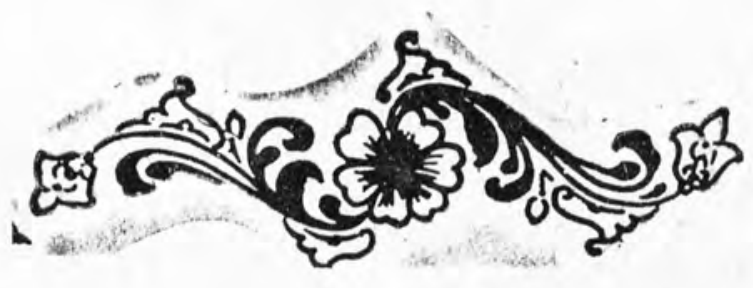




\section{كو}

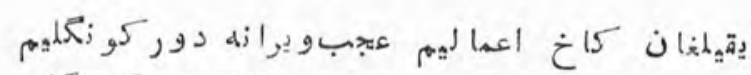

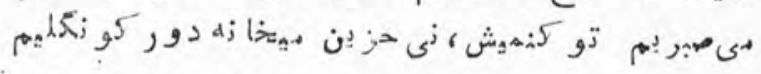

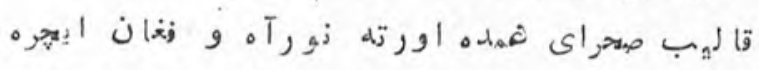

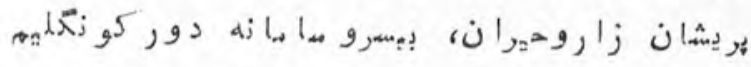

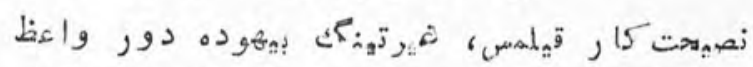

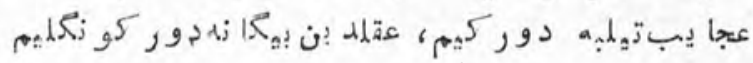

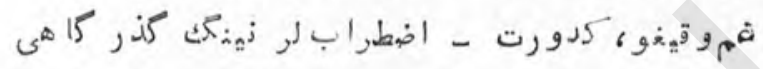

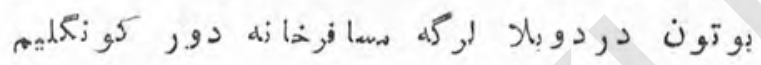

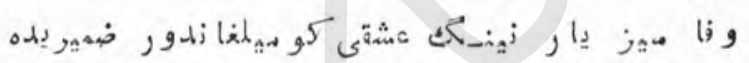

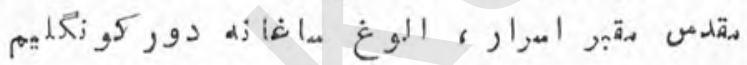

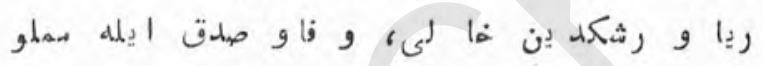

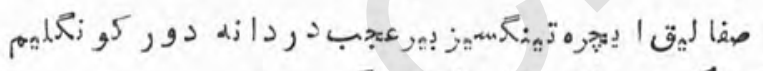

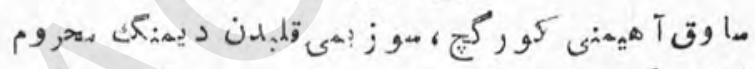

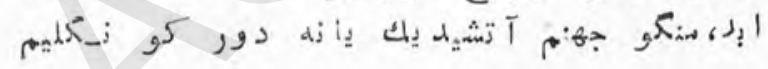

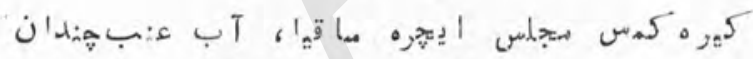

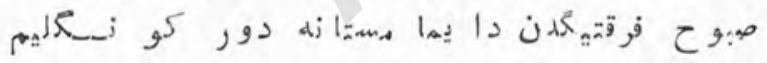

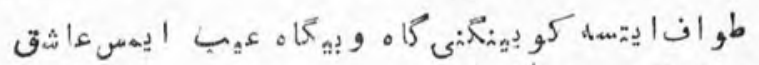

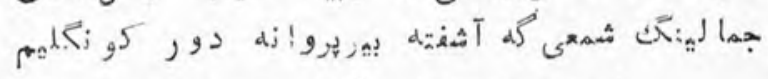

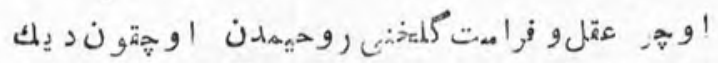

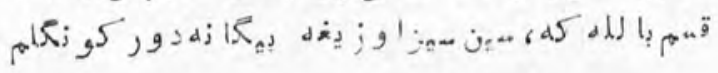

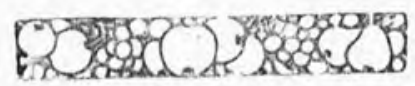




\section{كـعبمه الاوزبيـك}

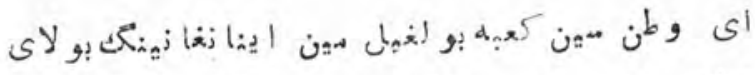

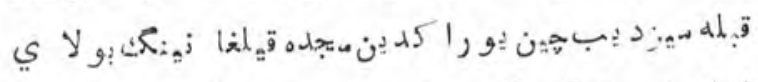

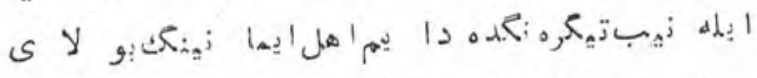

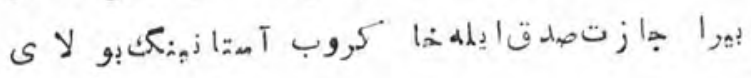

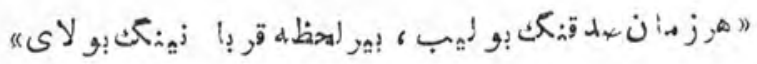

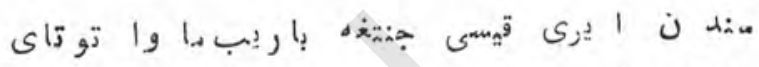

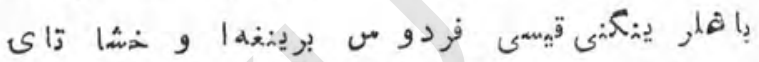

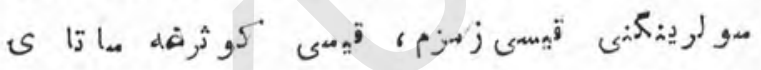

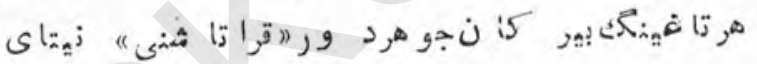

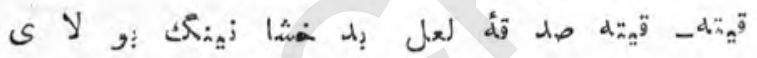

صا

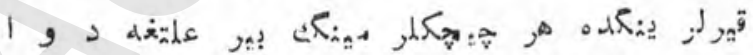

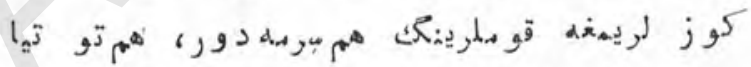

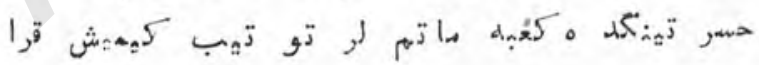
ك5r.

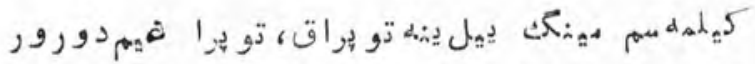

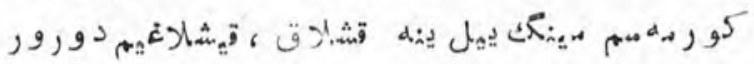

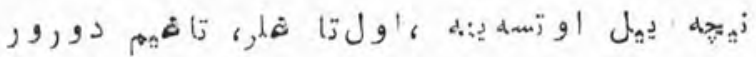

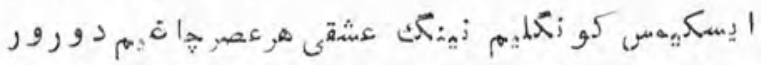

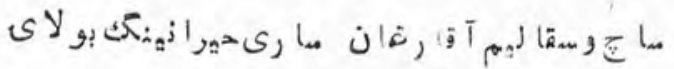




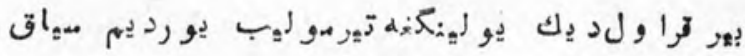

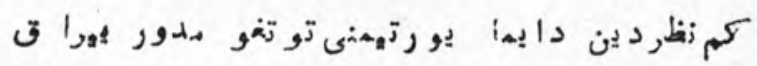

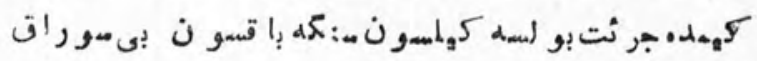

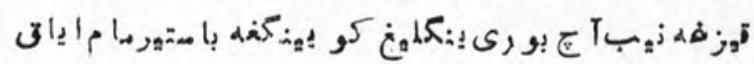

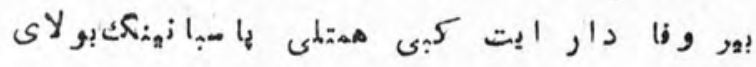

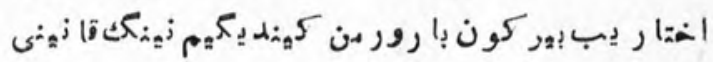

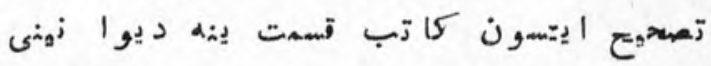

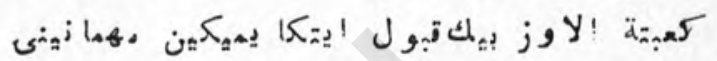

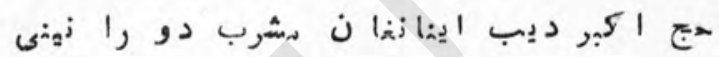

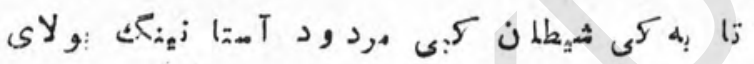

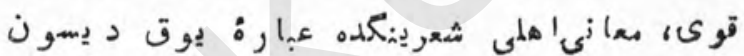

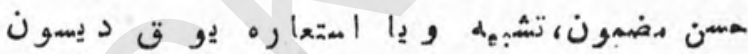

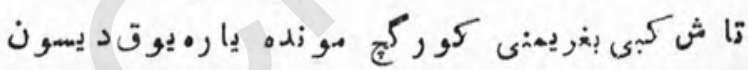

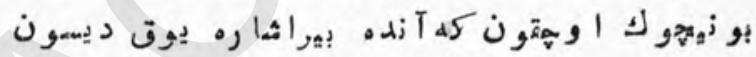

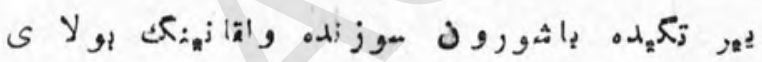

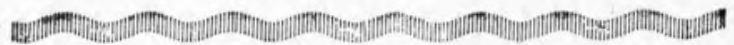

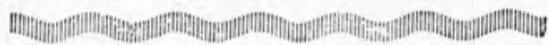

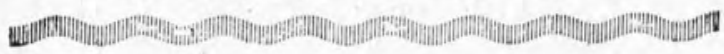




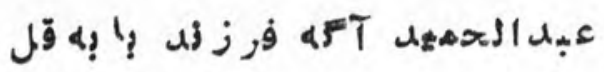

$$
\text { ت. ت ا }
$$

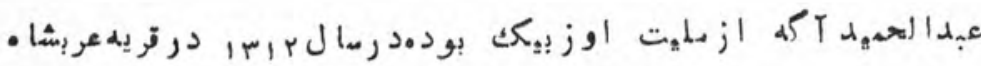

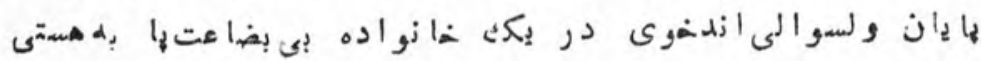

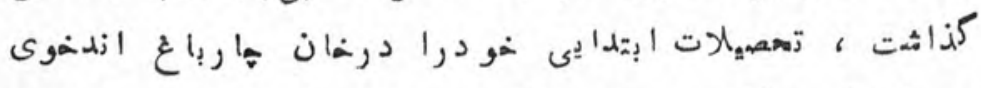

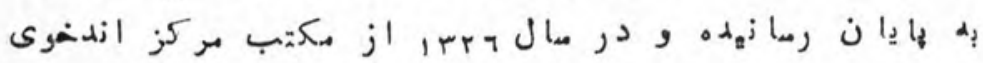

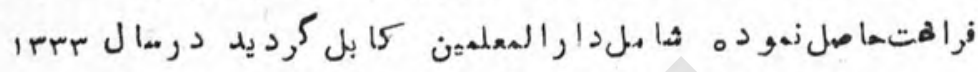

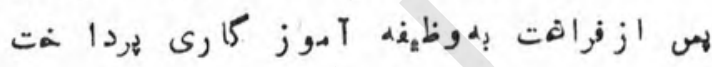

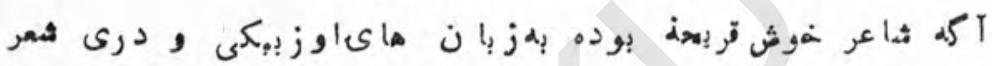

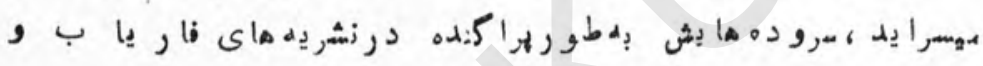

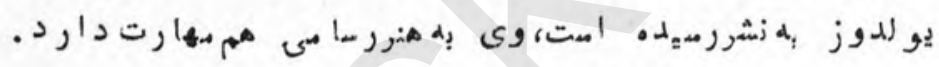

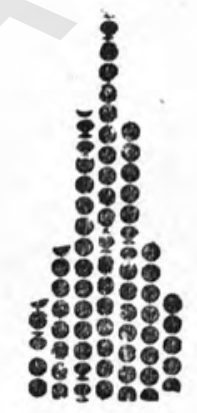

IOY 


\section{از خيانت بر حذر باش \\ ثام جهل زئده كى ازمعرفت برنور كن}

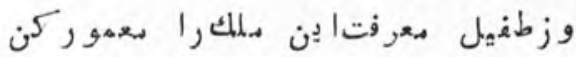

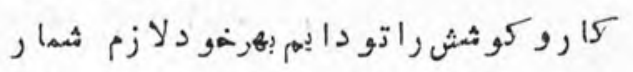

شهوة بيكا رهكى را ازمبر غود دور كن

$$
\text { روزوشبازندريى رفع عوبنو يش جاش }
$$

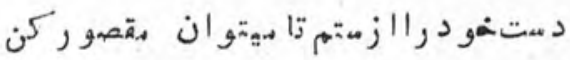

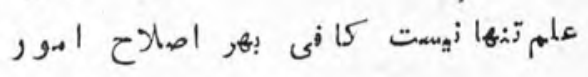

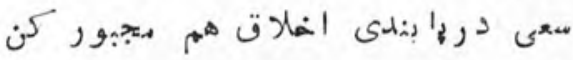

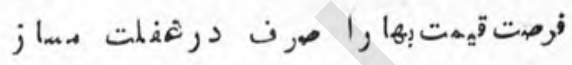

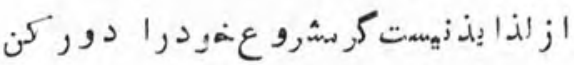

$$
\text { ازخيا نت برهذرباش وثشعار خود مساز }
$$

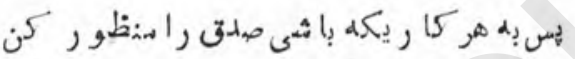

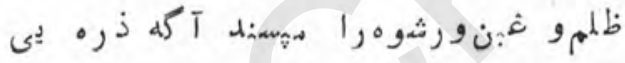

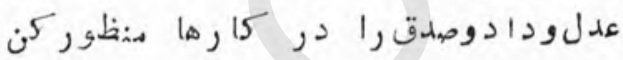

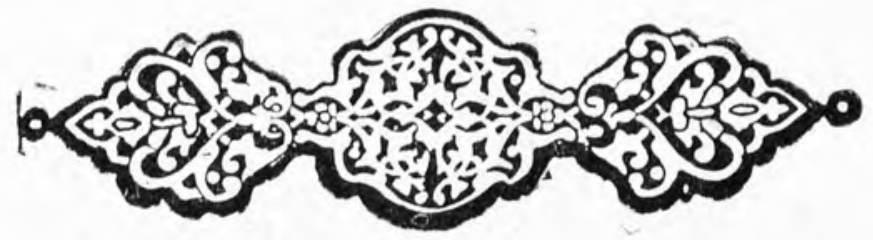


نلdرت

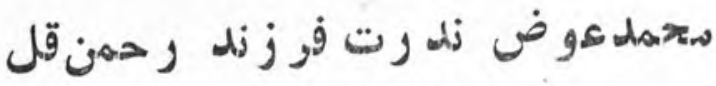
ت:HIF:

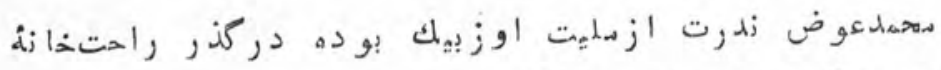

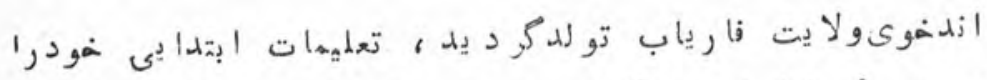

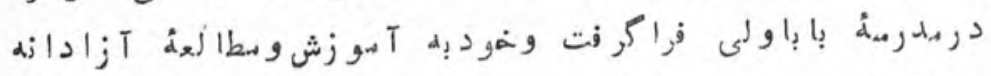

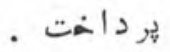

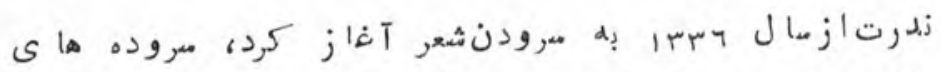

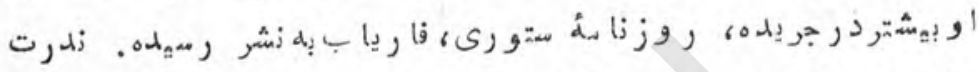

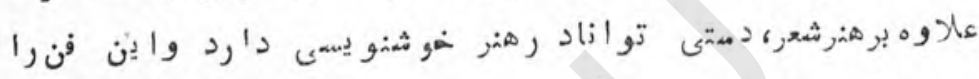

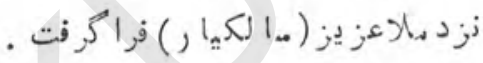

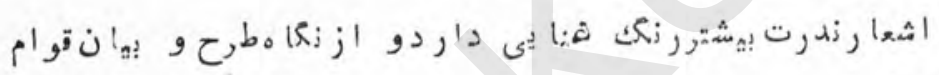

يا فيّه است .

108 


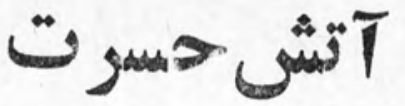

$$
\text { صبحكا هان دلبرم كربى زقا ب؛ آيد جيرون }
$$

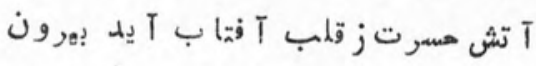

$$
\text { هرتماشاى جمال ل آن بت ثعرين اداد }
$$

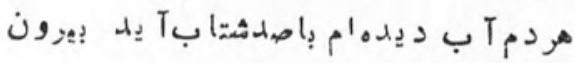

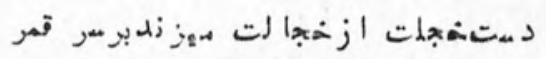

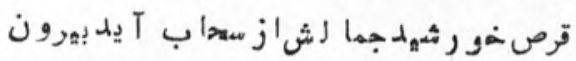

$$
\begin{aligned}
& \text { كرروددبالاى قبرندرت آن } 515
\end{aligned}
$$

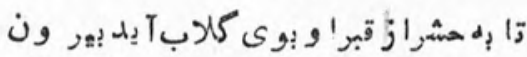

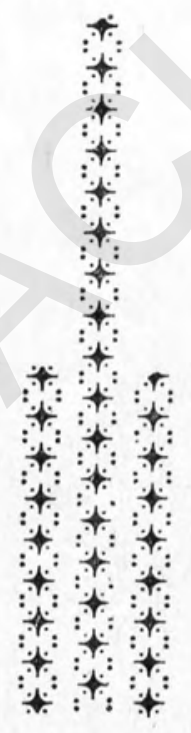


T ثشي هـجح 1

ك:د در إنسر عالم و فـن ثئا دل

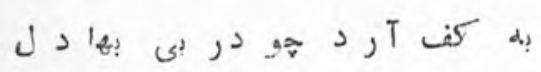

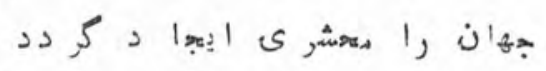

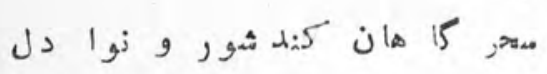

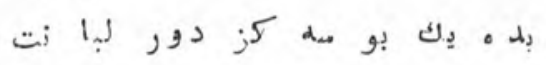

ازان جو يد بهدرد نهود دوادل

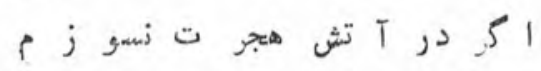

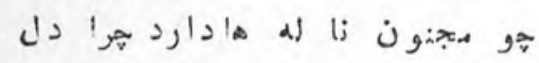

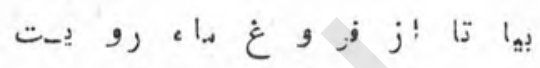

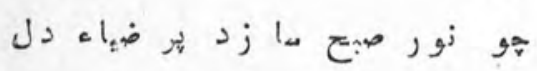

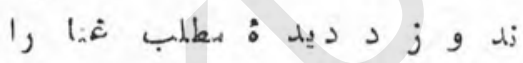

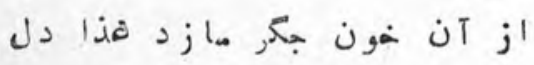

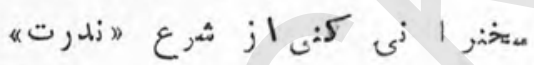

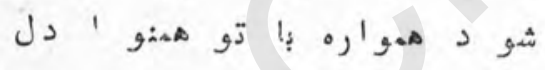

171 


\section{انور الذهويى}

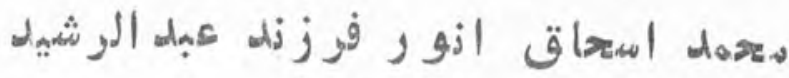
ت:

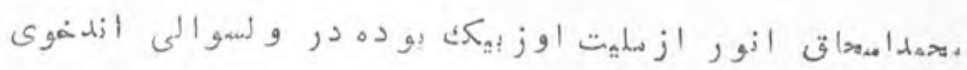

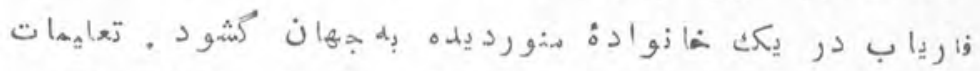

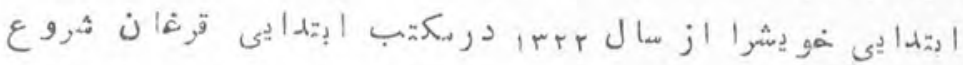

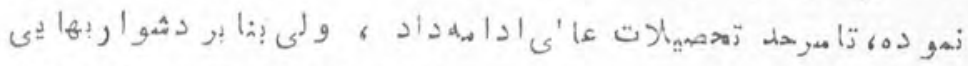

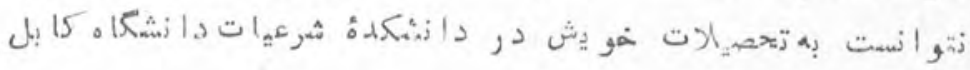
. 100 as

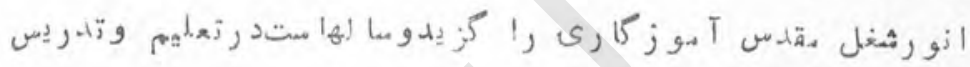

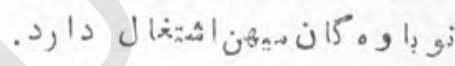

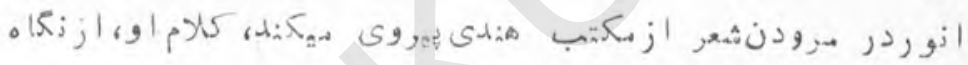

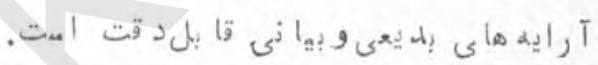

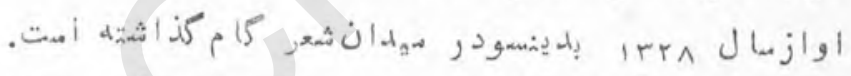

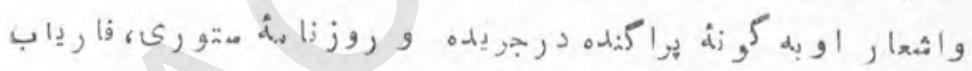

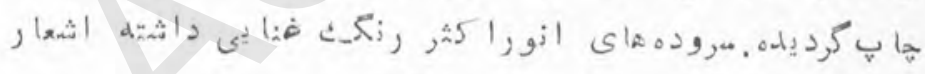

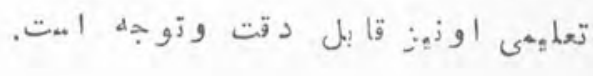

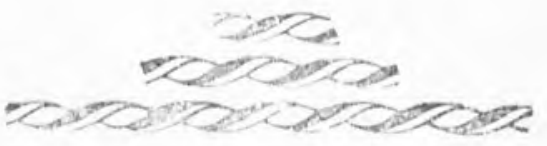


زاوكزاز

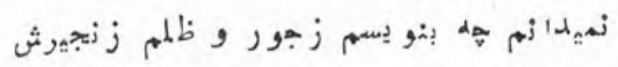

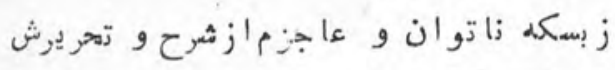

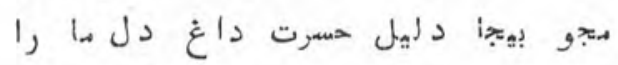

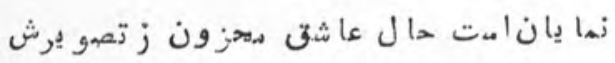

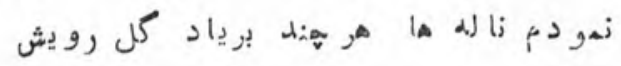

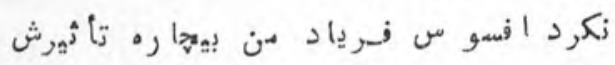

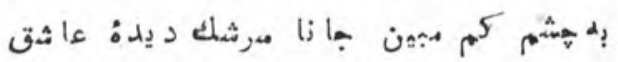

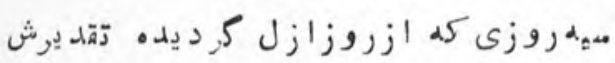

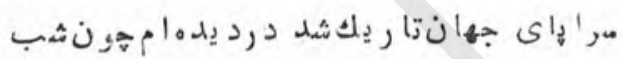

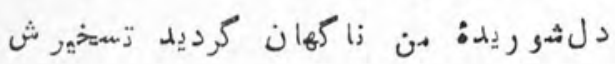

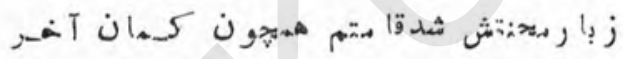

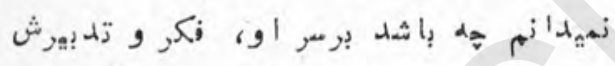

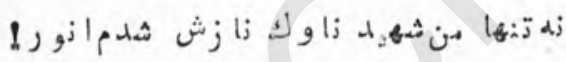

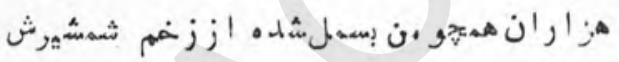

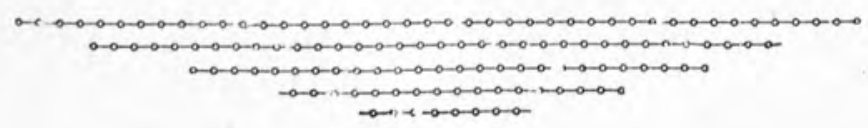

ITP 


$$
\begin{aligned}
& \text { J } \\
& \text { درهمن بلمبل به دياد } \\
& \text { دردلا وزئش خمار اين كلمتان بوده امدت }
\end{aligned}
$$

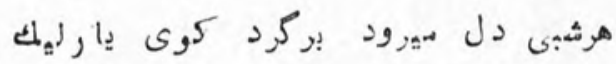

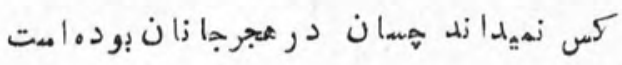

$$
\begin{aligned}
& \text { درحريهش روزوشب افتا ده دل بهرا ميد }
\end{aligned}
$$

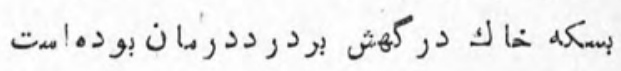

$$
\begin{aligned}
& \text { داثها دارد د لم ا ز حسر ت ديدار او }
\end{aligned}
$$

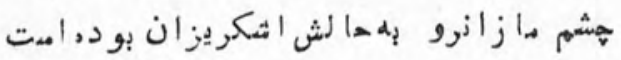

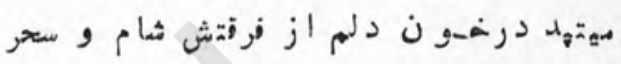

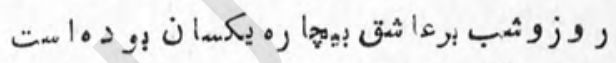

$$
\begin{aligned}
& \text { تا بكى با ثشيم دوراز دهنلت ایى مسروزاز }
\end{aligned}
$$

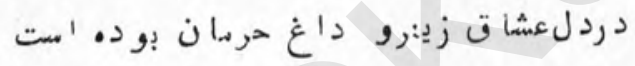

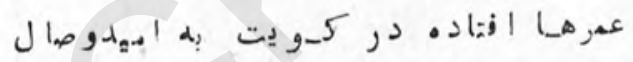

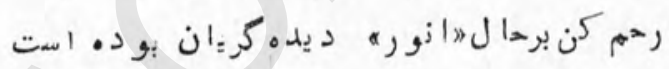

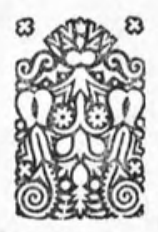




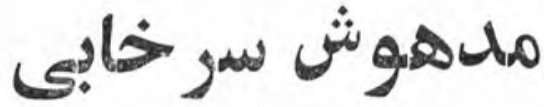

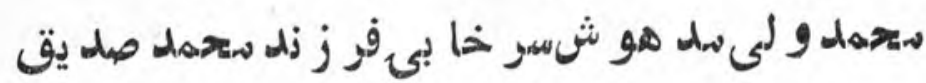

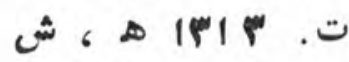

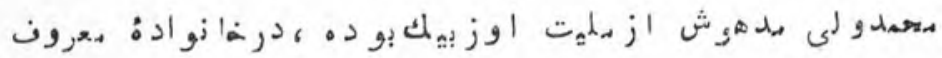

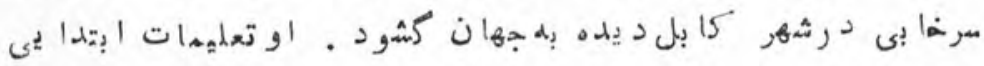

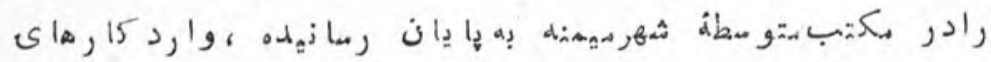

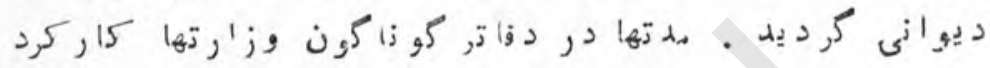

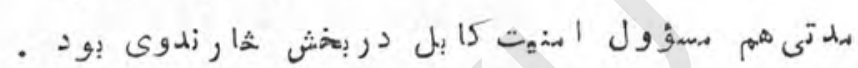

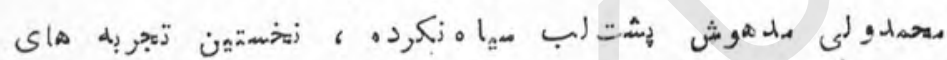

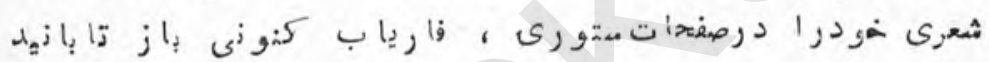

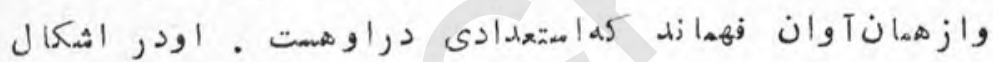

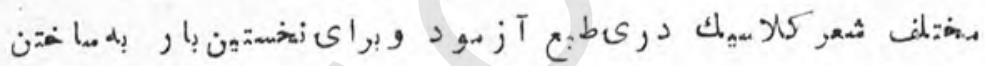

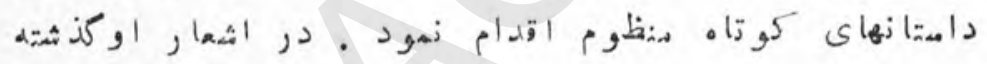

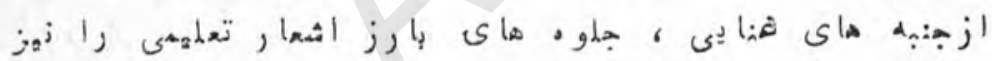

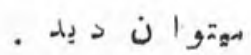

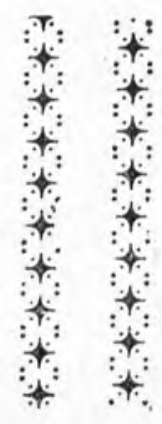




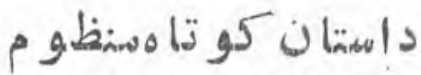

\section{كمشت شبان}

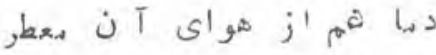

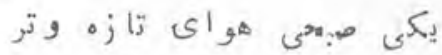

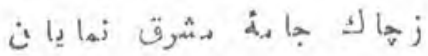

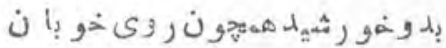

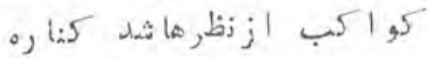

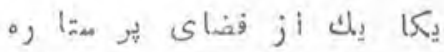

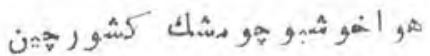

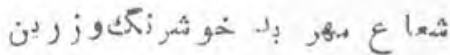

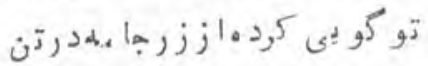

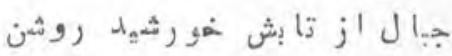
مئه *

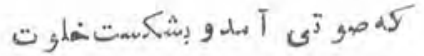

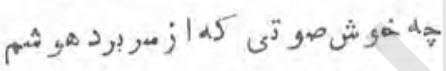

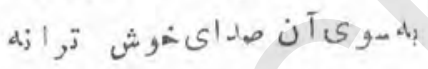

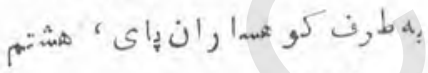

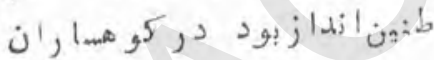

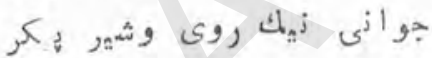

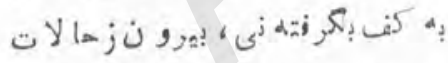

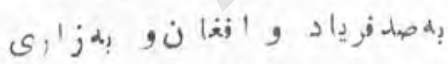

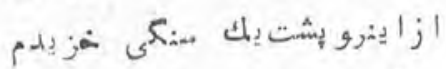

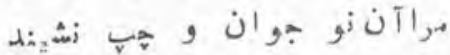

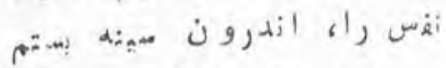

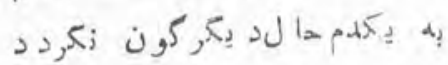
ماك آكث

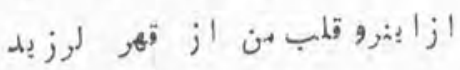

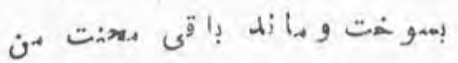

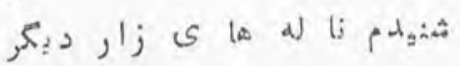

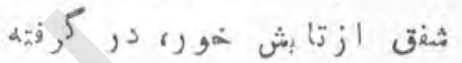
*

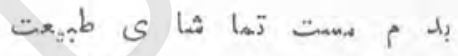

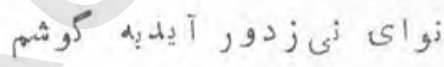

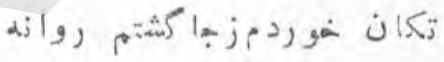

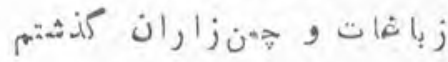

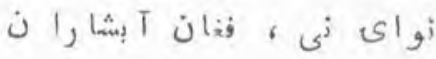
بهروى صخره بيى درواى شرثر

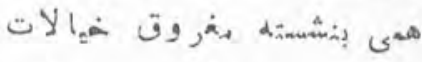

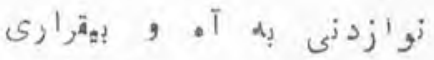

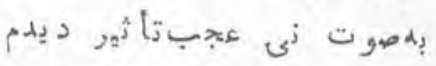
-

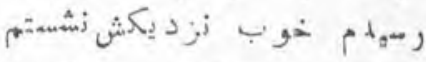

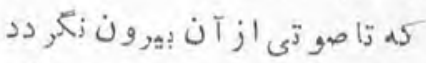

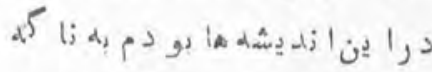

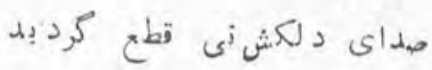

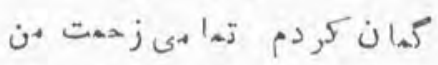

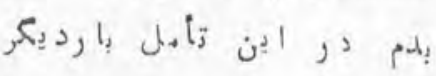


صادا ازعمق قلب إرهمى إنود

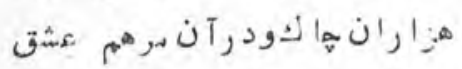

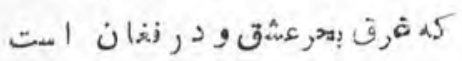

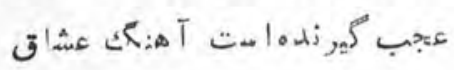

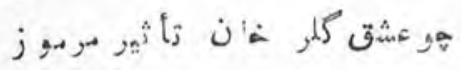

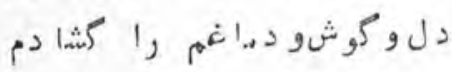

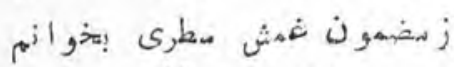

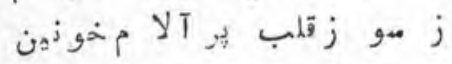

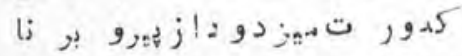

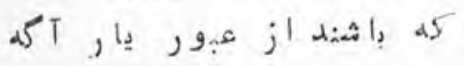
?

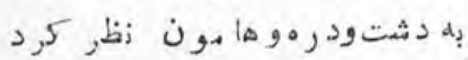

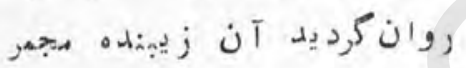

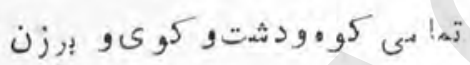

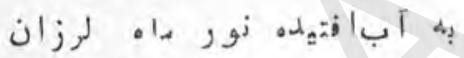

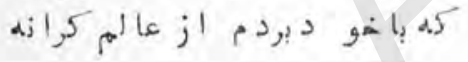

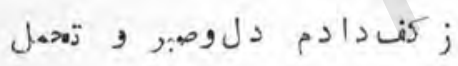
بـ

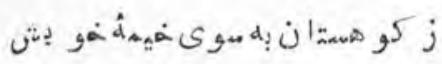

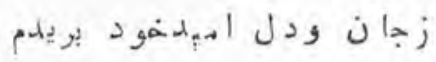

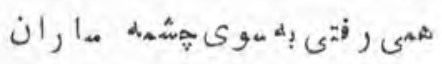

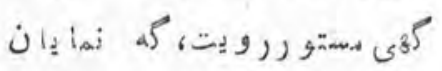

* *

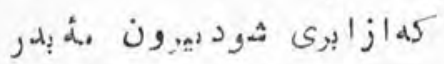

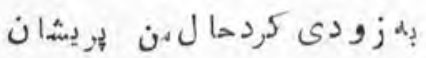

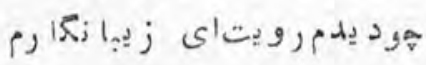

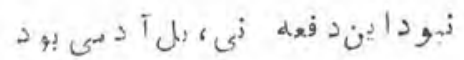
زأن

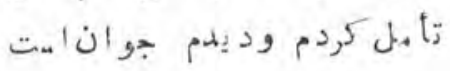

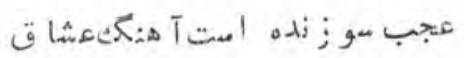

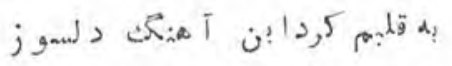

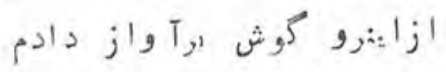

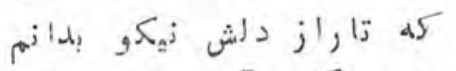
مئم

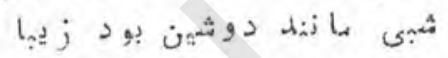

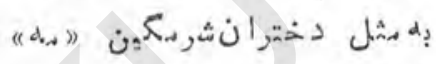

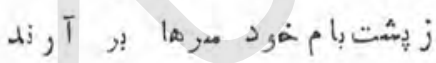

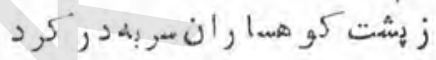
ربه

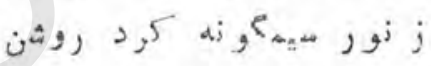
ن ز ز ز

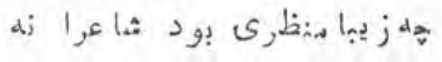

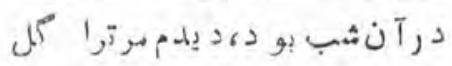
a_il

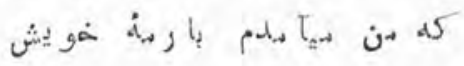

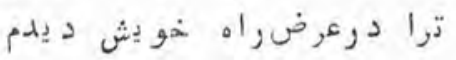

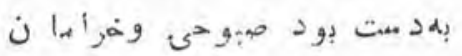

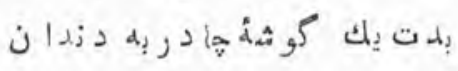
* رة

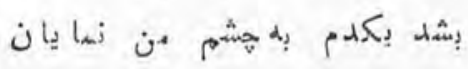

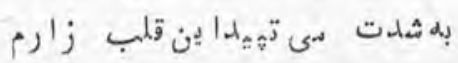


دلم را كرد توأم بإغم تو

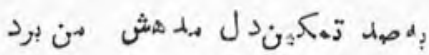

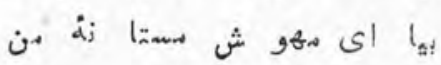

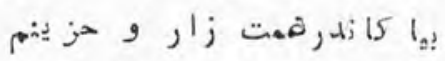
بـ

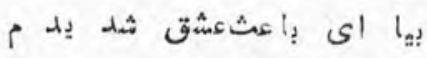

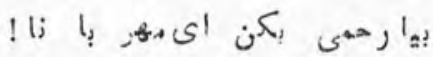

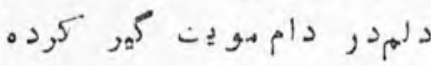

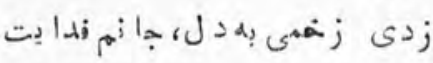

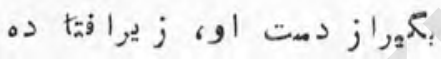

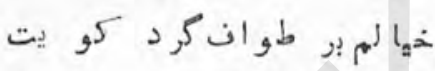

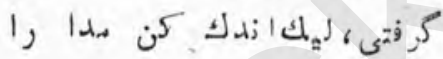

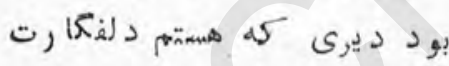

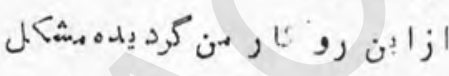

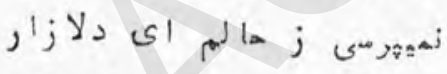

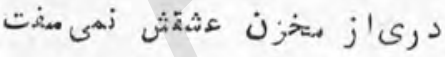

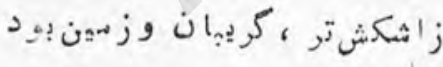

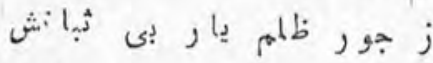

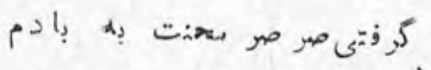
فر وشدد ر دل و اشكـــ ترمبر ديخت

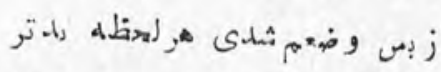
د, dj

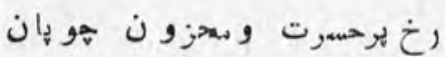
همى ثمد حال هن هردمان

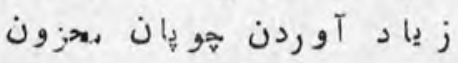

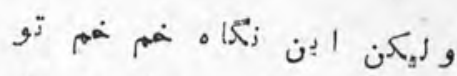
ز كنص:بر وقرار وهوش بن بن برد

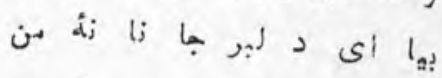

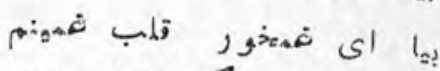
بـ

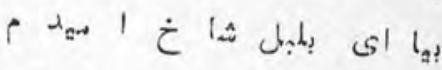

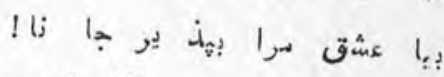

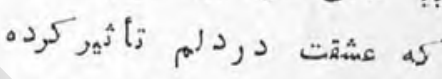

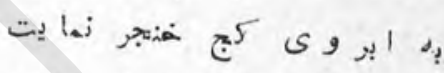

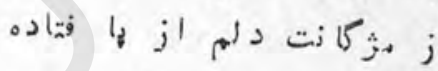

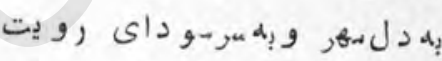

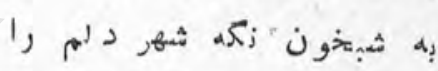

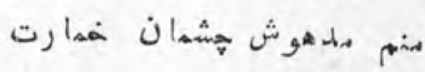

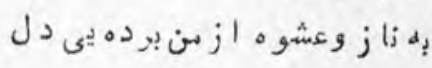

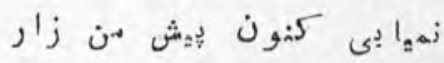

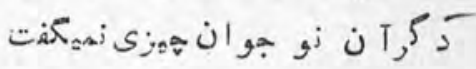
مهوش وا بتر و ز'ر وحز ين بود

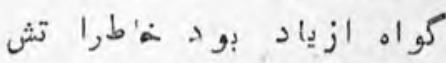

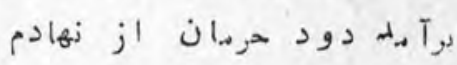
ترحم

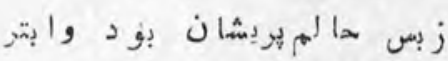
ز

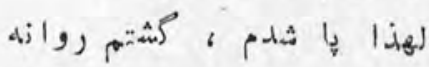

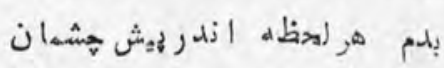




\section{مز آت}

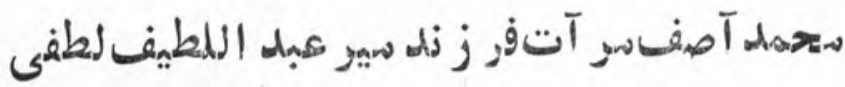

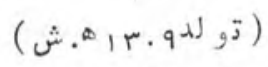

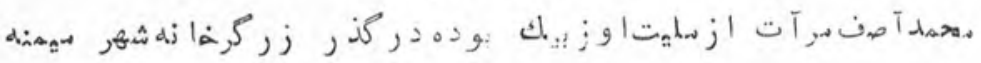

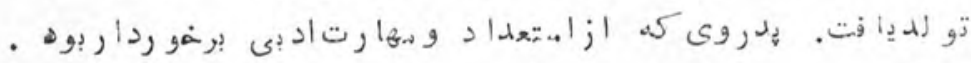

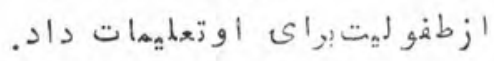

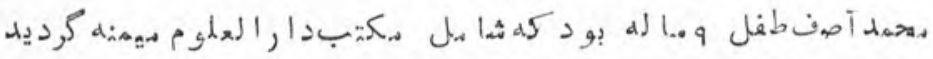

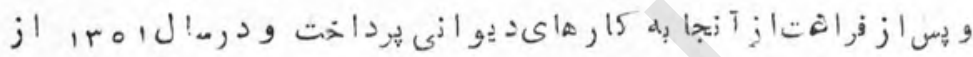

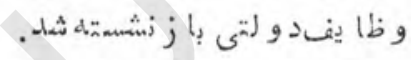

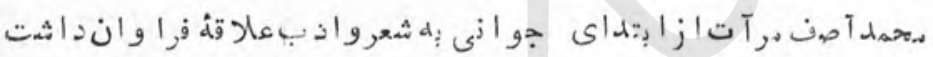

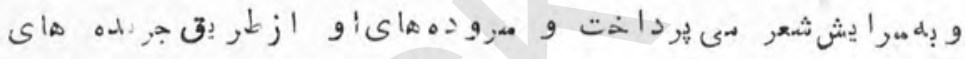

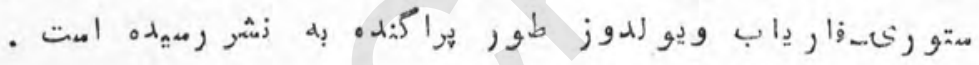

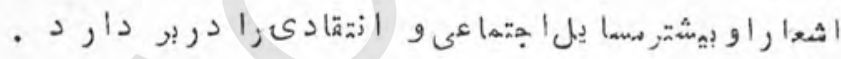

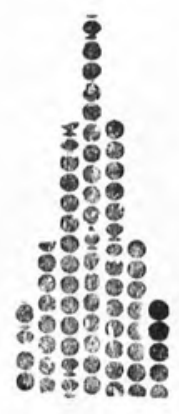




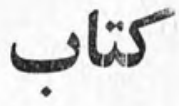

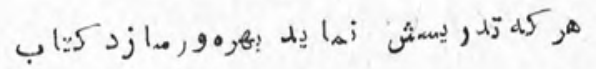

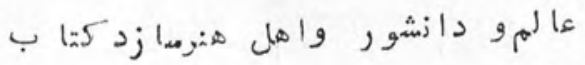

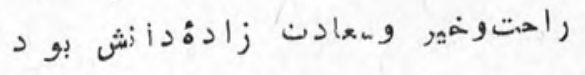

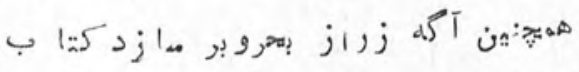

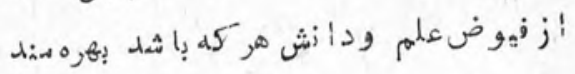

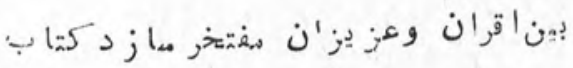

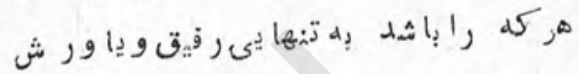

خاطرا فسرده رآ رآم ترماز

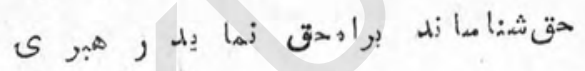

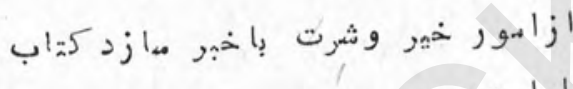

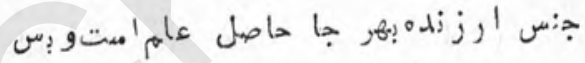

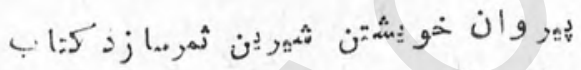

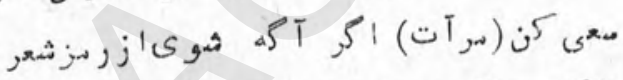

$$
\begin{aligned}
& \text { تا كا d ل }
\end{aligned}
$$

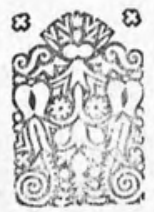


بارك آن

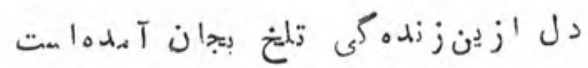

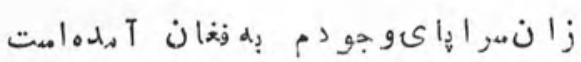

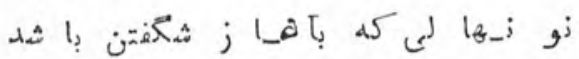

جه إf

نو عروسى كاله إود هرق غم همدسر خو يشش

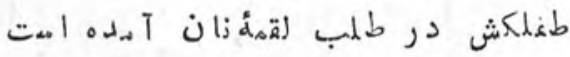

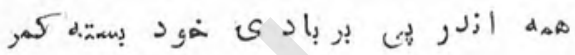

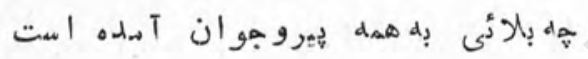

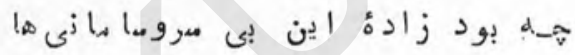

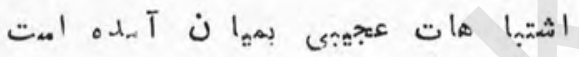

ومعت علم بشثر در دد و زفا ق آوردهن

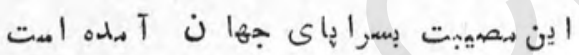

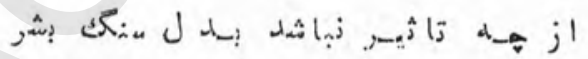

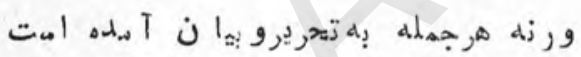

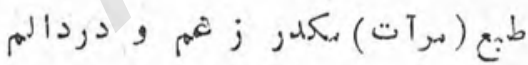

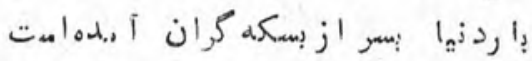

$|v|$ 


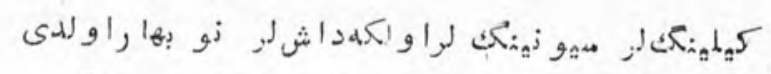

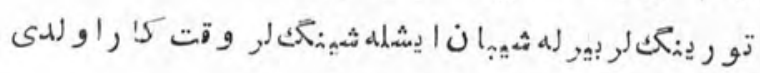

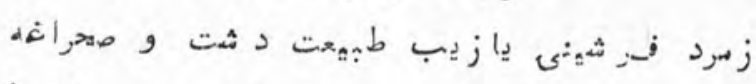

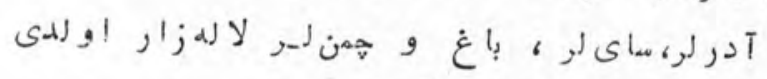

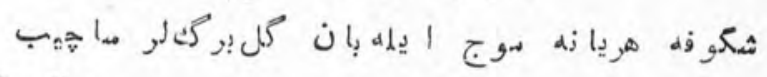

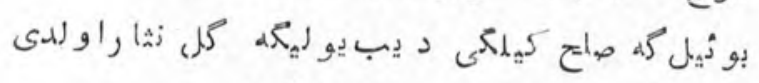

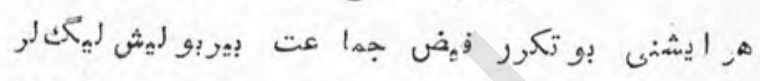

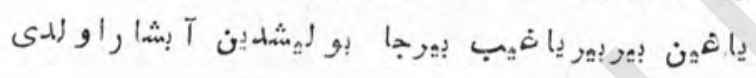

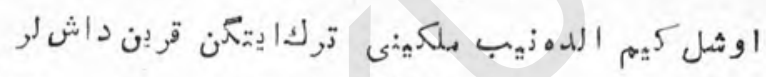

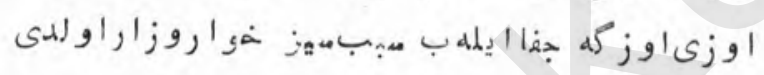

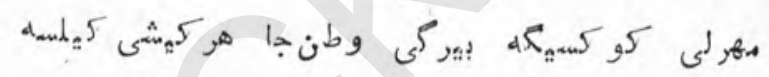

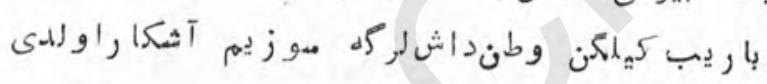

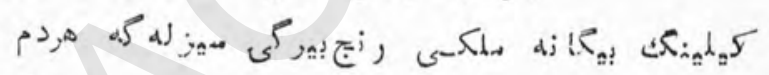

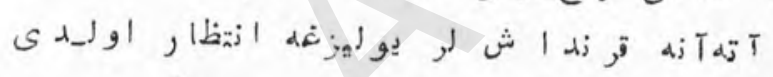

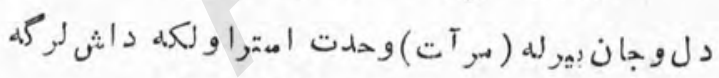

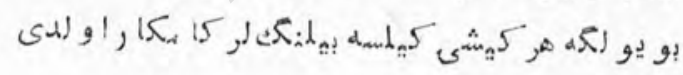

IYP 
نجم الهدين عيان فوز نهل صوفى همبر اه

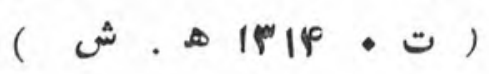

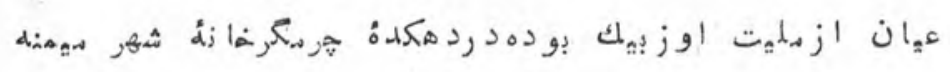

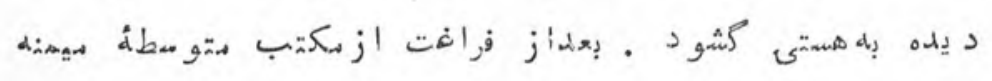

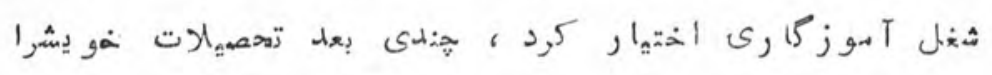

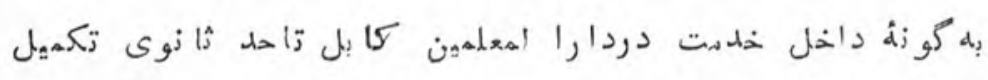

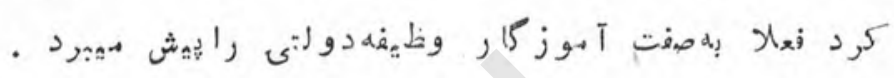

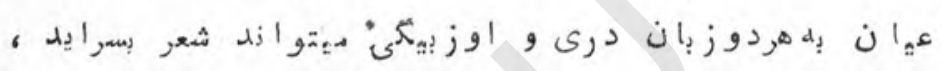

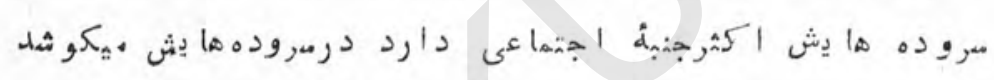

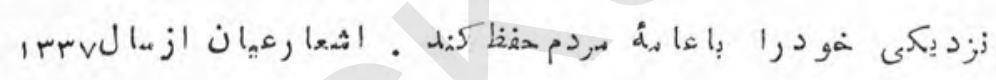

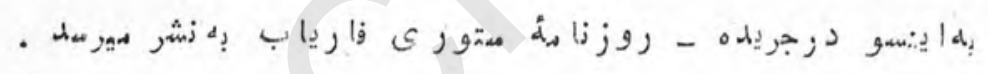

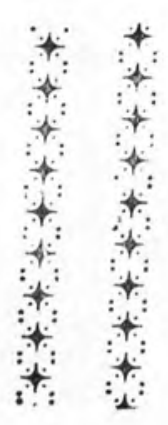

IrP 


\section{ل - مشكر ناز}

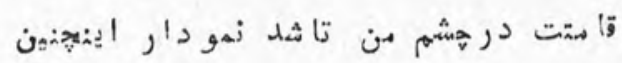

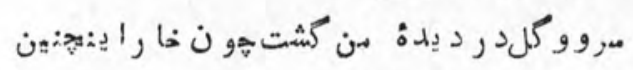

$$
\text { از جمالت شد هنو رعالم الى هـاه تمام }
$$

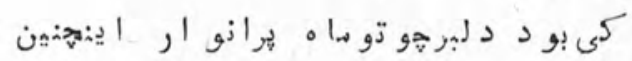

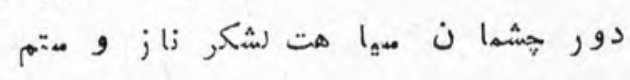

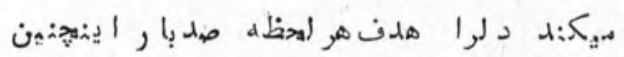

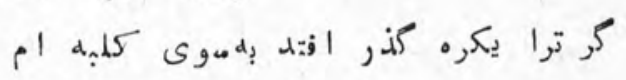

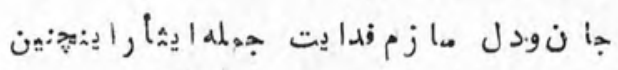

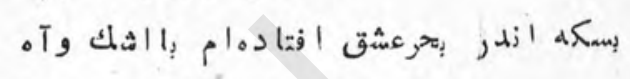

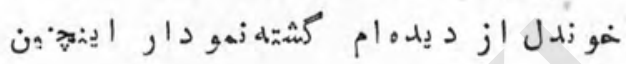

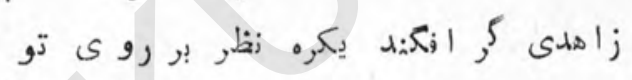

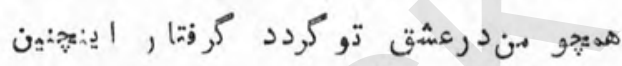

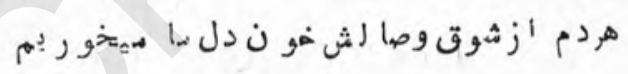

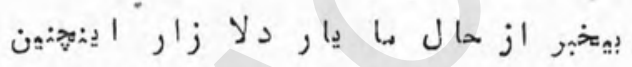

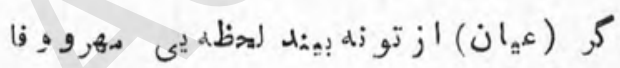

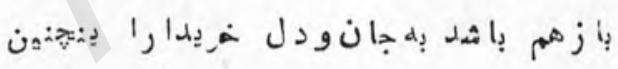


بوارتوفاني

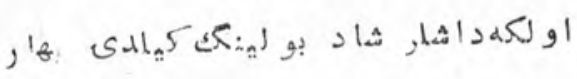

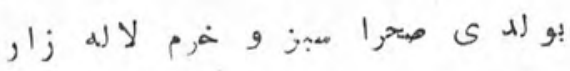

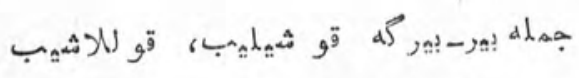

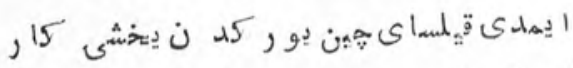

كـل تهر ينكلمر، ذو ق بيرله آ

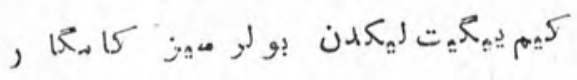

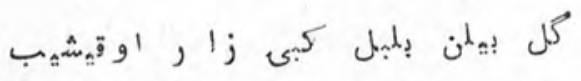

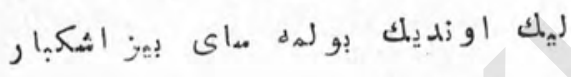

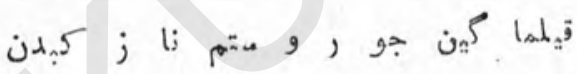

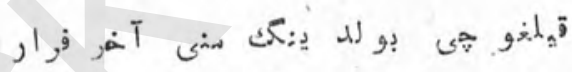

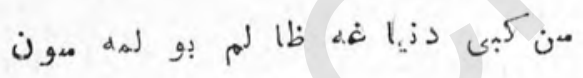

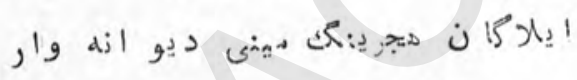

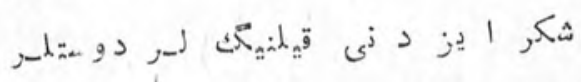

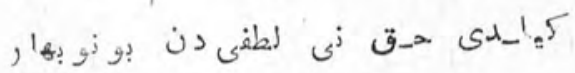

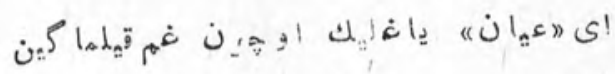

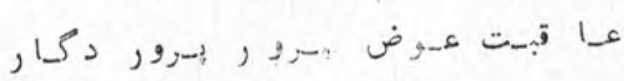

บากับกา

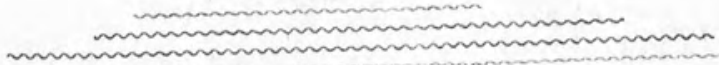

IVO 
خاش

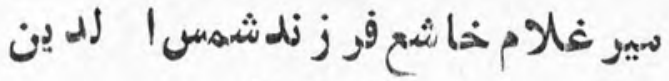
ت.هاPIDه . ش

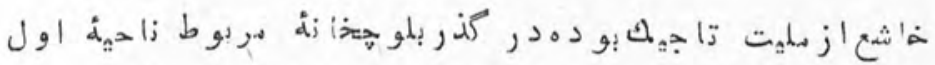

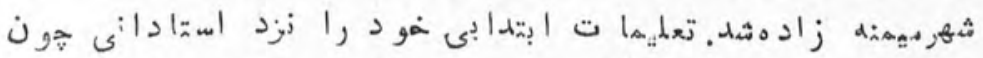

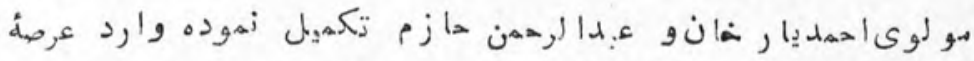

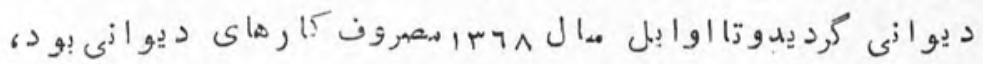
فانل

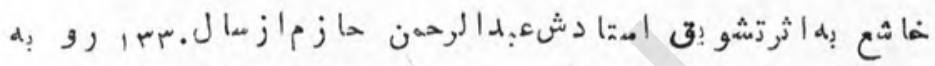

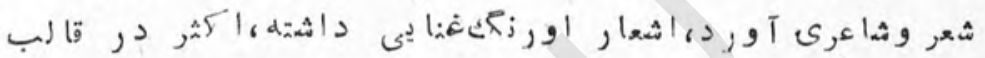

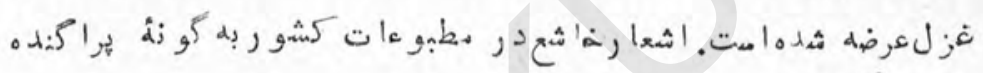

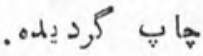

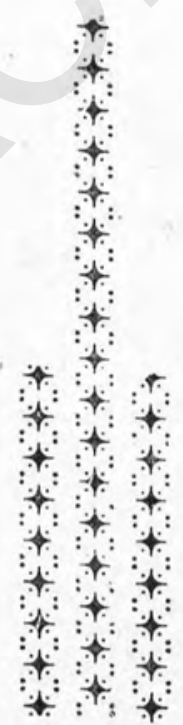

177 
خنافُبْتَ

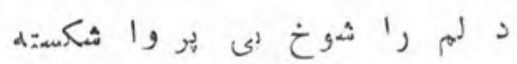

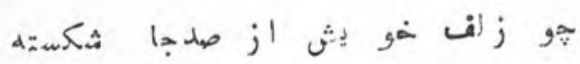

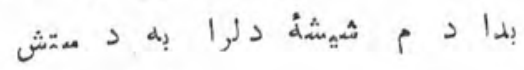

برل

هزن تير هلهمت بر دل

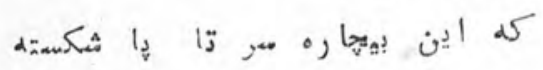

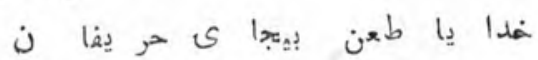

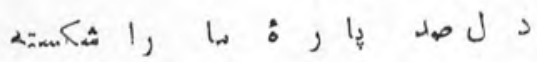

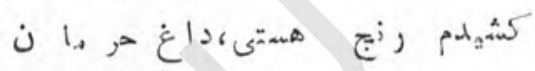

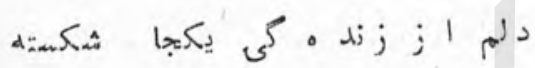

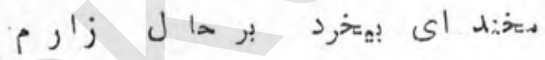

S A

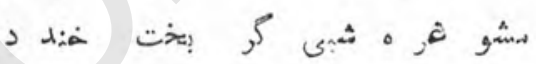

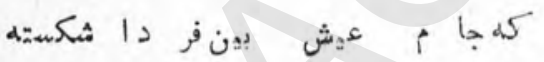

1,

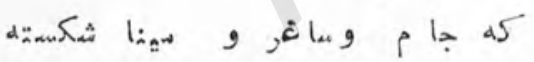

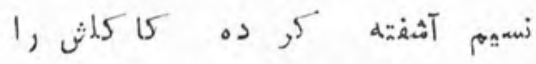

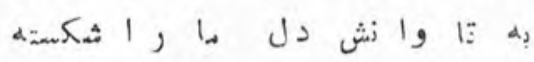

IVY 
داغيكه زآزار بقان ن درجكر هـا مـت

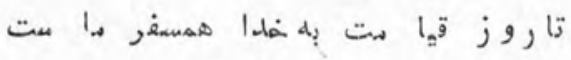

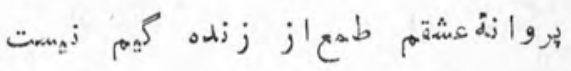

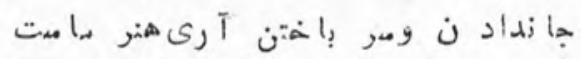

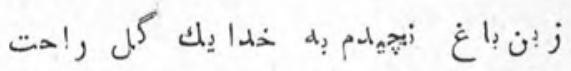

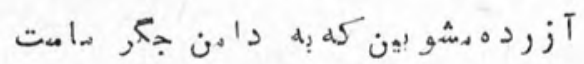

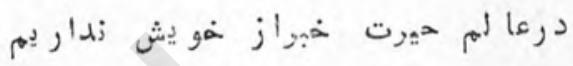

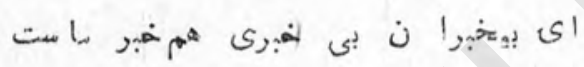

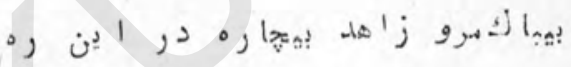

هشيدار مل د, كو

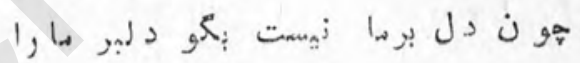

إيدلبر ها، دل برها، دل إه برهاهت

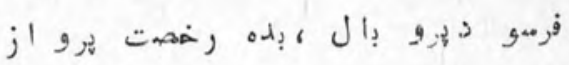

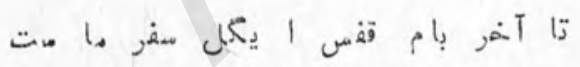

ازصبح وصال وشب هيجر انمبرم زهمست

إن سوى تو وروى توشام ومهر هامت

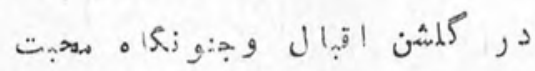

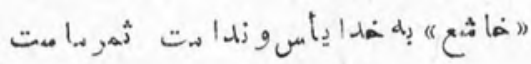

****************十**********************

IVA 


\section{له-يف تما تسا ر}

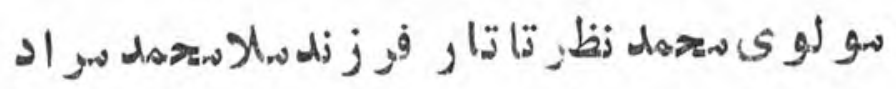
(

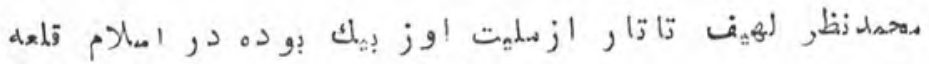

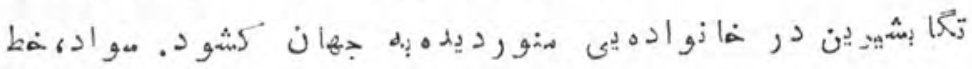

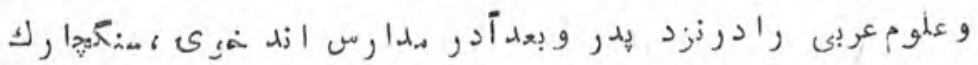

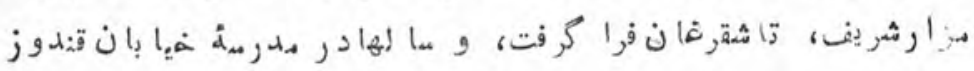

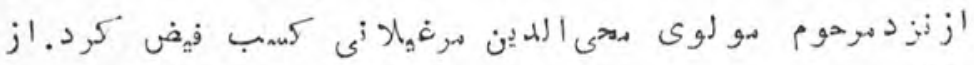

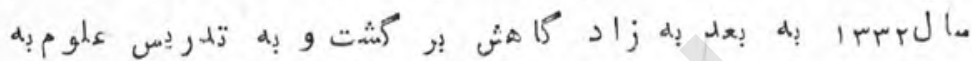

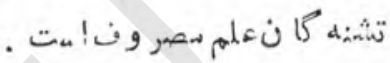

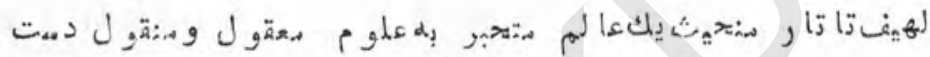

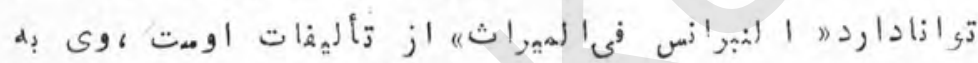

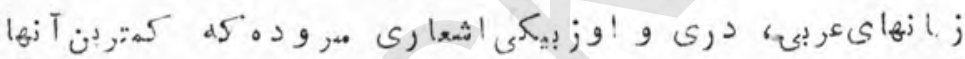

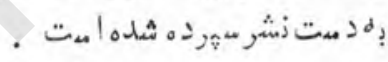

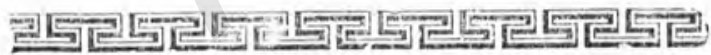

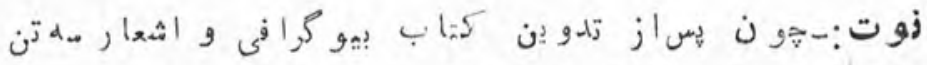

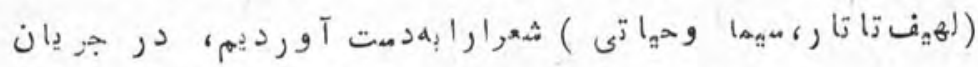

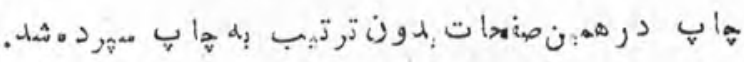




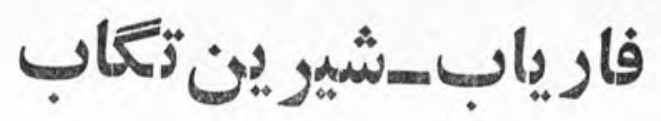

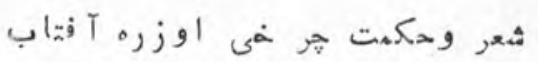

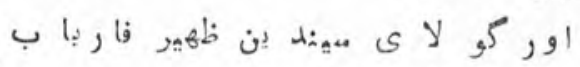

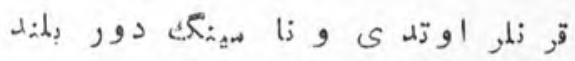

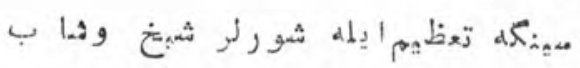

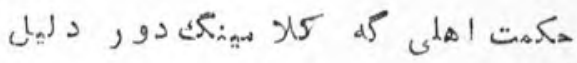

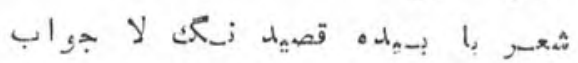

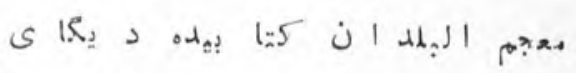

إبله

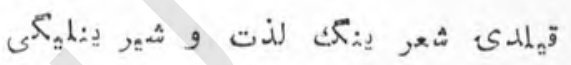

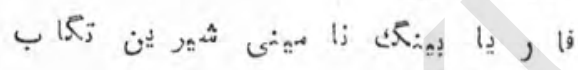

(s)

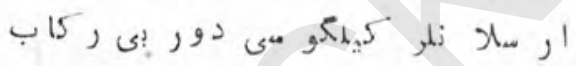

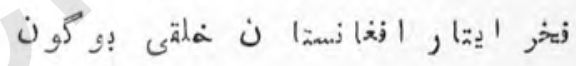

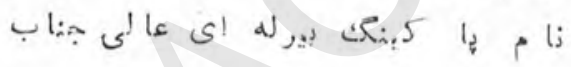

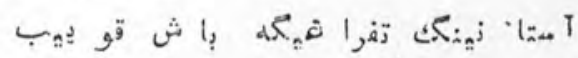

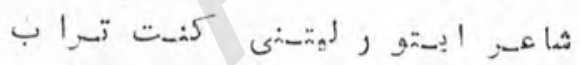

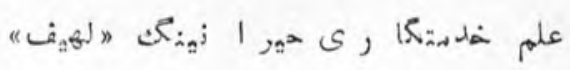

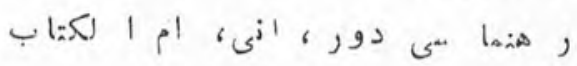

يازدى اخملاص وارادت :ميرله شهر

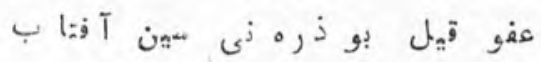

IA. 


\section{$\log i n$

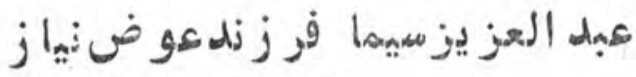 ( ش.D(pQQ-1P.p)}

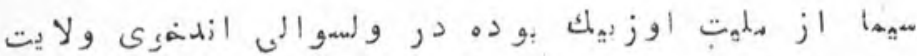

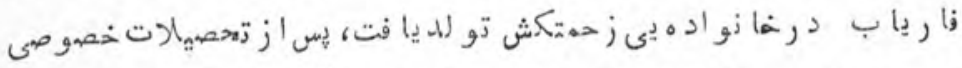

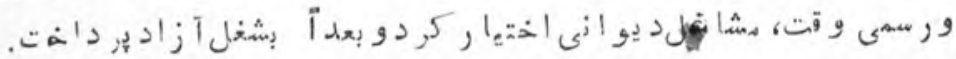

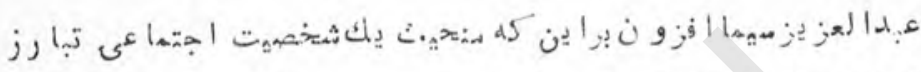

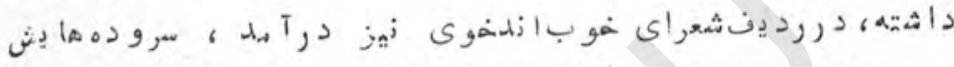

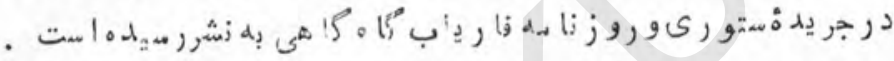

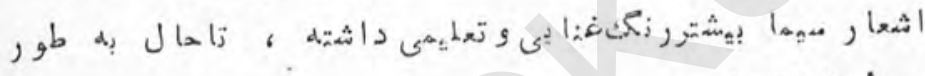

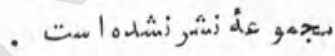

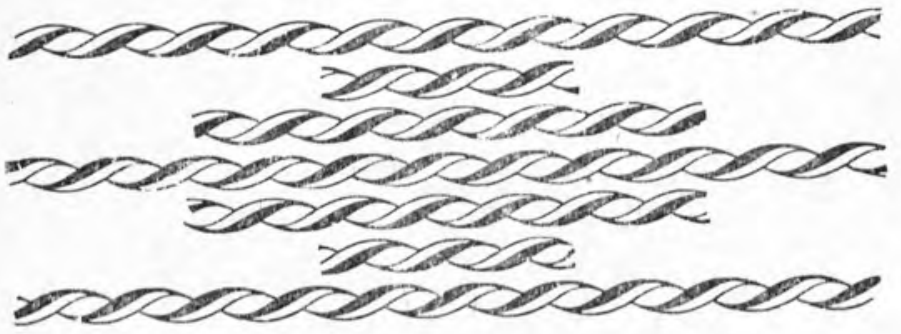


(S) ubol

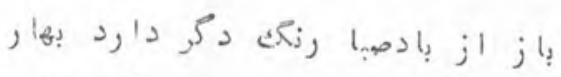

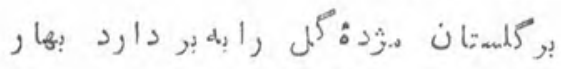

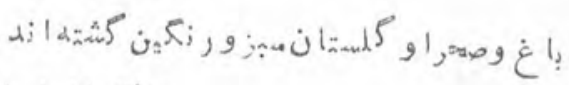

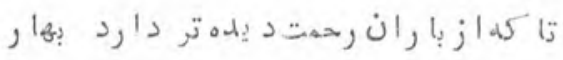

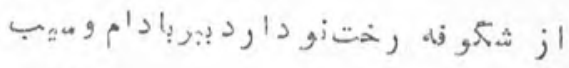

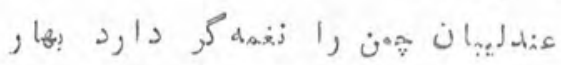

زوعرومان

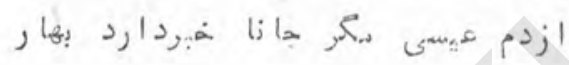

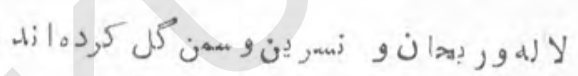

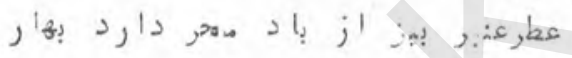

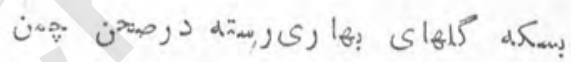

2,12 مار

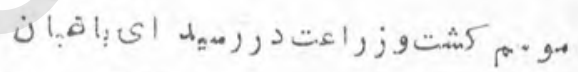

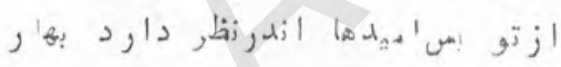

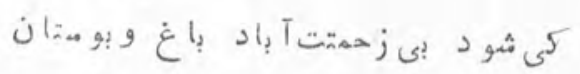

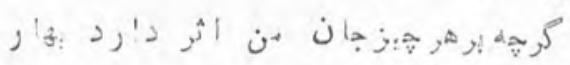

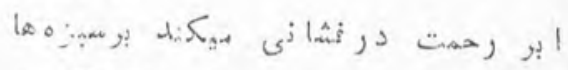

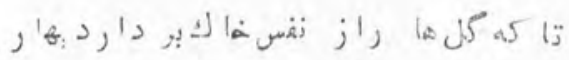

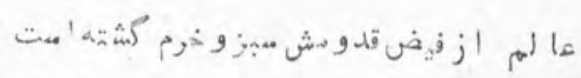

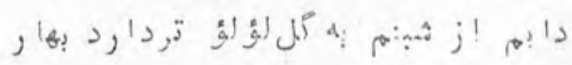

روزنوروزى بود بهمون افرادوطن

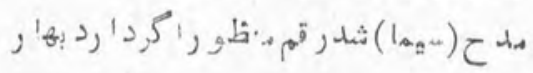

IAP 


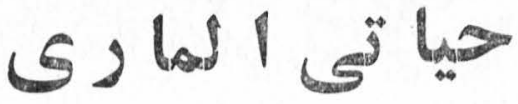

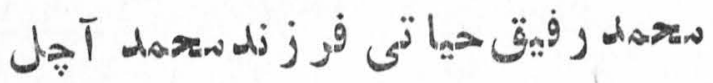

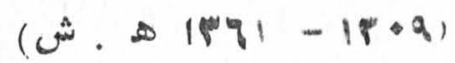

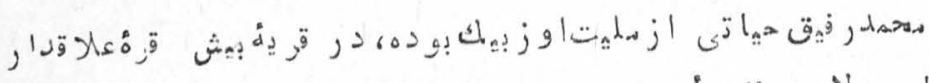

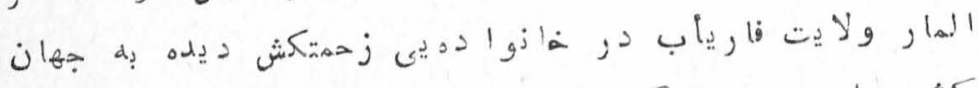

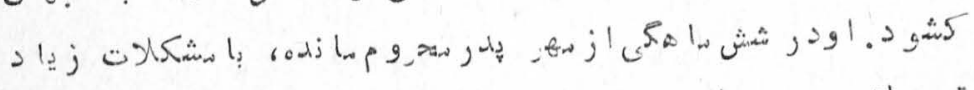

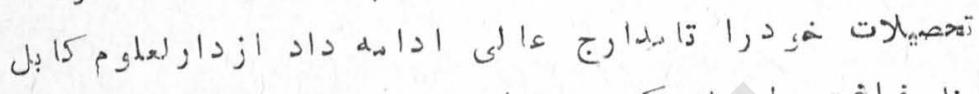

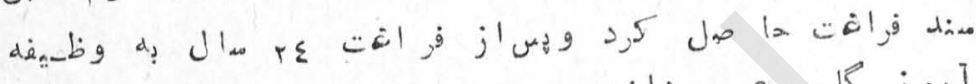
آ سو ز 15

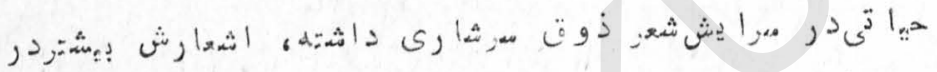

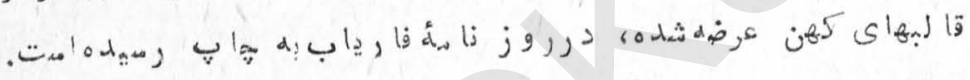

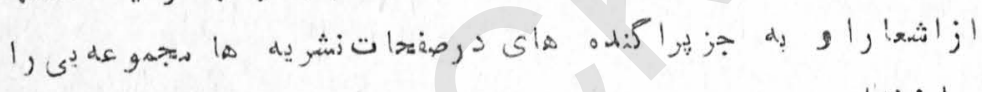

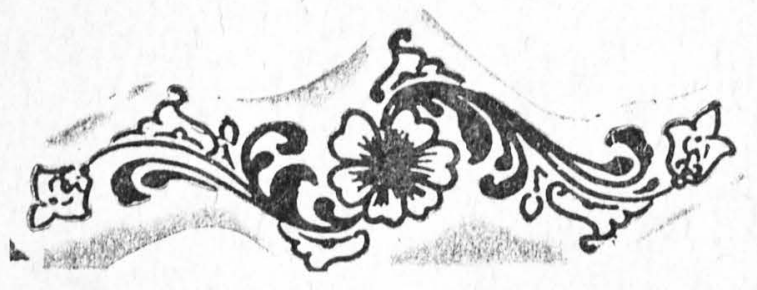


وطن

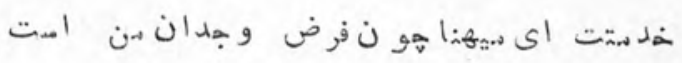

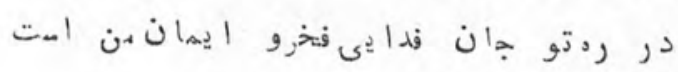

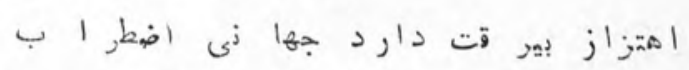

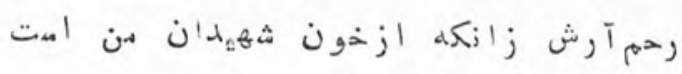

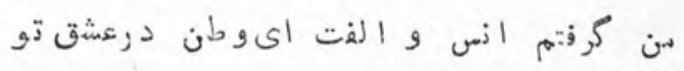

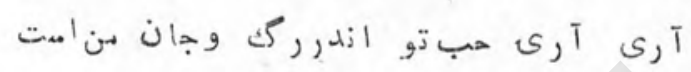

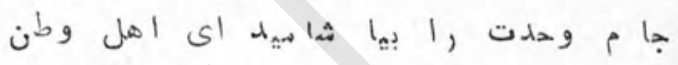

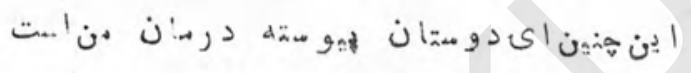

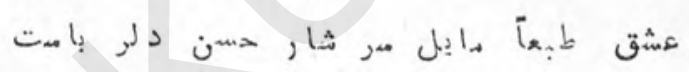

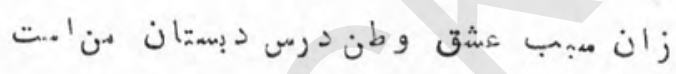

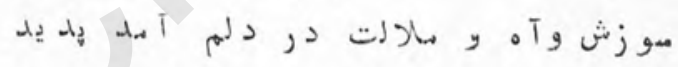

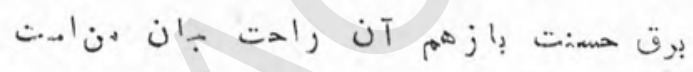

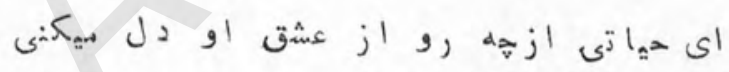

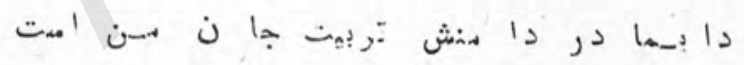

(4)

IAP 


\section{ج}

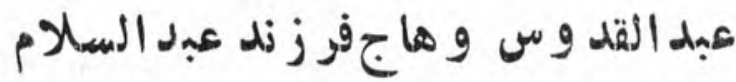

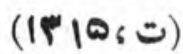

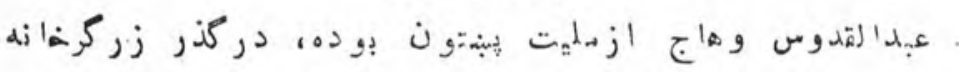

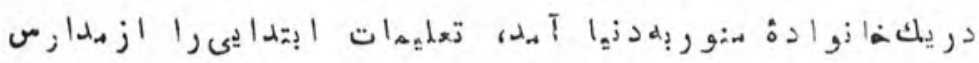

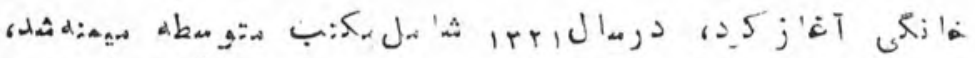

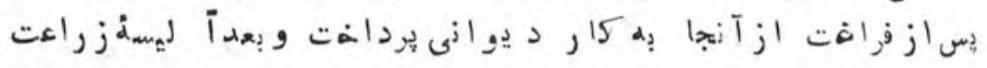

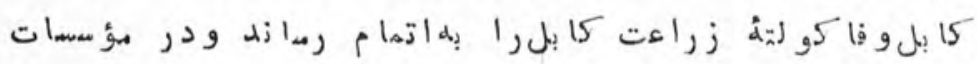

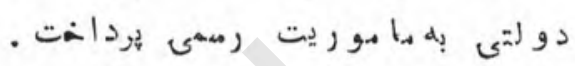

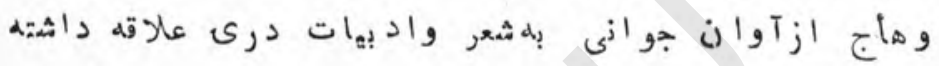

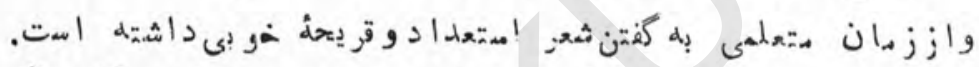

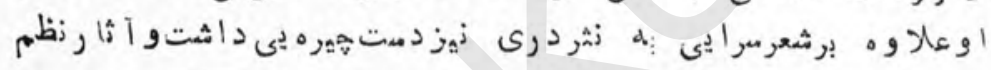

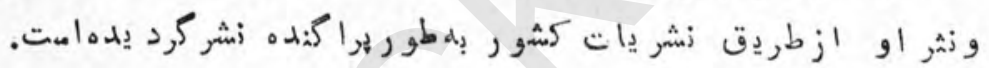

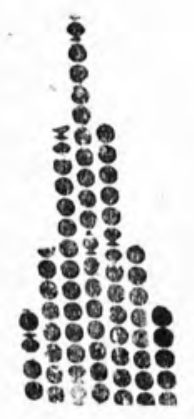




\section{نواى غم}

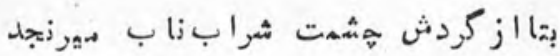

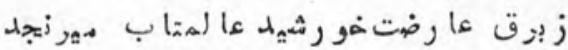

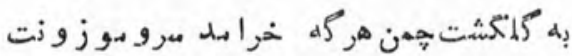

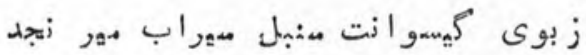

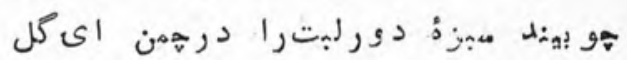

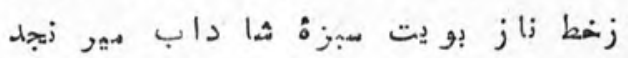

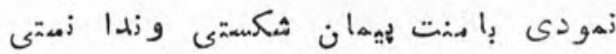
كالهاز

$$
\begin{aligned}
& \text { مكن'ى زاز بروردم جفا ها بردل ريشم }
\end{aligned}
$$

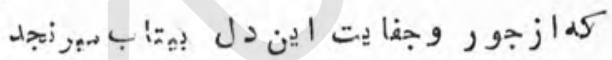

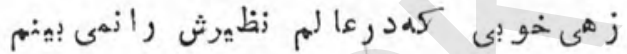

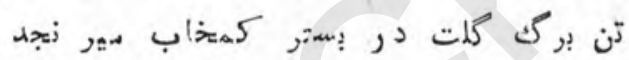

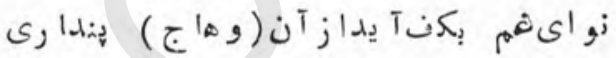

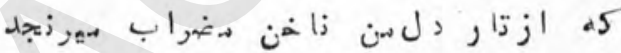

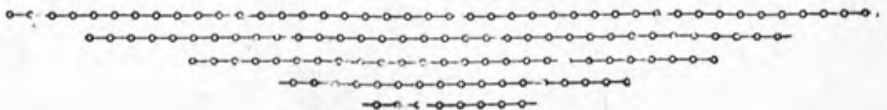


فد أئي

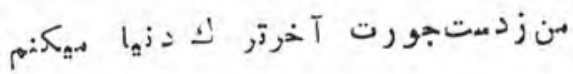

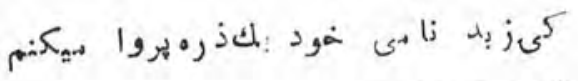

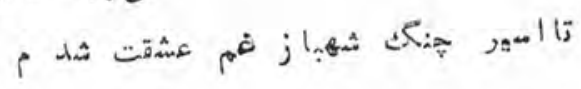

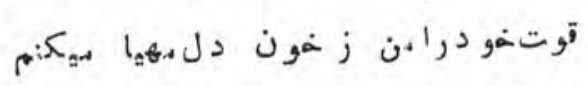

د بدهرا تاب وتوان ديدن رويتنما زيد

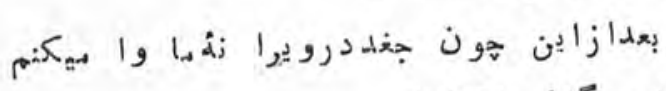

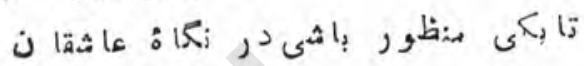

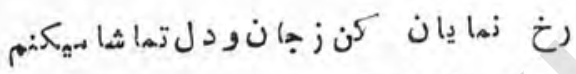

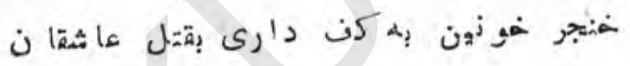

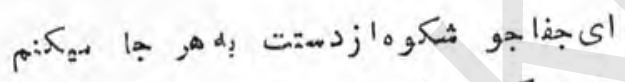

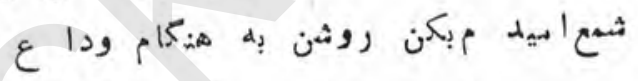

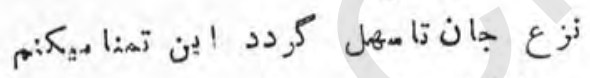

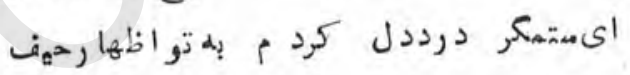

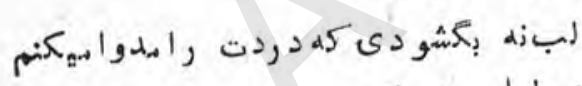

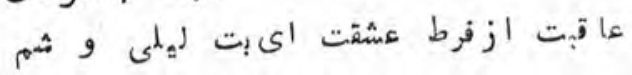

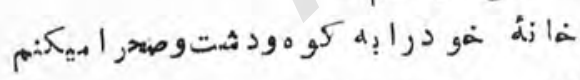

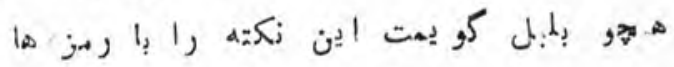

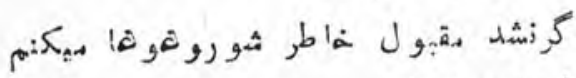

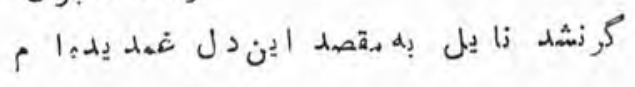

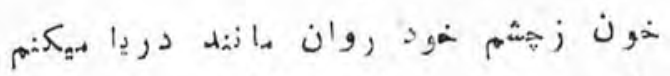

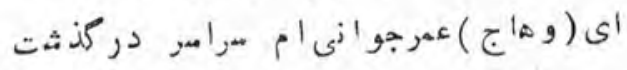

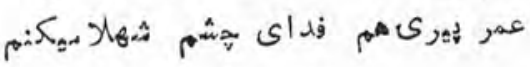

IAY 


\section{عظيمى

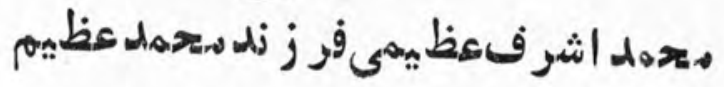

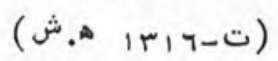

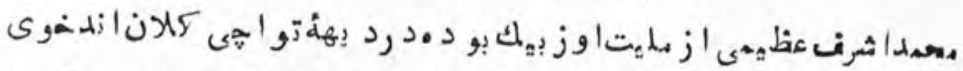

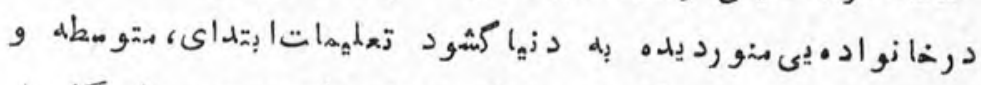

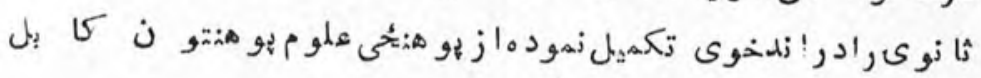

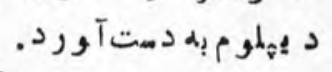

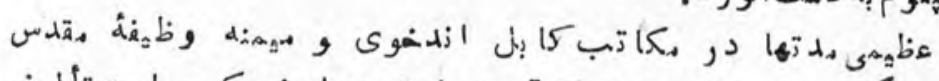

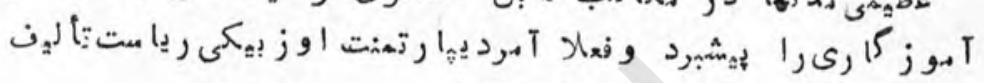

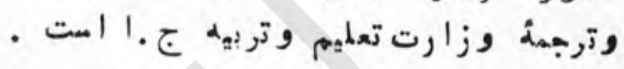

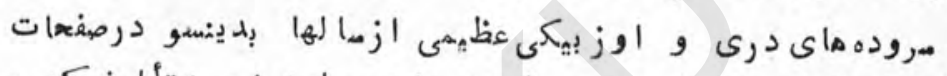

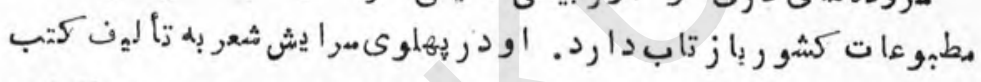

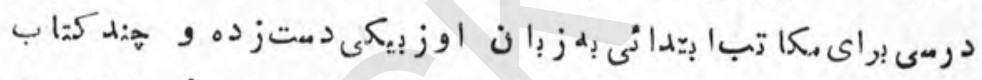

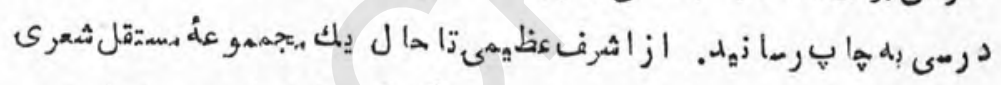

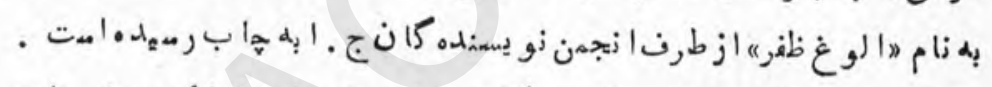

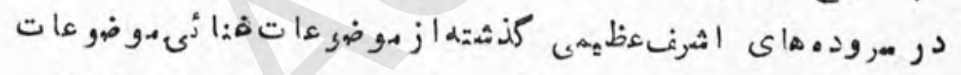

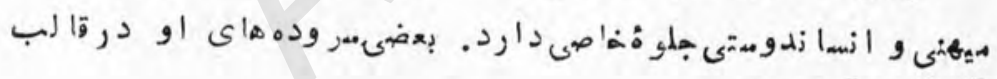

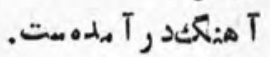


دوستلياك نواسى

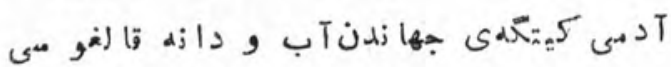

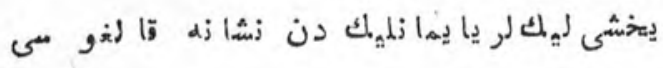

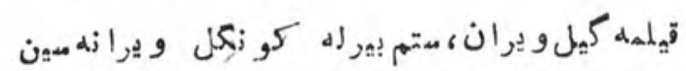

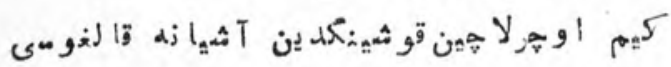

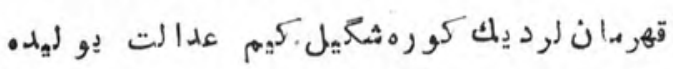

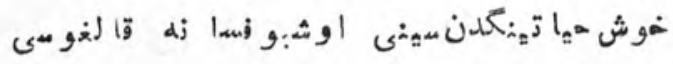

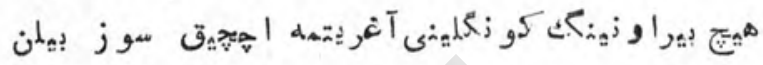

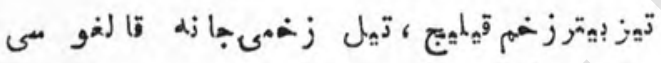

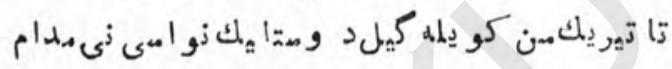

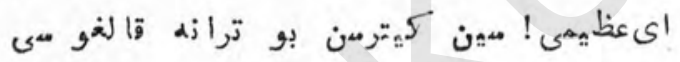

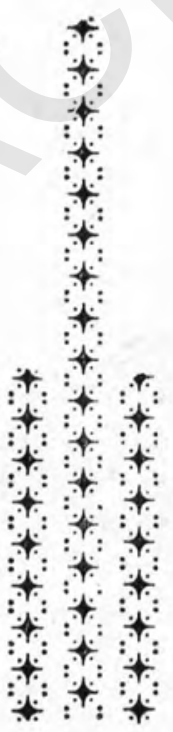

119 


\section{عشيق سوز ان \\ تو بها رومه بهش:تم تو كلمتا نم وطن}

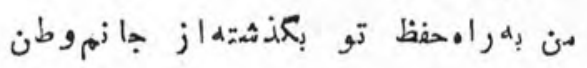

$$
\text { بهرآزادى تو قربان شيد ن آيدين لـن }
$$

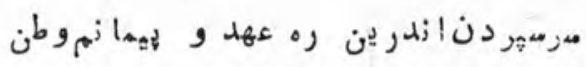

$$
\text { مرزمين راد مردان شجاعت زاتو يى }
$$

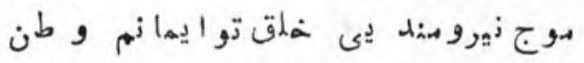

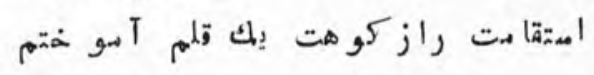

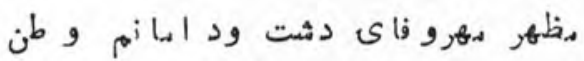

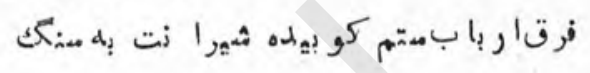

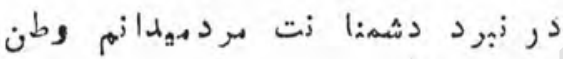

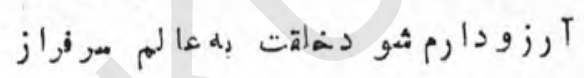

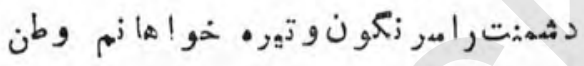

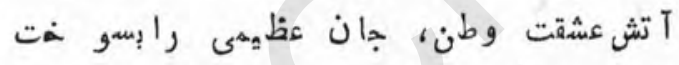

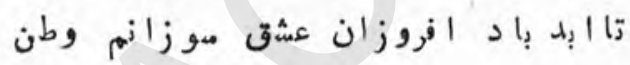

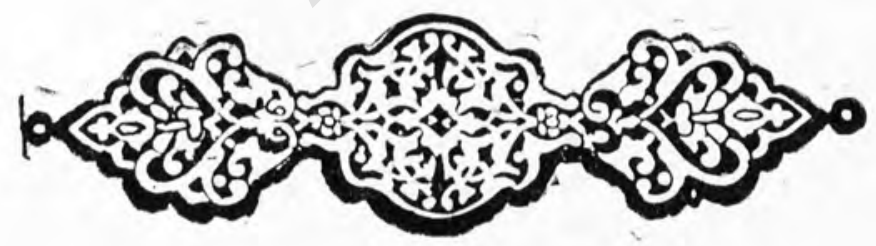




\section{مهر لمى آنه}

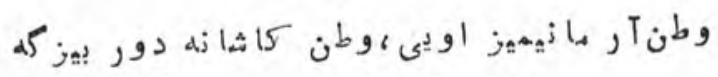

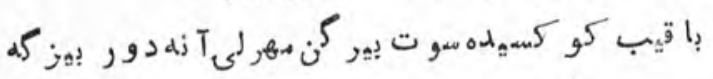

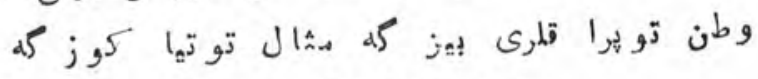

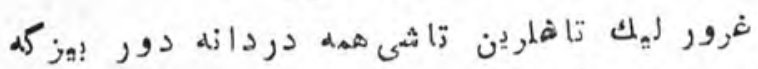

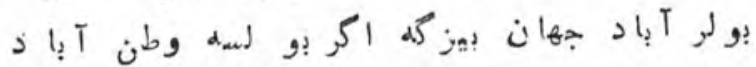

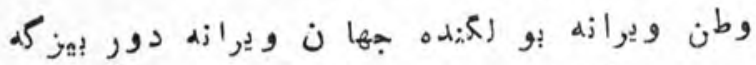

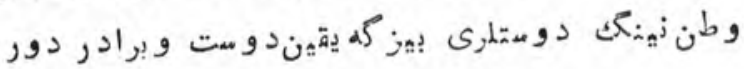

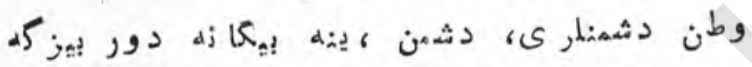

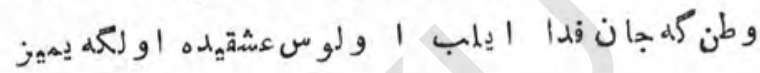

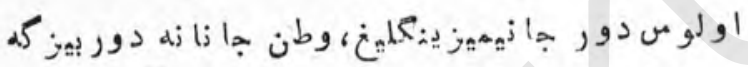

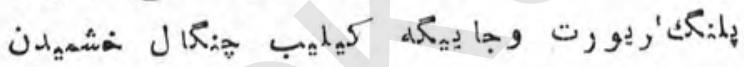

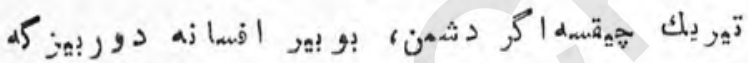

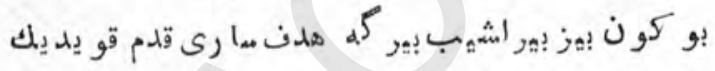

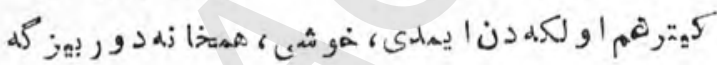

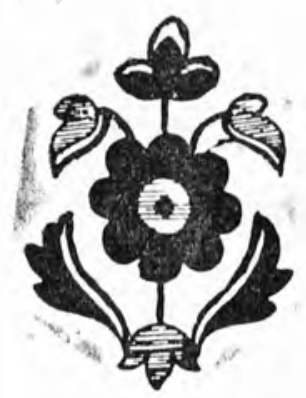




\section{ا فمسو سن}

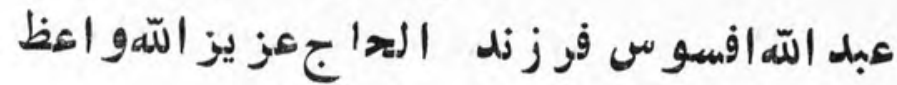

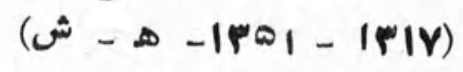

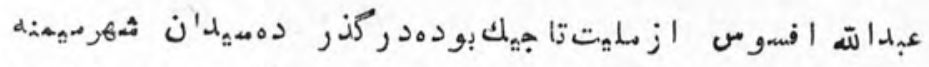

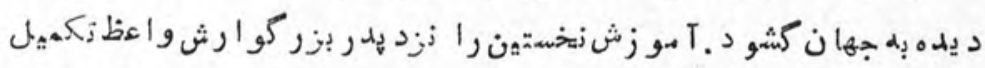

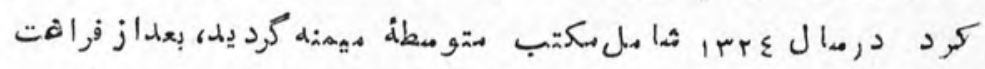

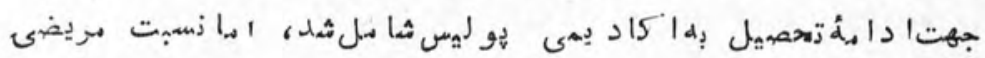

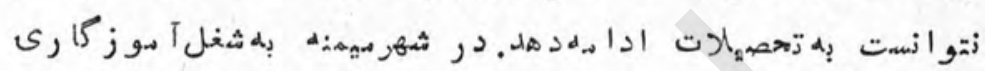

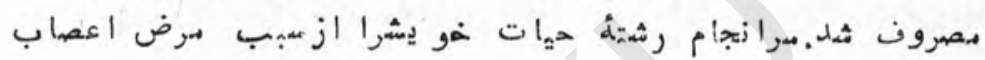

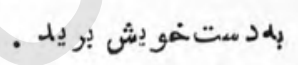

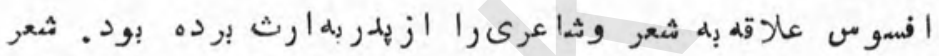

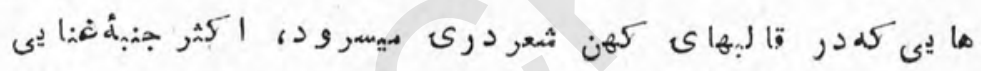

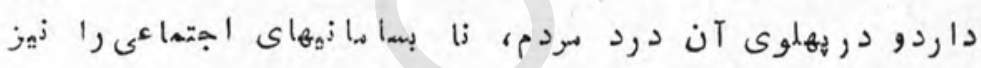

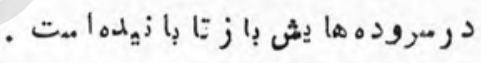


بأستُقبال غزل (واعظ)

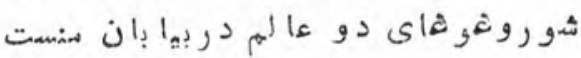

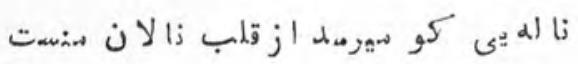

يرتوى كو در زنظرميا يد از كوش و ك:ار

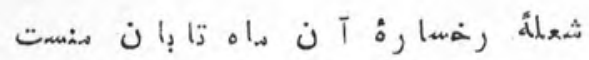

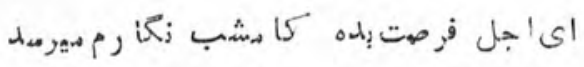

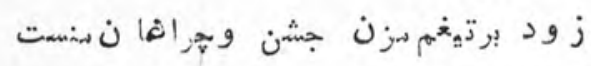

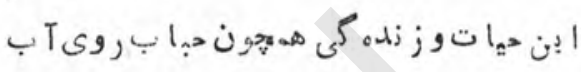

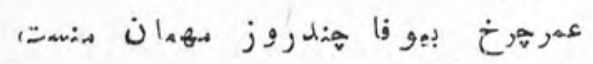

ازغم وا ندو مدور ران اشكازهششممر روان

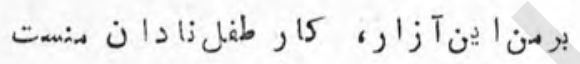

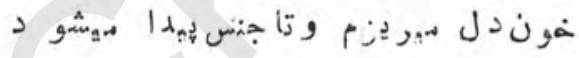

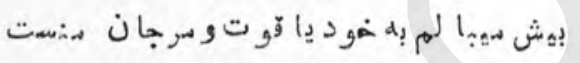

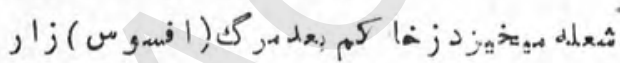

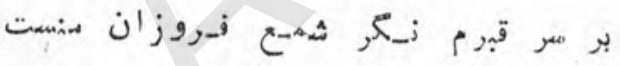




\section{سر شاك غم}

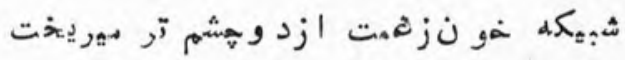

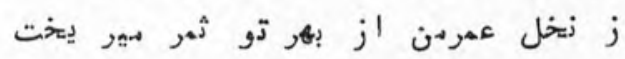

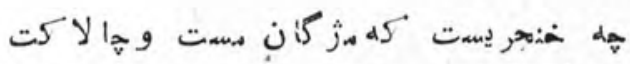

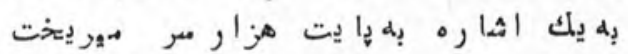

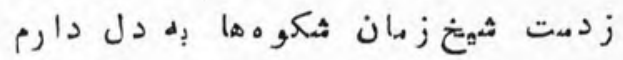

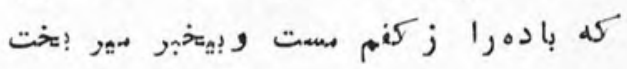

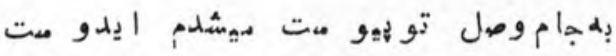

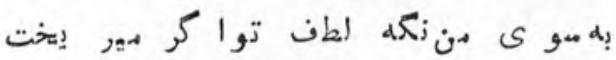

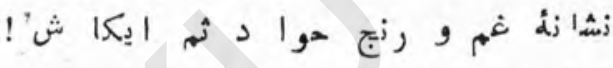

$$
\begin{aligned}
& \text { زما بهصهن جهان إيش وكم اثر بهير إيتت }
\end{aligned}
$$

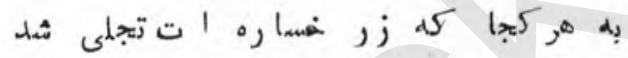

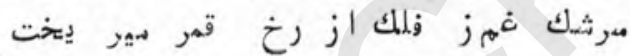

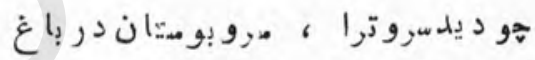

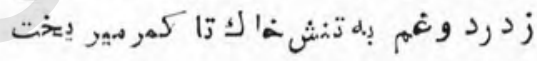

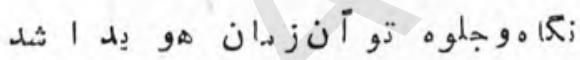

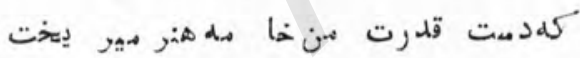

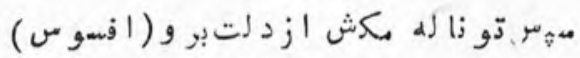

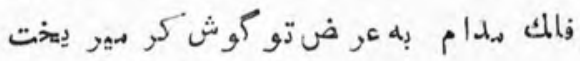

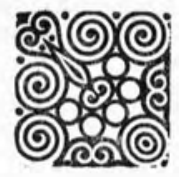


جورزمان

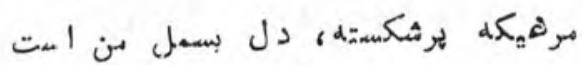

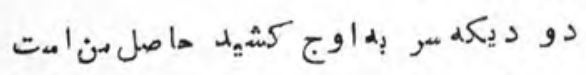

باتيغ كسر د سر زتنم إنن فيلك جدا

إنظت

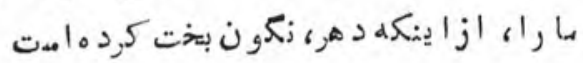

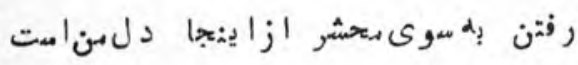

همن نصيبزيست مرا راحت از برش

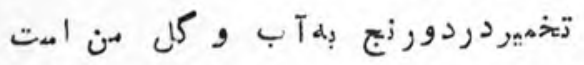

قسهت براى سر ز جفاى زمان بـثين

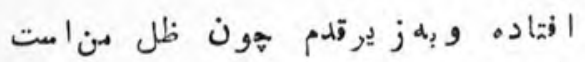

روزوشيم إندون تهث 15

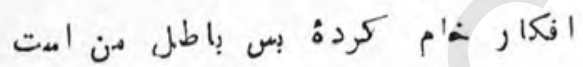

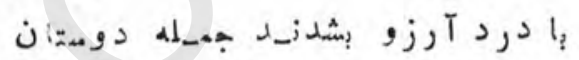

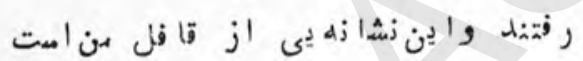

دل بى تهل زدمت جفا كمش دهر دون

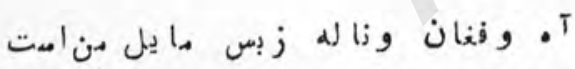

ا فسبو س دل زكنشمهاندر رثٔوفا

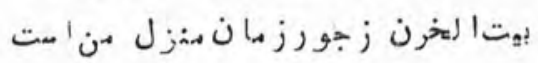

190 


\section{C!}

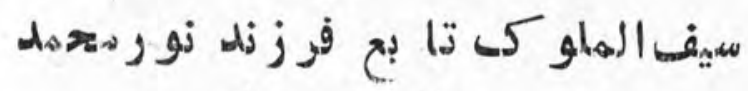

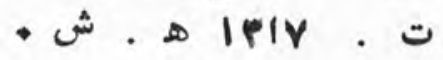

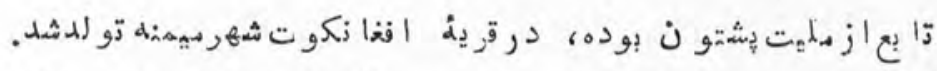

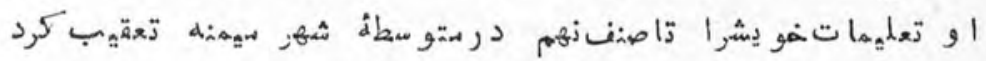

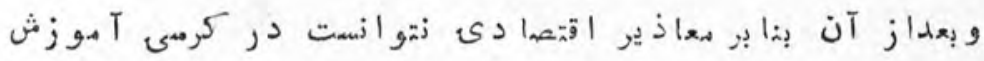

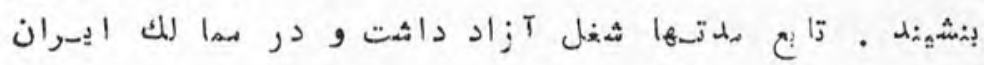

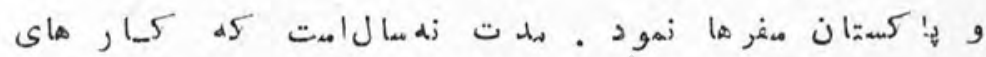

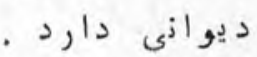

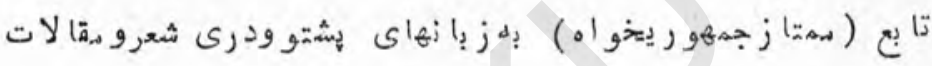

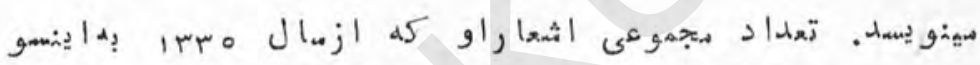

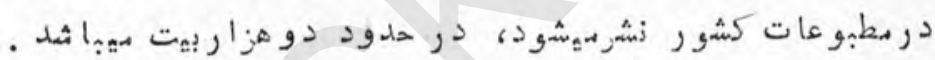

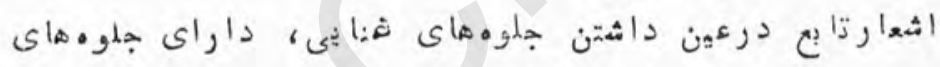

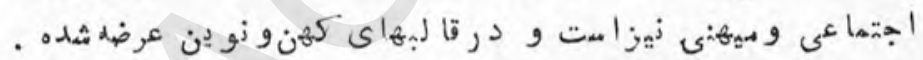

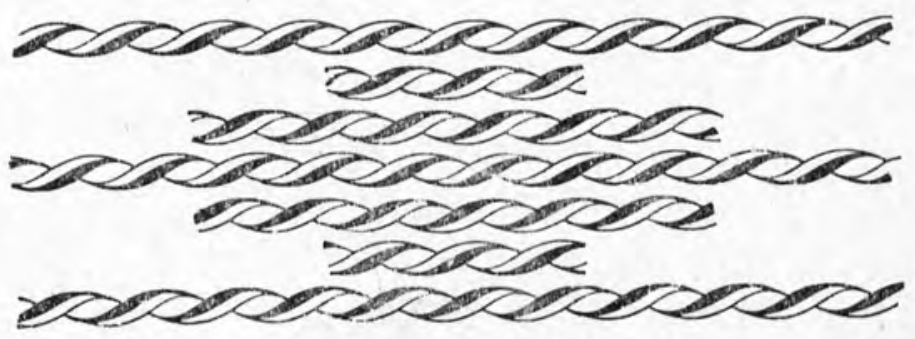


سوز بينوا لئى

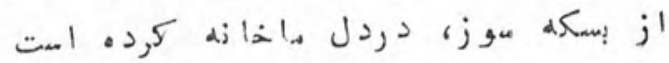

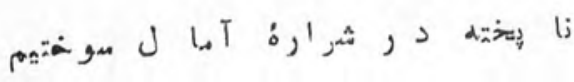

جون شاخه زأشكفته بها زنديم هاها رفصل

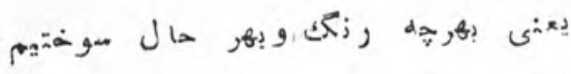

عزم و تلاش ها هله هار بى

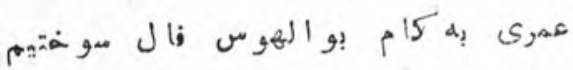

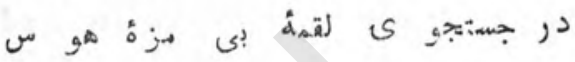

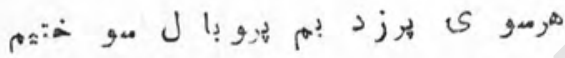

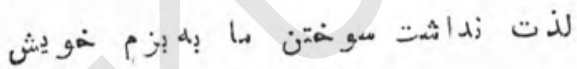

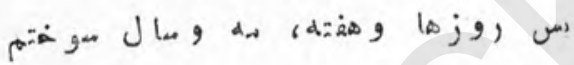

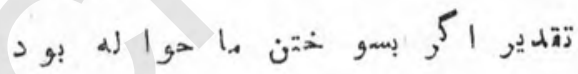

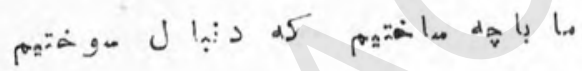

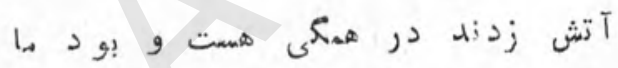

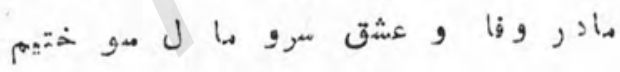

lav 


\section{Fناه بيخودى}

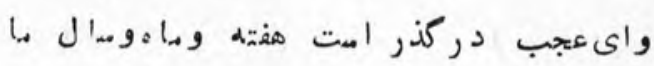

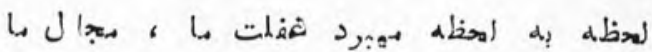

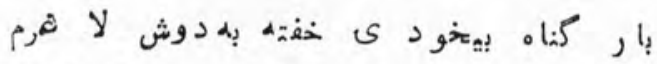

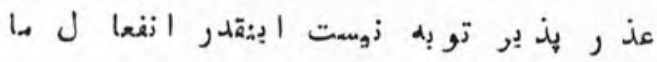

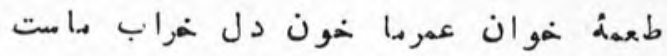

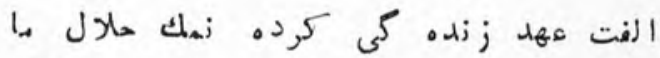

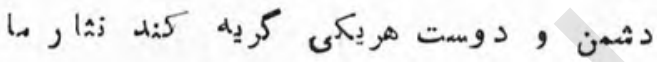

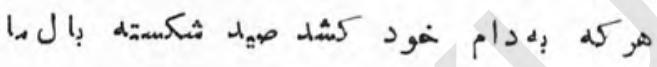

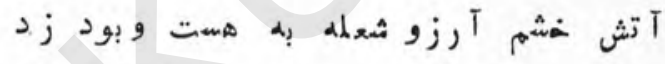

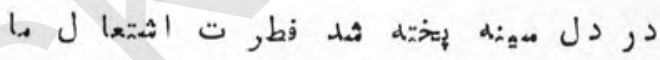

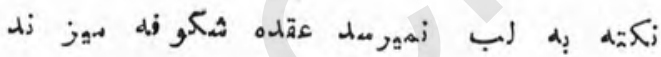

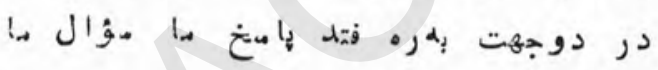

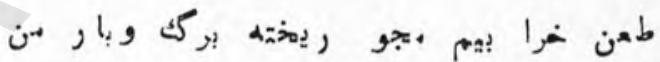

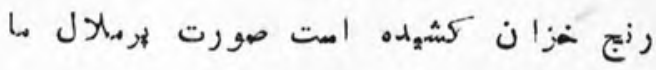

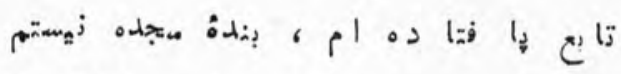

ز

(5) 
خاموشي

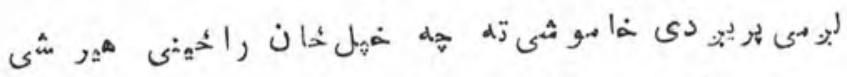

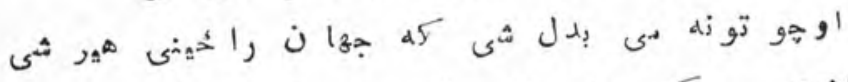

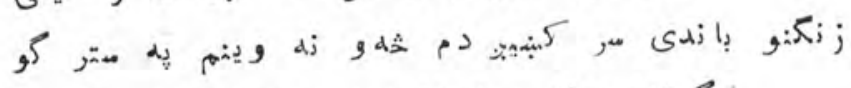

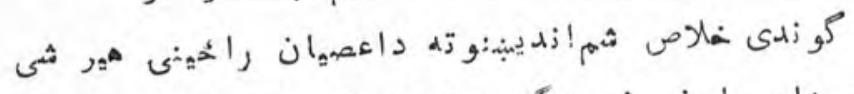

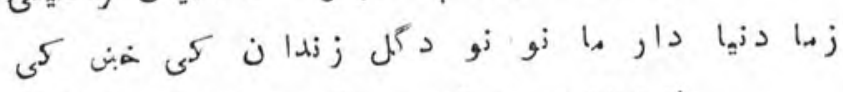

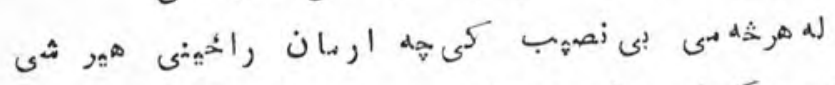

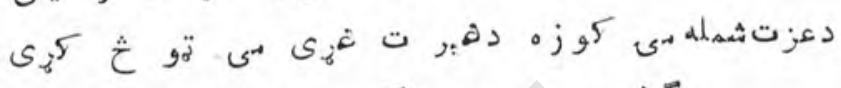

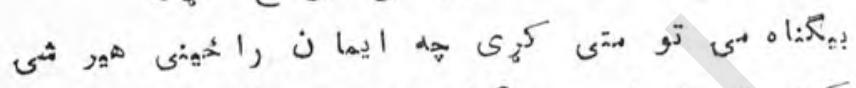

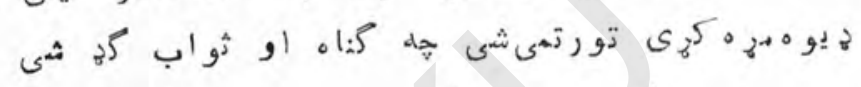

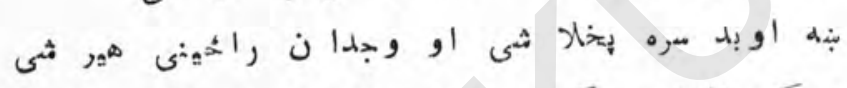

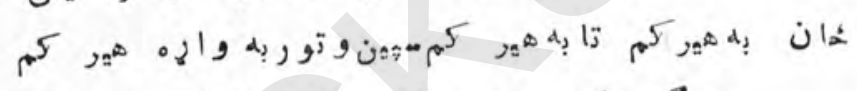

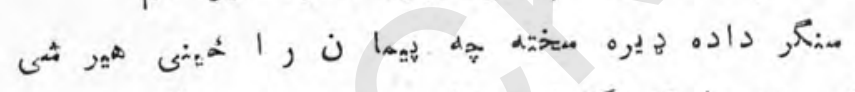

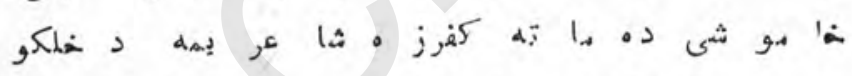

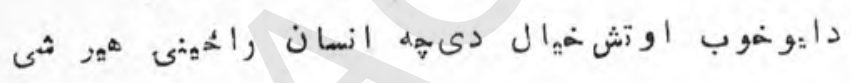

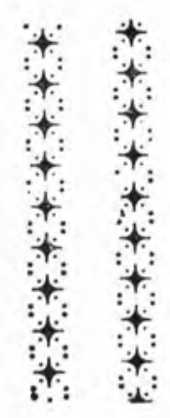

199 


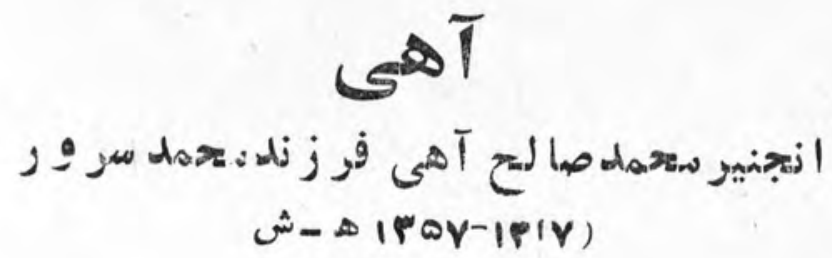

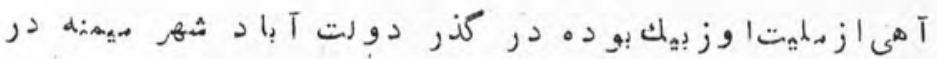

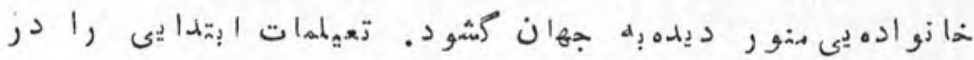

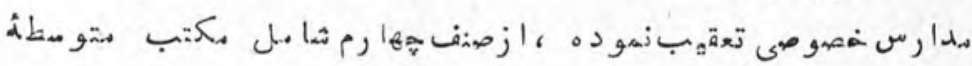

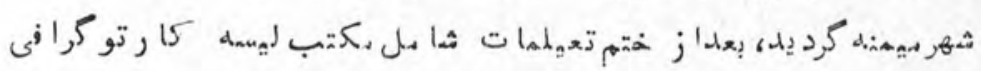

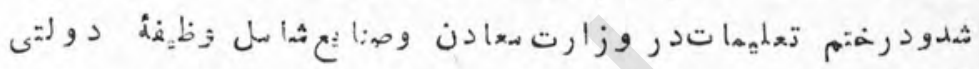

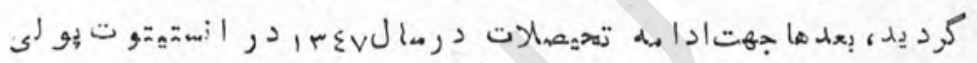

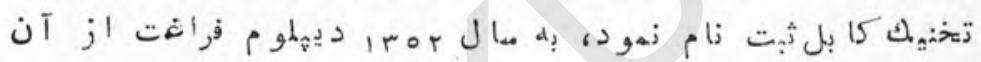

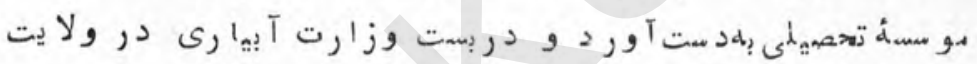

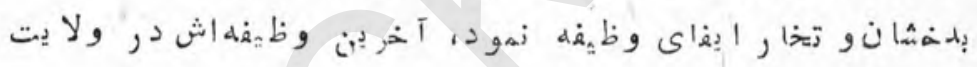

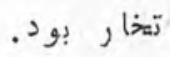

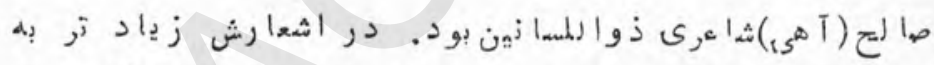

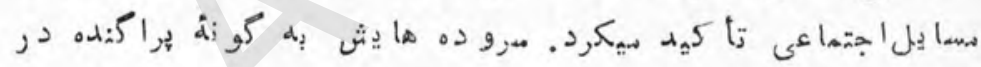

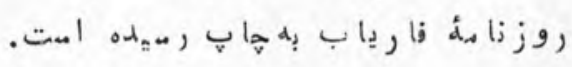




\section{ظالم اويى}

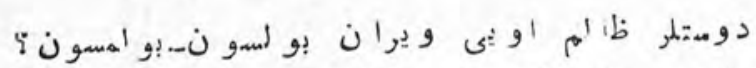

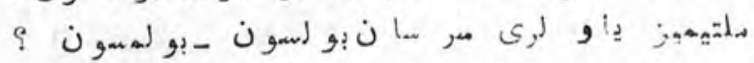

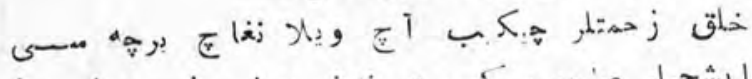

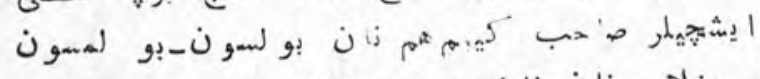

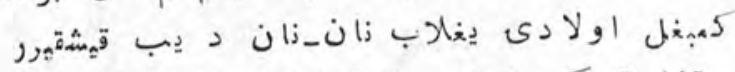

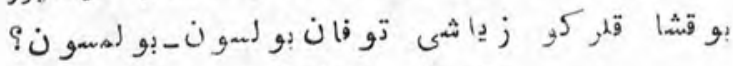

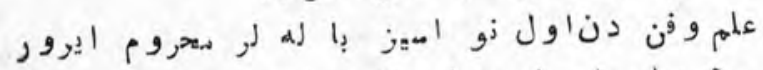

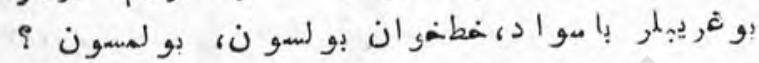

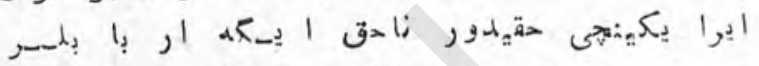

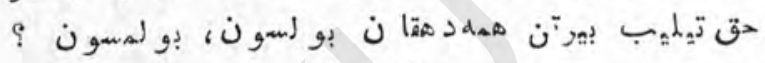

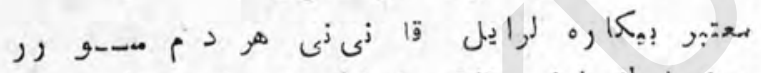

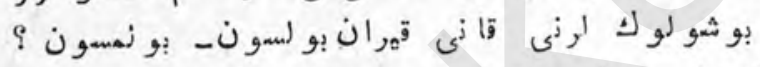

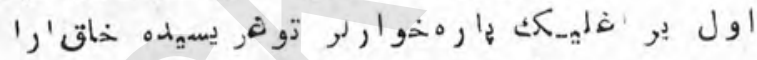

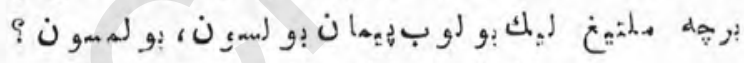

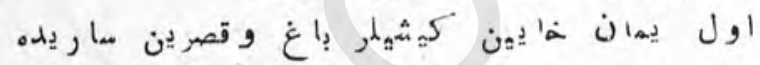

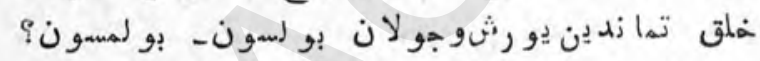

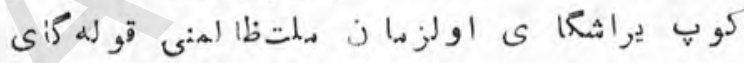

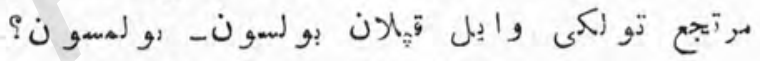

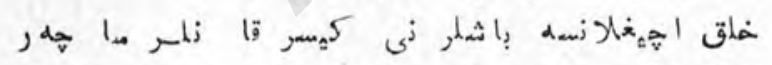

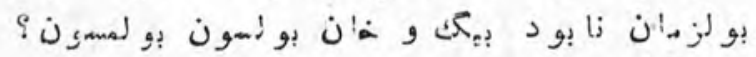

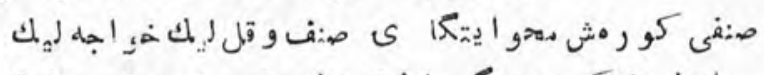

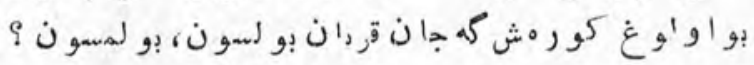

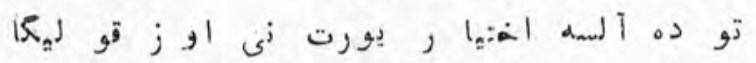

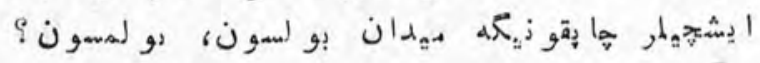

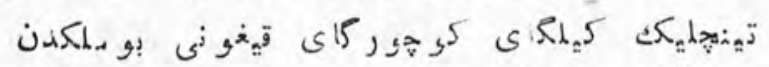

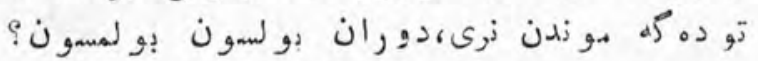




\section{باسو >}

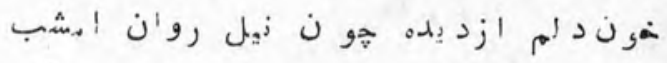

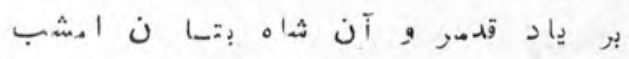

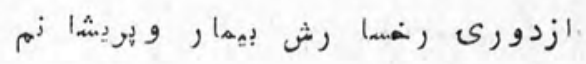

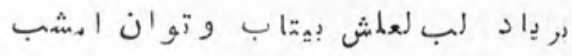

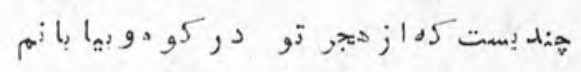

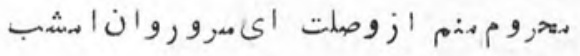

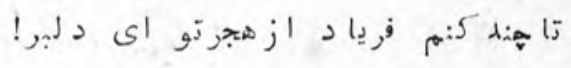

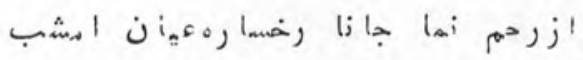

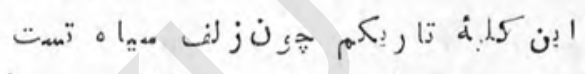

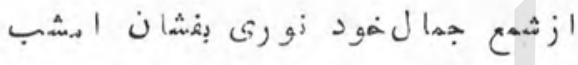

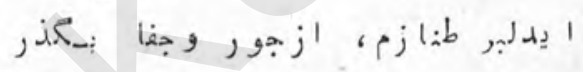

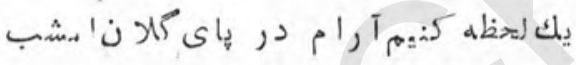

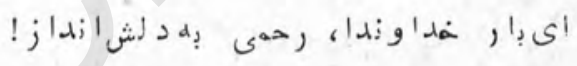

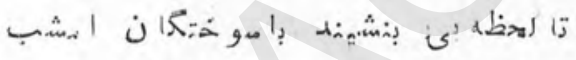

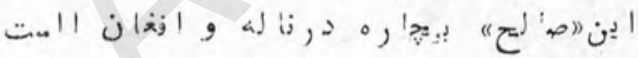

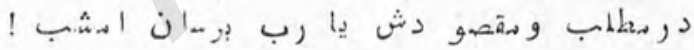

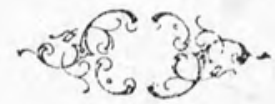




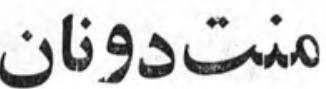

به لمز

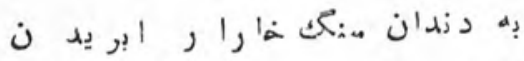

ن إن

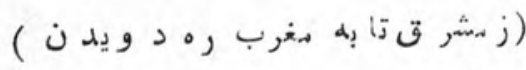

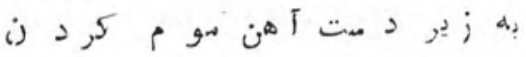

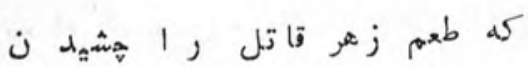

:

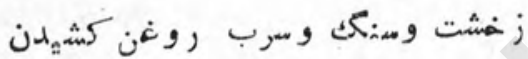

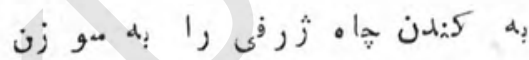

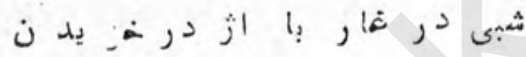

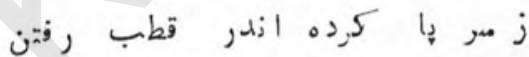

ن

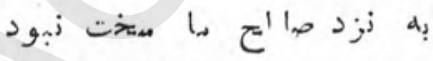

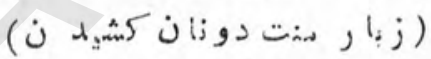

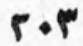




\section{مثبر

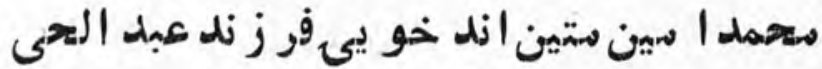 \\ ت:}

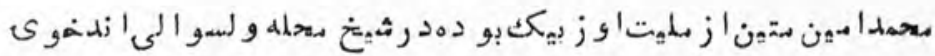

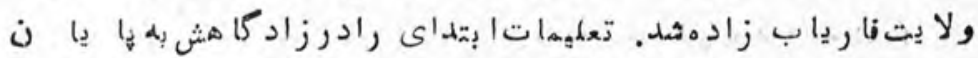

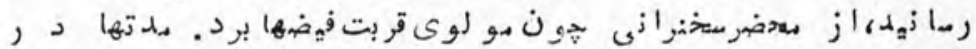

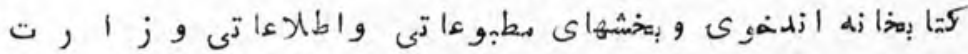

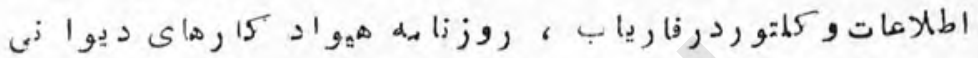

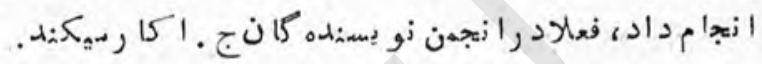

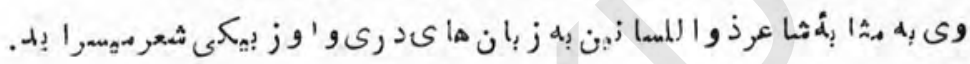

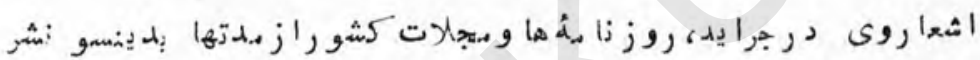

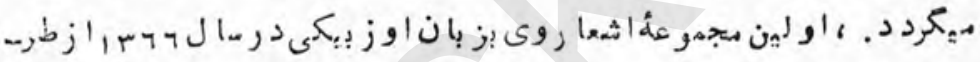

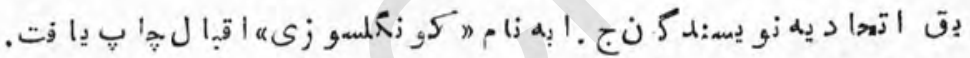

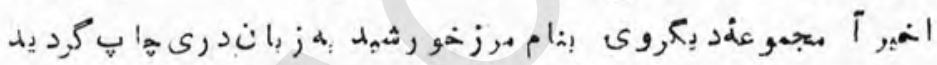

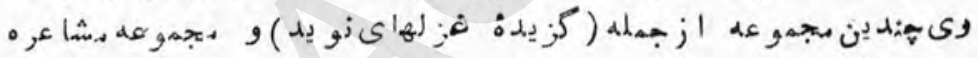

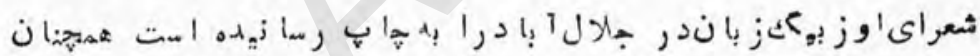

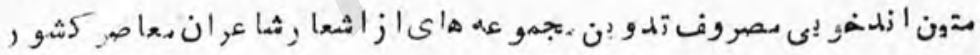

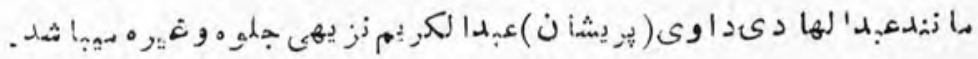

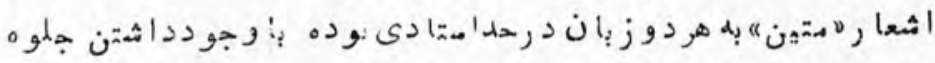

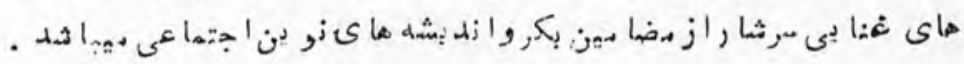


لعل نمكين

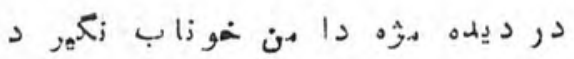

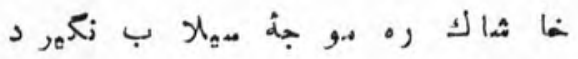

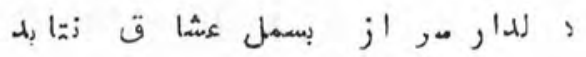

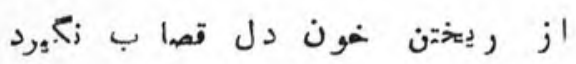

هانسمبم ولب دذتر رزدمثشب خملوت

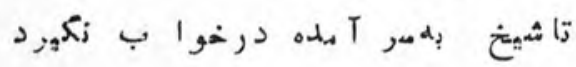

تسكين نشود خاطرآزرده درابن بزم

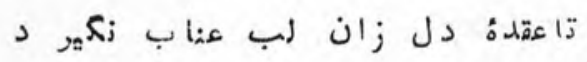

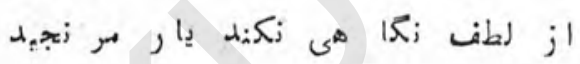

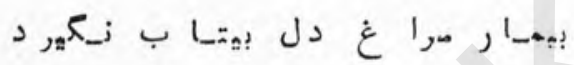

अ

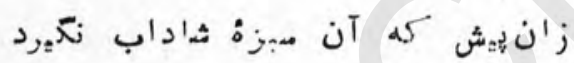

بر ت:كك زظرا ن ا إفت ذاتيست فسا هـت

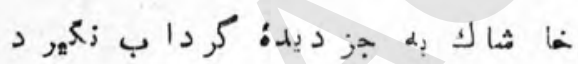

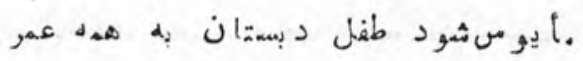

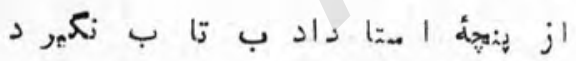

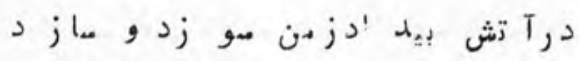

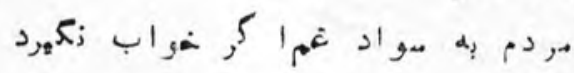

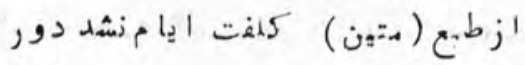

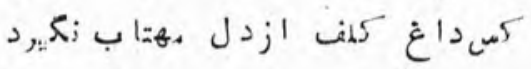

$p \cdot Q$ 
يار د ن ايوو

دلدارنى

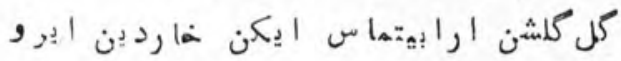

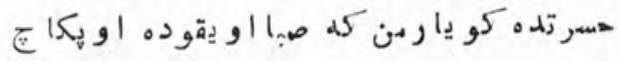

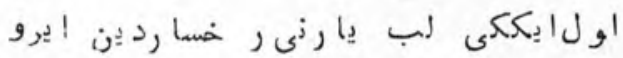

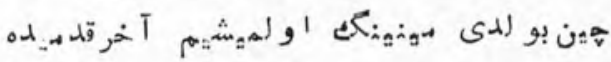

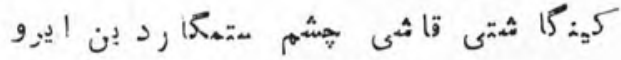

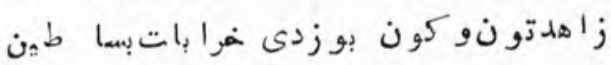

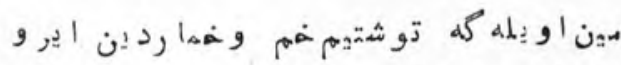

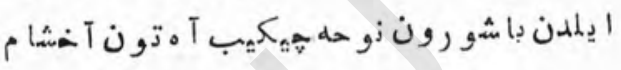

?

$p \cdot 7$ 


\section{إيككى إيناغه}

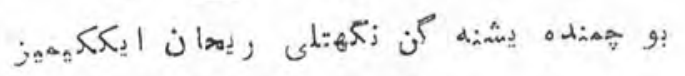

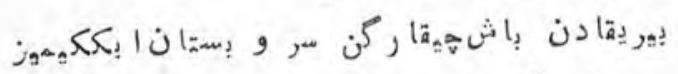

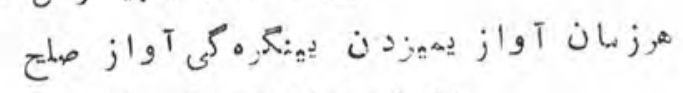

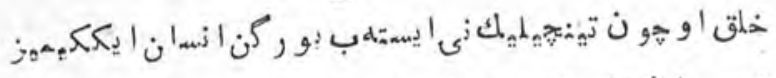

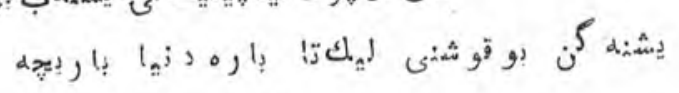

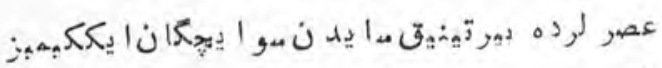

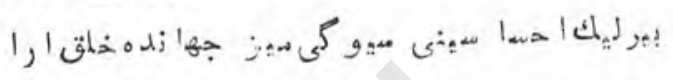

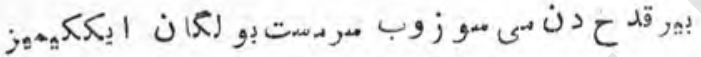

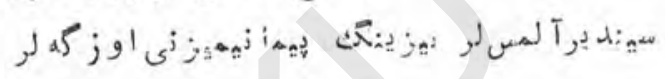

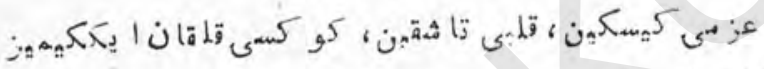

$$
1
$$

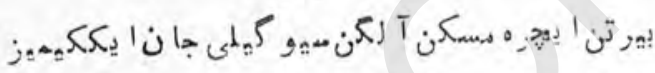

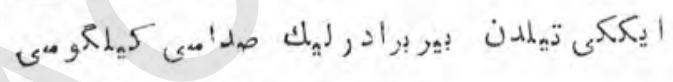

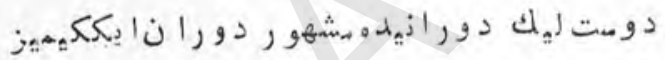

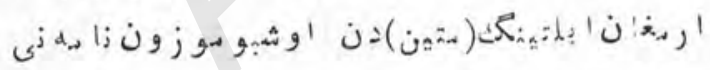

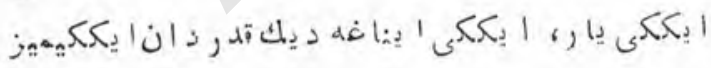

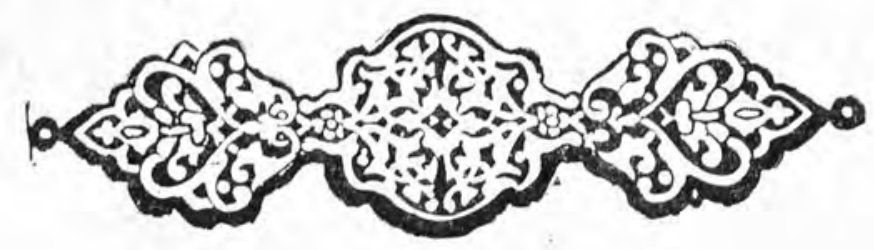




\section{فارو ق}

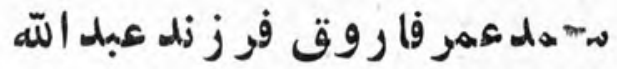

$$
\text { ( }
$$

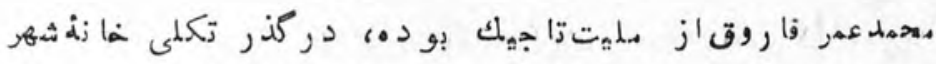

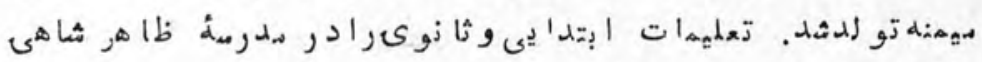

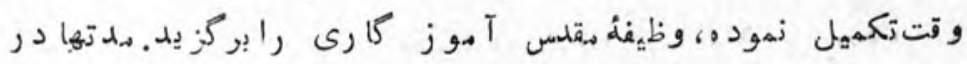

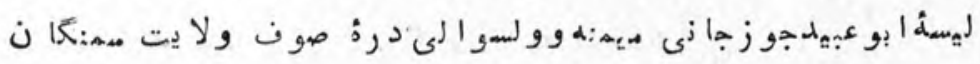

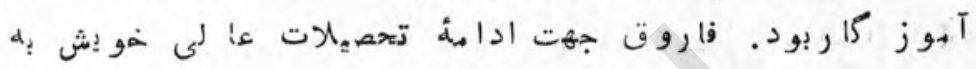

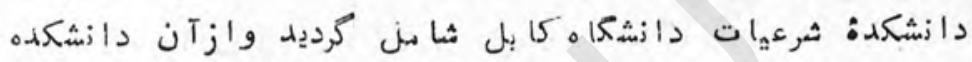

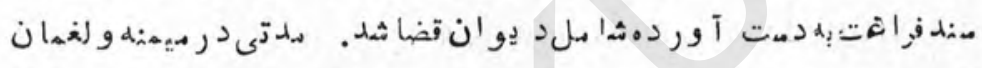

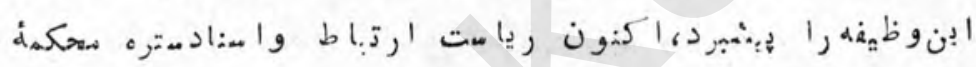

$$
\text { . } 2,1,2
$$

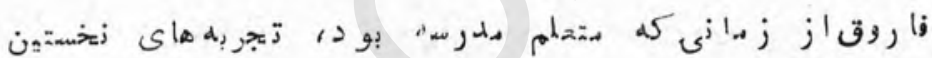

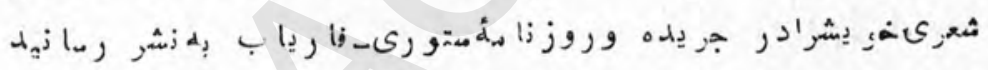

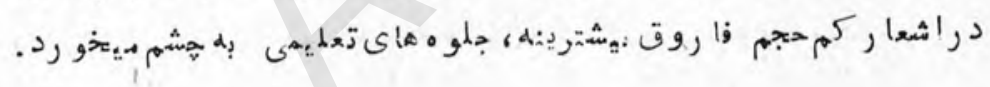

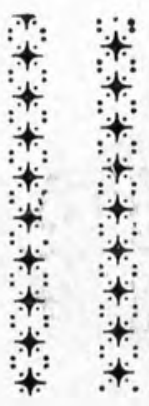


متاع دازش

اى براد رز ينتو غخودماز يتدر كار زيمت

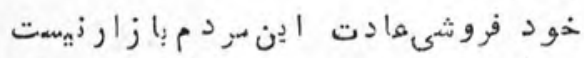

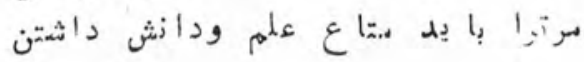

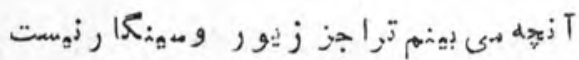

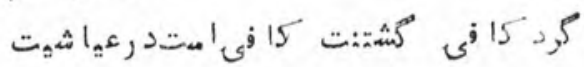

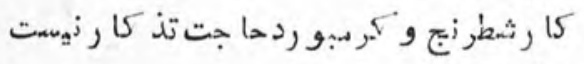

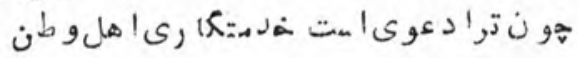

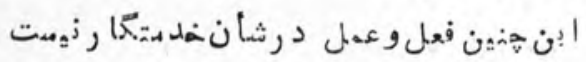

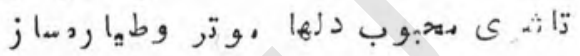

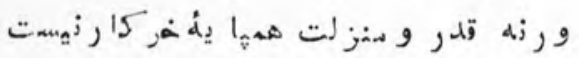

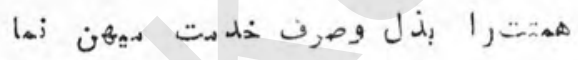

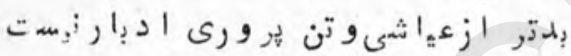

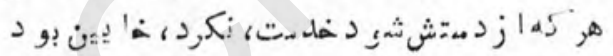

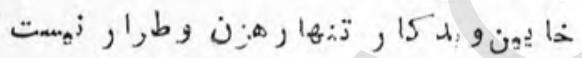

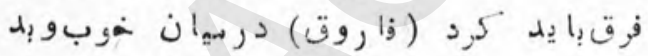

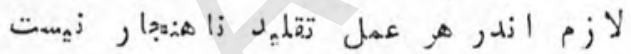

3

Q

$p \cdot q$ 


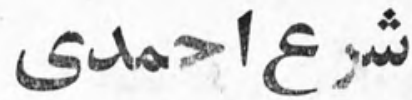

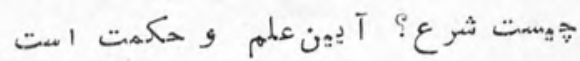

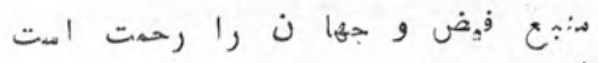

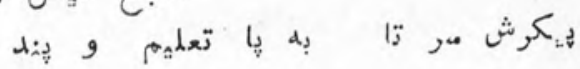

$$
\begin{aligned}
& \text { صورتش صلح ومدلام و وحلمت است }
\end{aligned}
$$

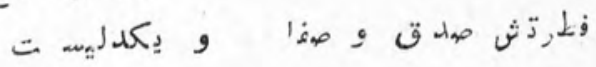

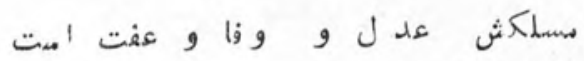

$$
\begin{aligned}
& \text { دشهن جهل است و شرك وكفر وظلما }
\end{aligned}
$$

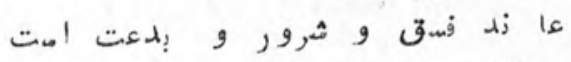

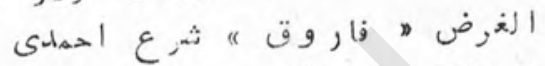

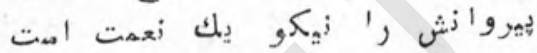

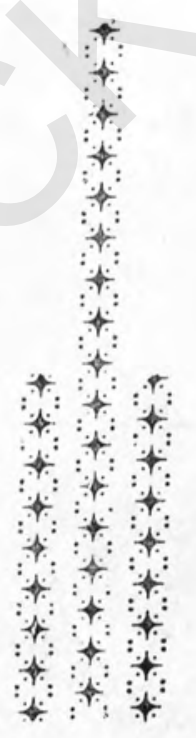


)

عبله القيو مر رحما نى فوز زله رحما نقل ( ) : Ipla )

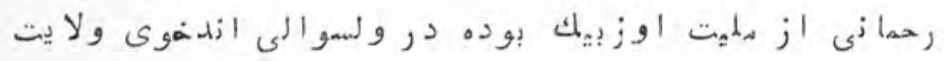

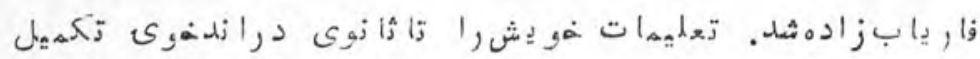

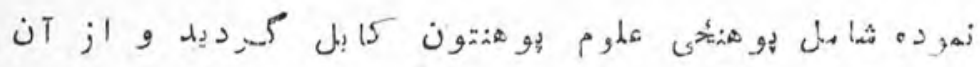

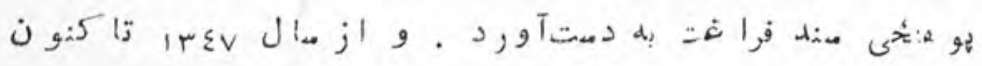
در هو كاتوزارت تعلميم وتربه در ولايات زار دِاب ، جوزجان

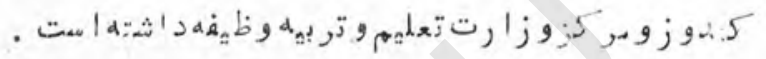

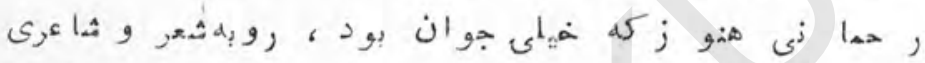

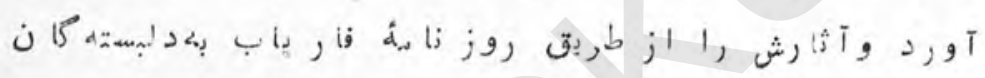

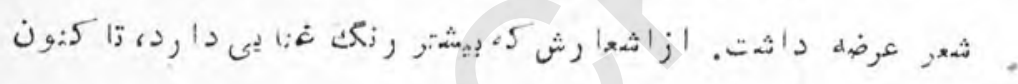

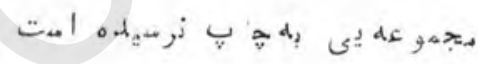

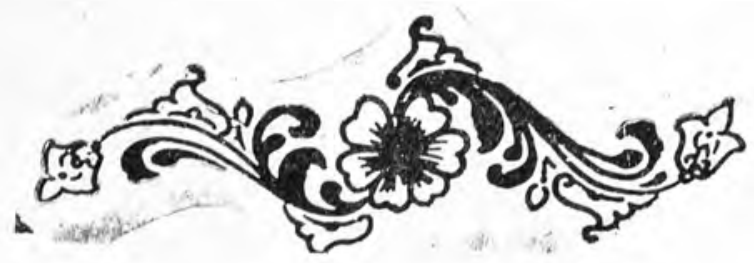

PII 
بهارو=ششت

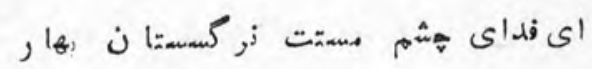

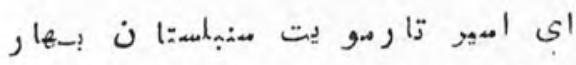

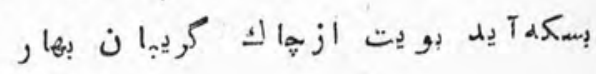

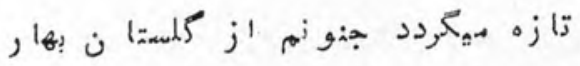

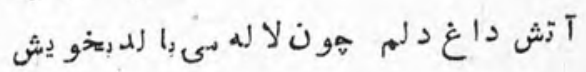

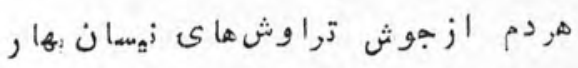

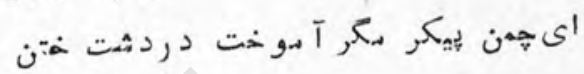

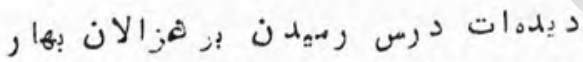

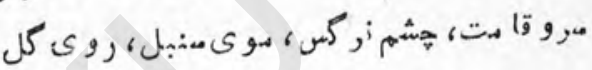

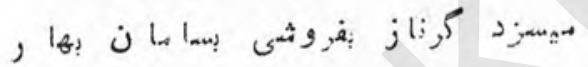

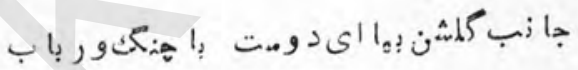

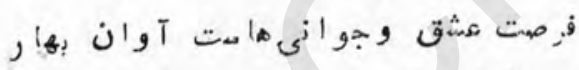

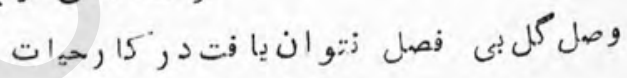

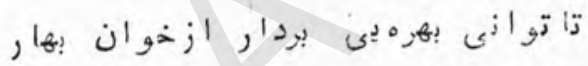

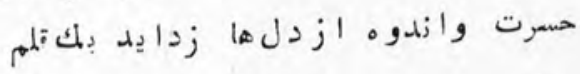

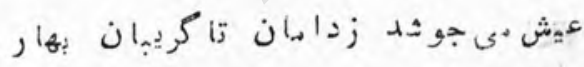

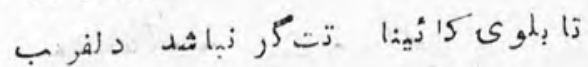

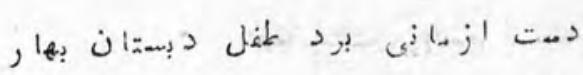

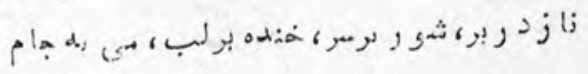

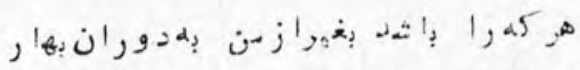

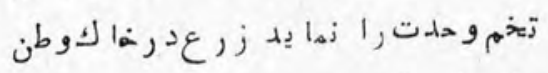

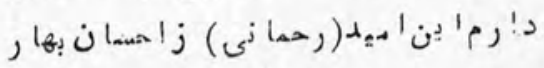

PIP 
زحمت استيى

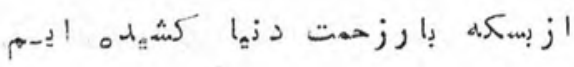

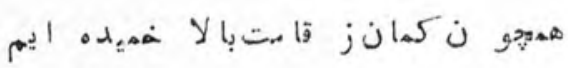

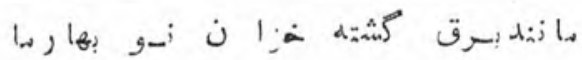

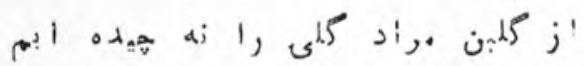

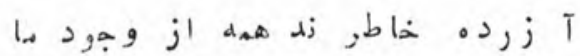

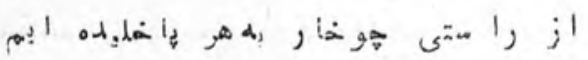

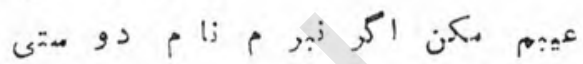

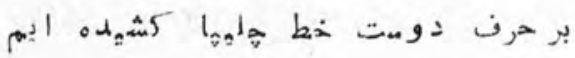

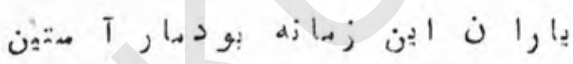

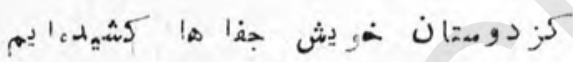

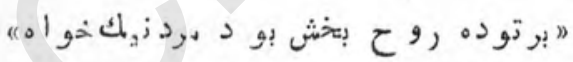

مإِ 15

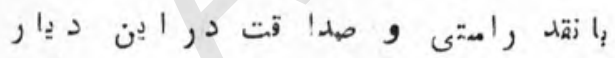

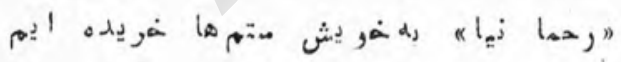

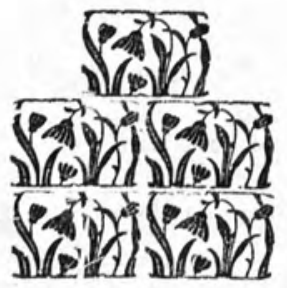

$p 1 p^{\prime \prime}$ 


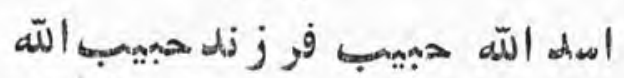

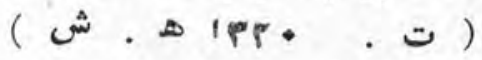

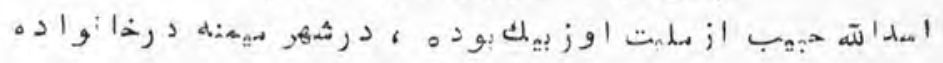

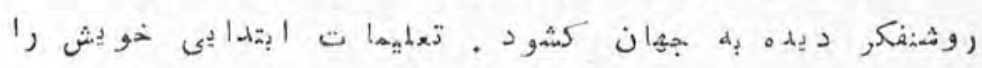
2

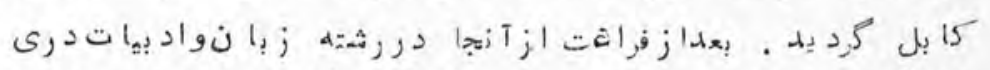

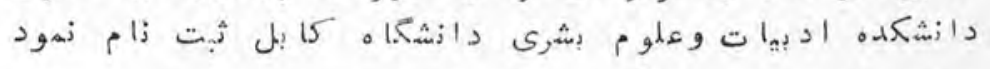

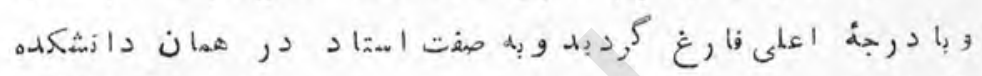

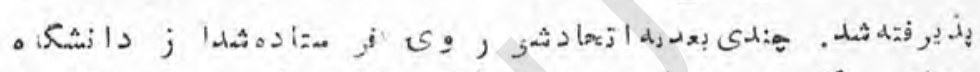

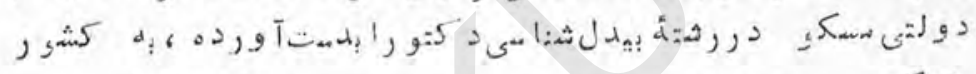

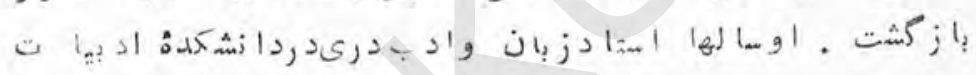

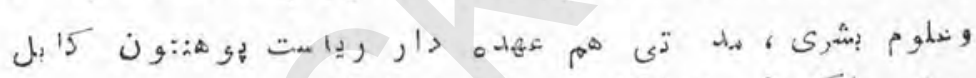

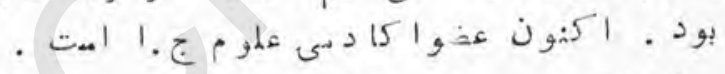

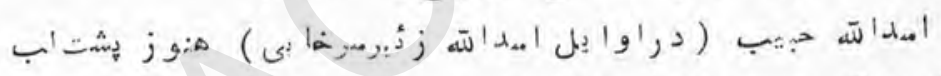

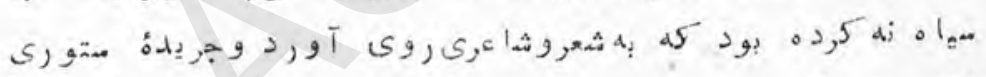

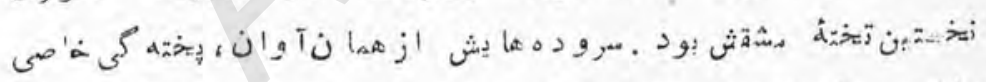

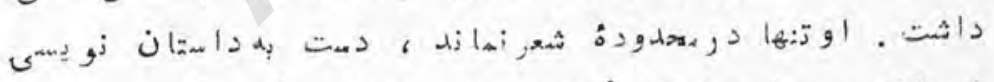

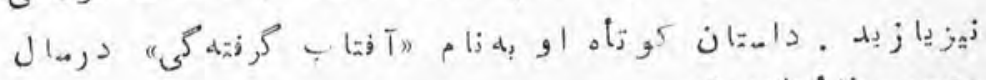
.

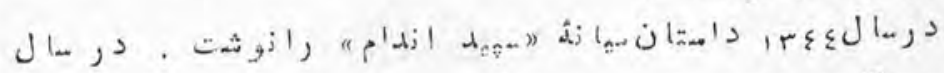

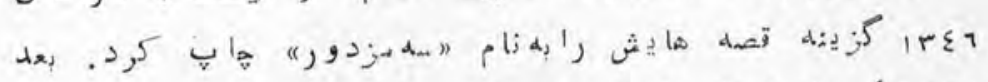

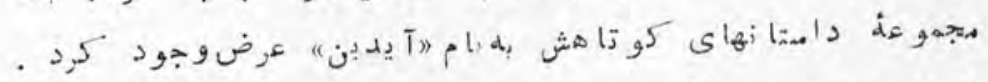

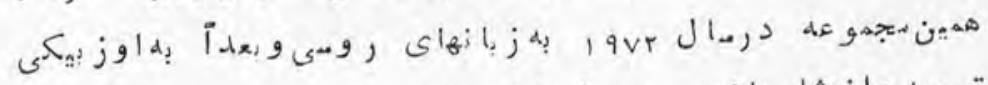

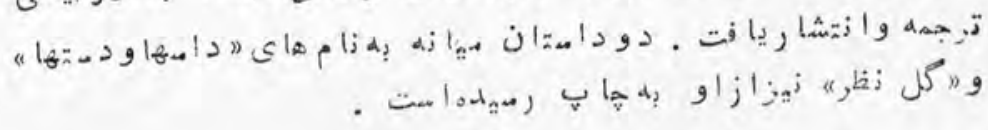
pif 


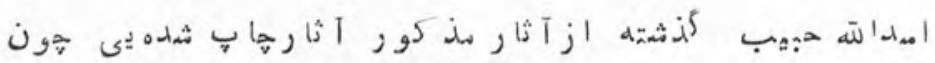

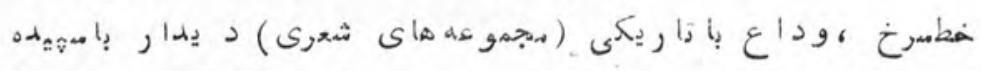

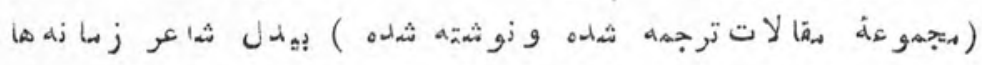

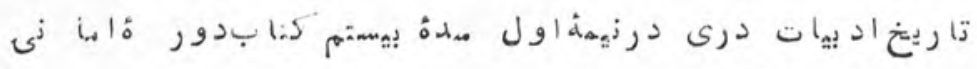

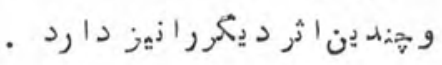

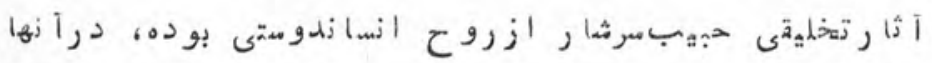

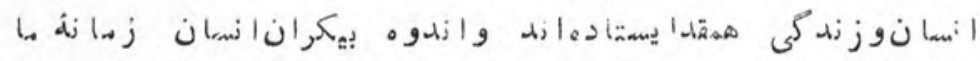

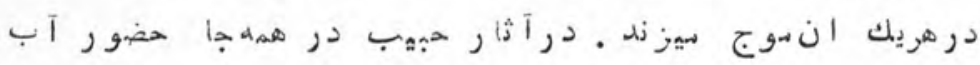

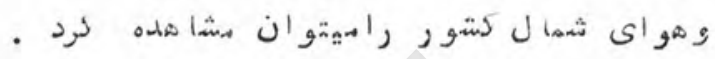

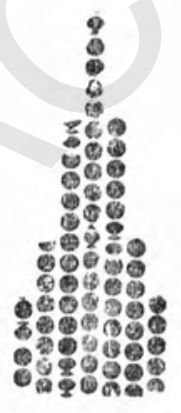




\section{نالجندون}

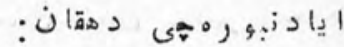

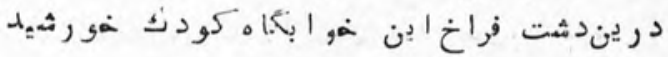

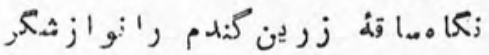

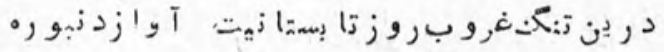

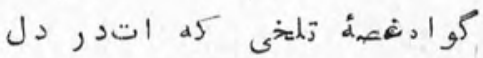

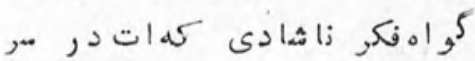

$$
\begin{aligned}
& \text { * * * * }
\end{aligned}
$$

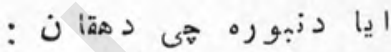

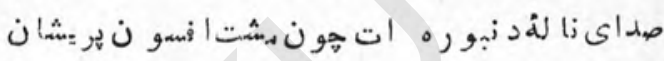

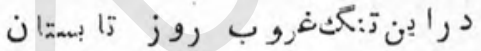

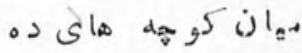

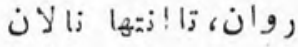

$$
\begin{aligned}
& \text { * } \\
& \text { * * }
\end{aligned}
$$

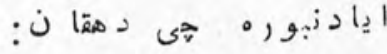

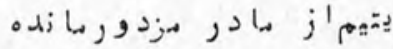

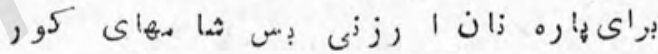

$$
\begin{aligned}
& \text { 吾 }
\end{aligned}
$$

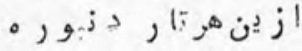

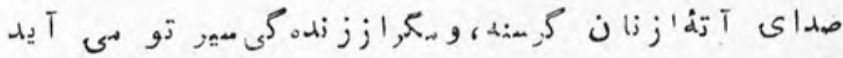

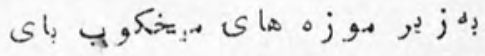

$$
\begin{aligned}
& \text { كل }
\end{aligned}
$$

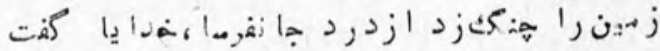

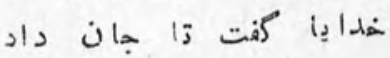

$$
\begin{aligned}
& \text { * * * }
\end{aligned}
$$




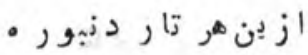

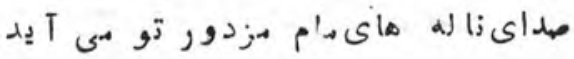

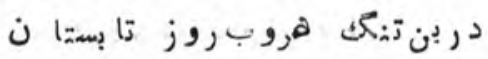

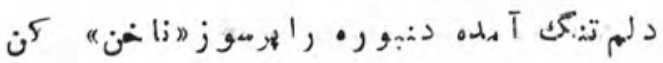

نان هاز

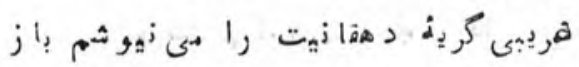

.

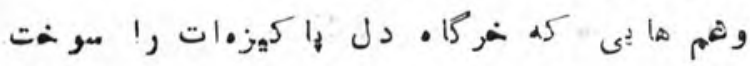

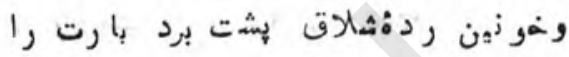

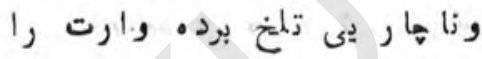

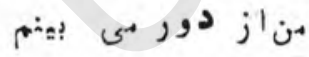

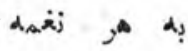

ب

* * *

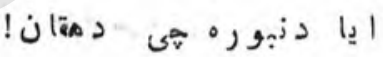

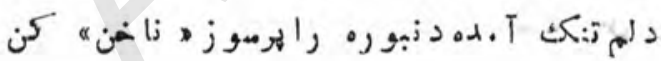

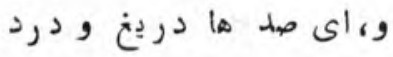

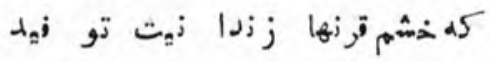

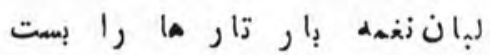

و

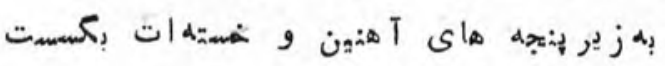

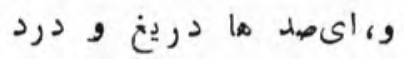

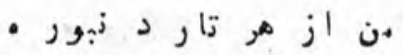

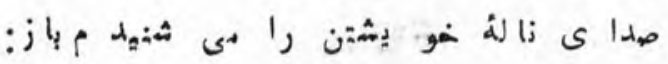

pIY 
زjز

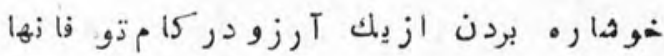

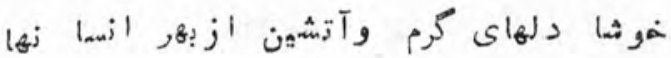

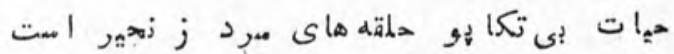

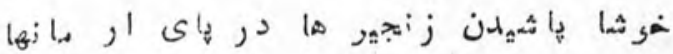

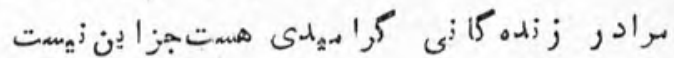

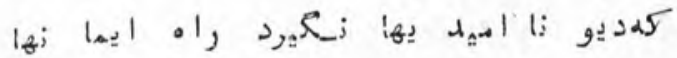

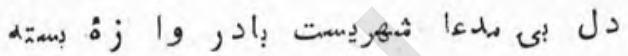

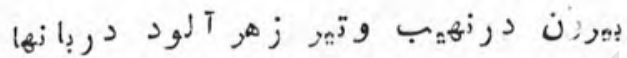

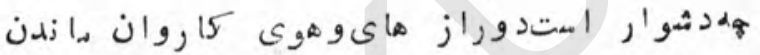

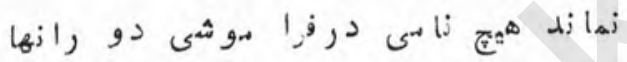

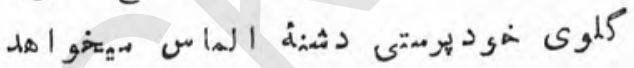

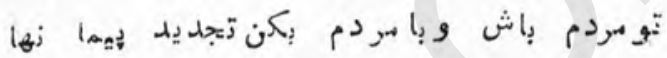

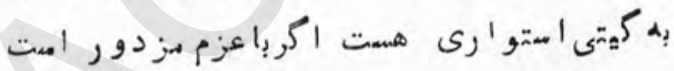

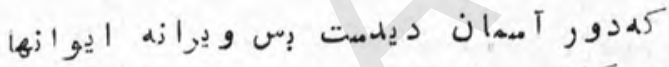

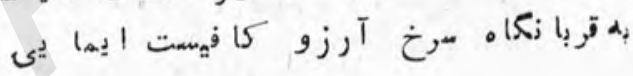

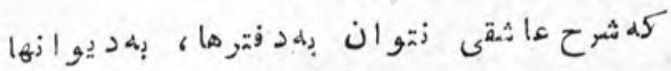

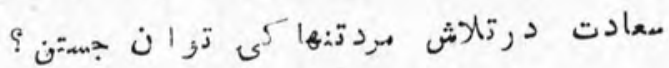

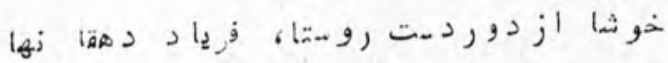

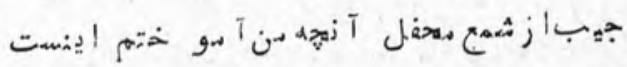

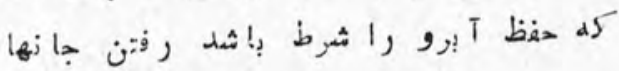

PIA 


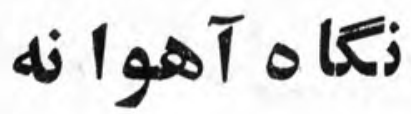

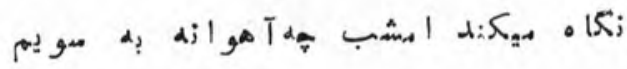

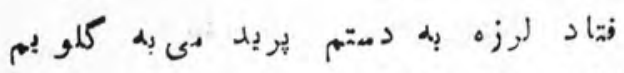

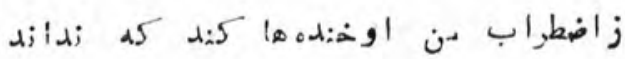

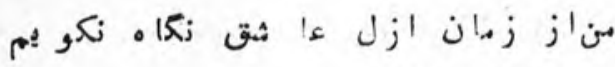

ردوز عشق ز إم روزكار برده. زيا دمام

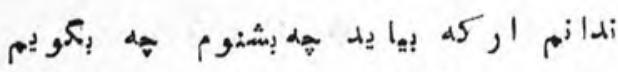

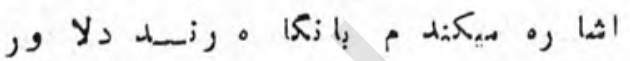

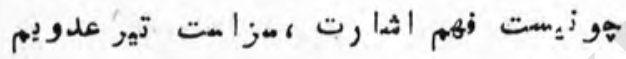

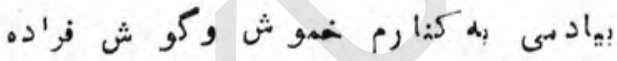

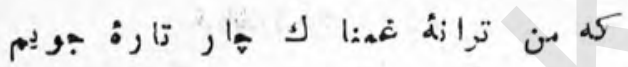

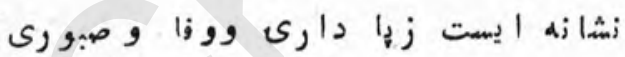

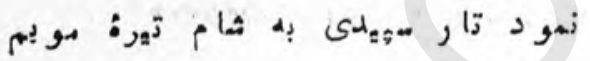

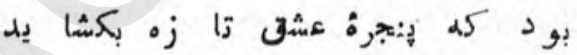

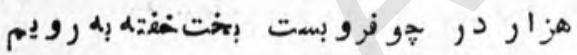

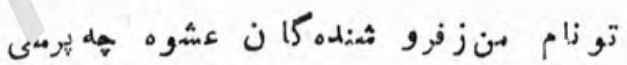

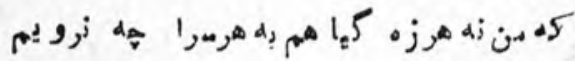

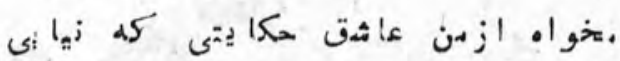

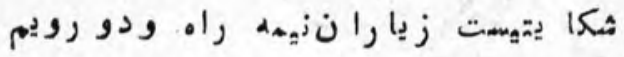

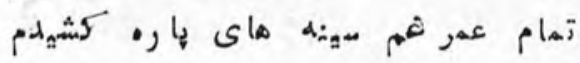

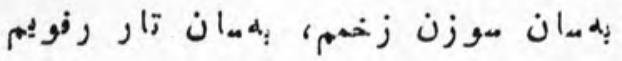

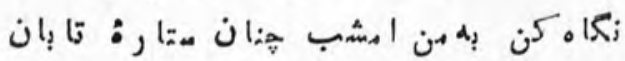

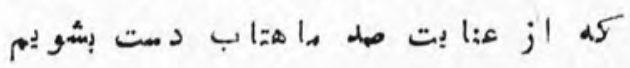

Pla 
عبدالجبارباذل فرزنالهمهملعثمان

ت ت

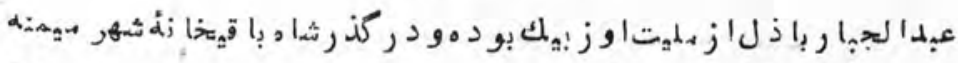

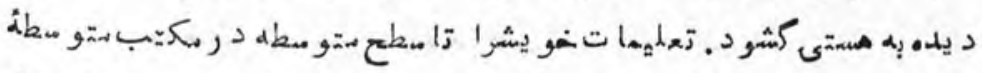

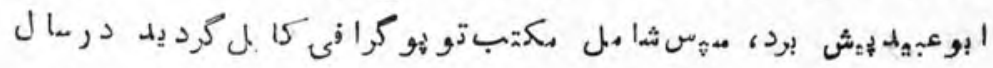

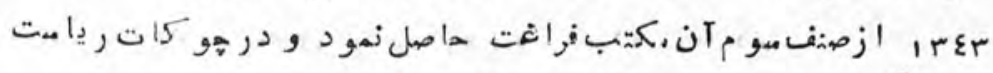

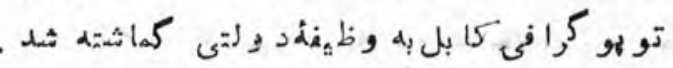

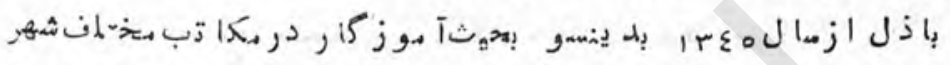

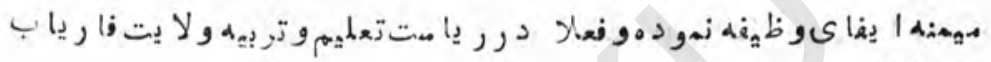

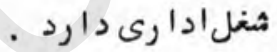

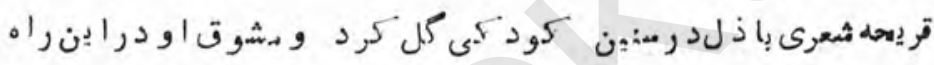

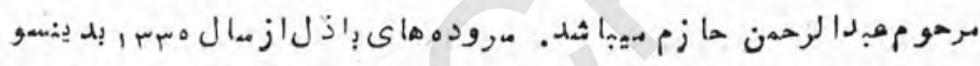

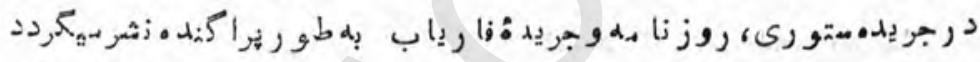

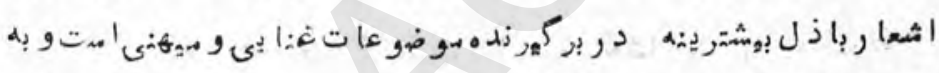

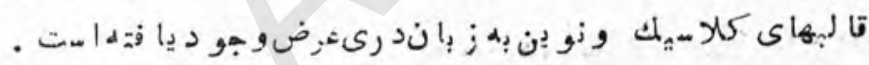

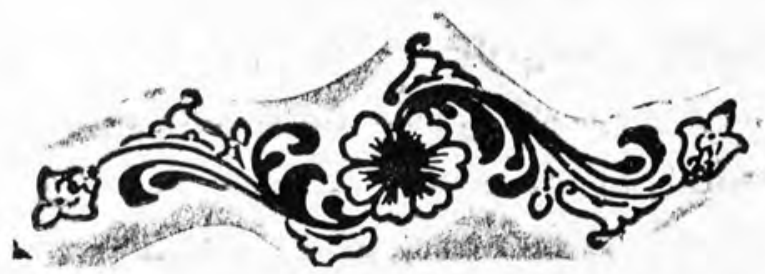

res 


\section{قطرة اشك

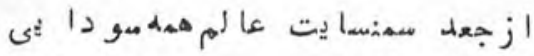

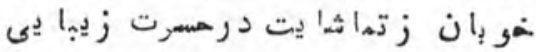

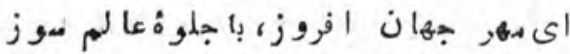

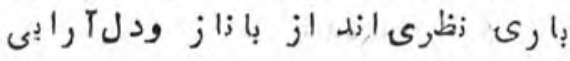

$$
\begin{aligned}
& \text { از جلموة رخسا رت هشمى زنشو دميران }
\end{aligned}
$$

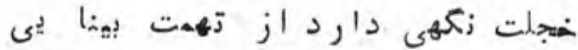

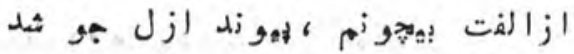

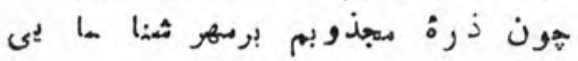

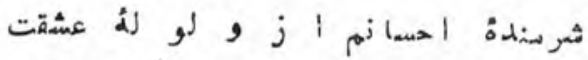

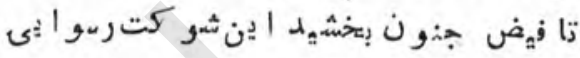

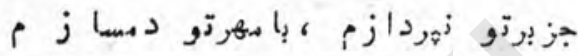

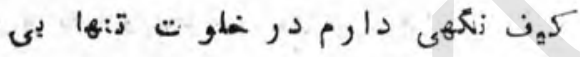

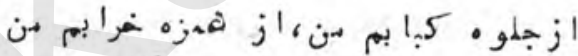

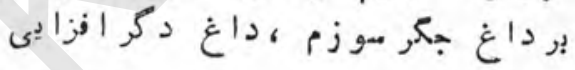

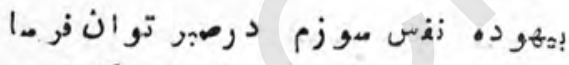

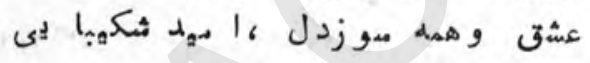

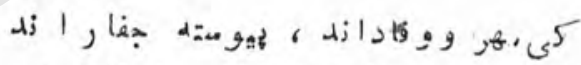

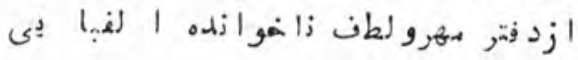

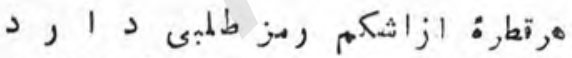

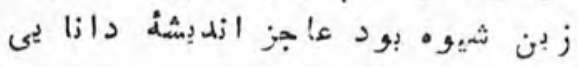

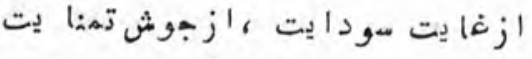

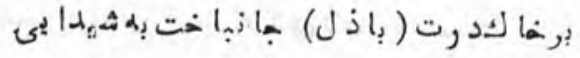

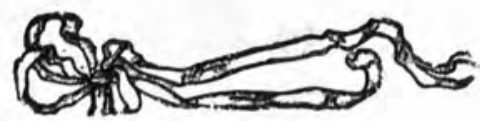




$$
\begin{aligned}
& \text { Gine } 01 \% 0
\end{aligned}
$$

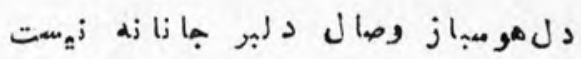

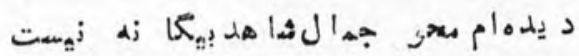

$$
\begin{aligned}
& \text { زالا } \\
& \text { خ:دهثادى الثربخث دل فرزازئه زئه }
\end{aligned}
$$

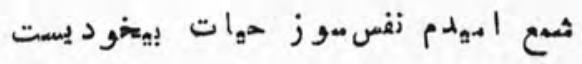

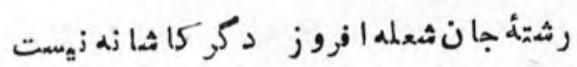

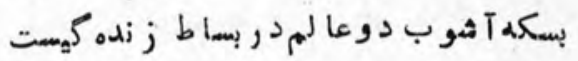

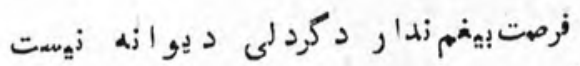

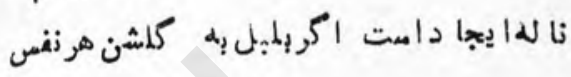

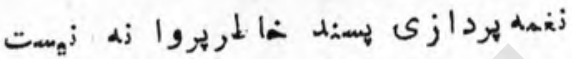

$$
\begin{aligned}
& \text { زd بهد ير و كعبه و بت:خا زه، دل دل كيرد قرار }
\end{aligned}
$$

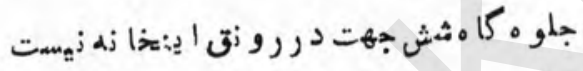

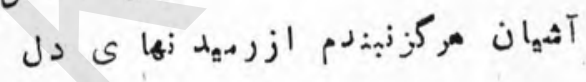

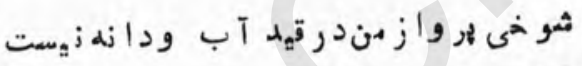

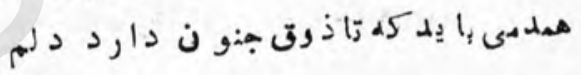

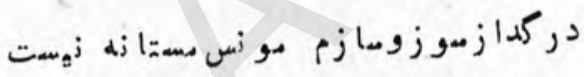

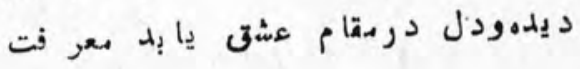

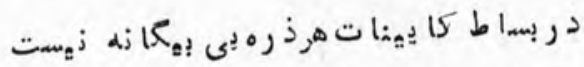

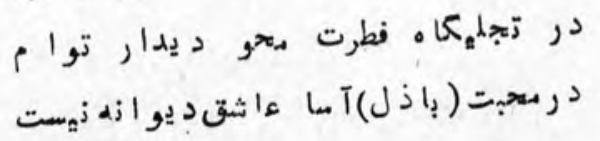

$$
\begin{aligned}
& \text { W }
\end{aligned}
$$

\section{rer}




\section{قارى غلامسخخى (محبى) تامبا هـ ش.}

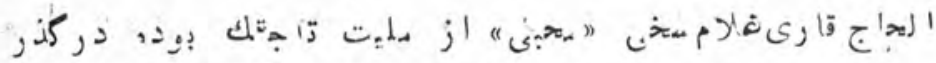

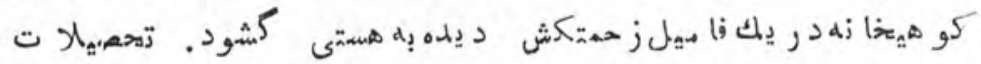

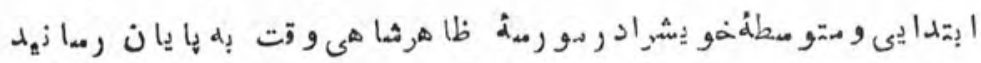

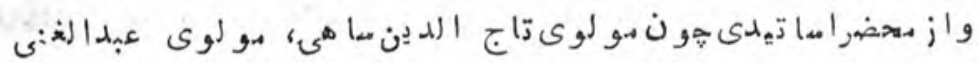

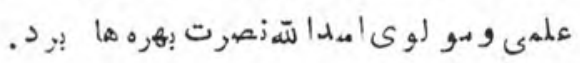

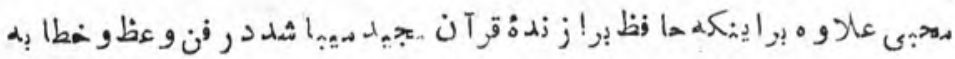

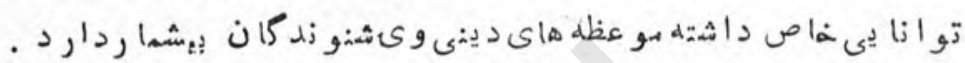

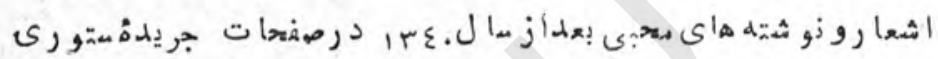

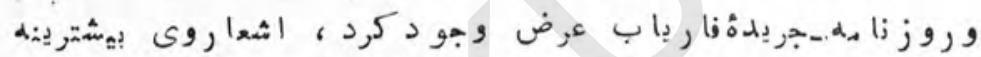

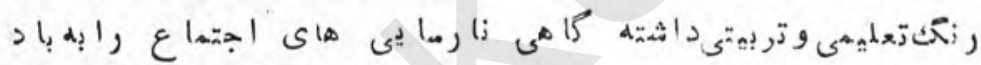

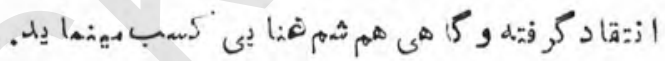

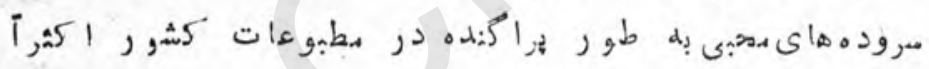

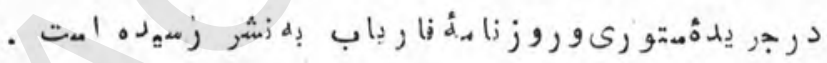

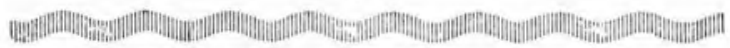

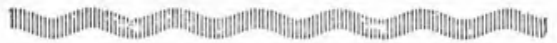

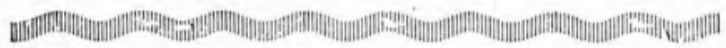


جشن شما مبا رك

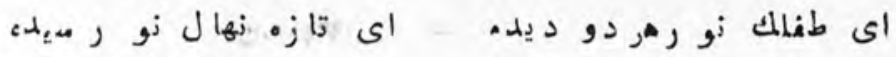

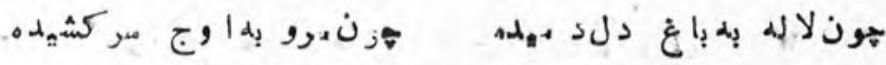

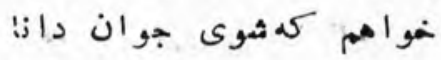

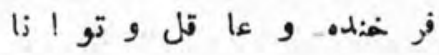

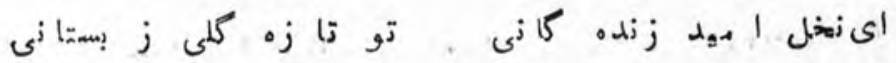

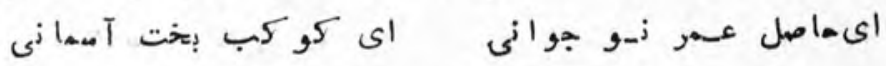
ك'

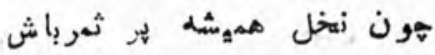

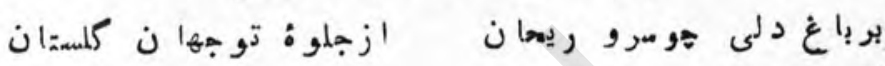

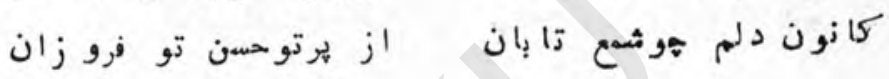

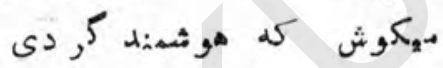

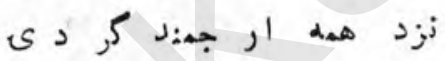

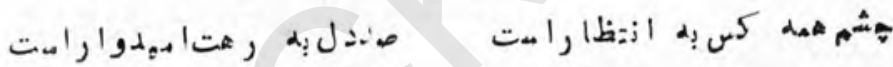

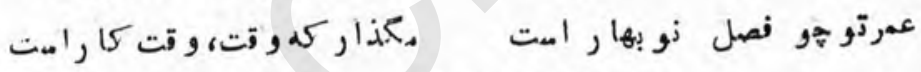

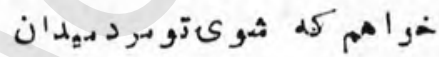

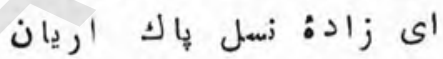

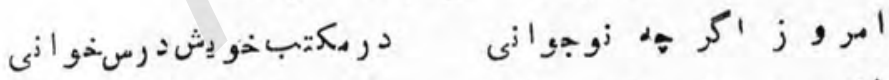

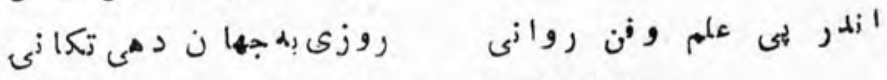

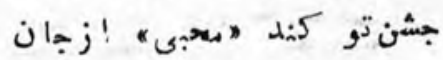

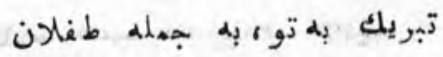

bpt 


\section{مقدم بهار}

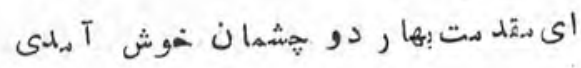

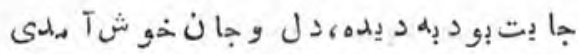

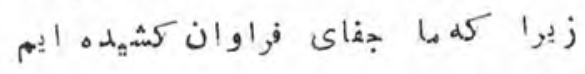

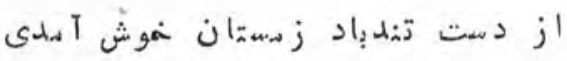

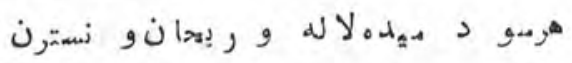

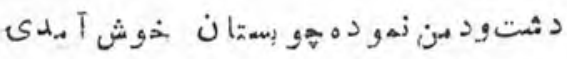

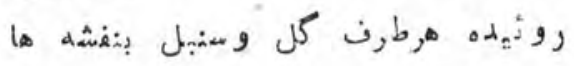

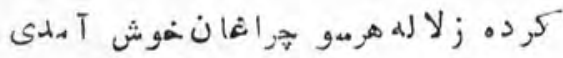

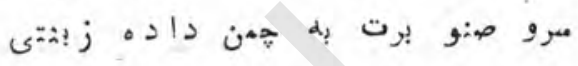

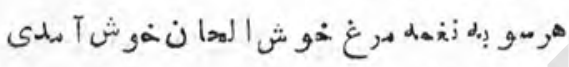

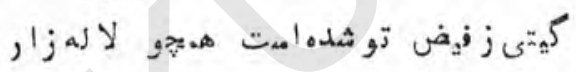

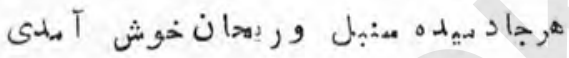

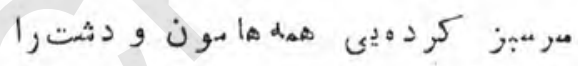

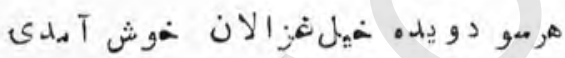

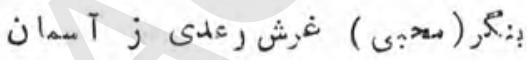

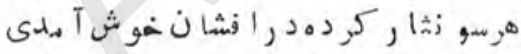

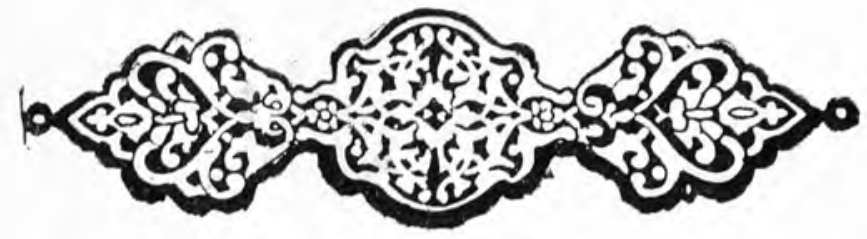




\section{حنيفتخاريان}

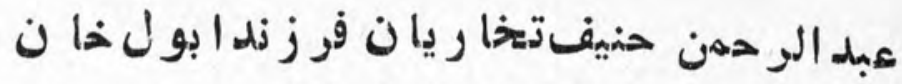

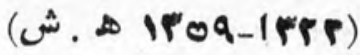

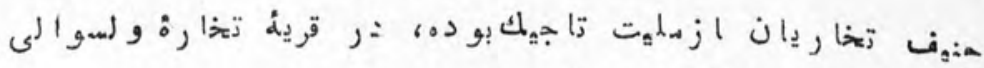

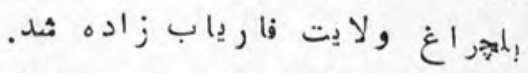

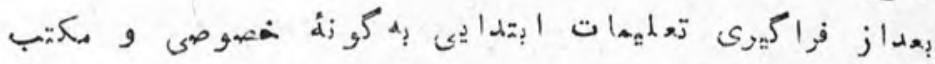

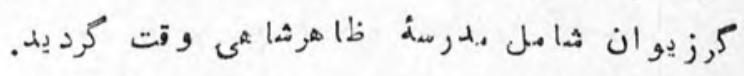

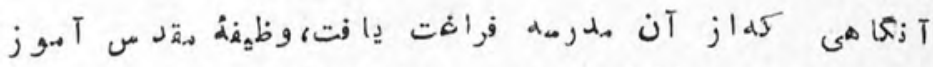

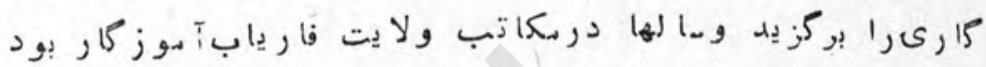

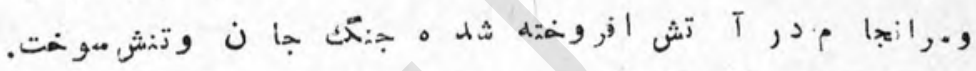

ازئ

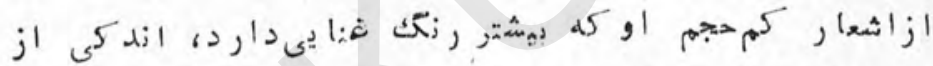

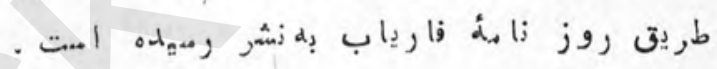

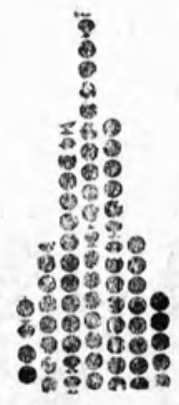


داغ نامر ادى

زصبح آرزودر زالدام تاشام هجرانش

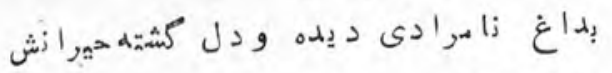

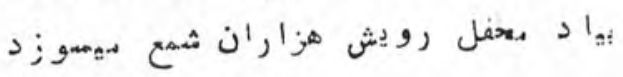

و

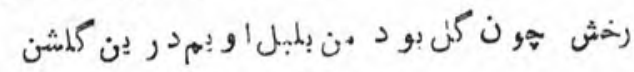

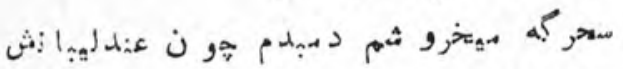

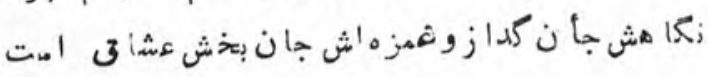

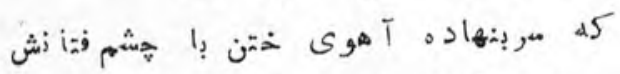

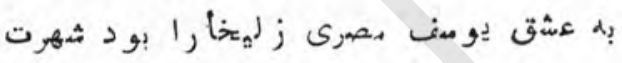

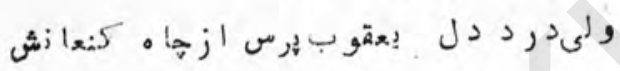

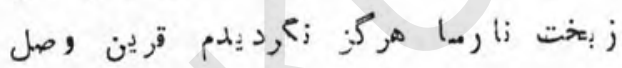

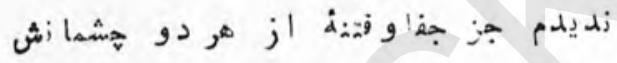

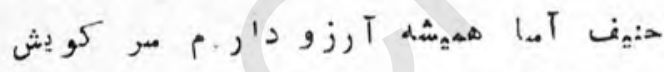

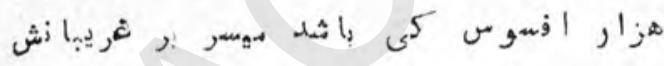

rev 
نزهت باخترى

عبد الوحيم نز هت با خترى فوز نه عبد القاد در

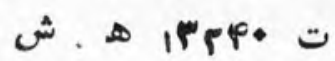

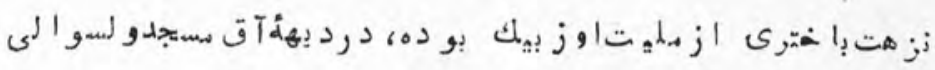

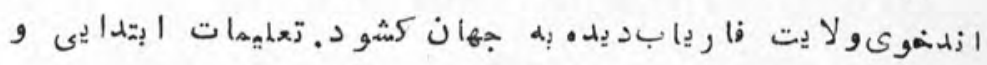

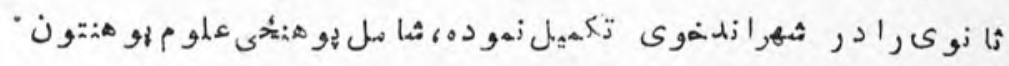

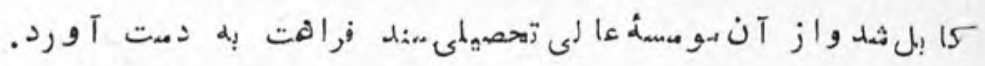

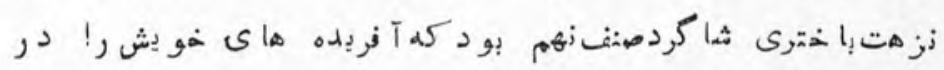

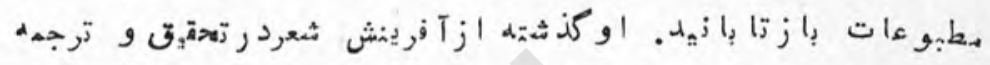

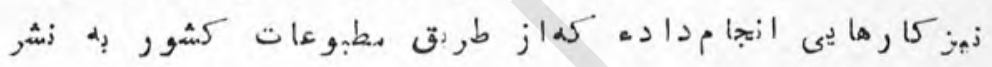

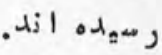

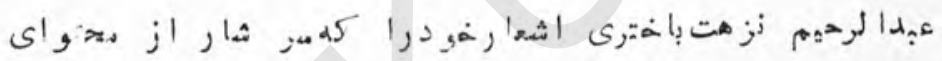

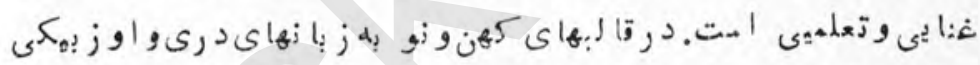

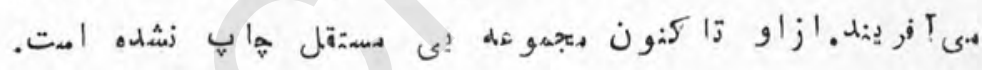

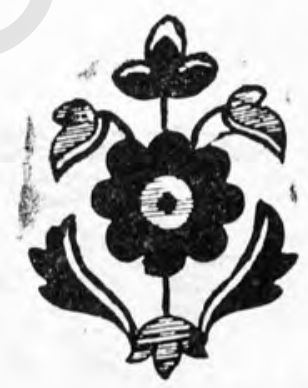

rea 
صلق خو اباتيان

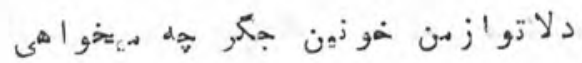

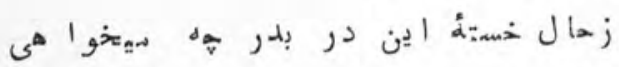

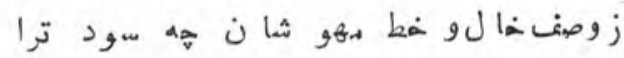

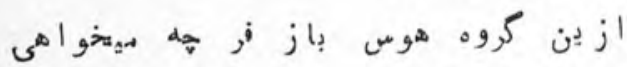

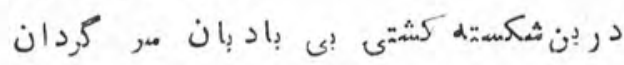

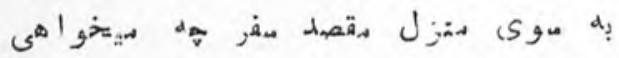

ك:ون كله كوش فيلك كر شده ز زعرة

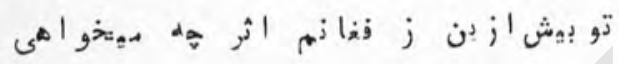

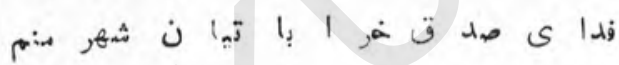

هل

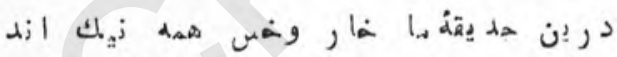

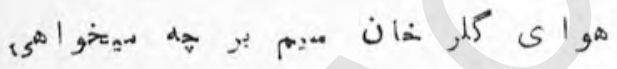

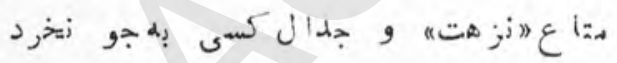

خذن

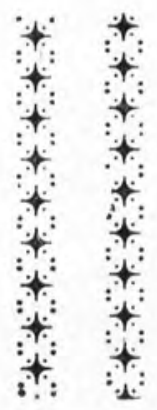

ppa 


\section{نورى}

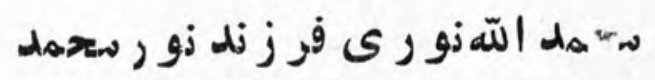

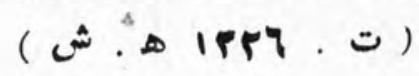

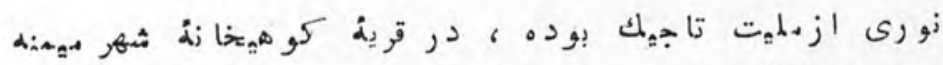

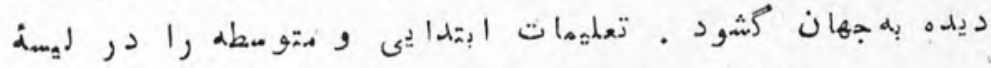

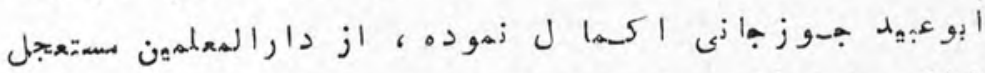

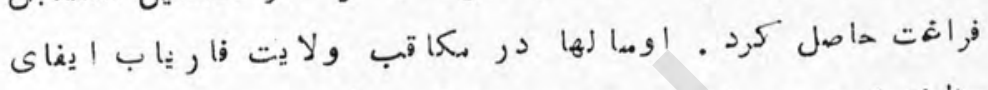

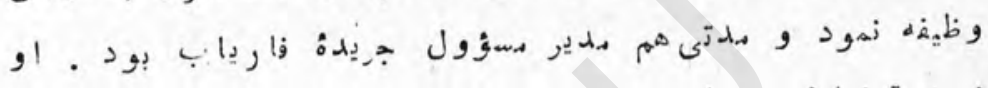

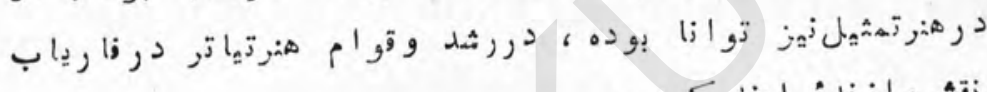

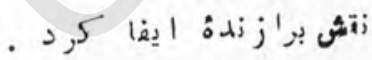

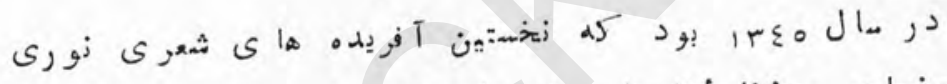

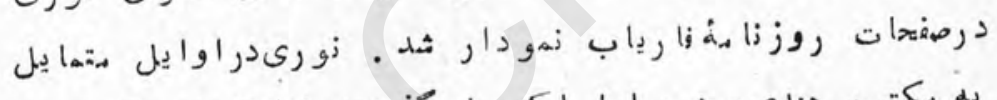

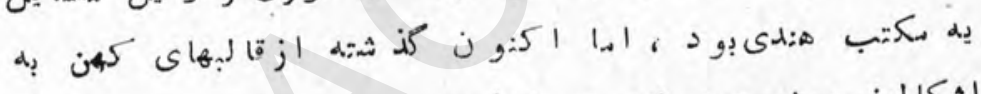

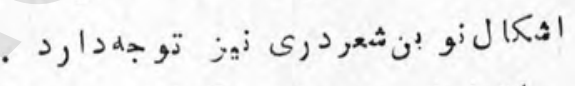

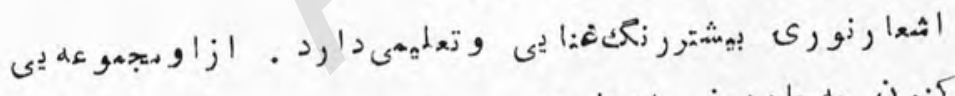
تاكنون

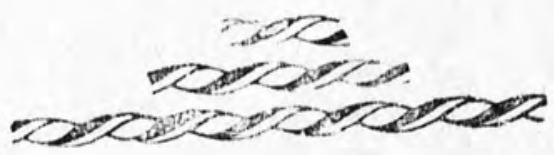




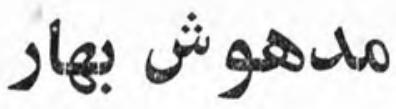

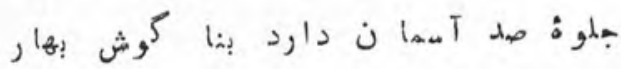

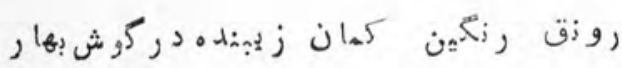

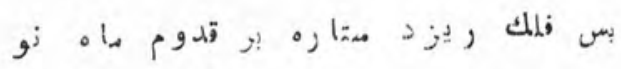
زان هدى كرد يده بهزادش قراسوش بهار

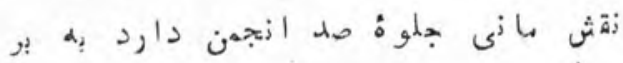

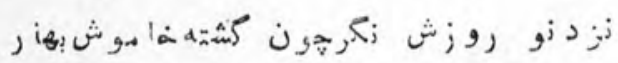

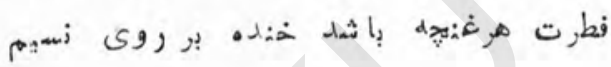

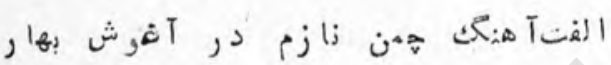

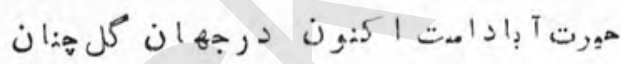

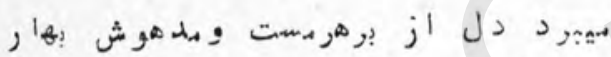

ط:ل

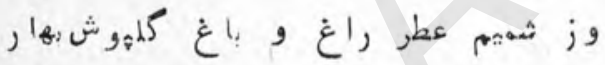

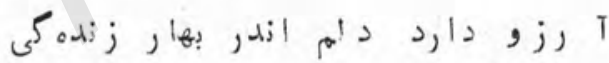

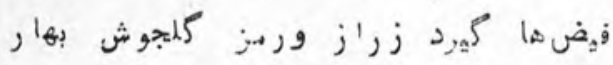

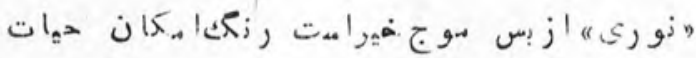

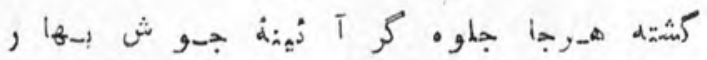

P I 
رزغك انجمن

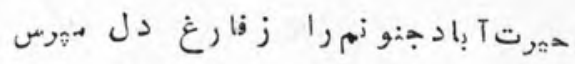

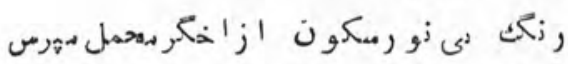

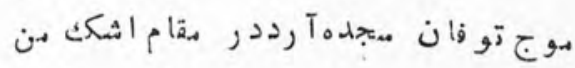

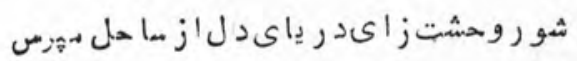

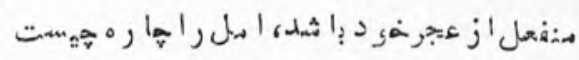

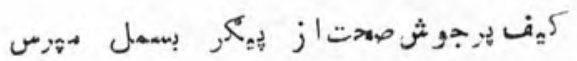

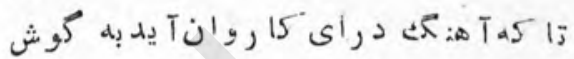

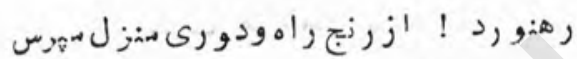

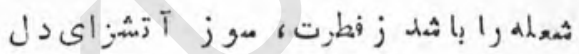

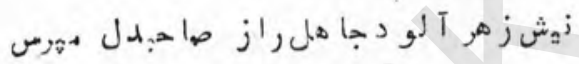

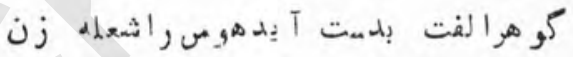

كام

;

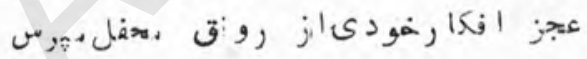

per 
مung:

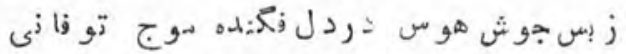

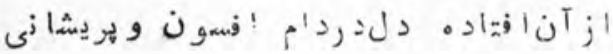

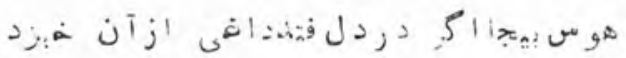

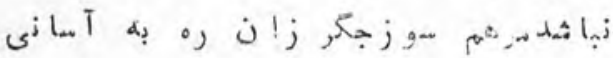

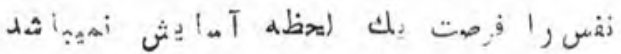

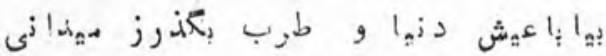

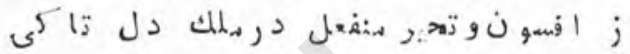

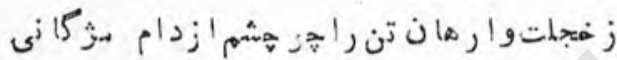

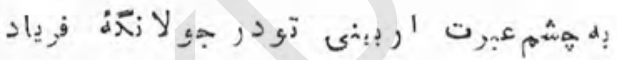

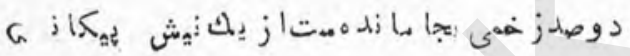

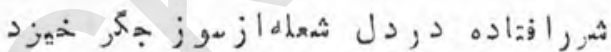

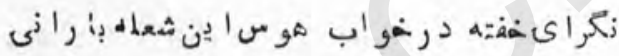

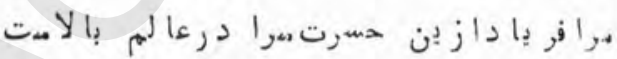

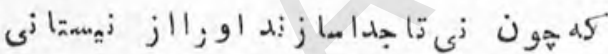

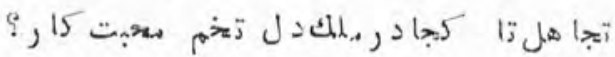

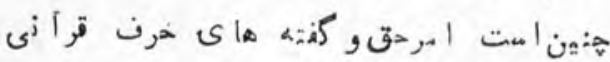

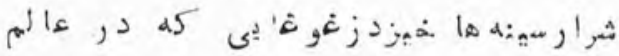

و

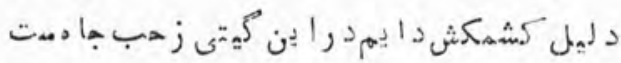

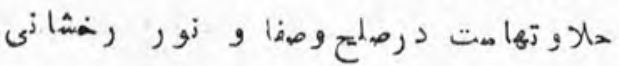

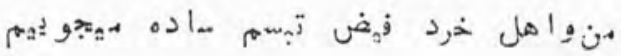

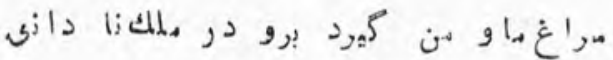

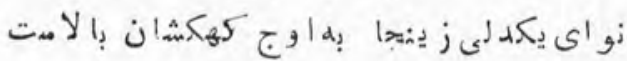

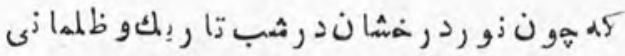

prF 
تصوير يك كدا

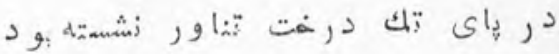

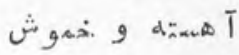

$$
\begin{aligned}
& \text { زا هـيد و سركرانه }
\end{aligned}
$$

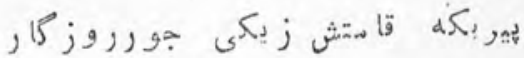

$$
\begin{aligned}
& \text { وزمردش زمان }
\end{aligned}
$$

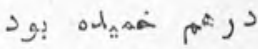

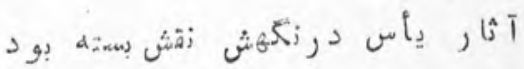

ماري

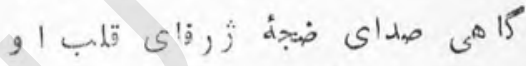

جو ن تير جازيكداز

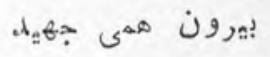

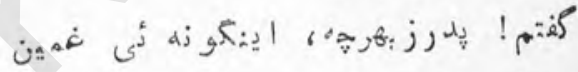

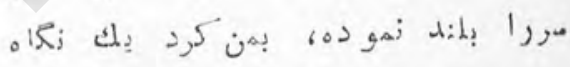

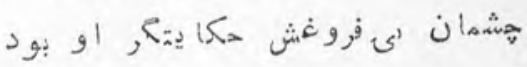

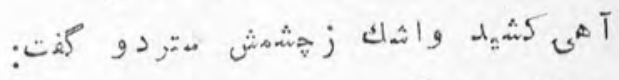

$$
\begin{aligned}
& \text { S. }
\end{aligned}
$$

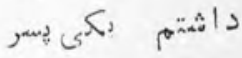

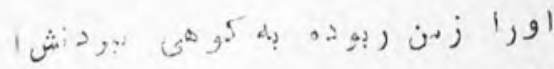
فرداى حادثة

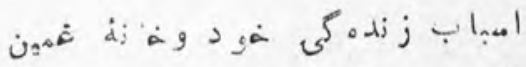

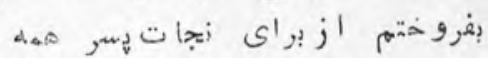

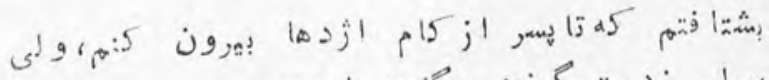

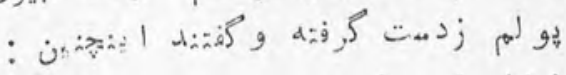
فرزئل تو برفت زت

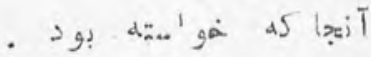




$$
\begin{aligned}
& \text { S }
\end{aligned}
$$

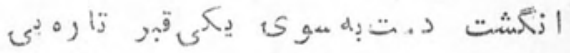

$$
\begin{aligned}
& \text { : تجن }
\end{aligned}
$$

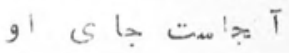

$$
\begin{aligned}
& \text { Il } \\
& \text { آ } \\
& \text { زان }
\end{aligned}
$$

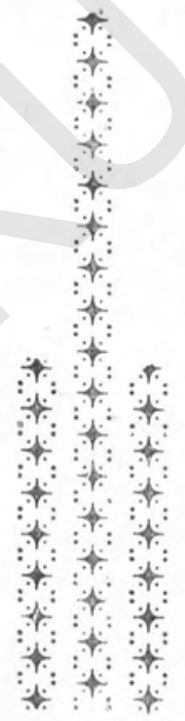


3

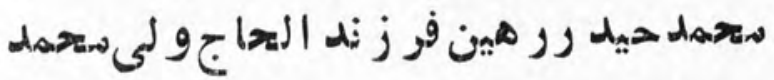

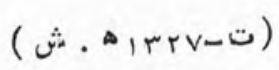

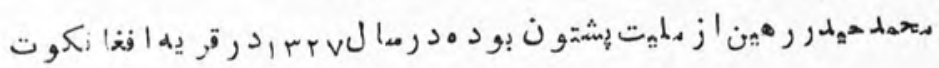

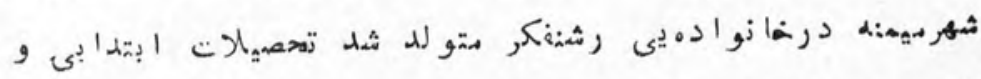

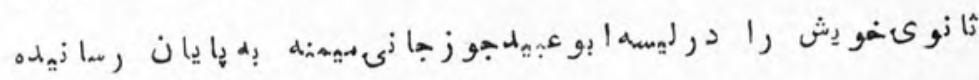

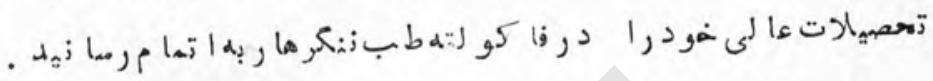

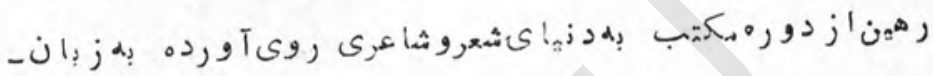

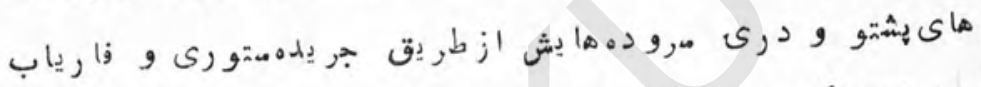

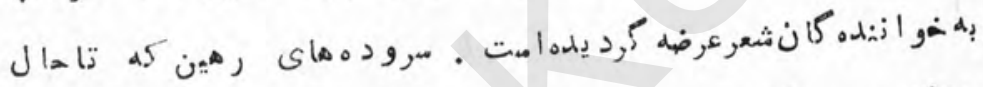

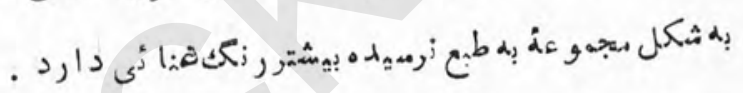

.

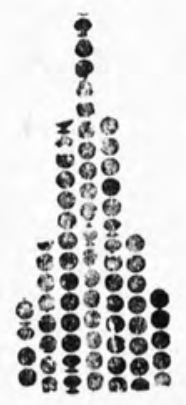

pry 


\section{دعرفانق_ـدح}

$$
\text { إو دلمت حه }
$$

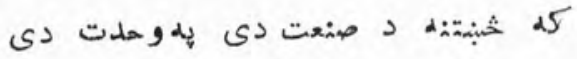

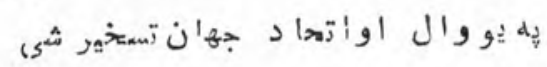

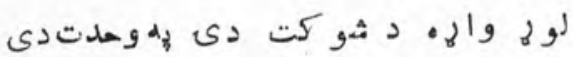

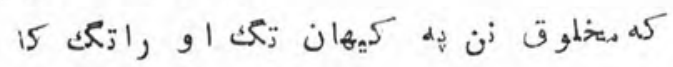

ها

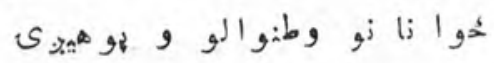

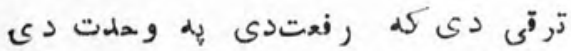

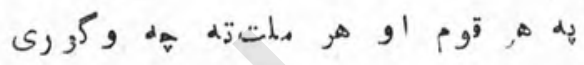

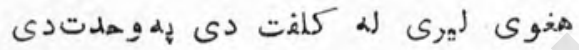

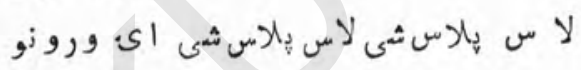

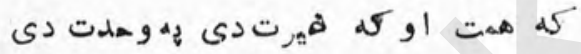

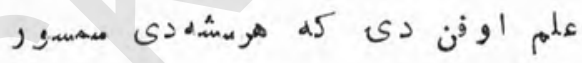

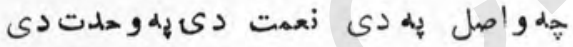

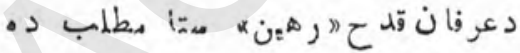

$$
\begin{aligned}
& \text { }
\end{aligned}
$$

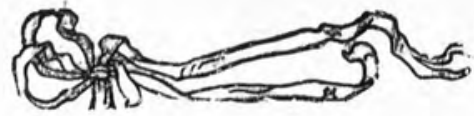




\section{ن ان}

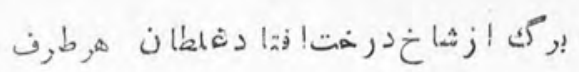

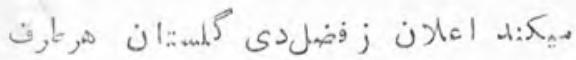

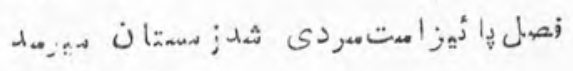

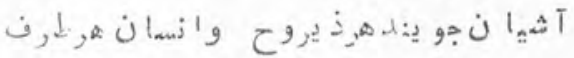

$$
\text { مبز وزار زنجى ومرخ وزرد اوراق شيجر }
$$

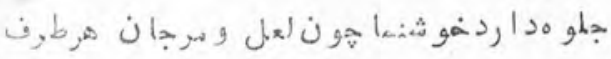

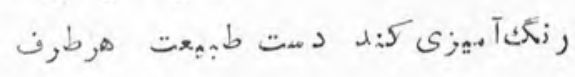

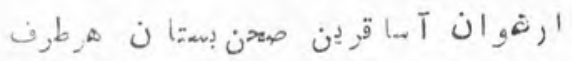

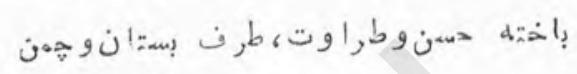

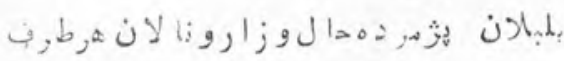

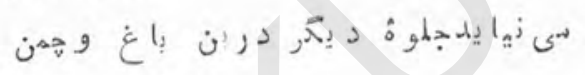

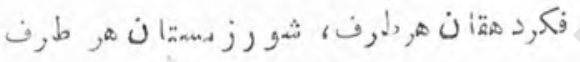

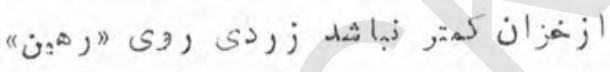

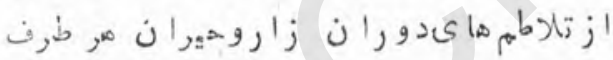

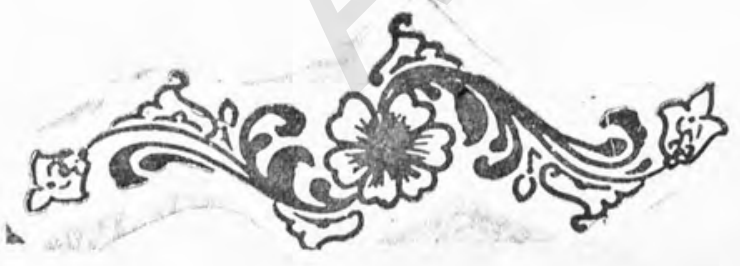

\section{peA}


شب حنا

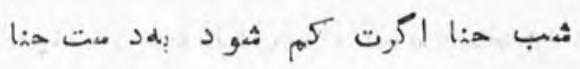

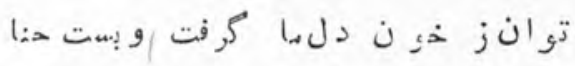

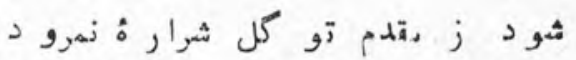

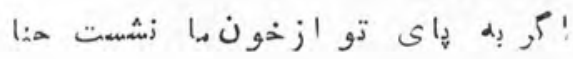

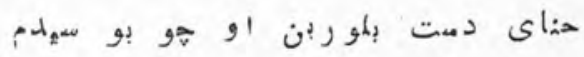

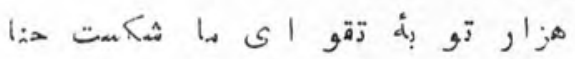

ثشنق

li: 2 ك

زخون ديدة صد ها هجو لن شهُهدانى

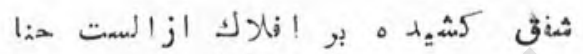

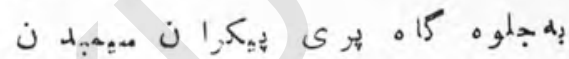

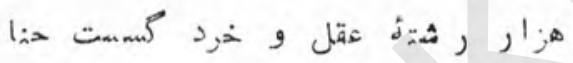

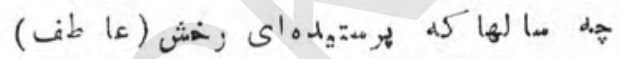

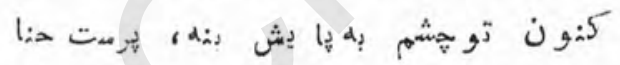

pp. 


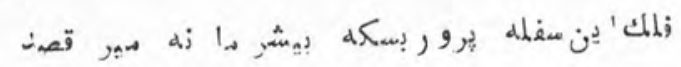

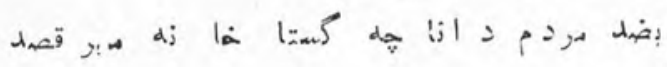

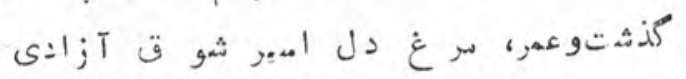

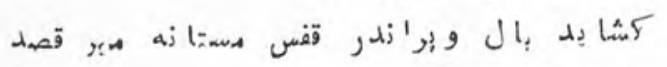

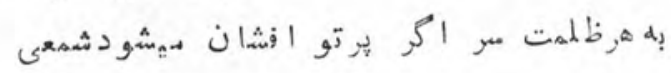

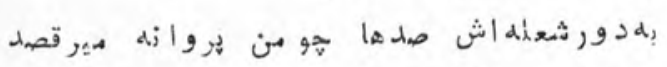

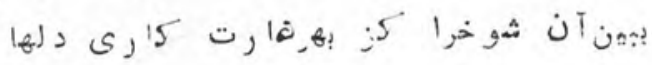

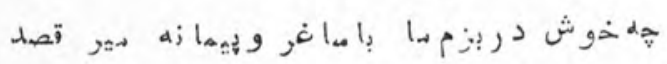

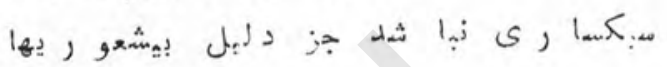

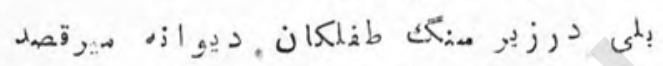

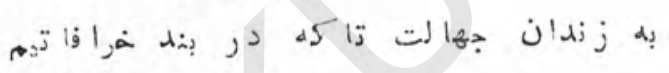

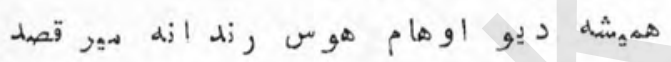

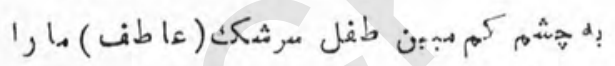

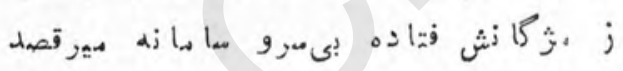

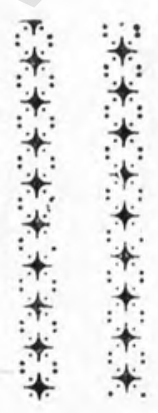

PFI 


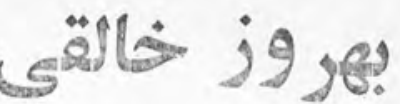

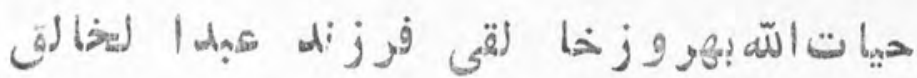

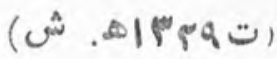

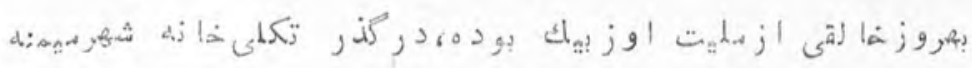

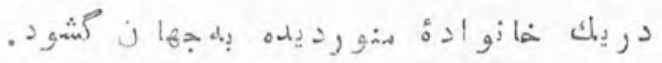

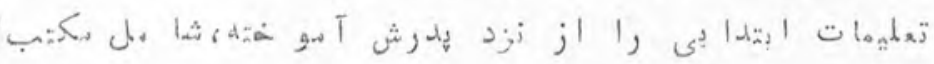

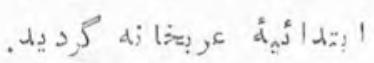

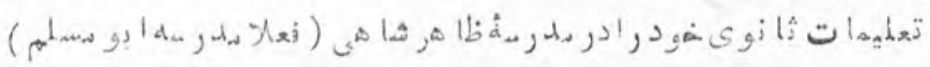

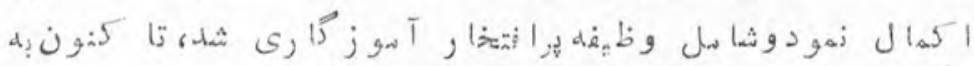

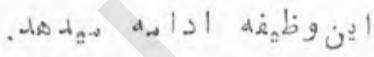

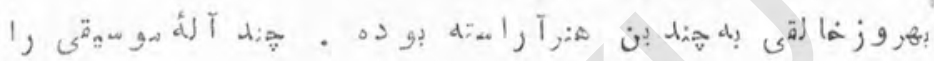

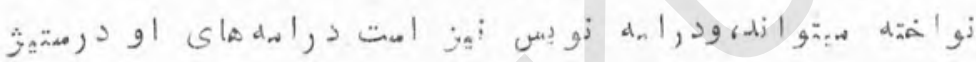

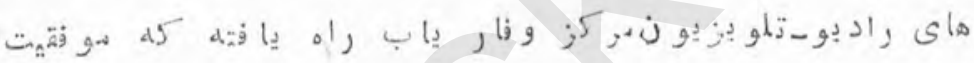

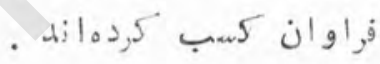

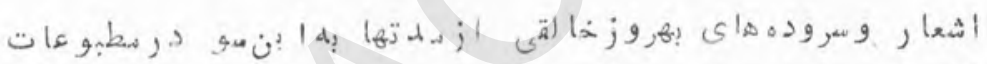

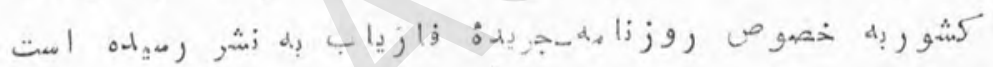

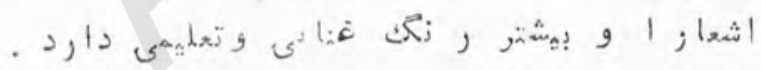

PFP 


\section{درد جلائي

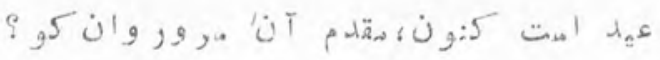

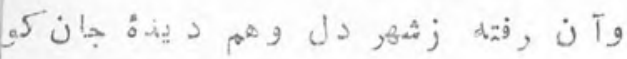

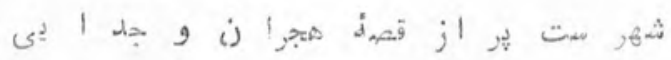

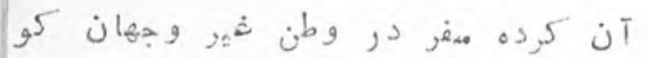

$$
\text { أنا }
$$

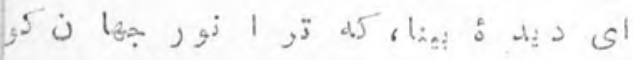

$$
\text { ؟ } 5 \text { ن }
$$

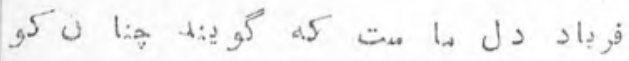

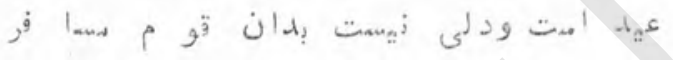

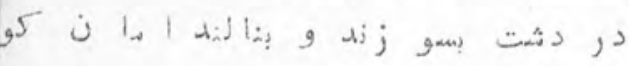

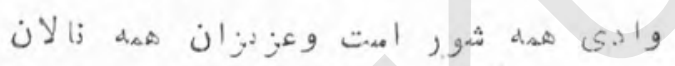

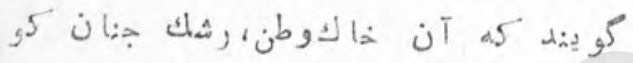

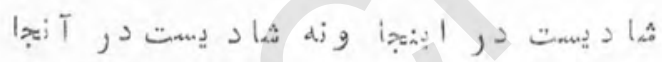

إى

$$
\text { أ5: }
$$

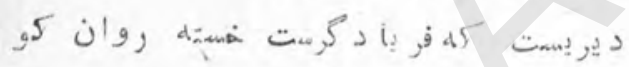

$$
\begin{aligned}
& \text { ت }
\end{aligned}
$$

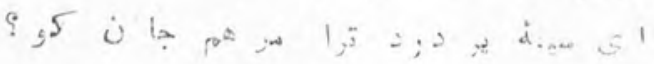

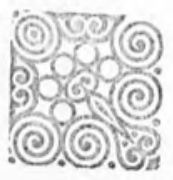

ppp 


\section{Lis}

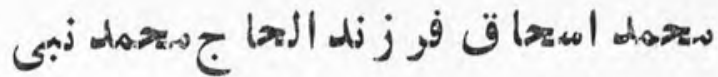

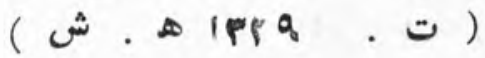

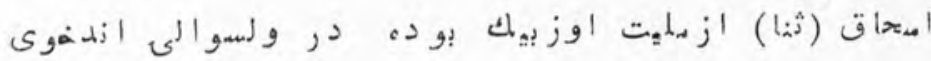

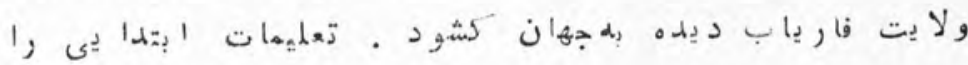

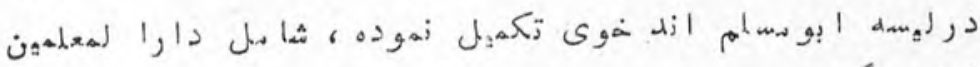

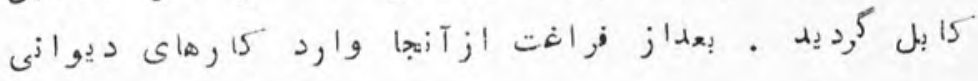

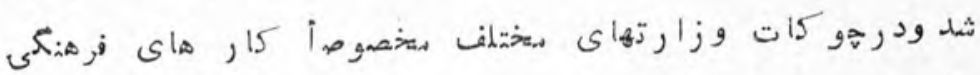

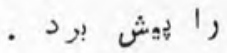

يردا

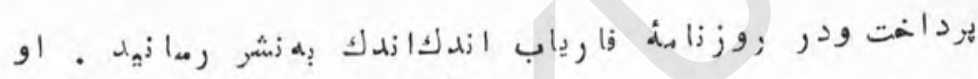

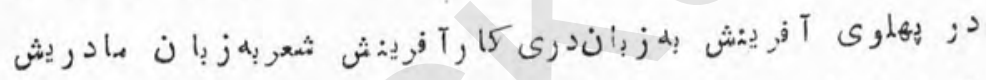

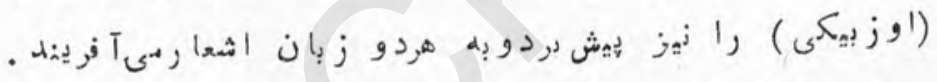

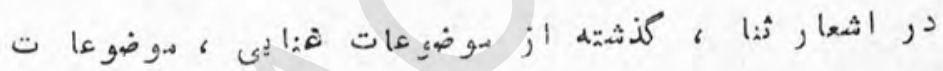

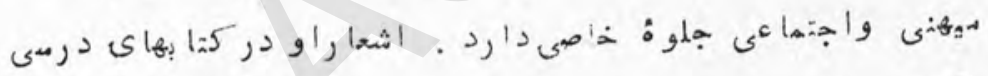

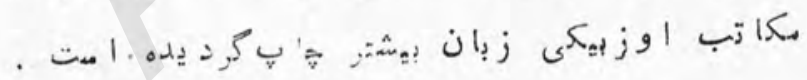

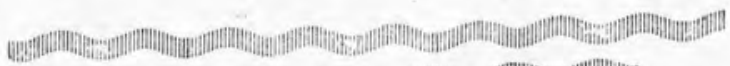

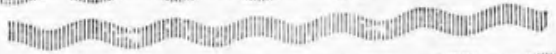
wantwown 
آئينأة صداقت

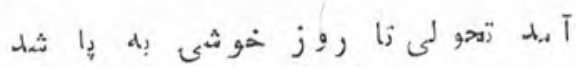

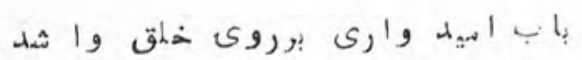

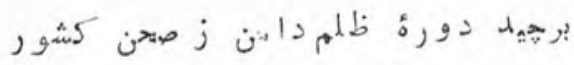

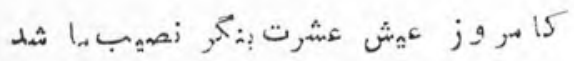

أردوى

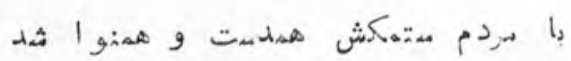

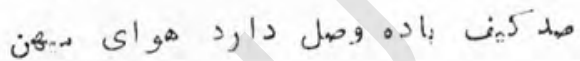

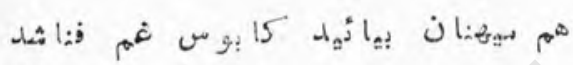

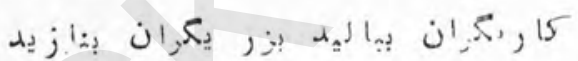

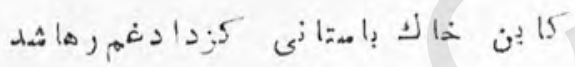

اقب! لخلق كششو رهو نصبهدم طلموع ك, دـ

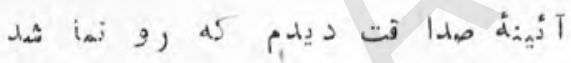

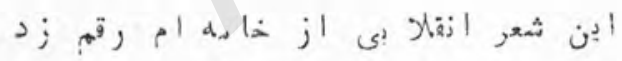

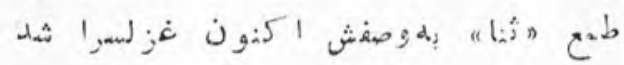

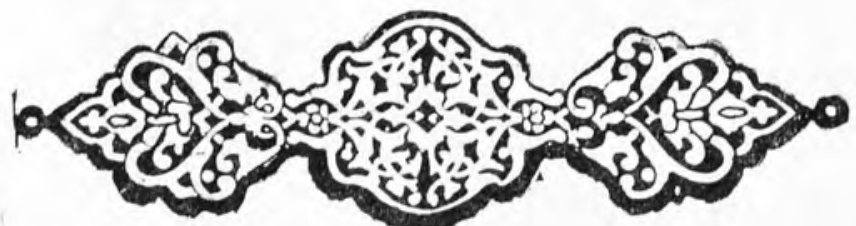

FPO 
slg? dis ji

Aiخ

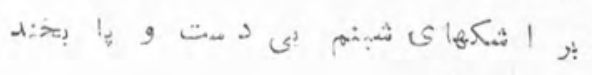

3 2

إى

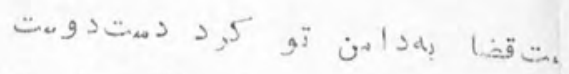

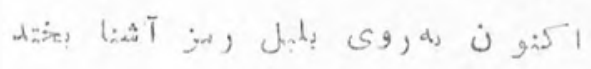

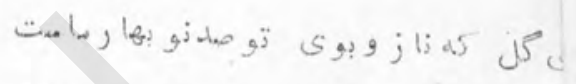

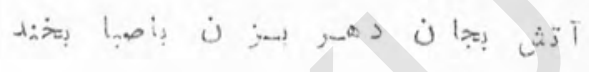

-

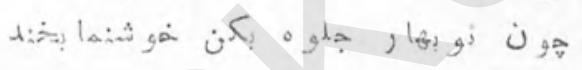

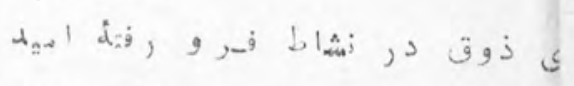

iخ

زان

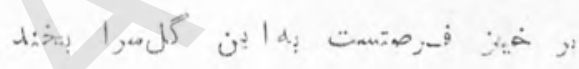

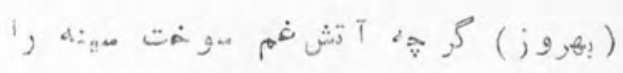

lit 


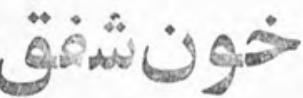

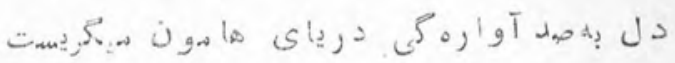

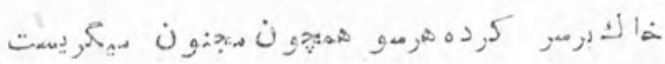

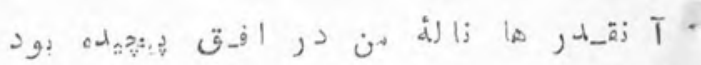

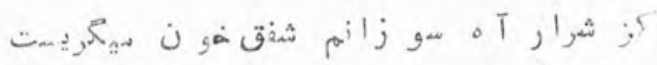

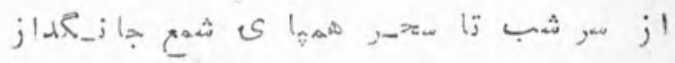

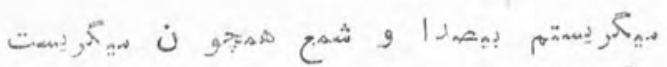

ن

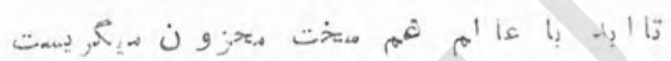

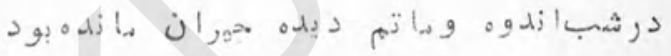

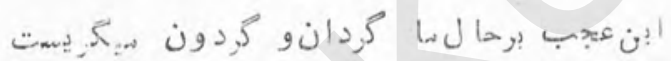

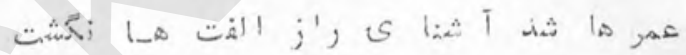

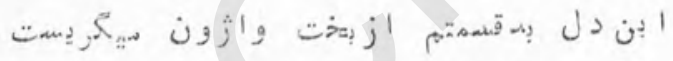

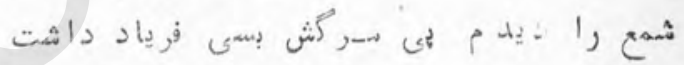

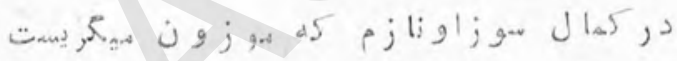

هر

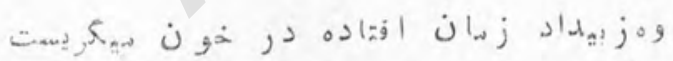

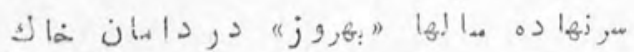

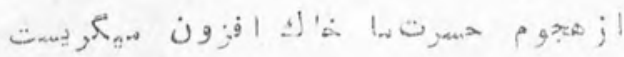

PFV 
ت

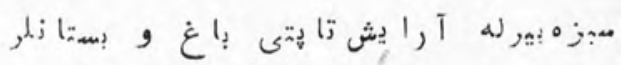

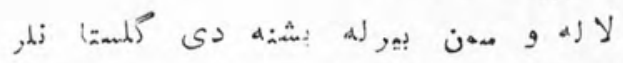

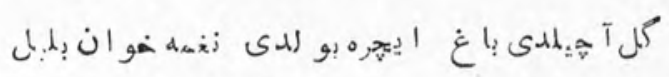

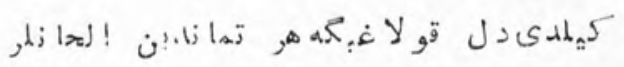

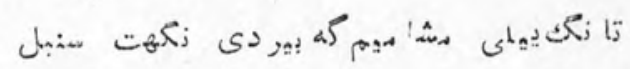

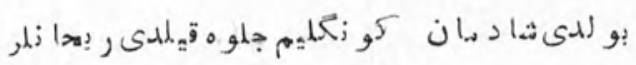

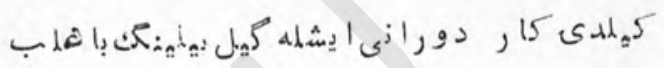

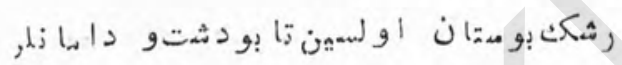

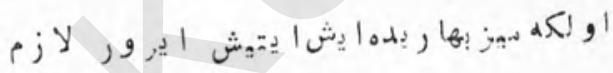

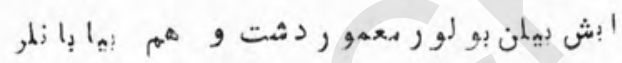

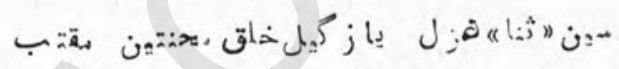

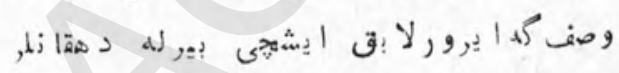

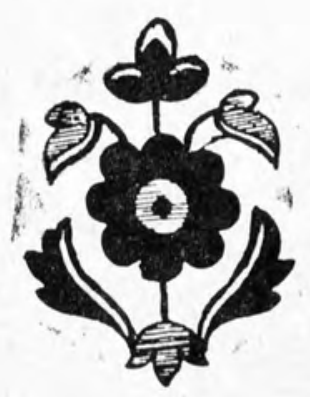

rfa 


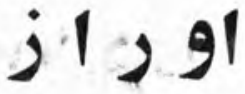

عبد الوحمم او راز فوز ند اورازمتحمد يفر" ت

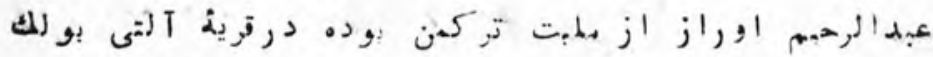

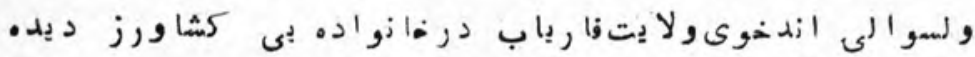

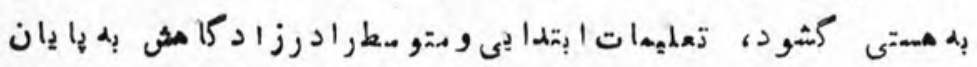

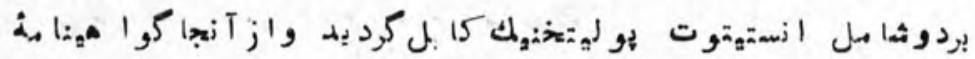

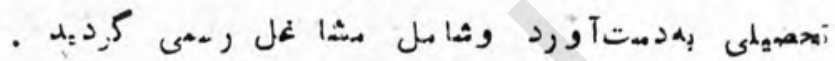

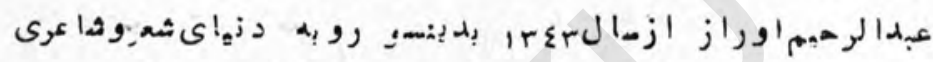

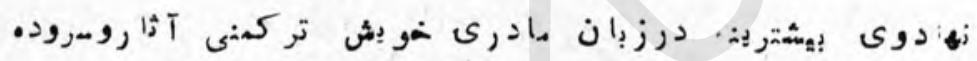

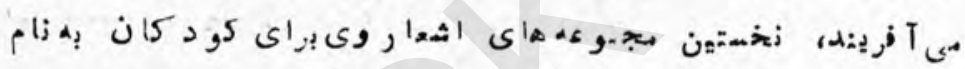

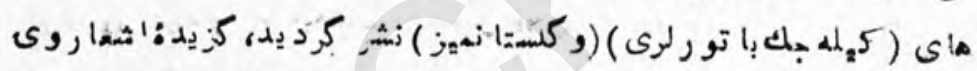

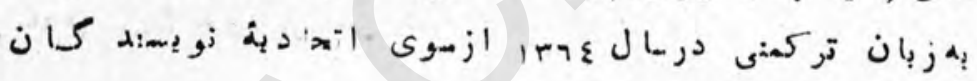

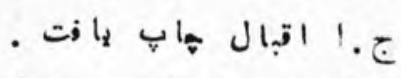

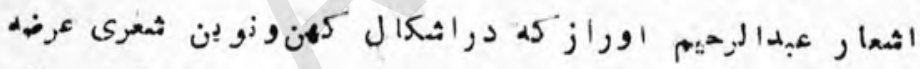

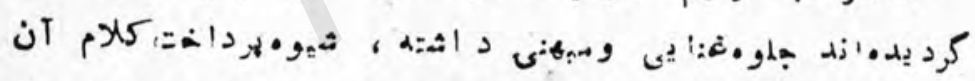

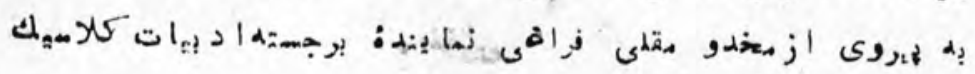

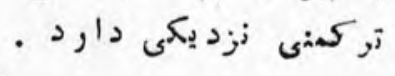

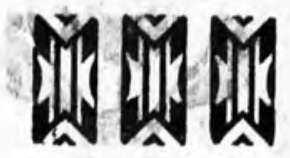




\section{غووىبولسيندور موشيضغك}

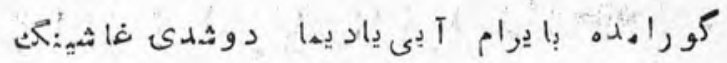

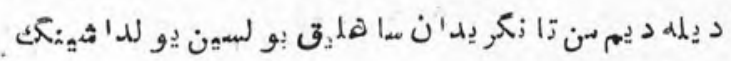

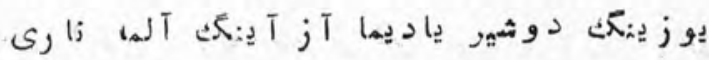

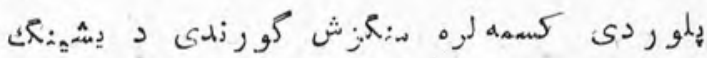

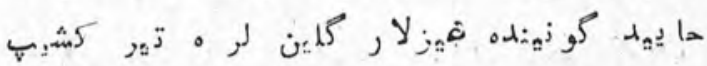
انز

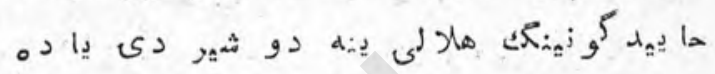

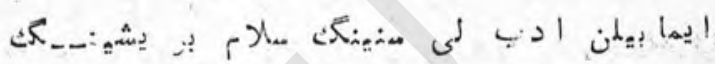

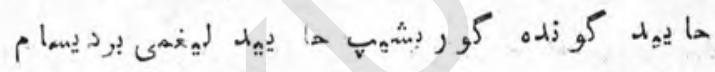

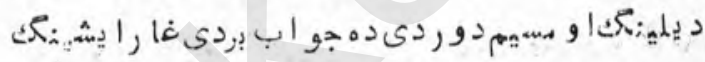

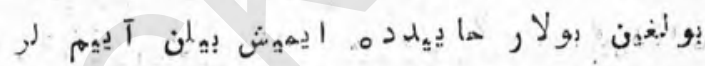

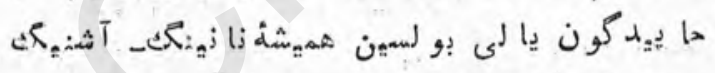

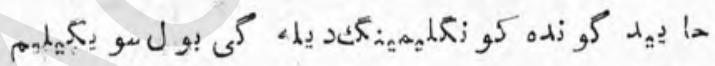

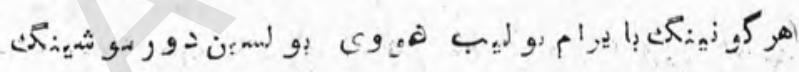

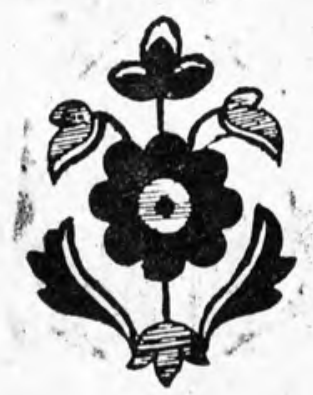




\section{غار ينخك آقجحه دانهلسى}

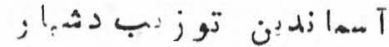

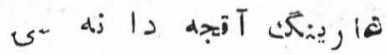

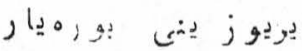

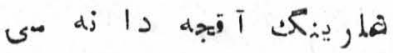

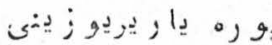

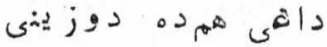

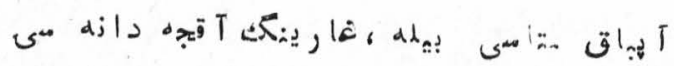

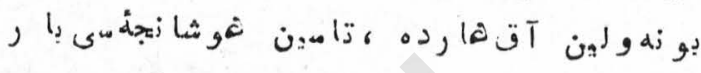

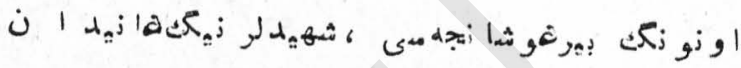

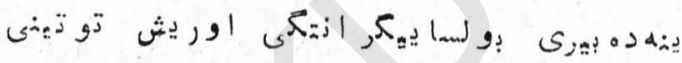

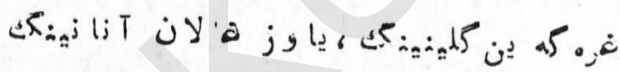

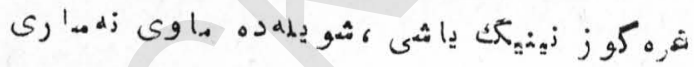

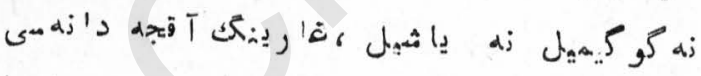

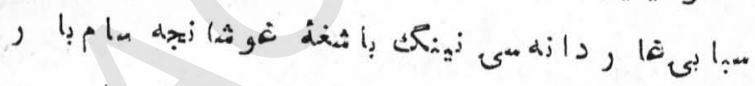

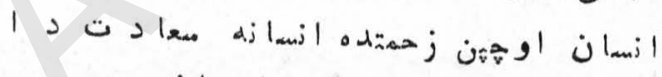

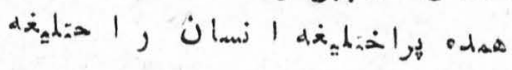

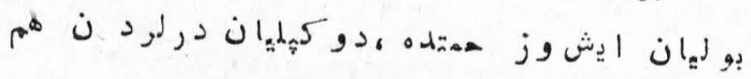

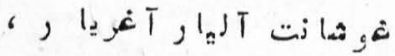

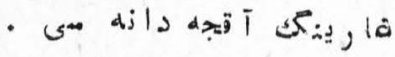

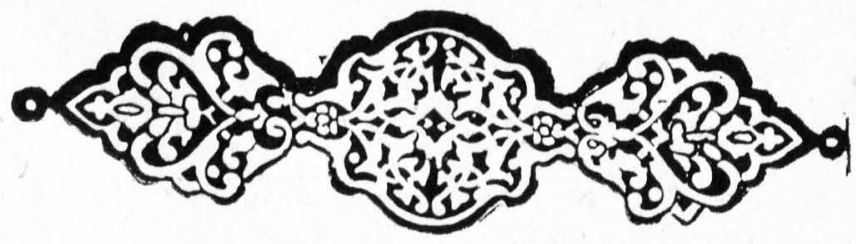




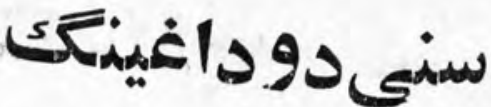

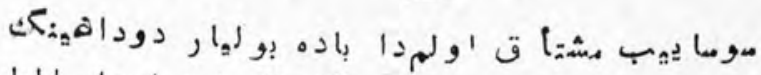

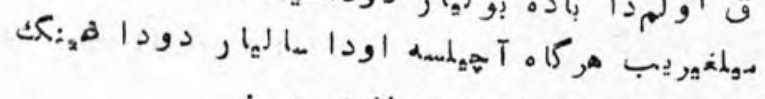

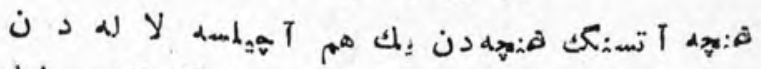

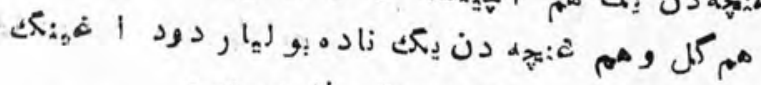

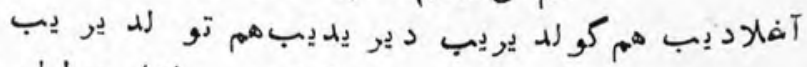

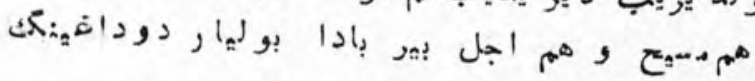

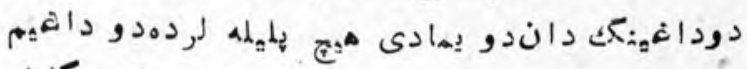

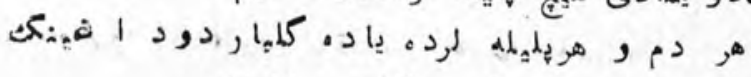

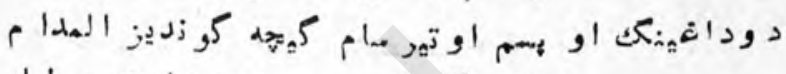

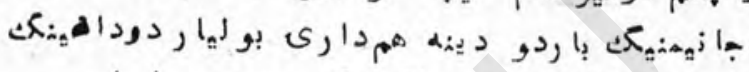

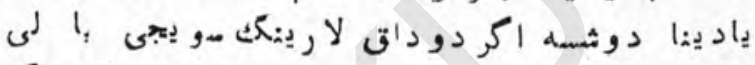

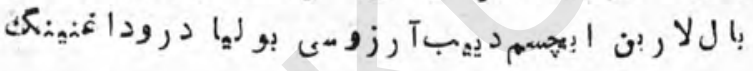

par 
فو و تن

عبد الرحهن فرو تـفوز زله عبد الوز زاق

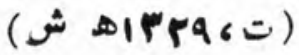

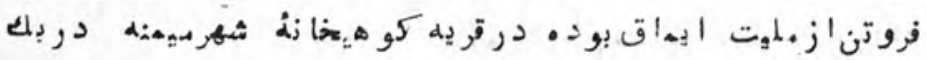

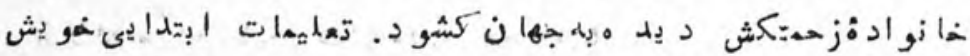

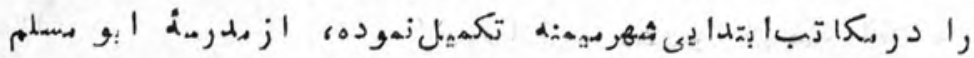

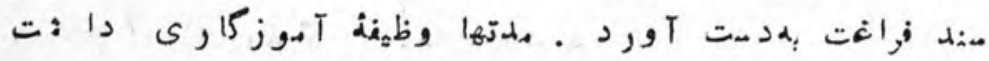

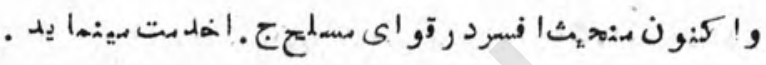

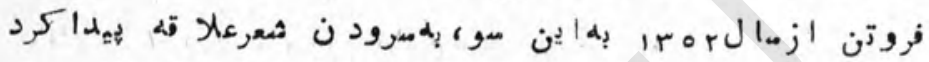

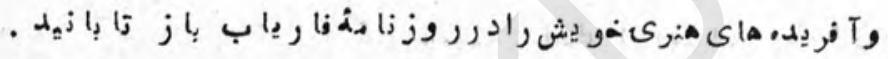

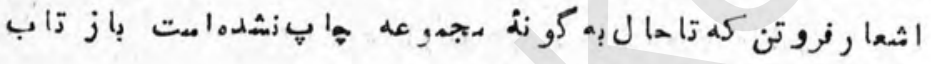

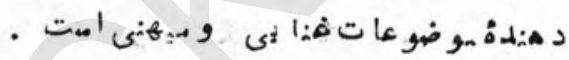

por 


\section{داغ نامر ادى}

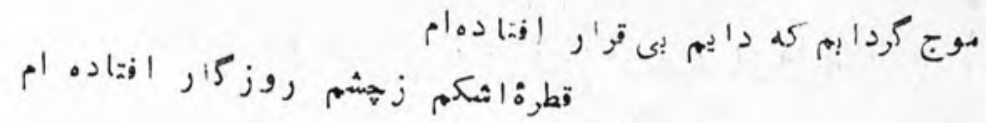

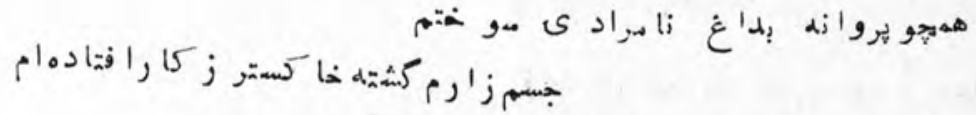

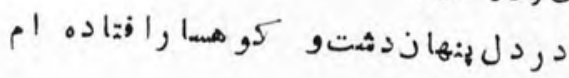

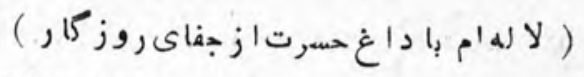

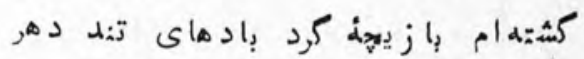

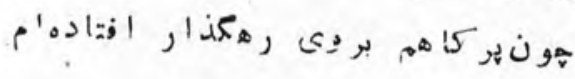

ك

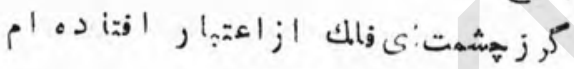
اى" فروتن" ازجفاى هرخ كردون عاقبت

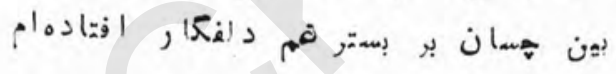

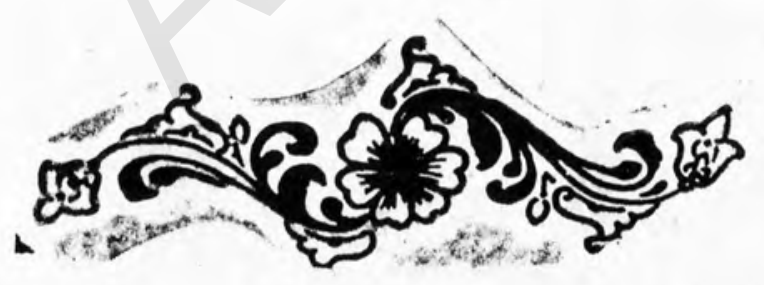


حسرت تنهايى

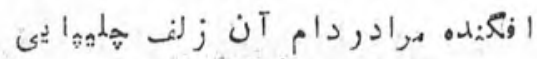

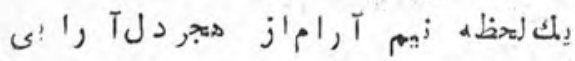

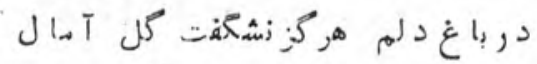

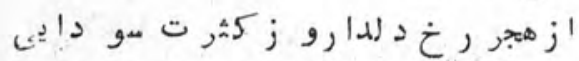

لj

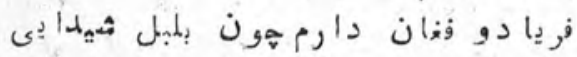

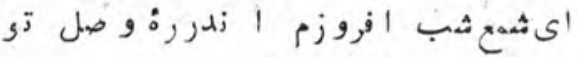

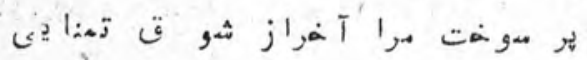

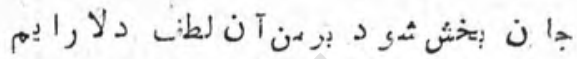

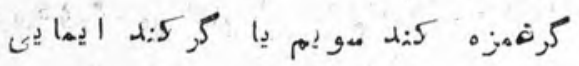

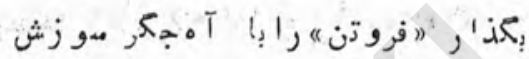

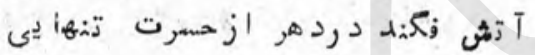

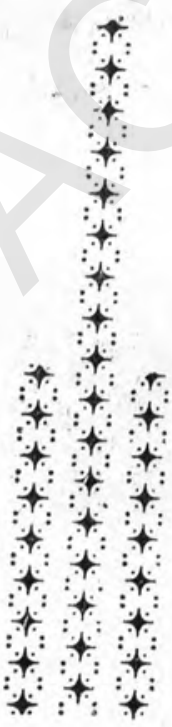

FOD 


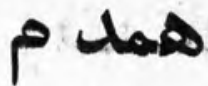

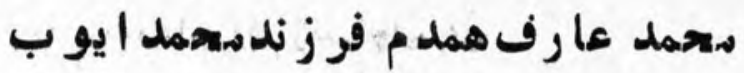

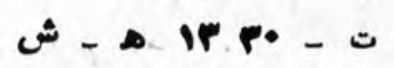

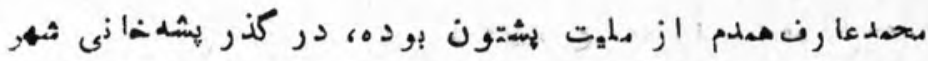

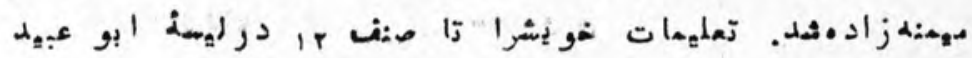

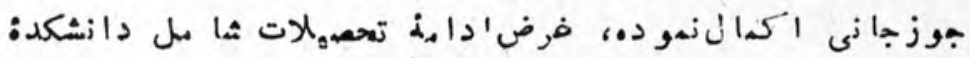

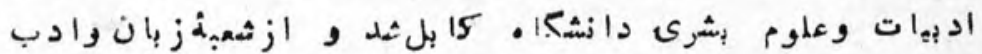

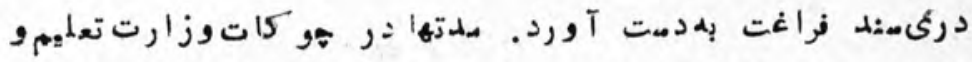

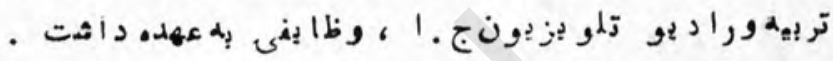

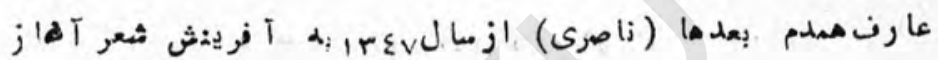

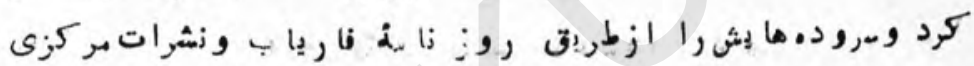

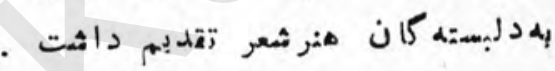

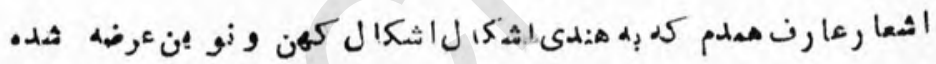

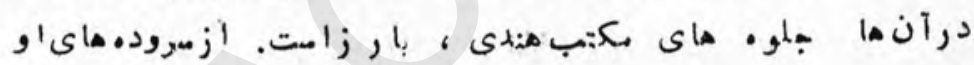

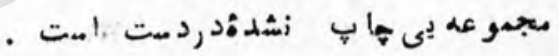

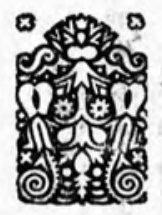


شمع كمرزتح

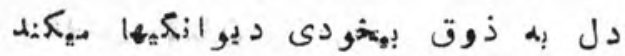

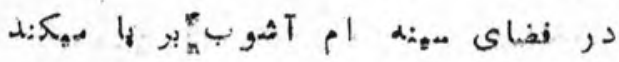

باز كن ما قى كريمان كز ثفنق زارثراب

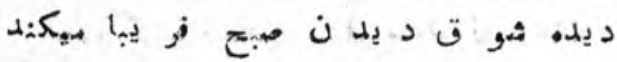

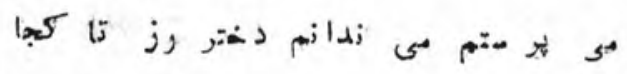

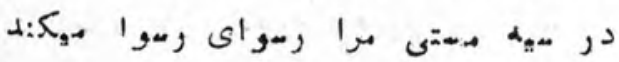

باد.

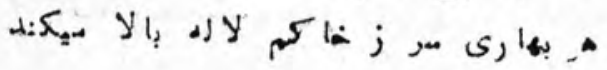

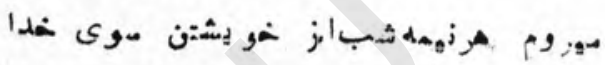

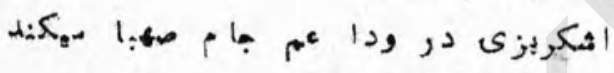

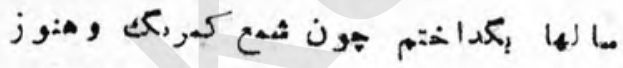

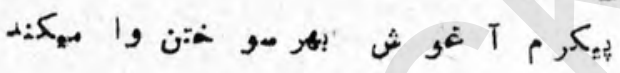

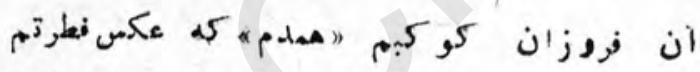

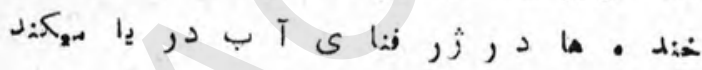

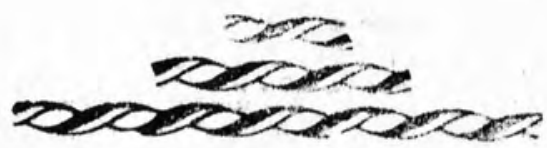

$r \otimes Y$ 


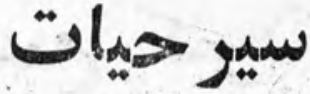

$$
\begin{aligned}
& \text { در شفق داغ طلموع آذ:اب آمهان } \\
& \text { دورتر از ماتم سردفروب كمكشان }
\end{aligned}
$$

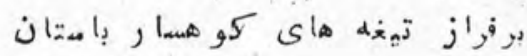

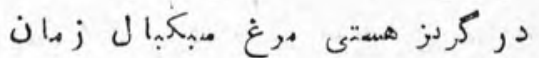

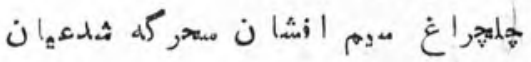

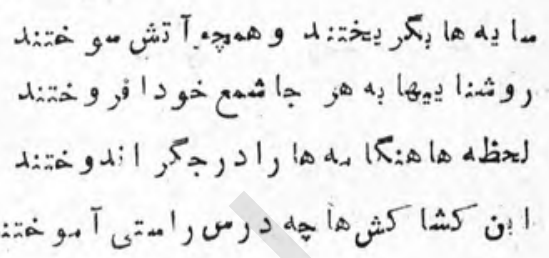

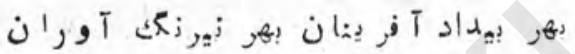

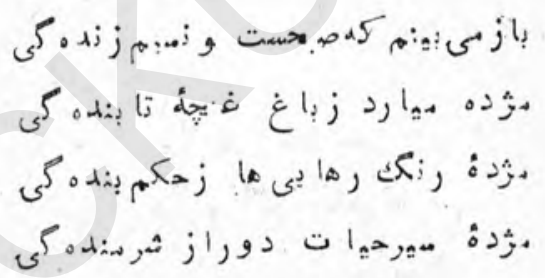

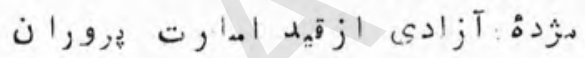

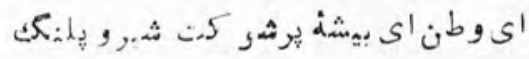

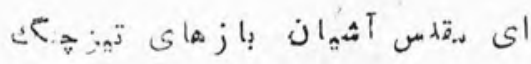

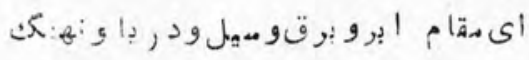

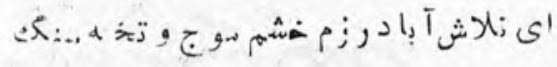

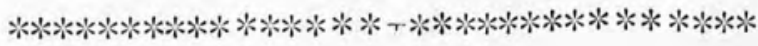


1>سيان مادر

كلكم زشو ق برغ سخ:ندان هادر امت

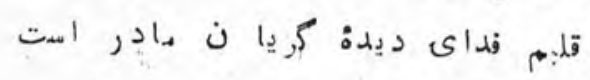

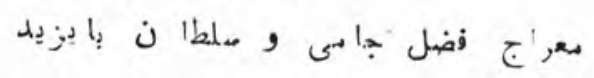

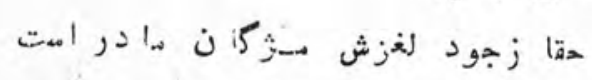

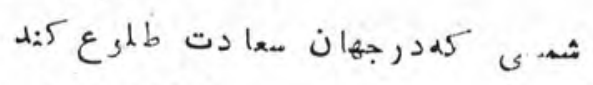

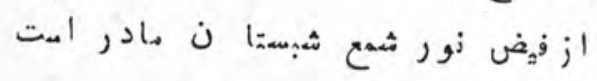

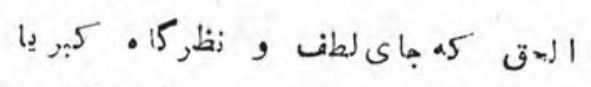

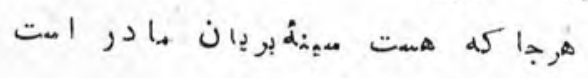

كاوس و, ك,قباد وفلاطون و, بوعلى

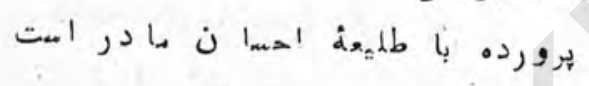

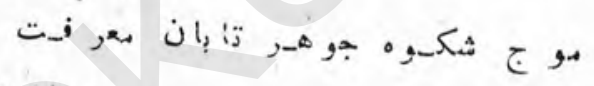

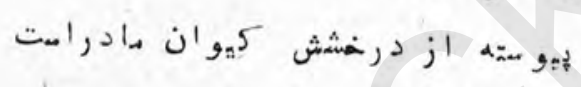

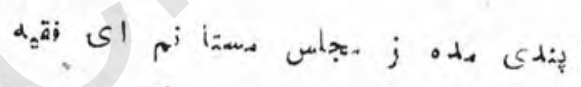

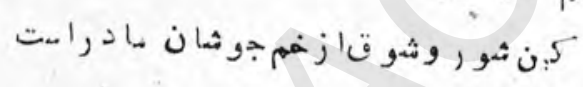

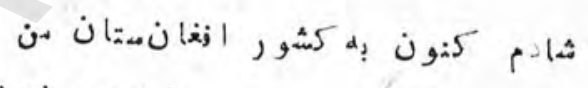

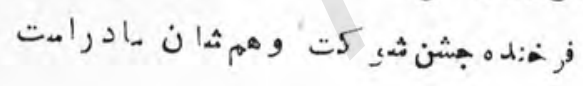

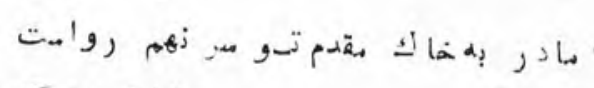

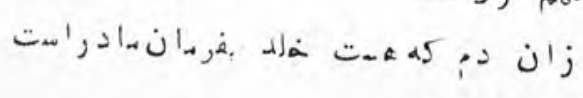

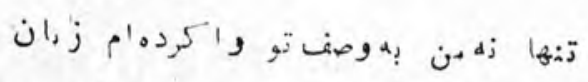

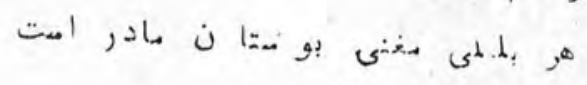

$$
\text { هزدور بى فروش فروزى اكر شوت }
$$




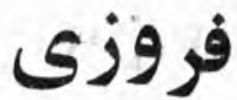

سيد نبى السهوروزى فوز ز زله مديد اما ن الله

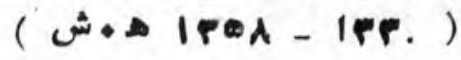

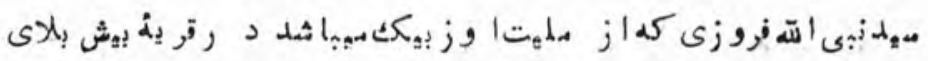

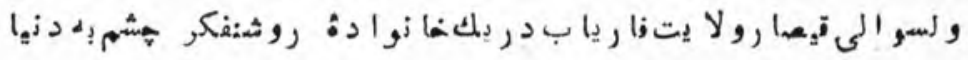

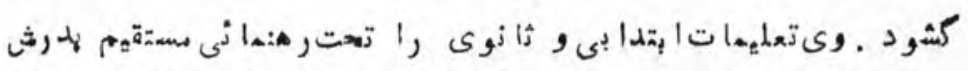

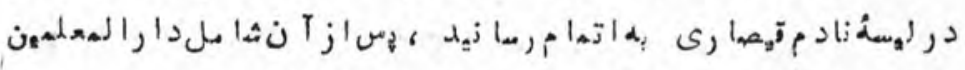

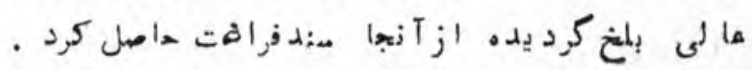

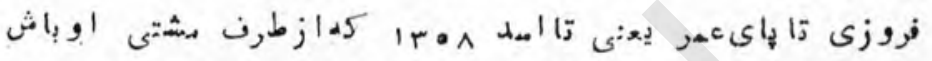

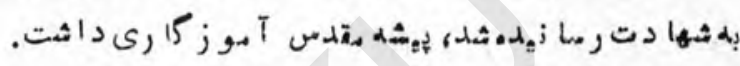

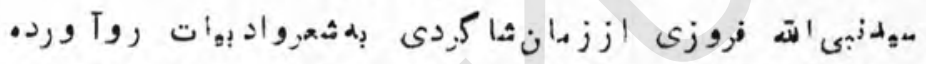

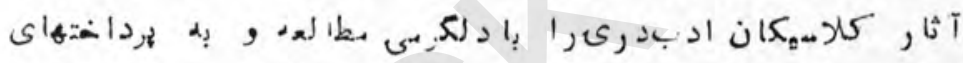

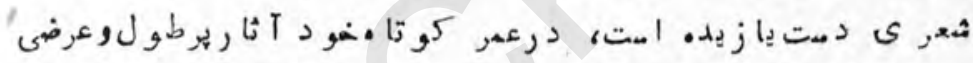

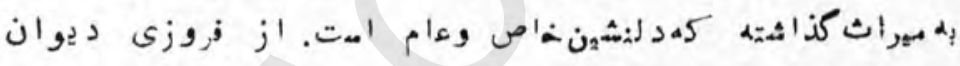

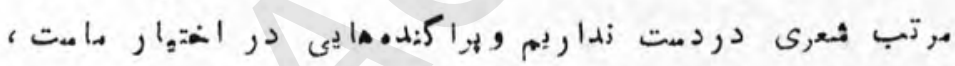

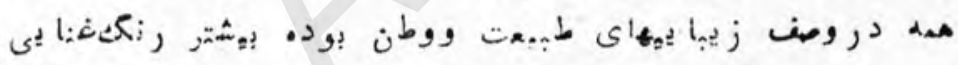

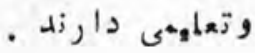

$r \cdot$ 


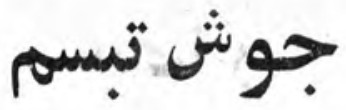

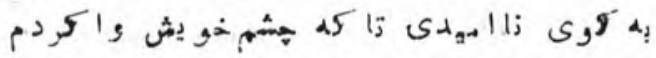

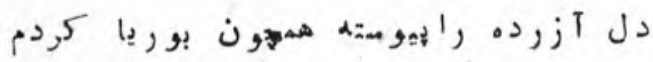

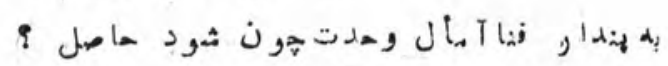

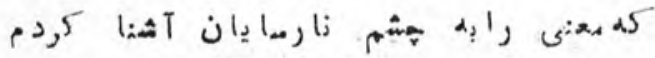

$$
\text { ز جوش يك تبسم لهد. }
$$

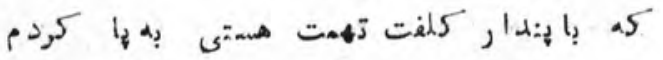

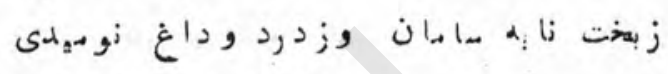

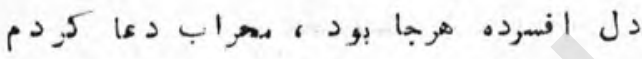

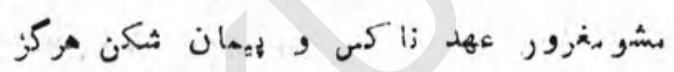

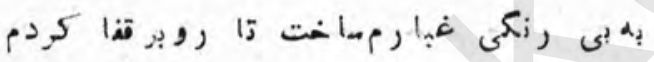

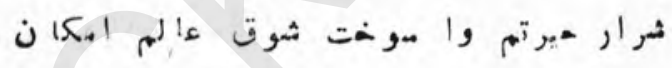

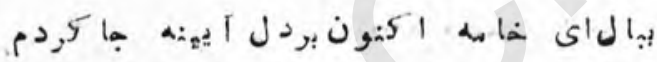

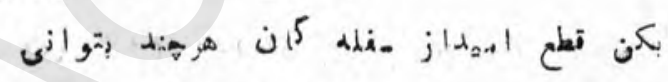

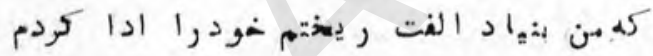

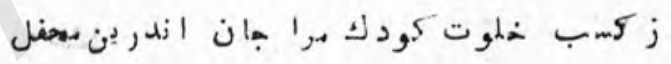

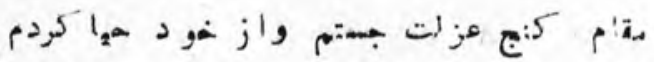

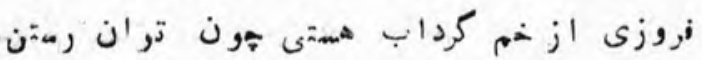

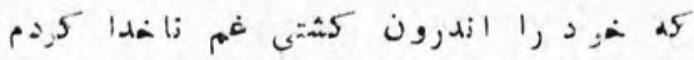

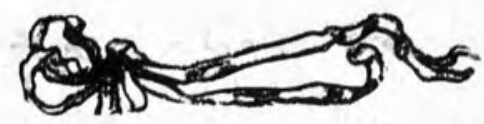


قيصا ر

خو ثما قيصا رو زتصل جا نفزا و يا سمن زارش

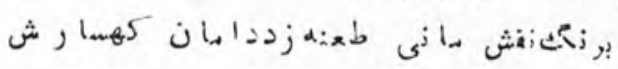

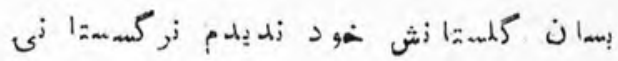

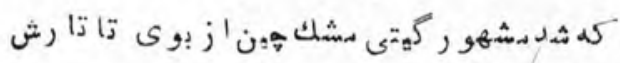

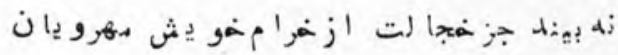

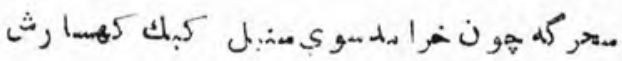

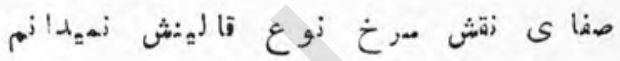

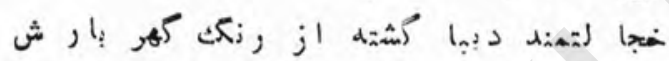

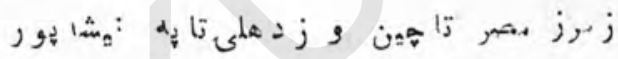

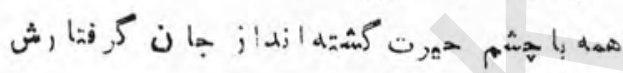

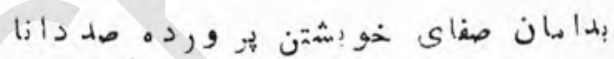

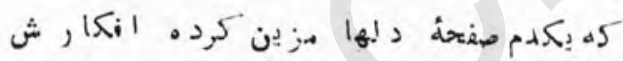

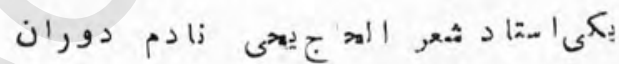

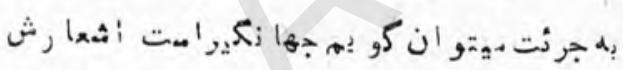

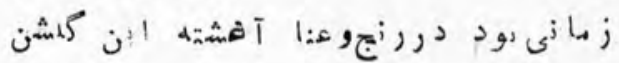

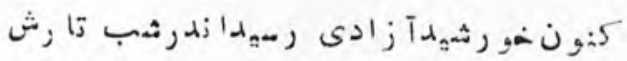

تاليل

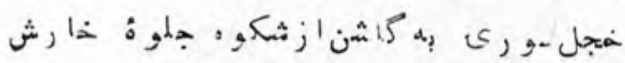

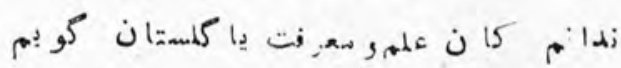

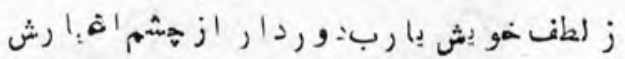

1

ris 


\section{وفا}

\section{متحمل اسلم وفافر ز زله متحمل افضل}

$$
\text { ( ش) 1ron-1rrq) }
$$

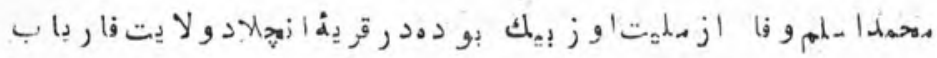

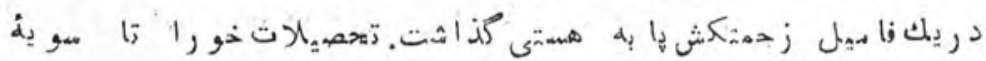

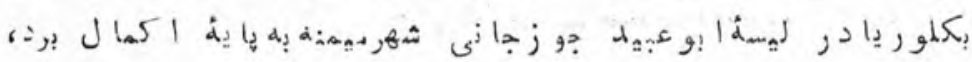

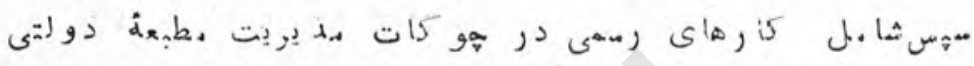

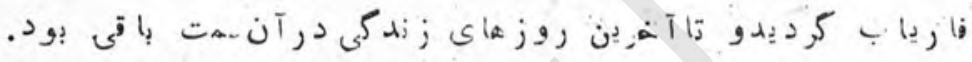

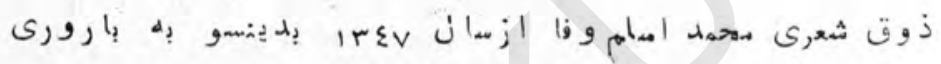
;

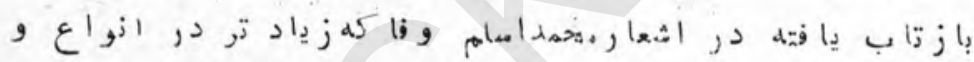

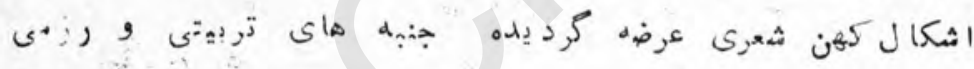

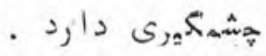

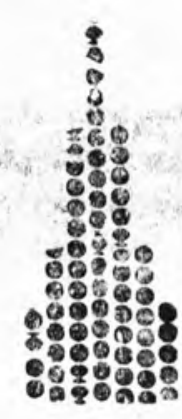




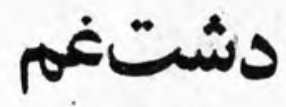

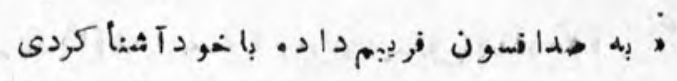

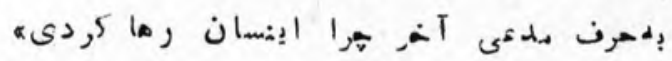

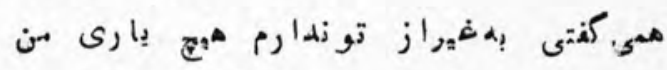

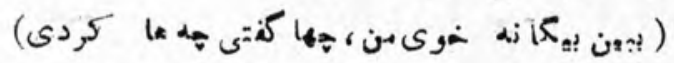

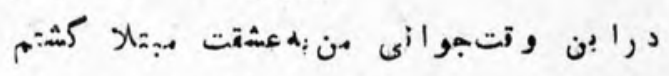

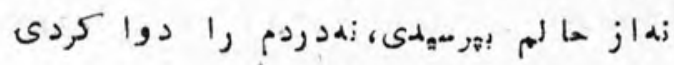

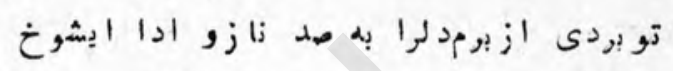

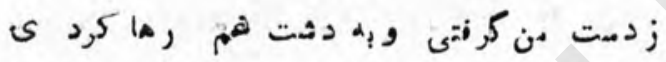

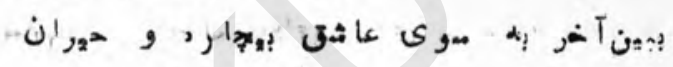

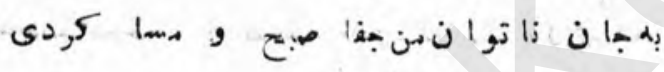

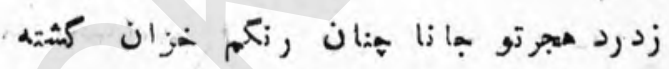

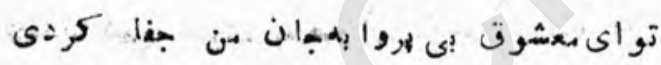

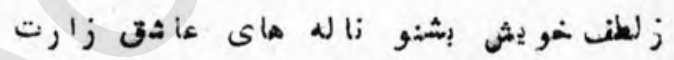

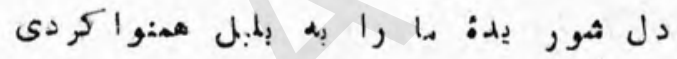

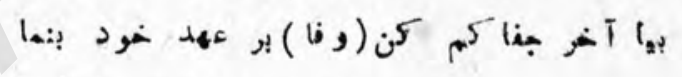

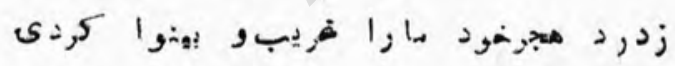

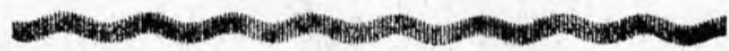

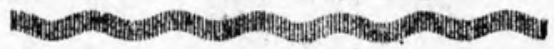

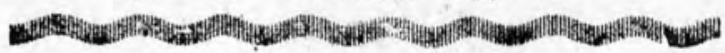


طرؤشيكين

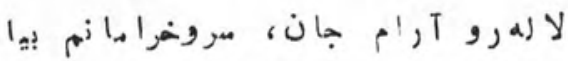

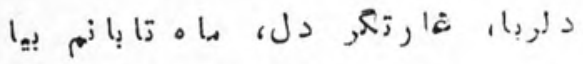

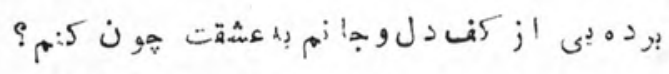

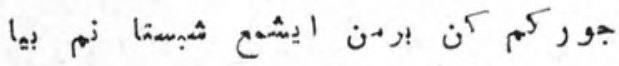

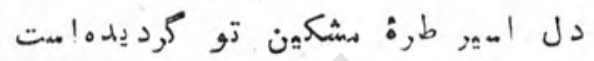

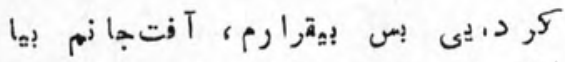

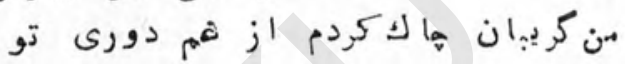

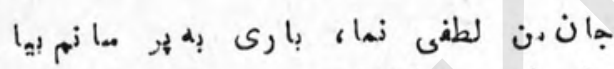

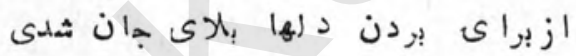

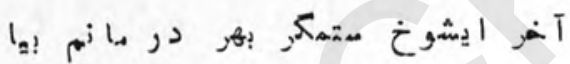

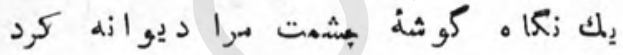

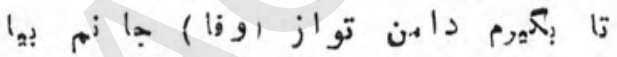




\section{شا يق وصال

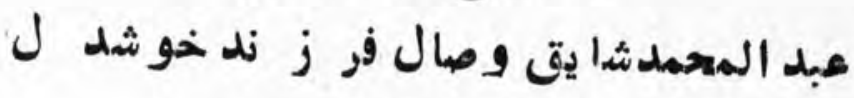

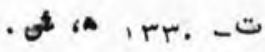

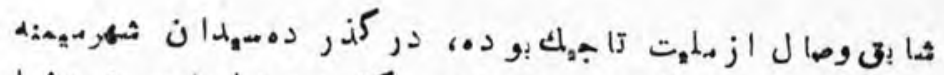

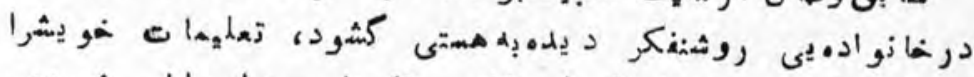

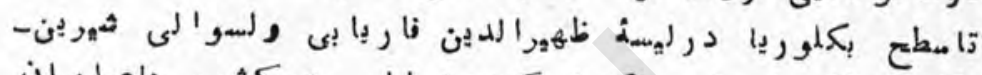

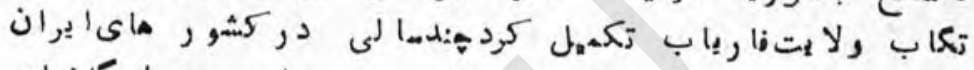

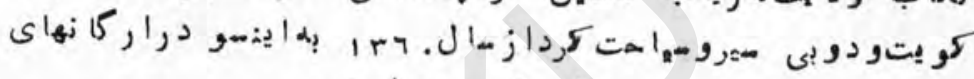

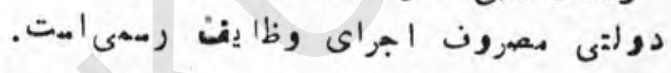

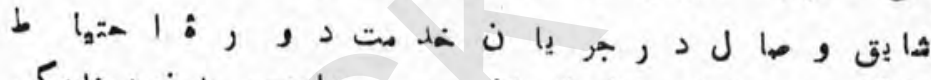

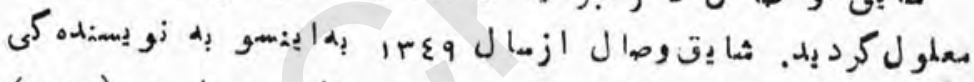

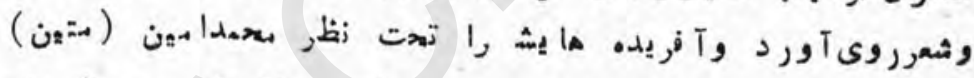

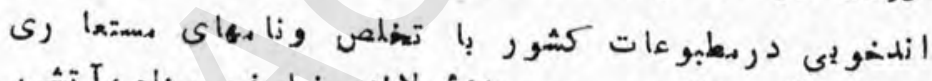

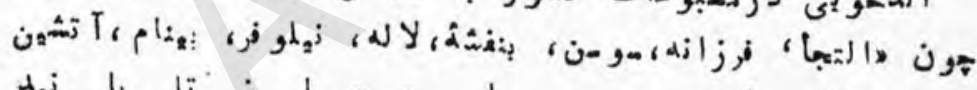

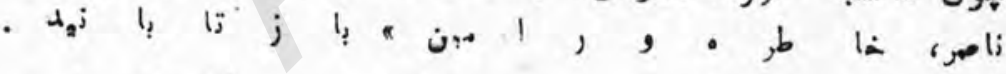

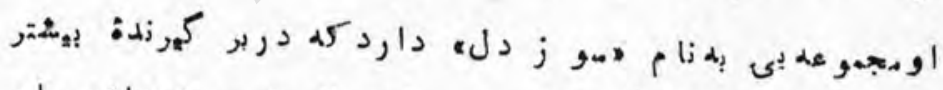

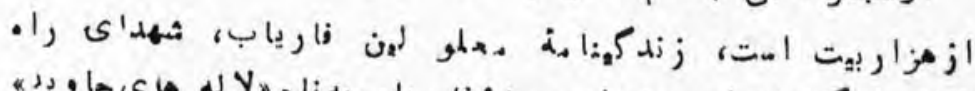

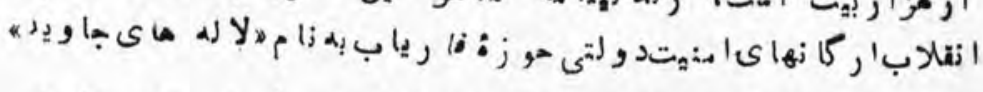

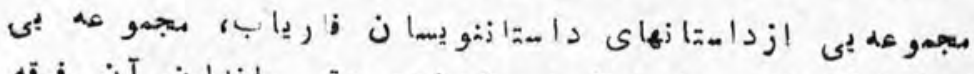

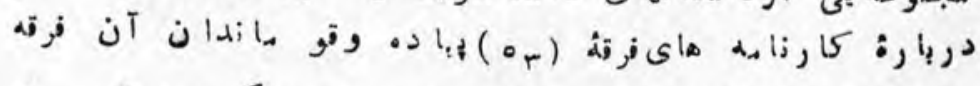

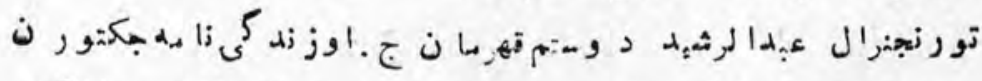

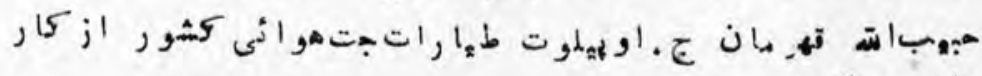

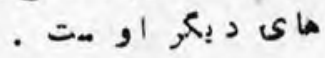

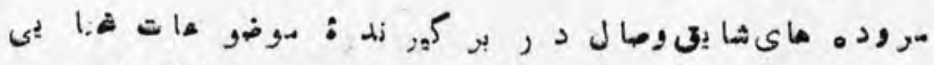

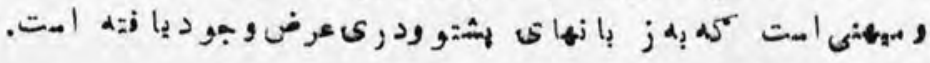




\section{جلوهُ حق تر}

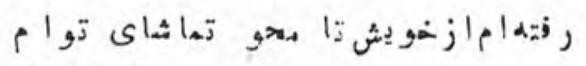

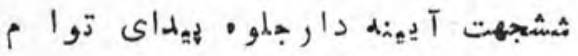

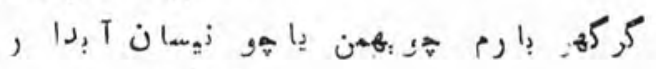

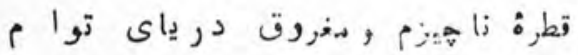

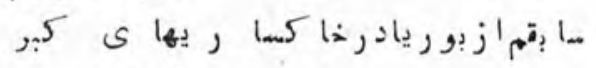

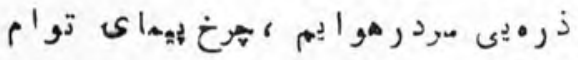

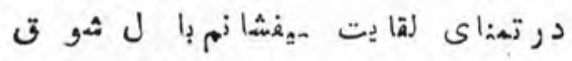

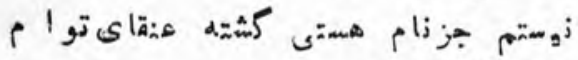

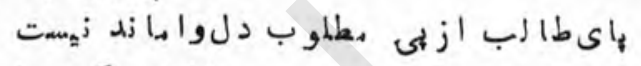

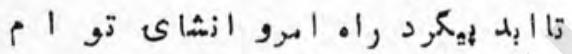

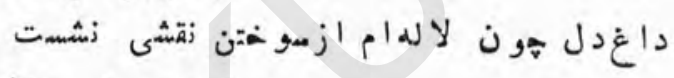

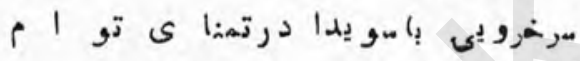

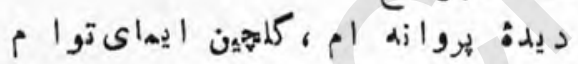

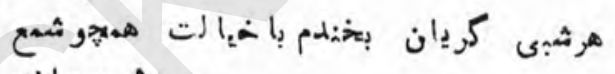

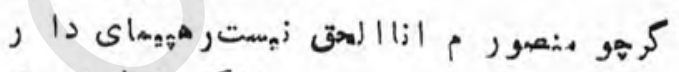

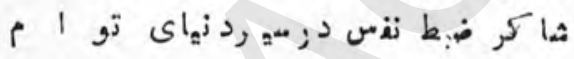

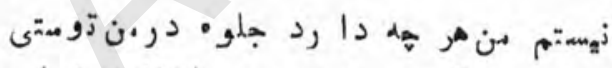

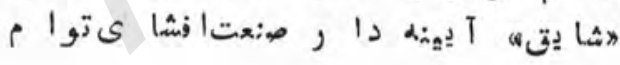

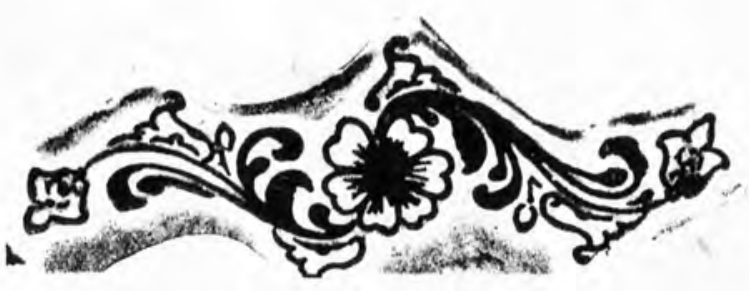




\section{أفسازئحنا}

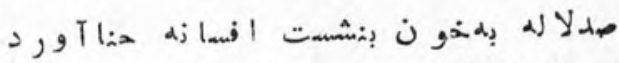

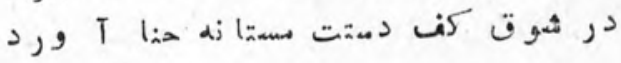

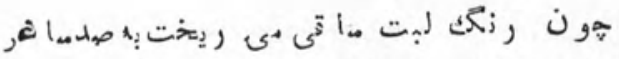

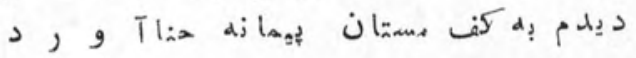

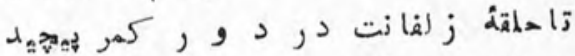

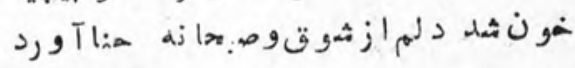

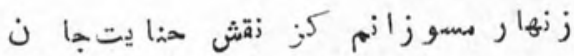

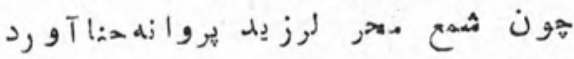

$$
\begin{aligned}
& \text { دوثينه هيه جاده }
\end{aligned}
$$

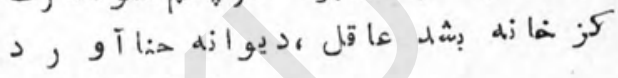

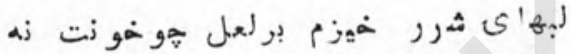

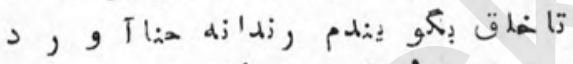

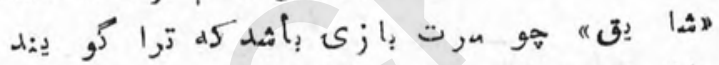

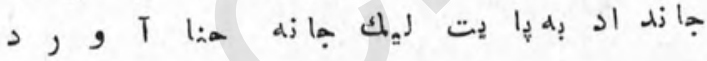

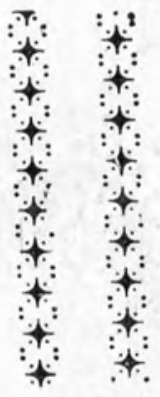


نزتخر هار تله

ز

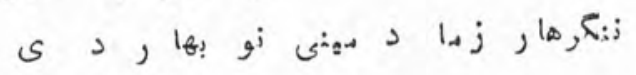

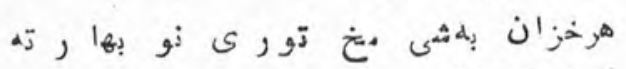

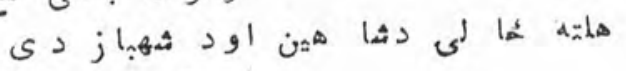

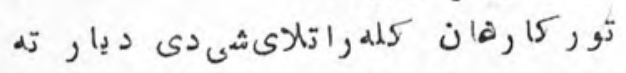

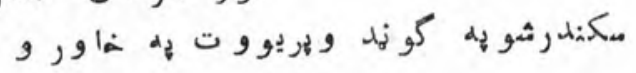

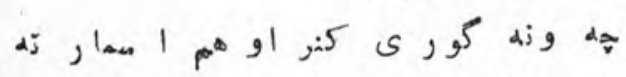

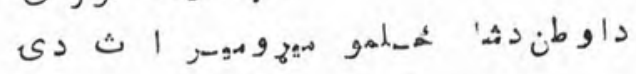

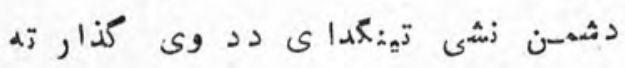

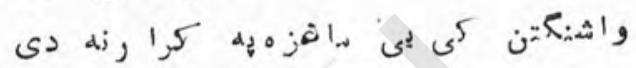

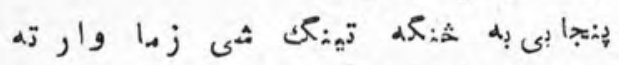

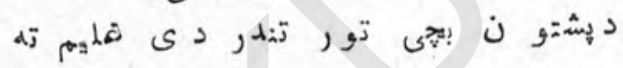

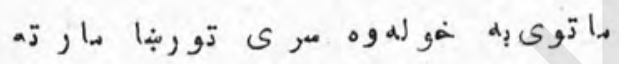

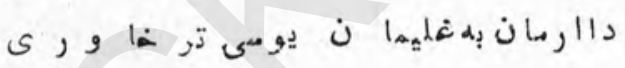

له

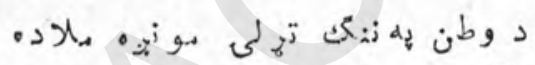

جأه

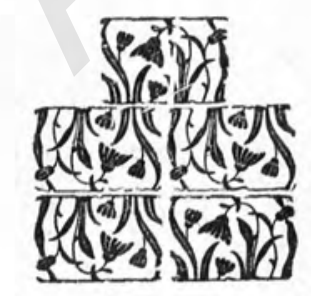

r) 
مخهس برغزل استا د خليل الههخيملى

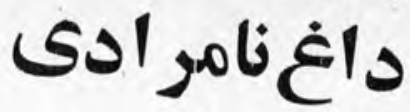

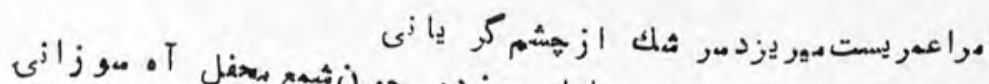

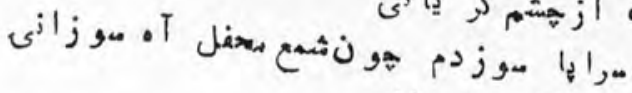

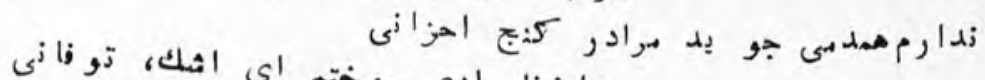

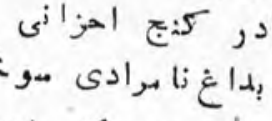

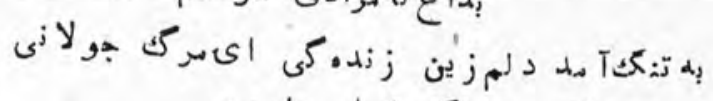

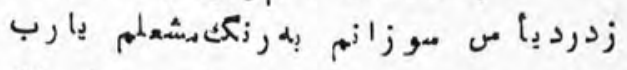

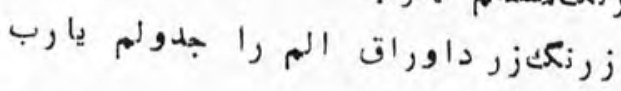

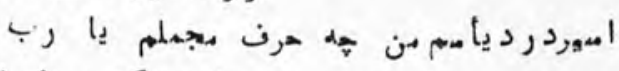

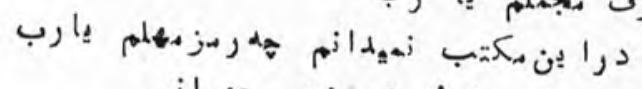

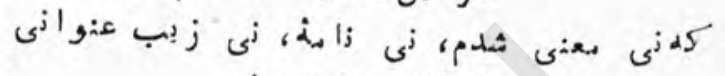

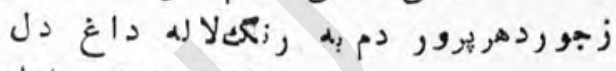

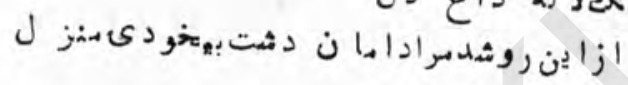

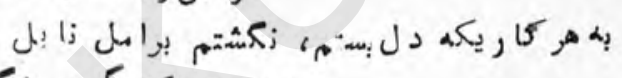

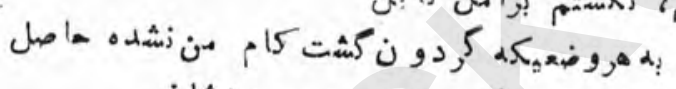

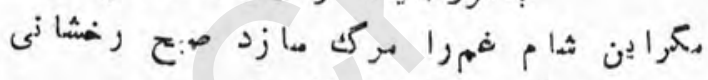

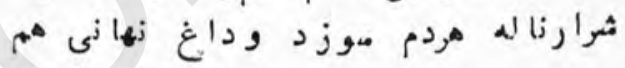

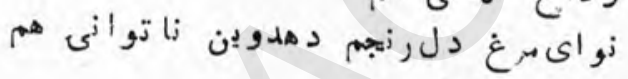

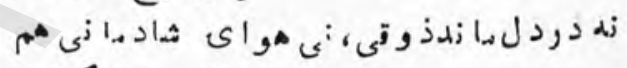

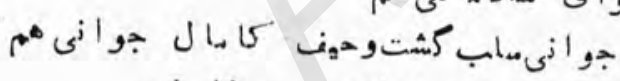

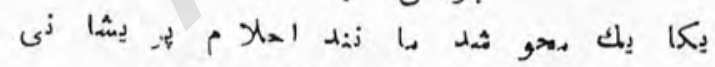

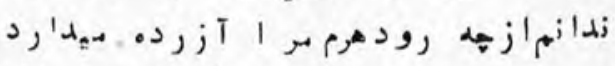

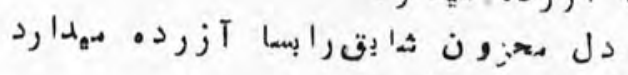

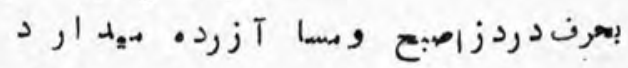

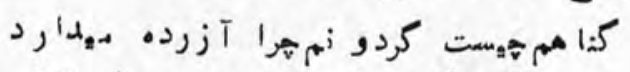

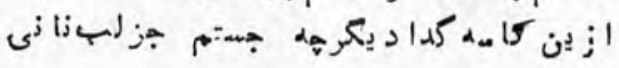

rv. 


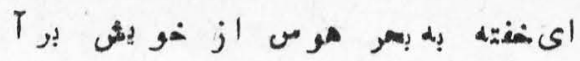

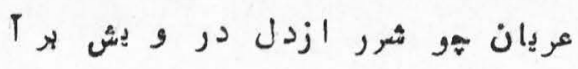

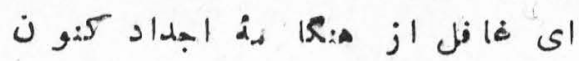

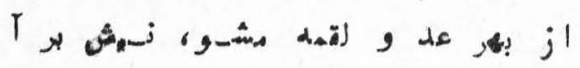

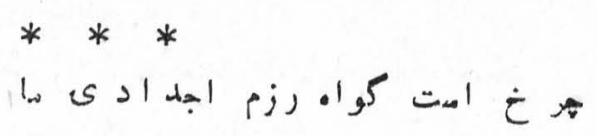

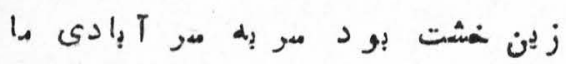

اي دئن نادان ههز نى لان وكزان

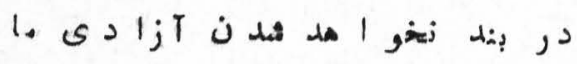

* * *

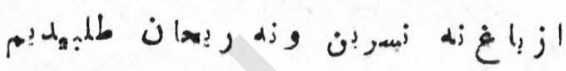

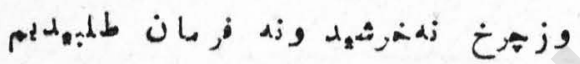

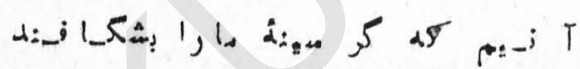

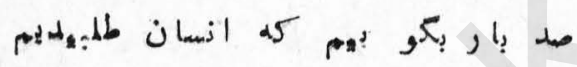

* *

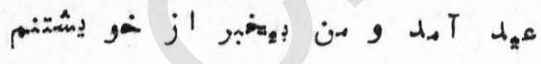

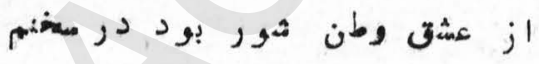

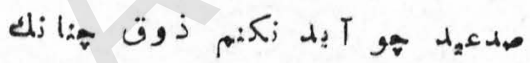

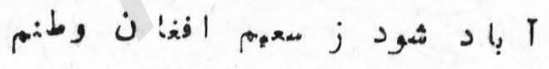

$r r 1$ 


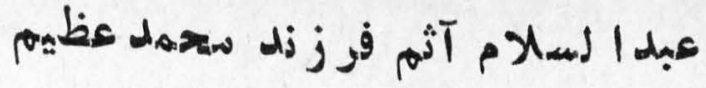

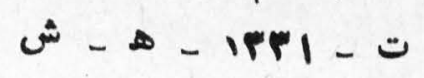

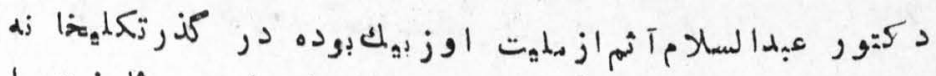

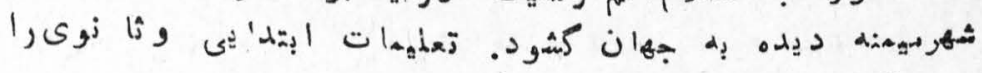

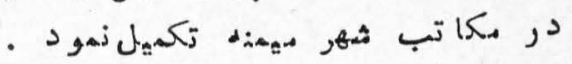

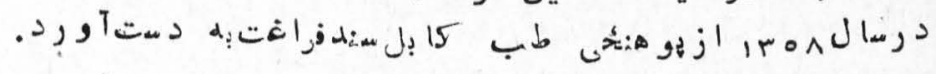

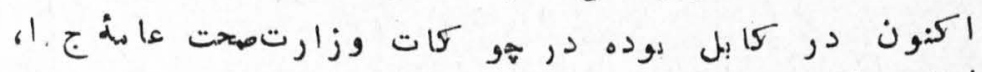

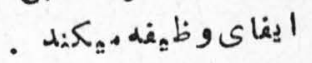

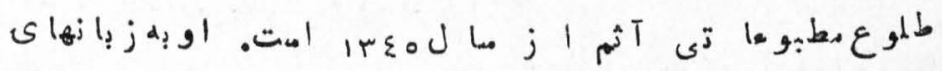

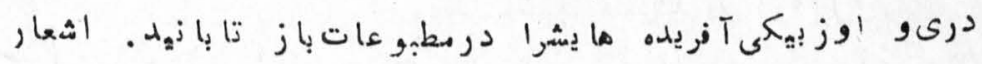

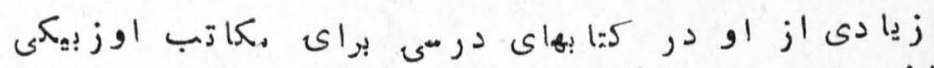

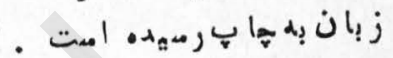

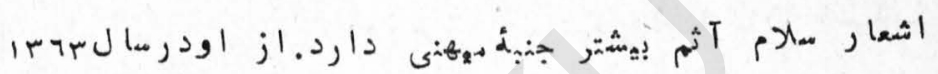

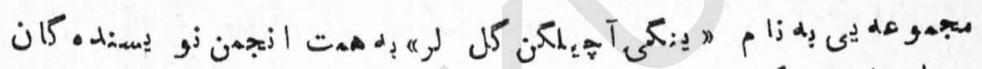
ج

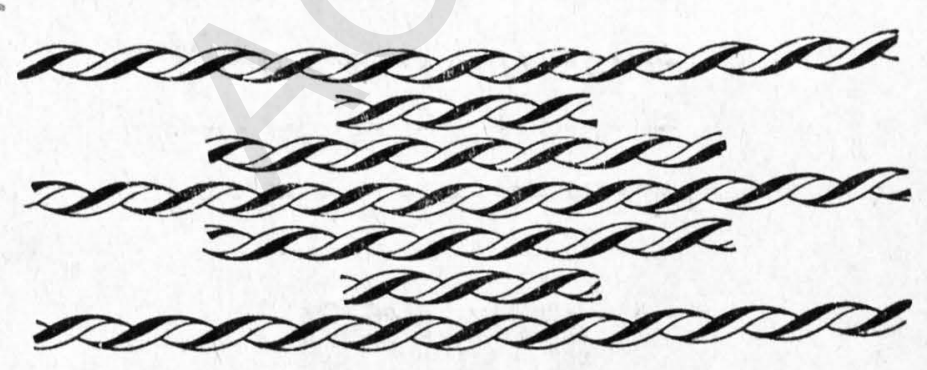

Prr 


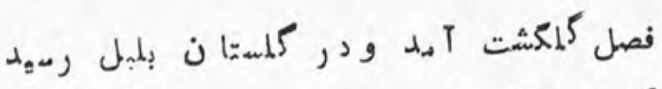

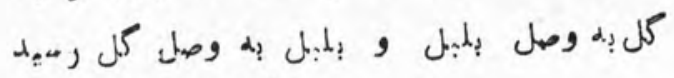

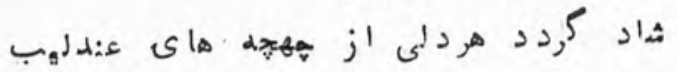

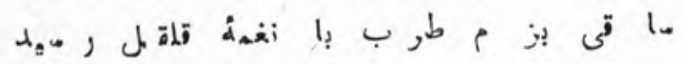

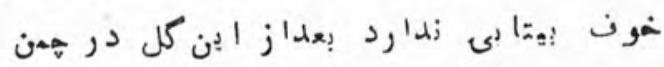

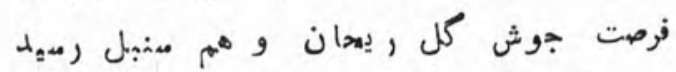

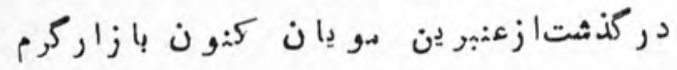

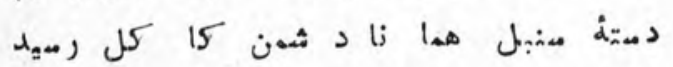

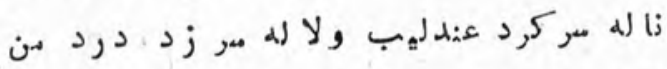

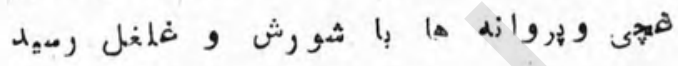

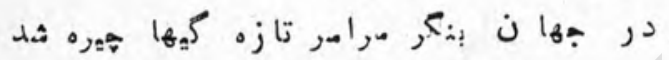

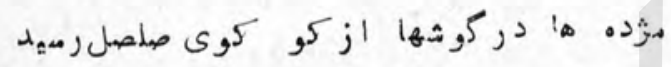

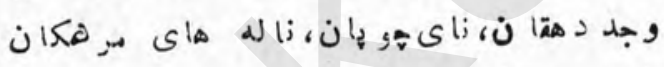

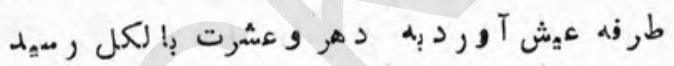

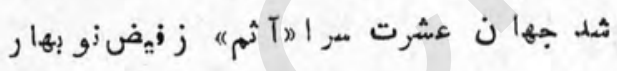

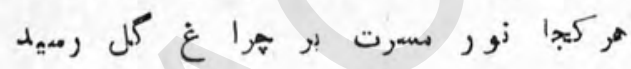

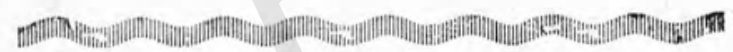

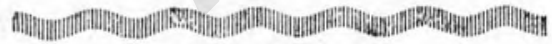

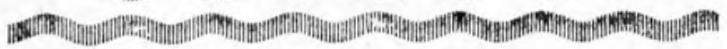

\section{pVP}




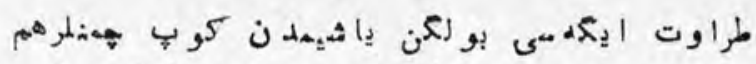

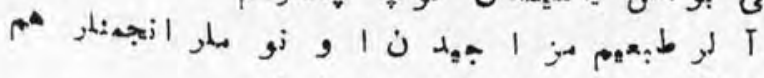

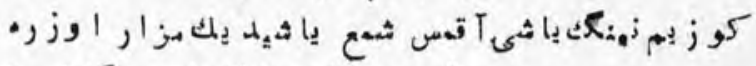

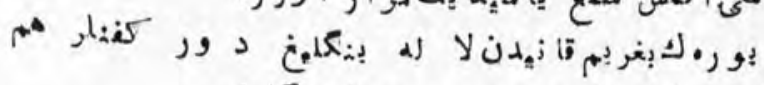

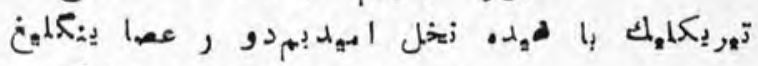

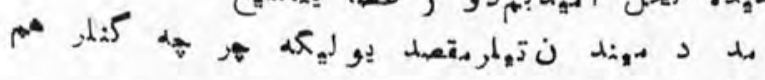

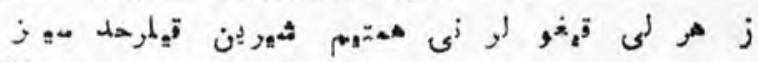

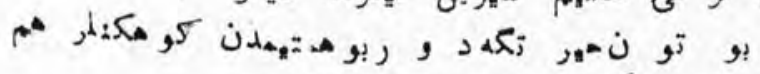

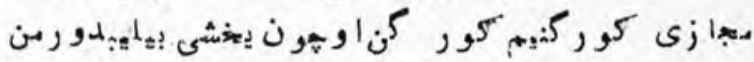

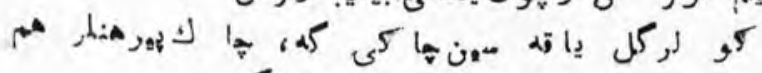

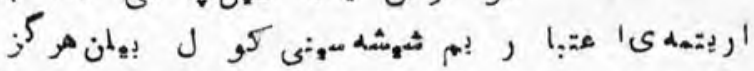

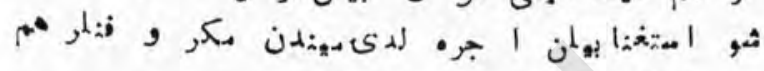

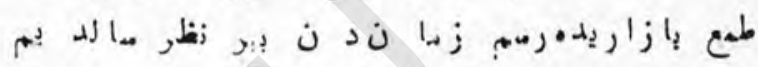

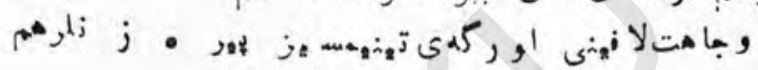

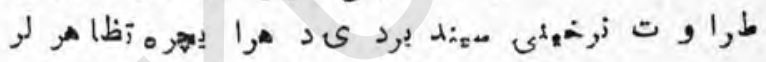

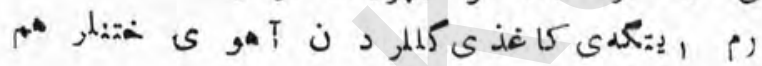

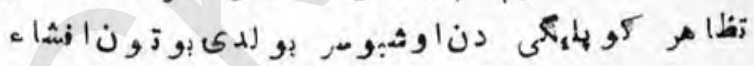

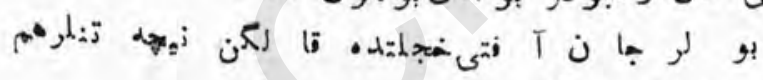

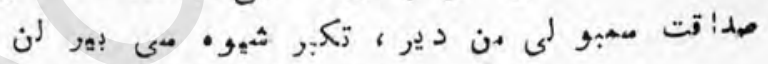

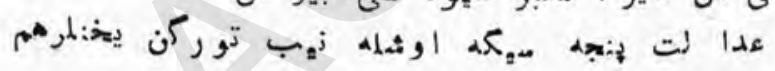

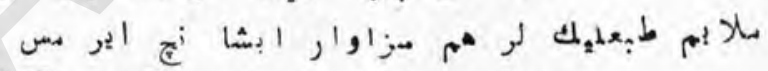

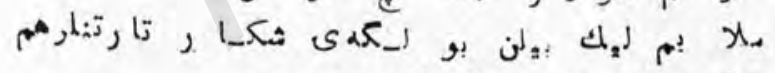

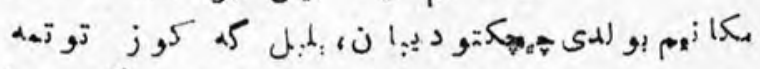

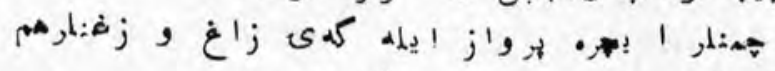

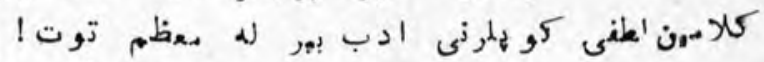

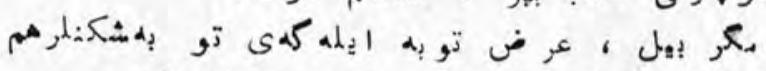

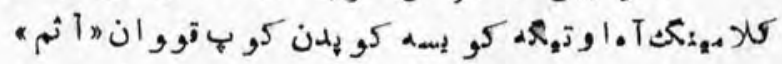

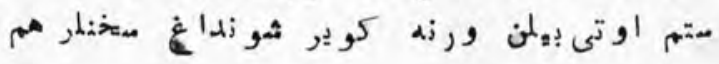

pre 
عطيف

سيد ديحمد كا ظمم عطيف فوز ز ند سيد ديحمد عثما ن

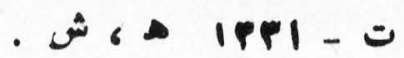

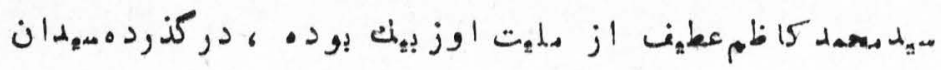

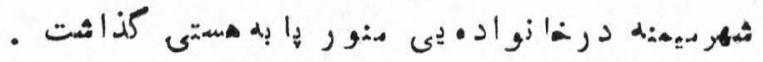

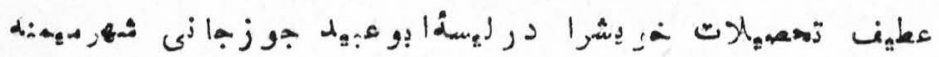

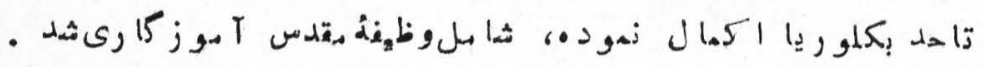

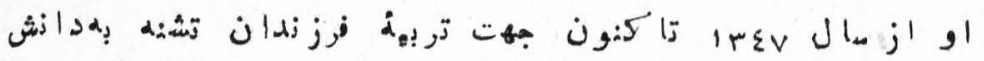

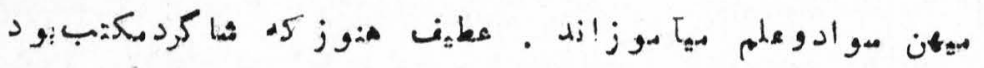

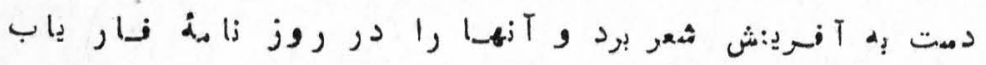

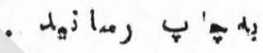

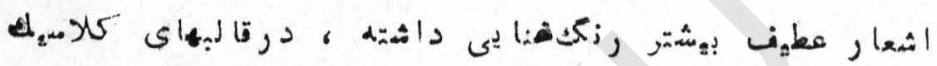

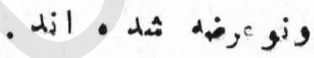

PYD 
نخهس بر غزل ر هى دبعير ى :

اقبا ل شعر

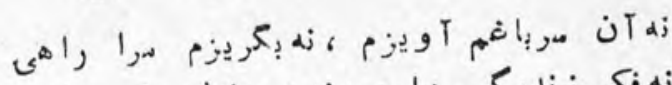

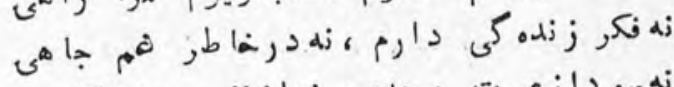

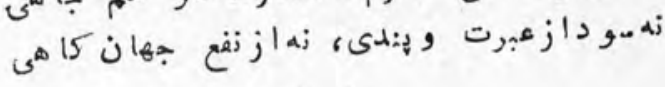

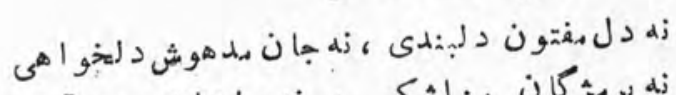

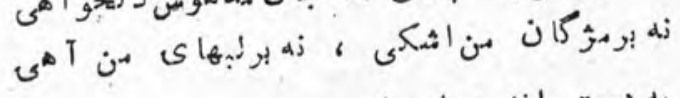

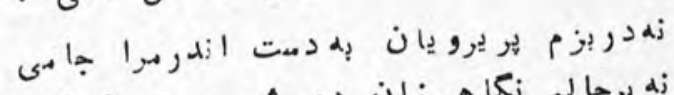

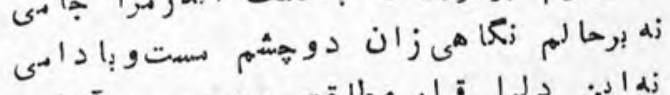

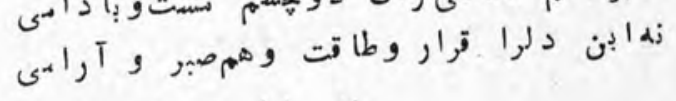

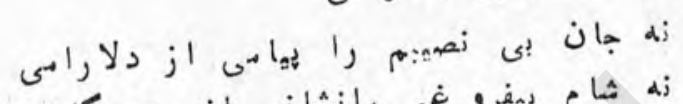

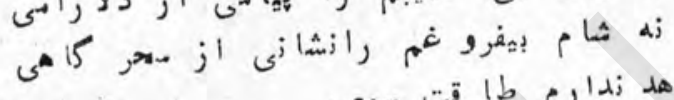

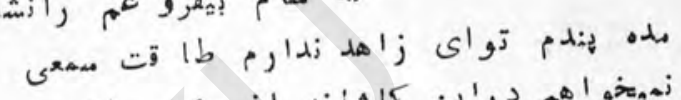

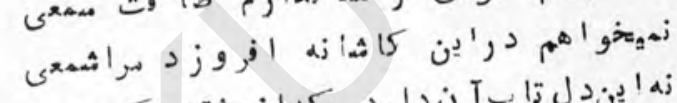

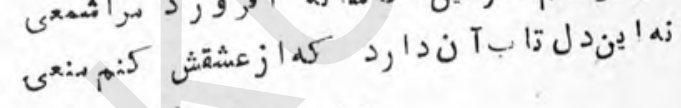

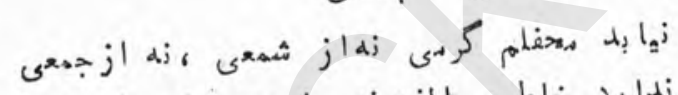

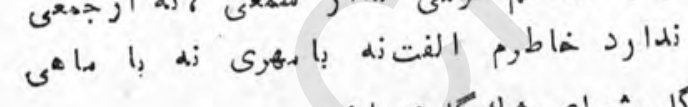

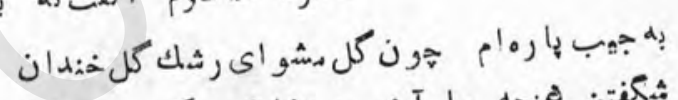

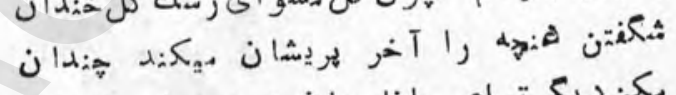

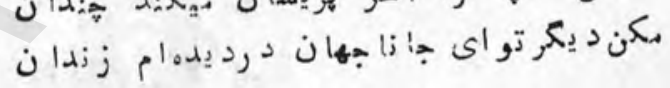

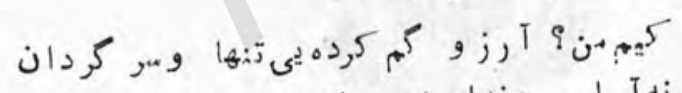

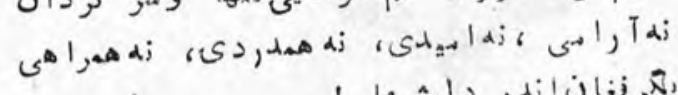

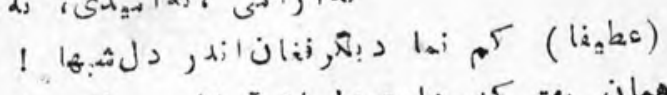

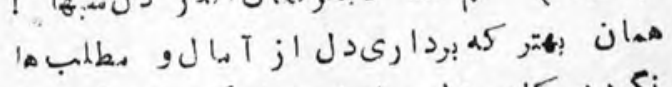

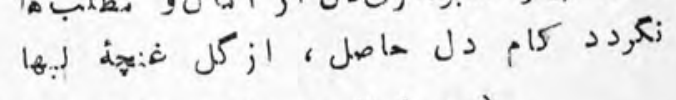

إنها

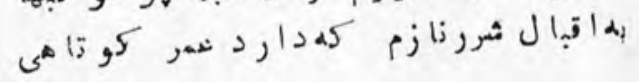

PV 
جشم نظر باز

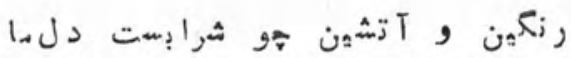

از آتش هجر ان هو كو كبا بست دل دل ما

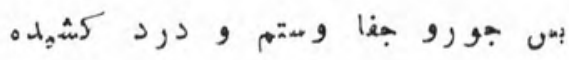

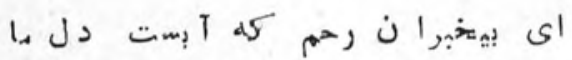

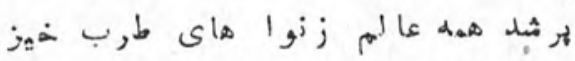

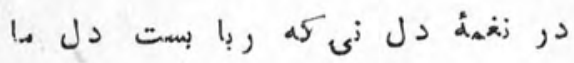

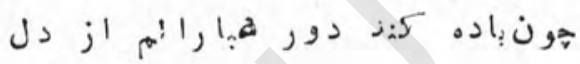

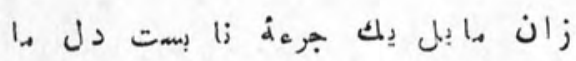

از كو هكن و بو. ميف ودجنون و جلالى

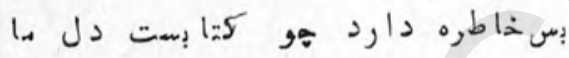

هون بركث خزانديده والنسرده و مهقجو ر

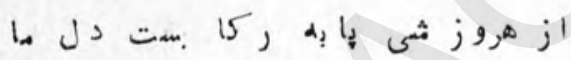

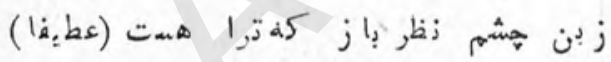

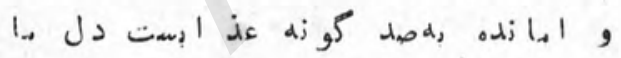

rVV 


\section{فطرتشكاك}

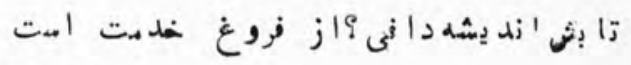

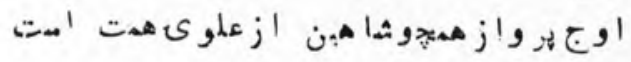

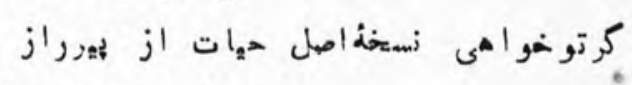

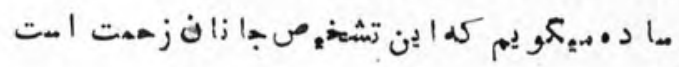

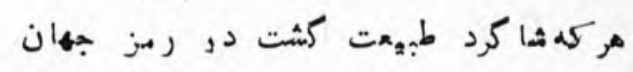

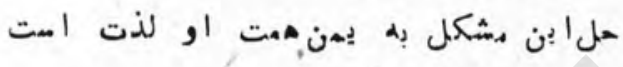

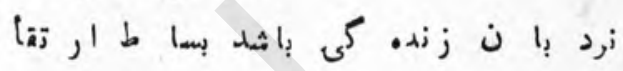

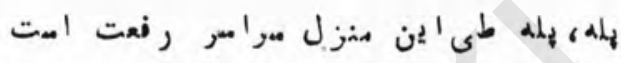

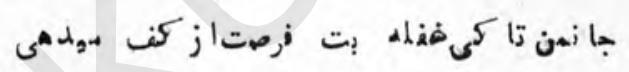

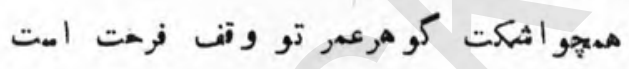

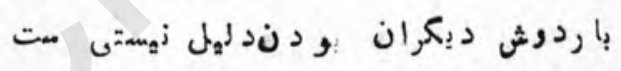

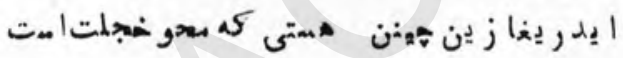

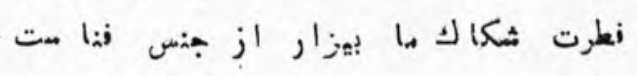

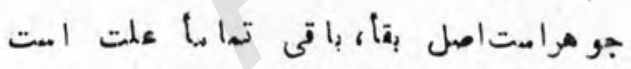

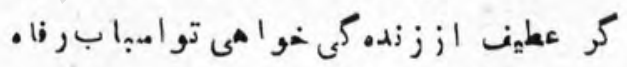

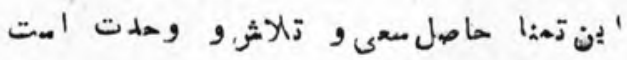

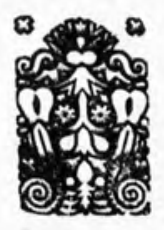




\section{قفاسى \\ عبد القهد وس قدهىفوز زند عبد المو من \\ (4)A rer-irrt)}

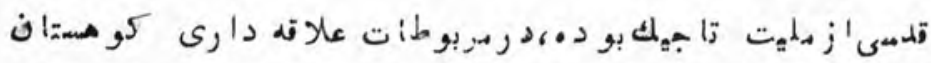

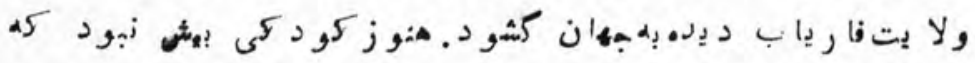

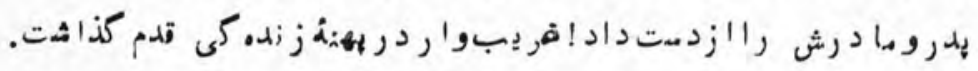

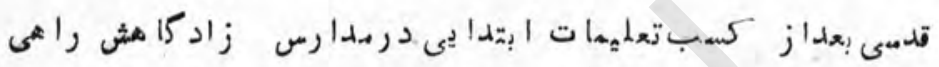

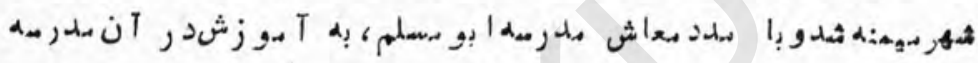

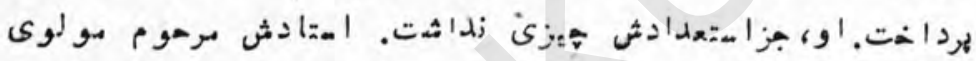

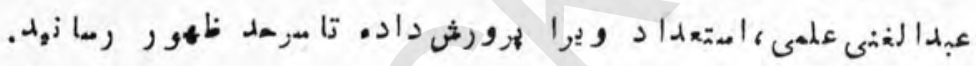

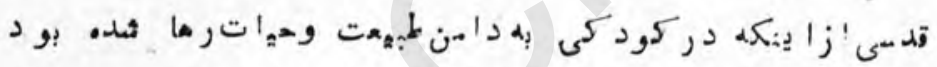

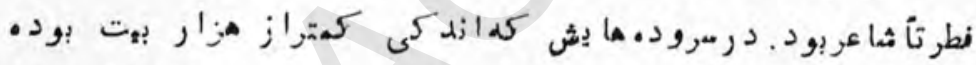

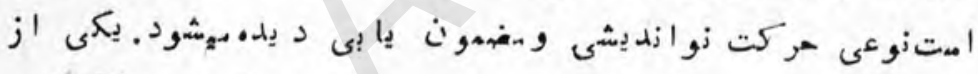

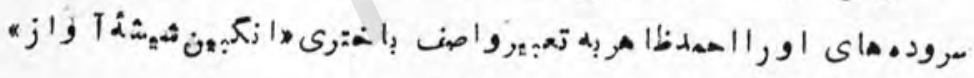

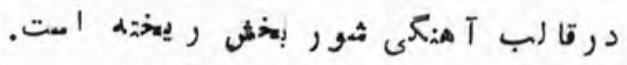

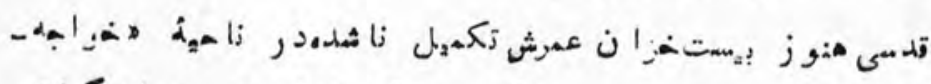

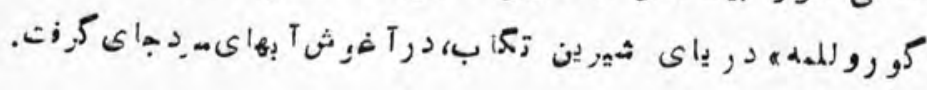

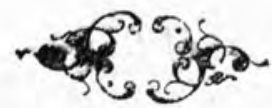


is

بو ر ياى فقر

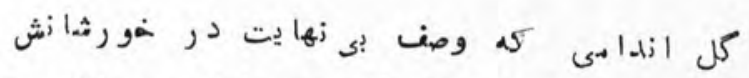

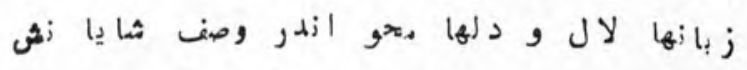

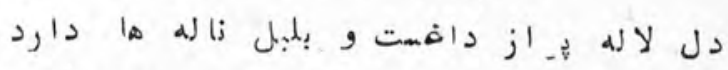

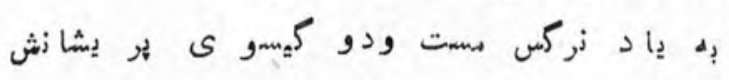

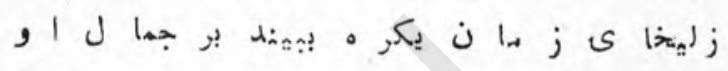

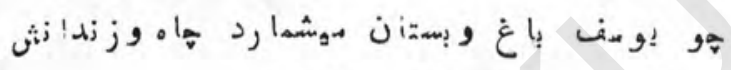

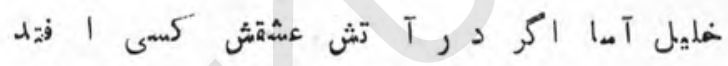

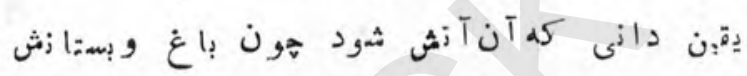

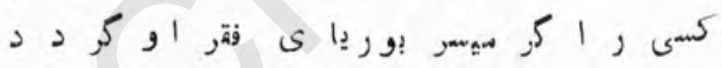

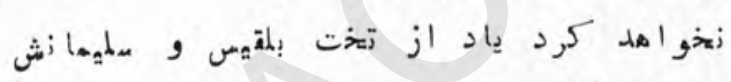

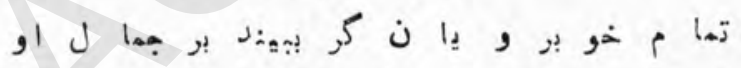

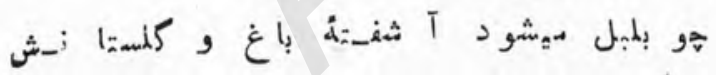

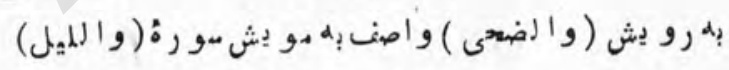

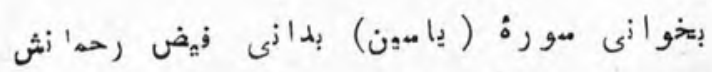

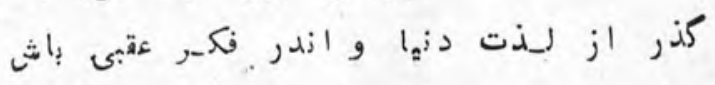

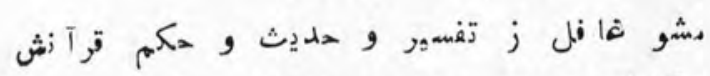

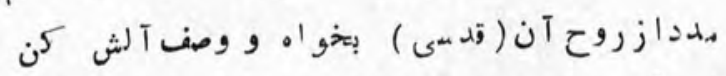

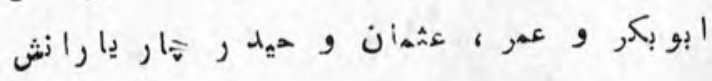


خز ان عمر

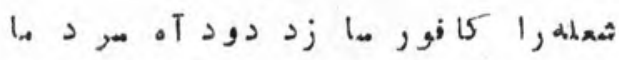

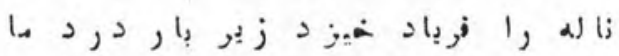

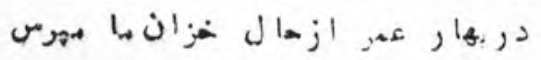

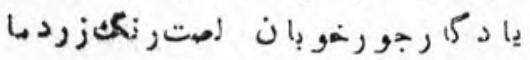

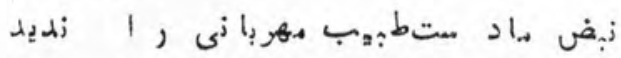

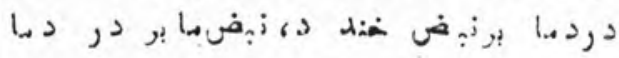

|زشرارآ •د ل تهرير كردم شعرو إهت

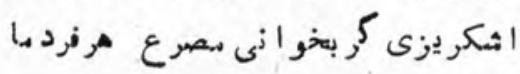

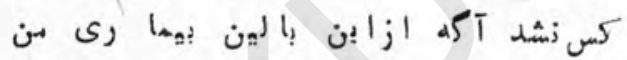

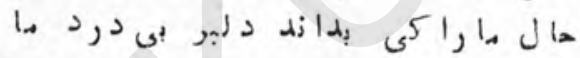

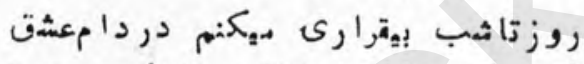

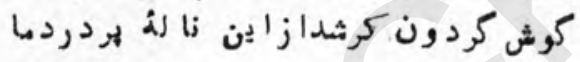

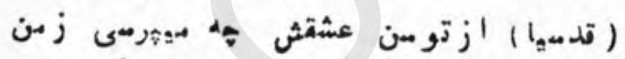

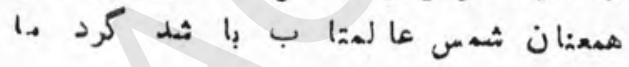

PAI 
كاش بودم لاله تاجو يُند دوريحرا مبرا

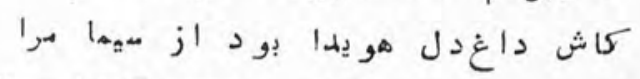

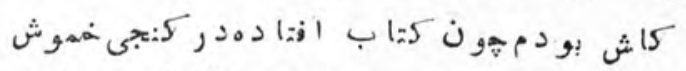

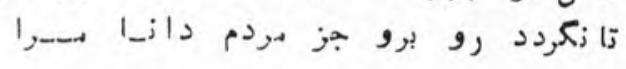

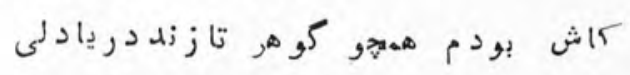

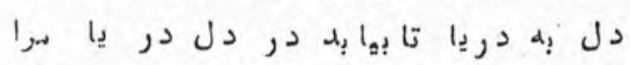

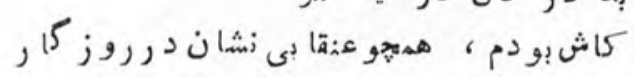

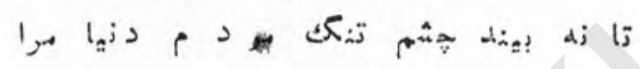

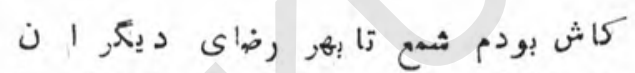

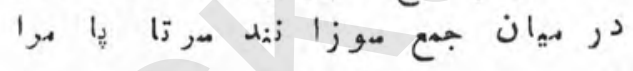

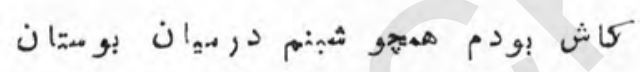

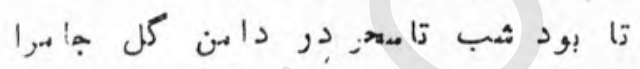

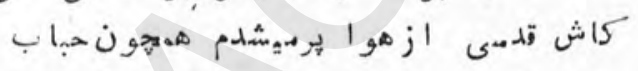

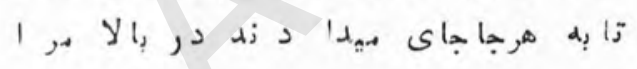

FAF 


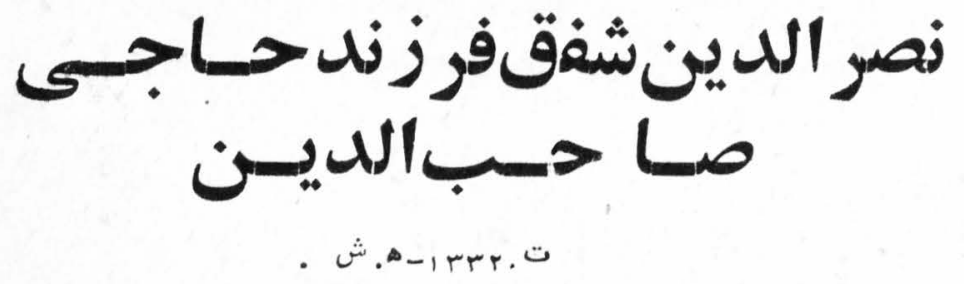

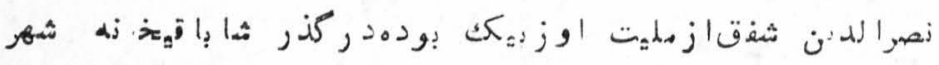

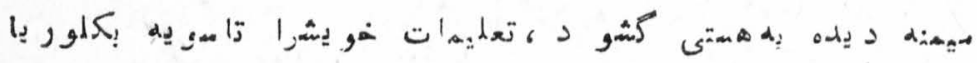

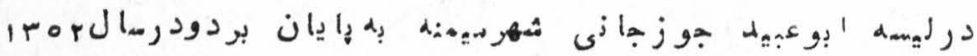

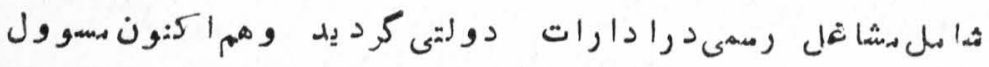

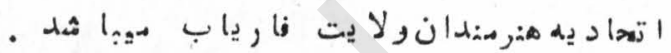

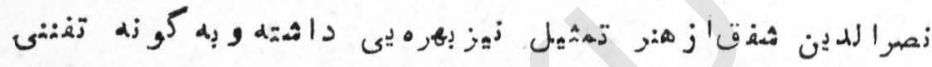

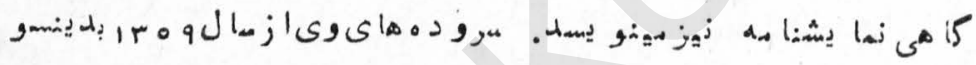

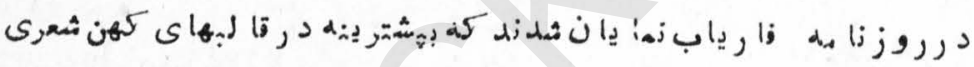

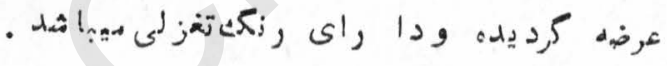

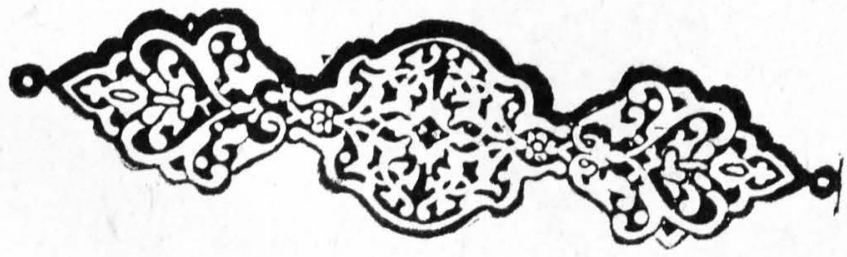




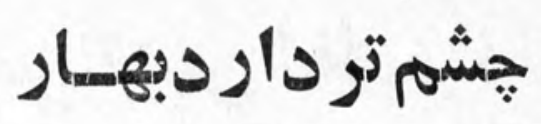

خرسنى ازمتاز

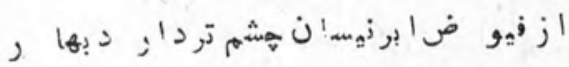

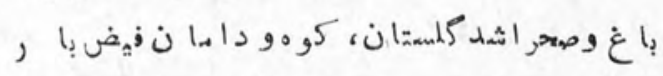

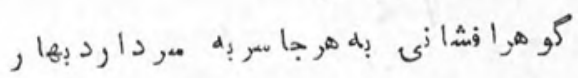

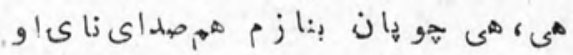

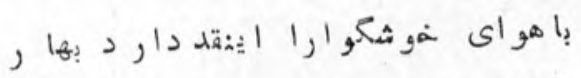

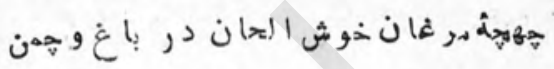

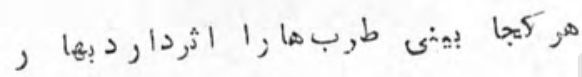

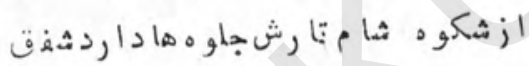

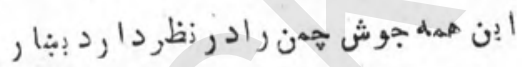

PAF 


$$
\text { كو جة تُههائى }
$$

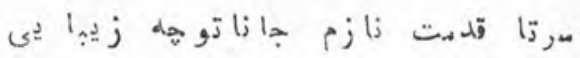

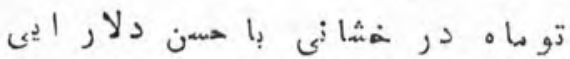

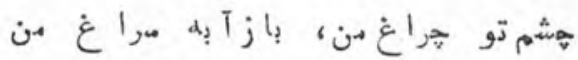

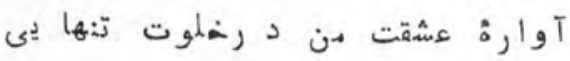

ازيرتو رخسارتا اكى مهر در خشانم

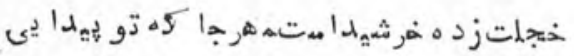

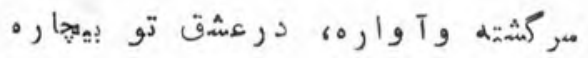

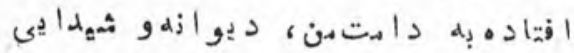

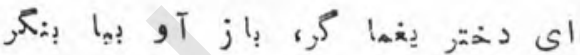

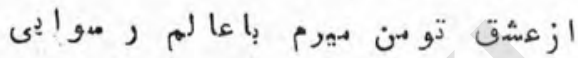

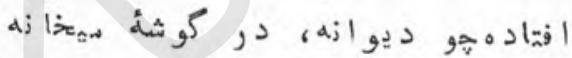

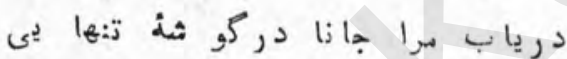

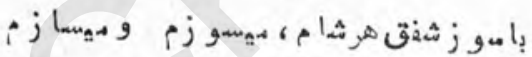

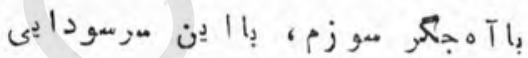

PAD 
همكار

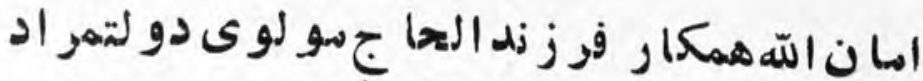

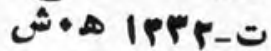

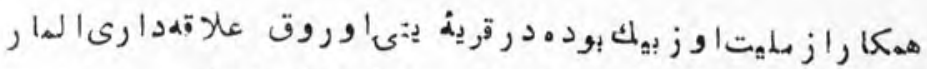

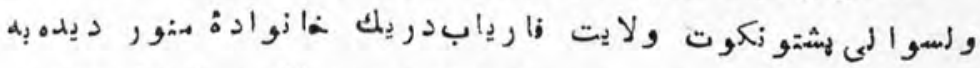

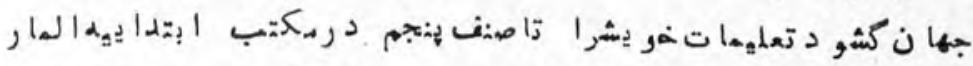

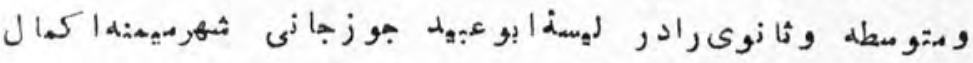

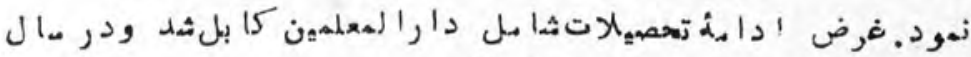

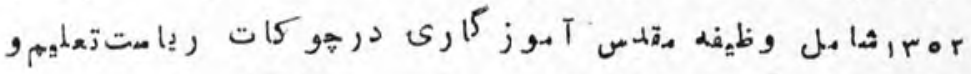

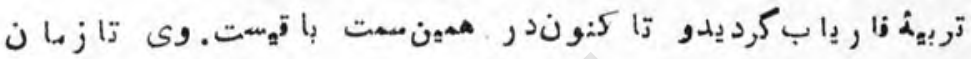

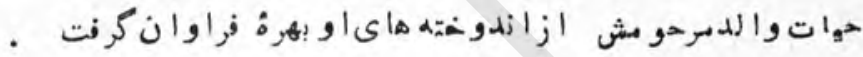

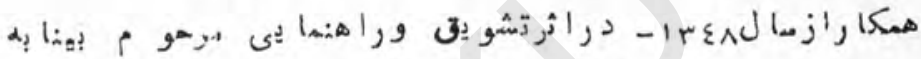

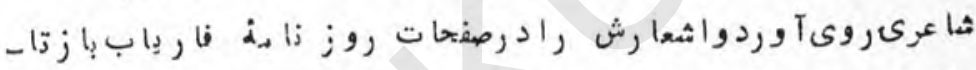

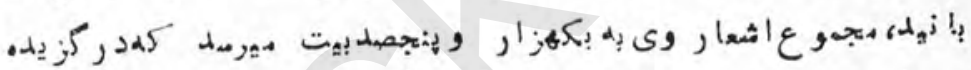

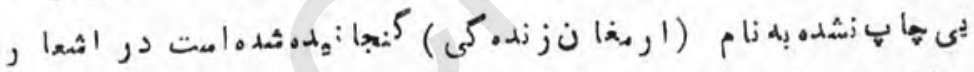

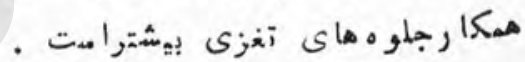

FAT 
تحفة بهار

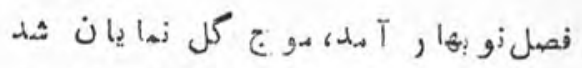

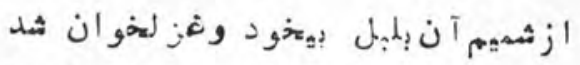

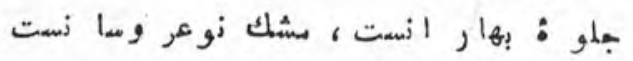

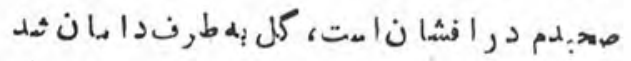

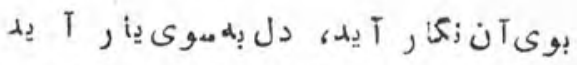

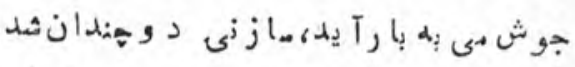

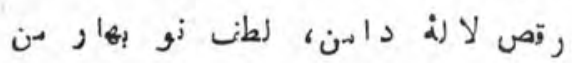

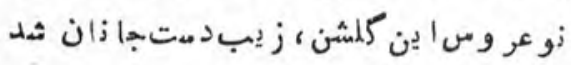

جوش زسترن إهنى، فرش شيا سمن إينى

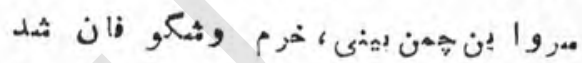

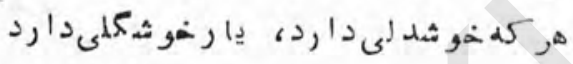

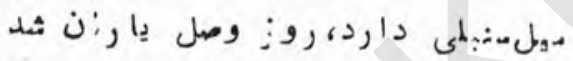

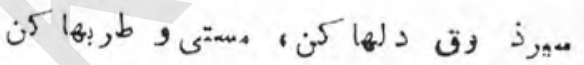

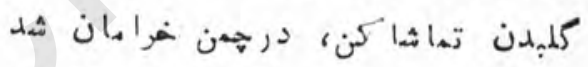

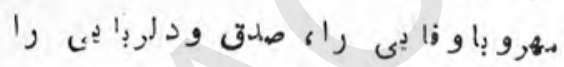

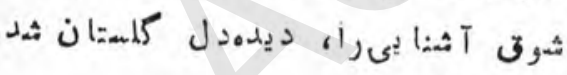

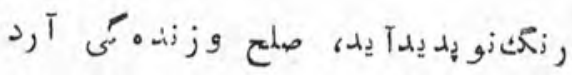

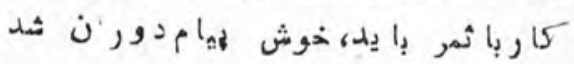

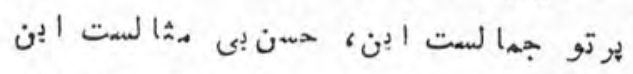

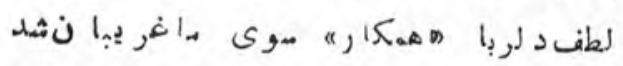

$* * * * * * * * * * * * * * * * * * *+* * * * * * * * * * * * * * * * *$

rav 


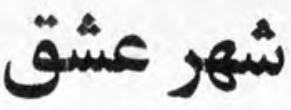

$$
\text { همراز شود آخر، جازازه إِه جا زازه }
$$

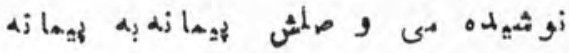

$$
\text { جيرون نتوان بردن ،د الدادمز شهر عشق كئ }
$$

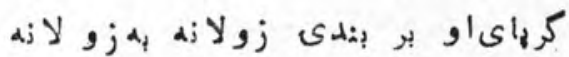

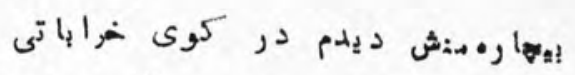

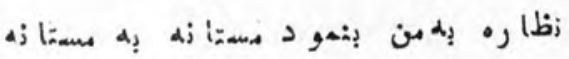

$$
\text { كث:م: كه شود دوزى،از فيض تو :هروزى نظه }
$$

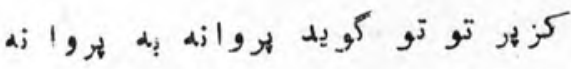

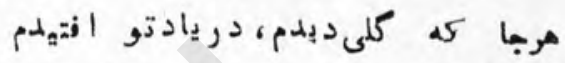

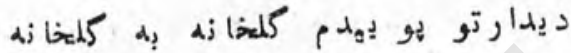

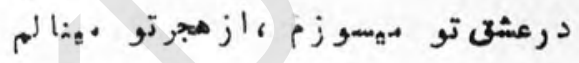

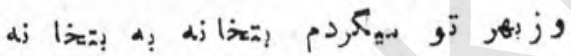

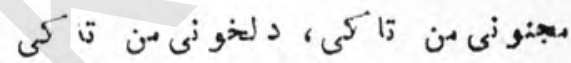

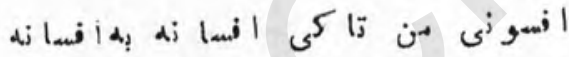

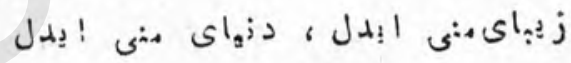

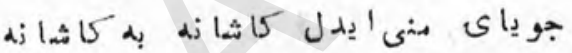

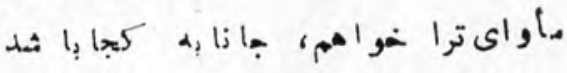

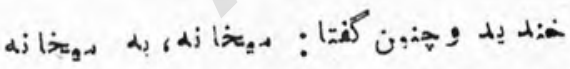

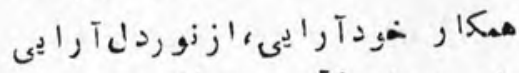

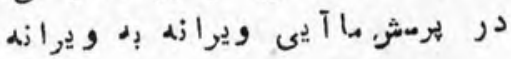

\section{5)}




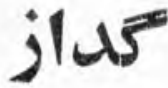

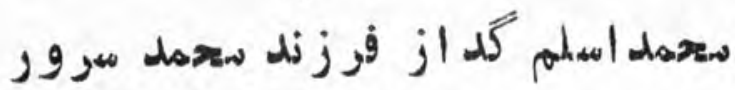

ت -

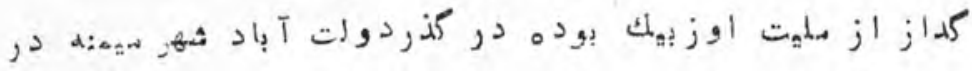

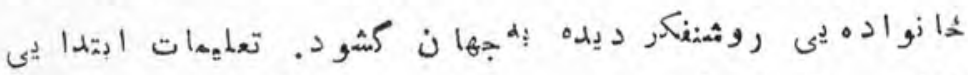

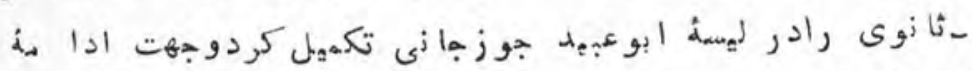

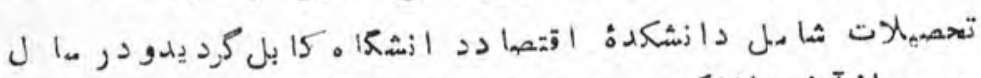

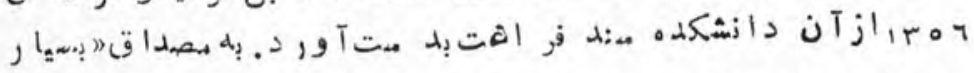

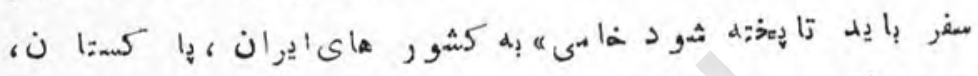

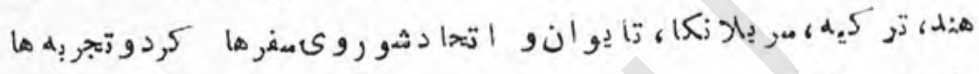

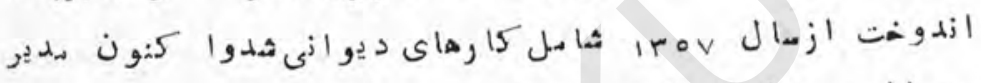

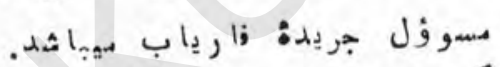

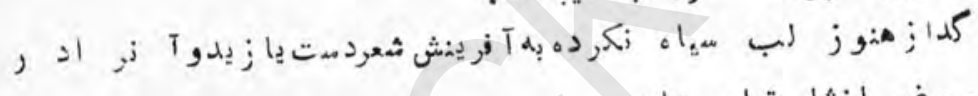

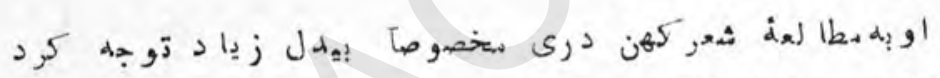

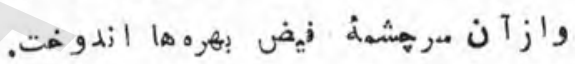

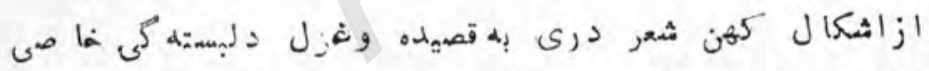

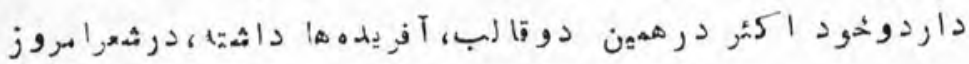

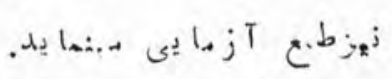

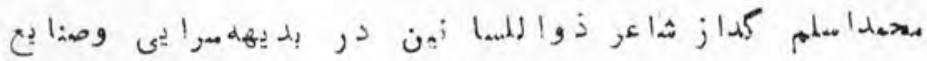

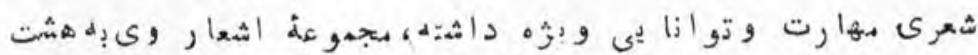

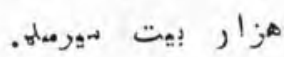

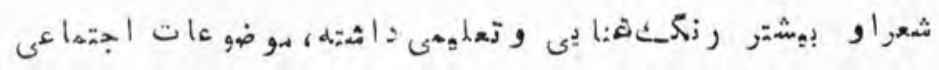

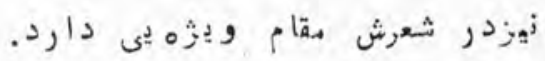




\section{سوزوساز}

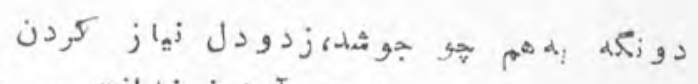

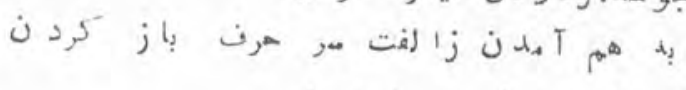

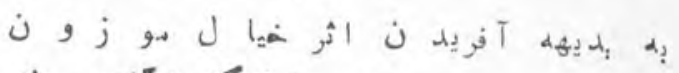

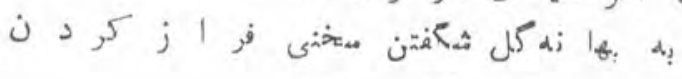

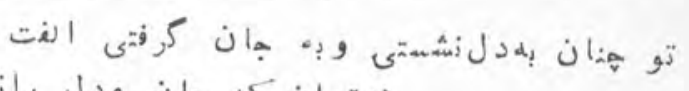

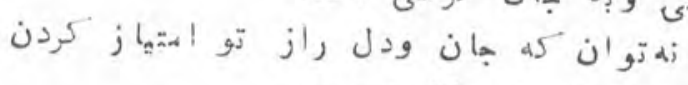

ا ثر زفس حله

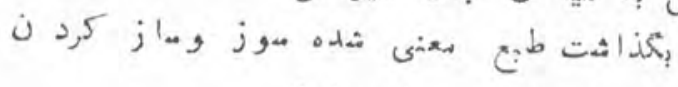

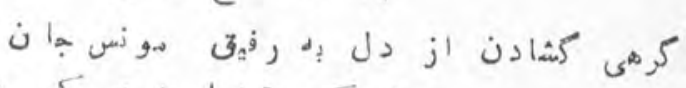

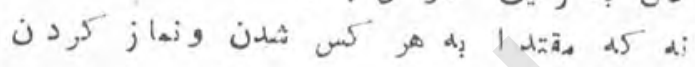

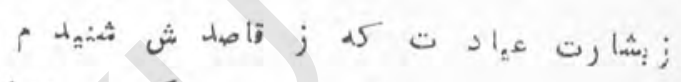

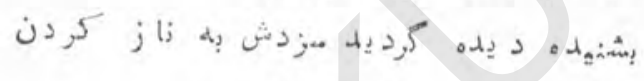

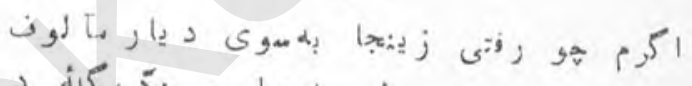

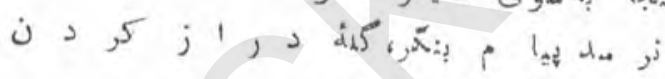

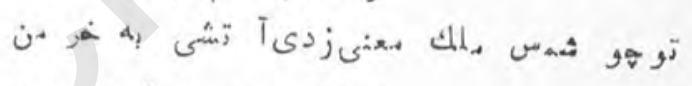

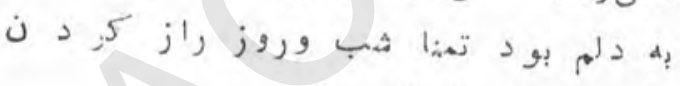

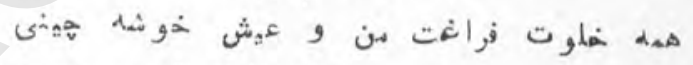

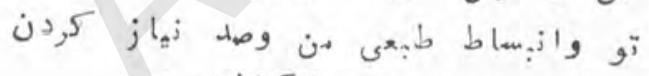

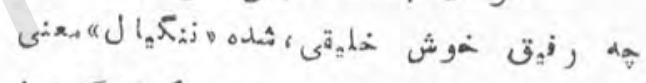

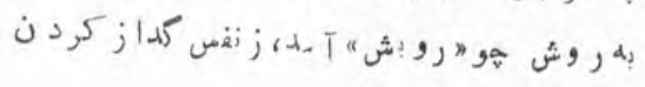

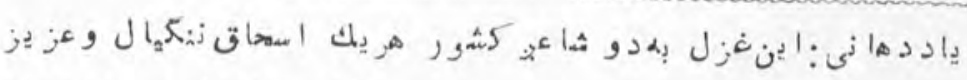

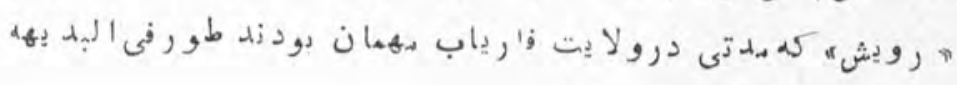

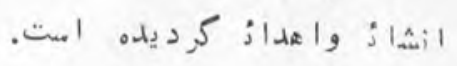


زعَه بسملان

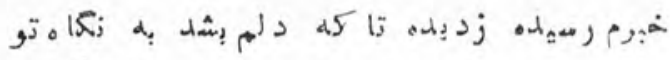
ز زئت

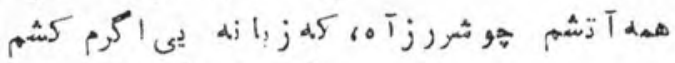

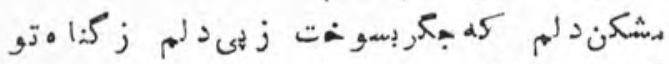

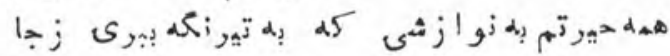

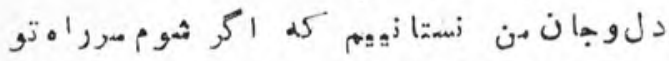

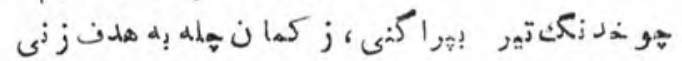

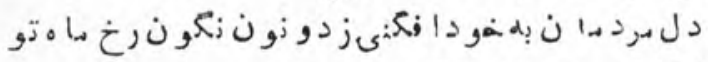

$$
\text { هب }
$$

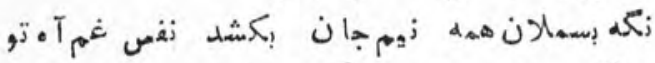

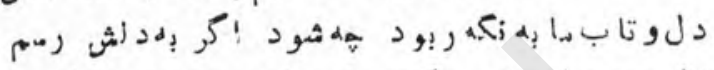

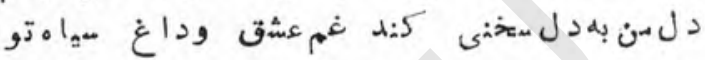

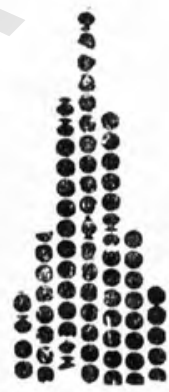

pal 


\section{صياد قاش}

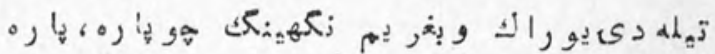

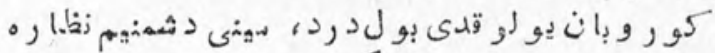

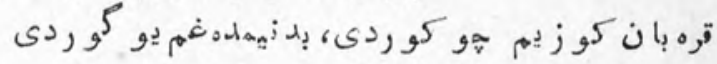

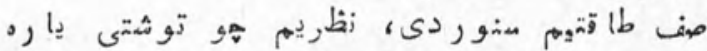

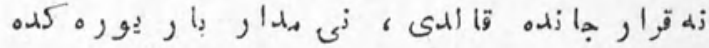

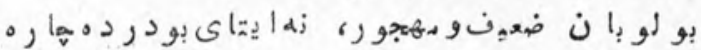

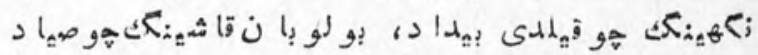

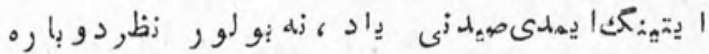

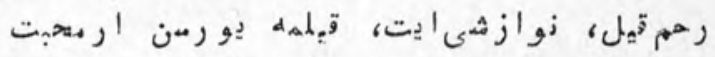

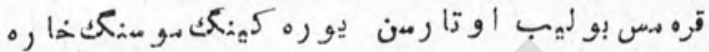

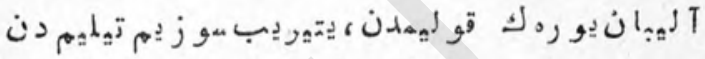

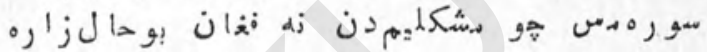

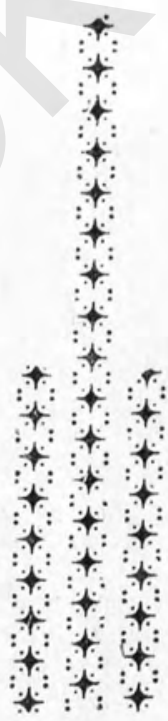


ادبكاه نواز ش

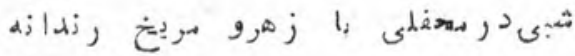

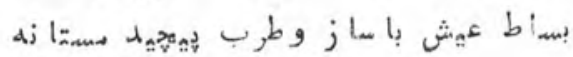

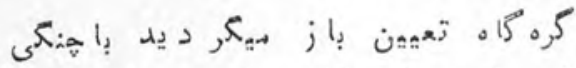

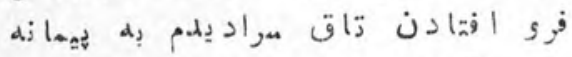

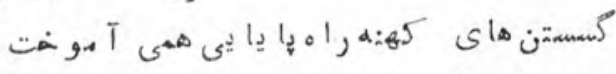

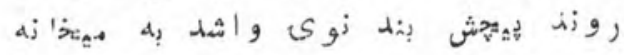

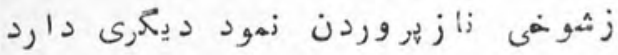

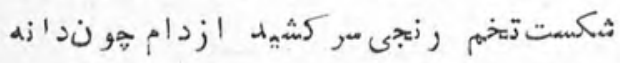

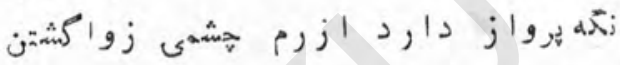

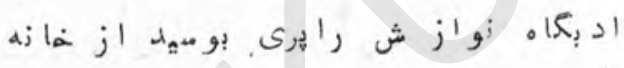

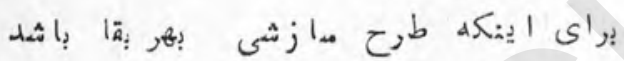

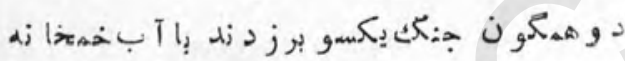

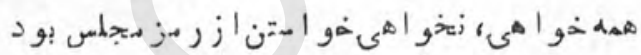

iز زله

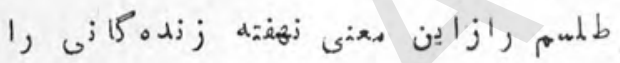

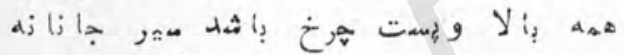

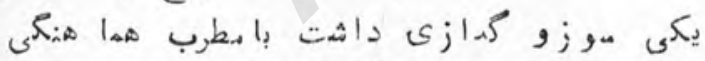

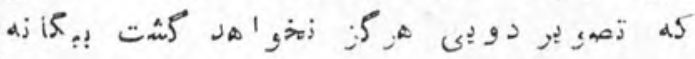

rap 
اشاشكدرد

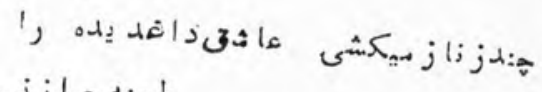

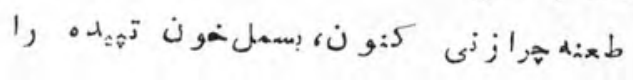

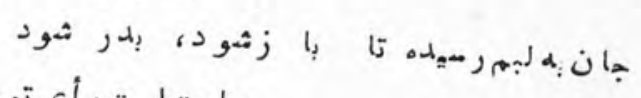

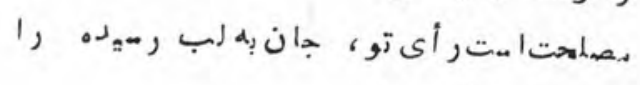

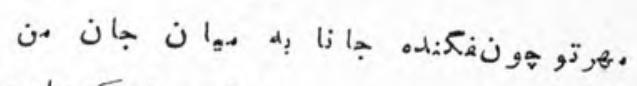

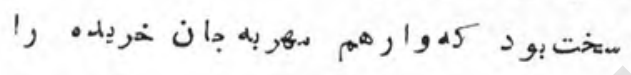

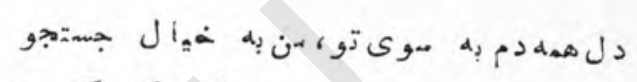

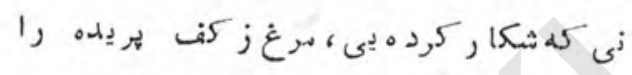

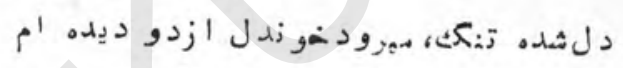

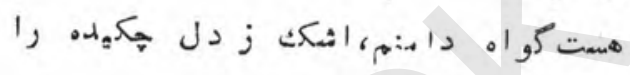

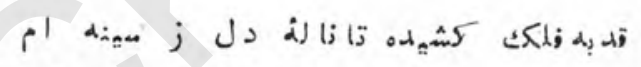

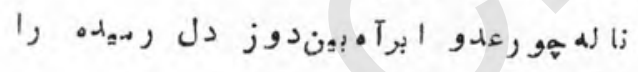

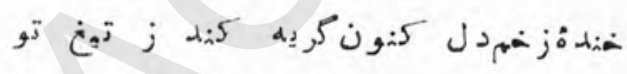

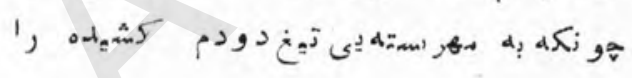

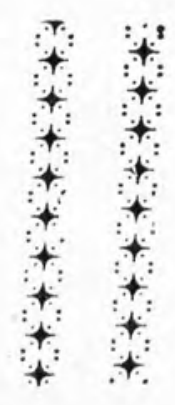




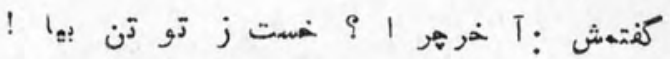

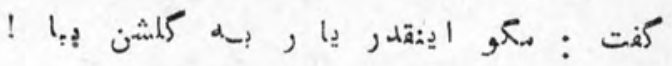

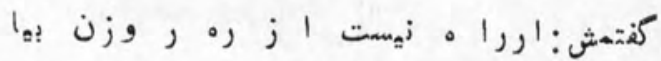

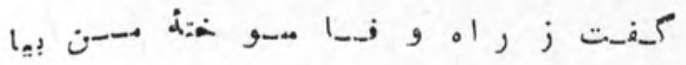

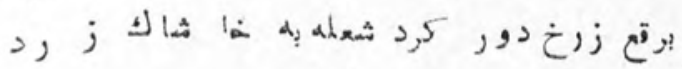

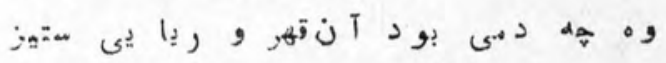

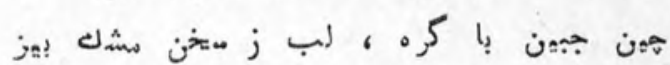

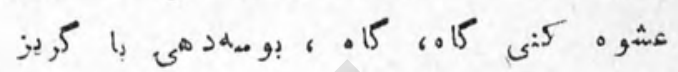

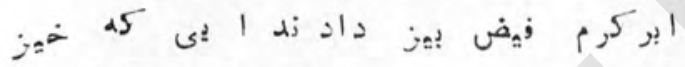

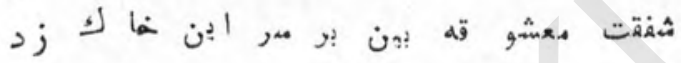

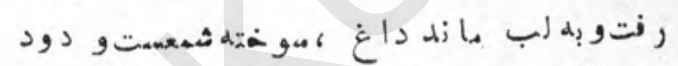

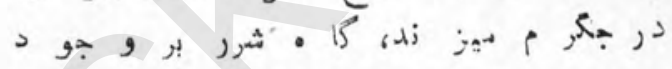

$$
\begin{aligned}
& \text { قلب ثمده در "كداز") تا كله به من مخود زهود } \\
& \text { صبر هدار وقرار از دل "هماد م" ربود }
\end{aligned}
$$

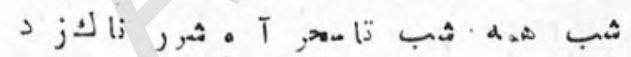

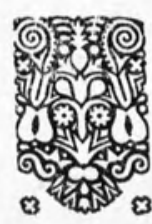




\section{بلوغ شعر

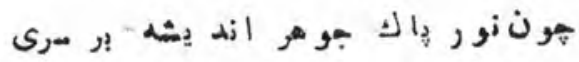

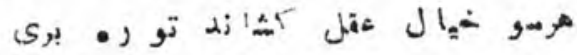

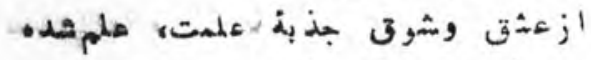

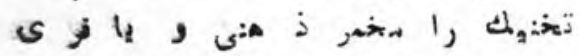

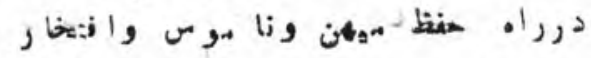

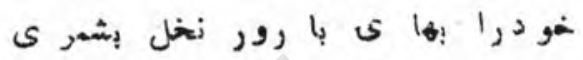

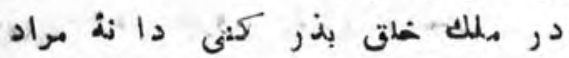

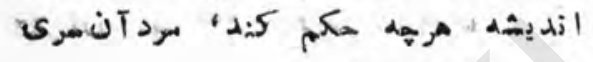

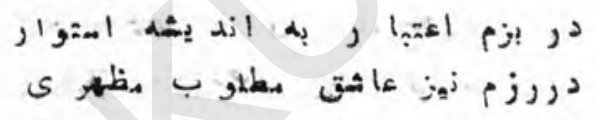

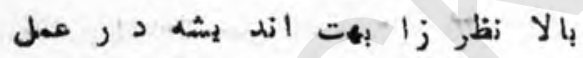

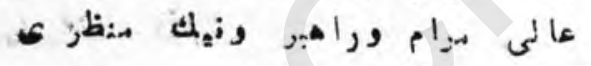

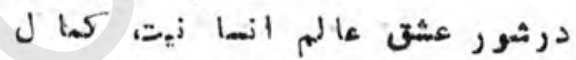

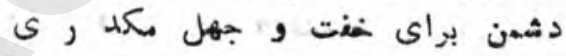

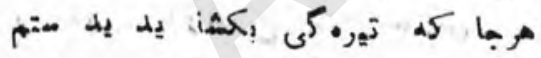

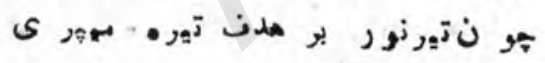

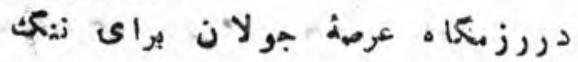

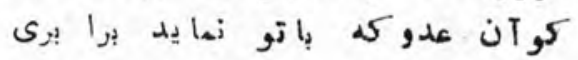

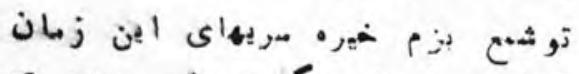

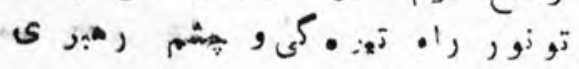

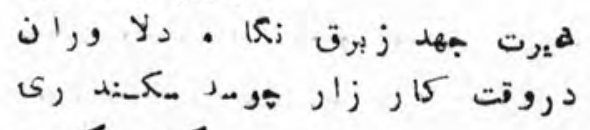

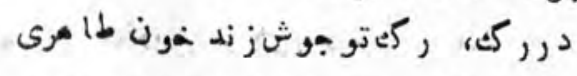

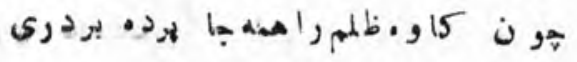




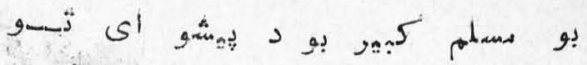

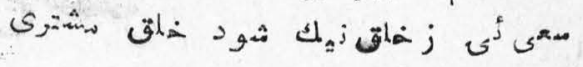

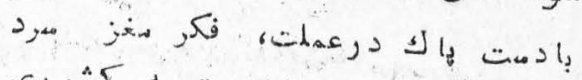

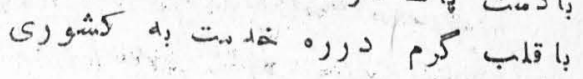

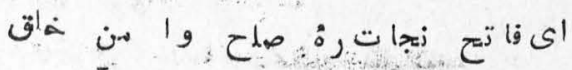
رز مت شده أ

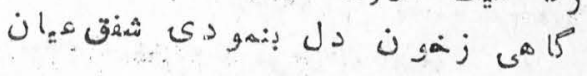

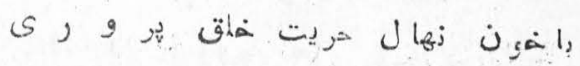

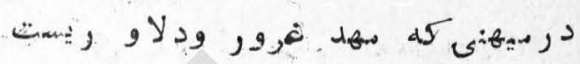

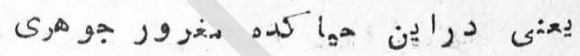

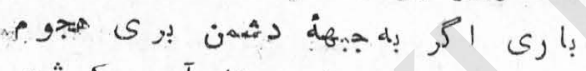

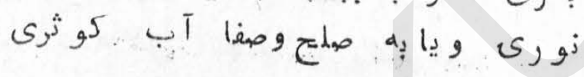

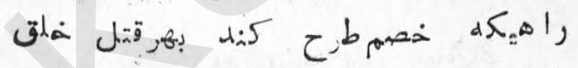
خ

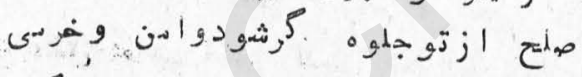

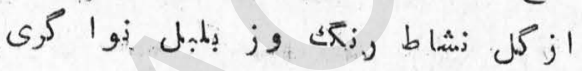

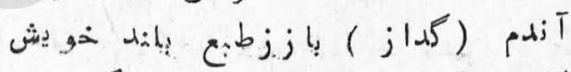

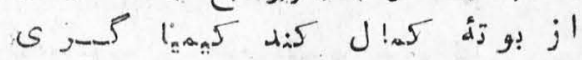

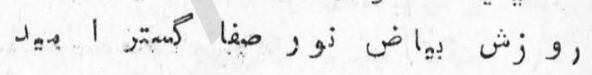

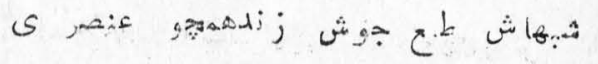

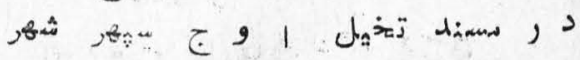

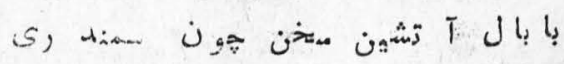

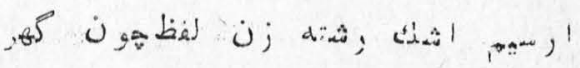

ज,

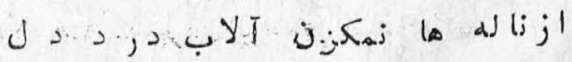

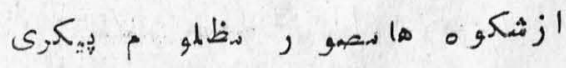

pan 
ज行

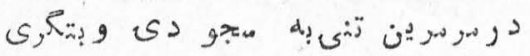

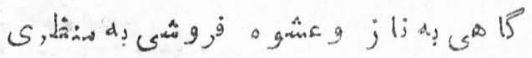

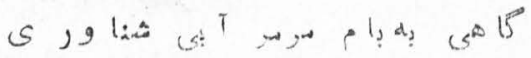

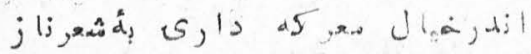

ى,

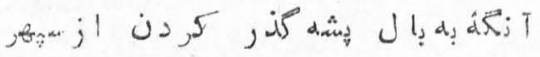

v

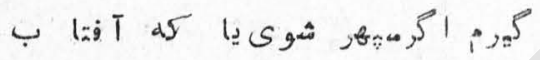

|

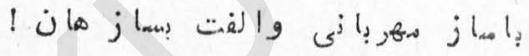

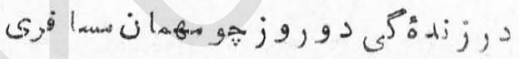

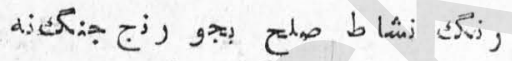

ى بر

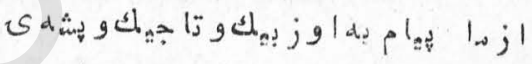

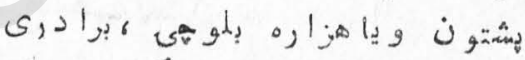

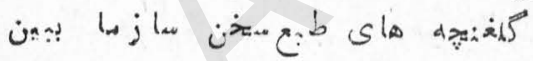

v, 9 ن

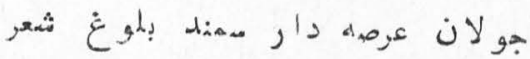

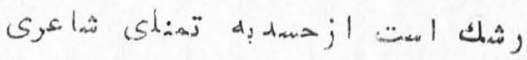

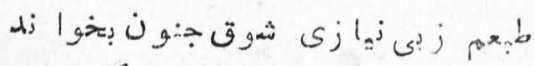

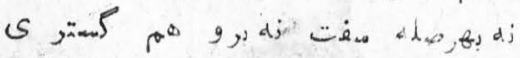

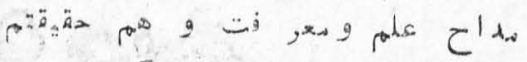

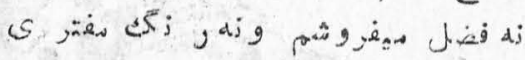

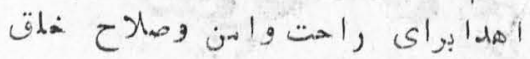

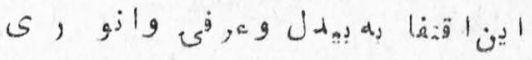

pqa 


\section{غزلمنقو ط (ازفنون شعرى )

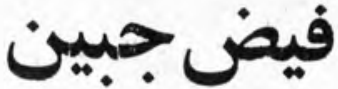

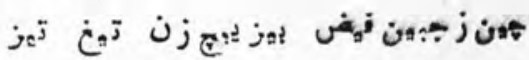

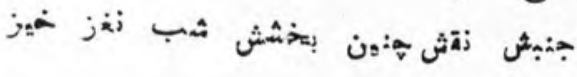

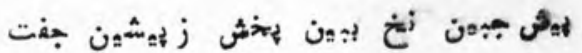

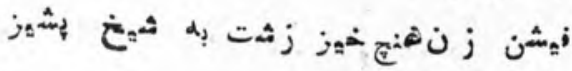

شغتتشبتبز ن، تن ز نشين ز زنخ

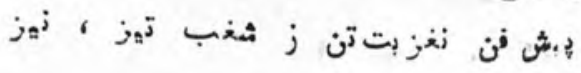

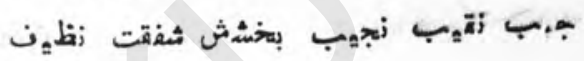

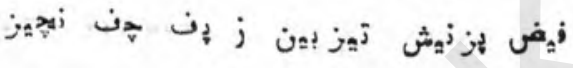

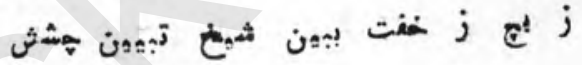

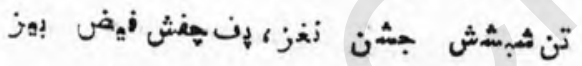

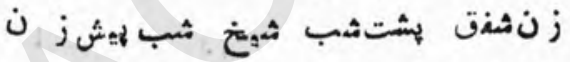

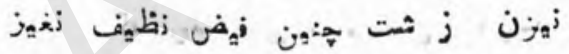

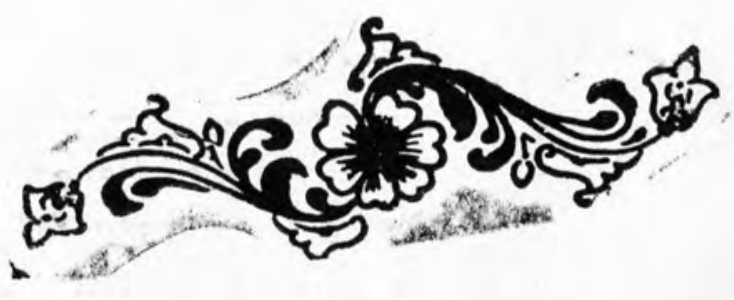


جوابرباعى لاجوابرودكى

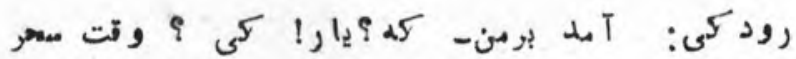

$$
\begin{aligned}
& \text { ترميد ز كله }
\end{aligned}
$$

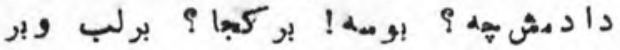

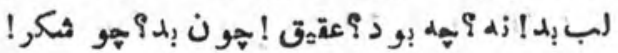

$$
\begin{aligned}
& \text { * * * * }
\end{aligned}
$$

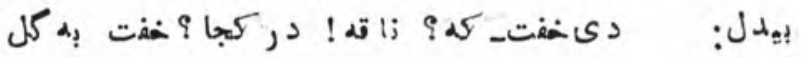

$$
\begin{aligned}
& \text { كردم هيه }
\end{aligned}
$$

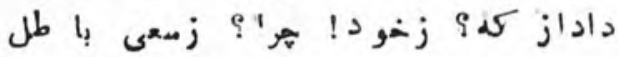

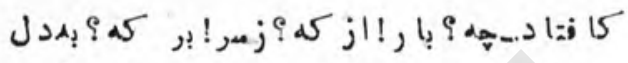

$$
\begin{aligned}
& \text { * } \\
& \text { * } \text { * }
\end{aligned}
$$

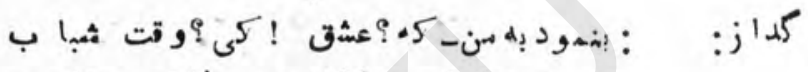

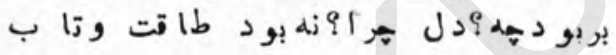

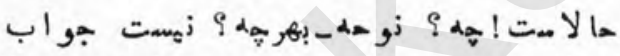

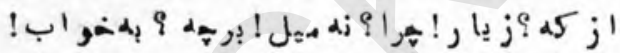

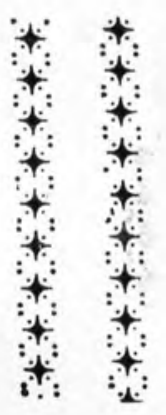




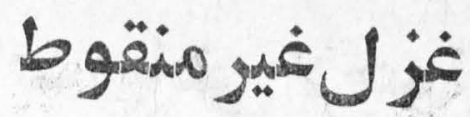

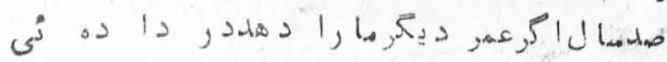

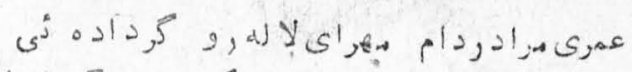

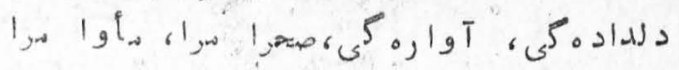

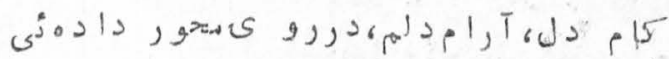

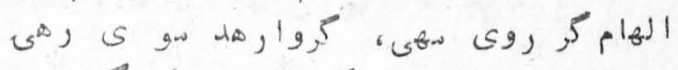

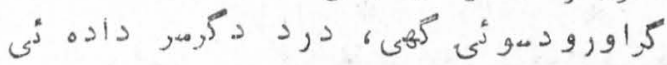

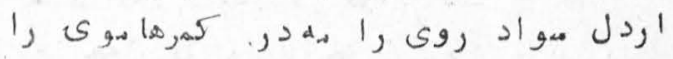

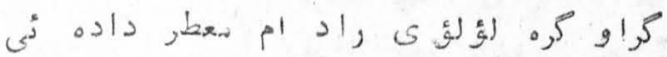

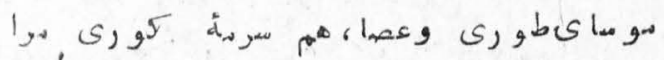

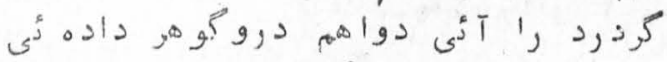

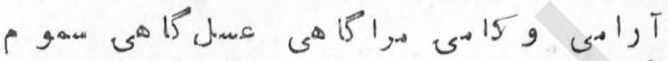

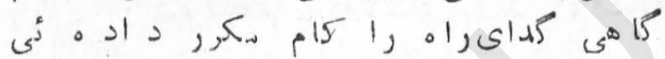

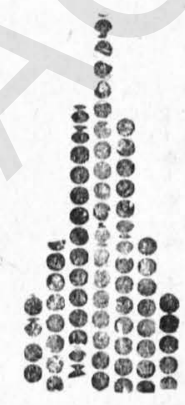


كل تنهوا

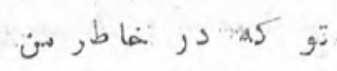

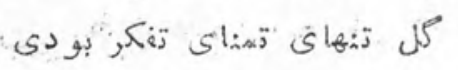

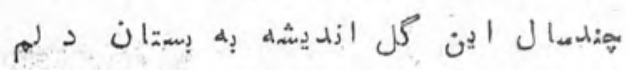

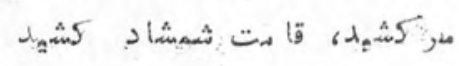

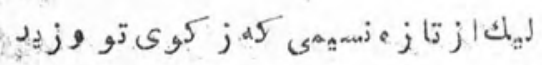

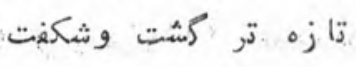

* * *

كرم كري. يد ميان سن وتو زآتش ودودم كران

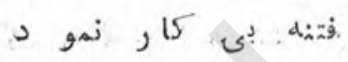

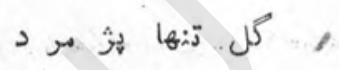

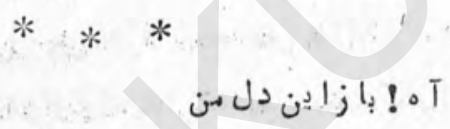

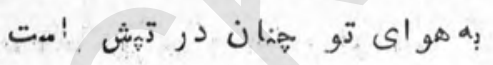

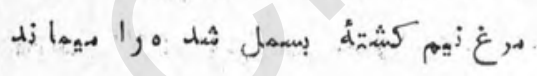

$p \circ r$ 


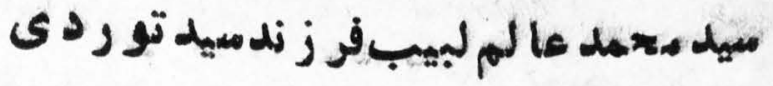 ش. - Irper}

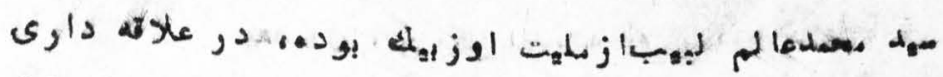

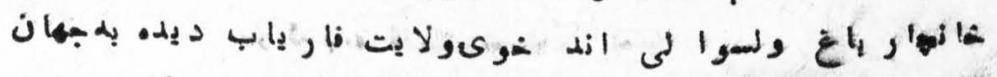

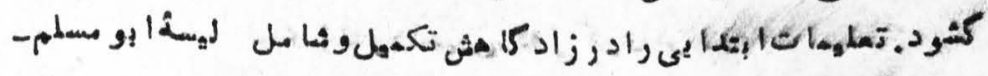

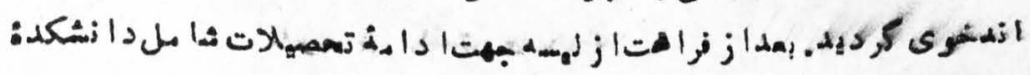

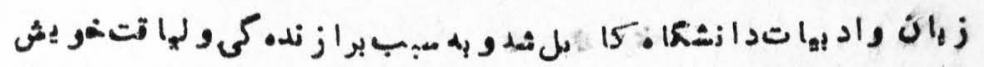

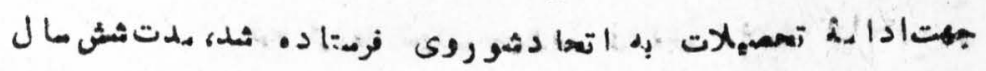

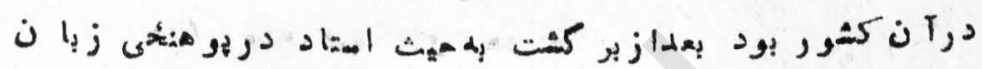

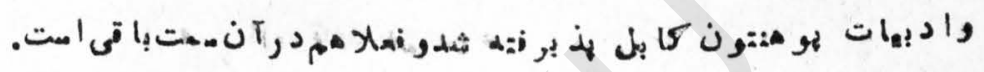

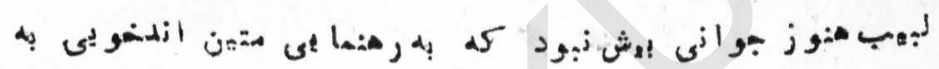

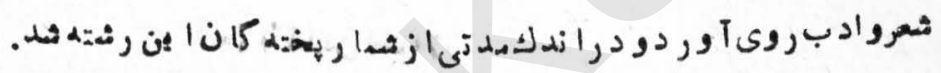

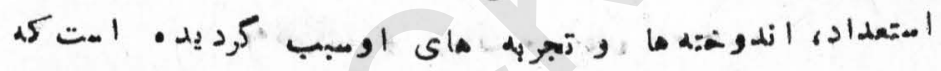

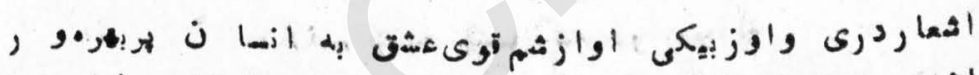

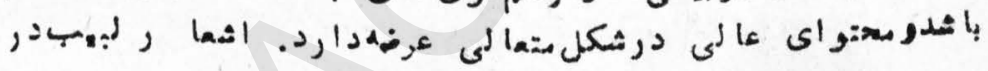

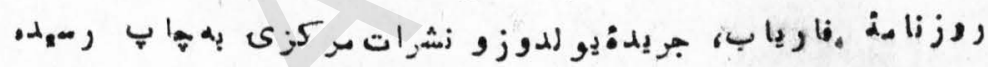

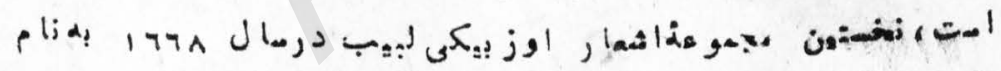

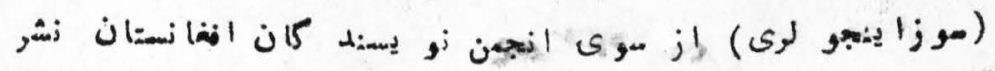

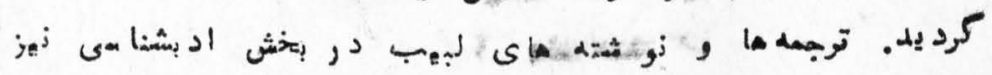
. ماند

\section{(5)}


قصيل ه هيمنه و صفيد ه.

\section{قوياش شهرى}

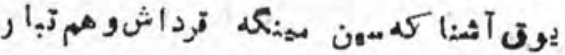

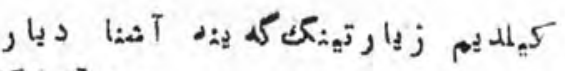

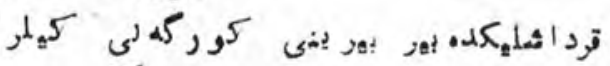

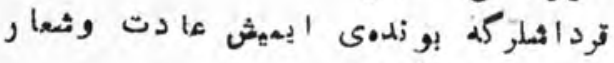

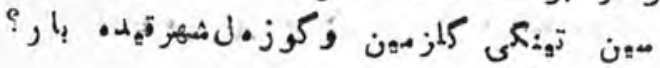

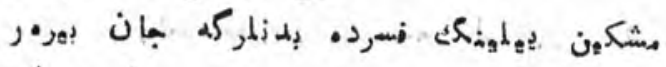

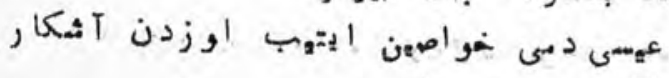

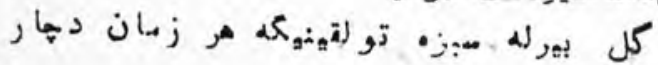

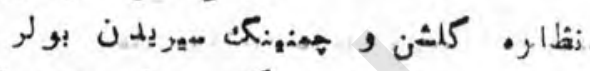

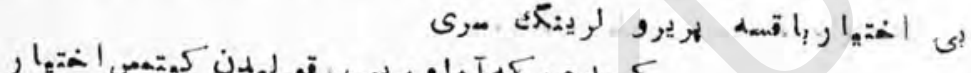

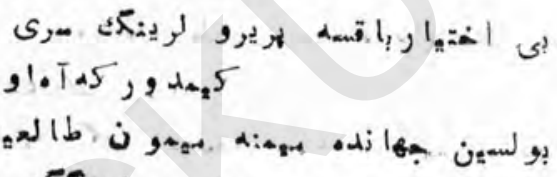

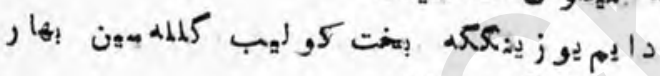

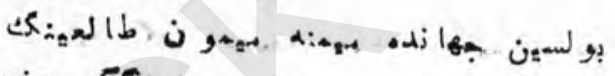

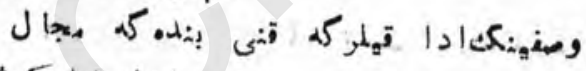

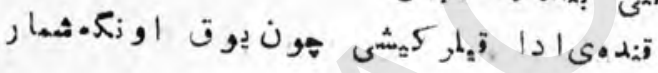

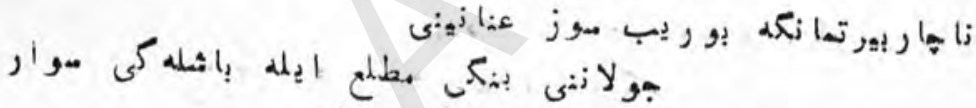

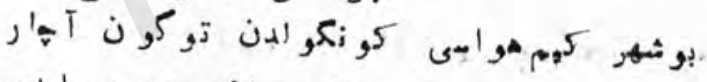

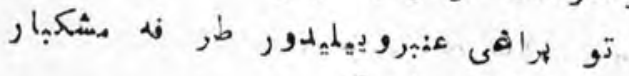

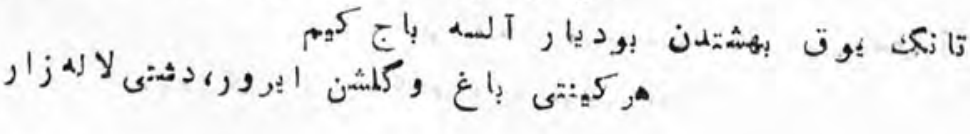




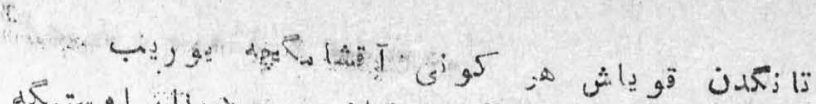

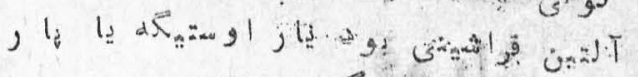

أ

بو

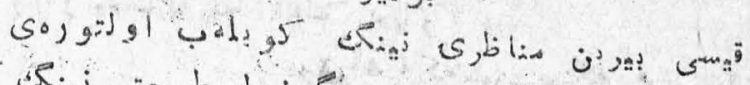

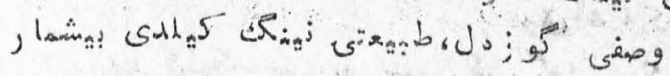

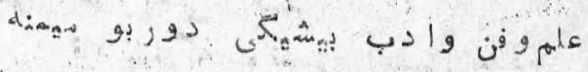

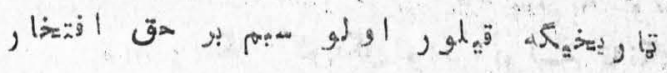

او

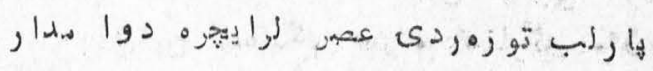

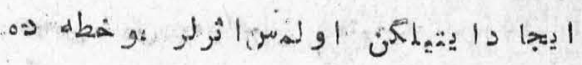

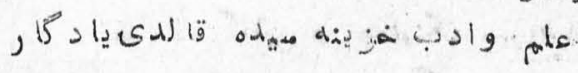

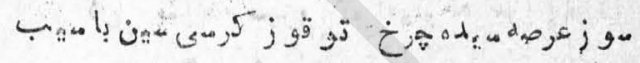

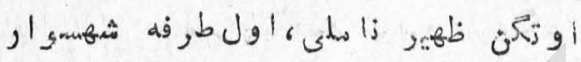

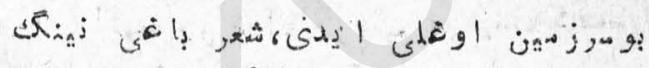

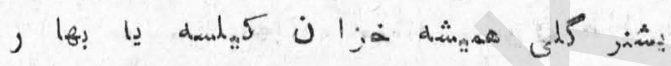

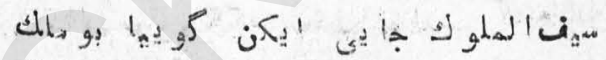

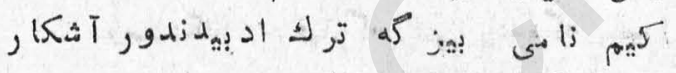

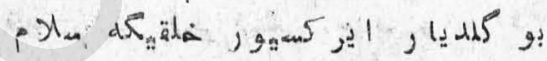

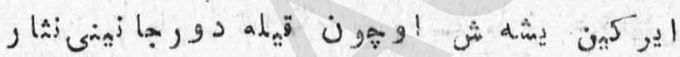

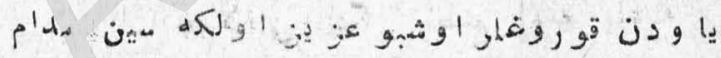

قال لهب

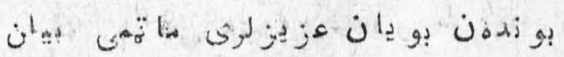

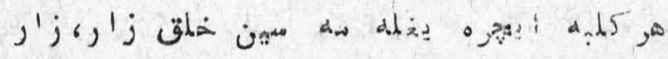

آسو

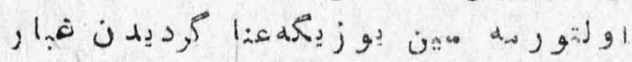

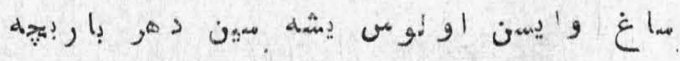

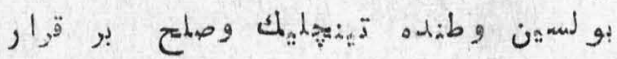

p. 7 
gجids jom

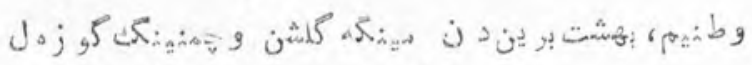

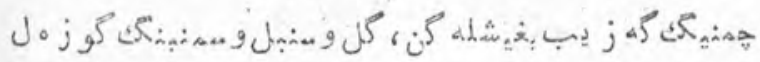

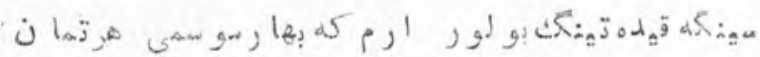

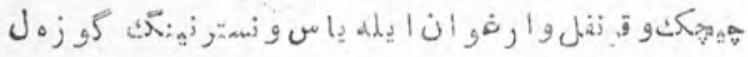

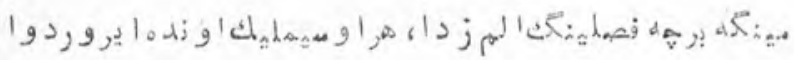

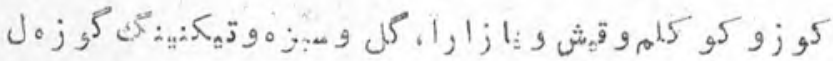

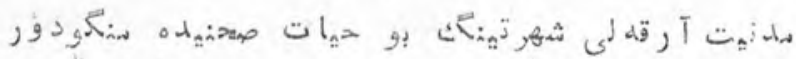

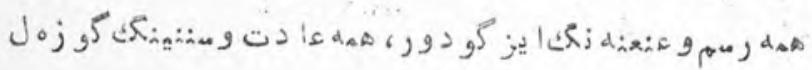

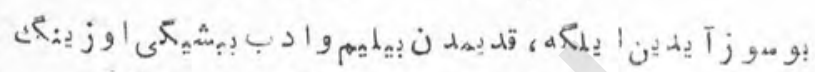

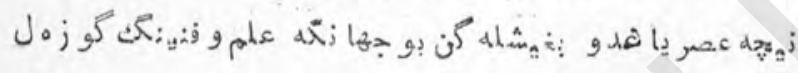

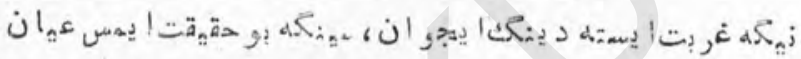

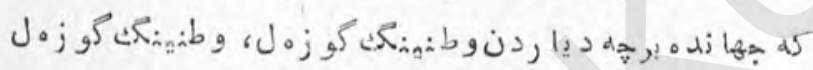

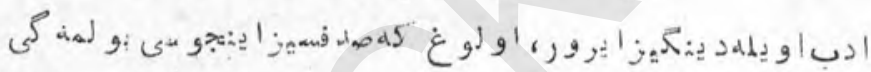

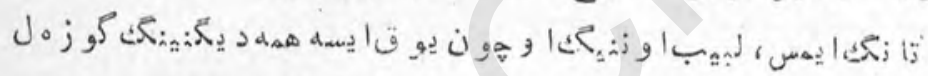

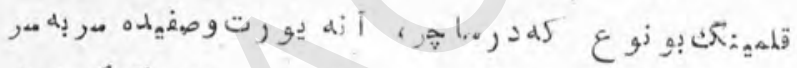

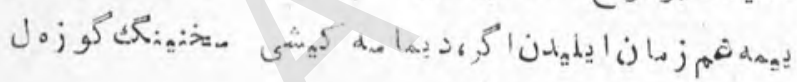

$P \bullet \gamma$ 
طبعبر دبار

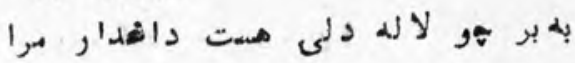

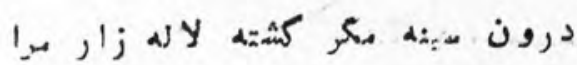

ثكمت رأكك زها يله اكر زهان دار مرن

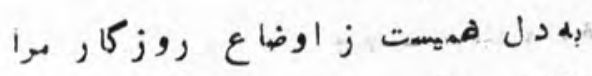

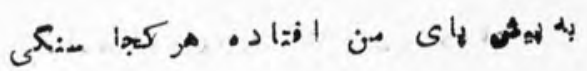

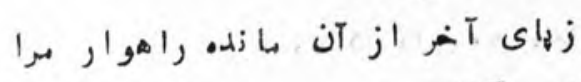

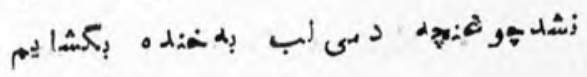

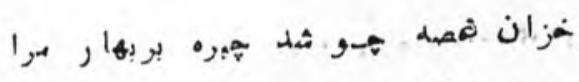

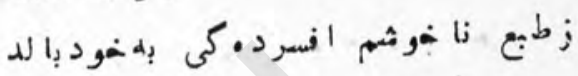

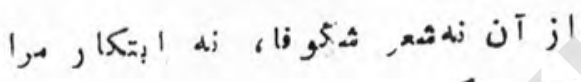

درابن ستهكد. كيرم دل ازتو بركيرم

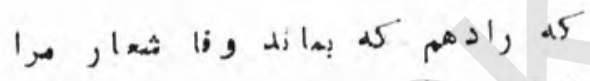

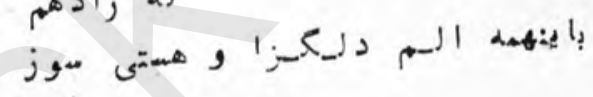

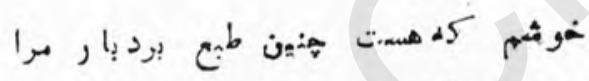

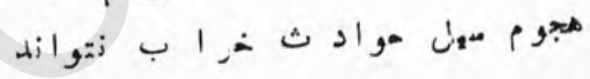

اجل

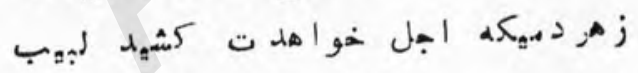

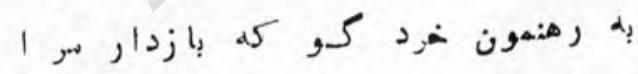

$r, \boldsymbol{A}$ 


\section{ل}

سيد اكروم كما لزفر زند ميد كمال الدين ( ) . IFrp )

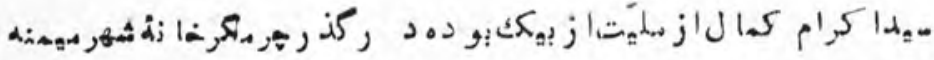

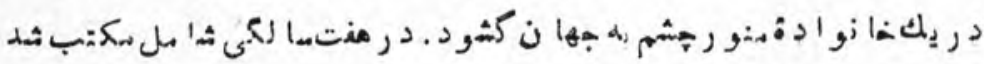

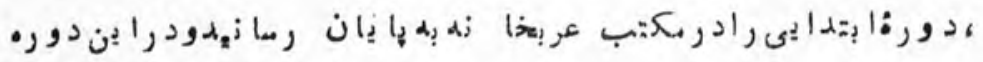

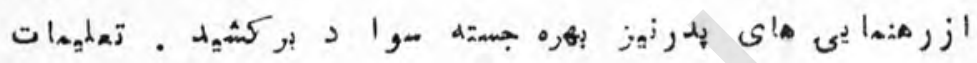

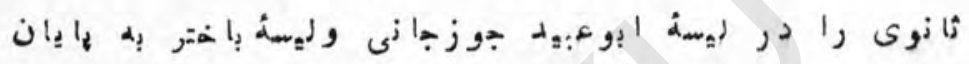

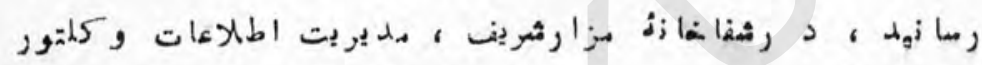

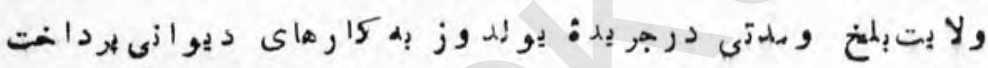

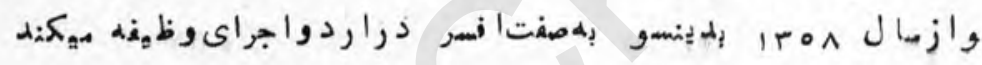

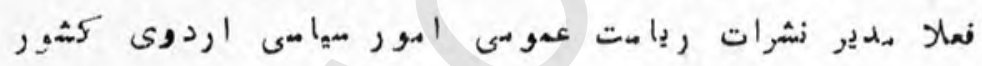

$$
\text { - دิ }
$$

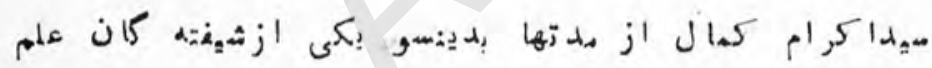

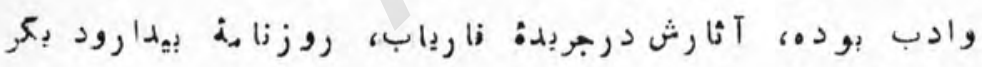

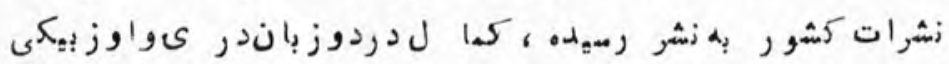

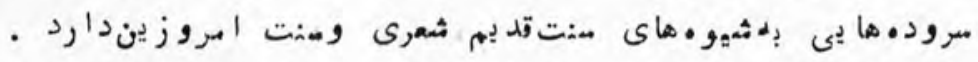

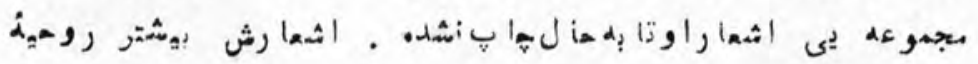

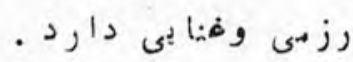




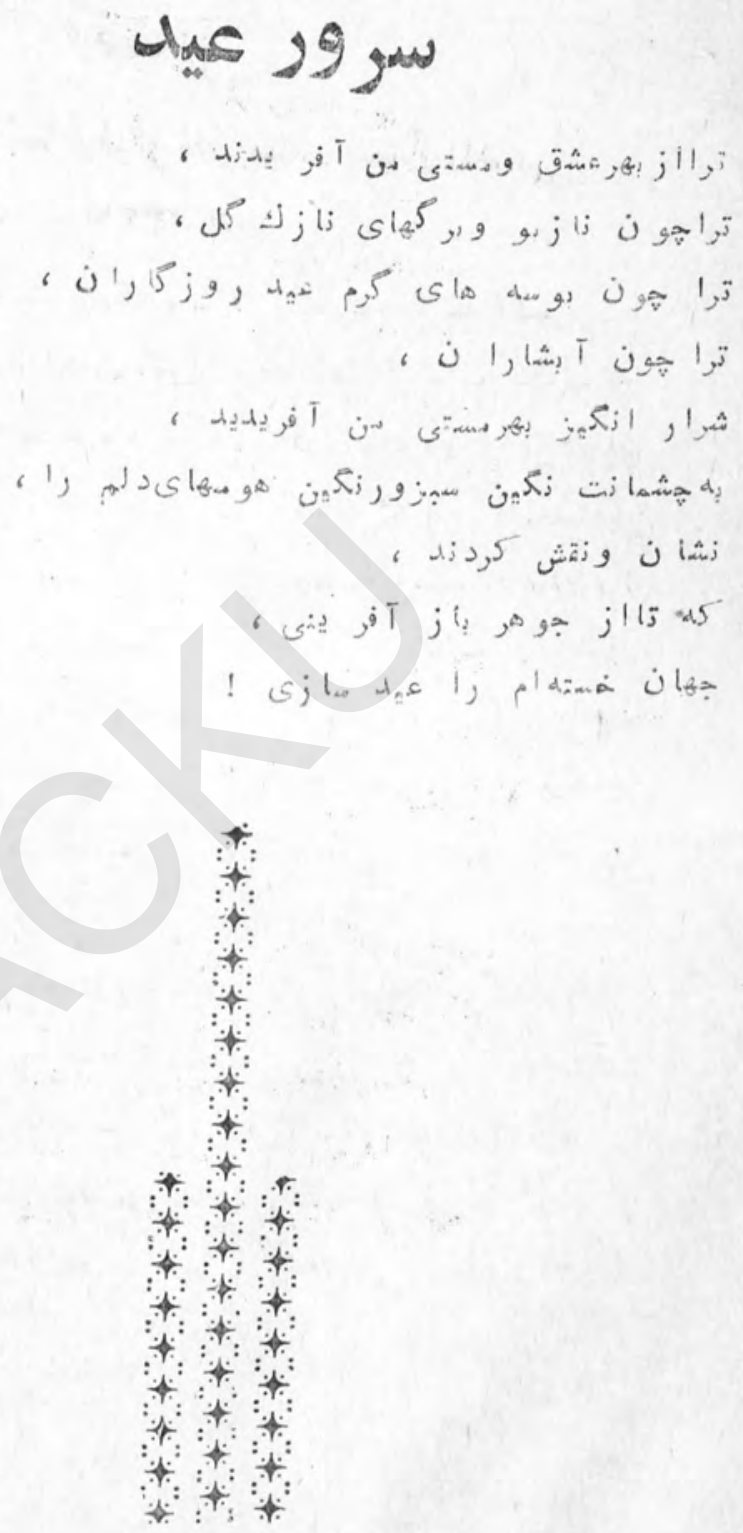




\section{تون}

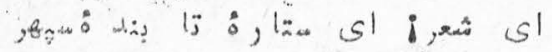

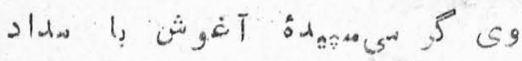

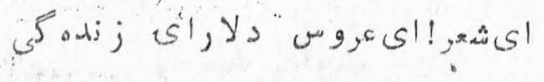

بو

$$
\text { * * * * * * * * }
$$

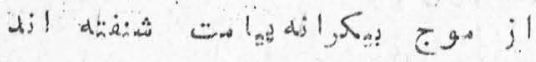

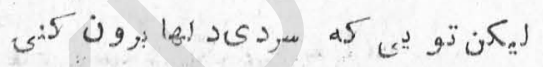

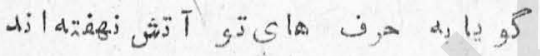

*

*

تو

قالم

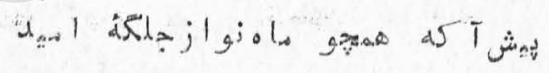

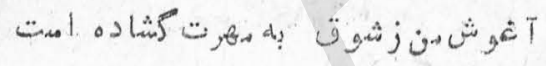

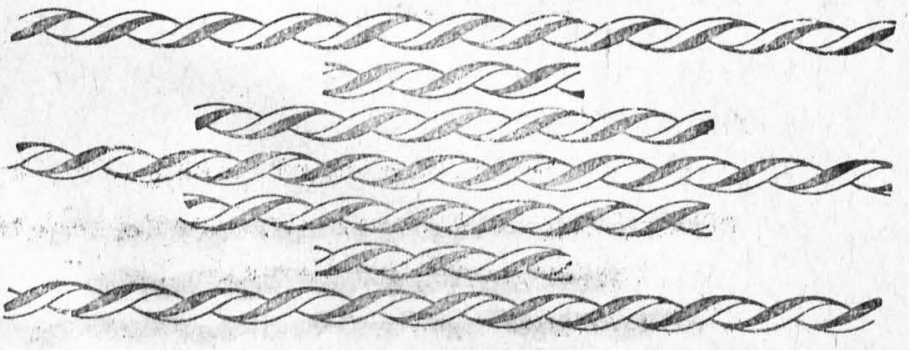




$$
\begin{aligned}
& \text { * * * * } \\
& \text { ائشمر!مرهم دربر كو يأ بى تو من }
\end{aligned}
$$

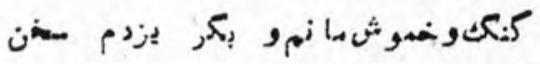

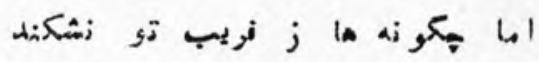

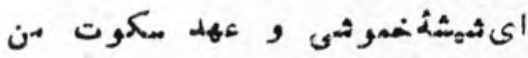

$$
\begin{aligned}
& \text { * * * }
\end{aligned}
$$

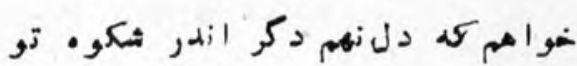

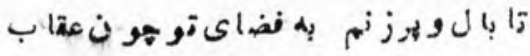

$$
\text { دراوج برجهاى تو هن مازه بيكنم }
$$

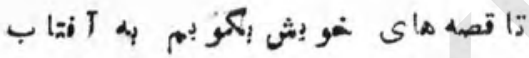

*

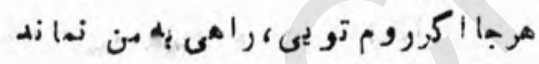

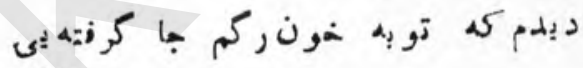

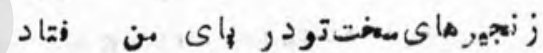

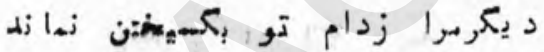

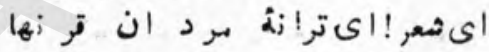

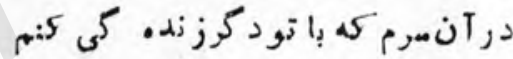

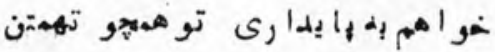

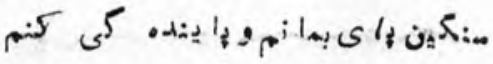

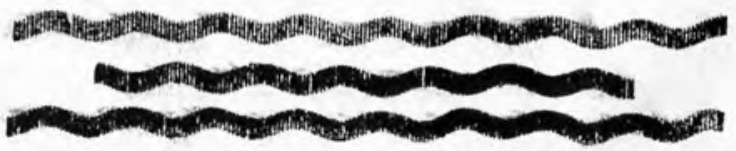




\section{راهى كه بايد رفت

$$
\text { نشار زتحد روان از براى رنجهران }
$$

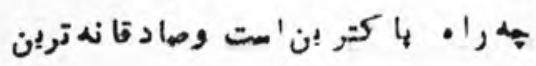

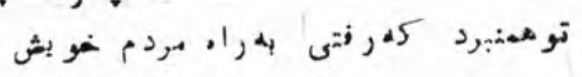

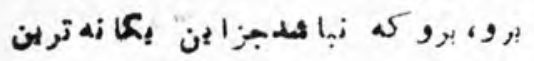

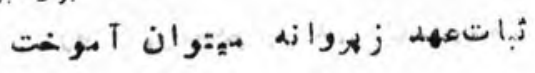

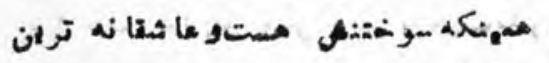

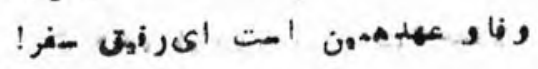

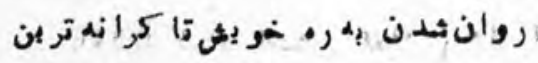

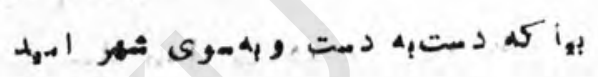

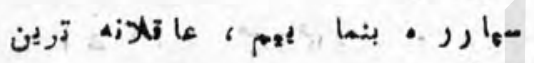

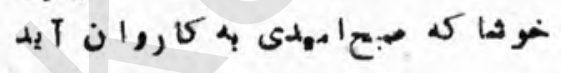

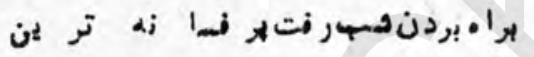

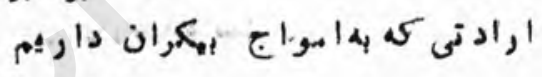

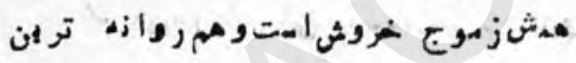

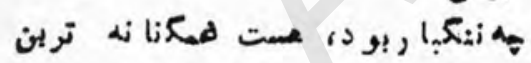

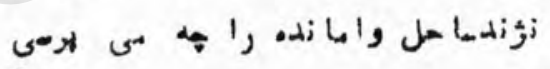

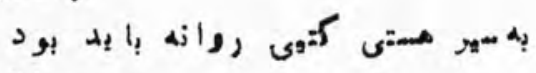

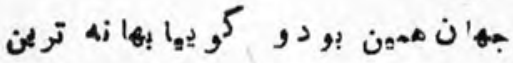

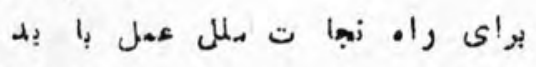

روانه بودن واعمال مادمازه تران

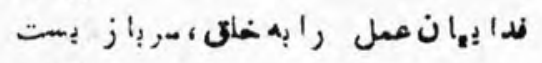

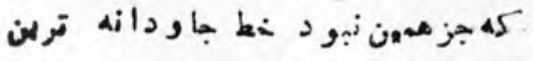

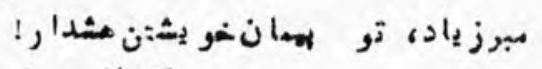

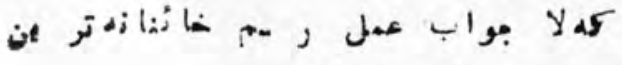

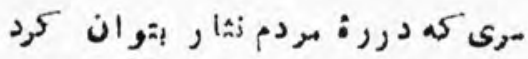

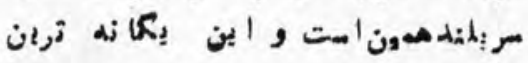




\section{حسرت خالقى}

نجيمب اللهحسر تخخا لقى فوز زله عبه الخخالق

. ت

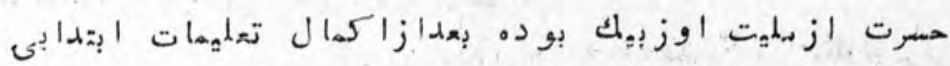

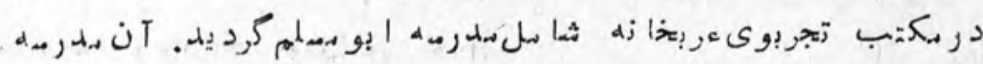

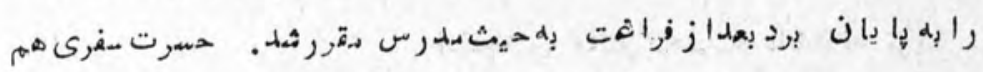

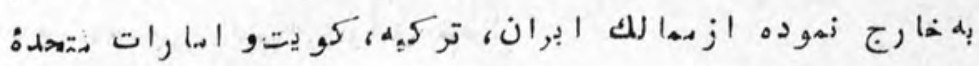

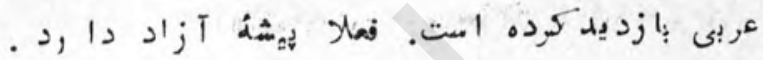

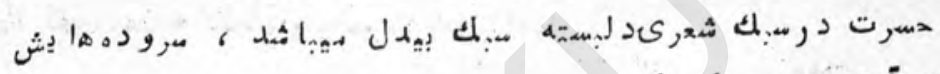

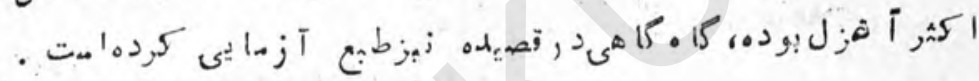

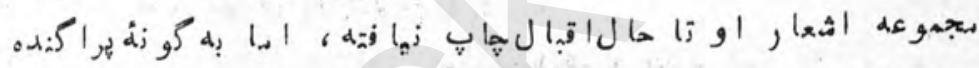

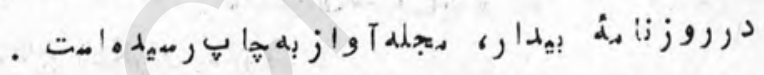

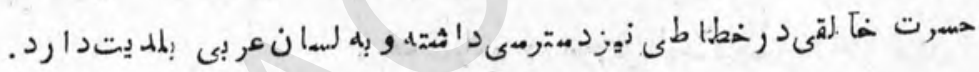

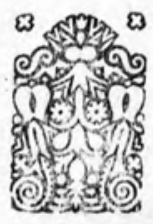


فطرتحق جويان

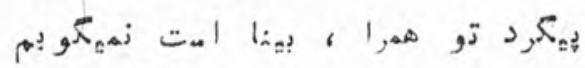

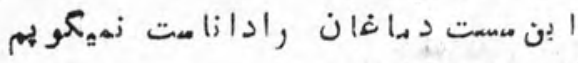

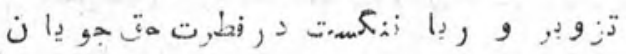

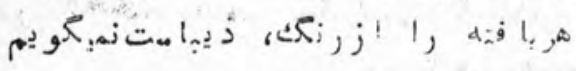

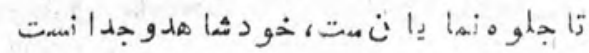

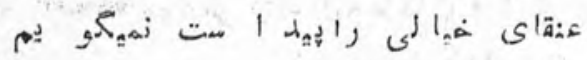

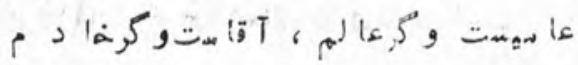

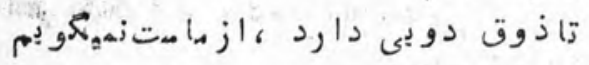

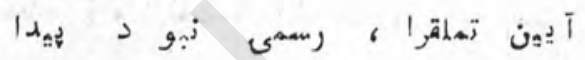

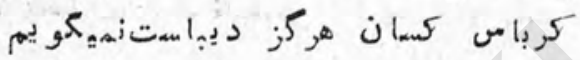

كرزتش بهد يو ارمتر، يا جان به ت:ش ؛ا رست

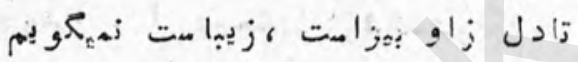

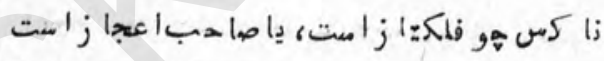

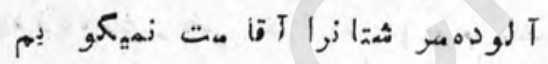

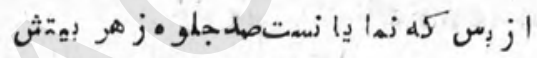

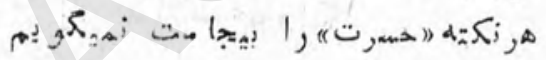

$\$ 10$ 
سحلدهاه الفت

جلو :الفت هبارى ازجهان هادرا مـ

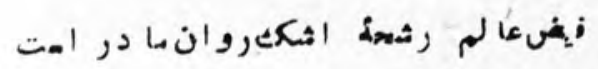

در

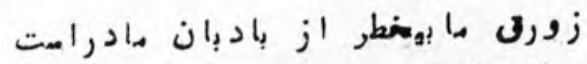

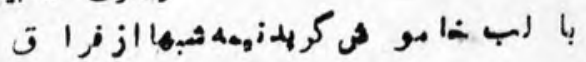

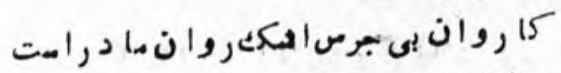

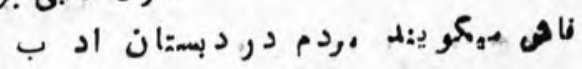

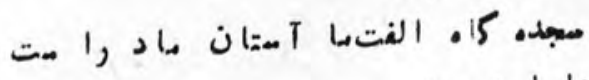

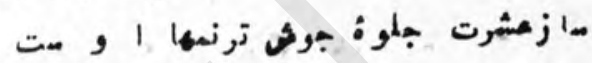

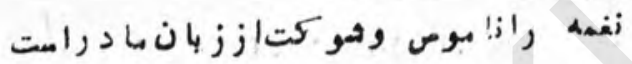

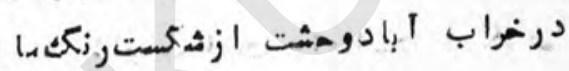

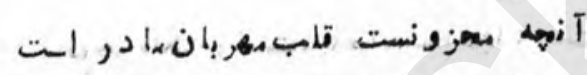

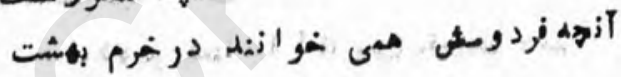

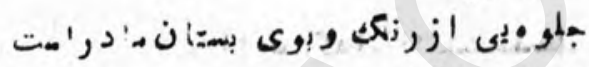

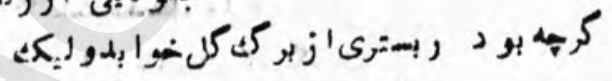

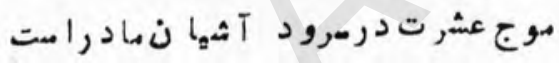

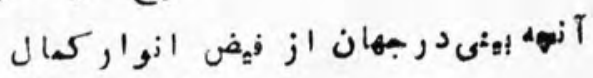

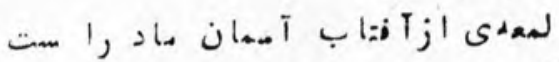

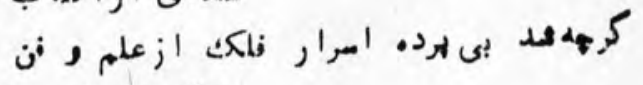

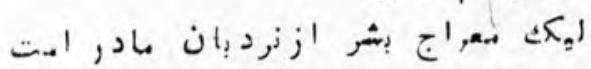

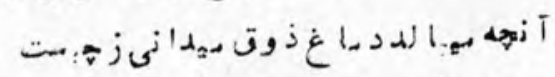

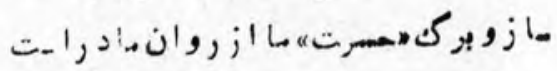

P17 
مخهمس برغز لحا فظ

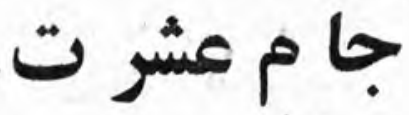

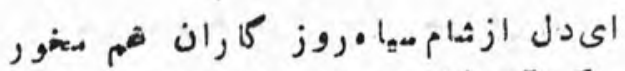

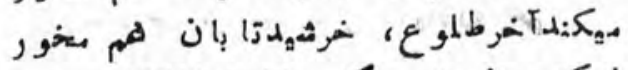

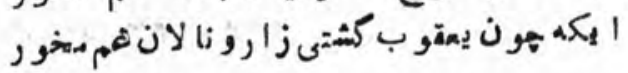

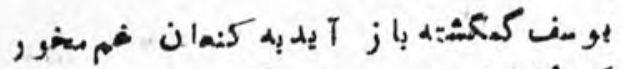

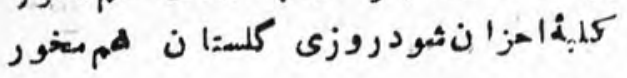

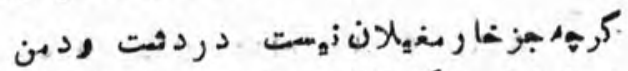

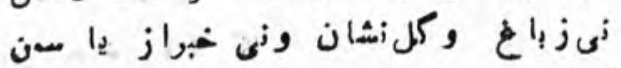

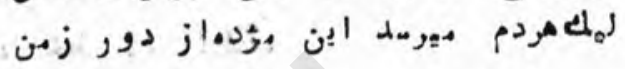

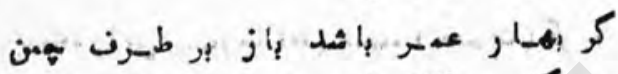

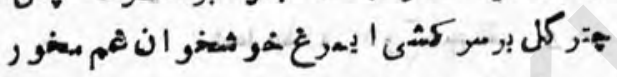

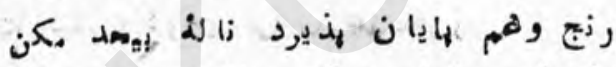

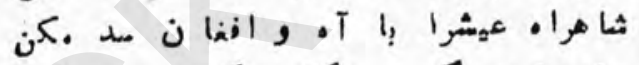
جامشرت كرم:سر كثت كاه

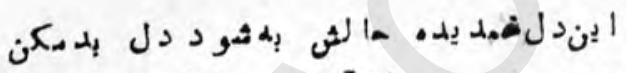

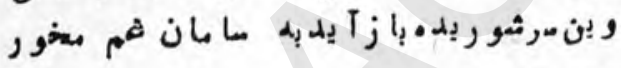

كربه كوش هيرخ هندى عرضداد ماد ما نرفت

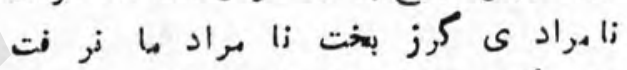

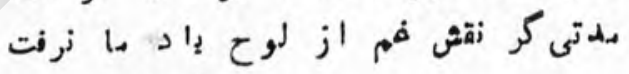

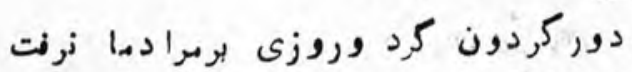

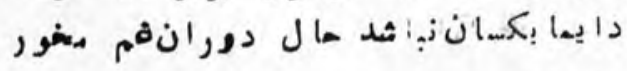

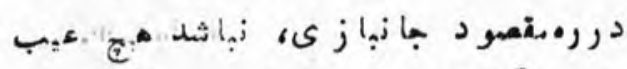

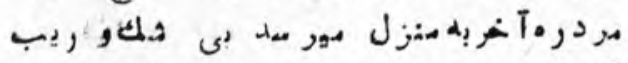

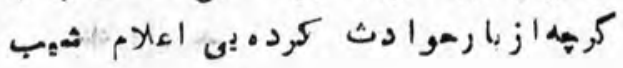

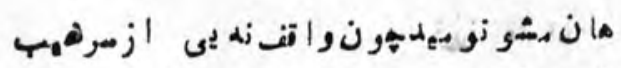

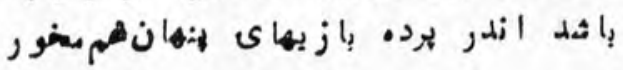

rir 


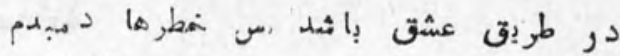

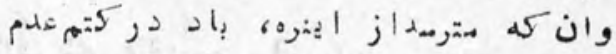

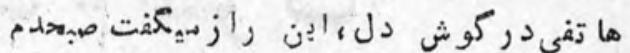

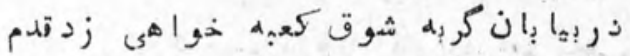

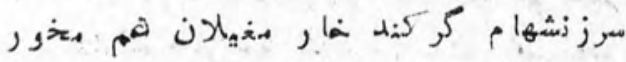

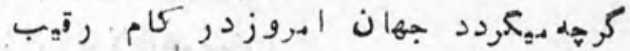

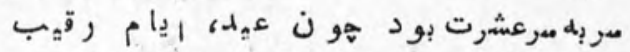

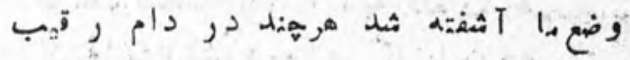

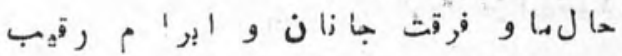

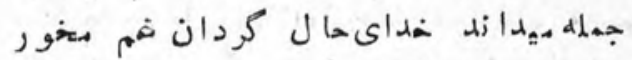

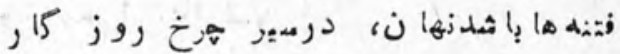

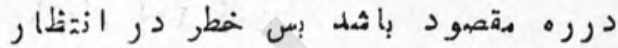

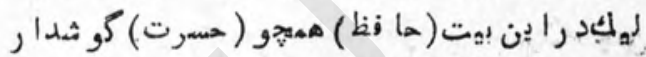

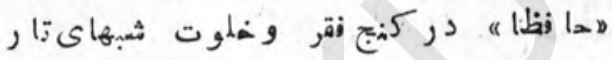

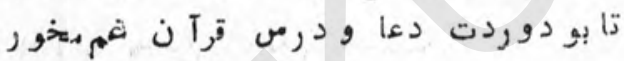

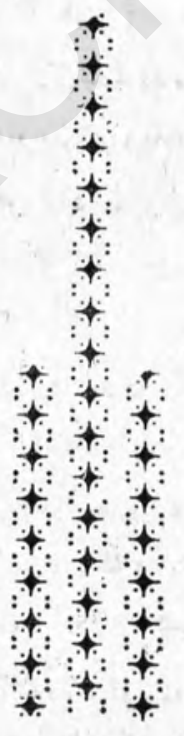


فو

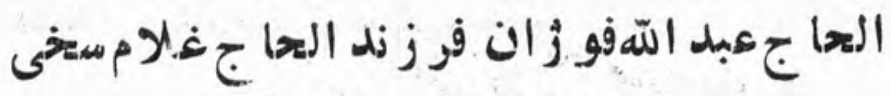
ت . I IFPO

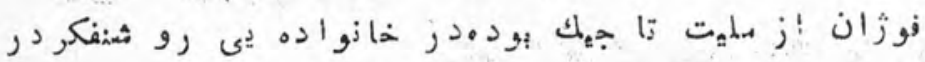

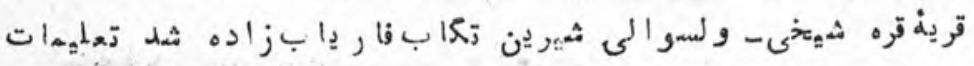

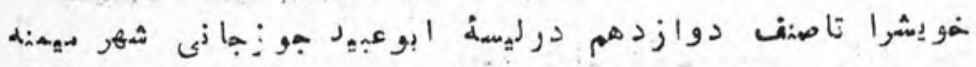

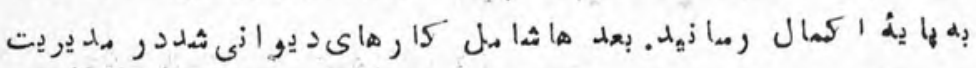

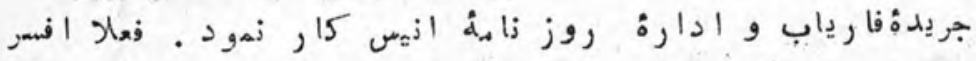

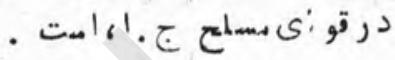

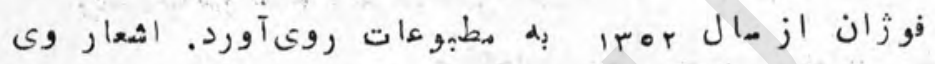

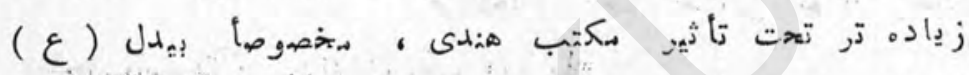

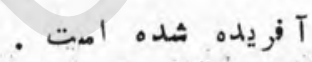

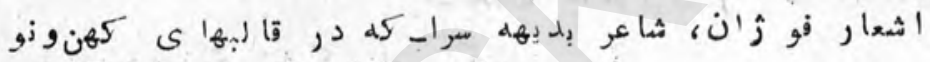

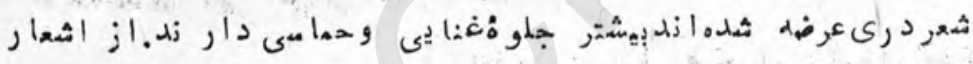

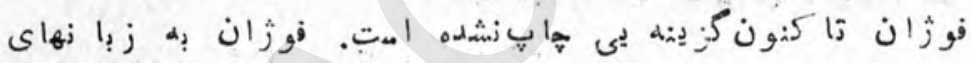

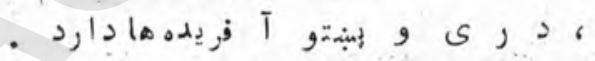

$P 19$ 


\section{نيرنكعثالفت}

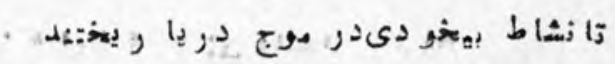

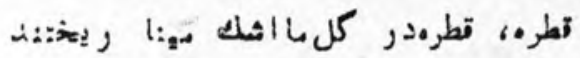

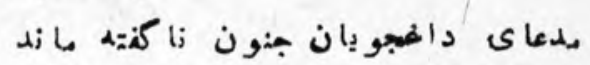

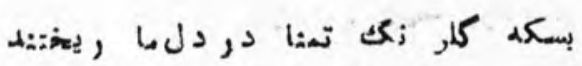

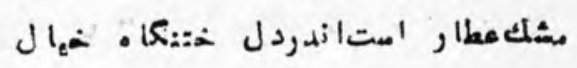

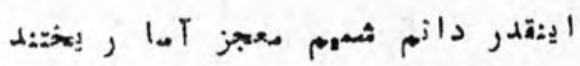

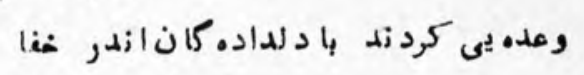

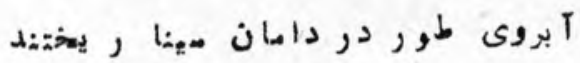

$$
\text { دامن يو مضف در يدند ومركو مكن شكست بروي }
$$

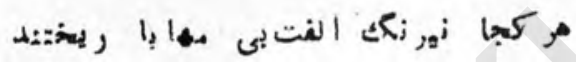

$$
\text { هشبهتآ سو د.كى برد نه از مبجنو ن و ريك }
$$

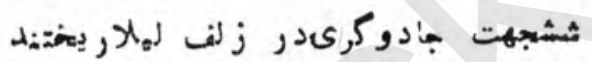

$$
\text { نطرت ديوانمكى ثيكيردل تاكشت باز }
$$

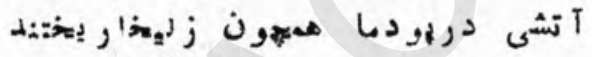

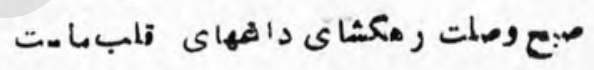

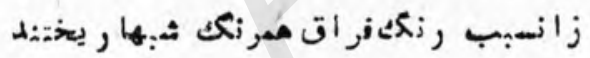

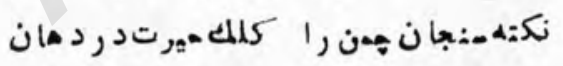

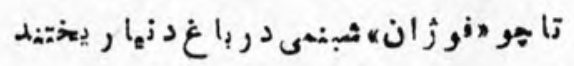

\section{(2)}


مغخمس برغزل بيد ل عليه الرحمه

\section{نلا}

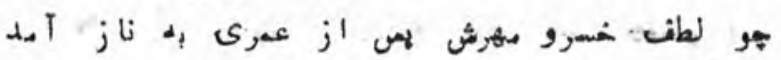

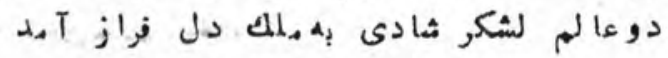

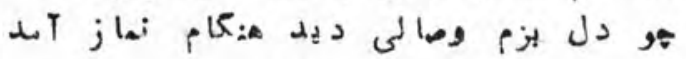

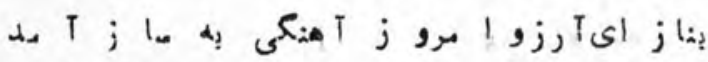

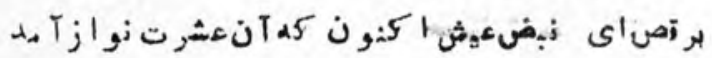

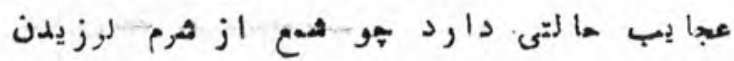

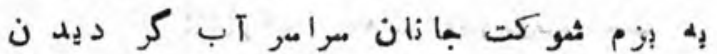

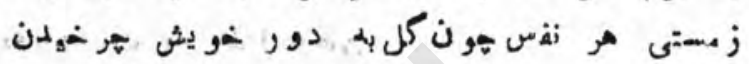

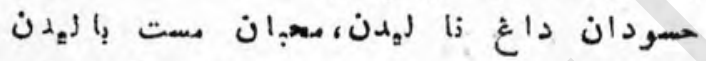

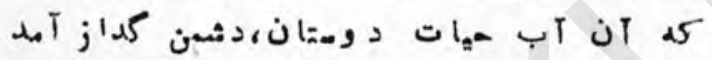

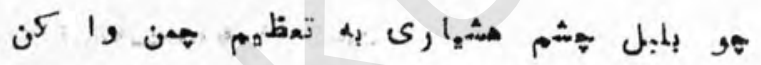

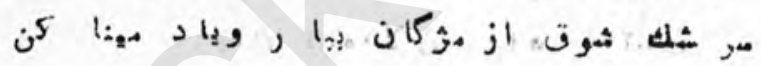

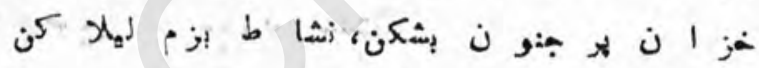

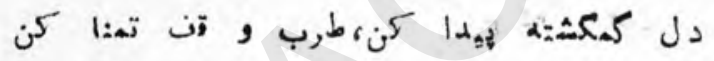

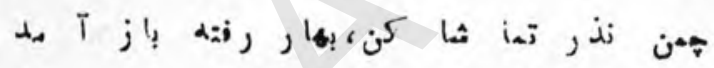

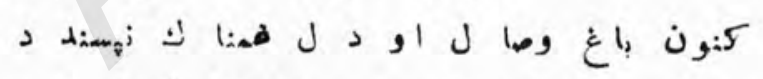

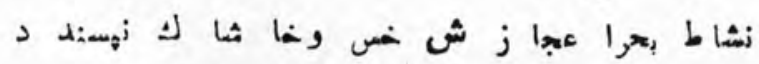

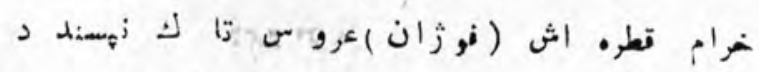

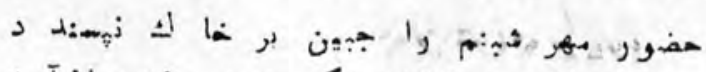

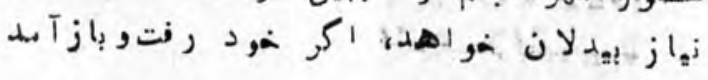




$$
\begin{aligned}
& \text { رباعىمنقوط } \\
& \text { شفت زئت زن نقش جيميش }
\end{aligned}
$$

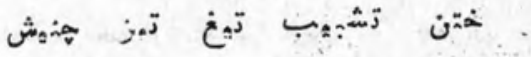

$$
\begin{aligned}
& \text { تا ثيب خيز تختج:ت إنغت }
\end{aligned}
$$

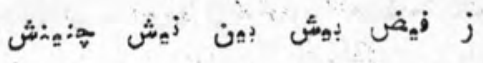

$$
\begin{aligned}
& \text { رباعيات }
\end{aligned}
$$

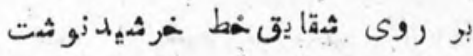

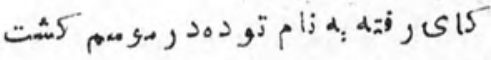

$$
\begin{aligned}
& \text { حزب تو به باراهت به كمزار بوطن }
\end{aligned}
$$

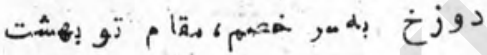

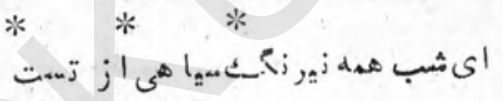

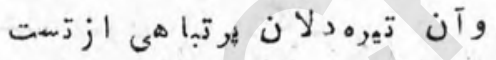

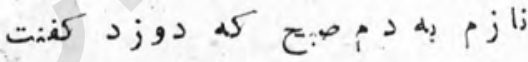

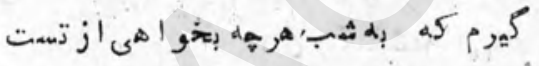

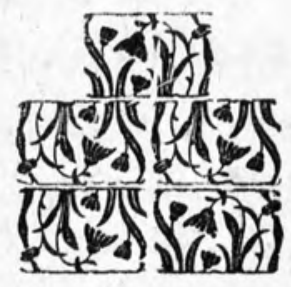




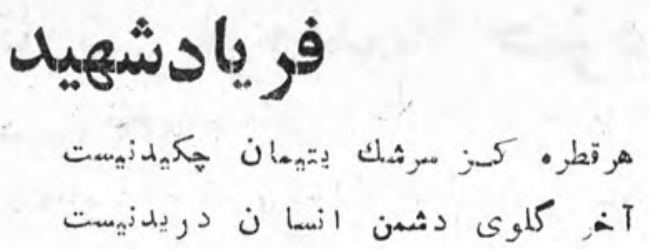

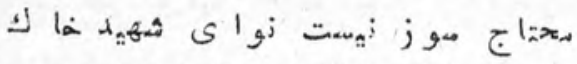

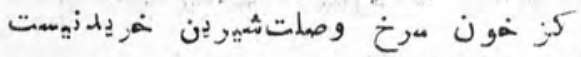

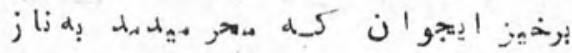

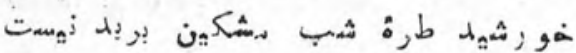

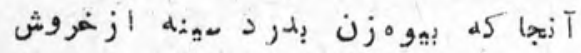

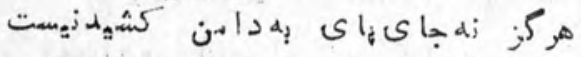

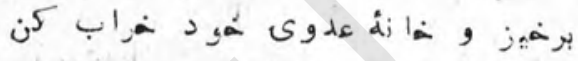

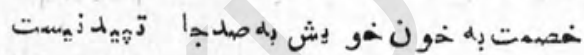

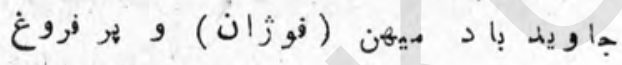

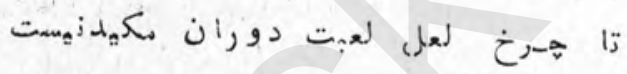

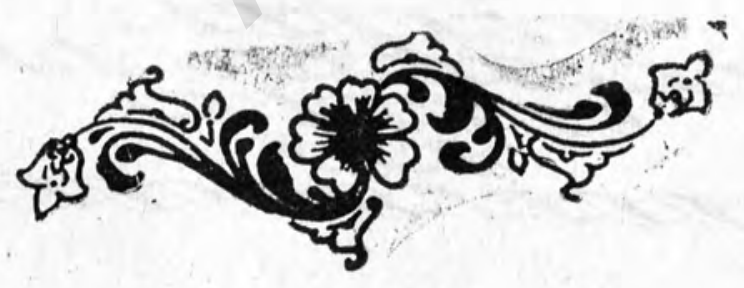




\section{عبدالاحدتارشىفرزندهلا حمزه}

ت

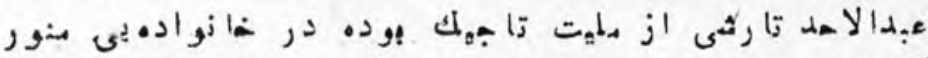

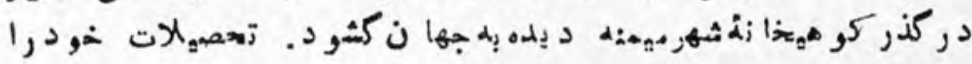

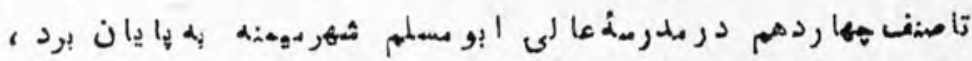

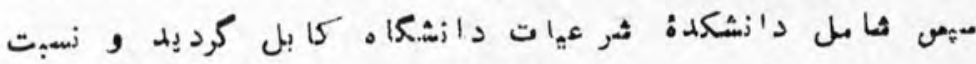

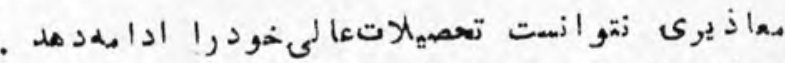

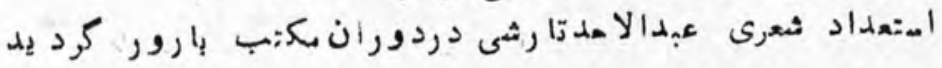

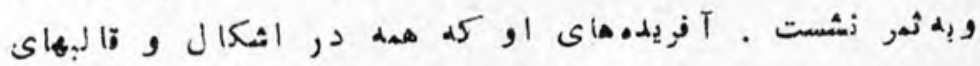

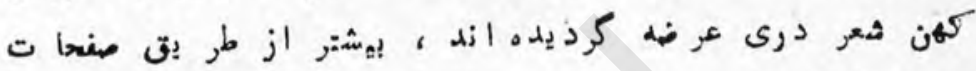

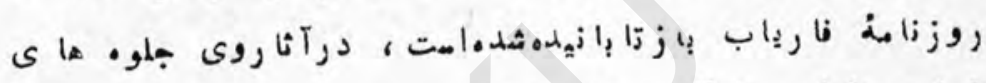

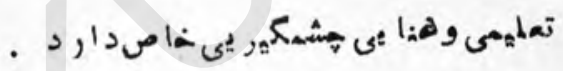

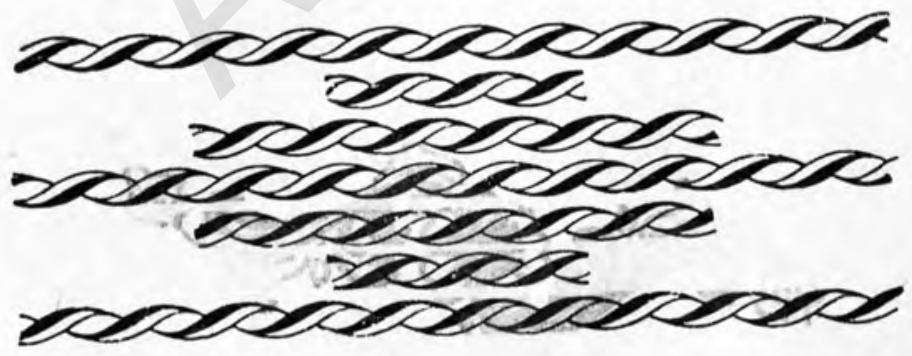


وقت

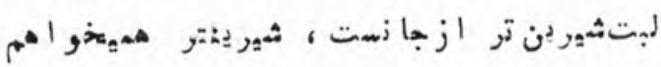

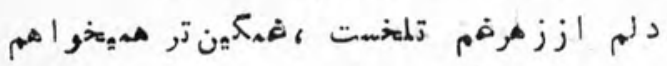

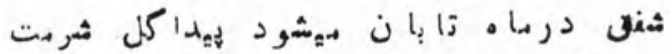

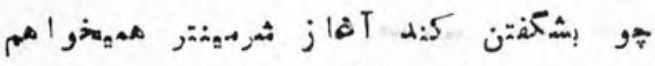

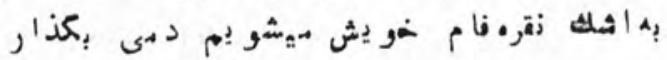

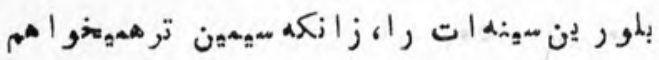

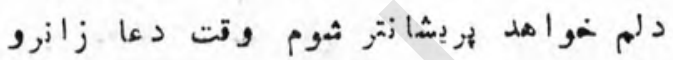

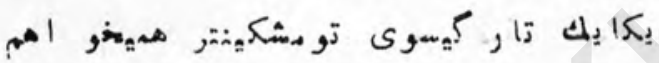

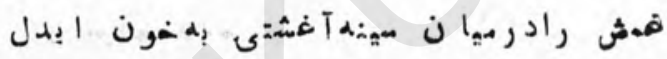

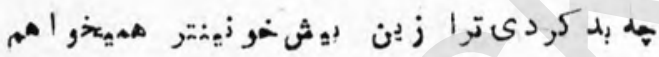

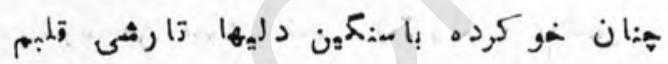

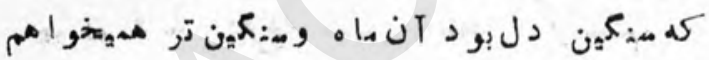

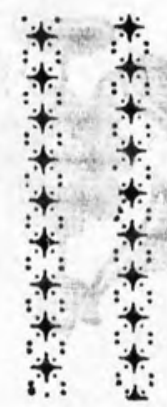

Pro 
كوهر يكاز_هله

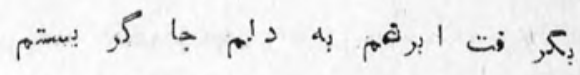

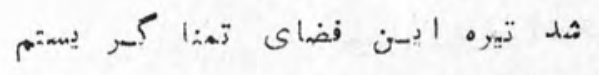

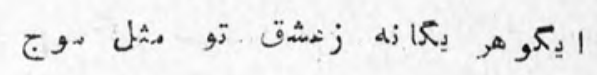

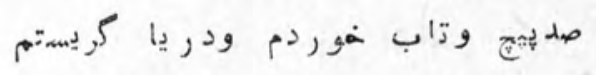

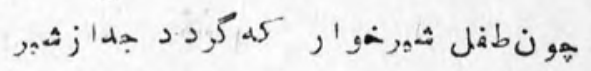

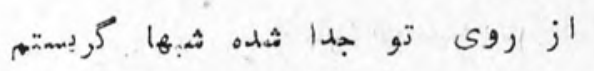

اشكى

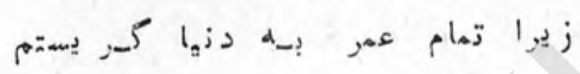

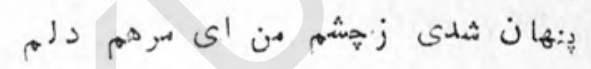

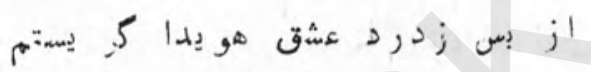

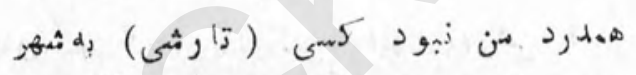

جو ن لاله 


\section{داغزنتك}

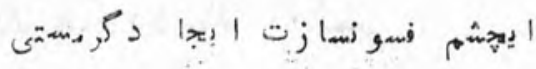

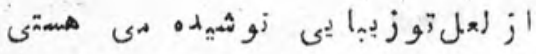

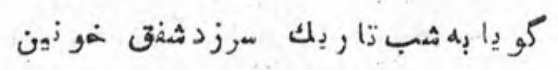

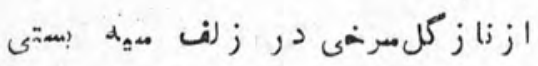

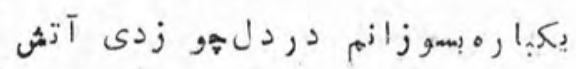

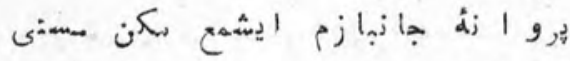

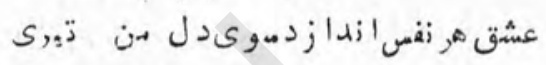

اى

$$
\text { اشكمه هو سى كلمكون از ديده فرو ريزد }
$$

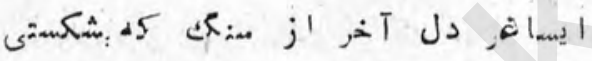

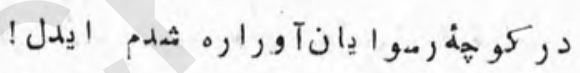

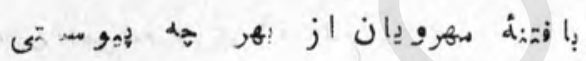

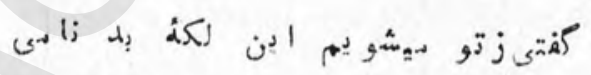

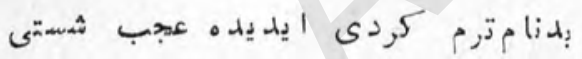

$$
\begin{aligned}
& \text { ازد ا غ كريز ت زيستاى تار رشى مسمكين }
\end{aligned}
$$

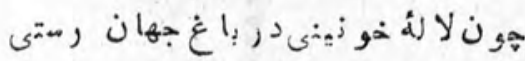

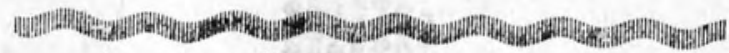

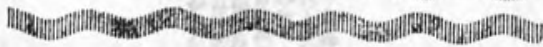

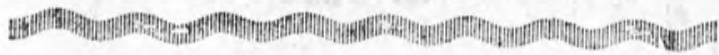


يلدا

فوز يه يلمدا فوزند عبد الاحده اولسى هـ هـ ت - Irra

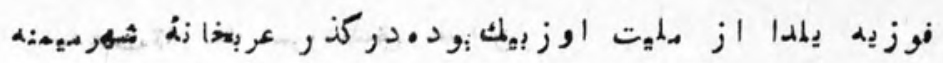

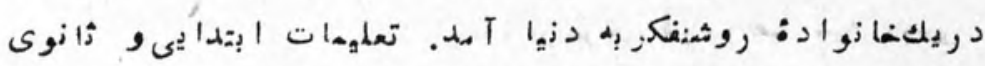

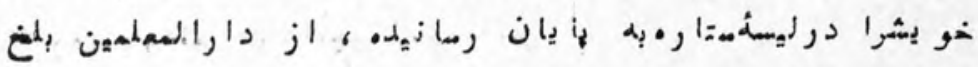

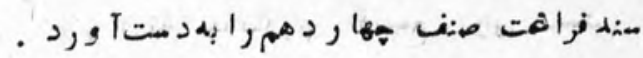

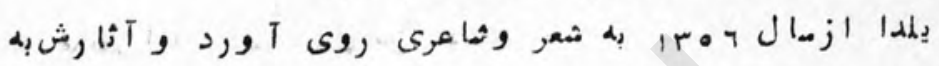

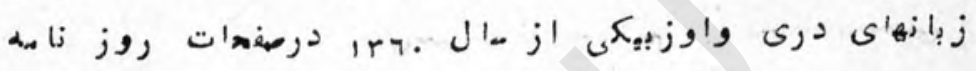

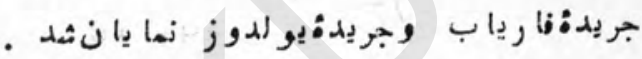

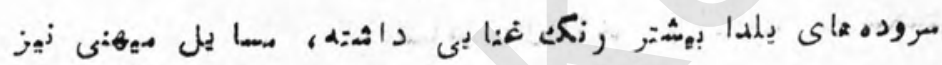

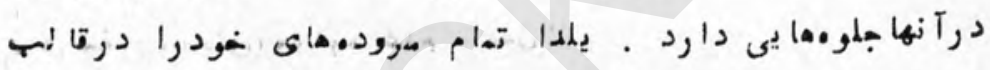

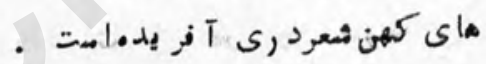

PrA 


\section{وطن عشّقى}

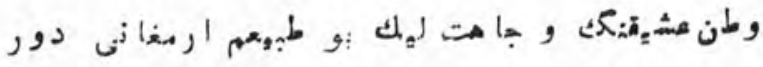

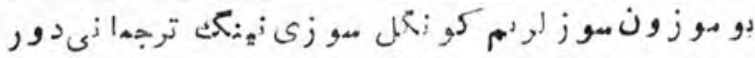

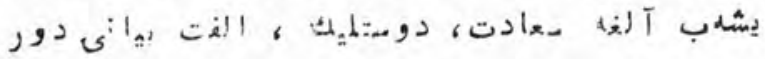

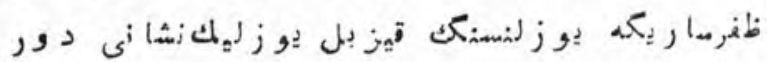

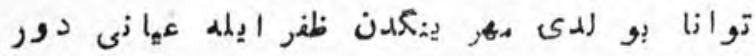

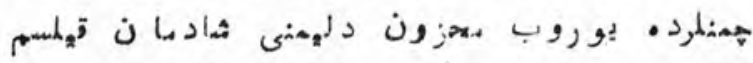

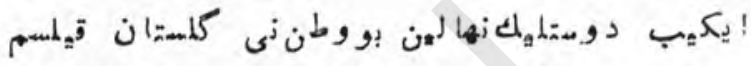

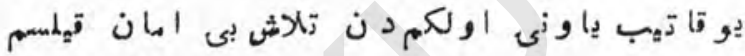

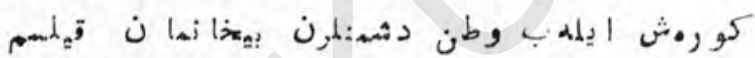

تلاق ايلهب بو عزم جاودان فخريم جهانىدور

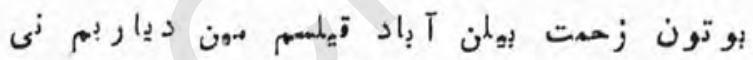

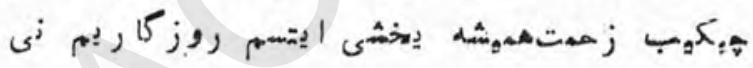

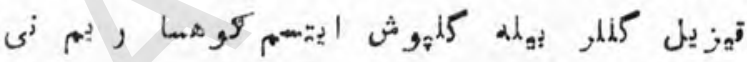

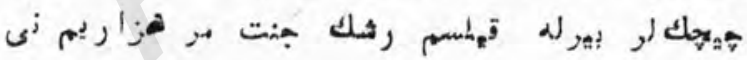

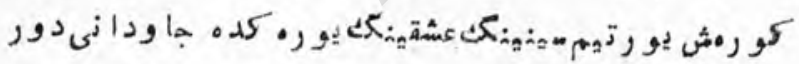

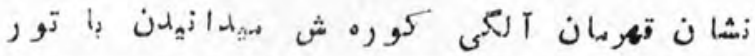

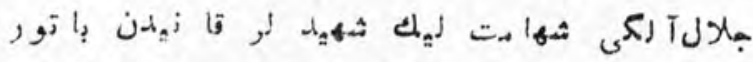

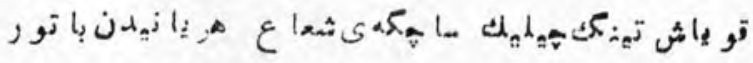

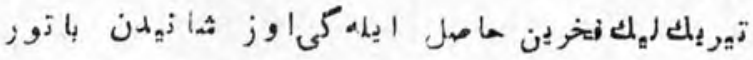

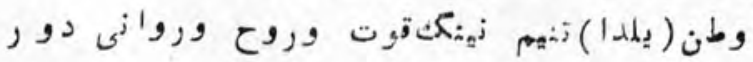

\section{触}




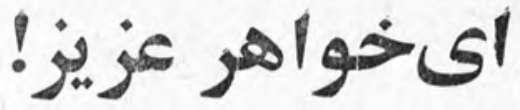

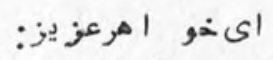

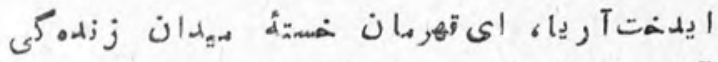

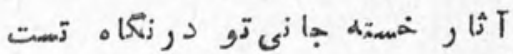

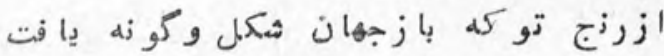

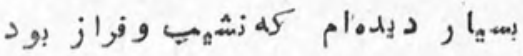

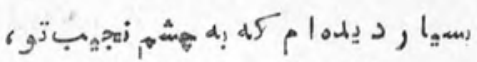

$$
\begin{aligned}
& \text { درد وملال بودوثمبما زكلماز بود }
\end{aligned}
$$

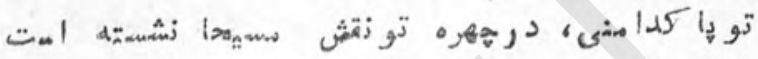

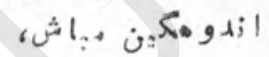

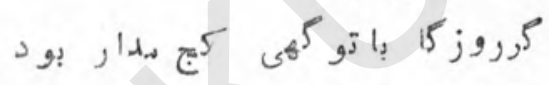

$$
\text { زيرانصيب توز أنو }
$$

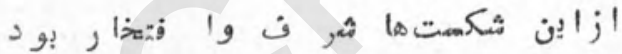

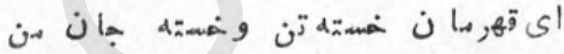

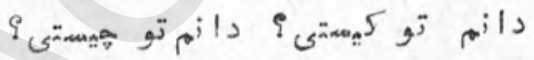$$
\text { ئكar }
$$

$$
\text { ، }
$$

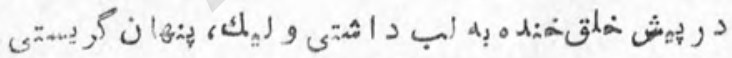

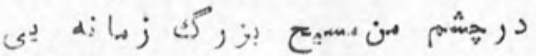

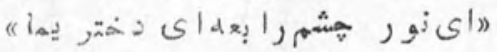

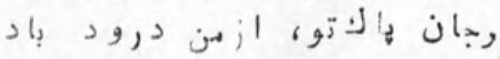

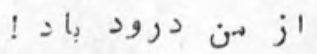

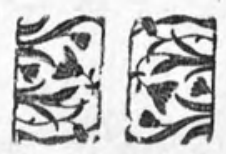




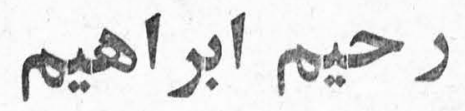

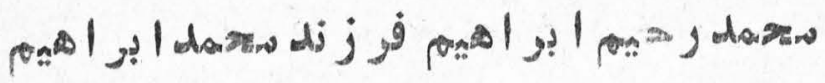

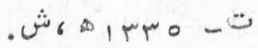

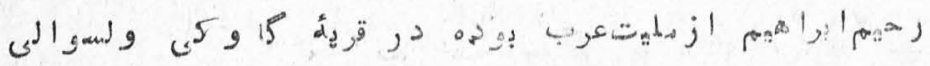

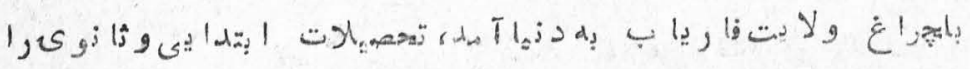

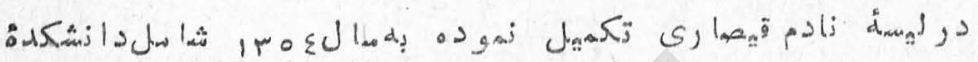

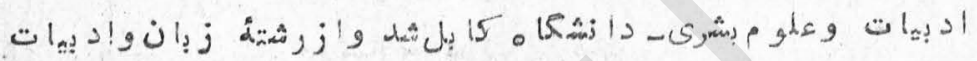

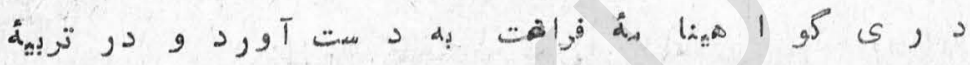

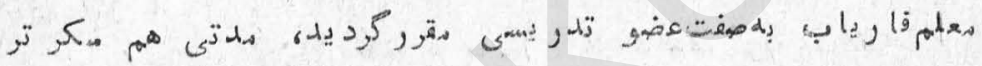

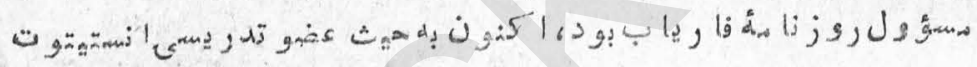

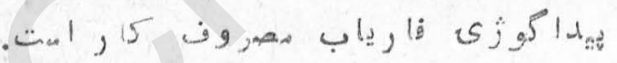

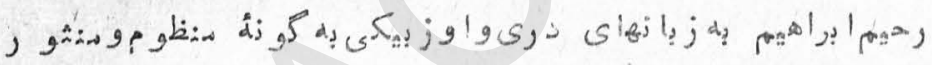

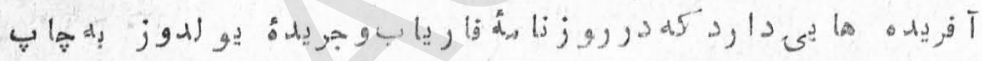
ر J

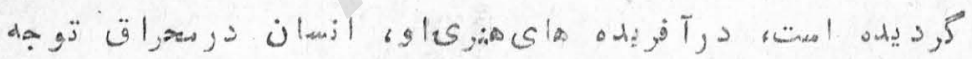

$$
\text { - 3, }
$$

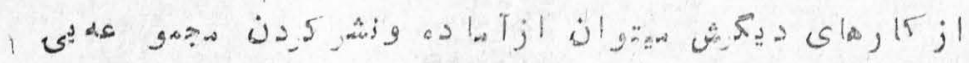

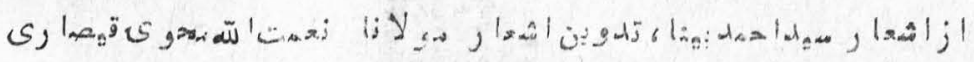

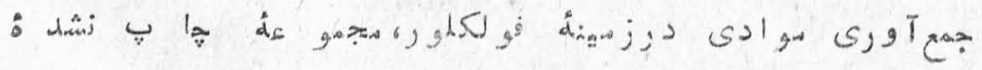

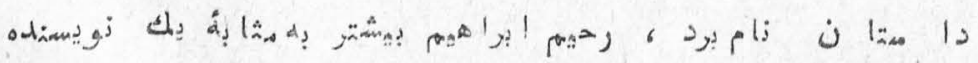

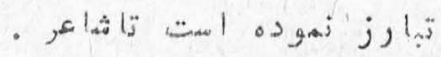

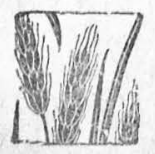




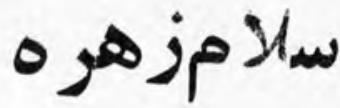

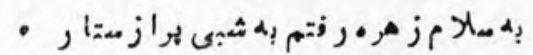

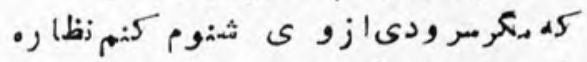

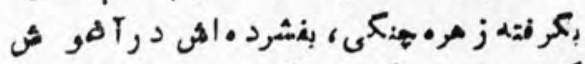

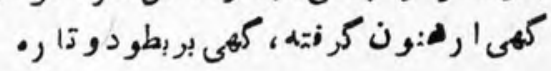

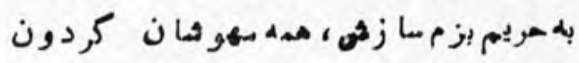

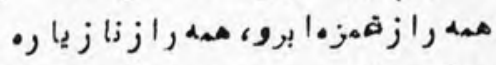

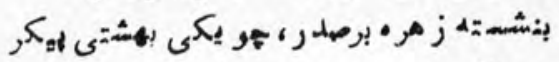

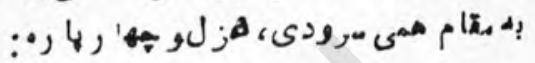

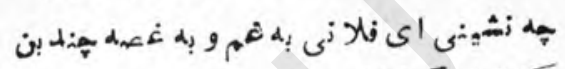

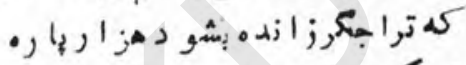

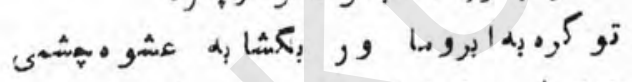

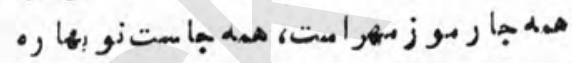

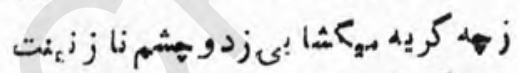

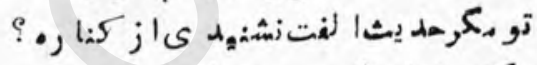

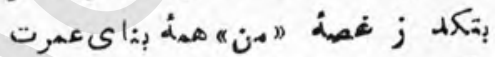

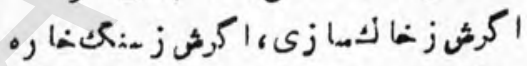

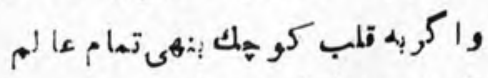

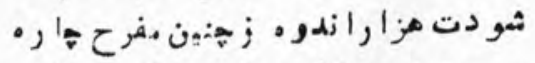

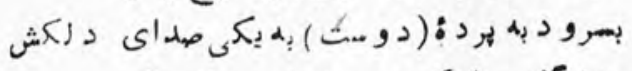

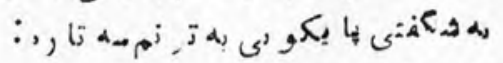

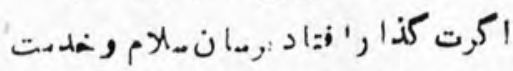

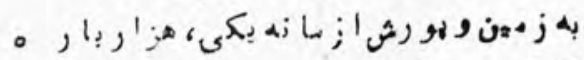

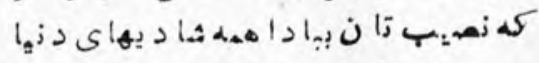

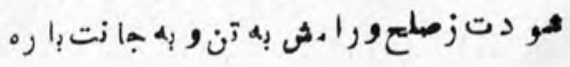


بر شط كاغذ

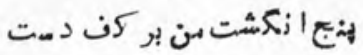

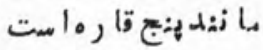

$$
\begin{aligned}
& \text { j=x j o! } \\
& \text { ا بن هنج بو ا برزيستت با مم } \\
& \text { در صر } \\
& \text { براد ربا همأ مدت } \\
& \text { د, كو هو }
\end{aligned}
$$

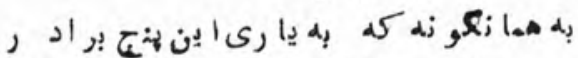

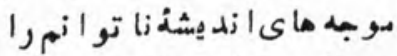

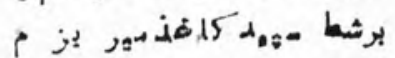

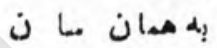

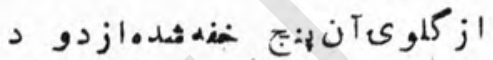

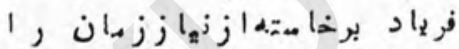

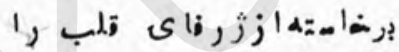

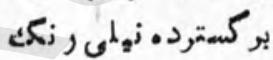

$$
\begin{aligned}
& \text { : } \\
& \text { ؟ }
\end{aligned}
$$$$
\text { ها }
$$

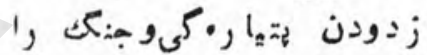

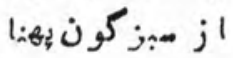

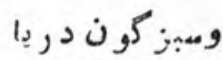$$
\text { آى مردم }
$$$$
\text { ما زئدة }
$$

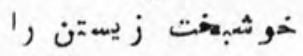$$
\text { و با 15م بون دون }
$$

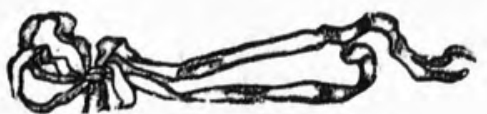




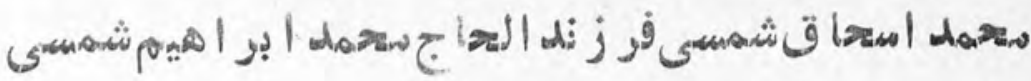
ت

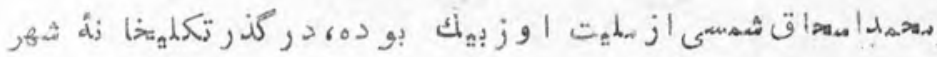

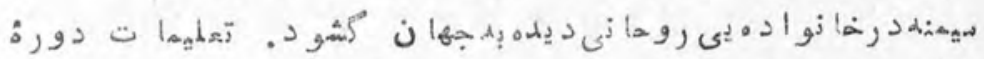

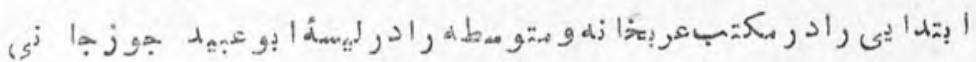

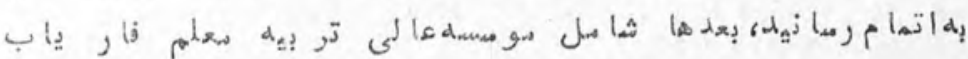

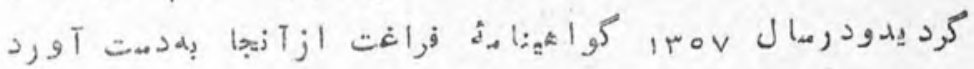

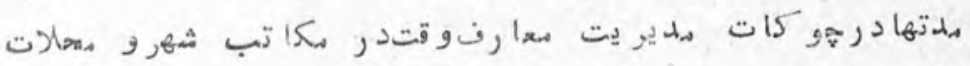

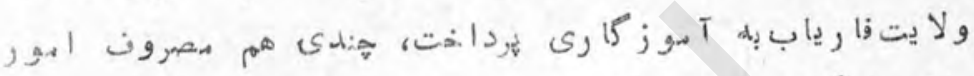

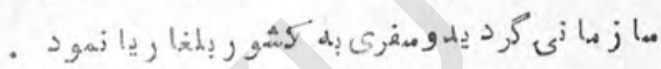

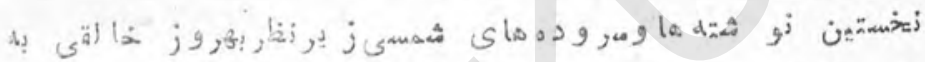

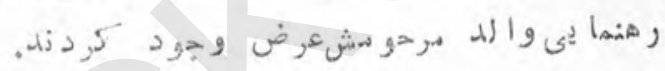

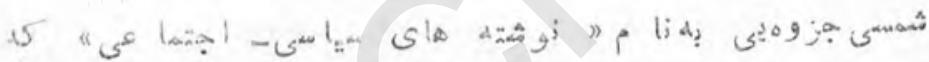

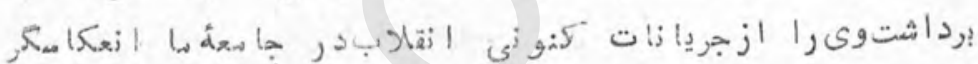

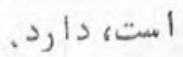

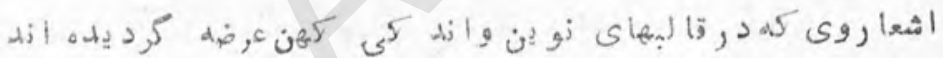

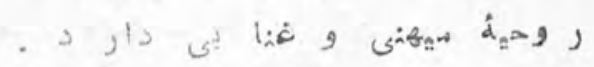

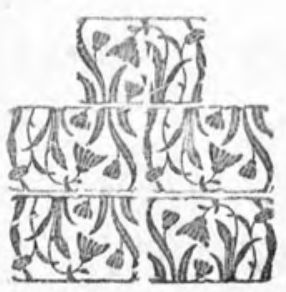

pre 


\section{شقايق}

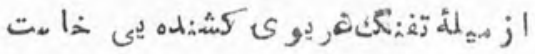

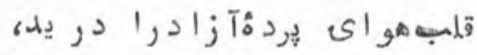

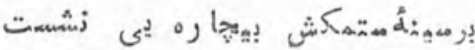

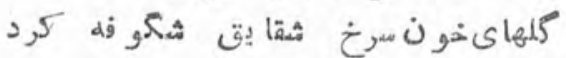

برنهيمرعز يزد لشهر يا نما

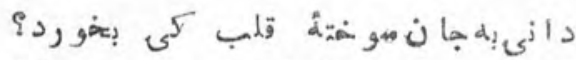

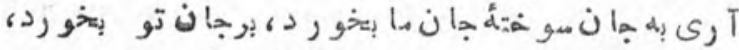

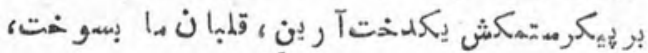

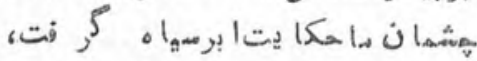

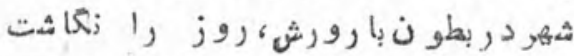

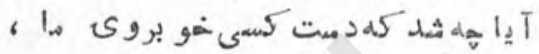

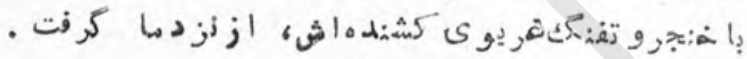

*

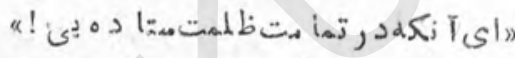

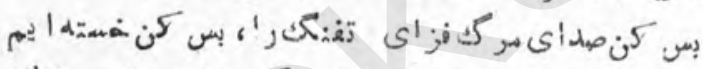

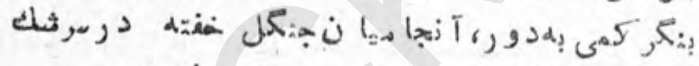

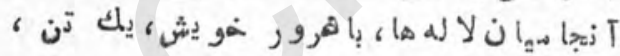

$$
\begin{aligned}
& \text { ' }
\end{aligned}
$$

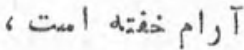

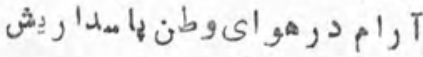

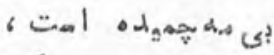

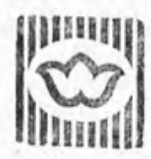

PPO 
بزم سرود

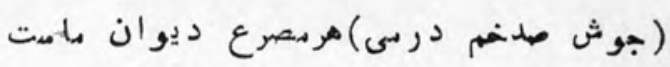

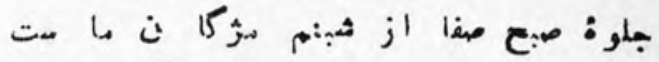

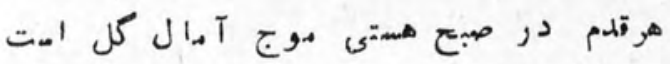

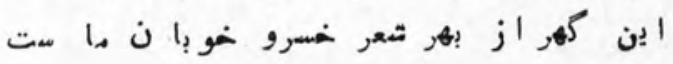

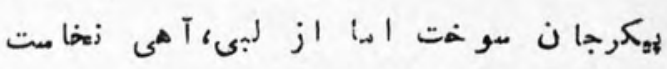

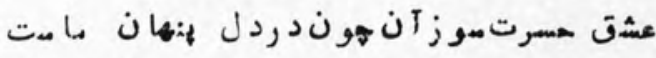

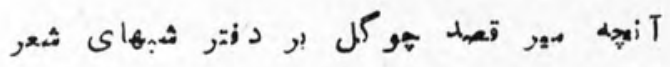

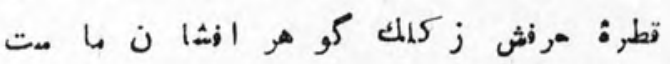

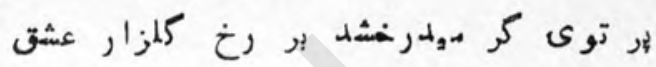

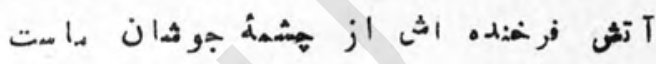

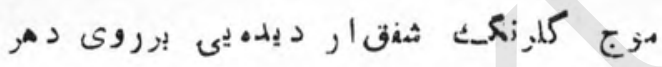

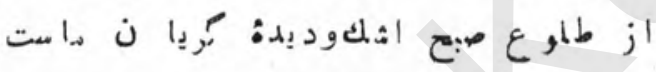

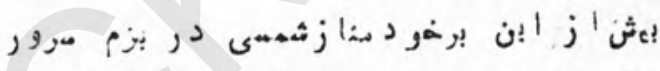

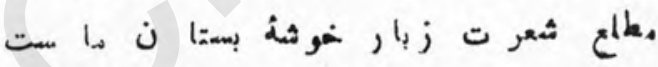

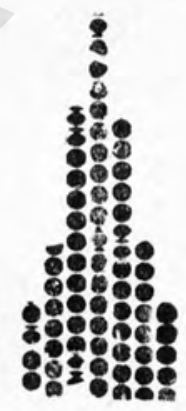

PFT 
هواى باغ

در Tكرإن فروغ دلازميز آفتاب،

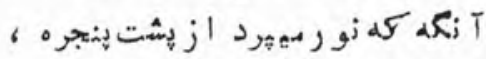

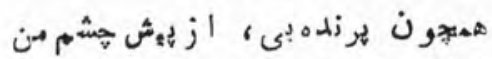

آزأكه

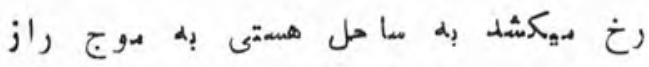

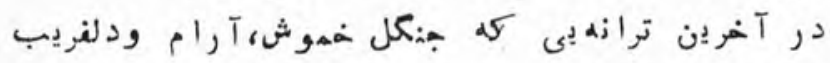

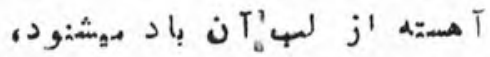

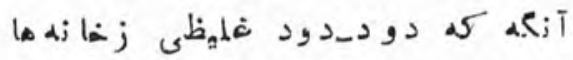

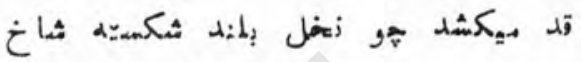

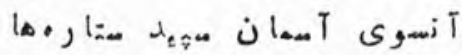

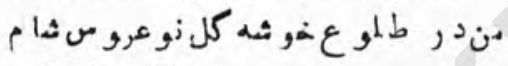

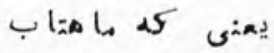

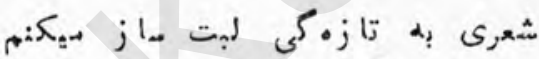

مأر

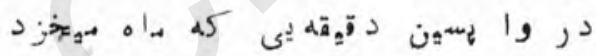

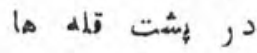

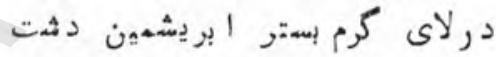

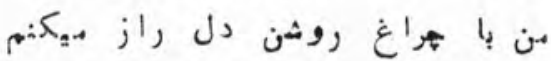

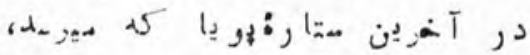

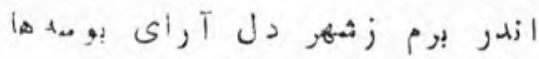

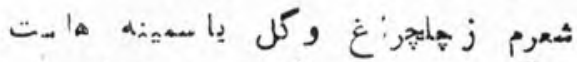

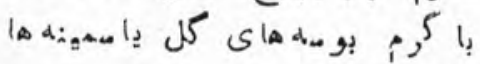

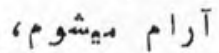

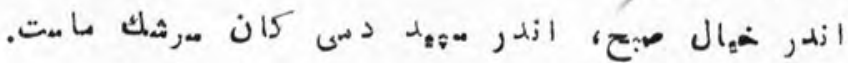

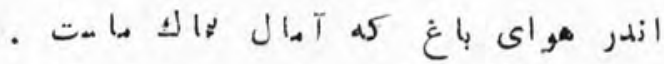

pry 


\section{$0.12 \sin 0$}

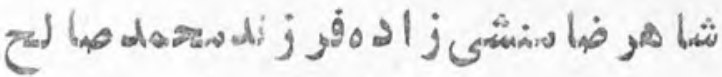 ش 6 D 1 P P - ت}

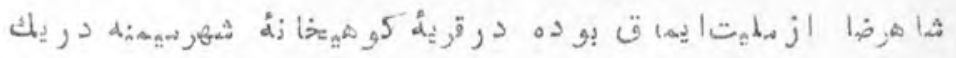

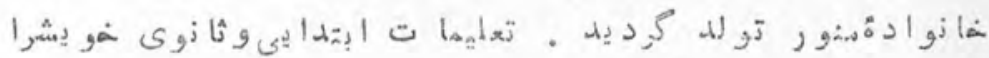

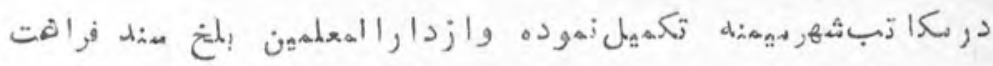

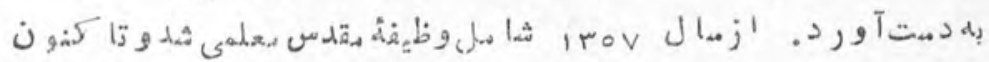

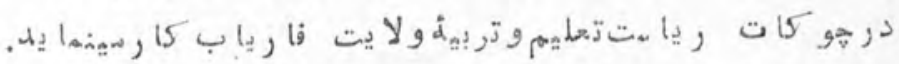

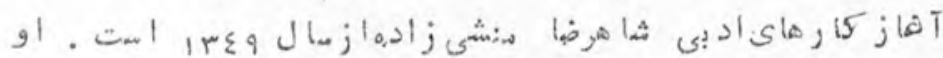

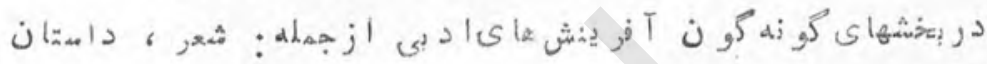

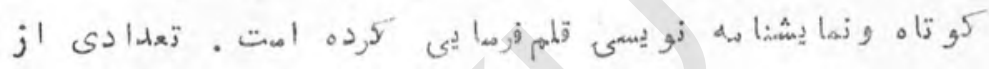

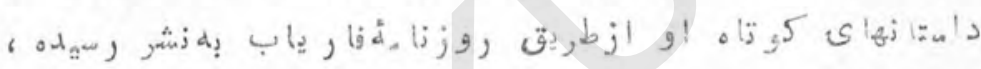

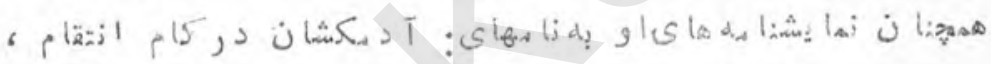

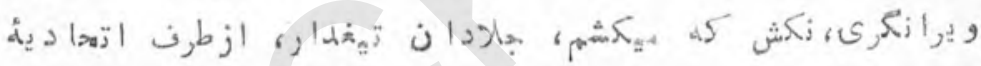

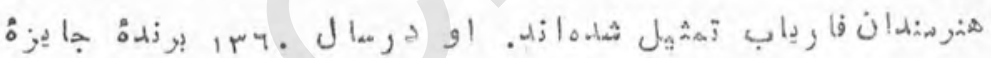

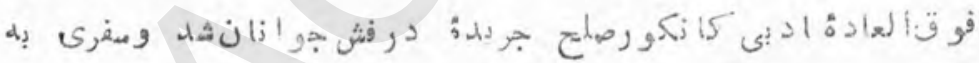

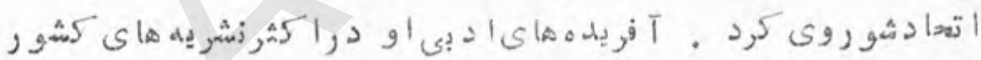

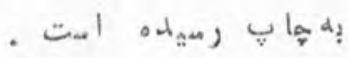

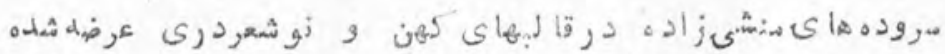

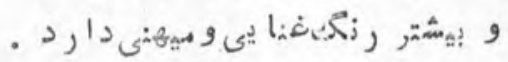

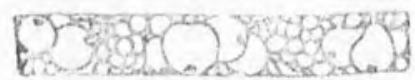




\section{كورنموكري}

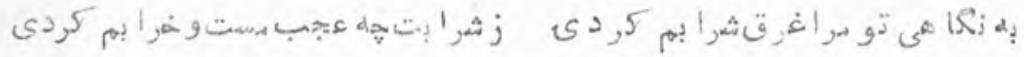

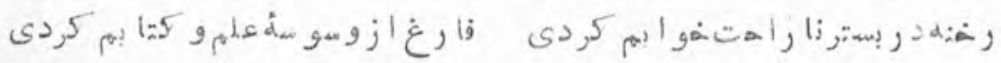

$$
\begin{aligned}
& \text { ى }
\end{aligned}
$$

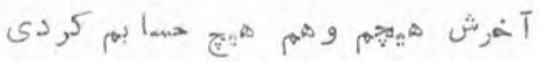

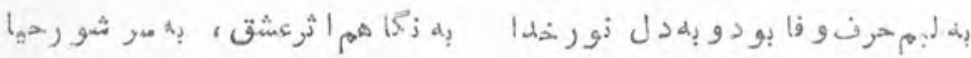

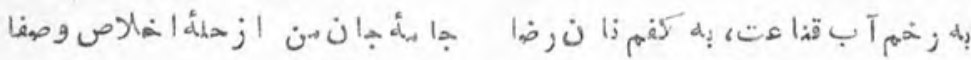

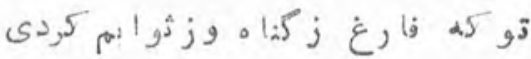

$$
\begin{aligned}
& \text { آ آمش ش }
\end{aligned}
$$

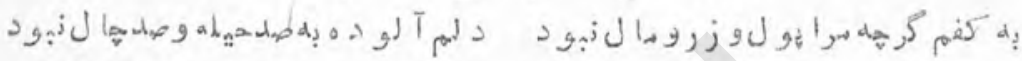

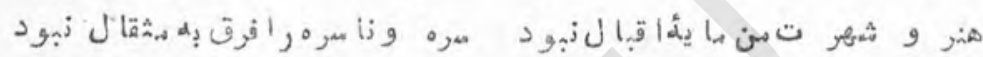

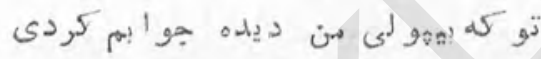

$$
\begin{aligned}
& \text { آنص ش }
\end{aligned}
$$

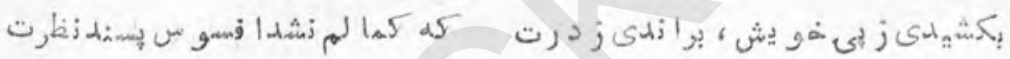

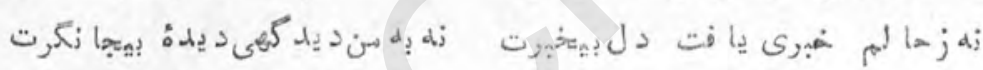

$$
\begin{aligned}
& \text { تو كa } \\
& \text { ا }
\end{aligned}
$$

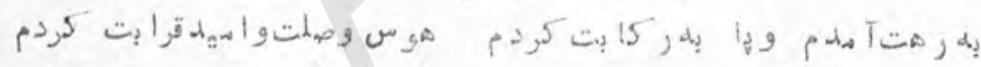

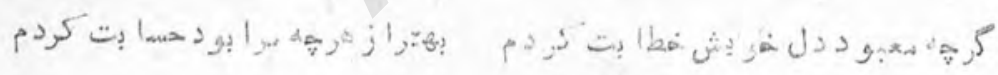

e

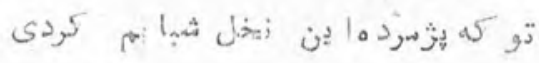

$$
\begin{aligned}
& \text { آ آش ش }
\end{aligned}
$$

\section{4.}


بل توين درد

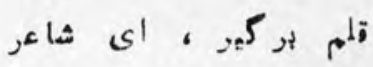

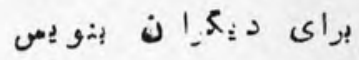

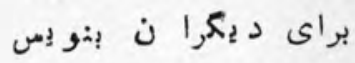

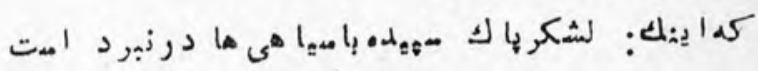
|

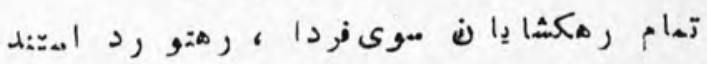

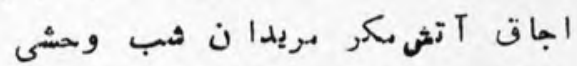

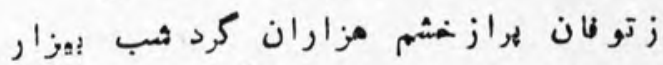

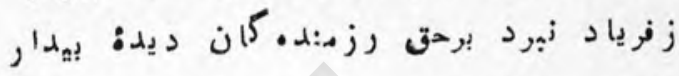

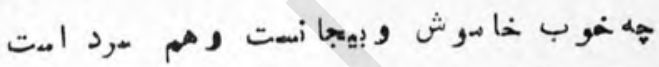

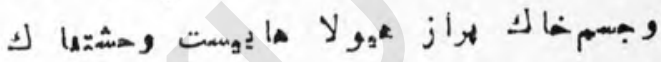

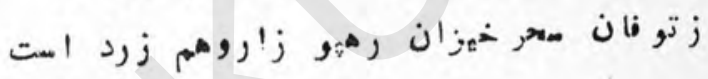
* * *

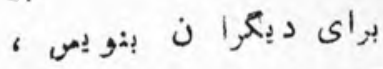

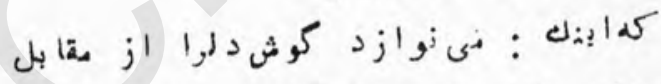

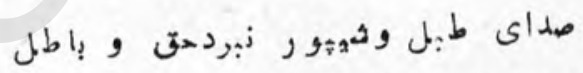

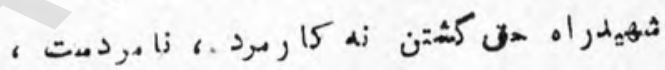

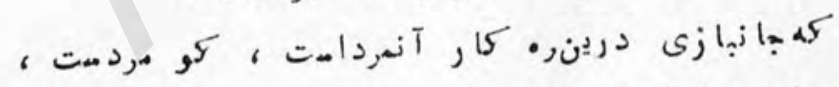

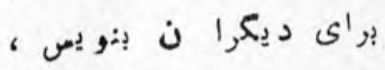
براى مردم ودمثن :

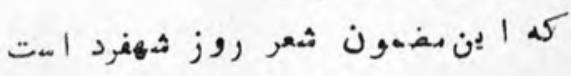

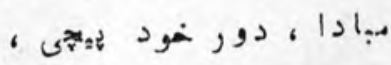

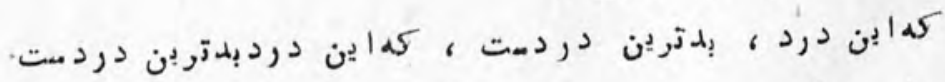

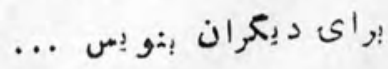

\section{pre}


زنله

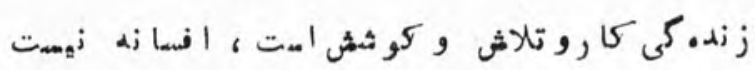

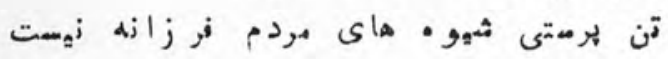

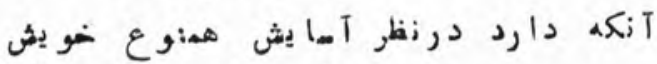

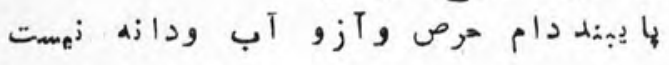

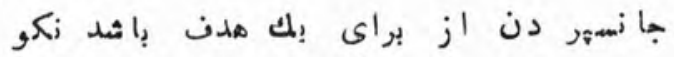

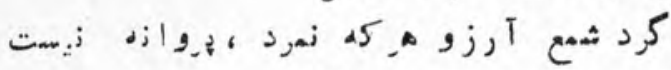

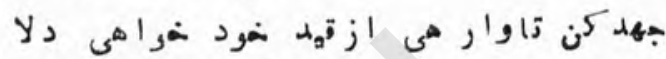

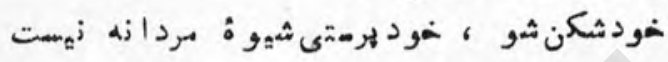

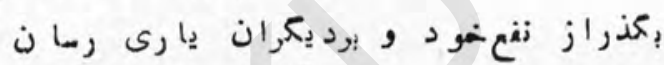

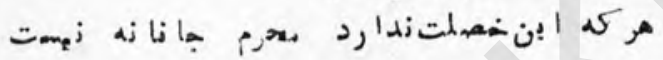

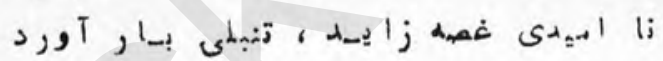

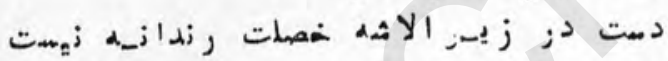

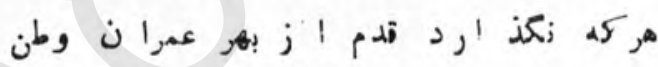

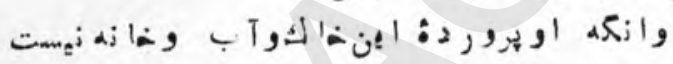

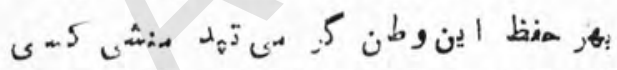

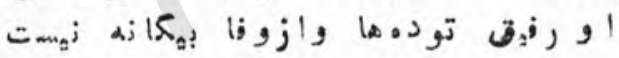

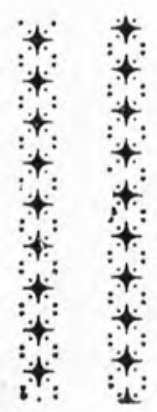

PFI 


\section{$\sum_{0}^{\infty} \sum_{\infty}^{2}$

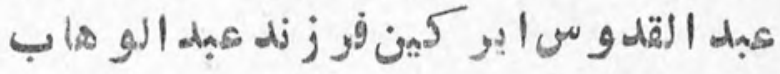

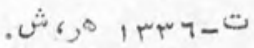

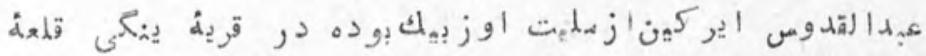

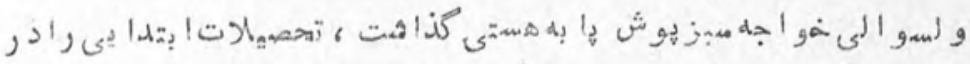

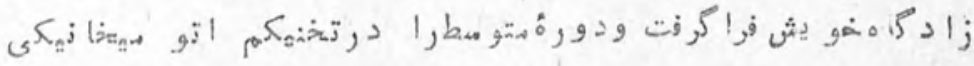

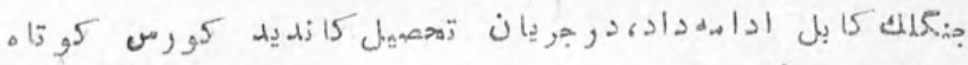

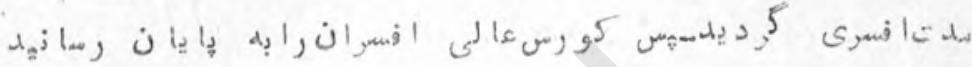

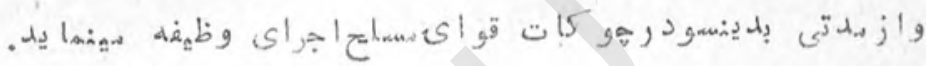

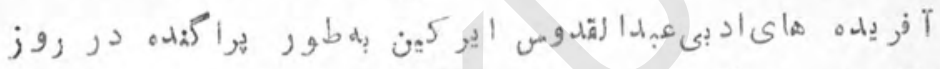

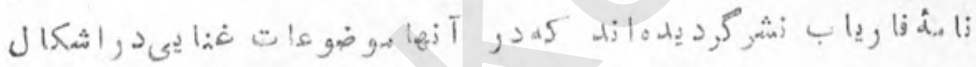

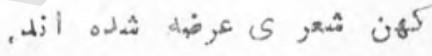

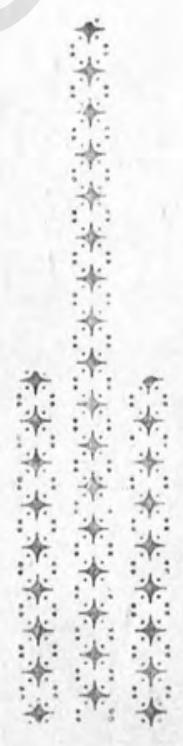


(G) Jluto Jgritgr

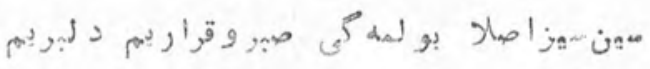

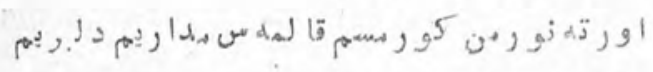

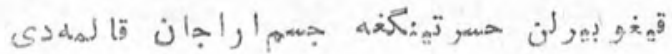

هo

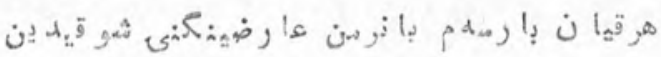

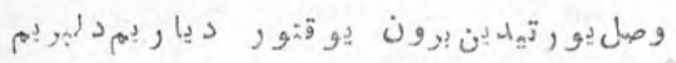

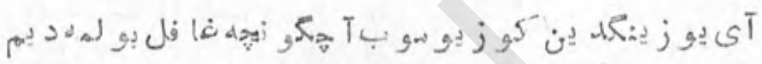

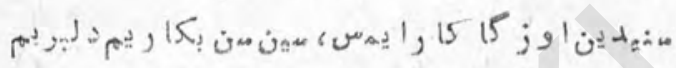

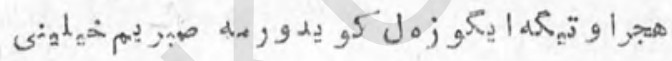

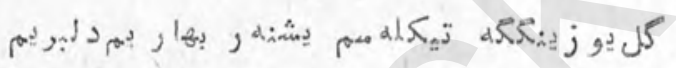

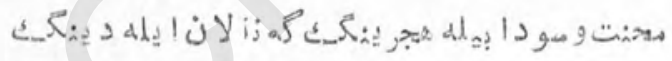

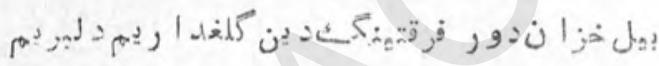

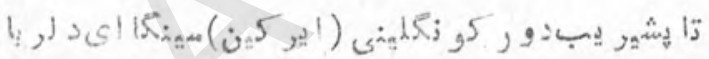

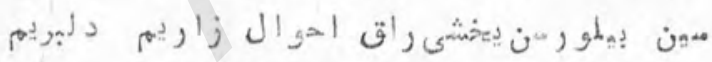

prop 


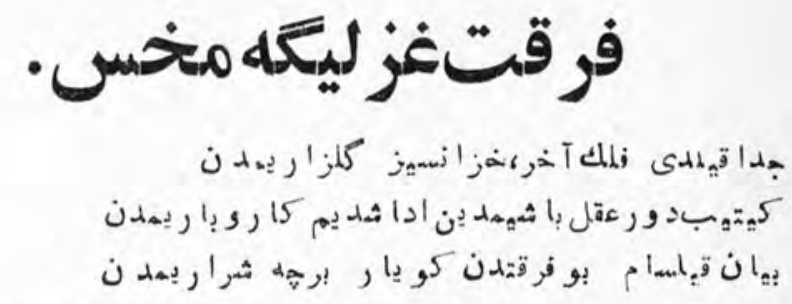

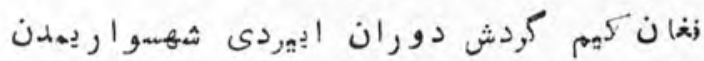

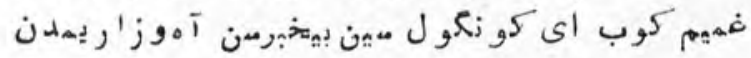

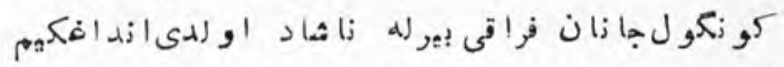

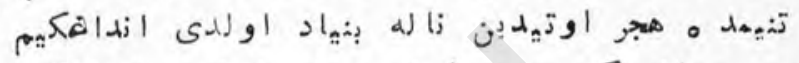

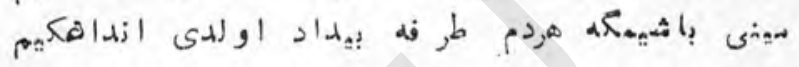

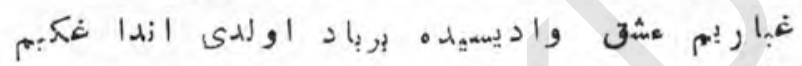

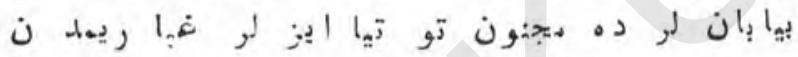

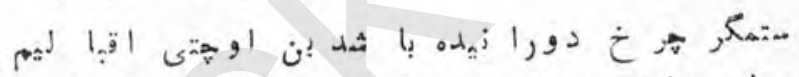

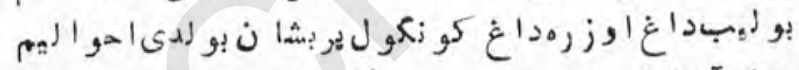

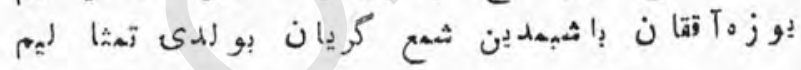

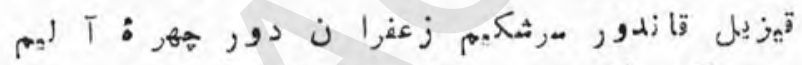

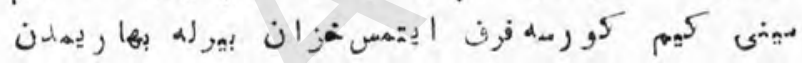

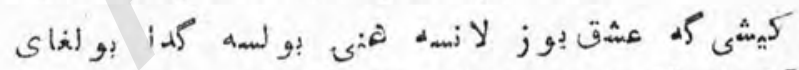

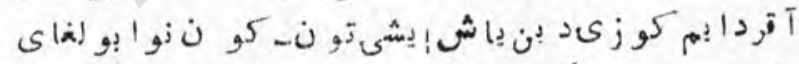

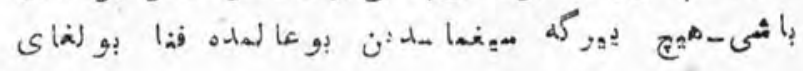

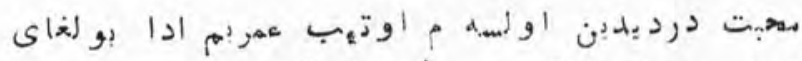

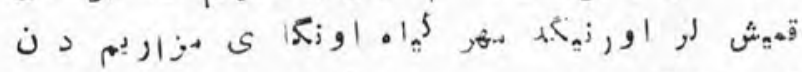

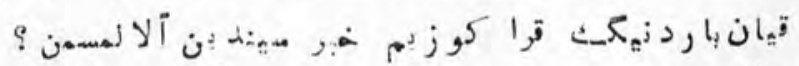

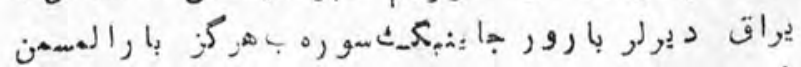

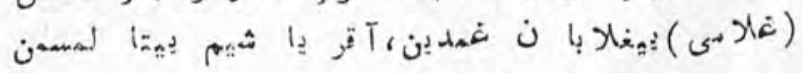

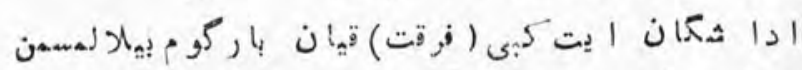

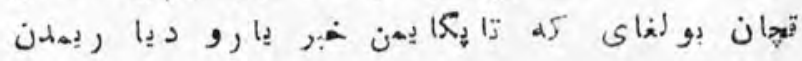


فلكتاز

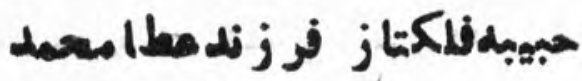

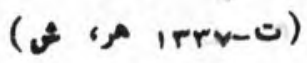

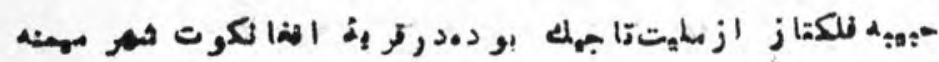

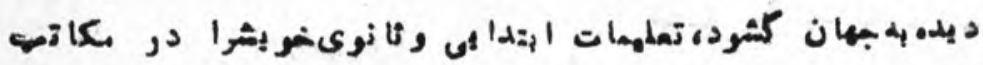

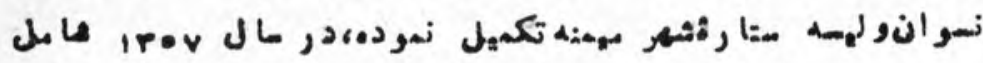

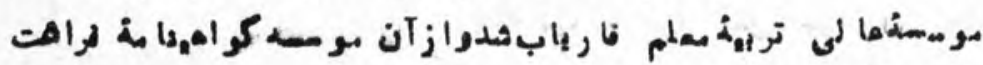

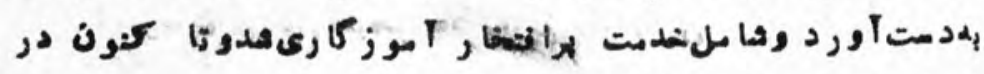

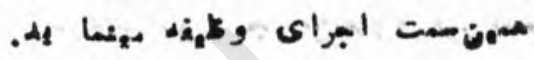

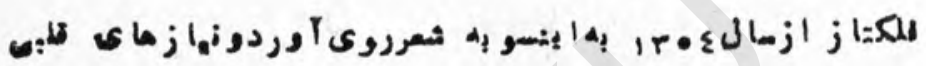

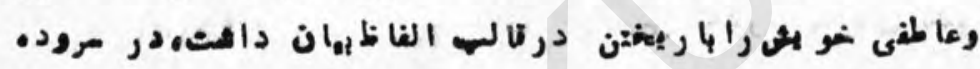

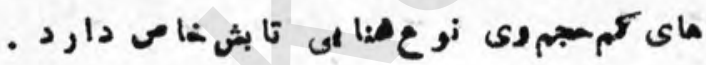

Pfs 


\section{جوانانوطن}

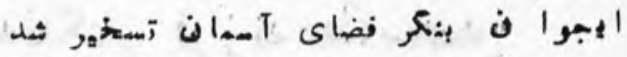

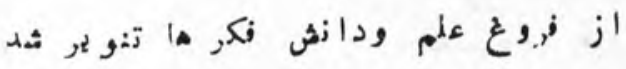

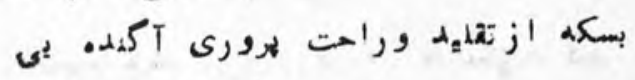

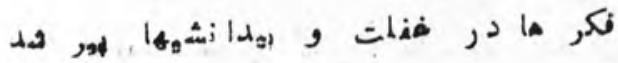

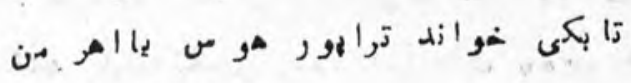

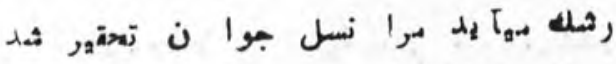

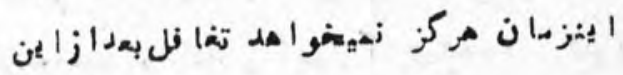

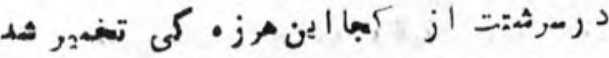

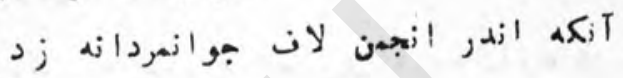

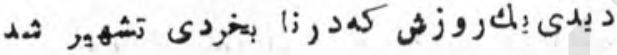

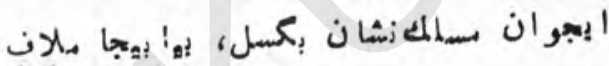

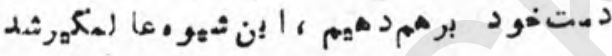

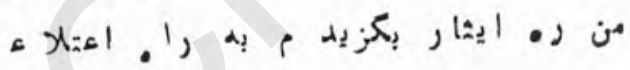

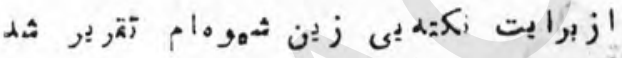

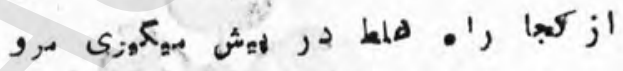

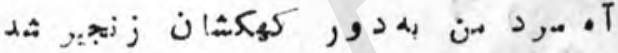

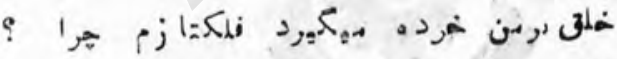

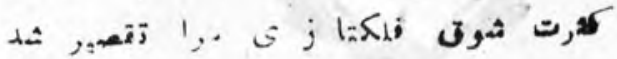

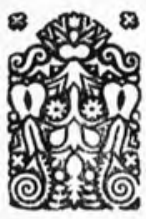


وصفحسن

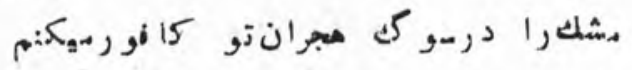

زل

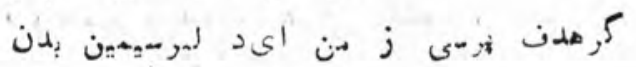

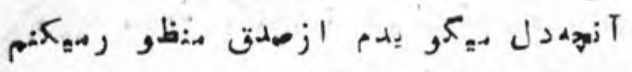

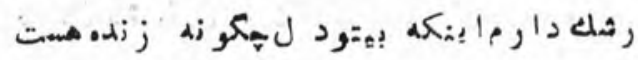

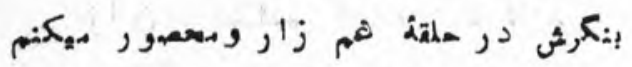

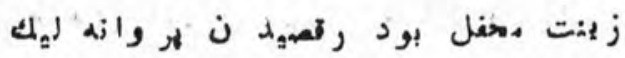

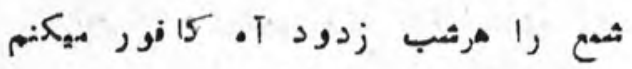

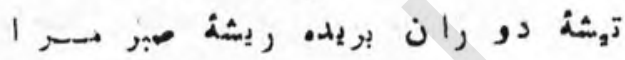

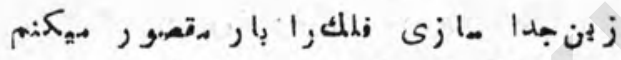

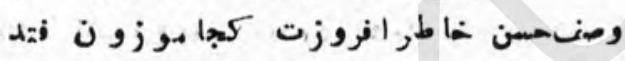

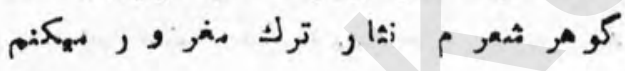

pFy 


\section{اللهيير دىطاهرىفر زندهمر اهقل Sinirrv-}

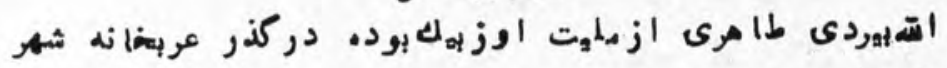

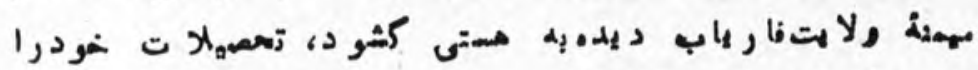

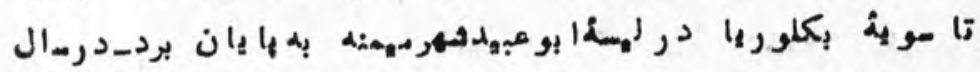

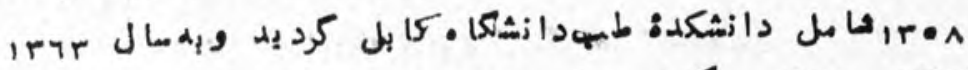

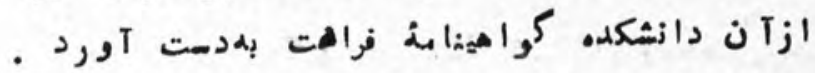

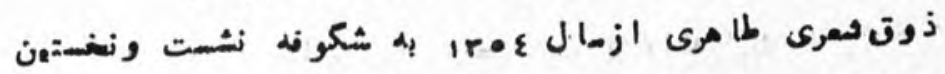

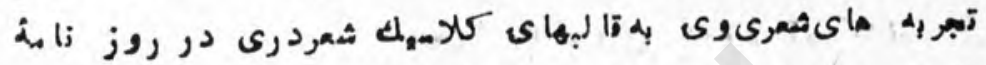

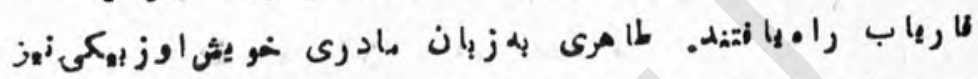

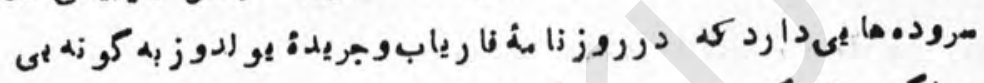

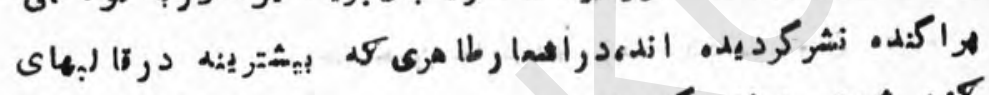

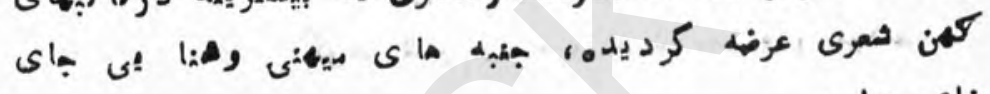
خاص دارد المن

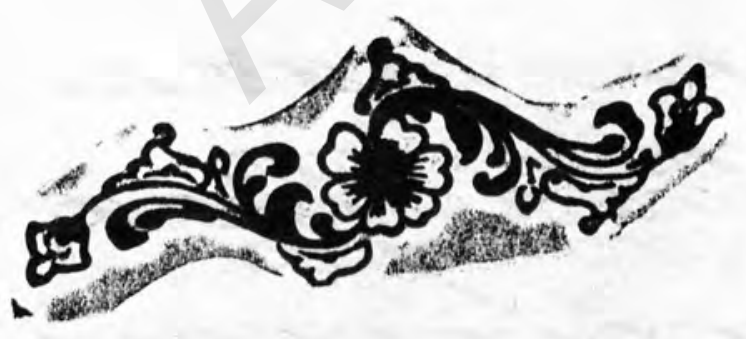




\section{ينكى بهار}

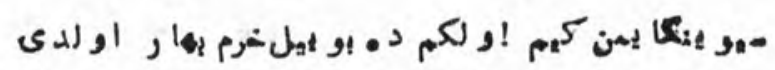

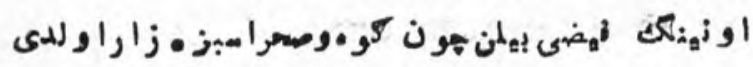

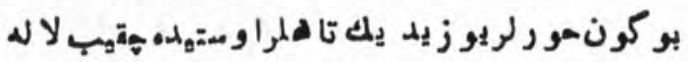

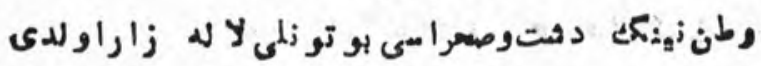

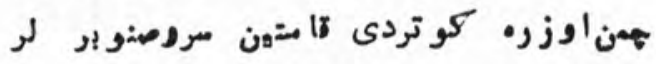

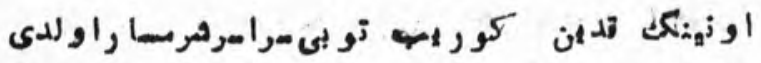

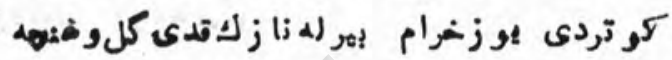

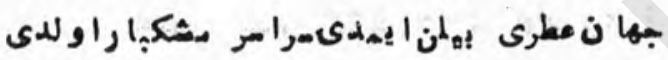

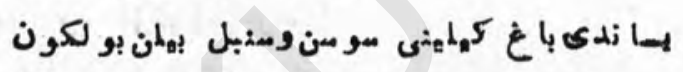

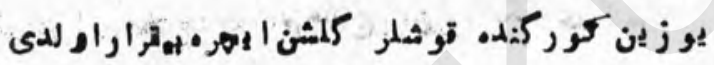

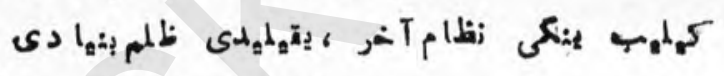

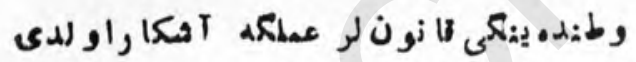

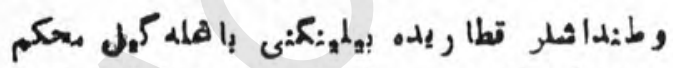

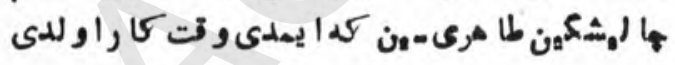

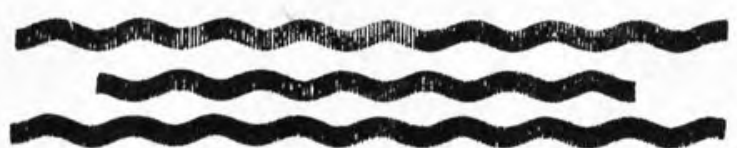


بيقـرارى

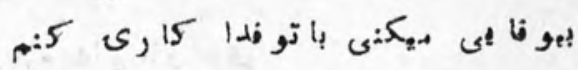

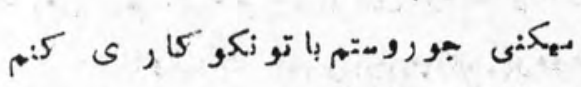

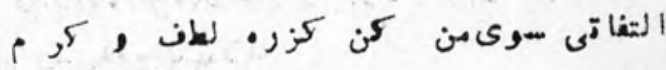

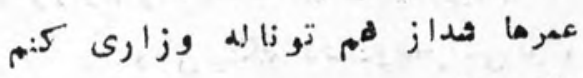

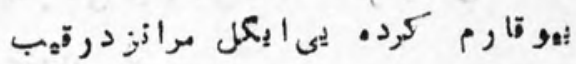

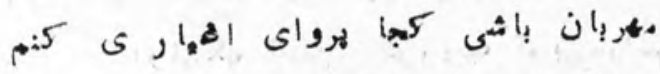

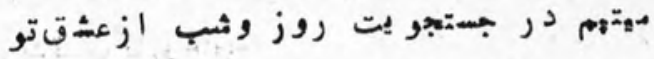

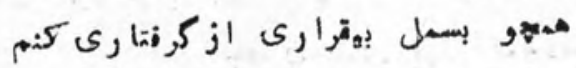

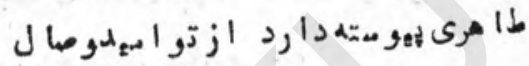

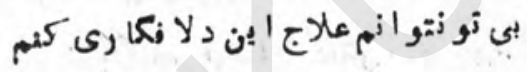


مقيهم

عبد الهقيم دقيم فر ز ند زظر متحمل ت - A IPYA

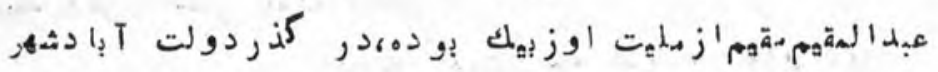

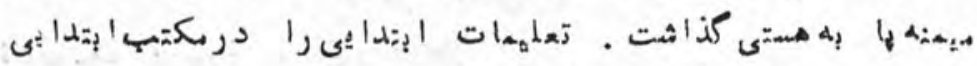

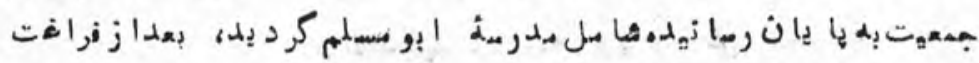

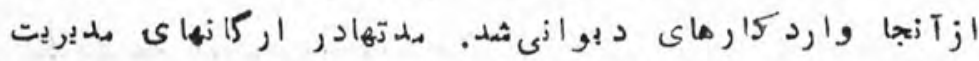

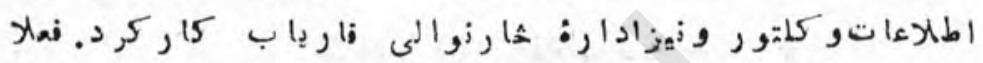

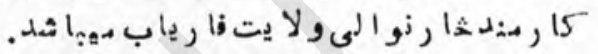

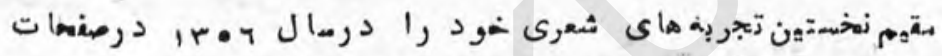

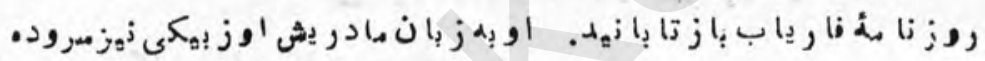

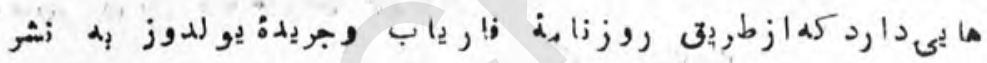

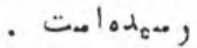

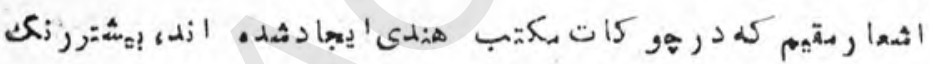

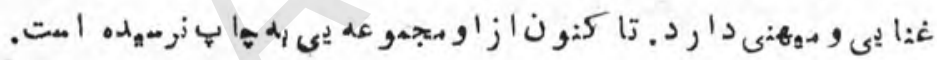

PQI 
درسمحمت

روزى زمضا كلودي طماز وجي دى

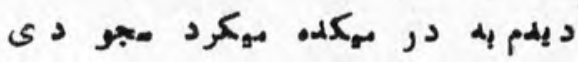

ثمنهنجه دمن رانفسى هون إيكثودى

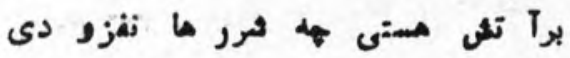

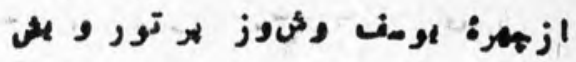

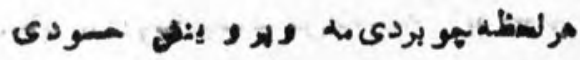

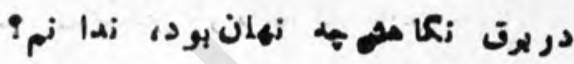

يكباره قرار ازدل وبانم بر بود بمد

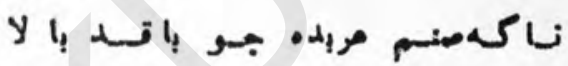

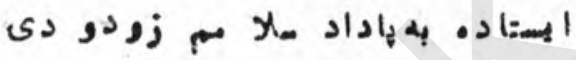

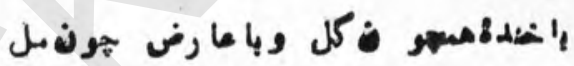

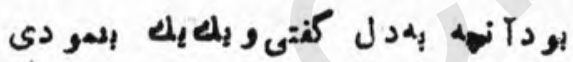

كهنم:ز هـه بازمز مسلُ در س معبت

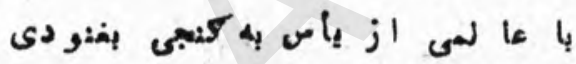

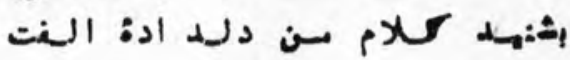

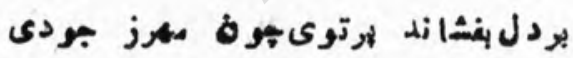

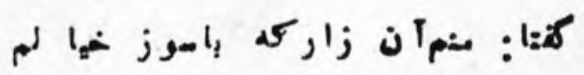

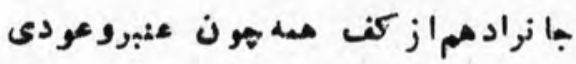

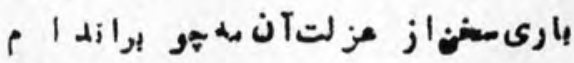

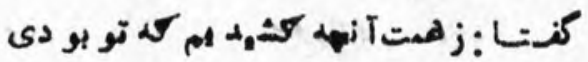

از

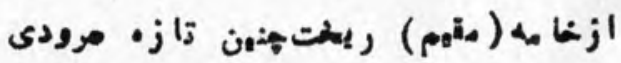


ايركينيشه ش

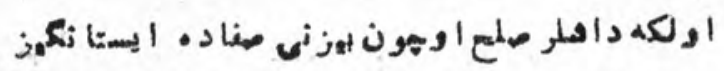

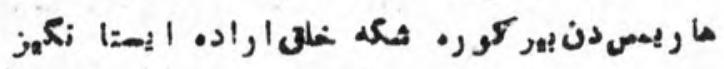

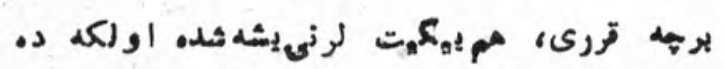

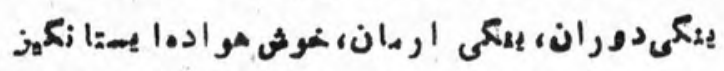

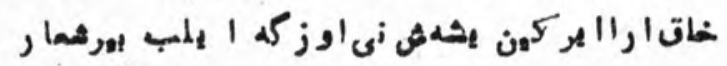

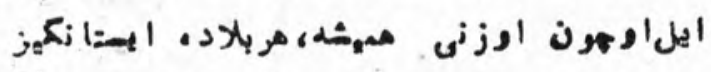

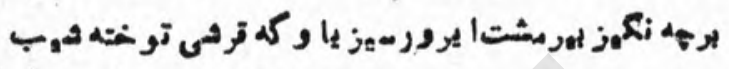

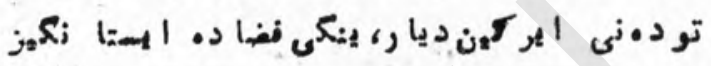

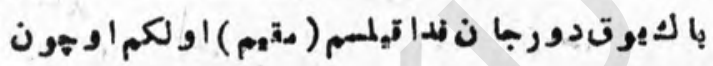

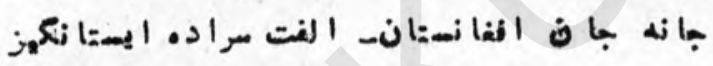




\section{تشر ي-فبهار}

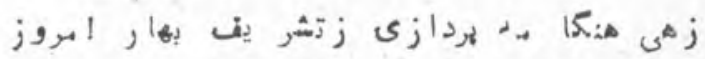

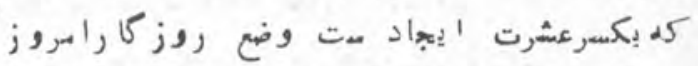

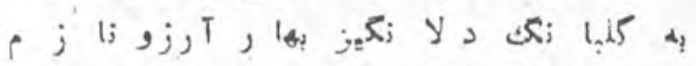

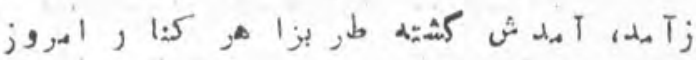

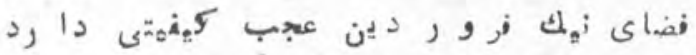

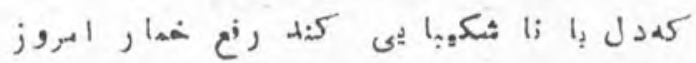

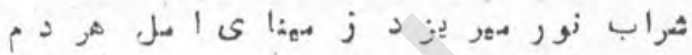

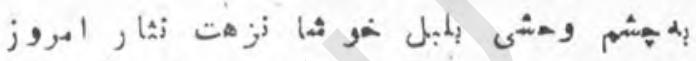

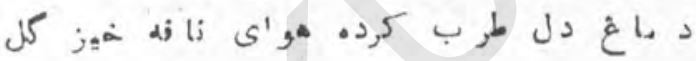
هه

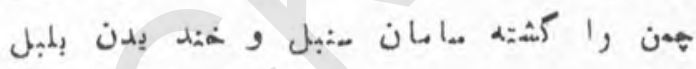

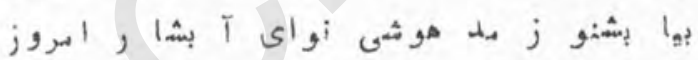

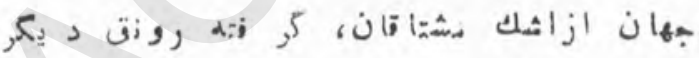

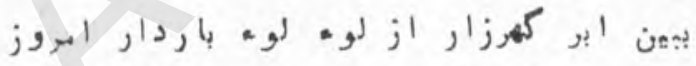

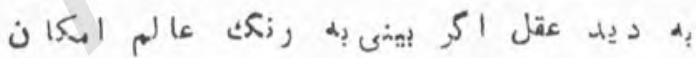

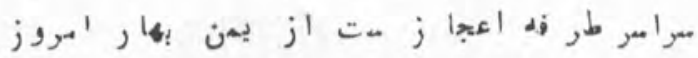

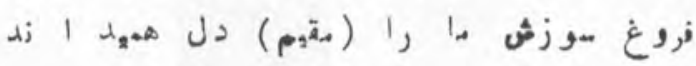

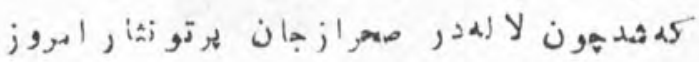

\section{(4)}




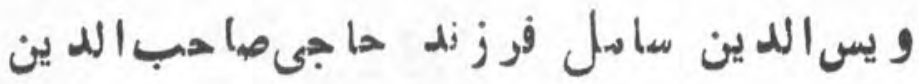

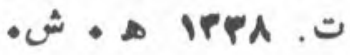

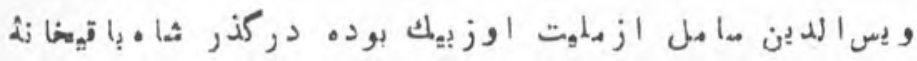

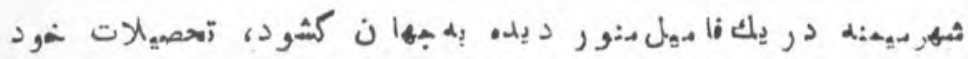

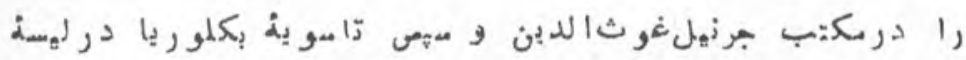

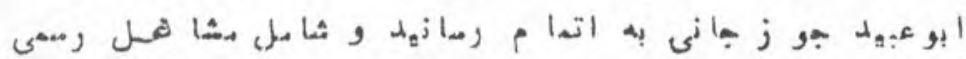
كرد بـد

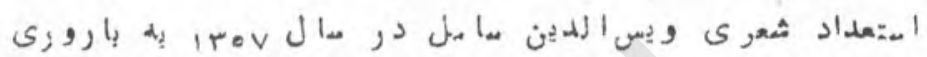

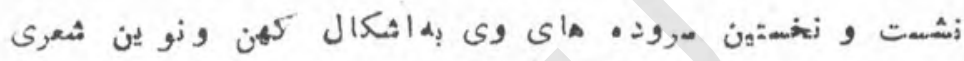

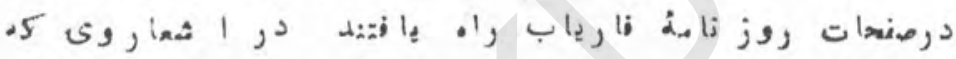

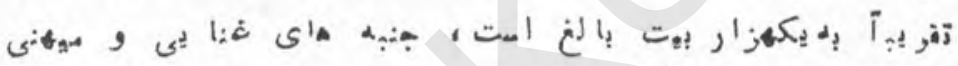
. د, در

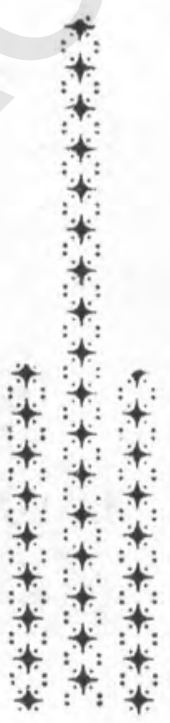

م D 
جشنبهار

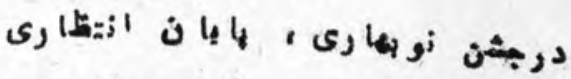

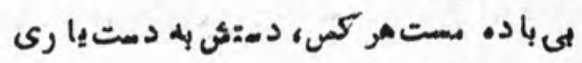

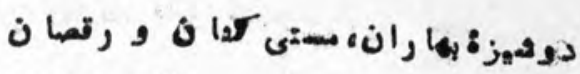

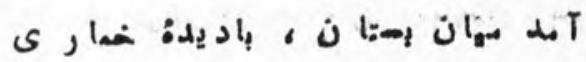

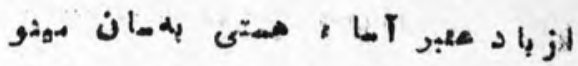

مرسو نواى بلبل ، برطرف هروف مرهزارى

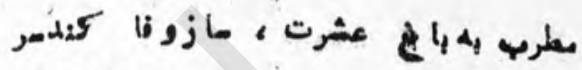

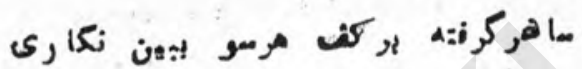

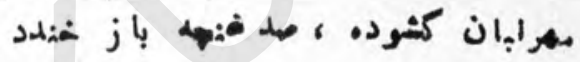

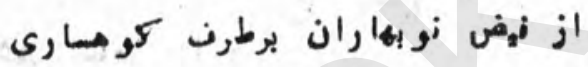

طلنل نسم زوسان، درعهدنو عرومان

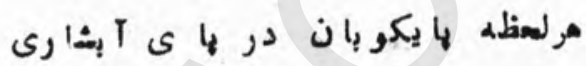

هردم زندترانه ، حزكع ودن و هما نه

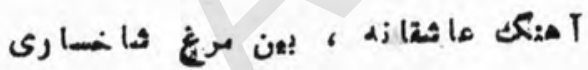

مدلاله جام بركف درجشن لاله رويان إنه

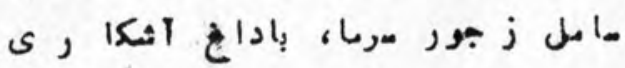


جلوه

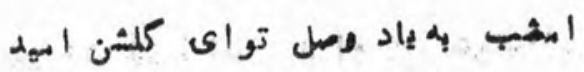

- Jla ja ja

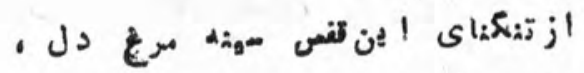

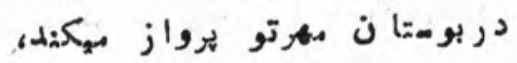

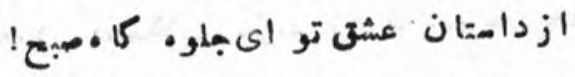

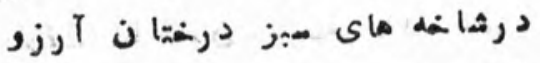

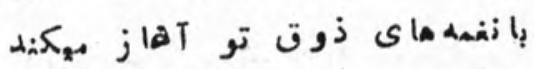

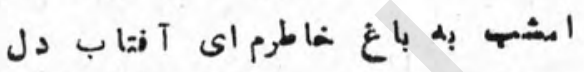

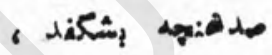

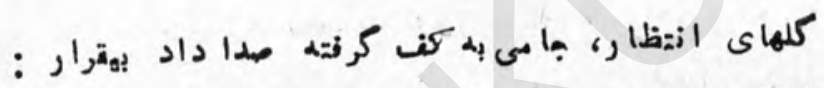

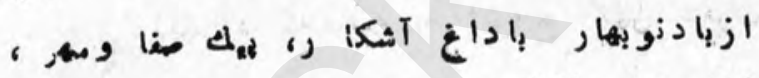

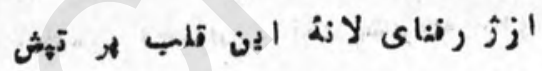

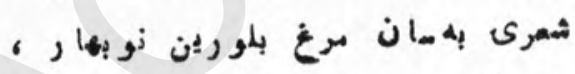

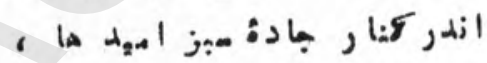

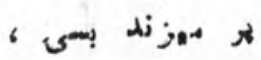




\section{ملكز اد}

عبد القيو م ملكز اد فر زند سو لو ى عبد الملكـ

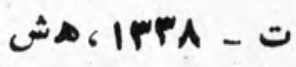

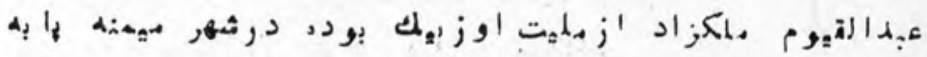

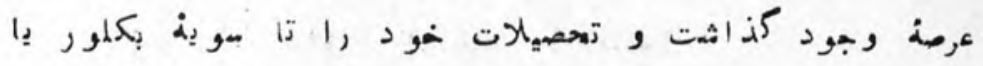

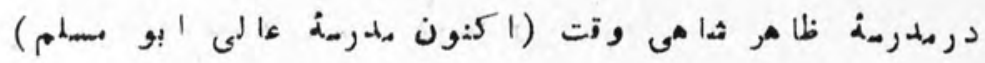

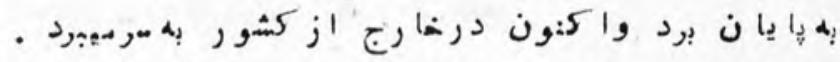

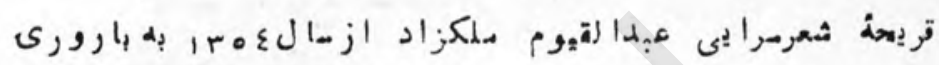

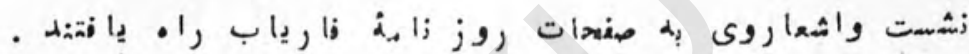

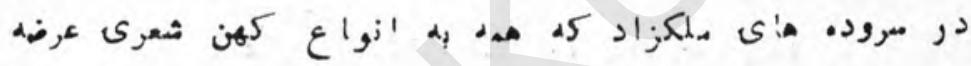

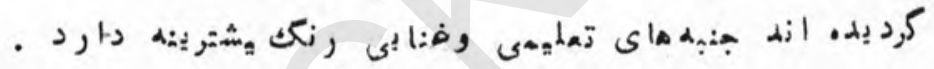

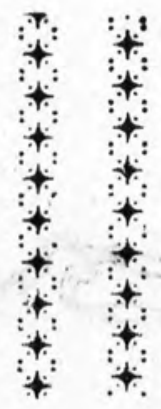




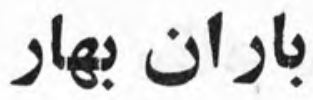

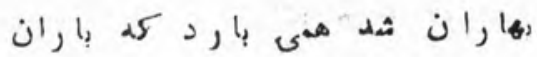

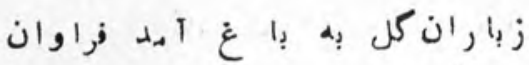

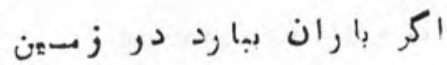

همى ديا بـى تو كلها

بود فرهت فزا اين مومبم خو ش

زجوش كل شمده هرمو هو هو بستان

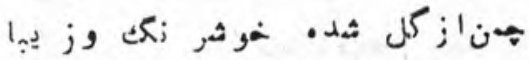

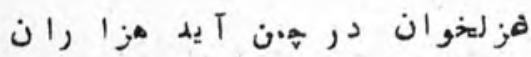

در' إنن نصل د'لا زكئز وطر بزا

ز مادى هر شود قلب عـز يسـزان

بو د ابن قدرت هرور دكـا

كله ماز د

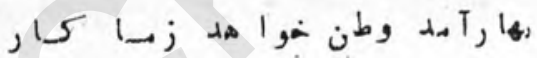

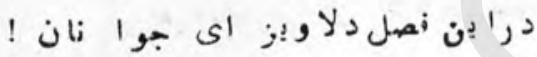

نهاتو تهد

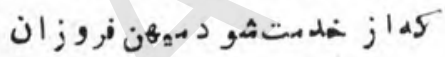

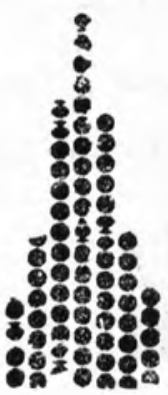

$p=q$ 


\section{مقام معلم}

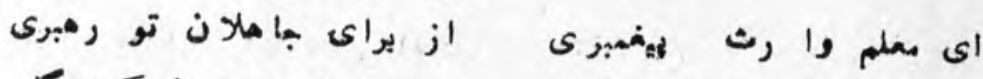

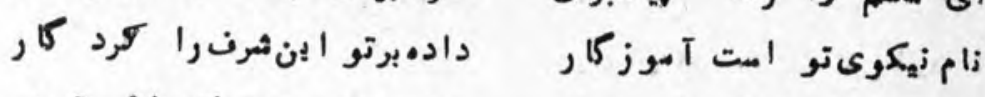

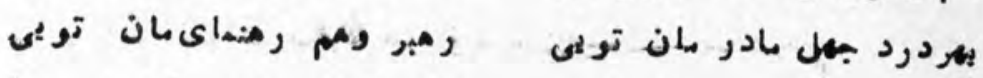

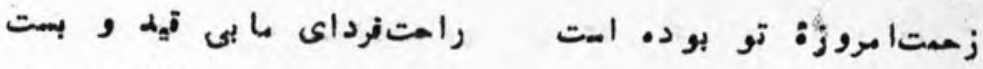

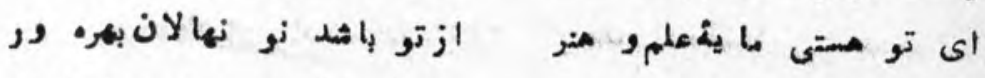

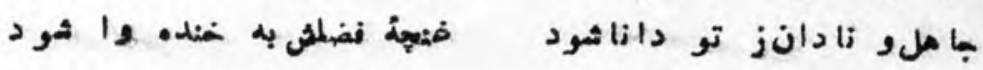

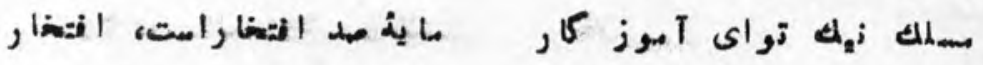

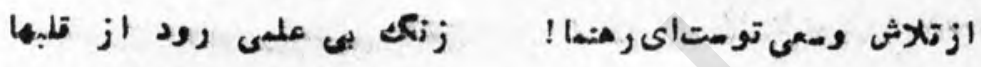

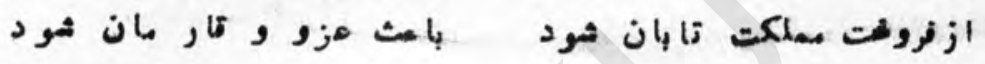

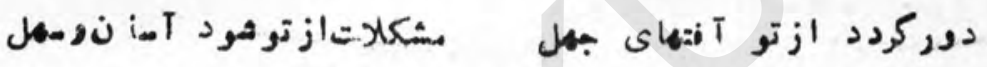

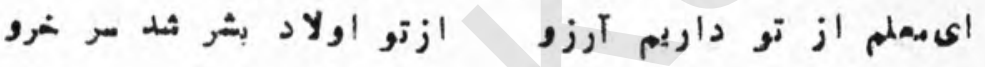

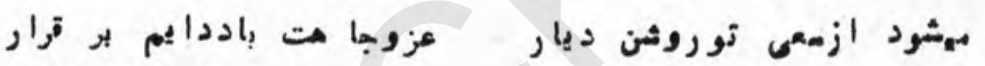

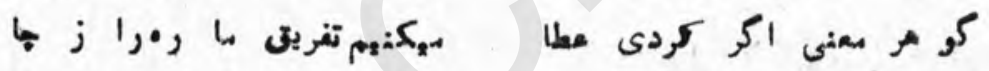

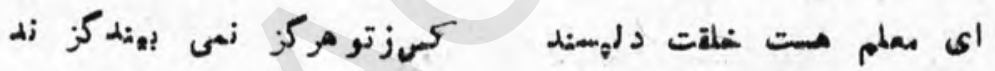

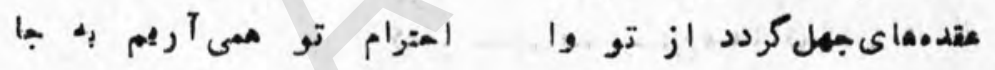

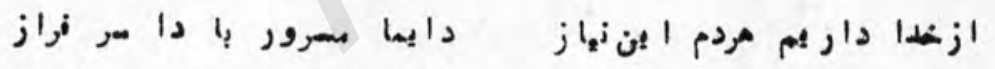

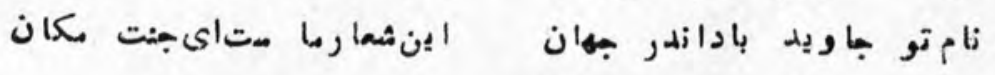

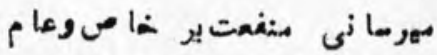

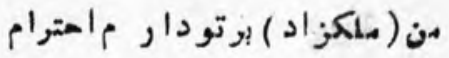




\section{औing

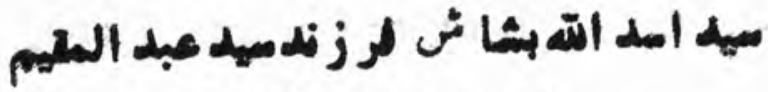$$
\text { (A. A irt.etera) }
$$

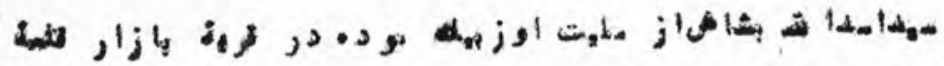

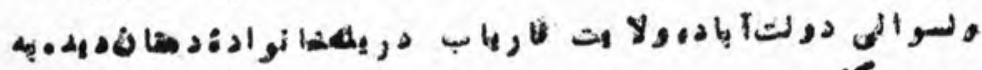

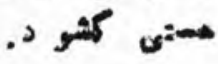

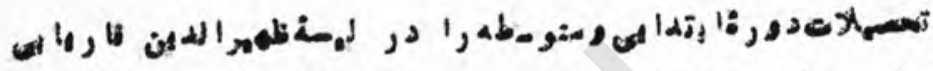

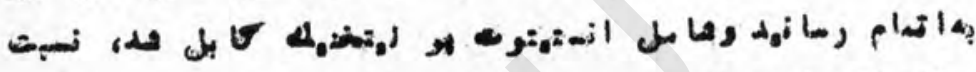

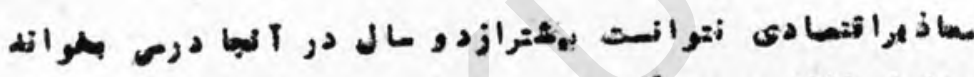

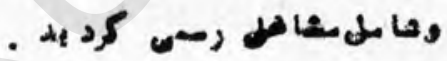

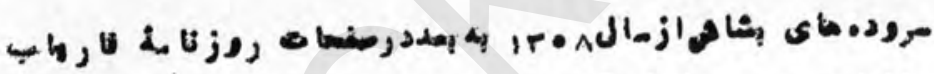

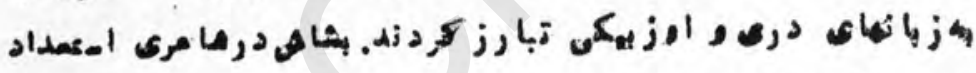

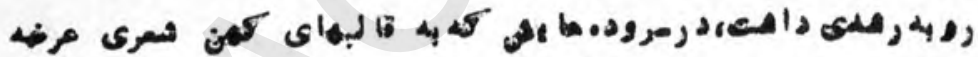

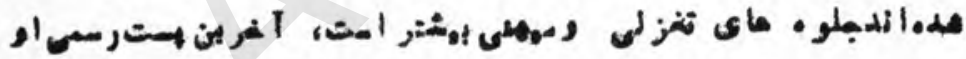

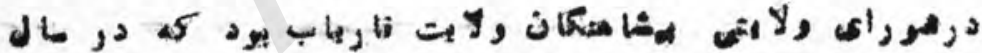

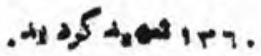

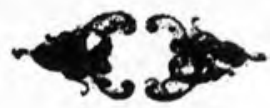




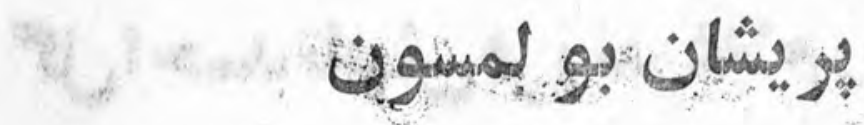

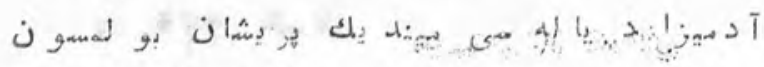

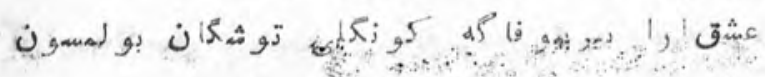

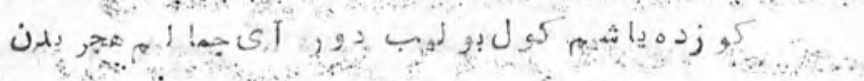

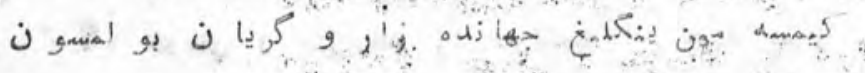

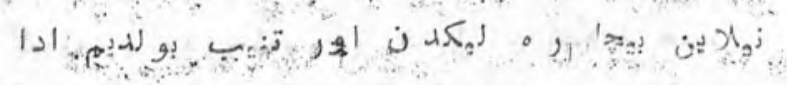

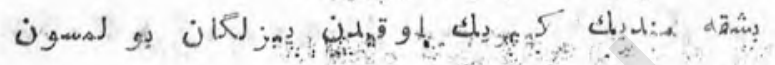

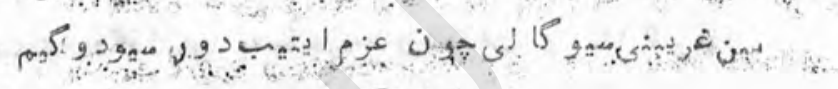

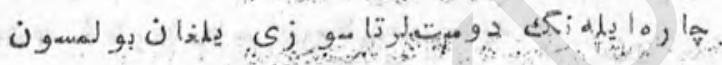

ز

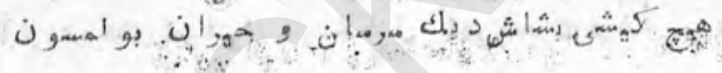

5

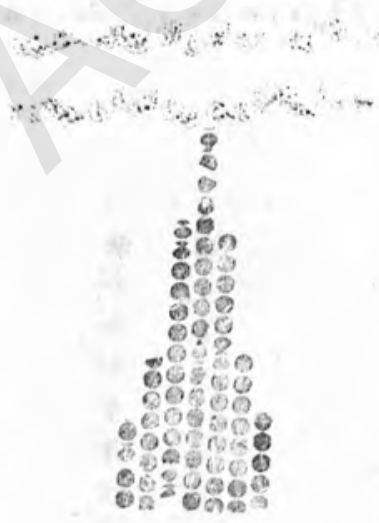




\section{درد فرا ق \\ ن}

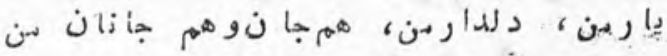

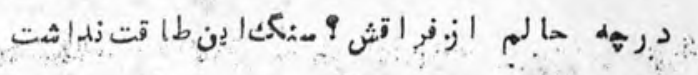

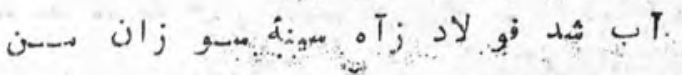

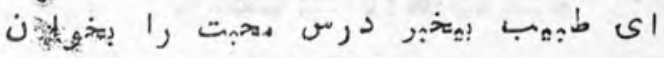

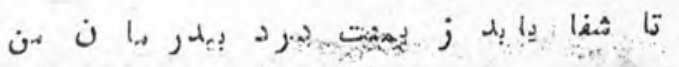

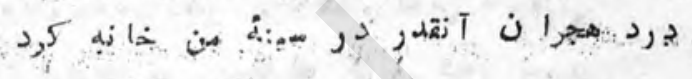

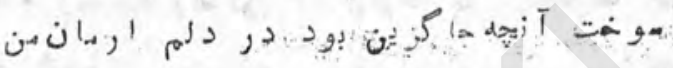

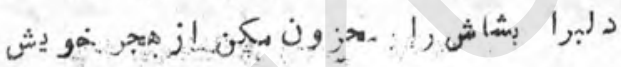

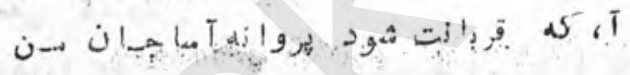

\section{D...6. on}

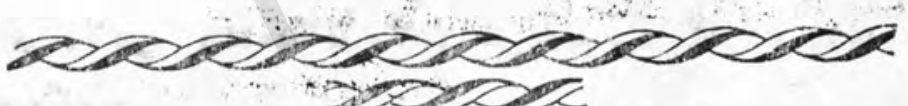

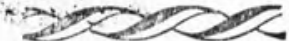
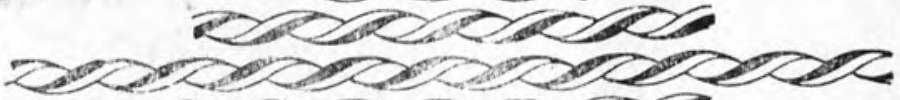

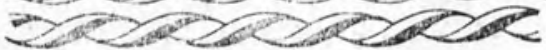

vosere

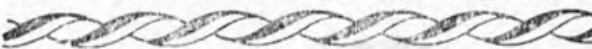




\section{مل احمد كانيشقوزند غلامروسول soirpase}

هو

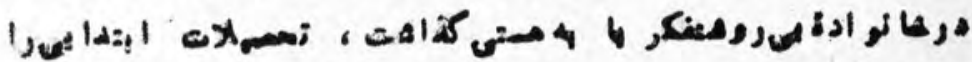

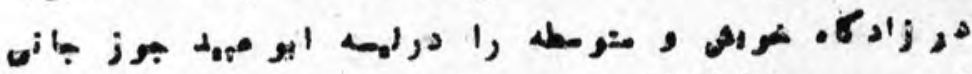

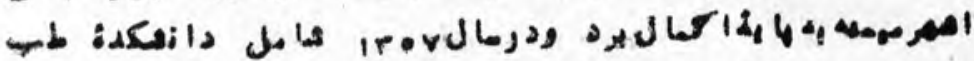
silis

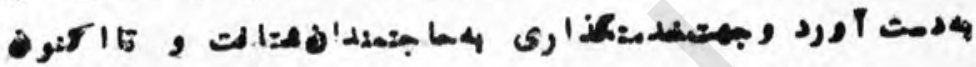

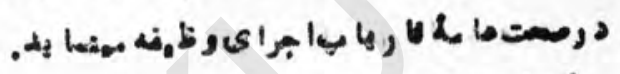

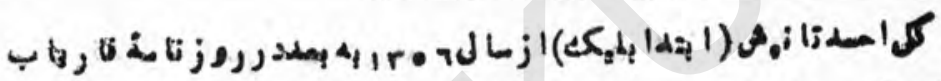

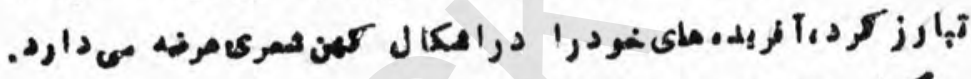

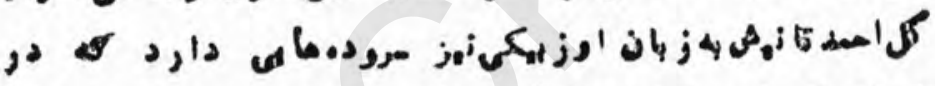
مان

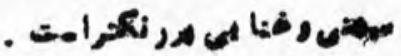

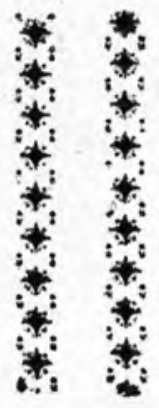


وطن

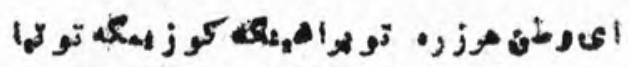

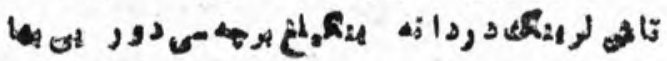
ما ثلكرة

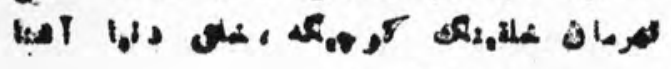

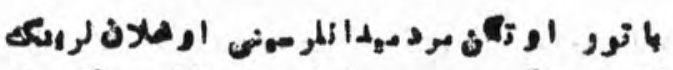

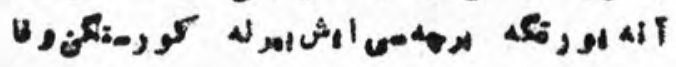

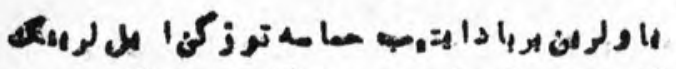

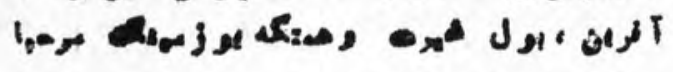

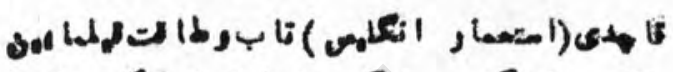

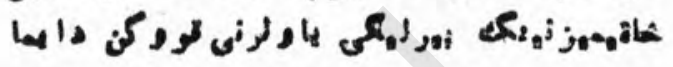

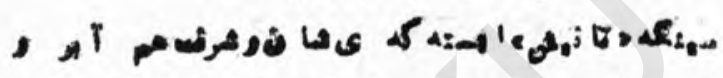

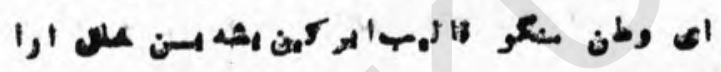

no 


\section{تائب

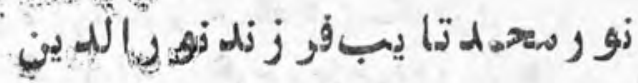

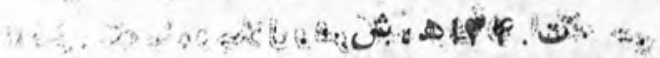

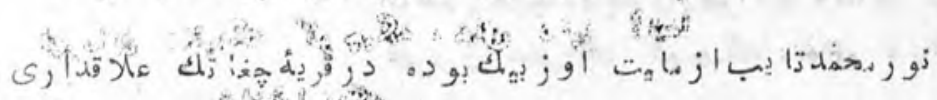
Sol $\left.b^{3}\right)$

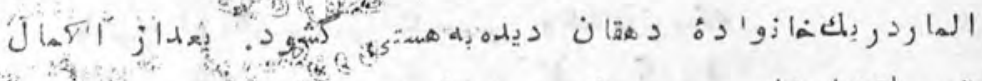

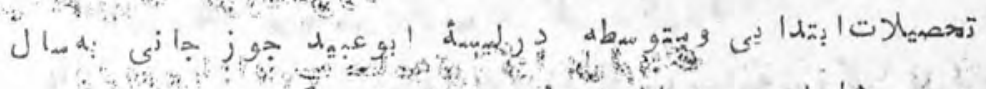

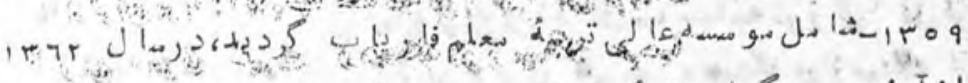

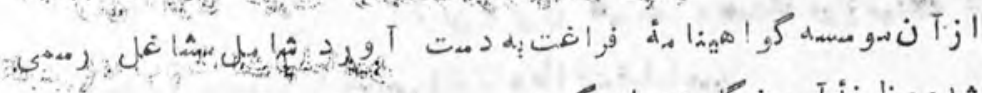

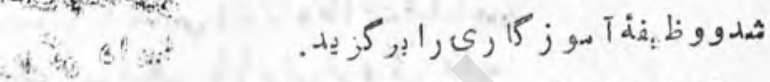

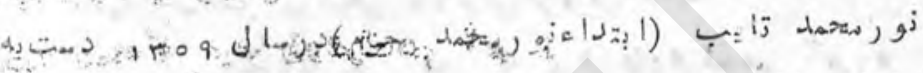

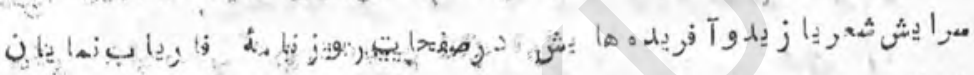

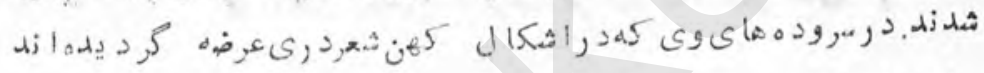

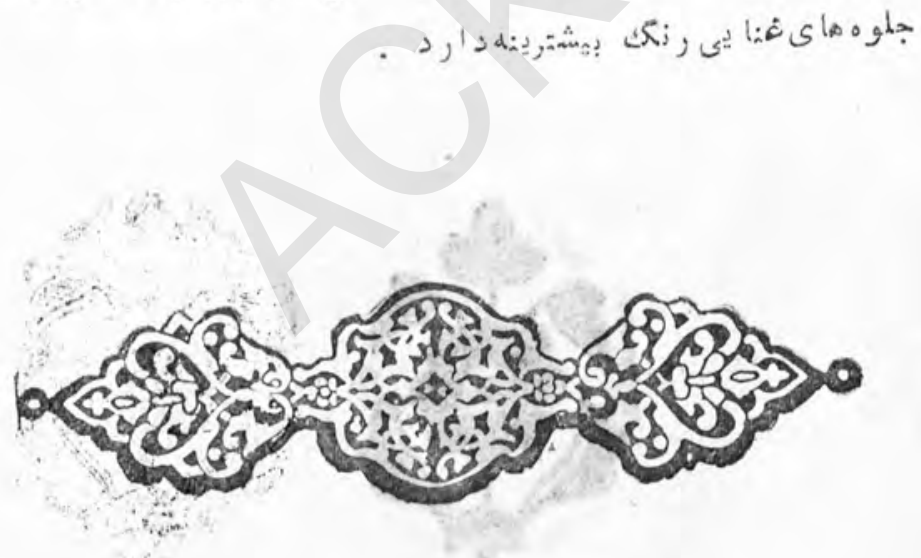


جو ر فلك

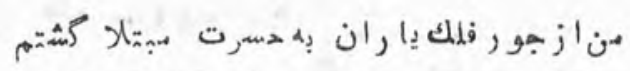

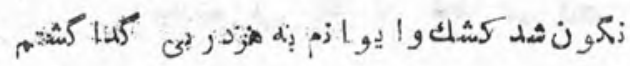

بd بازاן

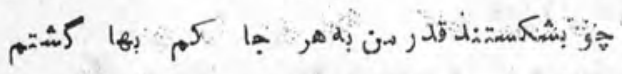

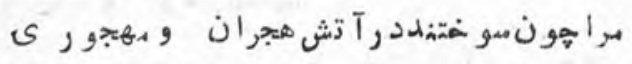

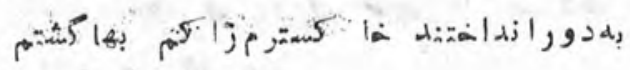

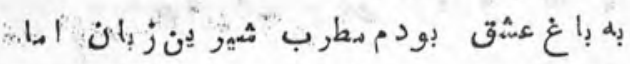

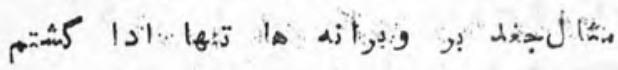

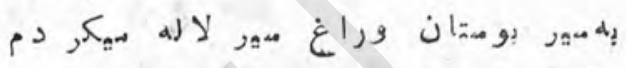

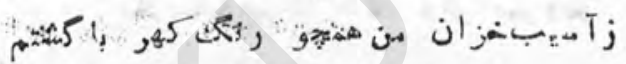

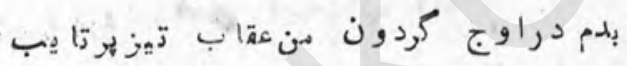

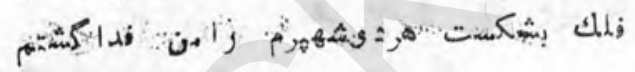

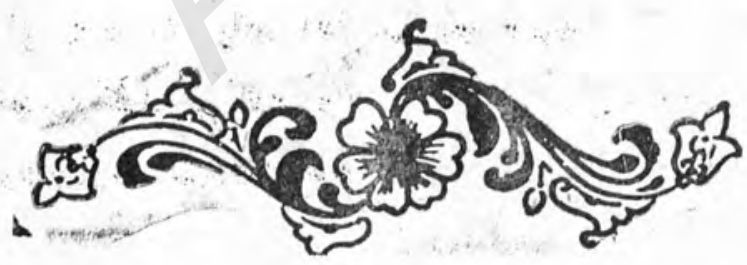

pqv 
غمزة بيداد

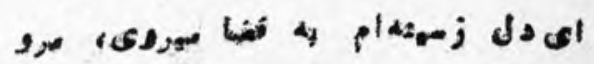

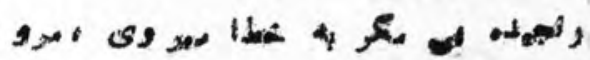

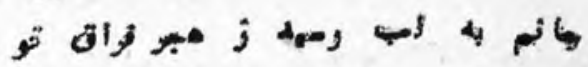

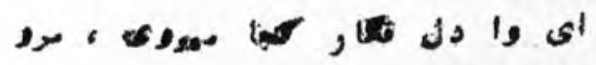

كا

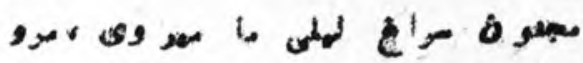

أ

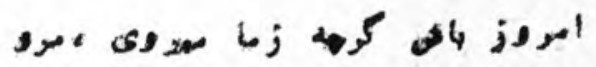

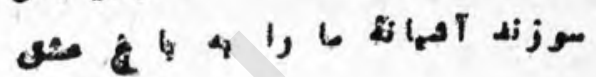

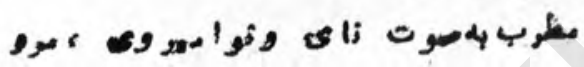

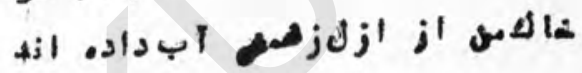

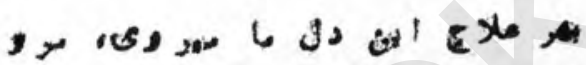

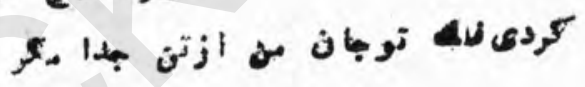

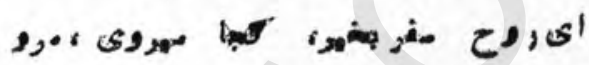

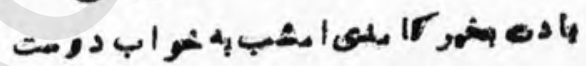

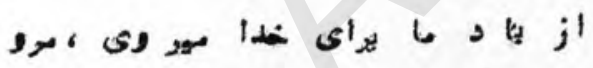

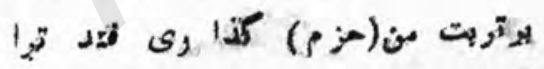

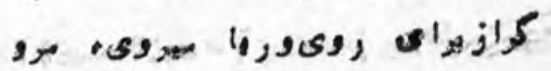

na 


\section{تاشقين بهائى}

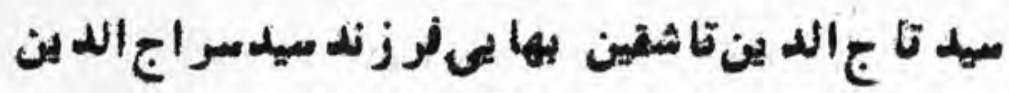
( A. IfP. - L) )

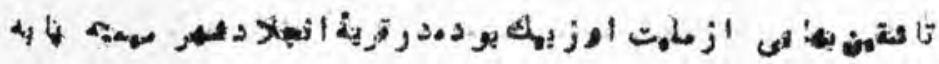

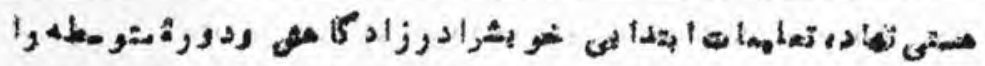

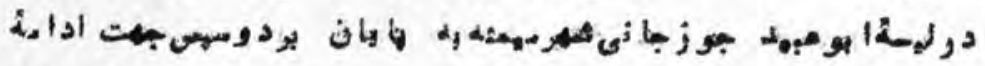
ô

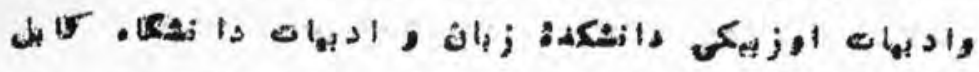

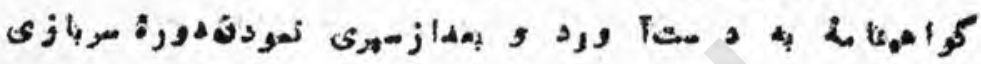

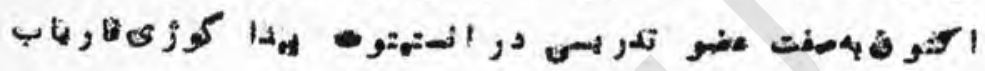

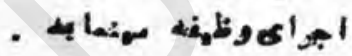

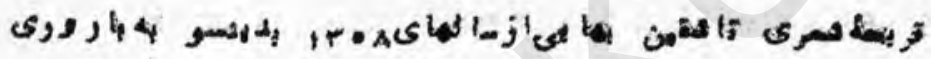

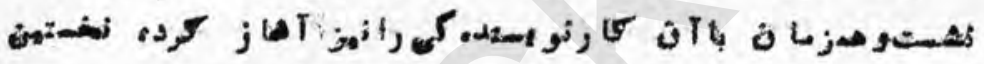

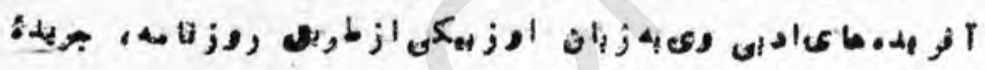
.

كز

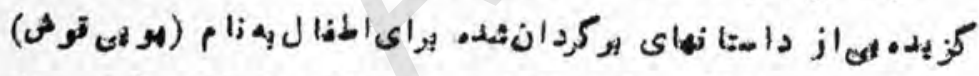

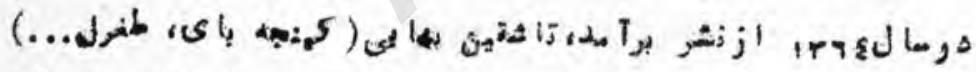

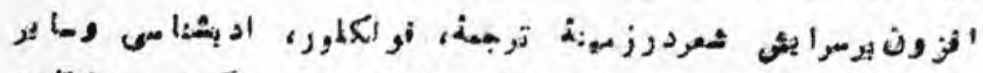

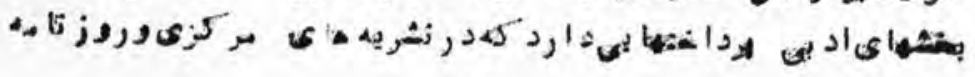

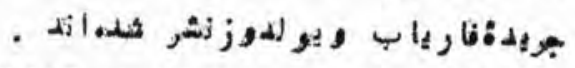

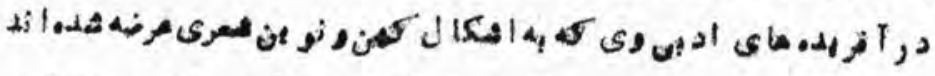

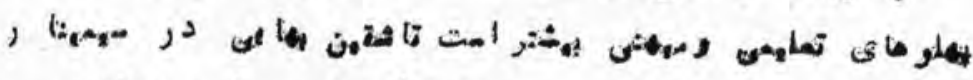

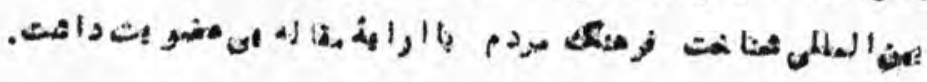




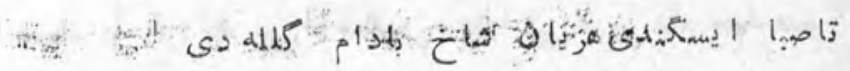

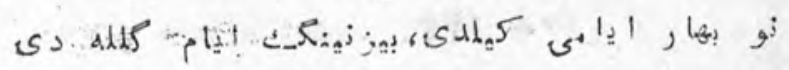

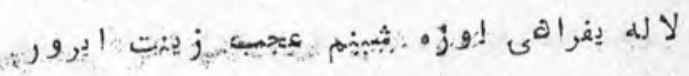

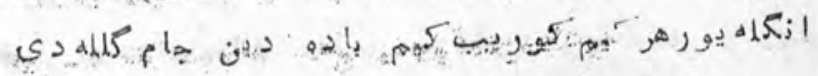

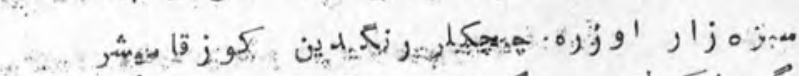

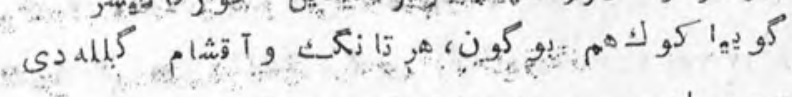

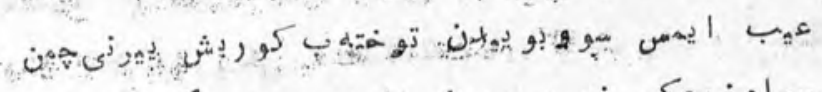

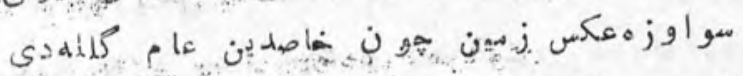

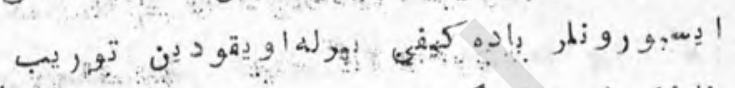

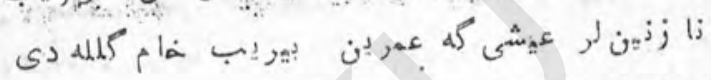

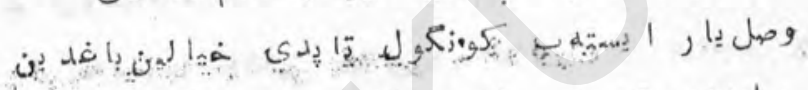

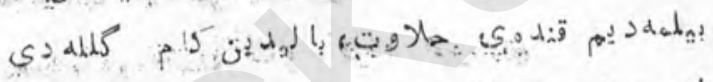

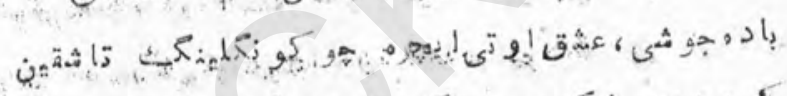

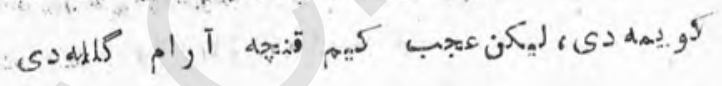

rv. 


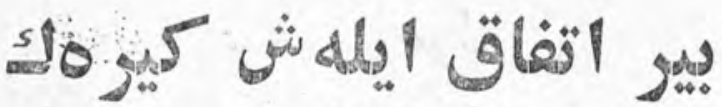
مخ

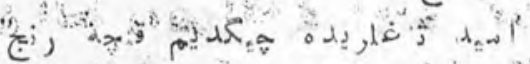

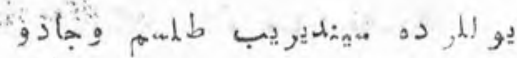

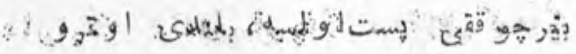

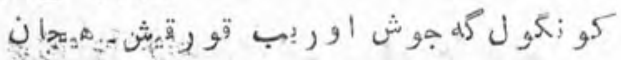

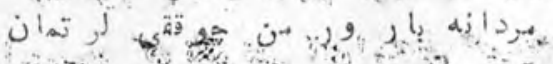

" كيز دئ

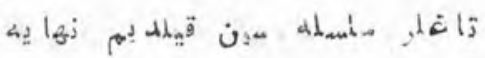

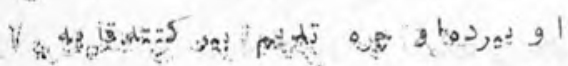

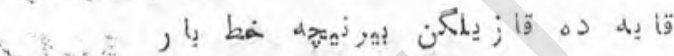

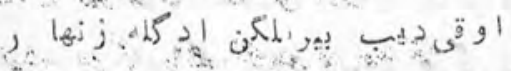

6.

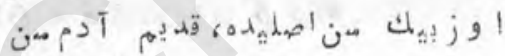

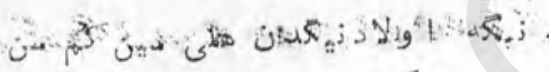

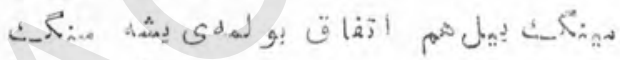
تو

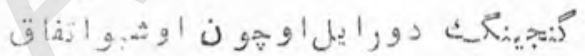

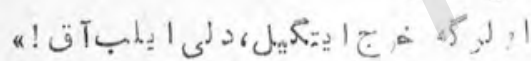

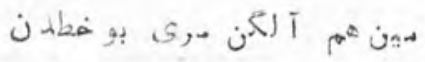

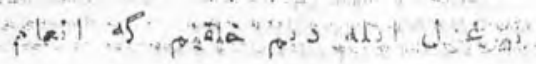

PVI 
مزل

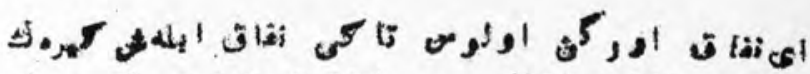
ا

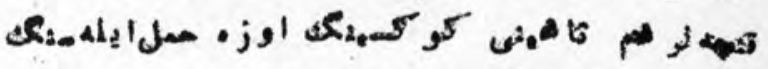

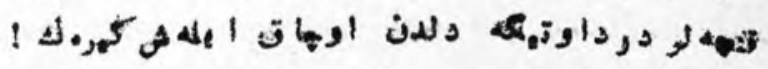

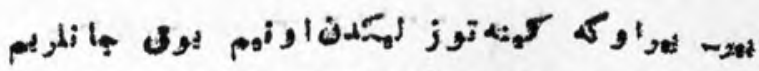

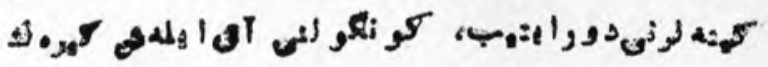

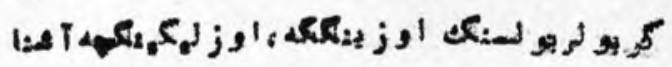
أوز J

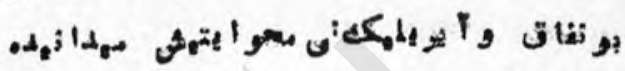

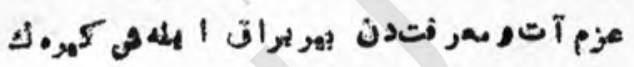

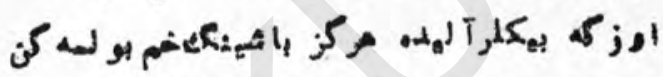

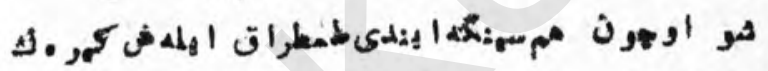

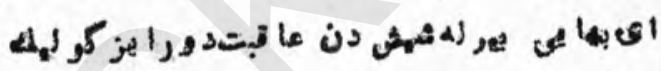

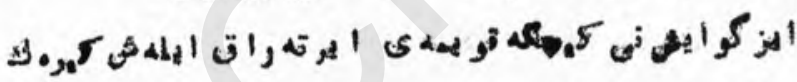




\section{اوزونيول}

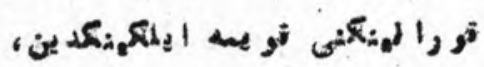

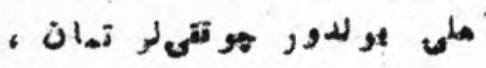

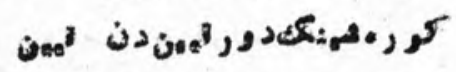

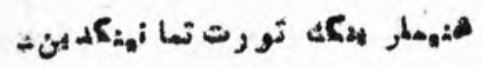

ا

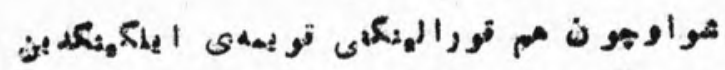
ا

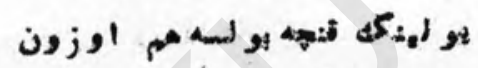

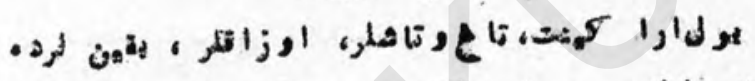

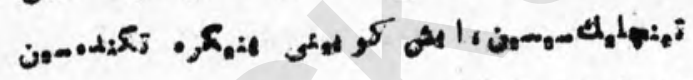

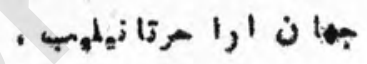

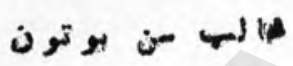




\section{plato}

قو

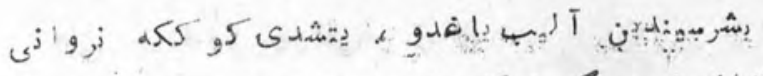

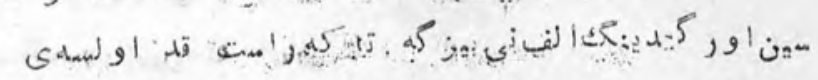

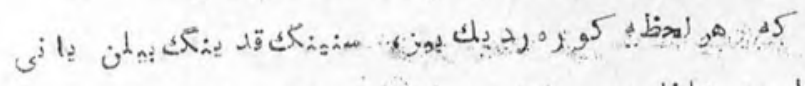

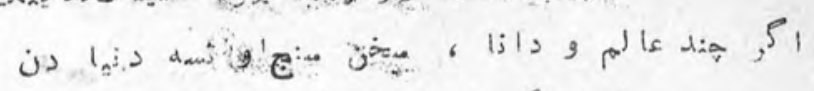

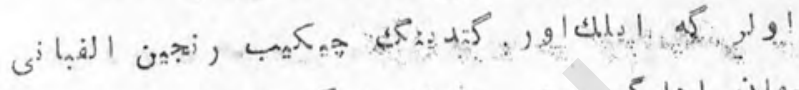

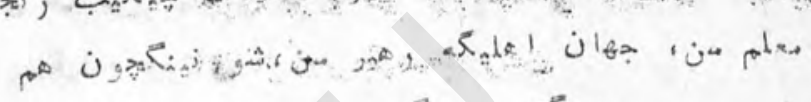

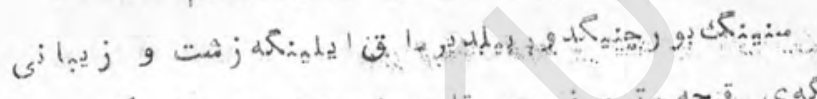

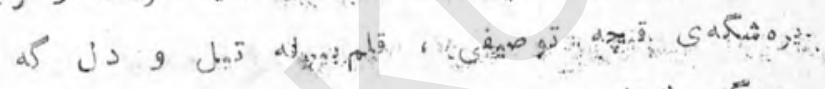

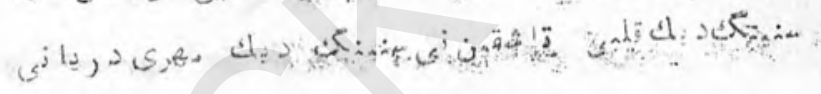

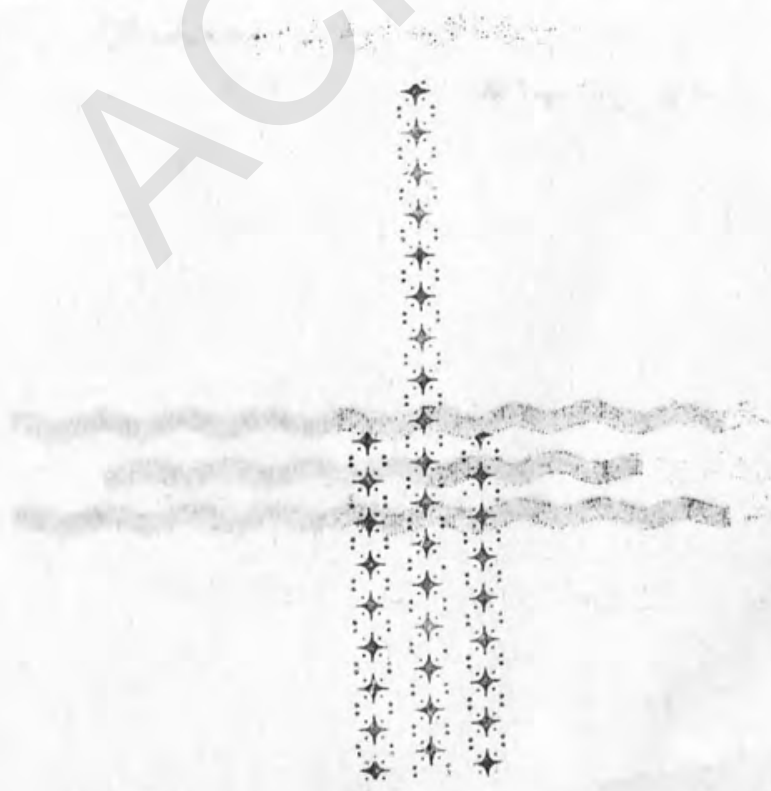




\section{$s^{j l 0} \int g \operatorname{lig} g^{5}$}

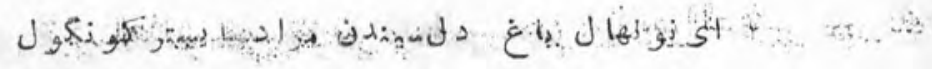

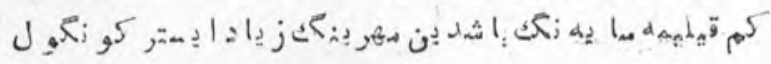

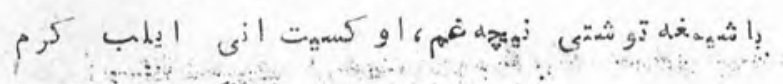

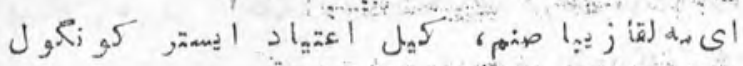

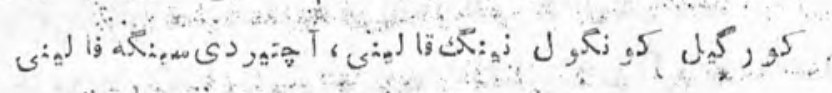

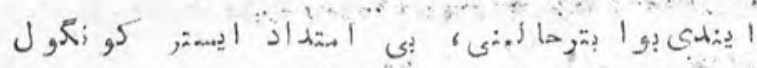

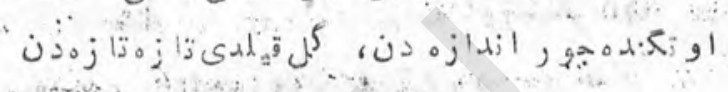

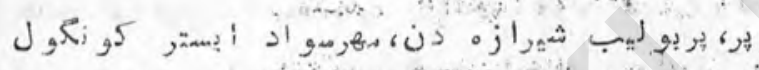

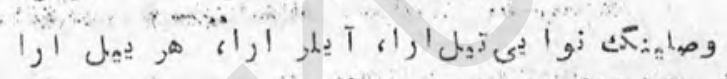

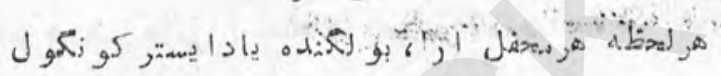

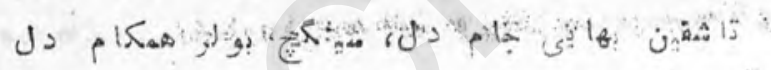

لح

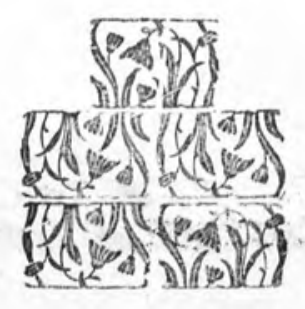




\section{آيسلطا ن خيرى}

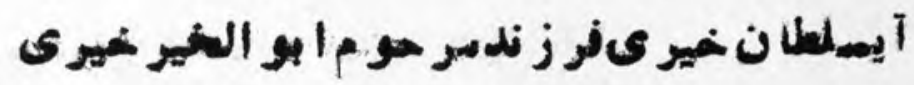

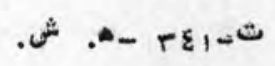

كمرد

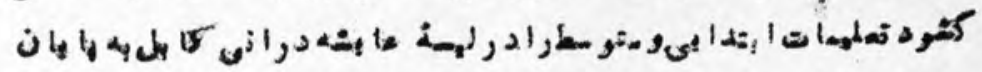

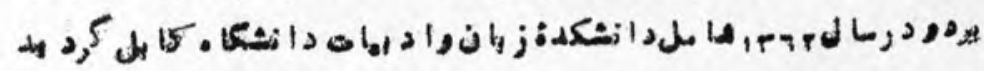

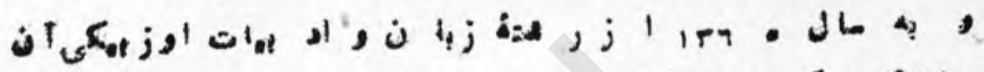

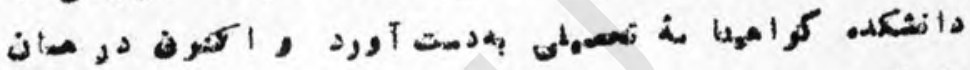

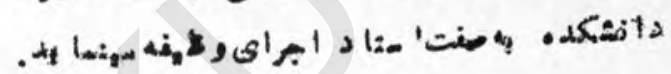

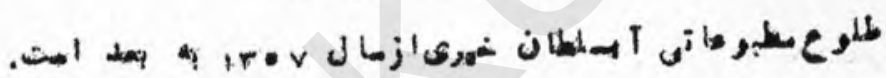

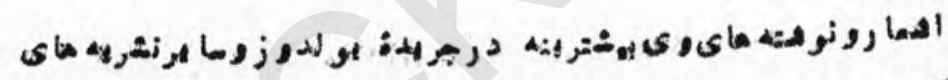

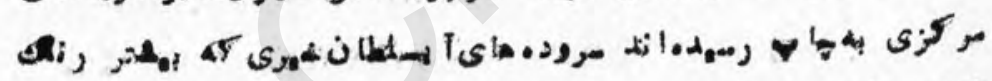

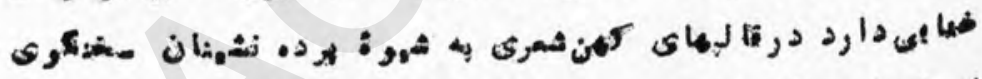

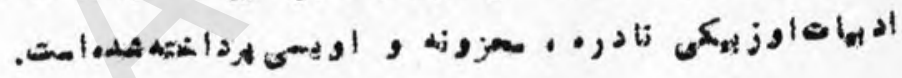

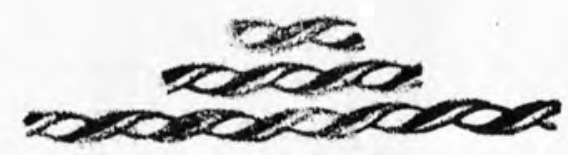




\section{تا زئزs}

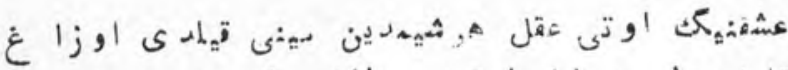

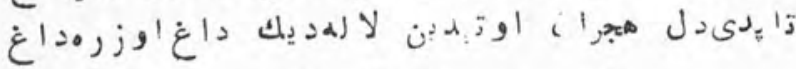

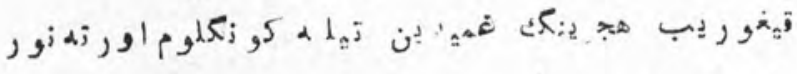

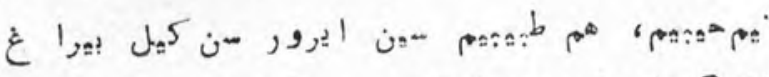

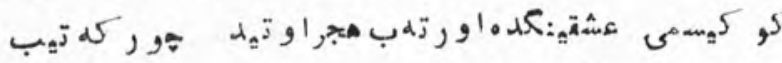

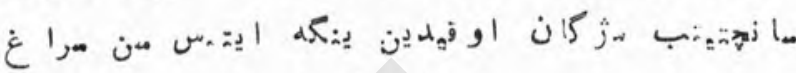

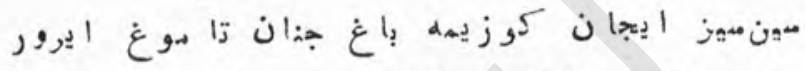

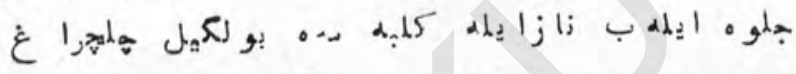

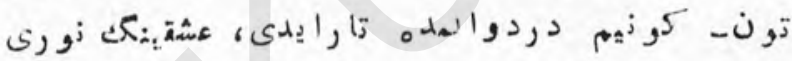

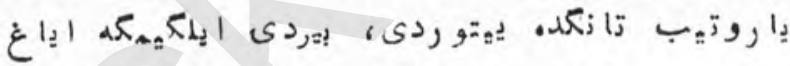

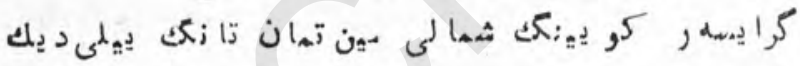

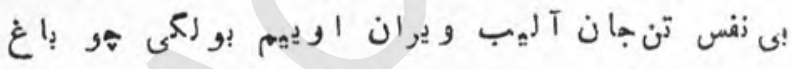

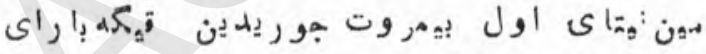

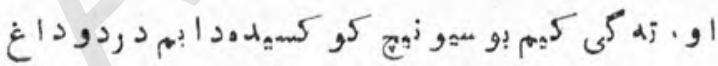

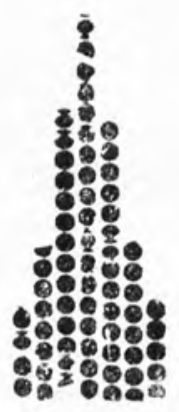




\section{وطن}

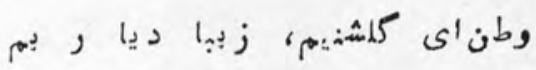

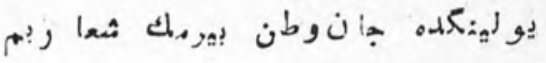

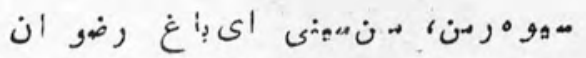

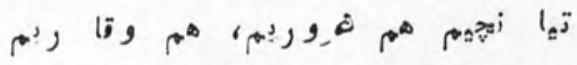

كلستيا

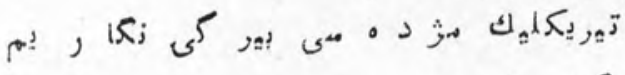

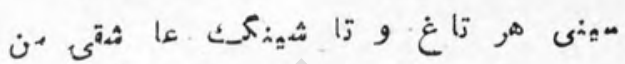

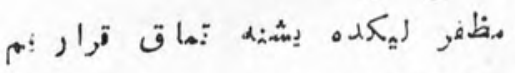

$$
\text { W }
$$

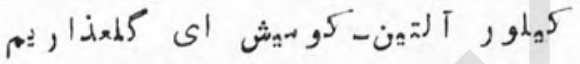

$$
\text { a) }
$$

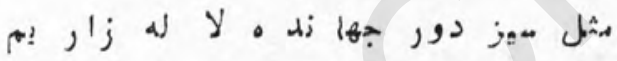

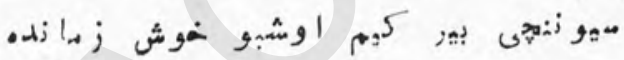

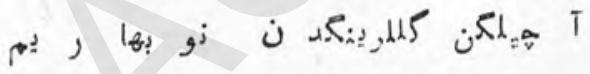

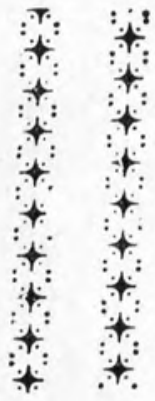




\section{كوهكن}

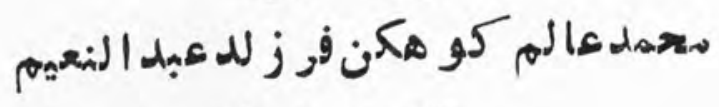

$$
\text { تصاع }
$$

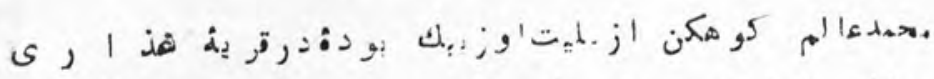

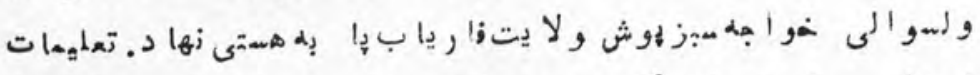

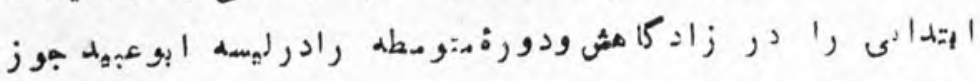

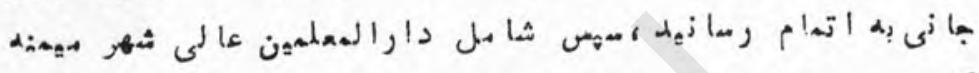

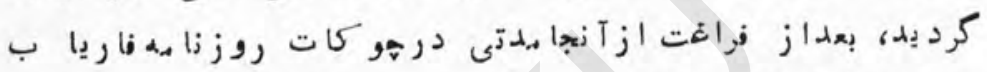

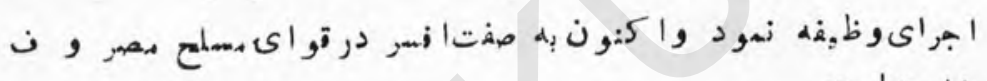

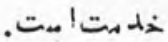

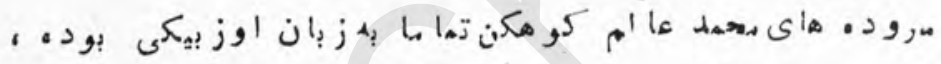

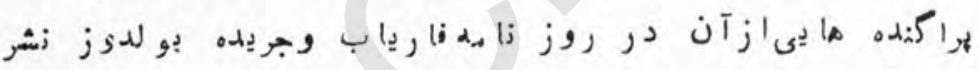

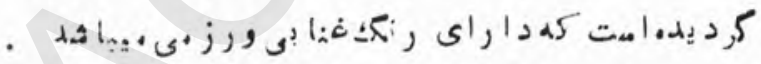

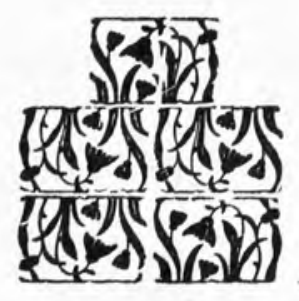




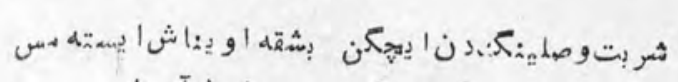

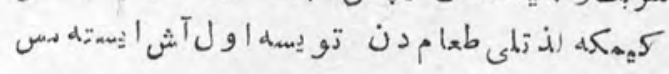

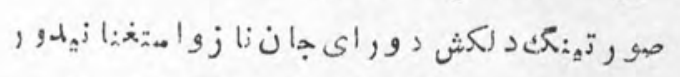

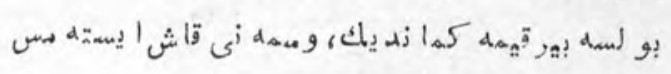

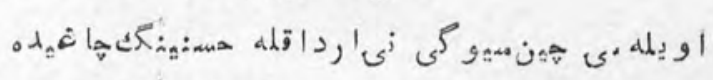

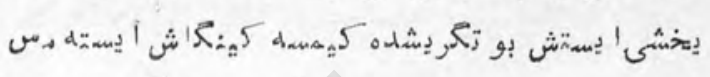

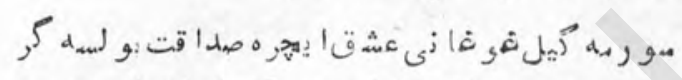

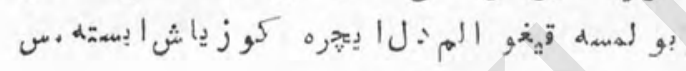

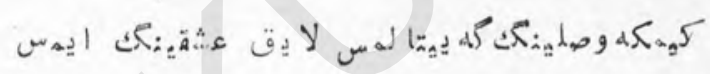

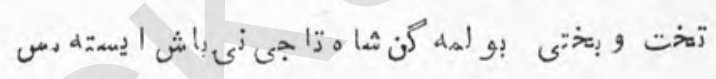

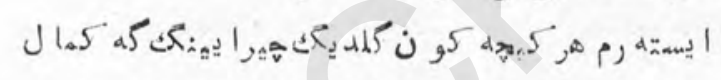

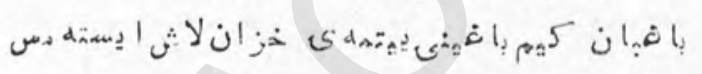

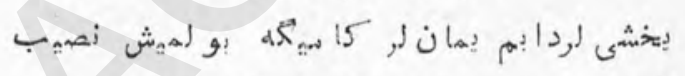

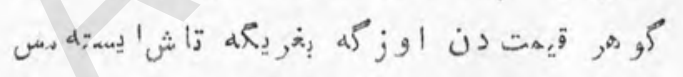

$P A$. 
قوياش آهنكى

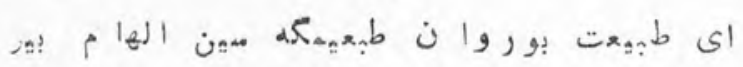

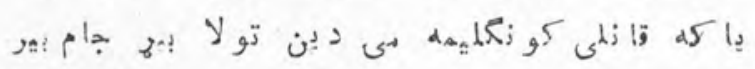

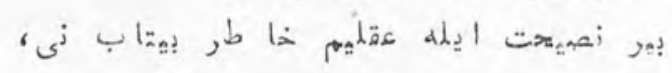

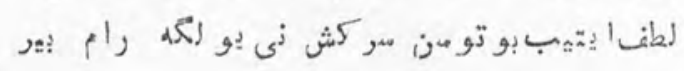

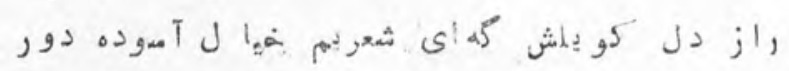

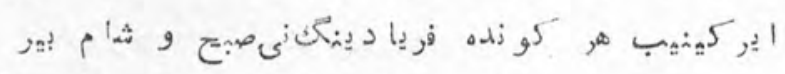

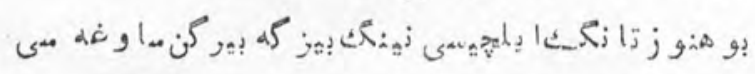

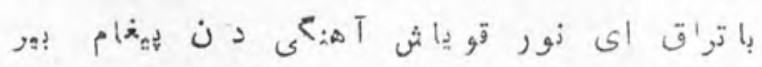

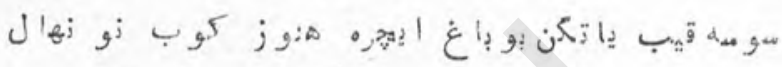

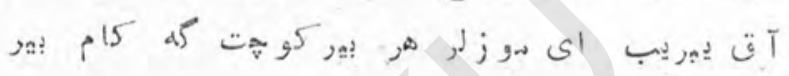

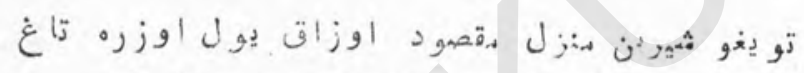

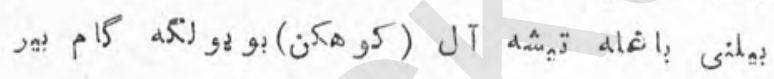

\%

-

군

(5)

PAI 


$$
\begin{aligned}
& 1 \text { ํㅜ }
\end{aligned}
$$

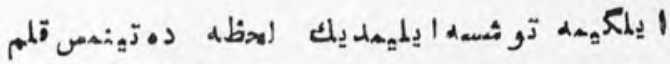

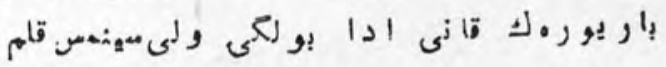

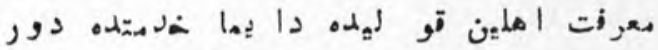

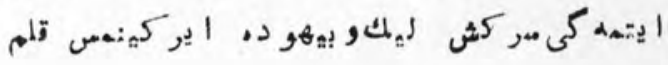

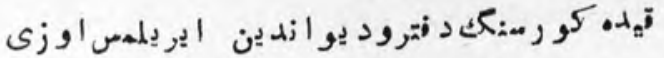

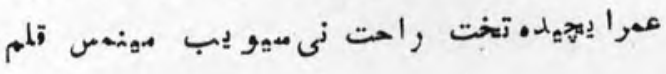

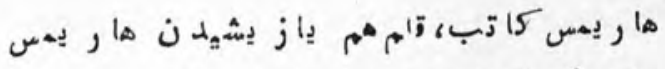

$$
\begin{aligned}
& \text { عششو • Sر }
\end{aligned}
$$

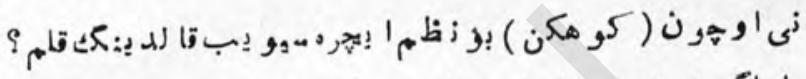

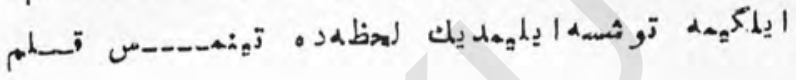

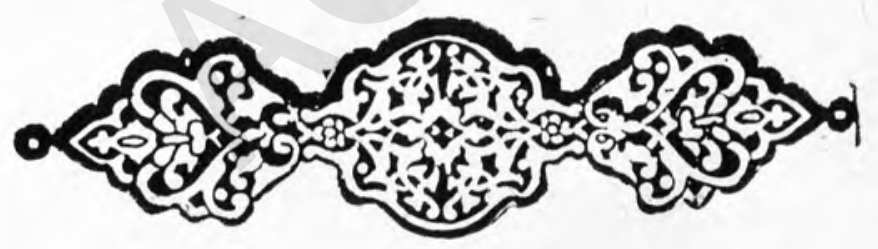




\section{سيو 3لى وطن}

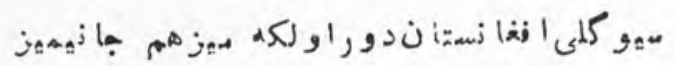

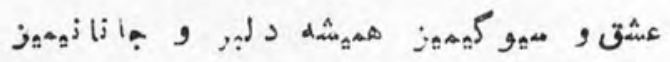

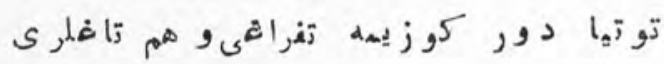

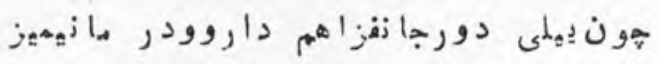

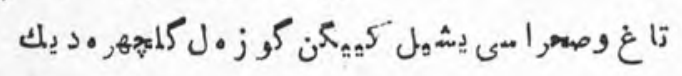

إنهاl

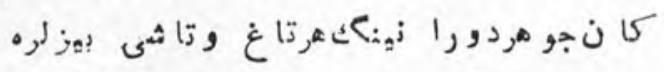

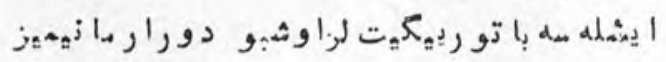

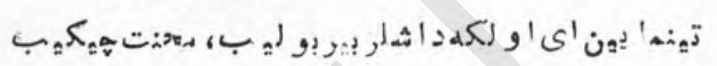

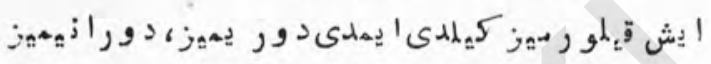

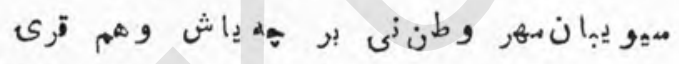

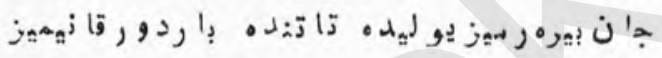

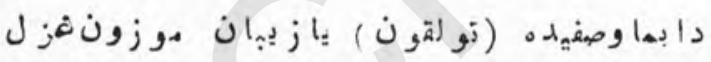

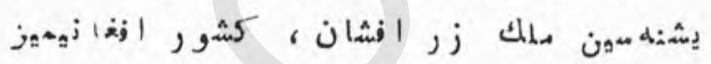

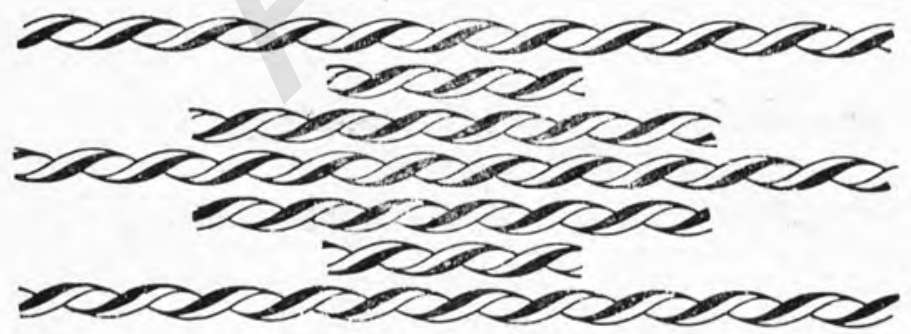




$$
\begin{aligned}
& \text { زلف جلييا }
\end{aligned}
$$

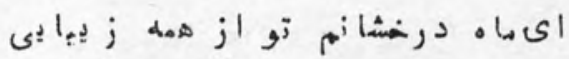

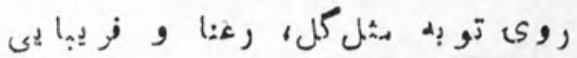

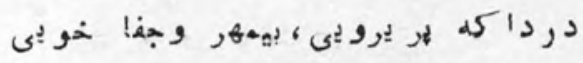

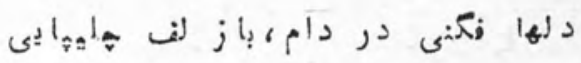

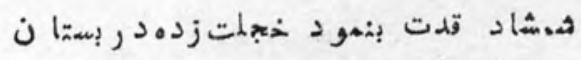

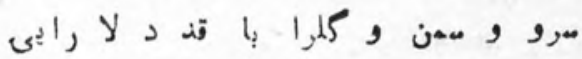

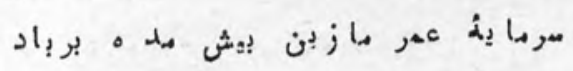

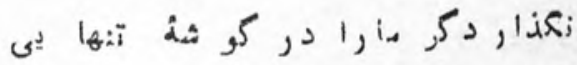

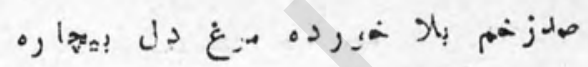

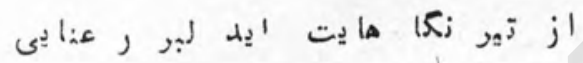

$$
\begin{aligned}
& \text { زجهى تو مكنا فغان إز درد تغا فل ها }
\end{aligned}
$$

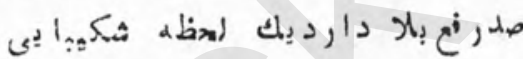

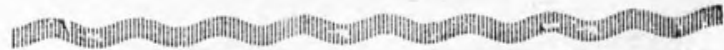

Athom

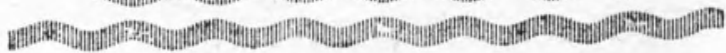


تولقون نجمى

غوث الده ين تو لقون نجهىفوز زيد نجم الده ين

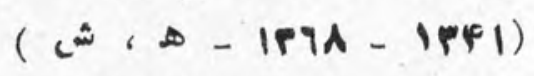

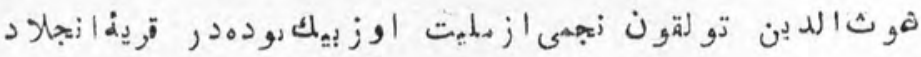

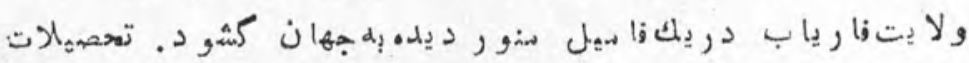

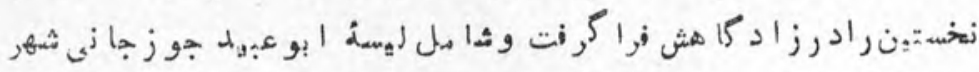

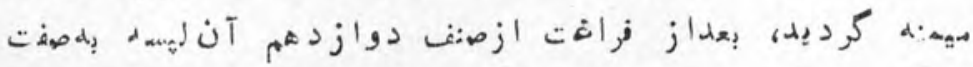

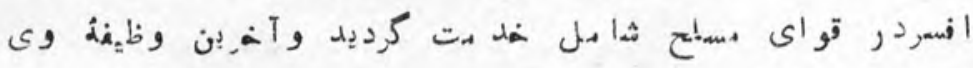

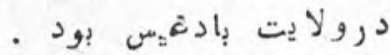

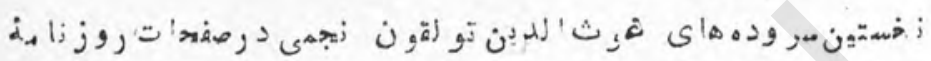

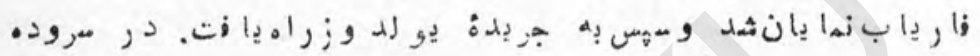

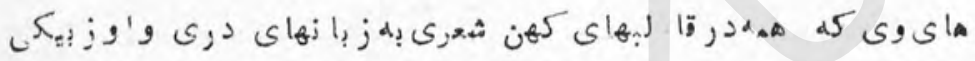

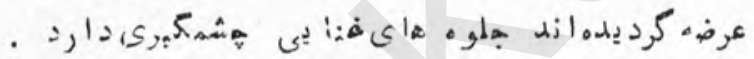

PAD 


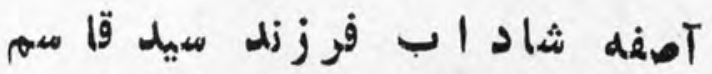

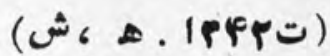

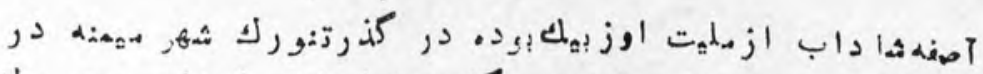

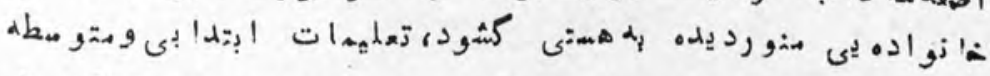

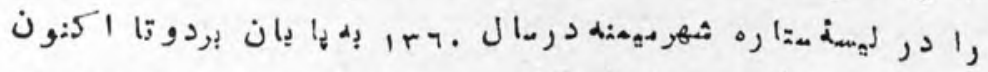

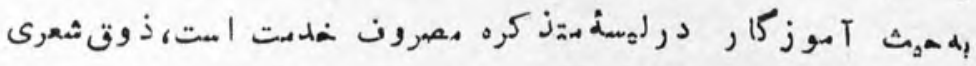

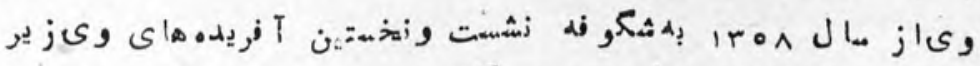

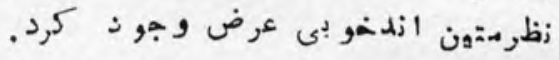

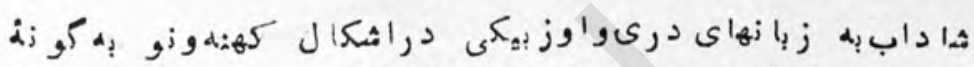

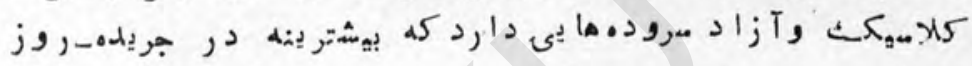

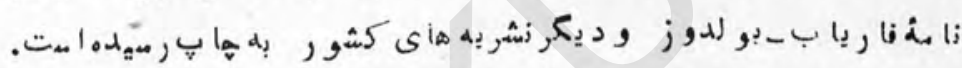

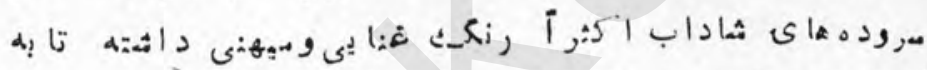

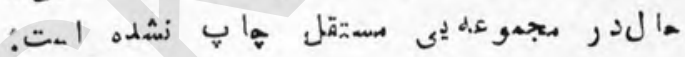

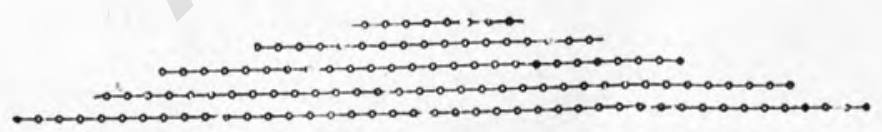

PAT 
معر كة عشاق

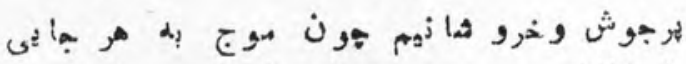

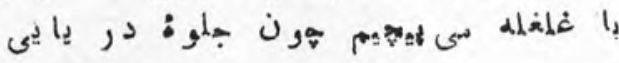

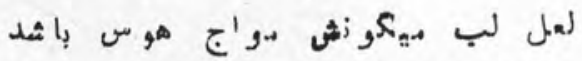

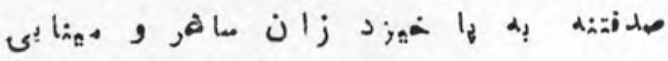

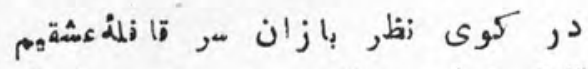

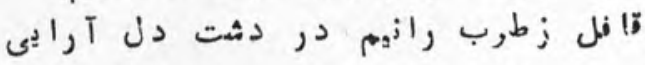

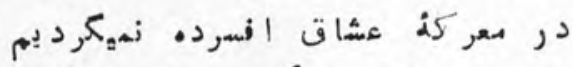

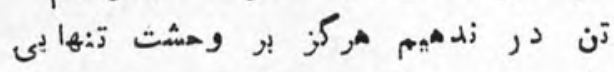

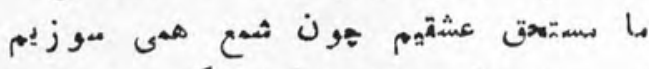

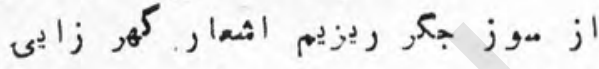

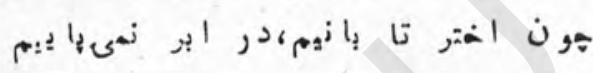

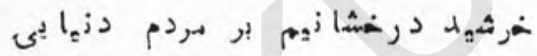

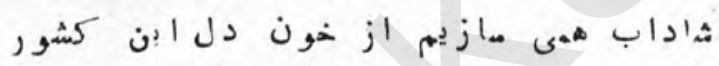

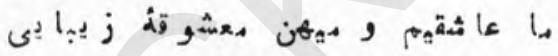

PAY 


\section{قيزغين سوز}

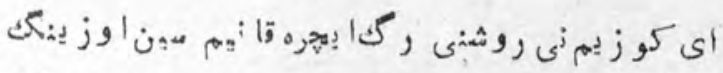

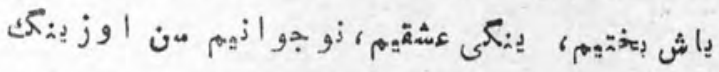

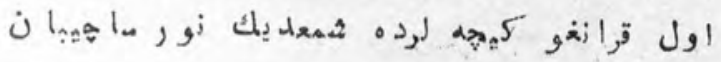

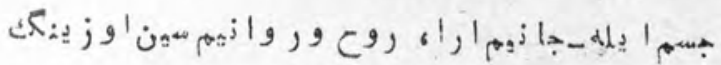

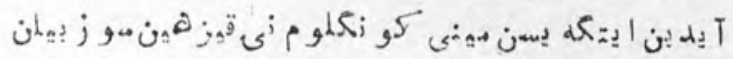

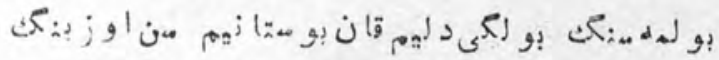

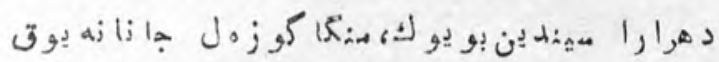

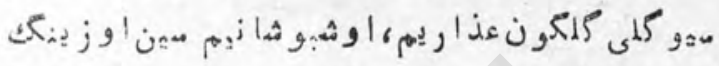

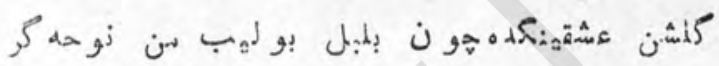

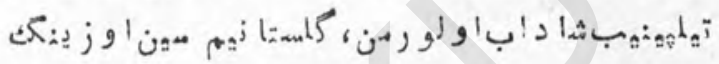

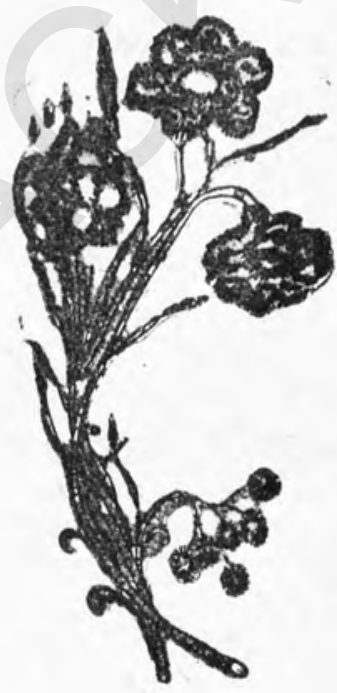




$$
\begin{aligned}
& \text { sodjicalb }
\end{aligned}
$$

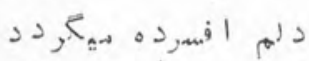

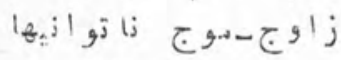

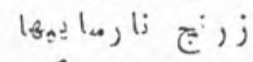

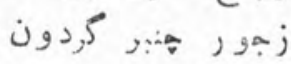

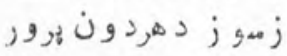

$$
\begin{aligned}
& \text { ا }
\end{aligned}
$$

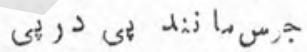

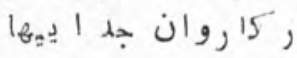

$$
\begin{aligned}
& \text { حكا بـت }
\end{aligned}
$$

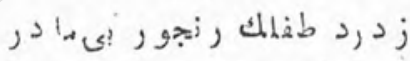

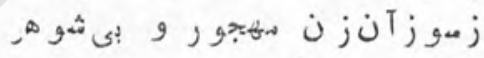

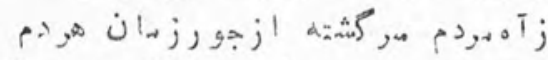

$$
\begin{aligned}
& \text { * } \quad * \\
& \text { * }
\end{aligned}
$$

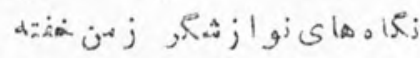

$$
\begin{aligned}
& \text { زئ日) } \\
& \text { | }
\end{aligned}
$$

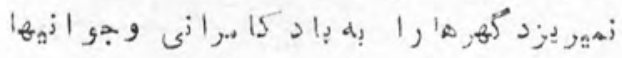

* *

$$
\begin{aligned}
& \text { لملوع } \\
& \text { ا }
\end{aligned}
$$

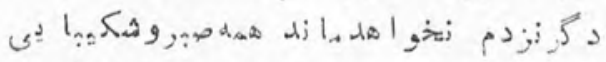

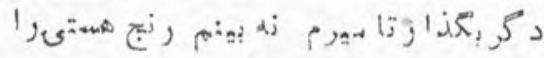

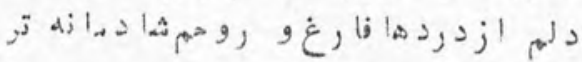

$$
\begin{aligned}
& \text {. j } 1 \text {, this }
\end{aligned}
$$




\section{كيوان}

\section{كبر ا كيو ان فوز ند عبدان الجليل

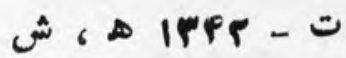

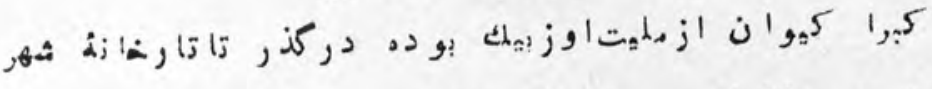

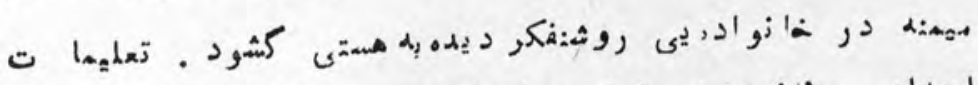

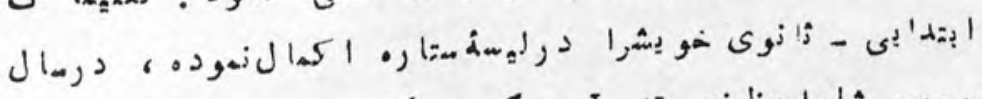

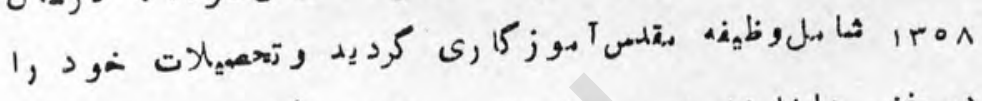

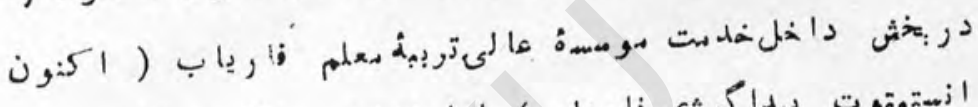

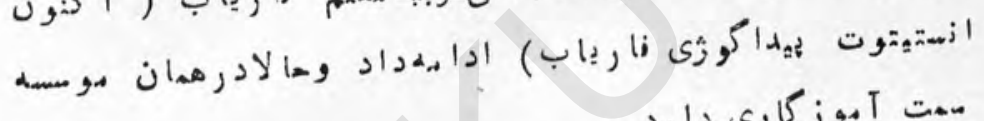
.

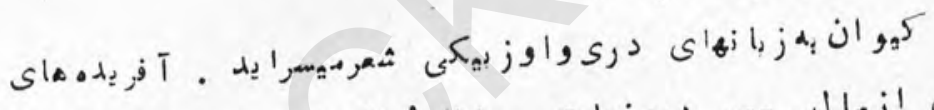

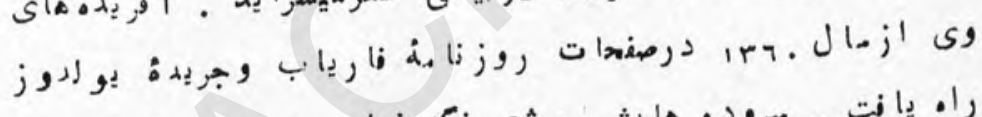

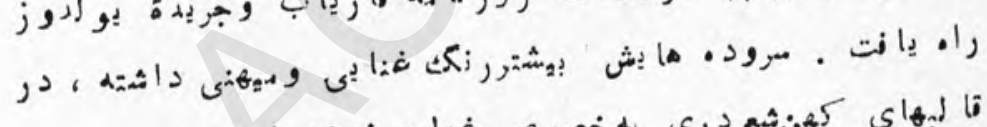

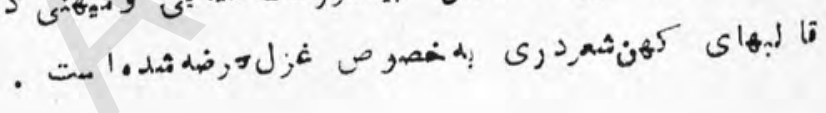

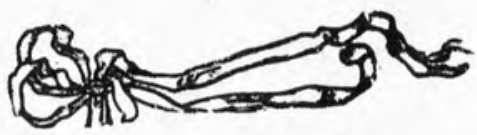


شهيد بهار ى

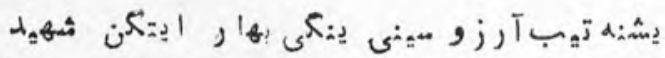

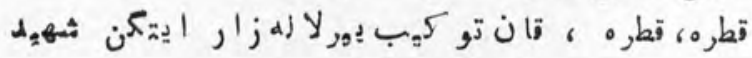

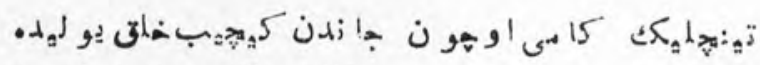

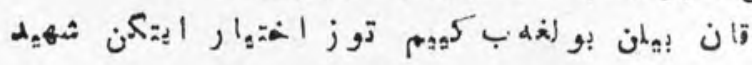

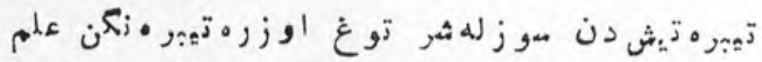

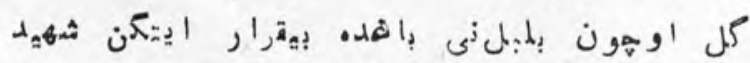

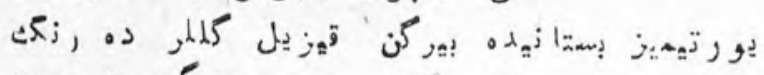

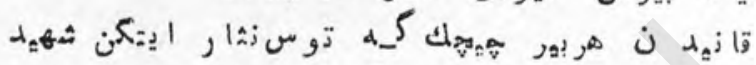

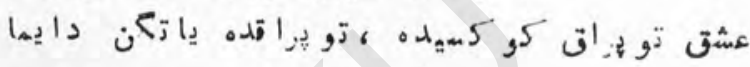

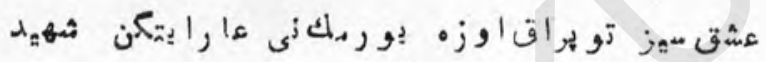

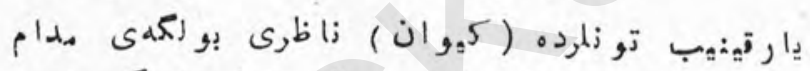

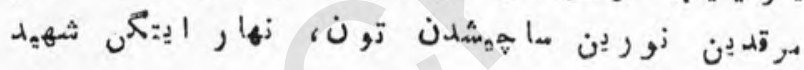

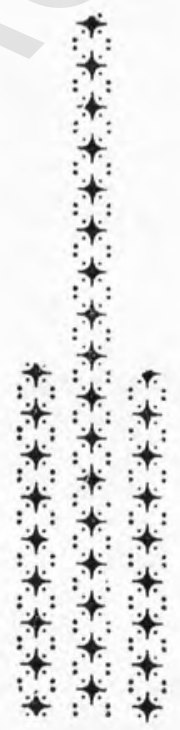

Pal 


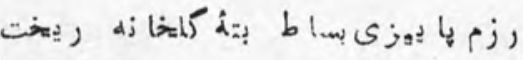

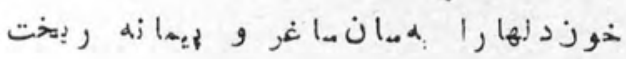

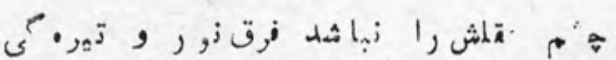

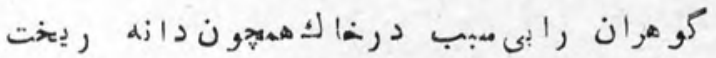

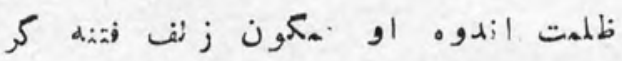

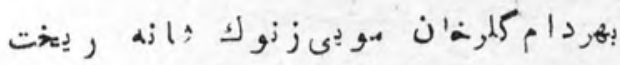

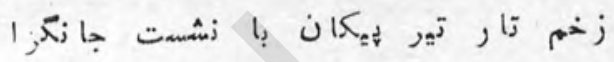

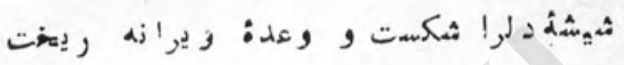

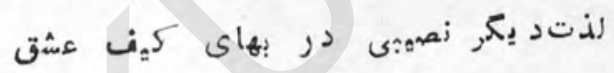

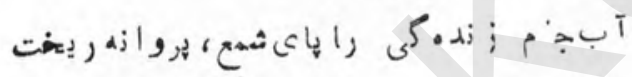

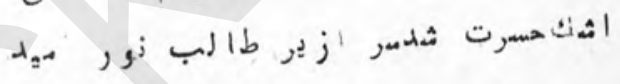

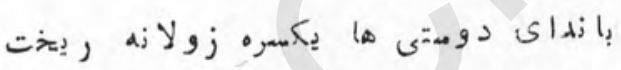

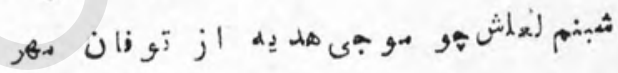

با تسبم قطره

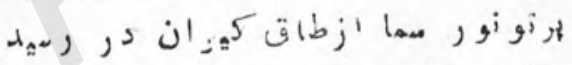

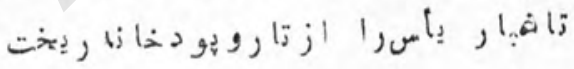

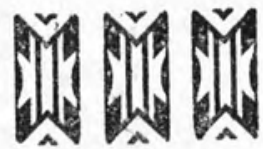

$p q=$ 
Santol

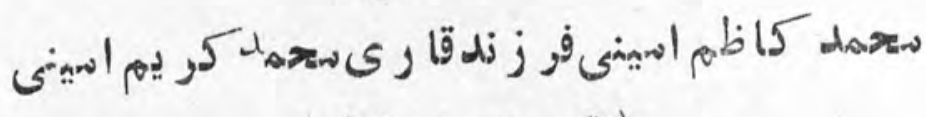

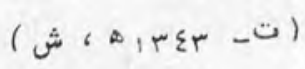

هola

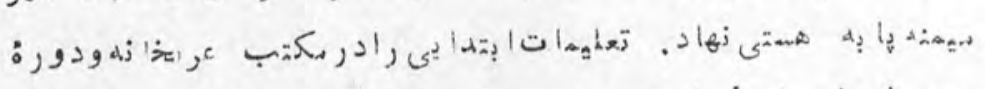

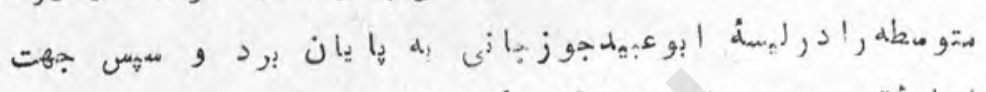

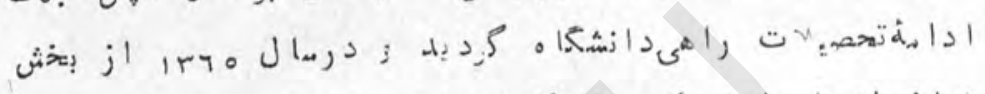

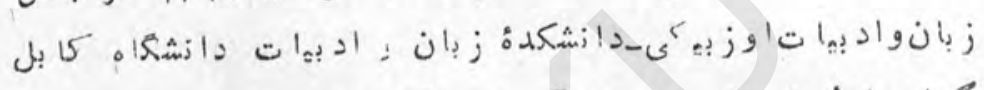

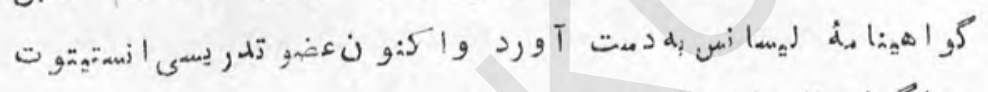
.

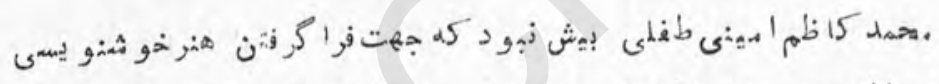

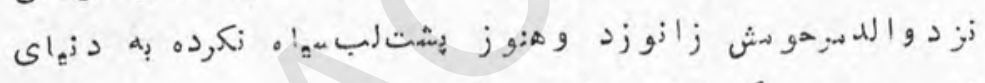

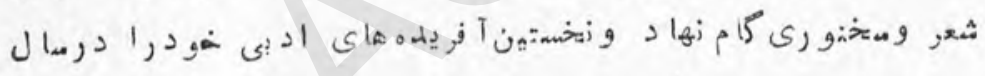

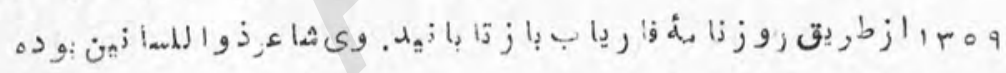

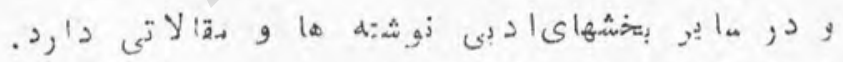

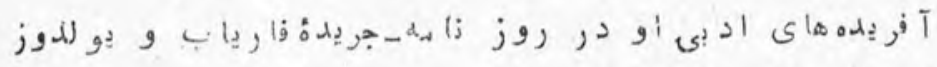

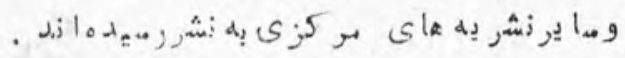

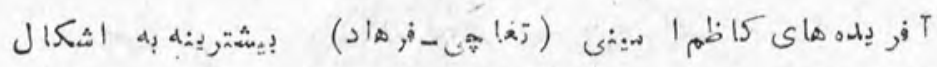

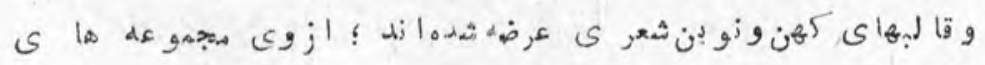
شعرى

$p_{\alpha} p$ 


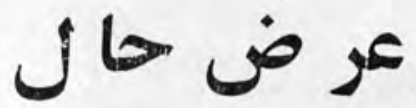

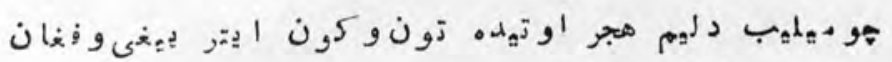

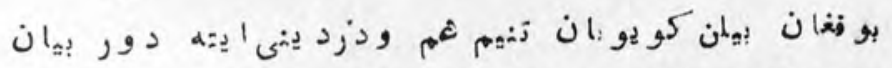

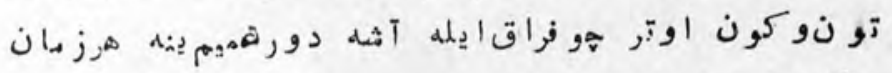

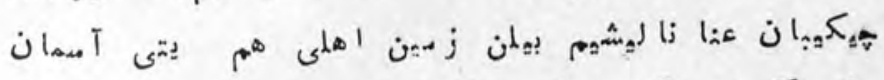

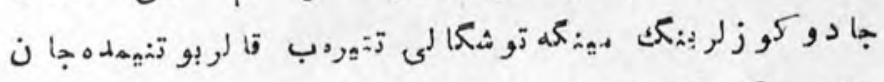

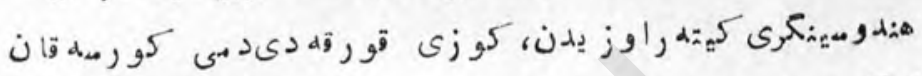

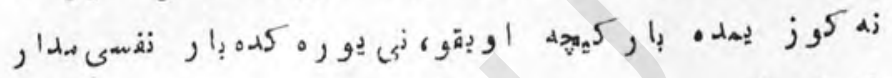

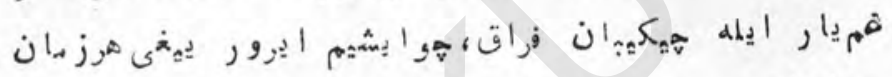

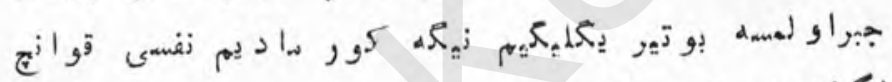

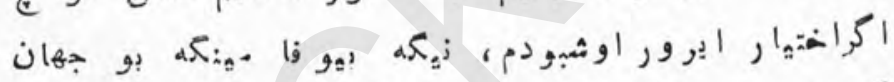

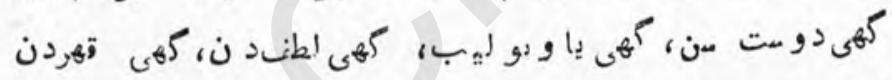

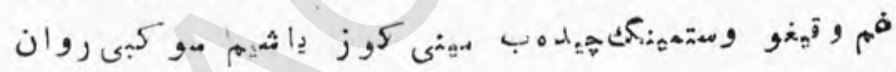

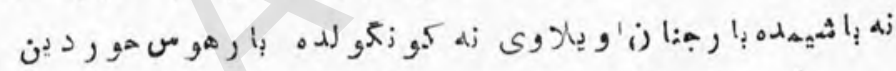

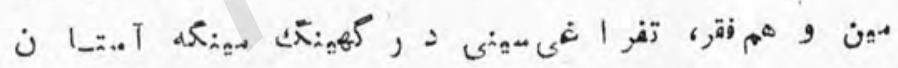

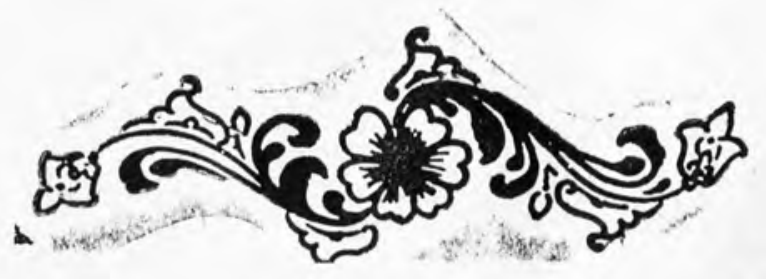




\section{(5)}

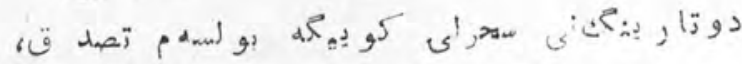

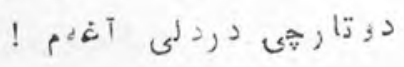

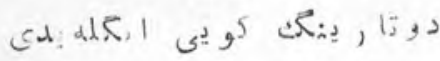

،

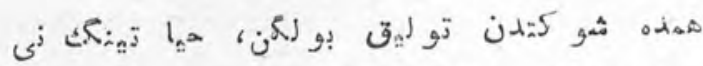

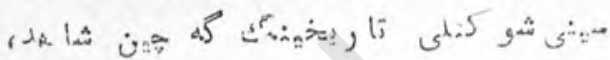

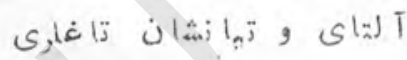

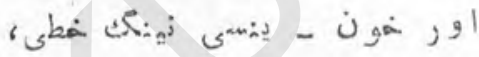

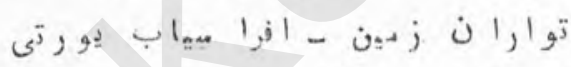

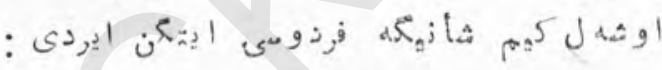

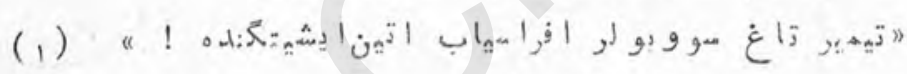

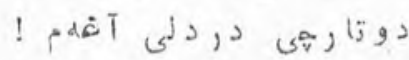

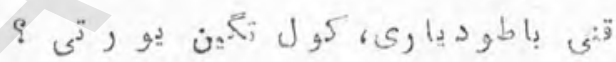

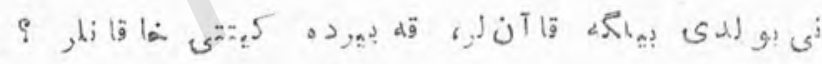

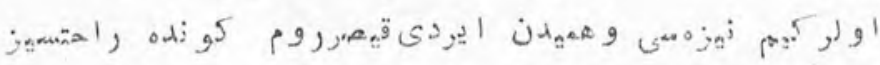

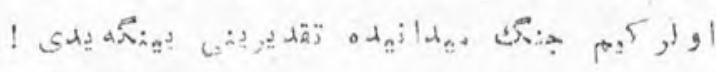

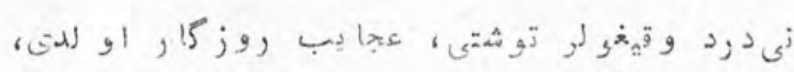

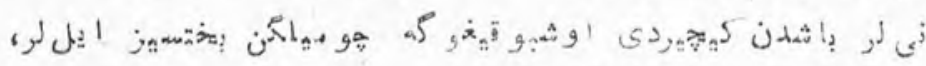

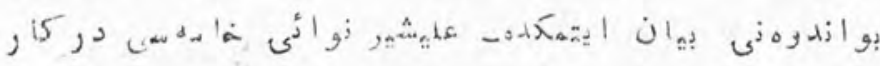

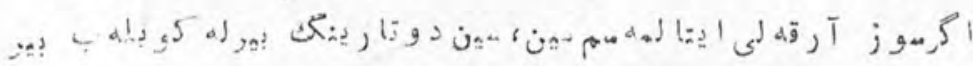

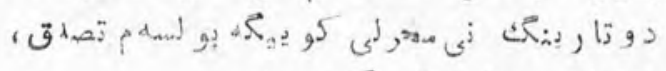

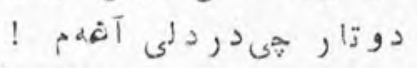

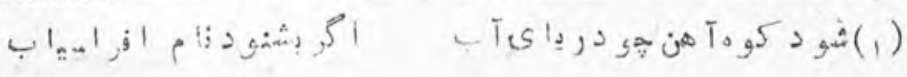

$$
\begin{aligned}
& \text { ( } 1090 \text { ) }
\end{aligned}
$$


مثنوىسوز تعر يفيله :

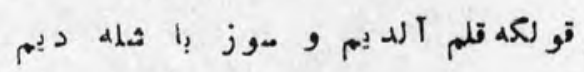

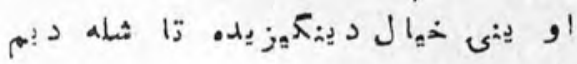

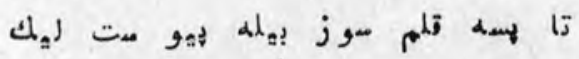

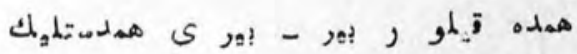

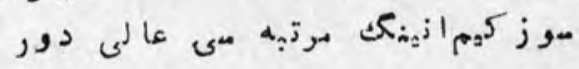

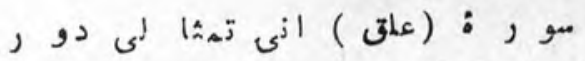

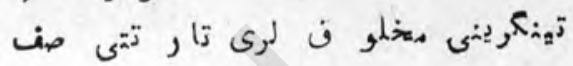

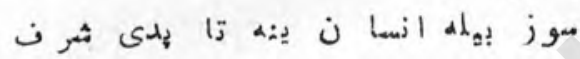

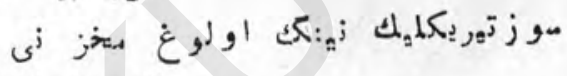

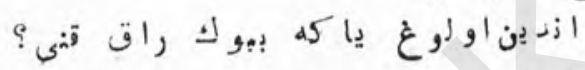

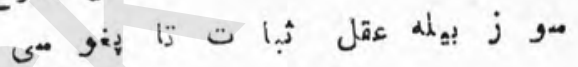

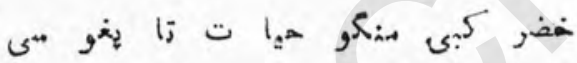

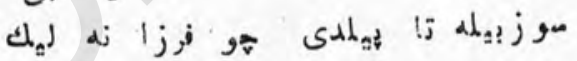

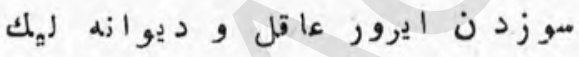

تن تيل| يرور،، موز ازهiك؛ جا نى دور

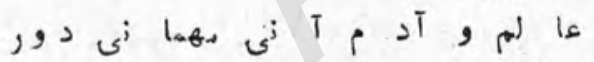

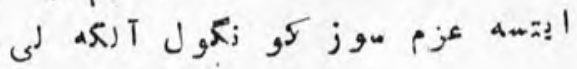

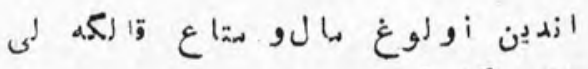

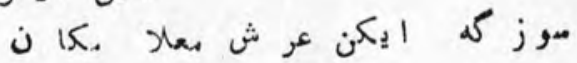
كوعر زأ دِا ب دور ور سوز عـان

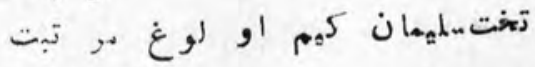

و

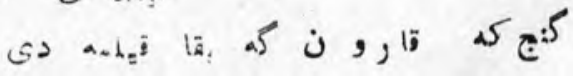

s) datal

ت تخ:

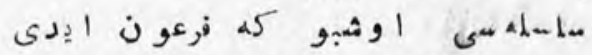

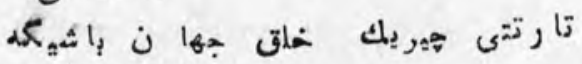

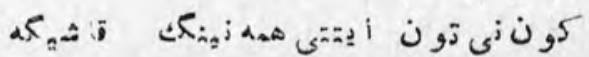

pay 
عاقل و اربا ب هير ر أكى ، ر أكى

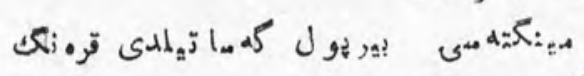

ق إa

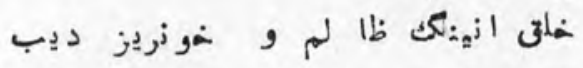

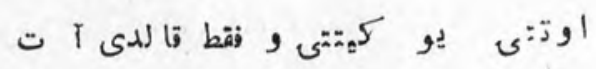

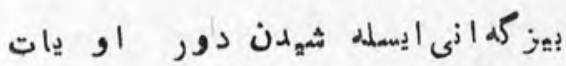

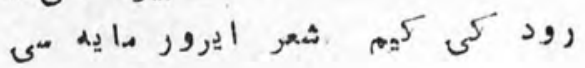

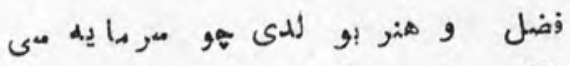

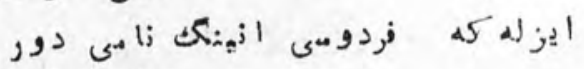

ه:كو ليك الك البته

يا ك:جها

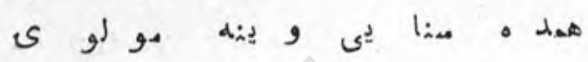

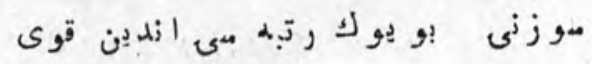

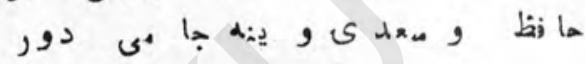

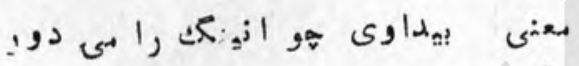

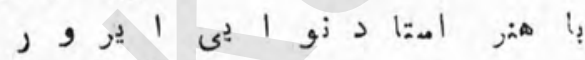

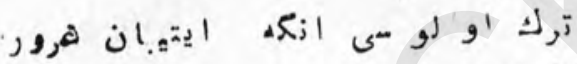

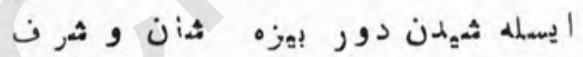

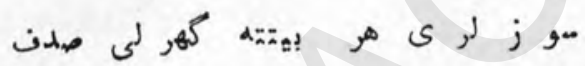

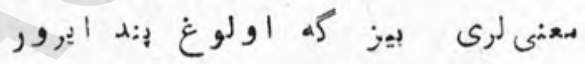

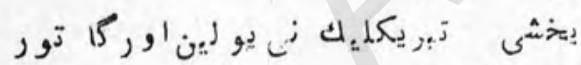

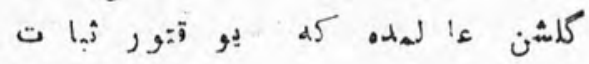

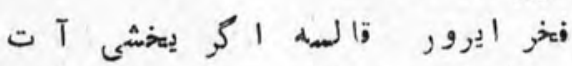

شاه كه بير رو ز زمداه

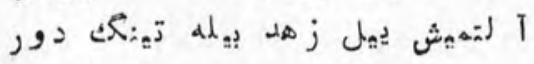

par 


\section{دشتيتيتا ن هور اس}

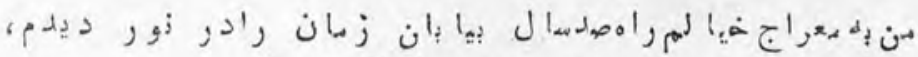

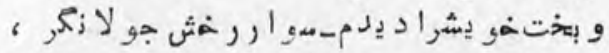

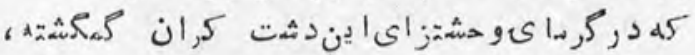

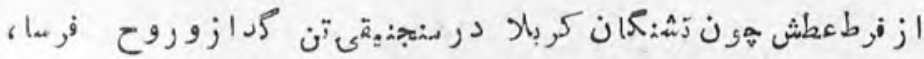

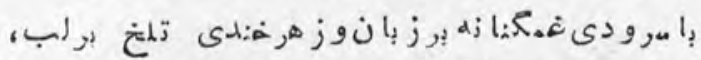

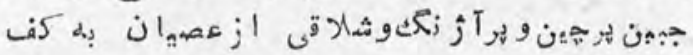

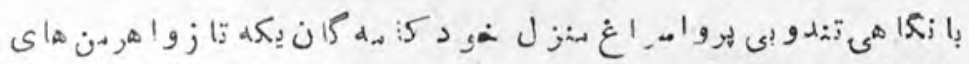

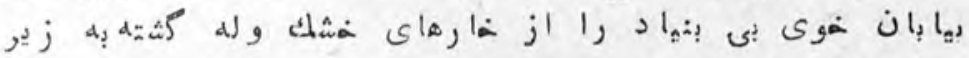

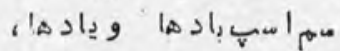

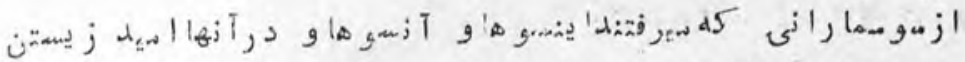

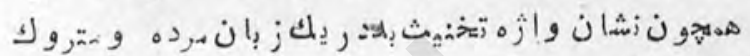

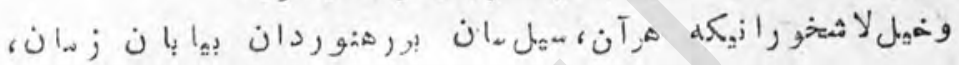

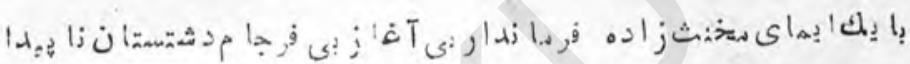

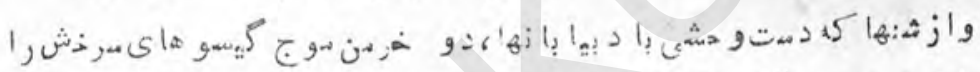

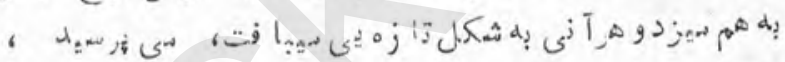

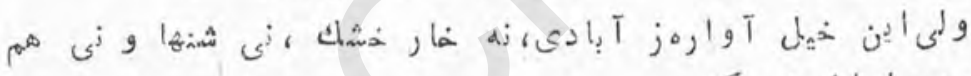

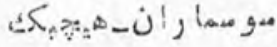

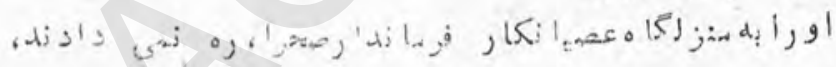

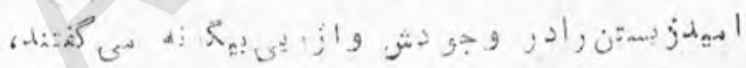

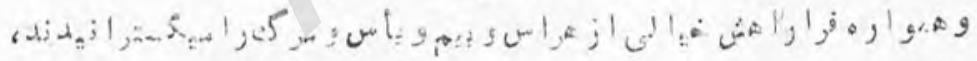

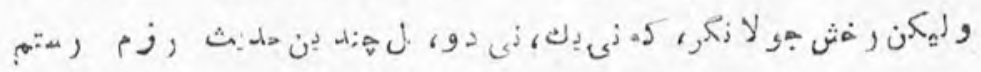

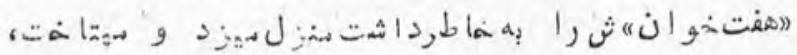

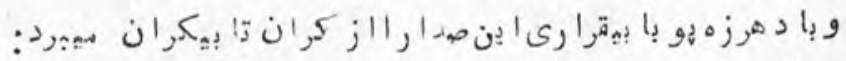

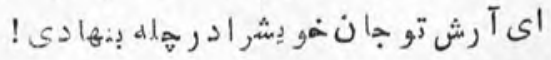


علو همت

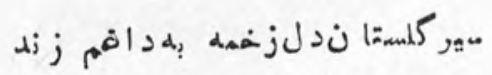

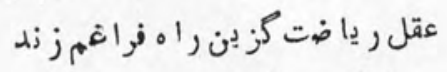

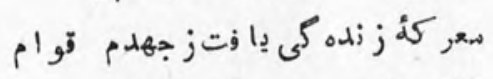

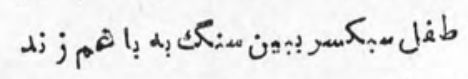

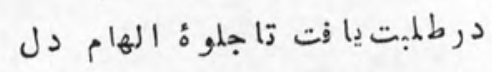

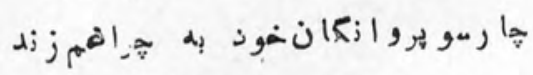

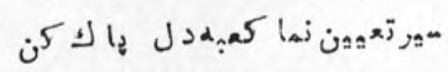

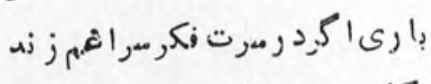

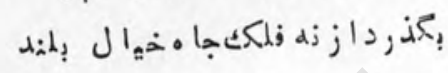

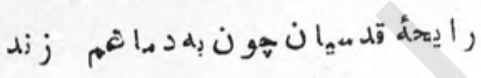

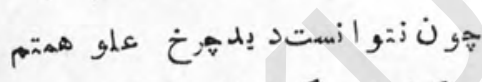

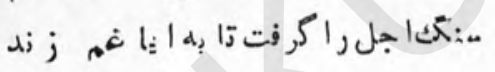

paq 
كائم

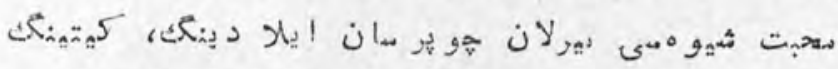

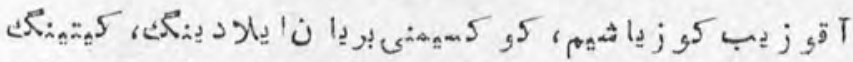

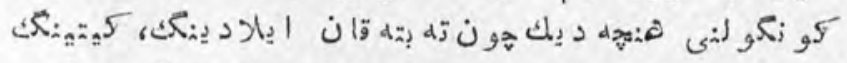

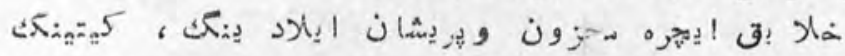
إذكى

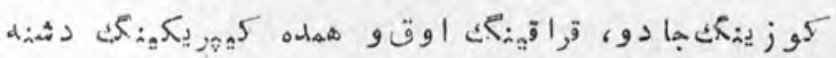

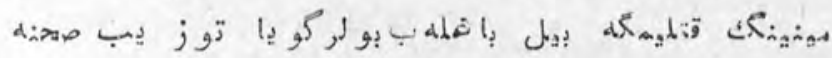

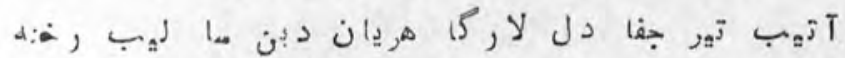
ز

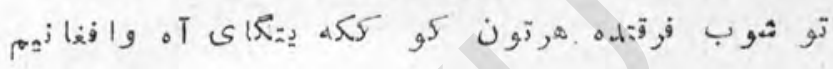

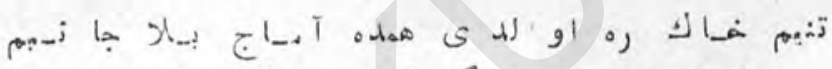

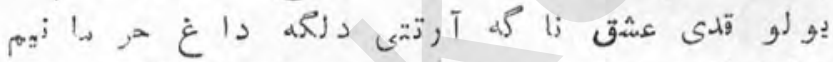

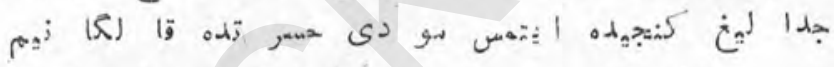

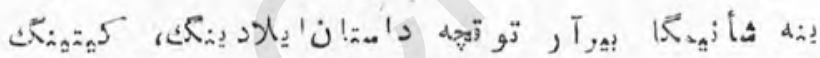

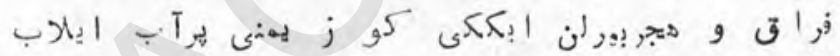

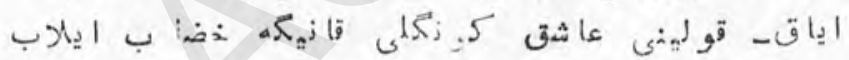

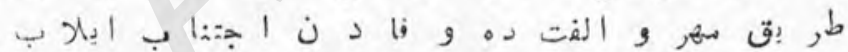

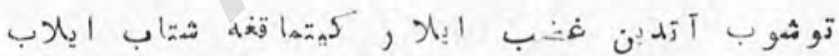

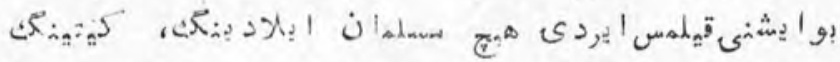

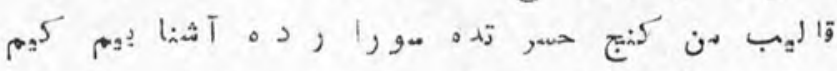

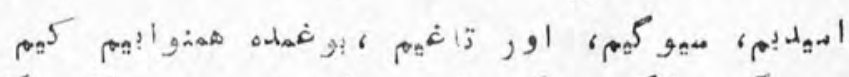

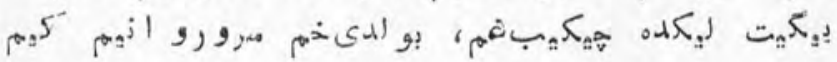

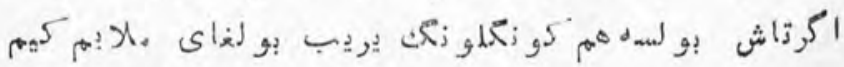

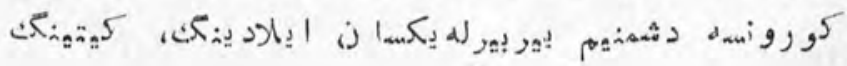

F.. 


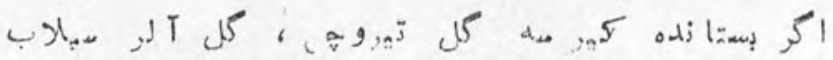

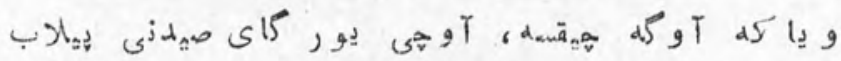

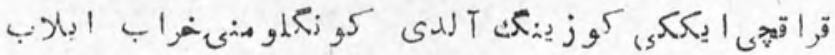

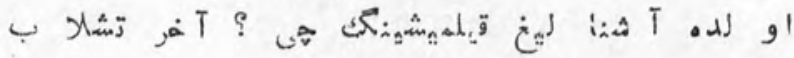

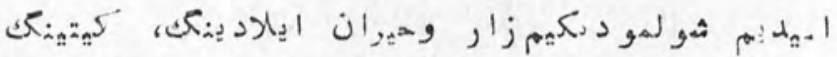

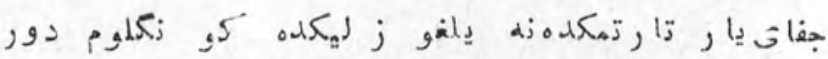

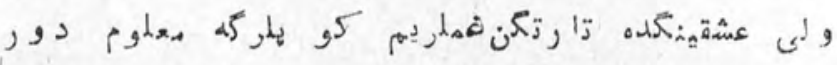

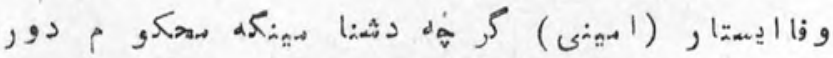

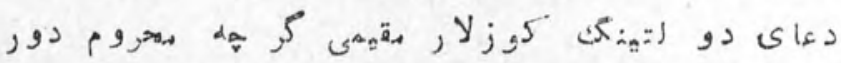

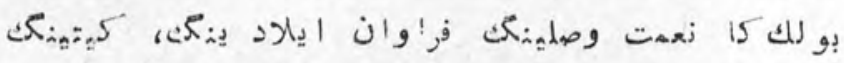

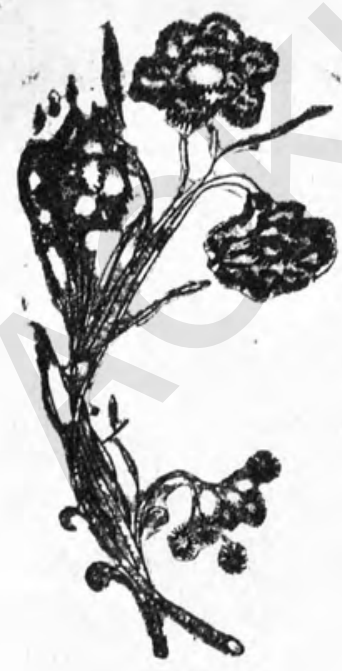


همايون خيرى

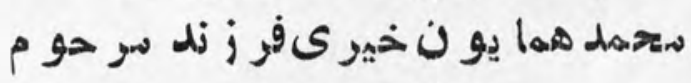

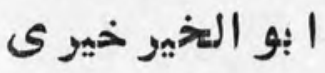

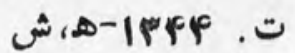

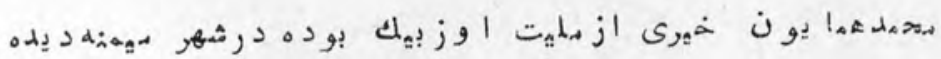

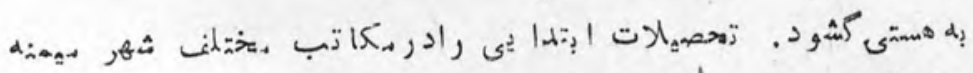

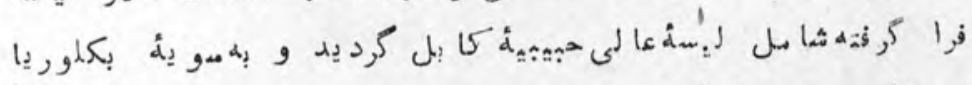

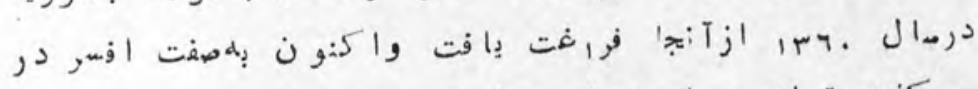

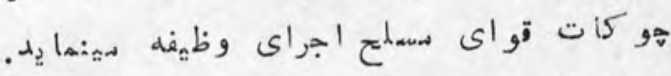

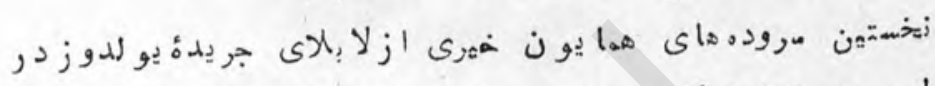

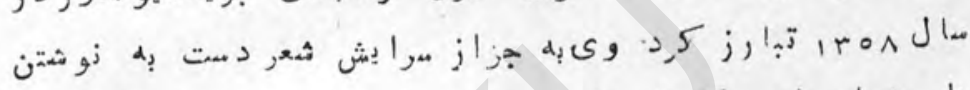

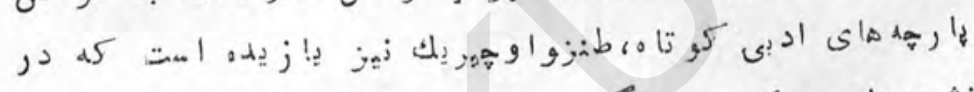

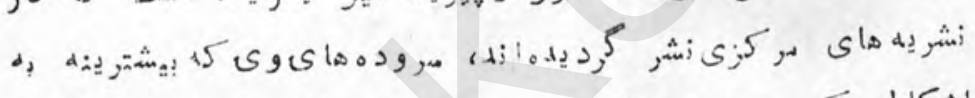

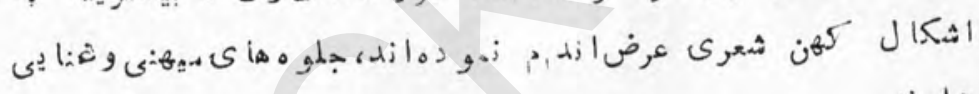

. Ai is

$f \cdot r$ 


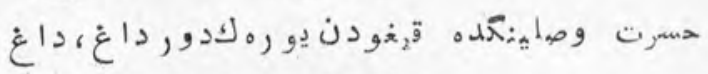

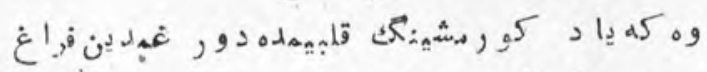

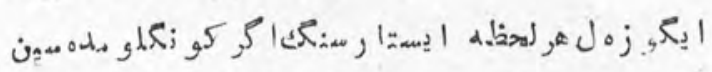

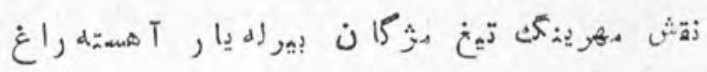

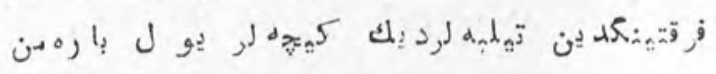

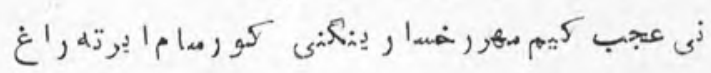

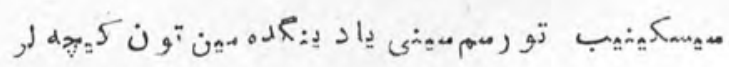

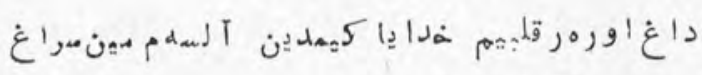

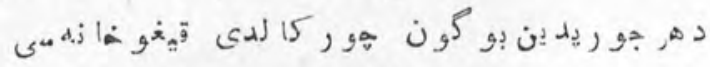

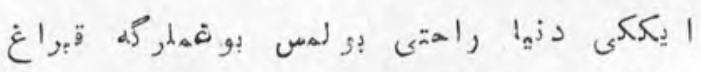

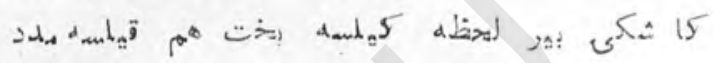

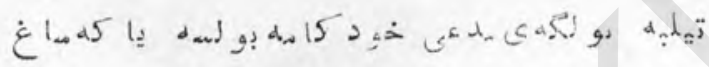

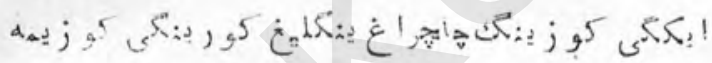

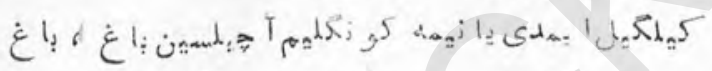

a

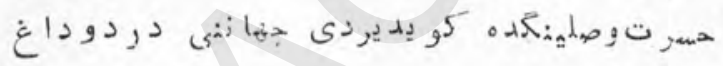

$p \cdot p$ 


\section{تكمله}

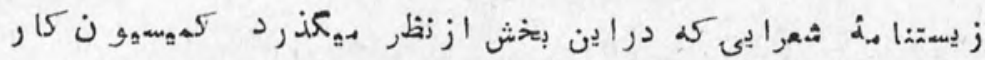

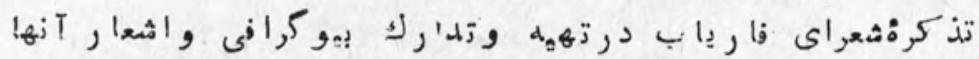

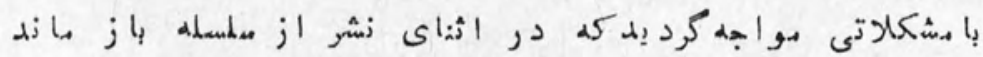

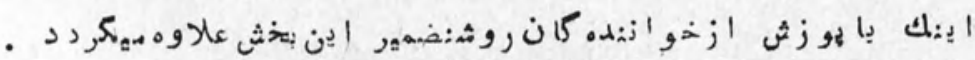

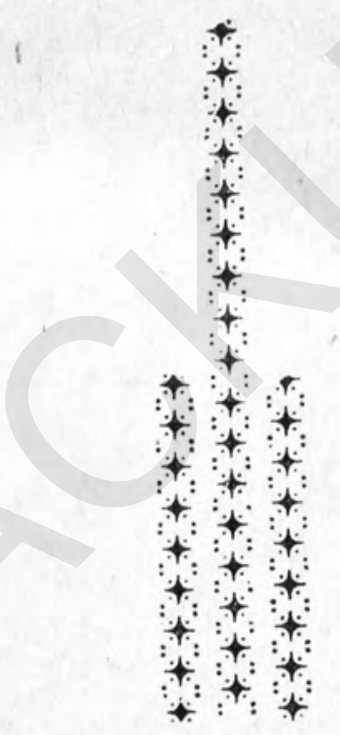

f.P 


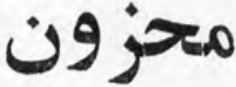

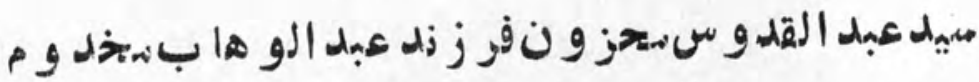

$$
\text { ( ش) IraD - ت ) }
$$

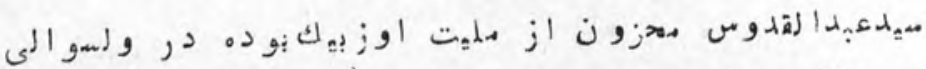

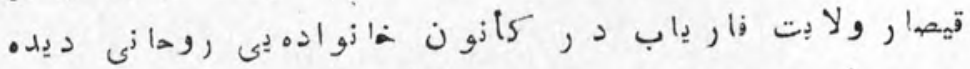

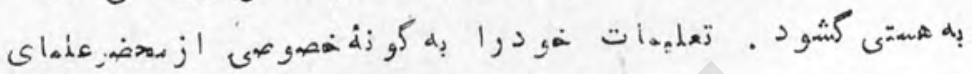

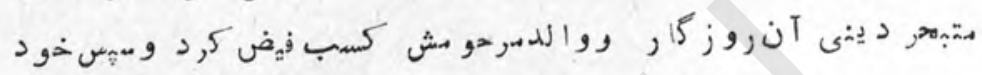

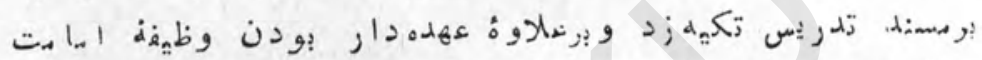

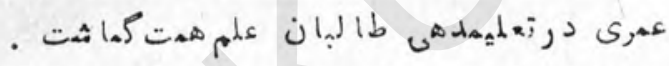

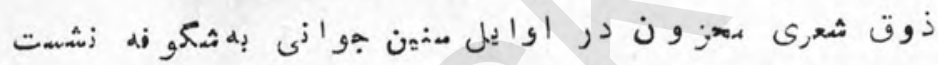

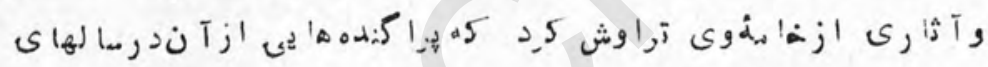

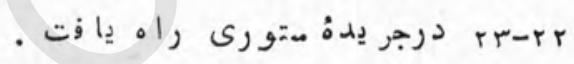

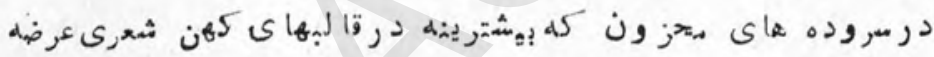

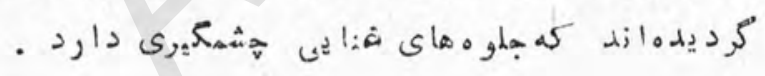

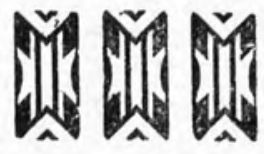




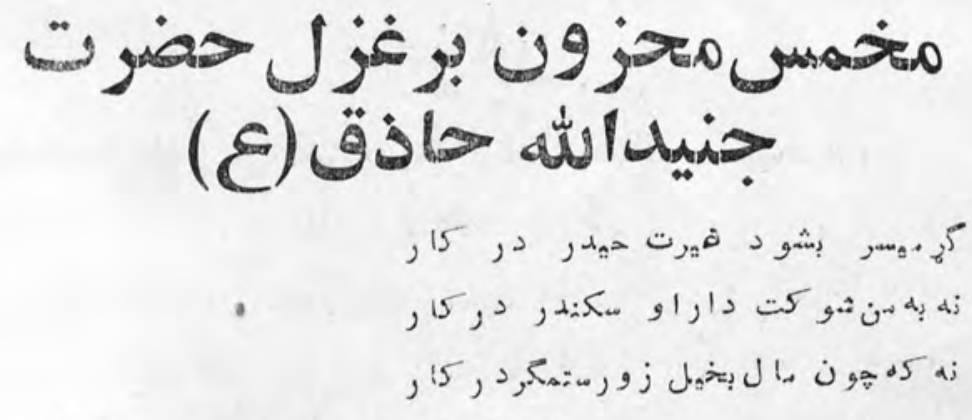

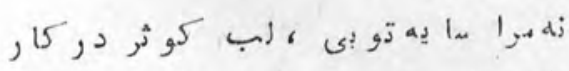

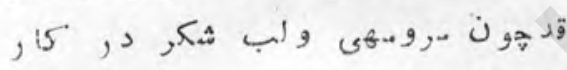

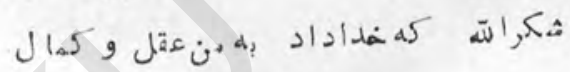

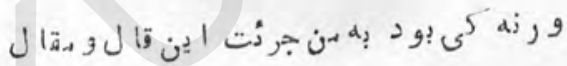
هله

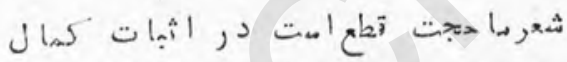

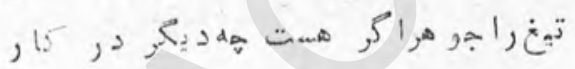

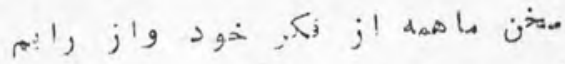

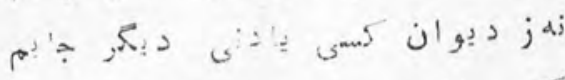

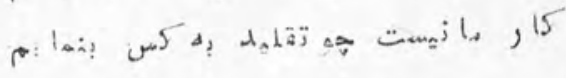

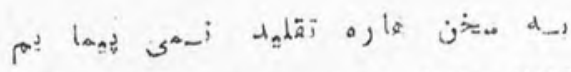

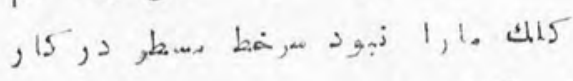

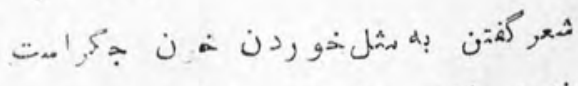

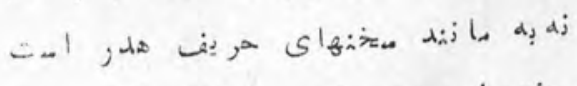

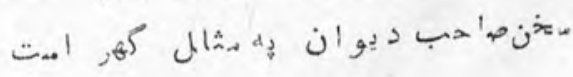

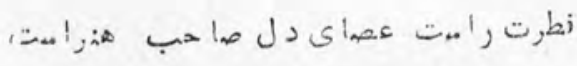

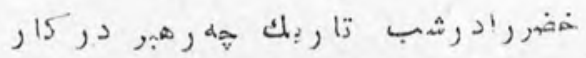




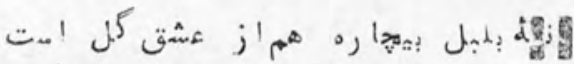

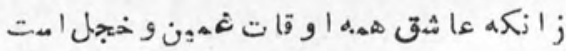

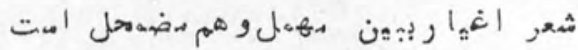

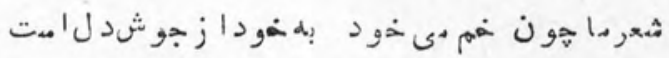

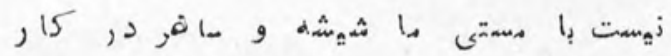

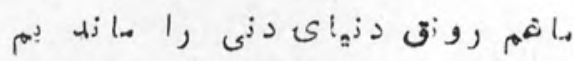

$$
\begin{aligned}
& \text { عشى ?يقودة }
\end{aligned}
$$

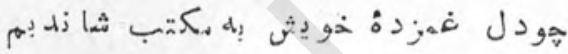

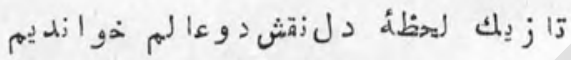

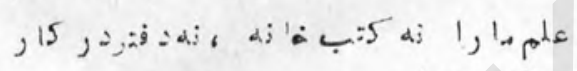

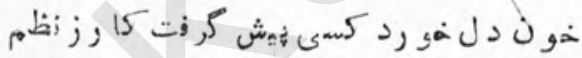

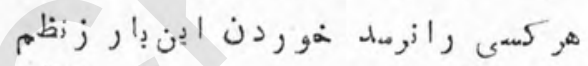

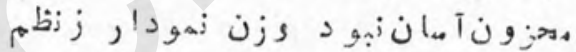

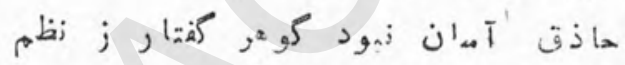

دل

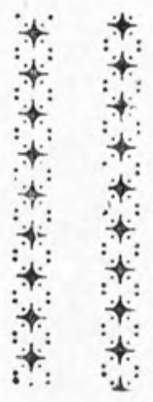




\section{ايشانج}

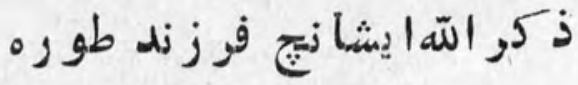 \\ (تهArrira)}

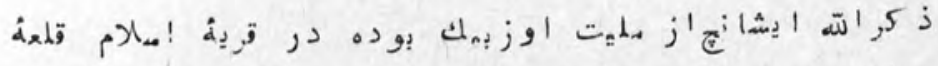

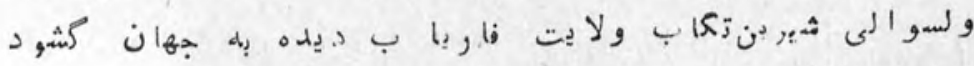

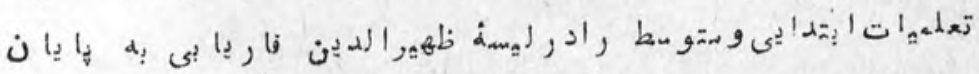

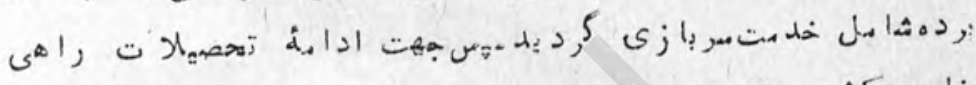

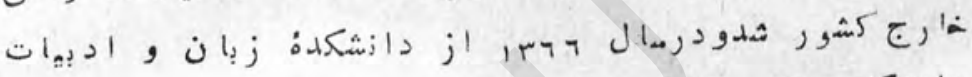

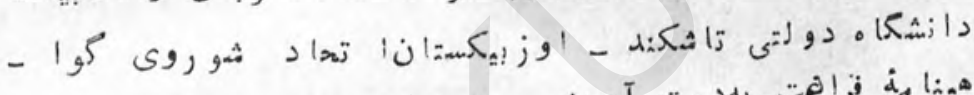

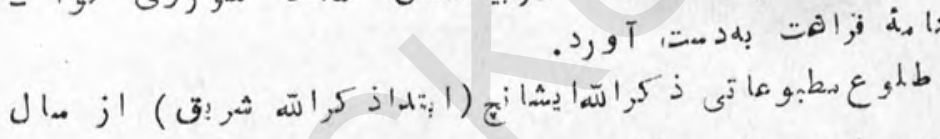

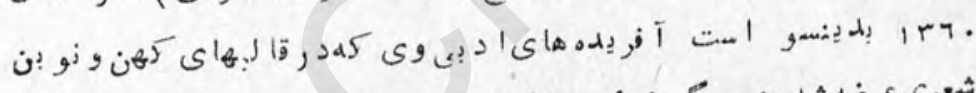

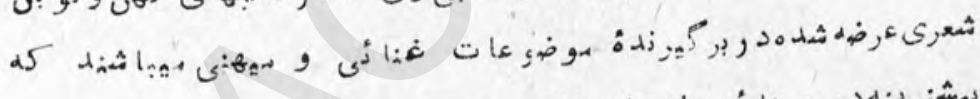

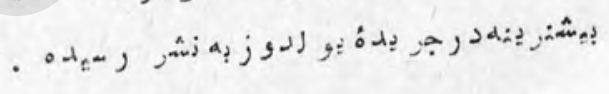


Mä́l

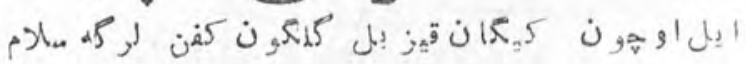

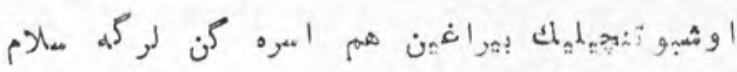

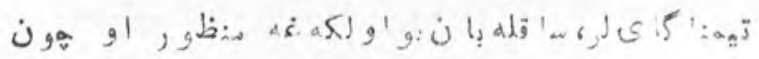

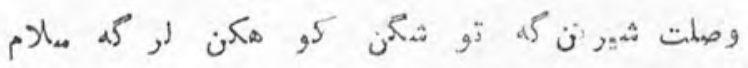

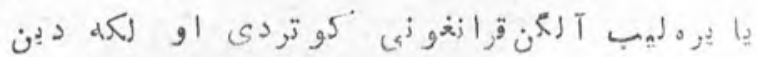

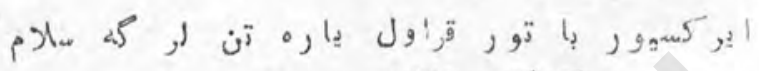

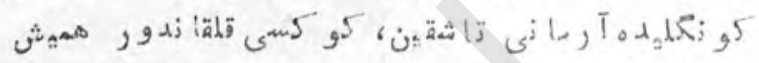

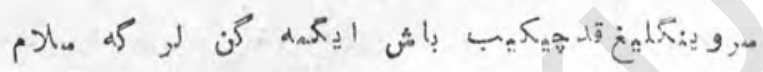

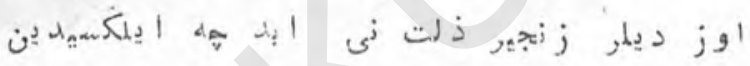

ارس نلان

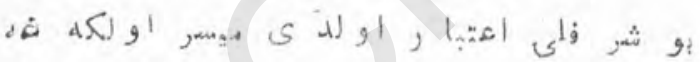

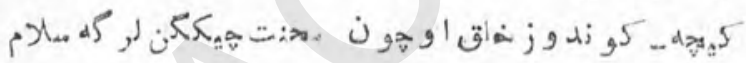

$p \cdot q$ 


\section{istomano}

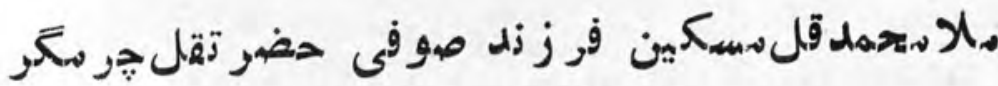
( ش، شIMIA-IFHA)

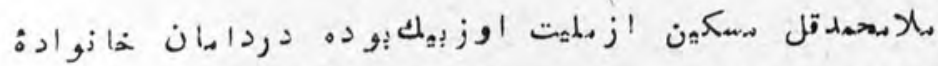

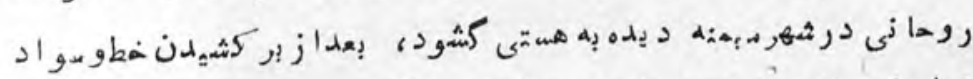

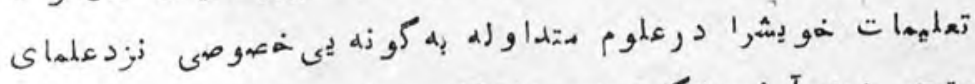

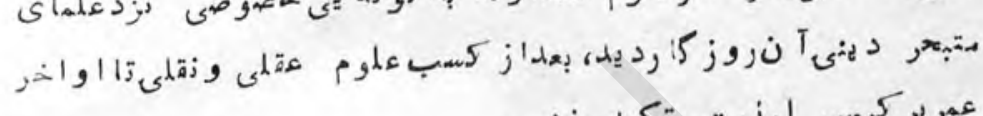

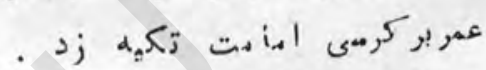

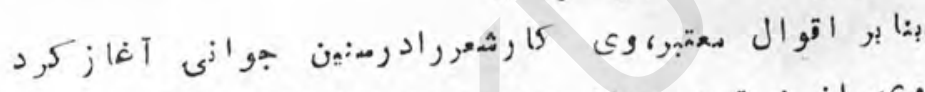

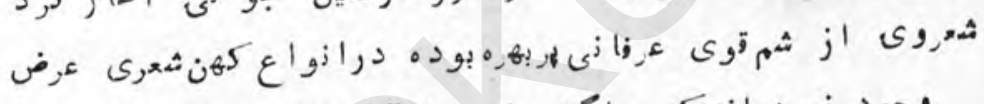

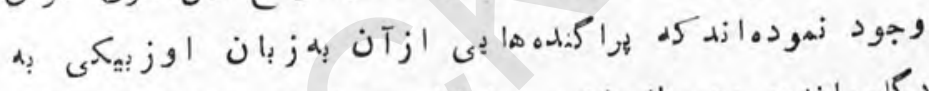

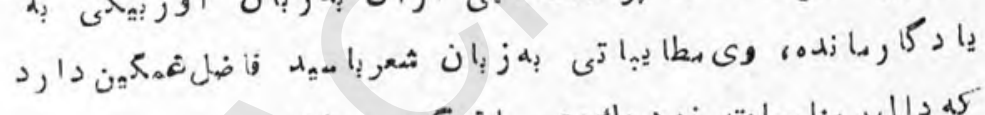

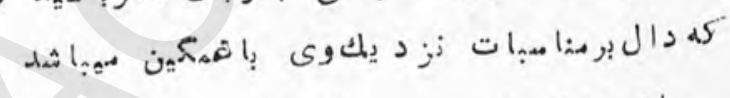

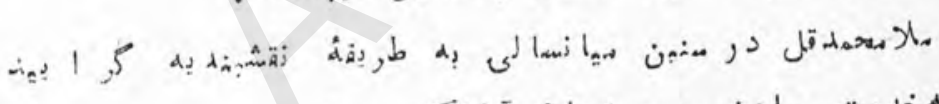

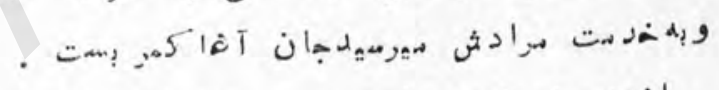

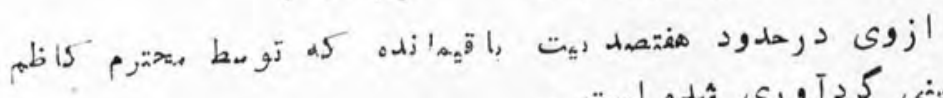

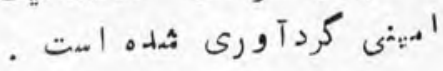

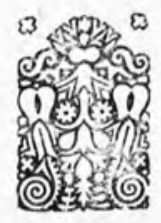




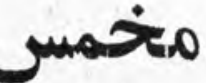

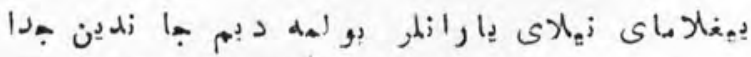

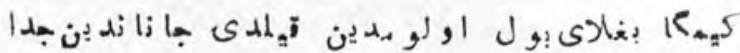

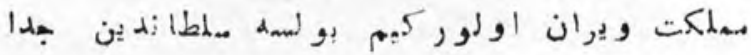

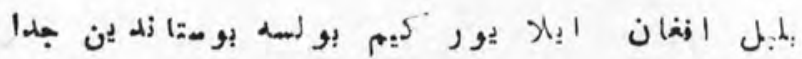

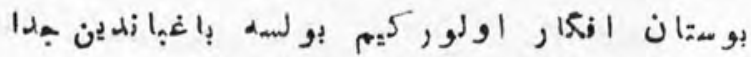

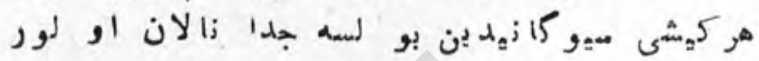

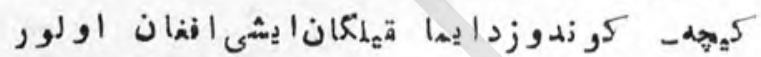

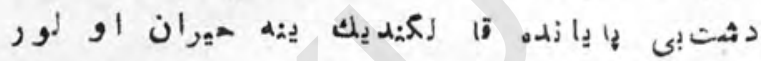

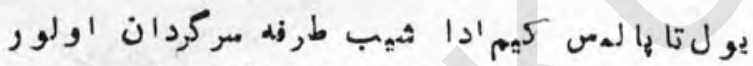

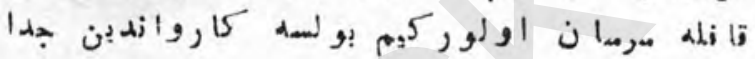

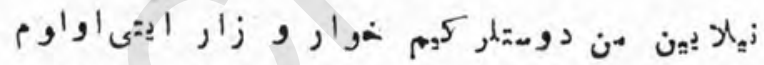

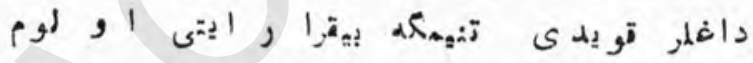

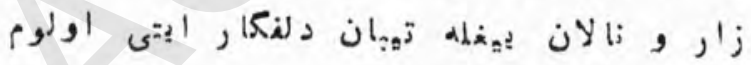

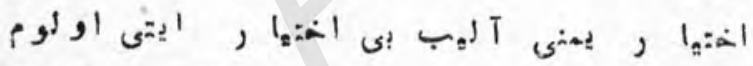

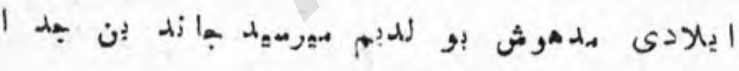

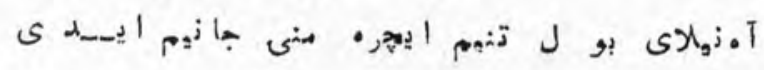

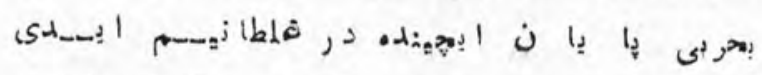

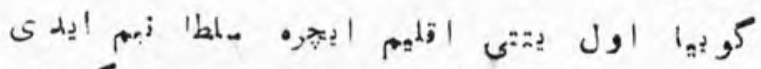

صar:

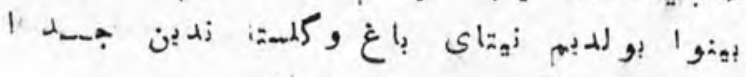

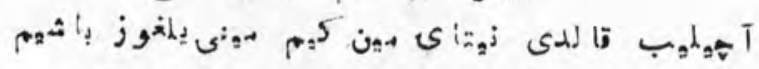

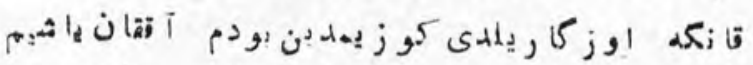

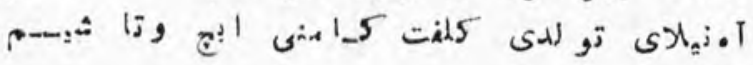




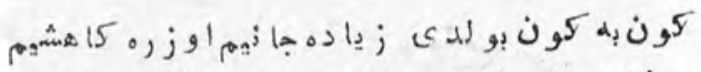

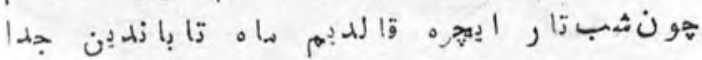

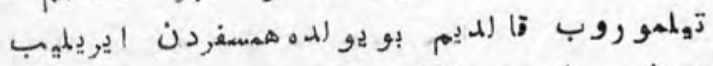

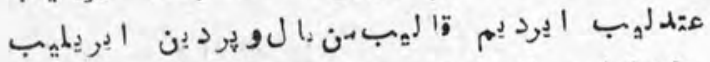

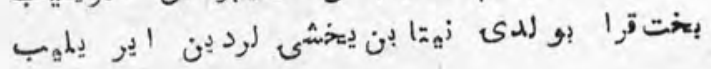

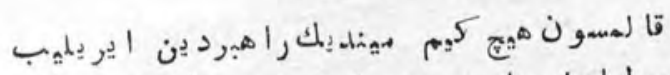

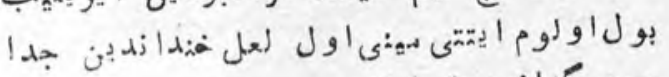

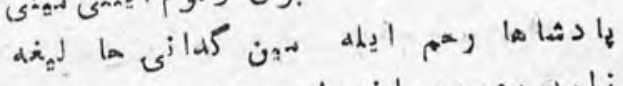

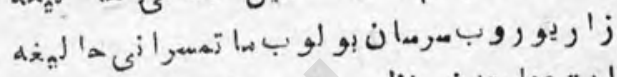

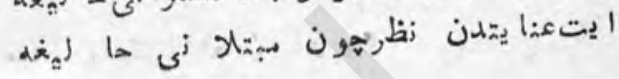

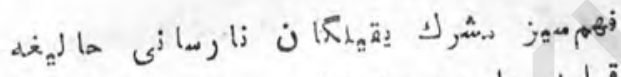

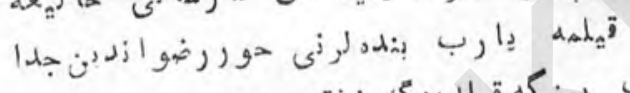

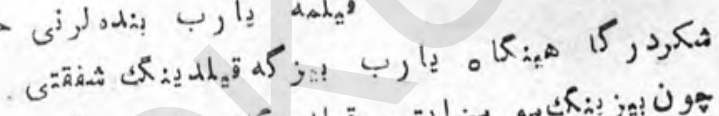

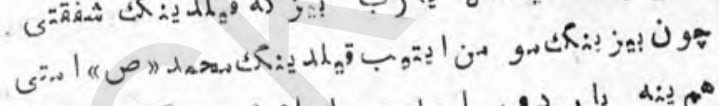

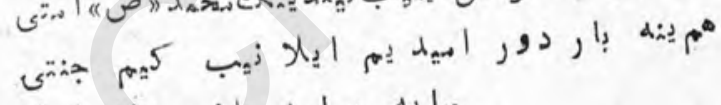

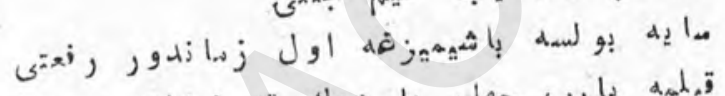

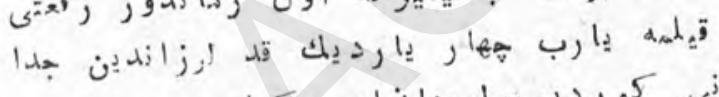

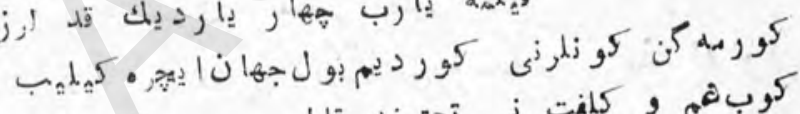

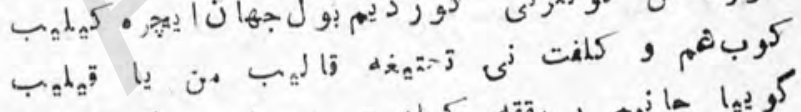

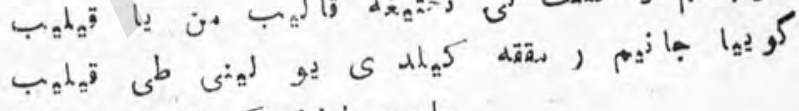

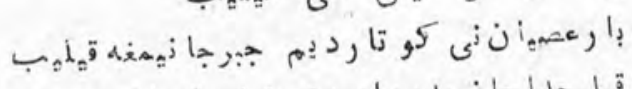

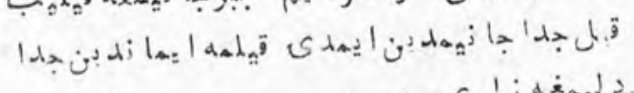

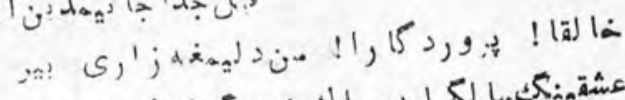

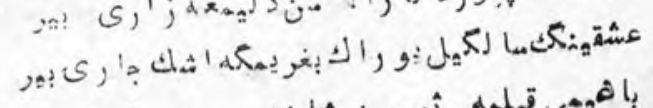

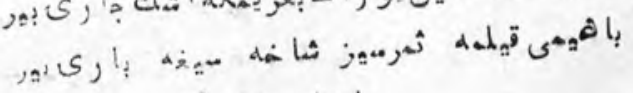

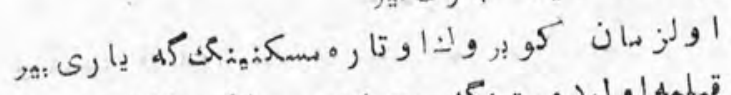

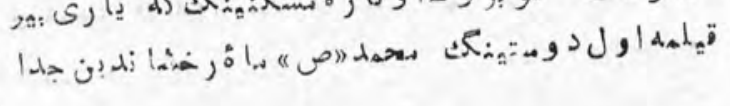

fir 


\section{ساهي}

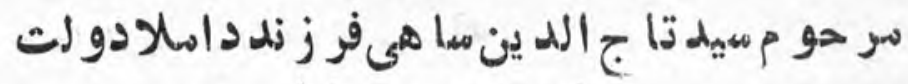

\section{(}

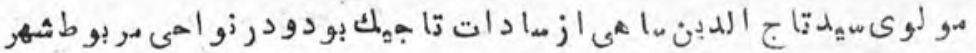

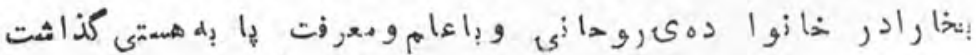

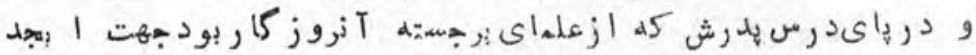

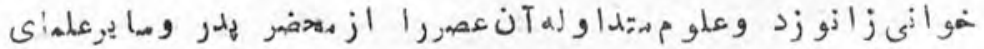

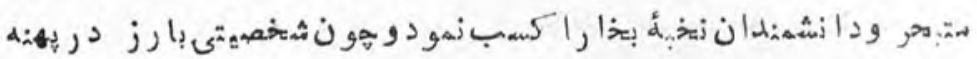

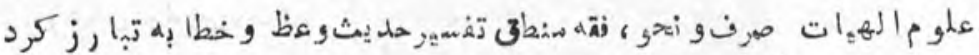

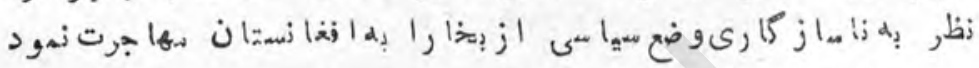

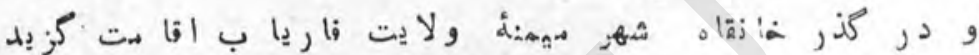

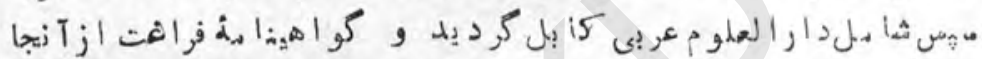

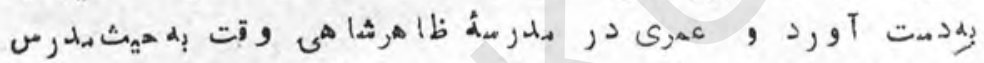

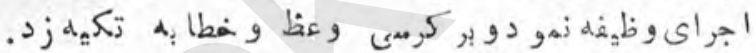

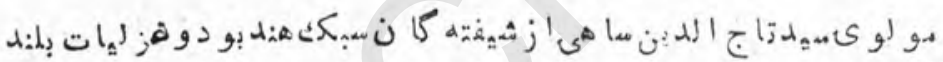

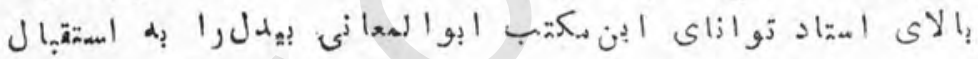

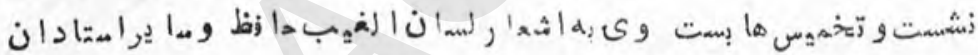

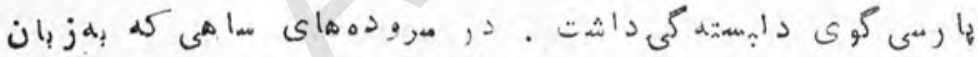

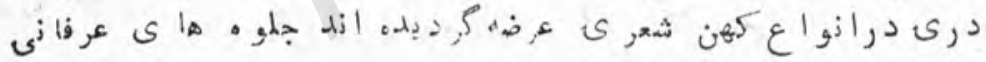

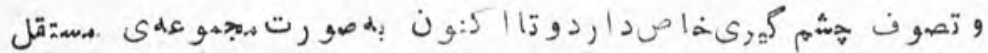

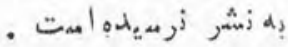


ثناى ايزدمتعال

إىها.ازل، ثمر ابد،اقد س واقدر 5.تراثر قدرتت إين كنبه الخضر

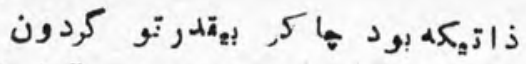

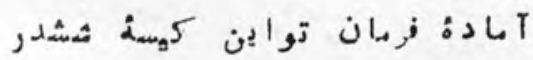

ازمسيهت ـلمطان تو در تلب دماند

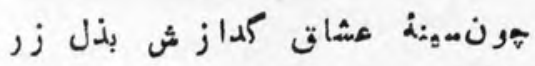

خاصهتجانزخ كمالات تود در دثت

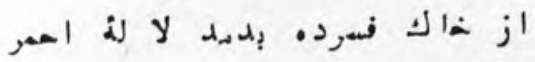

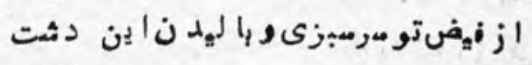

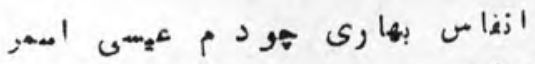

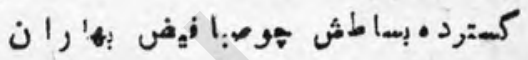

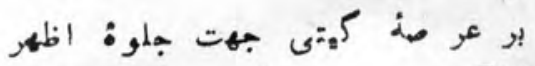

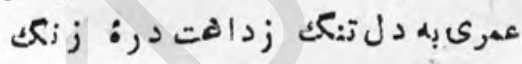

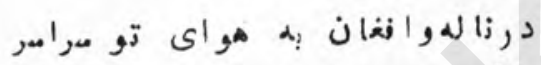

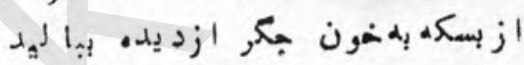

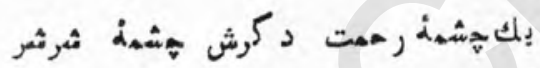

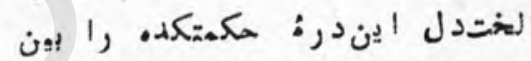

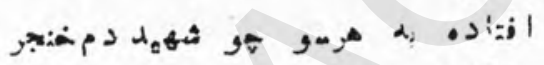

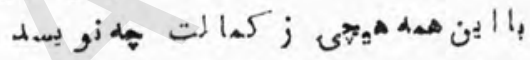

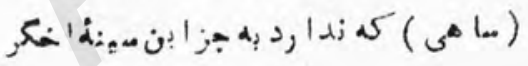

PIP 


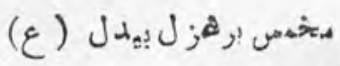

صنع لمثيزل

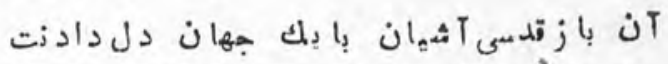

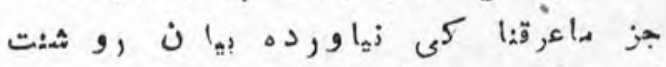

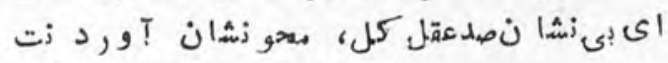

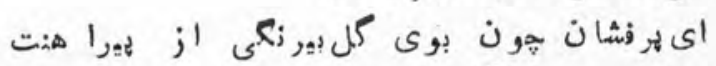

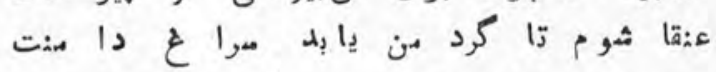

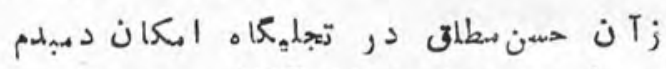

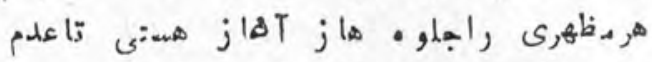

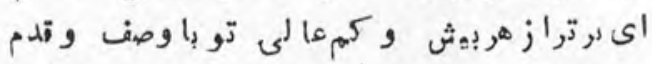

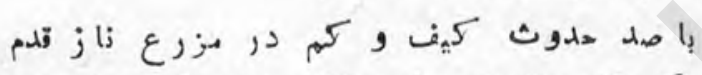

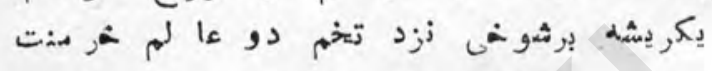

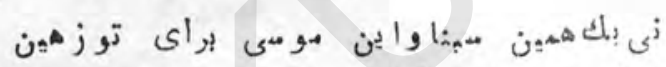

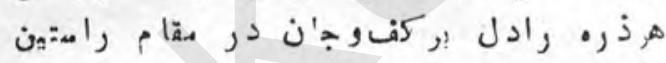

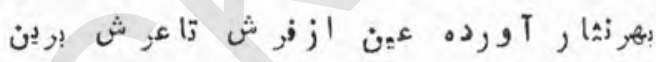

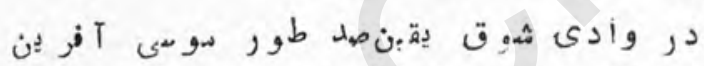

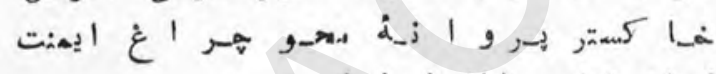

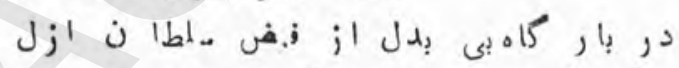

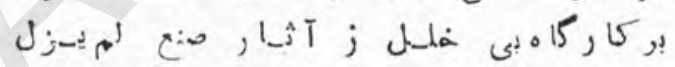

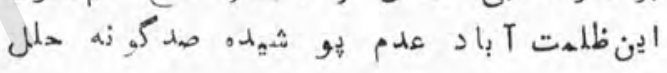

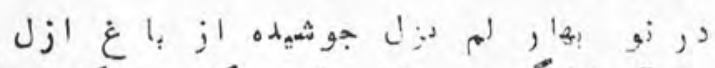

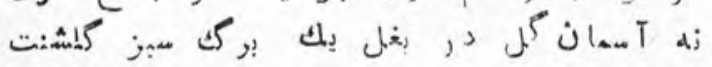

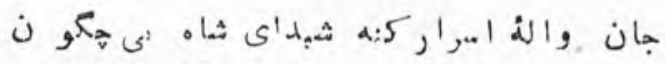

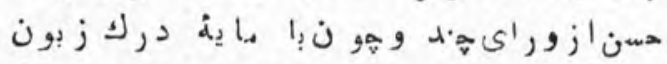

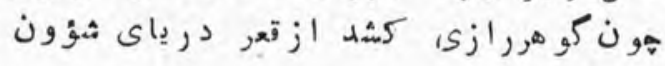

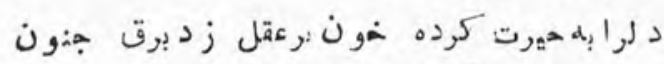

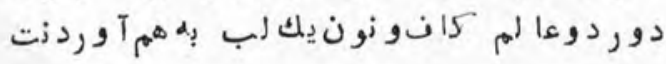

FIO 


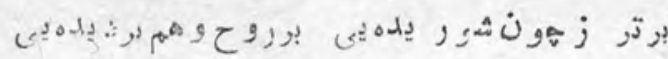

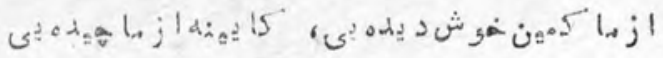

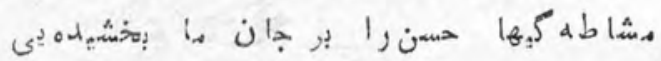

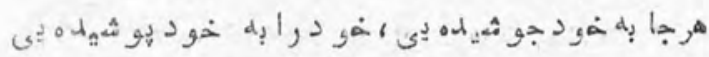

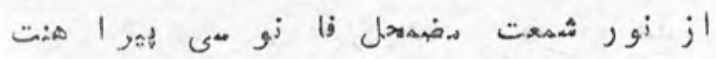

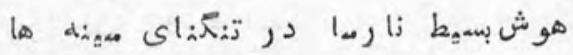

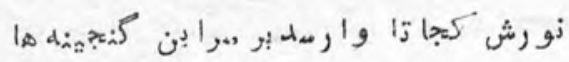

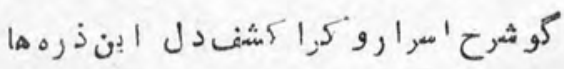

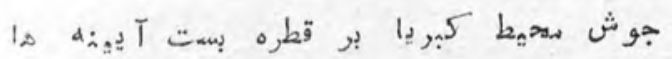

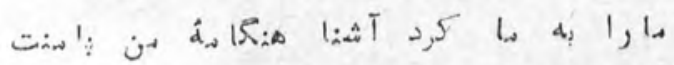

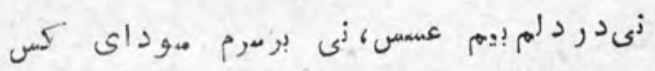

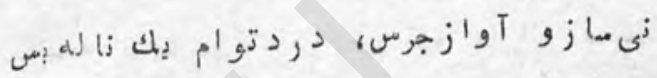

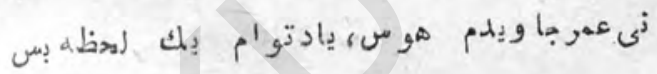

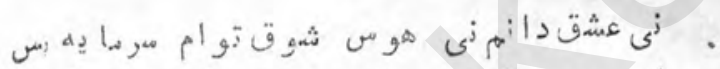

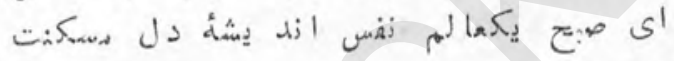

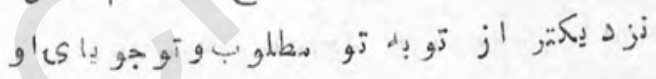

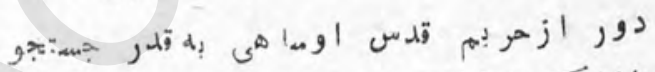

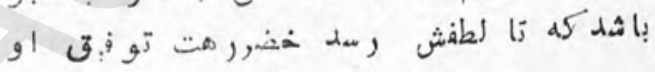

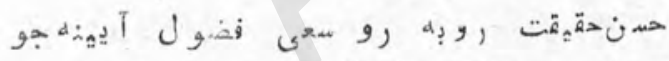

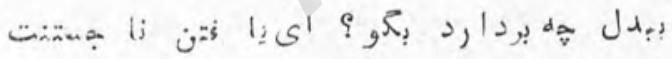

(4)

819 


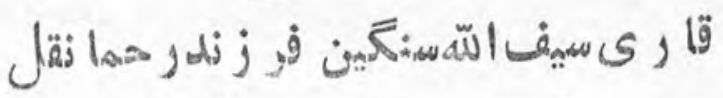

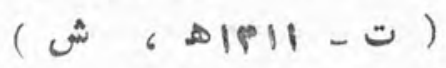

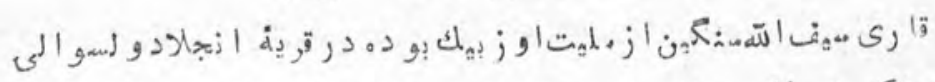

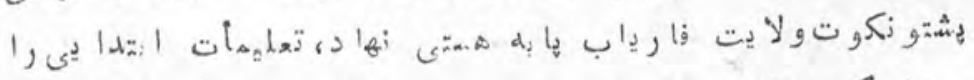

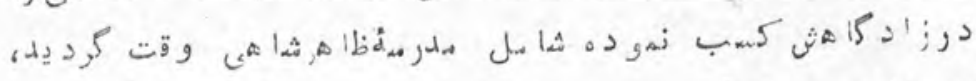

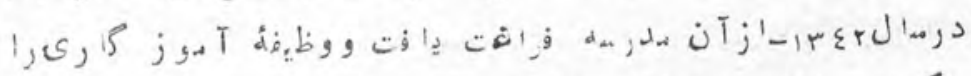

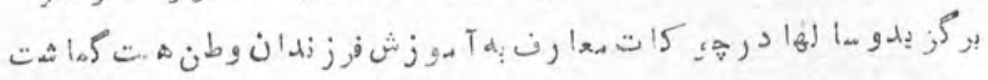

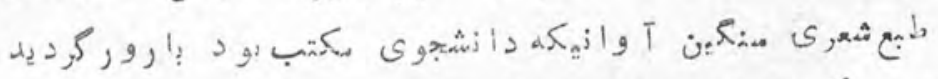

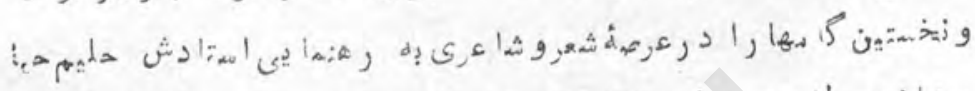

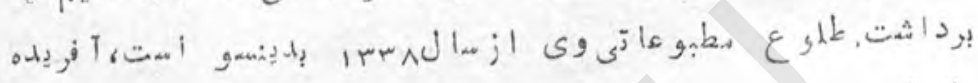

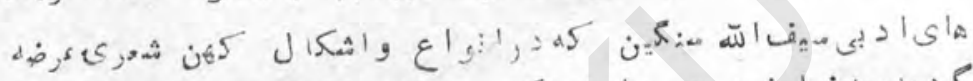

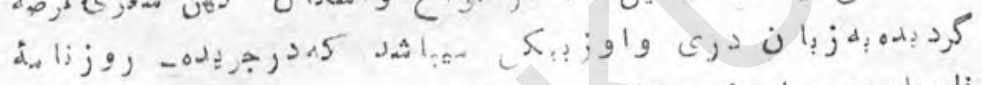

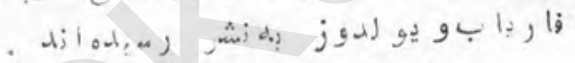

I.

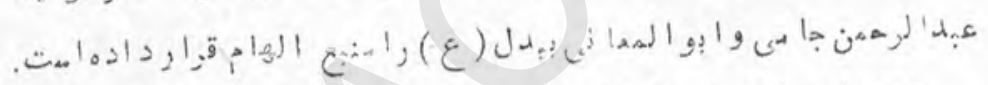

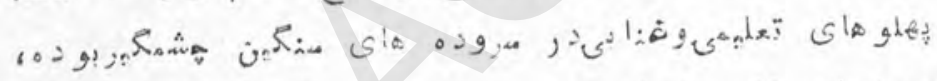

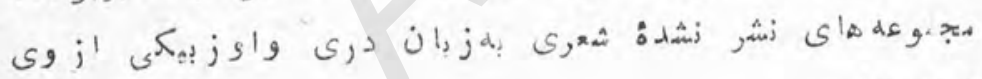

. 


\section{وطن مهرى}

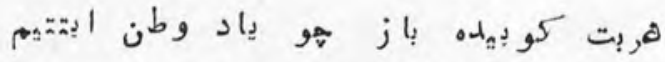

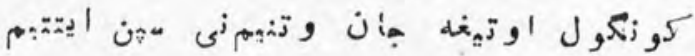

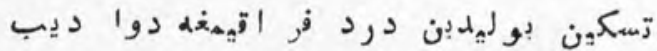

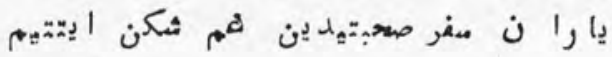

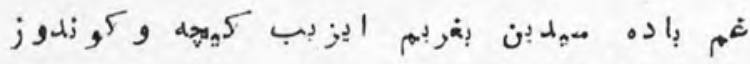

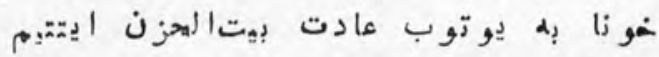

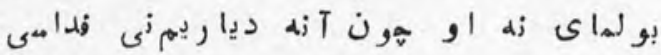

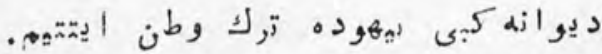

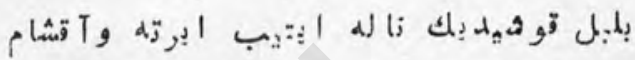

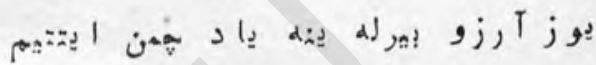

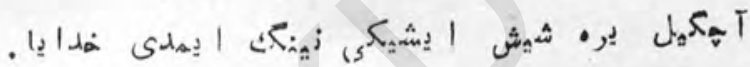

P 1 مان

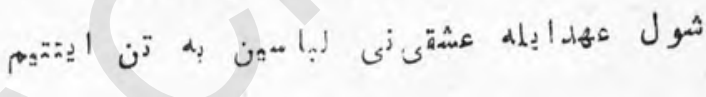

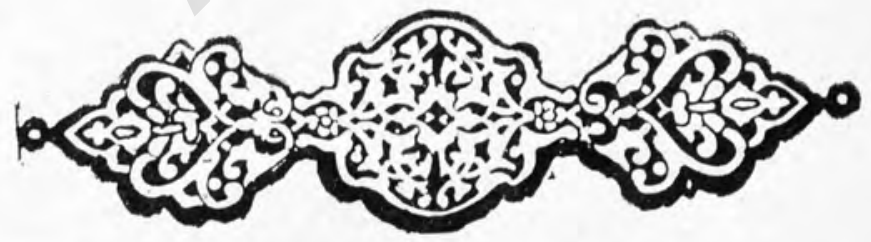




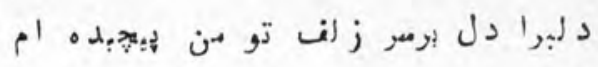

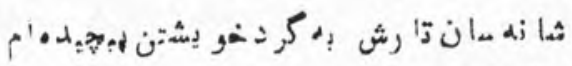

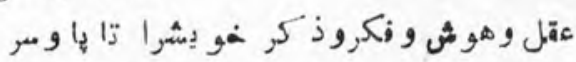

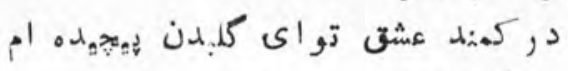

بر سراغ مروقدت دوش در إسعةان شدم

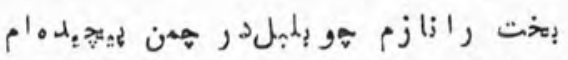

يو مف دوران زاهسا زت زميما شم بعديد

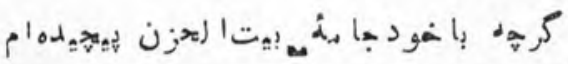

هرتو حسن تو هونشمع آش انروزد إهدل

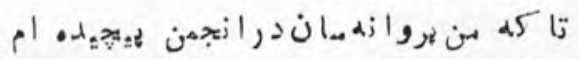

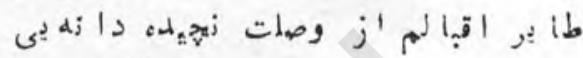

J

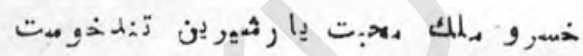

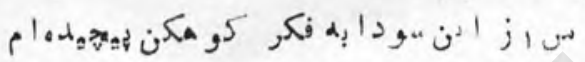

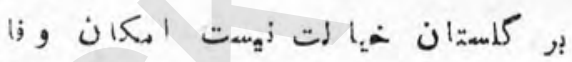

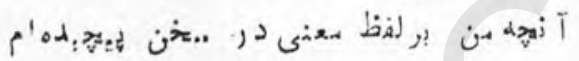

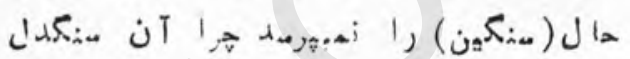

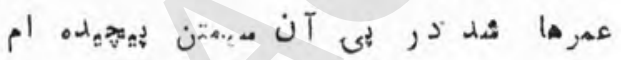

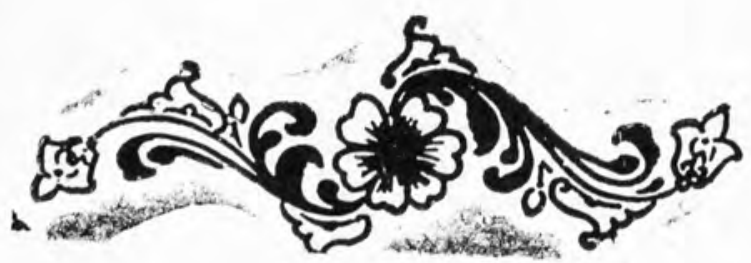

419 


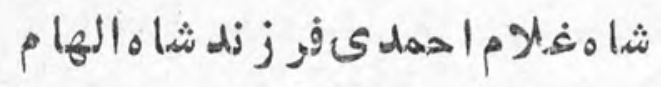

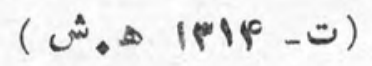

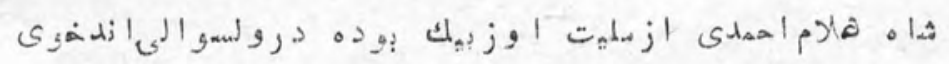

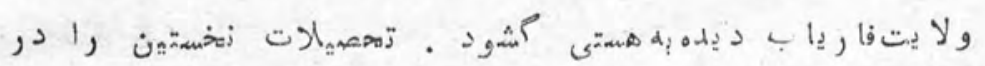

زاد اله

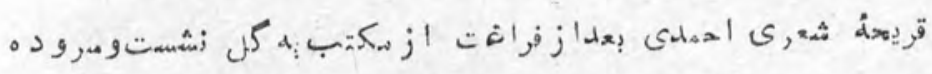

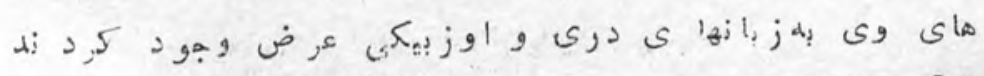

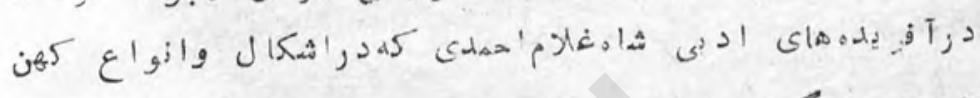

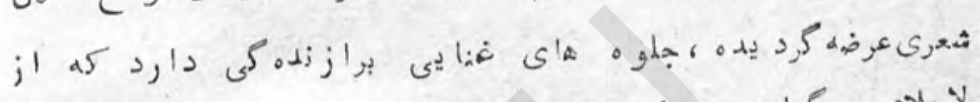

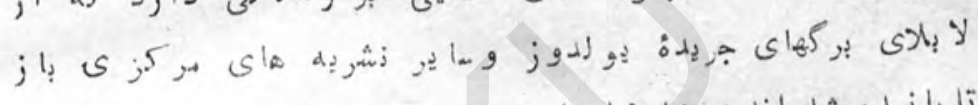

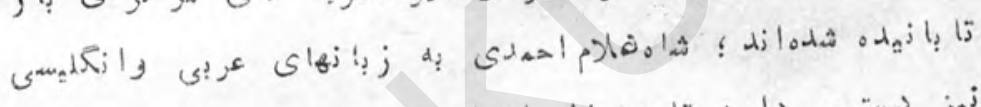

ز

.

PFo 
苟

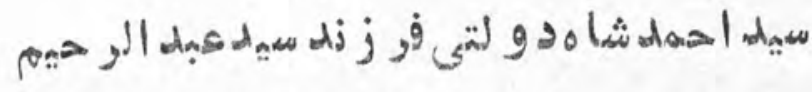

$$
\text { ( }
$$

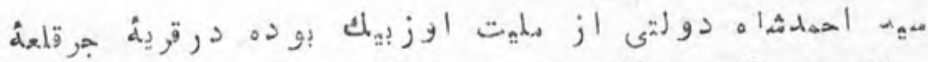

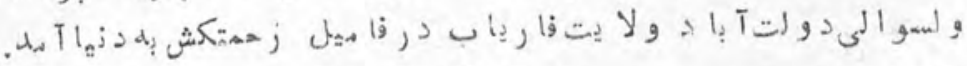

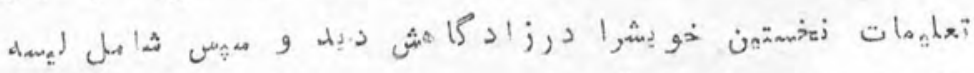

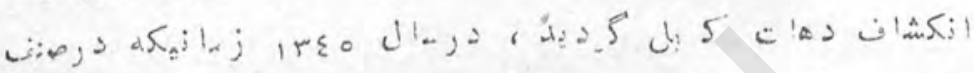

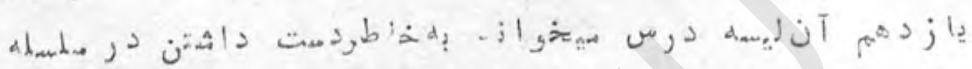

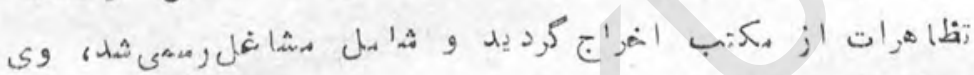

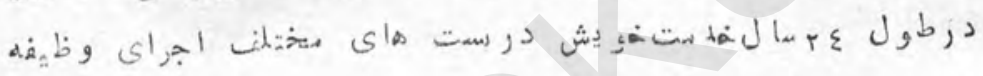

.

له:

些

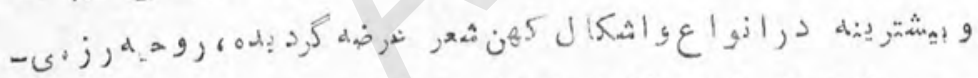

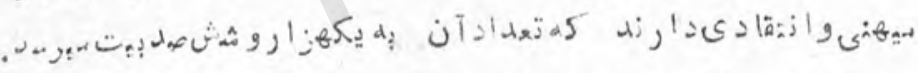

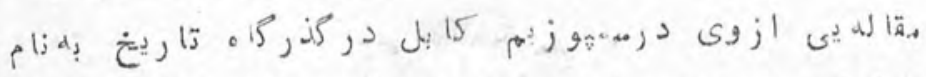

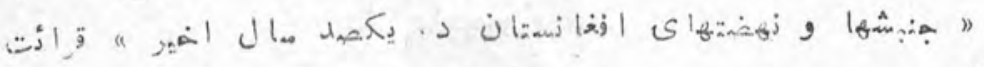

. .

P: 
اولكه آبادبولسون

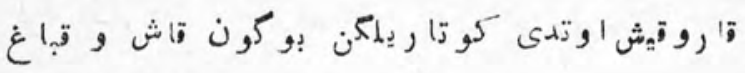

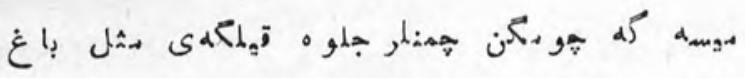

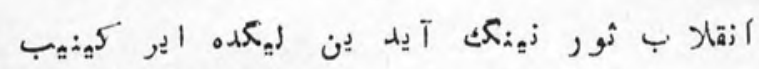

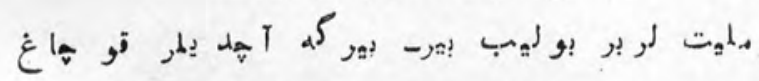

|

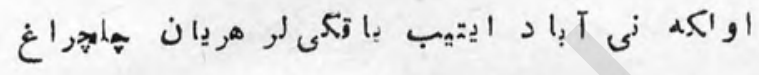

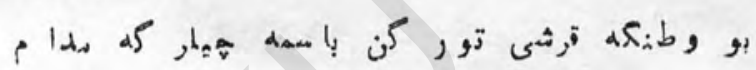

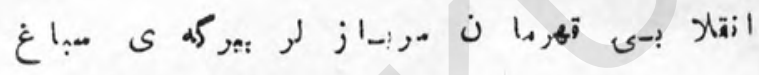

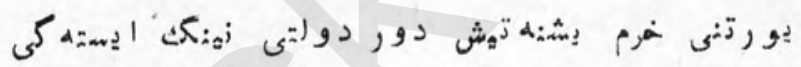

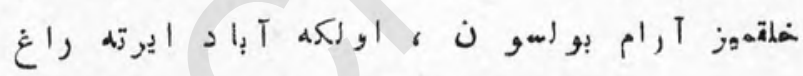

( دولت ( ) ( )

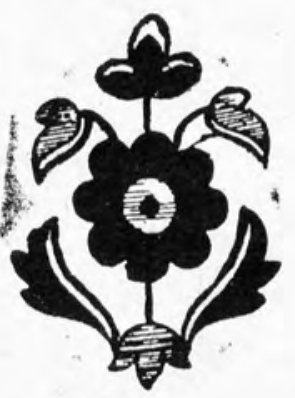

fPr 
راه صلح

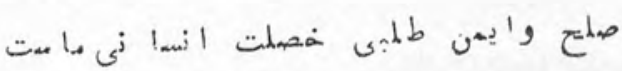

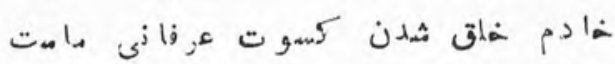

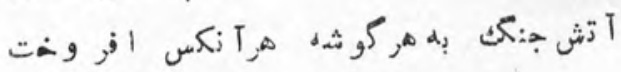

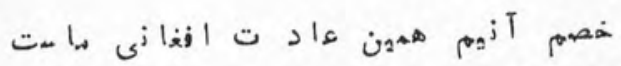

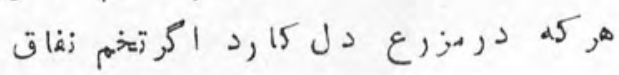

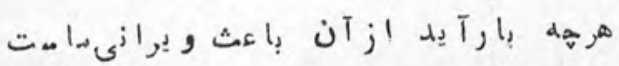

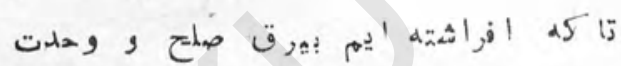

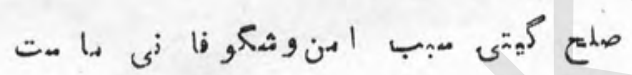

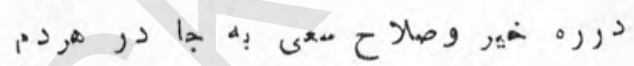

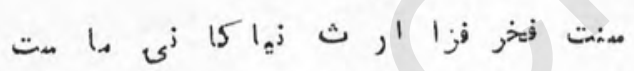

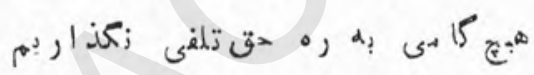

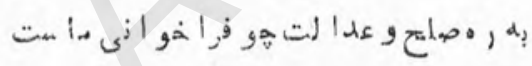




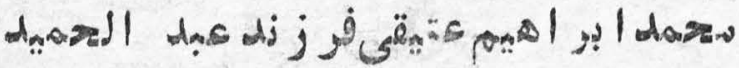

$$
\text { ش. . . . ت }
$$

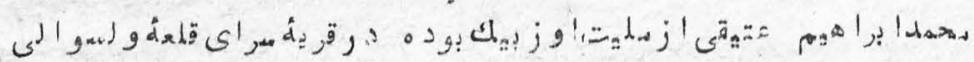

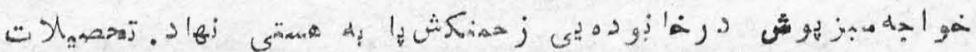

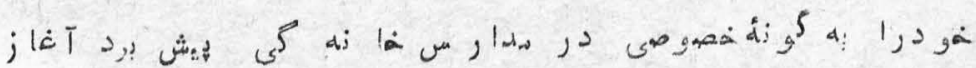

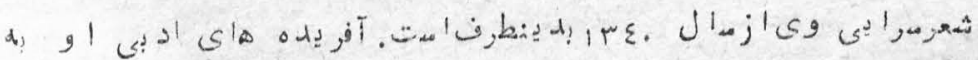

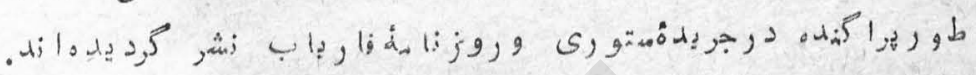

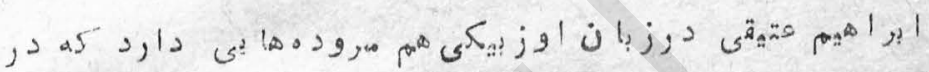

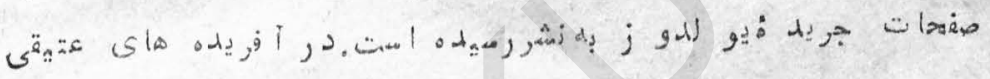

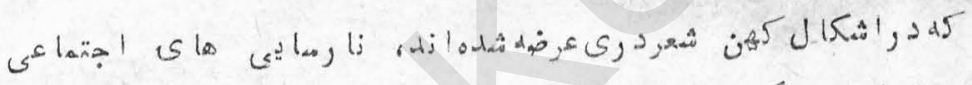

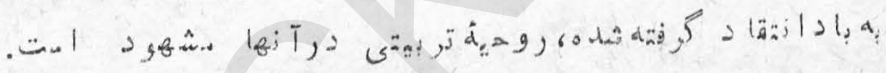

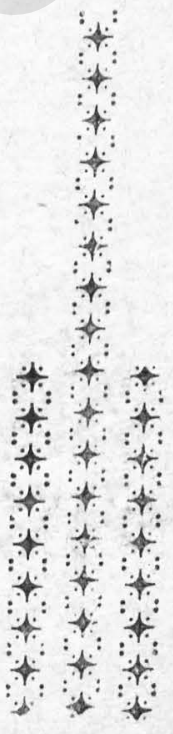




\section{ارز ش صلح}

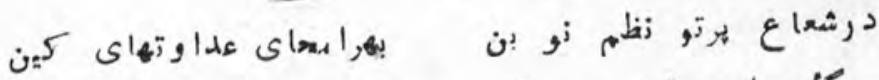

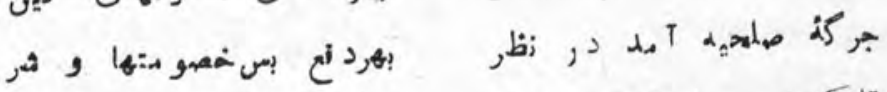

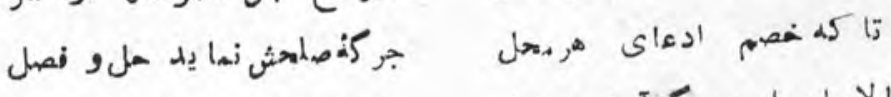

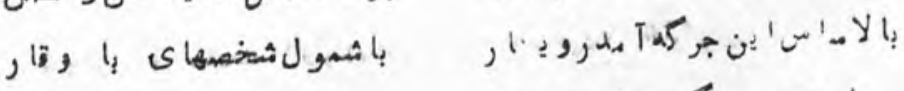

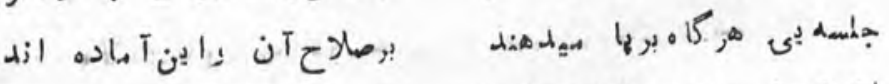

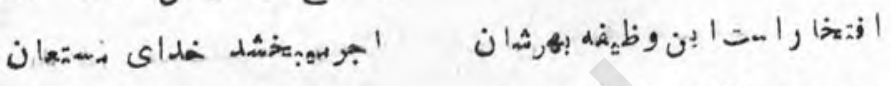

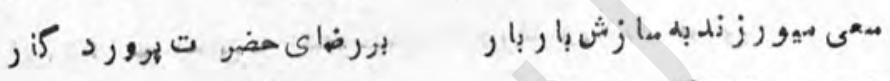

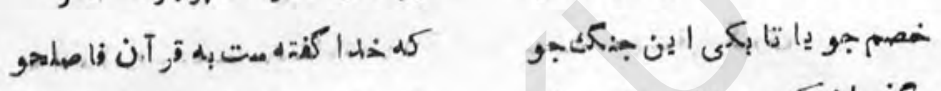

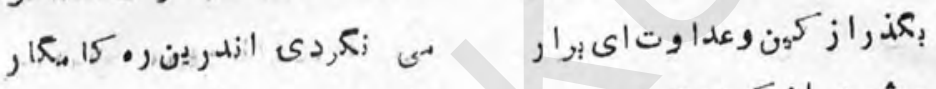

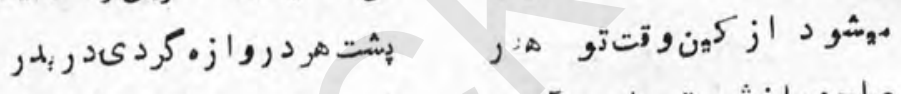

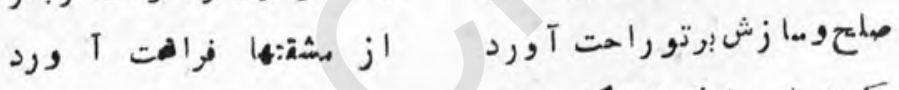

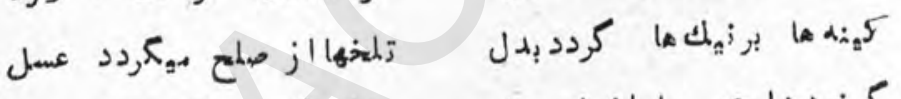

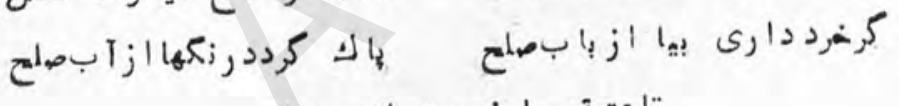

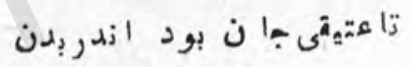

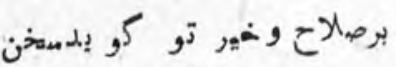

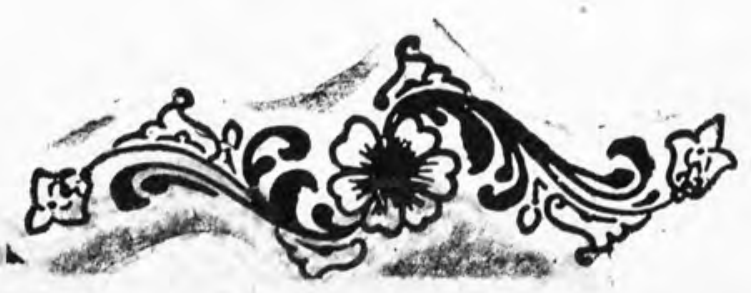




\section{9

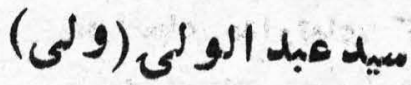 \\ (3)A |rin- qrqy)}

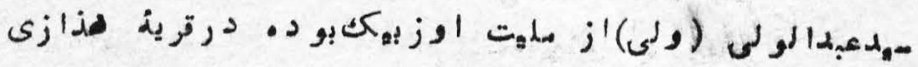

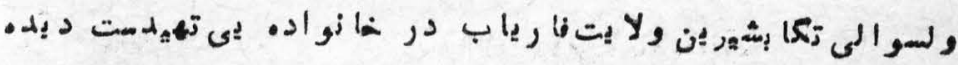

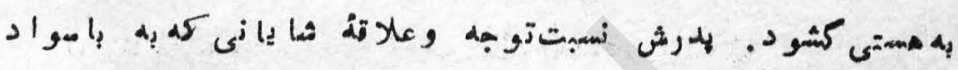

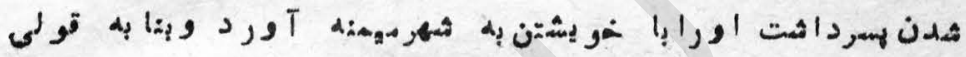

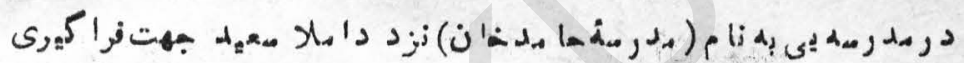

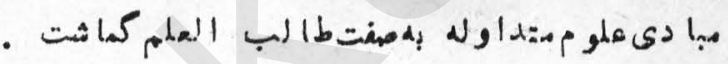

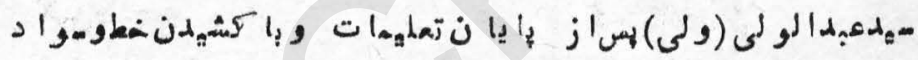

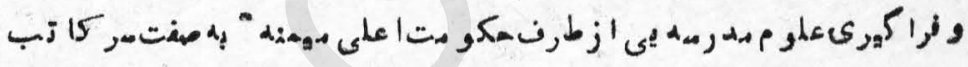

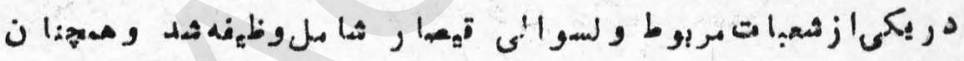

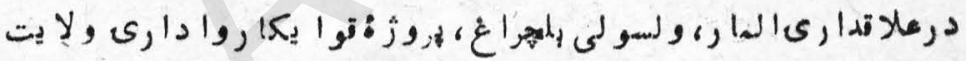

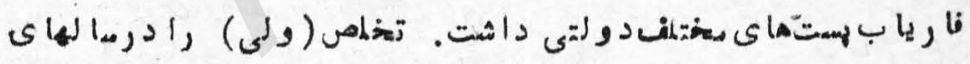

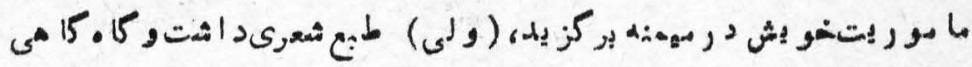

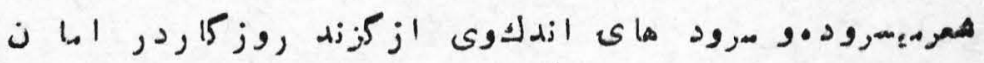

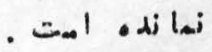

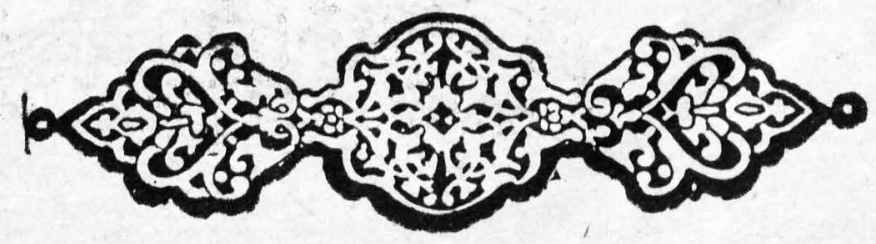




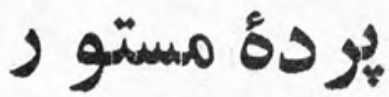

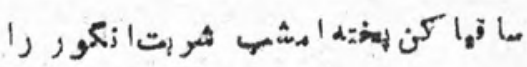

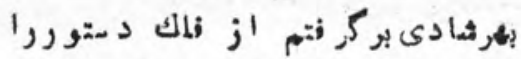

موى ازدر كا سل هو:نى براىعبرت اهت

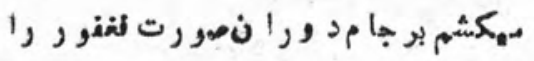

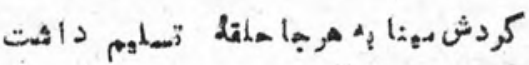

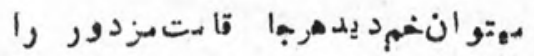

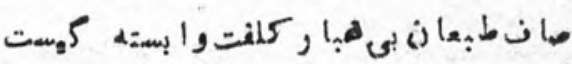

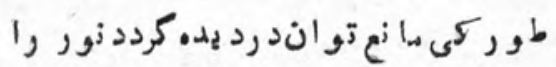

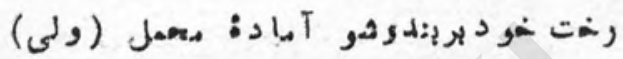

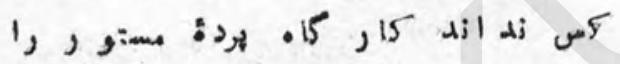

Pry 
مفتونقيصارى

سيد عبد الغفو رمفتو ن قيصا رى فوز ز زله سيد مسليما ن

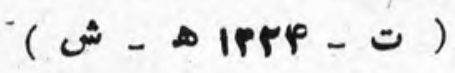

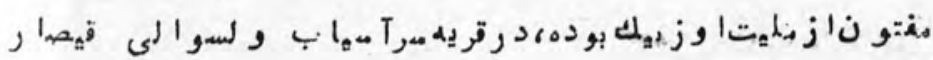

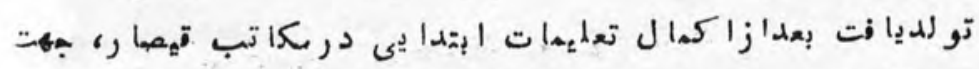

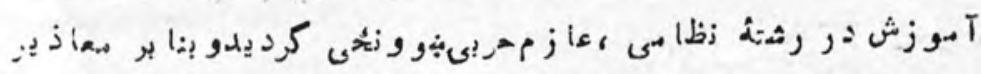

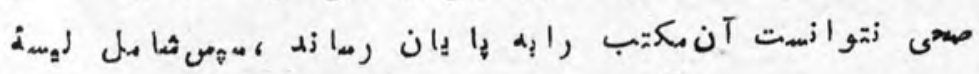

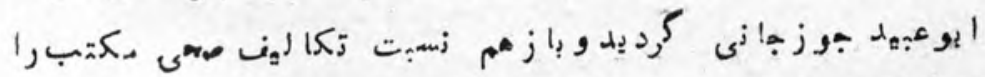

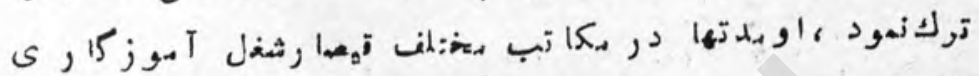

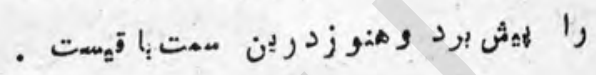

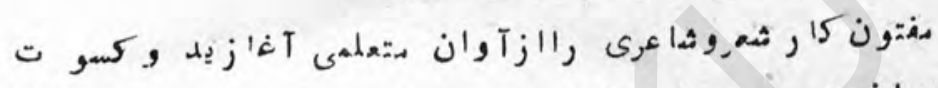

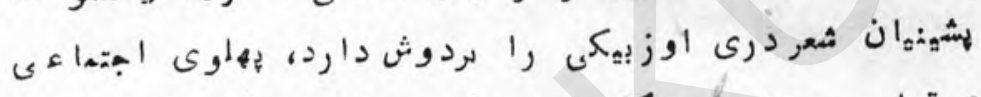

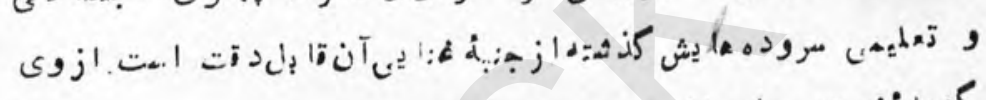

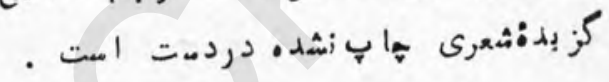

$\therefore$

2h

frA 


\section{زآماه آششين}

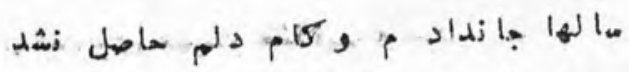

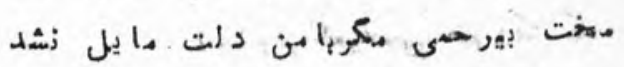

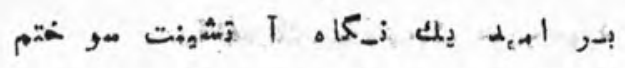

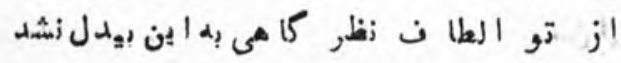

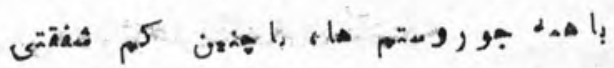

$$
\begin{aligned}
& \text { زقش ثهرت }
\end{aligned}
$$

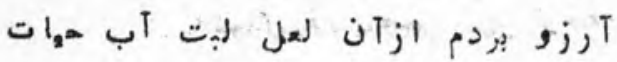

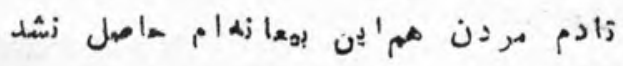

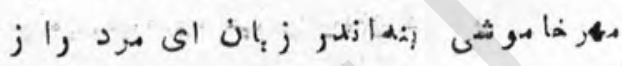

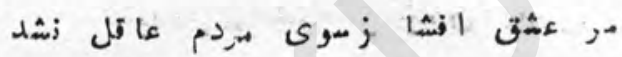

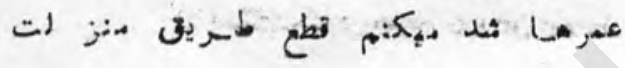

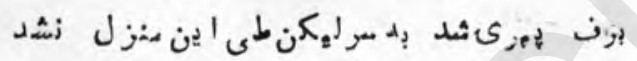

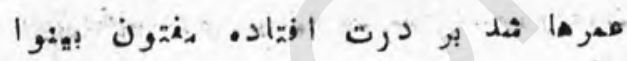

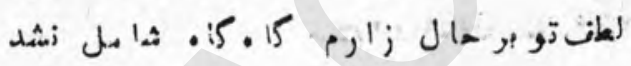

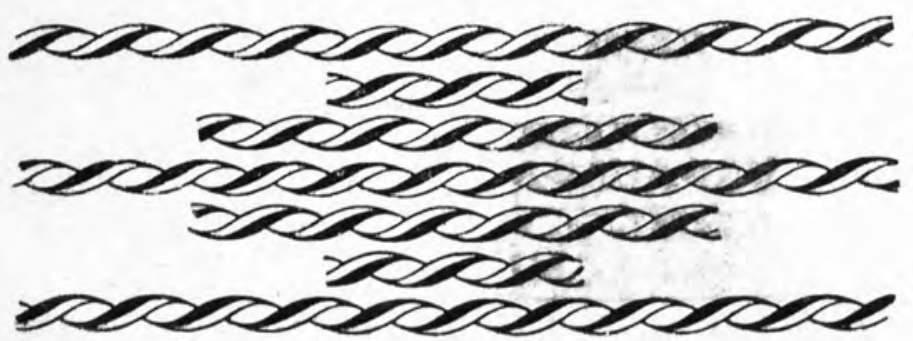


سيويملى اولكه

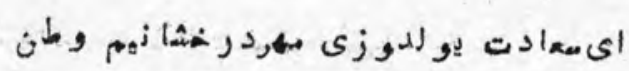

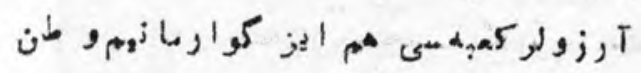

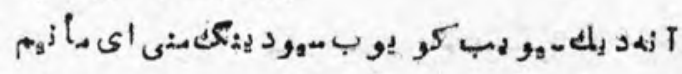

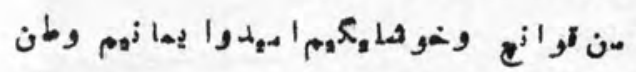

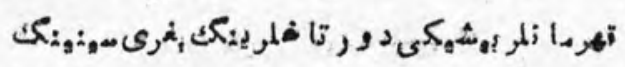

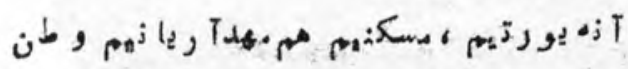

آسما:

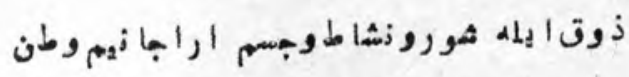

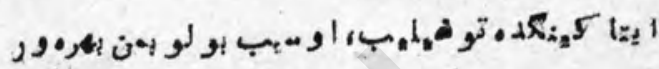

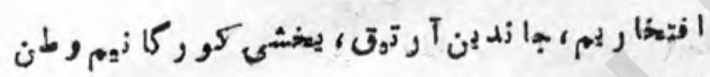

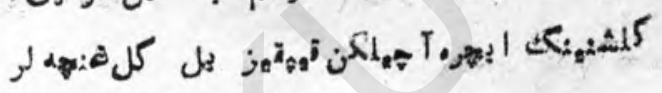

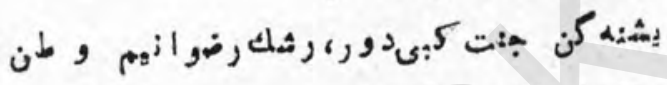

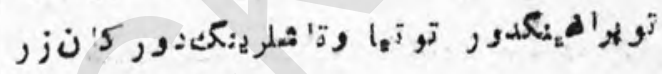

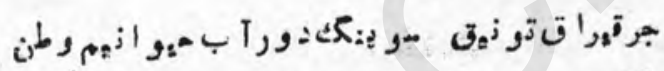

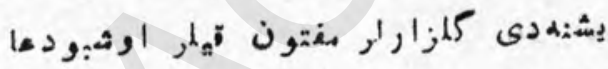

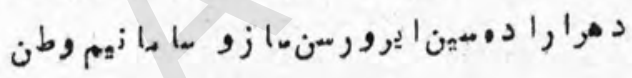

FP. 


\section{اظظهارسياسي}

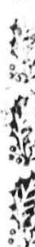

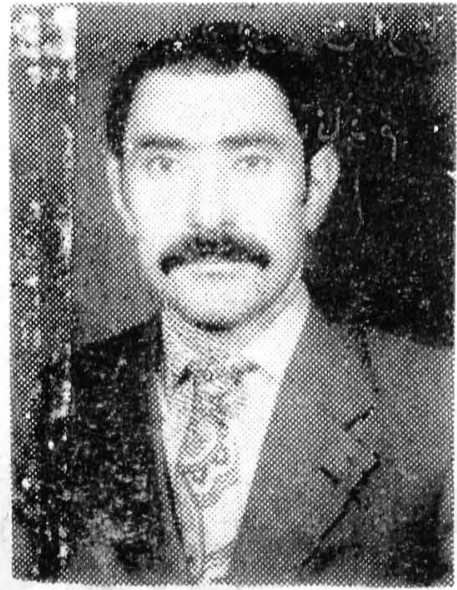

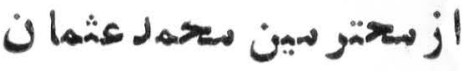

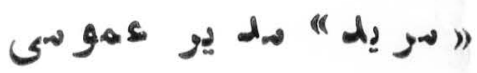

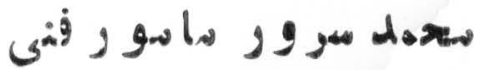

حفْي الله و حما ت الّه

ward

㱷

?

,

粼

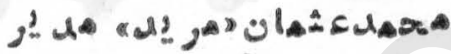

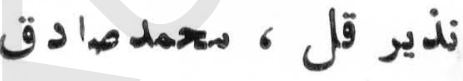

留

䇥

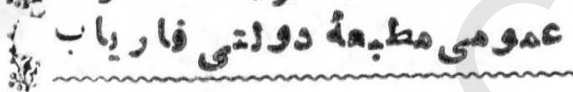

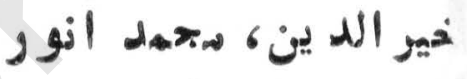

然

傮

⿸\zh14

籍

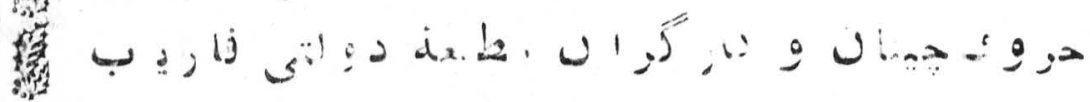

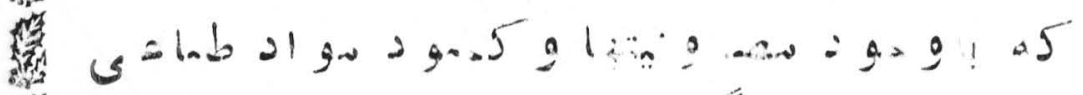

㩁

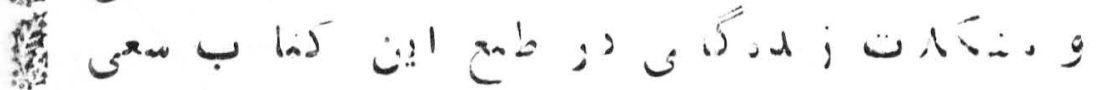

政

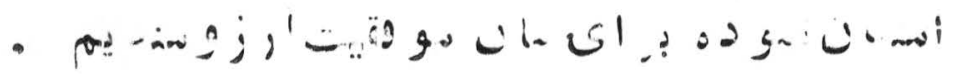

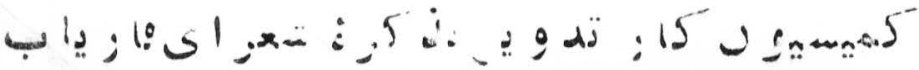

唯 
از انتشار راتجز يدة فار ياب ب

disino

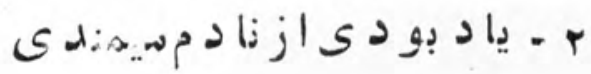

r - r

r ـ مشاعر ه

i

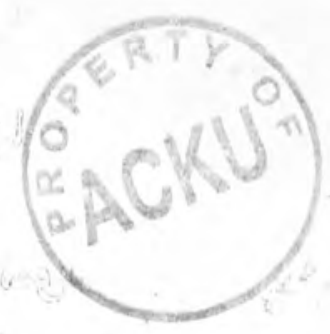

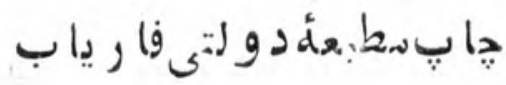

